\title{
The political accountability of EU agencies: learning from the US experience
}

Citation for published version (APA):

Scholten, M. O. (2014). The political accountability of EU agencies: learning from the US experience. [Doctoral Thesis, Maastricht University]. Datawyse / Universitaire Pers Maastricht.

https://doi.org/10.26481/dis.20140403ms

Document status and date:

Published: 01/01/2014

DOI:

10.26481/dis.20140403ms

Document Version:

Publisher's PDF, also known as Version of record

\section{Please check the document version of this publication:}

- A submitted manuscript is the version of the article upon submission and before peer-review. There can be important differences between the submitted version and the official published version of record.

People interested in the research are advised to contact the author for the final version of the publication, or visit the DOI to the publisher's website.

- The final author version and the galley proof are versions of the publication after peer review.

- The final published version features the final layout of the paper including the volume, issue and page numbers.

Link to publication

\footnotetext{
General rights rights.

- You may freely distribute the URL identifying the publication in the public portal. please follow below link for the End User Agreement:

www.umlib.nl/taverne-license

Take down policy

If you believe that this document breaches copyright please contact us at:

repository@maastrichtuniversity.nl

providing details and we will investigate your claim.
}

Copyright and moral rights for the publications made accessible in the public portal are retained by the authors and/or other copyright owners and it is a condition of accessing publications that users recognise and abide by the legal requirements associated with these

- Users may download and print one copy of any publication from the public portal for the purpose of private study or research.

- You may not further distribute the material or use it for any profit-making activity or commercial gain

If the publication is distributed under the terms of Article $25 \mathrm{fa}$ of the Dutch Copyright Act, indicated by the "Taverne" license above, 


\section{The Political Accountability of EU Agencies: \\ Learning from the US Experience}


(C) Miroslava Scholten, Maastricht 2014

ISBN 9789461593122

Production: Datawyse | Universitaire Pers Maastricht Cover design: Viktoria Kostebelova. 


\title{
The Political Accountability of EU Agencies: \\ Learning from the US Experience
}

\author{
Dissertation \\ to obtain the degree of Doctor at \\ Maastricht University, \\ on the authority of the Rector Magnificus, \\ Prof.dr. L.L.G Soete \\ in accordance with the decision of the Board of Deans, \\ to be defended in public \\ on Thursday 3 April 2014 at 10.00 hours
}

by

Miroslava Scholten

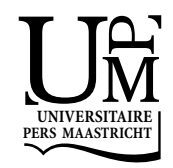




\section{Supervisor}

Prof. dr. L.F.M. Verhey (Leiden University, formerly Maastricht University)

\section{Co-supervisor}

Dr. Ph. Kiiver

\section{Assessment Committee}

Prof. dr. E.I.L. Vos (Chair)

Prof. dr. A.W. Heringa

Prof. dr. J. Lubbers (American University Washington College of Law)

Prof. dr. S. Vanhoonacker

Dr. K. Yesilkagit (Universiteit Utrecht)

This research project was financed by the Montesquieu Institute. 
Для моих родителей 


\section{Acknowledgments}

They say that completing a PhD dissertation is a great personal achievement since it is a test not only of one's intellectual capacity but also of one's character, largely discipline and persistence. While I would not argue against the stated opinion, I believe that such a personal achievement can be successful only in a supportive social environment, for which I would like to express my gratitude to a number of people.

First of all, I owe the deepest gratitude to my supervisors Prof. Luc Verhey and Dr. Philipp Kiiver for their trust in me and for all the comments, questions, corrections, and useful discussions, which have made this book possible at all! The financial support of the Montesquieu Institute is, of course, also appreciated.

Secondly, I am grateful for the feedback received from the members of the reading committee, namely Prof. Ellen Vos (chair), Prof. Aalt Willem Heringa, Prof. Jeffrey Lubbers, Prof. Sophie Vanhoonacker, and Dr. Kutsal Yesilkagit. I would like to thank Prof. Jeffrey Lubbers also for his generous support offered in Washington, DC, during my research visit to the Washington College of Law, American University.

During my field research in the US and the EU I have met a number of people who were willing to share their (practical) experience in relation to the questions which I have been investigating. I would like to show my appreciation for their input by listing only their surnames without affiliation due to the political sensitivity of the issues which we may have discussed: Botta, Breger, Crimmins, De Dios Ignacio, Desomer, Eisenberg, Fenneman, Fisher, Gerritsen, Huberman, Hudson, Jacquet, Jacobs, Jakl, Javelle, Jones, Jung, Kiewiet, Kokki, Kovacic, Lefebre, Levy, Lidinsky, Liebman, Maarit, Mulder, Oleszek, Pierot, Santoire, Serban, Smether, Tatelman, Toggenburg, van der Velden, and Vanhoorde. I am thankful to Prof. Strauss (Columbia Law School) and Prof. Vladeck (Washington College of Law, American University) for allowing me to attend their insightful lectures. The members and staff of the European Parliament and its committees, MEP Anne Jensen and MEP Jutta Haug in particular, also deserve to be acknowledged for their prompt reactions to my e-mail inquiries (see Appendix 2) and requests for interviews.

A big thanks goes to my colleagues from the Montesquieu Institute, UM Public Law Department and the latter's unofficial 'young Public law section' (Daniëlle, Christian, Joop, Pablo, Rob, Sandor, Sascha, and Wytze) for making a somewhat lonely PhD work a joyful experience. Also, I would like to use this opportunity to thank my new colleagues at Utrecht University, especially Marloes and Bjorn, for their contribution at the final stage of my dissertation.

Furthermore, for their continuous support and encouragement I would like to thank my friends and family from all around the globe, but especially from Russia, the Nether- 
lands, Ukraine, and Austria. I owe a very important debt to my parents for my carefree childhood and student years, which is a remarkable achievement given the chaotic situation in Russia in the 1990s and the beginning of the 2000s. My mom also deserves a special notice for baby-sitting for months, which made it possible for me to finish this book on time. The baby-sitting has also popped up quite often in the agenda of my mother-in-law during the last months of my $\mathrm{PhD}$ project, for which I am very thankful.

Last but by far not least a special appreciation is for a very special person in my life. It is a funny thing, Daniel, that when I think back about our shared $\mathrm{PhD}$ experience, the greatest highlight that comes to my mind is all those tasty dinners and glasses of wine that we had to celebrate the ups and discuss the downs of our PhD research projects. Well, despite or perhaps thanks to all those discussions and celebrations, our $\mathrm{PhD}$ years seem to have been quite fruitful resulting not only in the two books, but also in other joint ventures: our son Simon Daniel, cat Mesy, and a number of joint publications. I could not have wished for a better partner in my life!

Fieberbrunn, 30 December 2013 



\section{Table of Contents}

LIST OF ABBREVIATIONS ....................................................................

LIST OF TABLES, BOXES, AND FIGURES ...........................................XIV

CHAPTER 1. THE POLITICAL ACCOUNTABILITY OF EU

AGENCIES: AN INTRODUCTION ...................................... 1

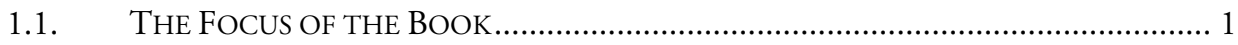

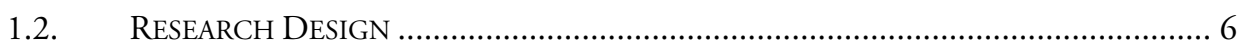

1.2.1. Defining, Investigating, and Assessing Political Accountability ................................ 6

1.2.2. Challenges in Studying the Political Accountability of EU Agencies ........................ 13

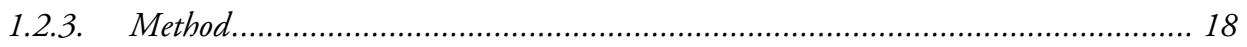

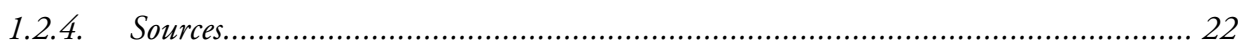

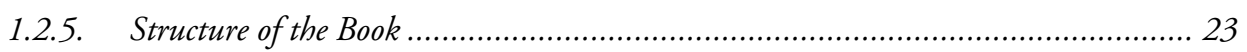

CHAPTER 2. HOLDING EU AGENCIES TO POLITICAL ACCOUNT....... 25

2.1. The EU POLITICAL ACCOUNTABILITY FORUM AND ACTOR: INTRODUCING THE COUnCIL, THE EUROPEAN PARLIAMENT, AND EU AGENCIES..................... 25

2.1.1. The Council and the European Parliament .......................................................... 26

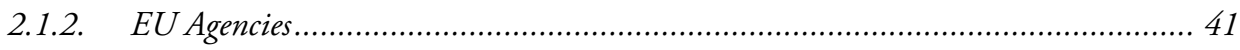

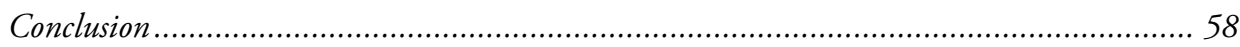

2.2. InVestigating the Political Accountability of EU Agencies ............... 59

2.2.1. Creation of and Delegation to EU agencies: at the EU Legislator's Discretion.......... 59

2.2.2. Appointment and Removal Procedures of EU agencies' Top Officials: a Playground for Political Influences..................................................................... 77

2.2.3. Accountability through Statutory Regulation: Theory and Practice of Reporting and Review Clauses ........................................................................................ 93

2.2.4. Financial Oversight: a Well-established Accountability Venue................................104

2.2.5. Scrutinizing EU Agencies' Performance: an Accountability Venue in Development .................................................................................................. 121

2.2.6. The 'Common Approach' on the Operation of EU Agencies: Going Forward or

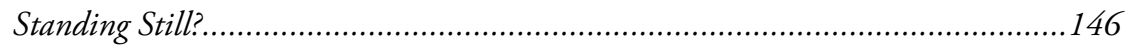

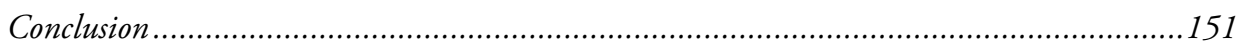

2.3. AsSESSING THE POLITICAl ACCOUNTABILITY OF EU AgENCIES ........................153

2.3.1. Availability of Accountability Mechanisms: Harmful Implications of Diverse

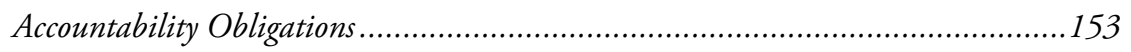


2.3.2. 'Unconsciousness' of Design of Accountability Provisions.....

160

2.3.3. Practical Application of Accountability Provisions: Facing a Number of

Challenges.

Conclusion

CHAPTER 3. HOLDING US INDEPENDENT REGULATORY AGENCIES TO POLITICAL ACCOUNT.

3.1. THE US POLITICAL ACCOUNTABILITY FORUM AND ACTOR: INTRODUCING THE US CONGRESS AND US INDEPENDENT REGULATORY AGENCIES...............169

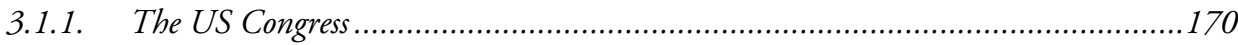

3.1.2. US Independent Regulatory Agencies.......................................................... 176

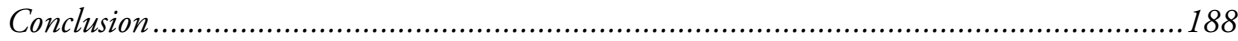

3.2. INVESTIGATING THE POLITICAL ACCOUNTABILITY OF US INDEPENDENT

REGULATORY AGENCIES .............................................................................189

3.2.1. Creation of and Delegation to Independent Regulatory Agencies: at Congress's

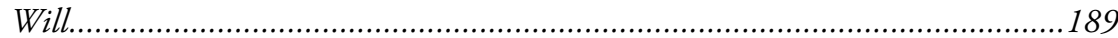

3.2.2. The Law and Politics of Appointing and Removing IRAs' Commissioners ..............201

3.2.3. Accountability through Statutory regulation of Agencies' Performance: Learning and Cautionary Experiences ...........................................................................211

3.2.4. The Annual Appropriations Process: 'The Accountability Venue'...........................231

3.2.5. Congressional Oversight: Strengths and Challenges..............................................243

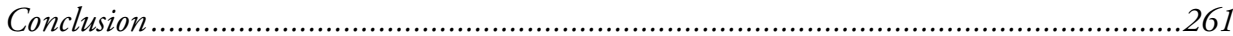

3.3. ASSESSING THE POLITICAL ACCOUNTABILITY OF US INDEPENDENT

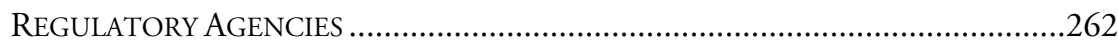

3.3.1. The Availability of Accountability Mechanisms: a Solid Arsenal Applicable to All..263

3.3.2. The 'Consciousness' of Design of Accountability Mechanisms................................267

3.3.3. The Practical Application of Accountability Mechanisms: Challenges and

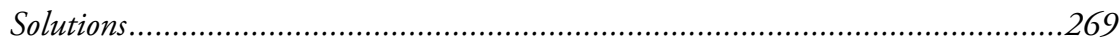

Conclusion 271

CHAPTER 4. THE POLITICAL ACCOUNTABILITY OF IRAS IN THE EU AND THE US COMPARED

4.1. The AVAilability of ACCOUNTABILITY MECHANISMS: DiverSity VS. UNIFORMITY .273

4.1.1. Similar Accountability Mechanisms .................................................................2. 274

4.1.2. Similar Mechanisms but Different Approaches...................................................2. 275

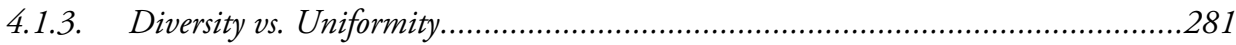

4.2. The Design of ACCOUnTABILITy MeChanisms: SpeCificity AND INTERPLAY 
4.2.1. Specificity of Accountability Obligations: Balancing between Too Few and Too Many Details and Obligations.....

4.2.2. Interplay between Accountability Mechanisms: Something for Future

Consideration in the EU.... 287

4.3. THE Practical Application OF ACCOUNTABILITY MECHANISMS:

PARTIAL RELEVANCE OF THE US EXPERIENCES. .290

4.3.1. Addressing the Challenges to Parliamentary Oversight ..........................................290

4.3.2. Addressing the Challenges to Using Sanctioning Tools .........................................295

Conclusion 297

CHAPTER 5. THE POLITICAL ACCOUNTABILITY OF EU AGENCIES: 'THE WAY FORWARD'

5.1. The NeCESSITY of A TREATy Provision.... 299

5.2. THE NECESSITY OF A LEGALLY-BINDING FRAMEWORK BASED ON A STREAMLINING APPROACH (S, M, AND L MODELS) 304

5.3. THE NECESSITY TO RENDER ACCOUNT FOR HOLDING EU AgENCIES TO

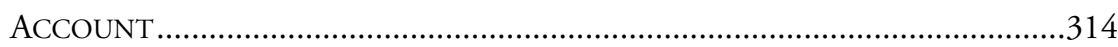

Conclusion. 318

CHAPTER 6. REFLECTIONS AND PROSPECTS.................................... 319

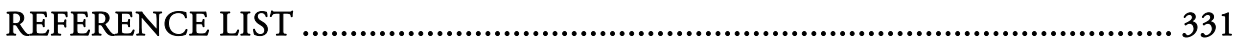

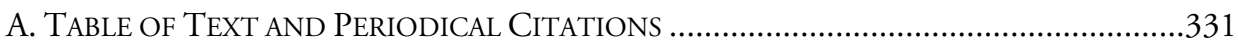

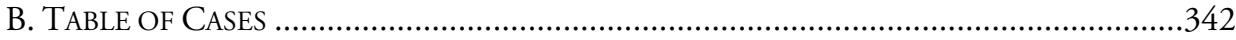

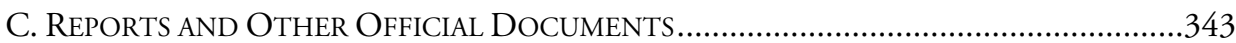

APPENDIX 1 THE POLITICAL ACCOUNTABILITY ARRANGEMENTS OF 35 EU AGENCIES........................................................... 347

APPENDIX 2 EUROPEAN PARLIAMENT'S COMMITTEES SCRUTINIZING EU AGENCIES ....................................... 377

APPENDIX 3 THE POLITICAL ACCOUNTABILITY ARRANGEMENTS OF 16 US INDEPENDENT REGULATORY AGENCIES ....... 381

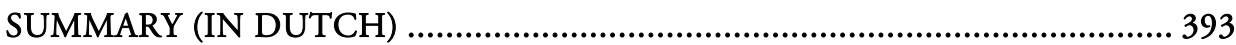

CURRICULUM VITAE ..................................................................... 401 


\section{List of Abbreviations}

\begin{tabular}{|c|c|}
\hline ACER & Agency for the Cooperation of Energy Regulators \\
\hline ACUS & Administrative Conference of the United States \\
\hline $\mathrm{APA}$ & Administrative Procedure Act \\
\hline BEREC & Body of European Regulators for Electronic Communications \\
\hline $\mathrm{CBO}$ & Congressional Budget Office \\
\hline $\mathrm{CdT}$ & Translation Centre for the Bodies of the European Union \\
\hline Cedefop & European Centre for the Development of Vocational Training \\
\hline Cepol & European Police College \\
\hline CFTC & Commodity Futures Trading Commission \\
\hline CJEU & Court of Justice of the European Union \\
\hline CPSC & Consumer Product Safety Commission \\
\hline CPVO & Community Plant Variety Office \\
\hline CRS & Congressional Research Service \\
\hline EASA & European Aviation Safety Agency \\
\hline EASO & European Asylum Support Office \\
\hline EBA & European Banking Authority \\
\hline ECDC & European Centre for Disease Prevention and Control \\
\hline ECHA & European Chemicals Agency \\
\hline EDA & European Defence Agency \\
\hline EEA & European Environment Agency \\
\hline EFCA & European Fisheries Control Agency \\
\hline EFSA & European Food Safety Authority \\
\hline EIGE & European Institute for Gender Equality \\
\hline EIOPA & European Insurance and Occupational Pensions Authority \\
\hline EMA (before EMEA) & European Medicines Agency \\
\hline EMCDDA & European Monitoring Centre for Drugs and Drug Addiction \\
\hline EMSA & European Maritime Safety Agency \\
\hline ENISA & European Network and Information Security Agency \\
\hline ERA & European Railway Agency \\
\hline ESMA & European Securities and Markets Authority \\
\hline ETF & European Training Foundation \\
\hline EU & European Union \\
\hline EUISS & European Union Institute for Security Studies \\
\hline EU-OSHA & European Agency for Safety and Health at Work \\
\hline
\end{tabular}




\begin{tabular}{|c|c|}
\hline Eurofound & $\begin{array}{l}\text { European Foundation for the Improvement of Living and Working } \\
\text { Conditions }\end{array}$ \\
\hline Eurojust & European Union's Judicial Cooperation Unit \\
\hline Europol & European Police Office \\
\hline EUSC & European Union Satellite Centre \\
\hline FCC & Federal Communications Commission \\
\hline FDIC & Federal Deposit Insurance Corporation \\
\hline FERC & Federal Energy Regulatory Commission \\
\hline FHFA & Federal Housing Finance Agency \\
\hline FMC & Federal Maritime Commission \\
\hline FMSHRC & Federal Mine Safety and Health Review Commission \\
\hline FRA & European Union Agency for Fundamental Rights \\
\hline Frontex & $\begin{array}{l}\text { European Agency for the Management of Operational Cooperation } \\
\text { at the External Borders }\end{array}$ \\
\hline FTC & Federal Trade Commission \\
\hline GAO & Government Accountability Office \\
\hline GSA & European GNSS Agency \\
\hline IRA & Independent regulatory agency \\
\hline IT Agency & $\begin{array}{l}\text { European Agency for the operational management of large-scale IT } \\
\text { systems in the area of freedom, security and justice }\end{array}$ \\
\hline NLRB & National Labor Relations Board \\
\hline NRC & Nuclear Regulatory Commission \\
\hline OHIM & Office for Harmonization in the Internal Market \\
\hline OMB & Office of Management and Budget \\
\hline OSHRC & Occupational Safety and Health Review Commission \\
\hline PRC & Postal Regulatory Commission \\
\hline SEC & Securities and Exchange Commission \\
\hline TEU & Treaty on the European Union \\
\hline TFEU & Treaty on the Functioning of the European Union \\
\hline the Fed & Board of Governors of the Federal Reserve System \\
\hline US & United States \\
\hline USITC & United States International Trade Commission \\
\hline
\end{tabular}




\section{List of Tables, Boxes, and Figures}

\section{Tables}

Table 2.1. The Council and the European Parliament (EP): evolution of shared legislative and budgetary powers ............................................................ 31

Table 2.2. The legal basis for the creation of the existing EU agencies ......................... 61

Table 2.3. Correlation between the legislative role of the European Parliament in passing the EU agencies' founding acts and the presence of hearings obligations 66

Table 2.4. Correlation between the legislative role of the European Parliament in passing the EU agencies' founding acts and the Parliament's involvement in the appointment of the members of the management

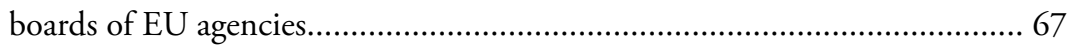

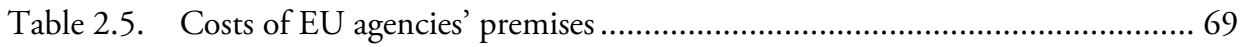

Table 2.6. Removal of EU agencies' directors: relevant statutory clauses ....................... 92

Table 2.7. Specificity of statutory obligations to submit annual reports in relation

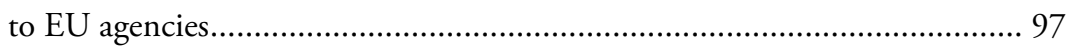

Table 3.1. The annual appropriations process in the US .............................................234

Table 4.1. Creation and Delegation Standards in the EU and the US compared..........278

Table 5.1. Political Accountability Models: S, M, and L sizes ....................................310

\section{Boxes}

Box 1. US reporting obligations: an extract from the Government Performance and Results Act of 2010

Box 2. Reporting requirements - an extract from the Postal Regulatory Commission's founding act

\section{Figures}

Figure 2.1. The European Parliament giving discharge 


\section{Chapter 1. \\ The Political Accountability of EU Agencies: an Introduction}

\subsection{The Focus of the Book}

The growing scope of delegation to and proliferation of EU agencies is one of the major developments in the EU institutional landscape since the 1990s. ${ }^{1}$ As of this writing, there are $35 \mathrm{EU}$ agencies located across the Union to regulate a vast range of sectors, including health, food, and transport. Their number has tripled since $2000,{ }^{2}$ and their proliferation has been accompanied by the growth of powers given to them. EU agencies are no longer merely information-gathering assistants of the Commission and national authorities, they may enjoy decision-making and supervisory powers. For example, among the recently created agencies (2010) are the three 'financial agencies', namely the European Banking Authority (EBA), European Securities and Markets Authority (ESMA), and European Insurance and Occupation Pensions Authority (EIOPA). They can, among other things, adopt "individual decisions requiring competent authorities to take necessary action" if the Council determines the existence of an emergency situation when "the orderly functioning and integrity of financial markets or the stability of the financial system of the Union" is seriously jeopardized (Article 18 of Regulations 1093/2010, 1094/2010 and 1095/2010). Considering the potential strength of the given power, it is not surprising that the delegation of such "a large measure of discretion" 3 to one of these agencies (ESMA) has been recently challenged before the Court of Justice of the European Union.

The nature of EU agencies' tasks makes them quite similar to national ministries and agencies, especially with respect to the impact they may have on society. As an example, in the aftermath of the 2008 financial crisis, the just mentioned ESMA has become exclusively responsible for the registration and supervision, including the right to impose sanctions, of credit rating agencies in the EU, the latter contributed in part to the recent financial crisis by misleading the credibility status of credit-giving institutions with their unjustified rat-

\footnotetext{
${ }^{1}$ Curtin and Dehousse (2012) P. 193.

${ }^{2}$ Before 2000 there were approximately ten EU agencies, ten years later there were more than 30 EU agencies.

${ }^{3}$ Case C-270/12 Action brought on 1 June 2012 - United Kingdom of Great Britain and Northern Ireland v Council of the European Union, European Parliament.
} 
ings. ${ }^{4}$ Furthermore, "the absence of formal authority does not necessarily mean that" EU agencies are "deprived of any influence." Dehousse notes in this respect that, for instance, recommendations of the European Medicines Agency, which can advise on, among other things, the lists of elements allowed being used for the manufacturing of medicines, "are systemically rubber-stamped by the Commission" which is, according to him, hardly surprising because "if an institution pooling the best expertise available at the European level warns against the dangers of a given pharmaceutical, the 'political power' could not ignore its advice without taking substantial risks." ${ }^{6}$ Moreover, even soft law and supervisory functions may have norm-setting effects and "form an integral part of Union law" (Recital 51 of Regulations No 1093/2010, 1094/2010, and 1095/2010 establishing EBA, EIOPA, and ESMA respectively).

Consequently, the creation of, delegation to, and rapid proliferation of EU agencies have enhanced the pressure on the EU's democratic credentials. EU agencies are created without a specific treaty provision by the EU institutions whose democratic legitimacy and accountability have been debated for a long time. ${ }^{7}$ Furthermore, the political accountability of EU agencies faces several challenges. First, it involves the questions of who holds EU agencies to account and how. The Commission shares the conclusion of the Ramboll evaluation of $26 \mathrm{EU}$ agencies that it is "sometimes made accountable for what is beyond its responsibility." Yet, the European Parliament opines that "the autonomy which is to be conferred on the agency in respect of technical matters falling within its remit does not relieve the Commission of its political responsibility for the agency's activities." In addition to the absence of clear accountability roles of the EU main institutions, ${ }^{10}$ legal and practical concerns exist in relation to the political accountability of EU agencies. For instance, the draft report of the European Parliament's Committee on Employment and Social Affairs

\footnotetext{
${ }^{4}$ Final Report of the National Commission on the Causes of the Financial and Economic Crisis in the United States, Conclusions. P. xxv.

${ }^{5}$ Dehousse (2008) P. 790, 799.

${ }^{6}$ Ibid.

7 Verhey and Claes (2008) P. 3.

${ }^{8}$ Analytical Fiche $\mathrm{Nr}^{\circ} 31$ 'Commission's Role', P. 4; The Ramboll Evaluation, Volume I. P. 25.

The Ramboll Evaluation is an evaluation of 26 EU agencies prepared in 2009 by the Ramboll ManagementEureval-Matrix evaluation group (further referred to as: 'the Ramboll evaluation'). The Commission initiated this evaluation for the interinstitutional discussion of the Commission, the European Parliament, and the Council of EU agencies' operation, which took place within a specially created working group on agencies (2009-2012). The work of the group produced analytical fiches on individual topics concerning the creation and operation of EU agencies and concluded with a 'Common Approach on EU agencies', annexed to the Joint Statement of the EU three main institutions; the 'Common Approach' is analysed in Chapter 2.2.6.

${ }^{9}$ Motion for a Resolution 'Further to Question for Oral Answer O-93/05 pursuant to Rule 108(5)', P. 3.

10 "What is needed, if European Community action is to be more effective, coherent, legitimate and transparent, is for the institutions to be able to assume their responsibilities fully. To achieve this, their respective roles must be clearly determined and current practices changed where necessary" (Communication from the Commission "The operating framework for the European Regulatory Agencies' COM(2002) 718 final, P. 2).
} 
noticed that "relations between the decentralized European agencies and the European Parliament are inadequate. MEPs are often very poorly informed of the functions these agencies fulfil and what they actually do." ${ }^{11}$ The legal concerns include the fact that the treaties lack a legal basis for the creation of agencies and the creation of an accountability framework.

The existing concerns dictated the necessity of reforming the political accountability of EU agencies which has been on the agenda of the EU main institutions since 2001. ${ }^{12}$ At the same time, since "the proliferation of EU independent agencies has been camouflaged by the insistence that these agencies are only information-giving entities as opposed to command-and-control regulatory entities," 13 the political accountability of EU agencies seems to have dropped beneath the academic research radar. Yet, in recent years scholars have been increasingly suggesting that EU agencies' "administrative functions may also involve policy-making," ${ }^{14}$ which in turn increases the salience of the political accountability of EU

\footnotetext{
${ }^{11}$ Draft Report on the proposal for a regulation of the European Parliament and of the Council establishing a European Training Foundation (recast), 2007/0163 (COD), 07.01.2008, Committee on Employment and Social Affairs, P. 6.

12 The White Paper on European Governance (COM (2001) 428 final) was followed by Communication from the Commission 'The operating framework for the European Regulatory Agencies (COM (2002) 718 final), Draft Interinstitutional Agreement on the operating framework for the European regulatory agencies (COM (2005) 59 final), Communication from the Commission to the European Parliament and the Council 'European agencies The way forward' (COM (2008) 135 final), and the 'Common Approach' on EU agencies (June 2012); the latter is discussed further in Chapter 2.2.6.

${ }^{13}$ Shapiro (2005) P. 353.

${ }^{14} \operatorname{Vos}(2003)$ P. 142.
}

See, also, other experts in the field, for instance:

- "In reality, some of the agencies do have some regulatory functions, such as drug licensing, and most are engaged, not perhaps in command-and-control regulation, but in a variety of "soft" regulation modes. Certainly, at best it would be naïve to assert that the European Environmental Agency is not regulating when it gathers data and publishes an analysis of that data purporting to show that French industrial pollution is adversely affecting German vineyards" (Shapiro (2005) P. 353).

"One should not underestimate the importance of instrumental functions. From production and dissemination of high quality information to technical assistance, instrumental functions play a decisive role in the implementation of European policies. $\langle\ldots\rangle$ the distinction between instrumental and final powers is not always certain" (Chiti (2009) P. 1405).

Soft administrative rule-making powers are "not necessarily linked to technical implementation matters, but actually amount to policy-making and (soft and sometimes hard) coordination of Member States activities coming close to legal harmonization. At the level of direct administration, this soft administrative rule-making activity is highly relevant as it influences single-case decision-making by these Union entities, such as on the lawfulness of company behaviour and agreements, state aids and the granting of licences and market authorizations. At the level of indirect administration, the Union's soft administrative rule-making activity has not only effects on the national legislator responsible for the transposition of EU law, but also for administrative bodies (such as national regulatory and supervisory authorities in specific sectors) that have to apply EU law and national courts" (European Parliament, Checks and balances of soft rule-making in the EU, Study for the European Parliament, PE 462.433. March 2012. P. 8). 
agencies. This issue is important also from a broader perspective of the ongoing debate on the quality of democracy concerning the EU structures and decision-making processes because of the essentiality of political accountability in promoting democratic legitimacy. ${ }^{15}$

The rapid proliferation of EU agencies has certainly attracted the attention of a number of scholars from legal and other disciplines, such as political science and public administration. ${ }^{16}$ Some scholars focused on the legality of their creation, or the position and the role that EU agencies have been playing within the EU institutional constellation, especially within the EU emerging executive power, ${ }^{17}$ while others analyzed questions such as EU agencies' functional necessity ${ }^{18}$ and autonomy. ${ }^{19}$ A number of reports produced by or for the EU institutions offered good overviews of the existing de jure but also de facto concerns and challenges to various aspects of EU agencies' operation, including staffing and discharge. ${ }^{20}$ Whereas the issue of EU agencies' independence and accountability has also been noticed by scholars, this question has been largely discussed by means of a limited number of case-studies ${ }^{21}$ or at a rather general level, which is not surprising considering the great number of EU agencies and considerable differences between their accountability arrangements. ${ }^{22}$ While the existing studies have provided a good point of departure, a comprehensive study on the political accountability of all EU agencies seems to be a necessary supplement. ${ }^{23}$

Being a salient, yet underinvestigated, topic, the political accountability of EU agencies is the focus of this book which aims at (1) filling the gap of knowledge about the existing political accountability arrangements of EU agencies and (2) upon a comparative analysis

\footnotetext{
${ }^{15}$ Following Beetham and Lord there are three "legitimating qualities of democracy: the popular authorisation of political leadership, accountability of power holders to the public and representative government." Concerning democratic deficit of the EU "accountability is one of the core instruments to promote legitimacy" (Beetham and Lord (1998) P. 60).

${ }^{16}$ According to Vos, "The literature on European agencies is by now abundant" (Vos (forthcoming in 2014) P. 13). ${ }^{17}$ Chiti (2000 and 2009), Vos (2000 and 2014), Kohler-Koch and Rittberger (2006), Curtin (2007 and 2009), Griller and Orator (2010), Hofmann and Morini (2012). The agency phenomenon has been also discussed in a number of edited volumes, such as Zwart and Verhey (2003), Curtin and Wessel (2005), Geradin et al. (2005), Busuioc et al. (2012), Everson et al. (forthcoming in 2014).

${ }^{18}$ Dehousse (1997), Yataganas (2001), Kelemen (2002).

${ }^{19}$ Groenleer (2009).

${ }^{20}$ Agencies' discharge (2006); Agencies: Origin of tasks, local conditions and staffing (2007); Best practice in governance of agencies - A comparative study in view of identifying best practice for governing agencies carrying out activities on behalf of the European Union (2008); Budgetary implementation of EU agencies: the use of EC appropriations by agencies and the assigned revenue instrument (2008); Opportunities and feasibility of establishing common support services for EU agencies (2009); and Agencies' buildings (2009).

${ }^{21}$ The comprehensive study on the accountability of EU agencies offered by Busuioc (2010) focuses on different types of accountability and offers insightful empirical evidence based on the investigation of five EU agencies.

22 Everson (1995), Shapiro (1996), Vos (2000 and 2005), Curtin (2005), Dehousse (2008).

${ }^{23}$ See, e.g., Christensen and Lægreid ((2006) P. 38-39) who argue for the necessity to investigate the political accountability of the executive within and beyond the nation-state.
} 
with the US, offering recommendations to the EU representative institutions on what to consider when adjusting the political accountability of EU agencies in the course of the ongoing reform of the operation of EU agencies. To this end, it investigates how the political accountability of EU agencies is arranged and what the EU representative institutions should consider when adjusting the existing accountability arrangements in the course of the ongoing reform of the operation of EU agencies.

By analyzing the political accountability arrangements of all $35 \mathrm{EU}$ agencies and comparing them with a jurisdiction that has more than a century-long experience concerning the matter at stake, the US, this study shows that excessive diversity dominates the current situation in the EU. As an example, the European Parliament has the power to question 16 (out of 35) directors of EU agencies on their performance and there are 12 different procedures used in relation to appointing EU agencies' directors. Conversely, the organization of the political accountability of US independent regulatory agencies (IRAs) is done in quite a uniform way. In fact, the rules and practices governing the political accountability of US IRAs before Congress do not differ that much from how the US Congress hold all other agencies to account.

While not being an accountability problem as such, excessive diversity has harmful consequences with respect to the political accountability of EU agencies and also to the legitimacy of the EU. The diverse accountability arrangements shadow the existing gaps in the delegation-accountability chain between individual EU agencies and the EU representative institutions, and hence also "the ultimate principals, the citizens." ${ }^{24}$ For instance, while an obligation to submit an annual report to the EU representative institutions seems to be the general practice, the Community Plant Variety Office (CPVO) is not formally obliged to do that. Moreover, the existing excessive diversity is not based upon clear reasons of why accountability obligations of individual EU agencies, including those who enjoy similar functions and were created in the same period of time, (should) differ. Created in 1994 and enjoying similar decision-making powers (registration of plant varieties and trade marks respectively) the earlier mentioned CPVO and the Office for Harmonization in the Internal Market (OHIM) submit annual reports to different EU institutions: to the Commission in the case of CPVO and to the Commission and the European Parliament in the case of OHIM. The lack of justifications behind the existing differences has negative implications for the EU democratic legitimacy; "it is doubtful that the exercise of public authority may be perceived as legitimate if it is not understood." 25

This study concludes by putting three recommendations forward for the EU representative institutions to consider in the ongoing reform of the operation of EU agencies. It argues for the necessity of (1) a treaty provision regulating the possibilities to create EU agencies and delegate to them certain powers supported by an obligation to set up an accounta-

\footnotetext{
${ }^{24}$ Auel (2007) P. 504.

${ }^{25}$ Dyrberg (2002) P. 83.
} 
bility framework of EU agencies in a secondary legislative act; (2) a legally-binding accountability framework based on a streamlining approach (e.g., S, M, and L models) to organize the political accountability of agencies in a more uniform and reasoned, yet flexible, way; and (3) introducing and adhering to measures promoting the accountability of EU representative institutions for holding EU agencies to account. Such measures are necessary to promote incentives for the EU representative institutions to stick to their accountability tasks and to enhance the legitimacy of the EU structures and processes. Whereas this study derives its conclusions primarily from the analysis of relevant legal texts, official documents, and multi-disciplinary academic literature, it also offers the results of the semistructured interviews conducted with top-level officials from EU and US IRAs and (political) institutions as a supportive material.

\subsection{Research Design}

Before this study turns to addressing the main research question, it is necessary to say a few words about how it investigates it. With this intention in mind, this section presents the major concept that this study deals with, the concept of political accountability (1.2.1.), and other methodological issues, namely challenges to studying the political accountability of EU agencies (1.2.2.), method (1.2.3.), sources (1.2.4.), and the structure of the volume (1.2.5.).

\subsubsection{Defining, Investigating, and Assessing Political Accountability}

\section{The Purposes of Accountability}

"Accountability is one of those golden concepts that no one can be against." 26 The reason for that lies with the fundamental character of accountability and its purposes which are "to provide a democratic means to monitor and control government conduct, for preventing the development of concentration of power, and to enhance the learning capacity and effectiveness of public administration. ${ }^{27}$ It serves three purposes addressed by Bovens from three perspectives - democratic, constitutional, and learning. The democratic perspective implies "the degree to which an accountability arrangement or regime enables democratically legitimized bodies to monitor and evaluate executive behavior and to induce executive actors to modify that behavior in accordance with their preferences." 28 What is important

\footnotetext{
${ }^{26}$ Bovens (2007) P. 448.

See also, Curtin et al. (2010): "accountability is one of those golden concepts that are relatively uncontested in the sense that there is intuitive agreement that public institutions or authorities should render public account for the use of their mandates and for the manner in which they use public resources" (P. 929-930).

${ }^{27}$ Bovens (2007) P. 462; see, also: Bovens et al. (2008) P. 225.

${ }^{28}$ Bovens (2007) P. 465.
} 
from the constitutional perspective is "whether the arrangement offers enough incentives for officials and agencies to refrain from abuse of authority." 29 "The learning perspective obviously focuses on the question of whether the arrangement enhances the learning capacity and effectiveness of the public administration." 30 "Behind these three perspectives lurks a far bigger, more abstract concern of accountability. Accountability is indirectly of importance because, ultimately, it can help to ensure that the legitimacy of governance remains intact or is increased." 31

Accountability may promote legitimacy by providing a safeguard against the breach of rules, contributing to social acceptability by promoting justifications, and ensuring authorization of positions of unelected offices by people's representatives. ${ }^{32}$ Thus, accountability can promote both formal and social legitimacy. ${ }^{33}$ It promotes formal legitimacy when it provides a check on whether "applicable legal requirements were satisfied when the entity in question was set up" and it facilitates social legitimacy when it ensures a means of promoting the general acceptance of those who exercise public authority within. ${ }^{34}$ "Legitimacy could be acquired only by a government based on the consent of the governed." 35 All in all, accountability can be seen as a value in its own right, and it is instrumental in ensuring (democratic) legitimacy as it "is a tool to minimize distrust." ${ }^{36}$ The importance of accountability in the EU lies in "making the Union's structure more democratic and the Union's decision-making process more legitimate." ${ }^{37}$

\section{Defining (Political) Accountability}

While the necessity of accountability is difficult to argue against, the concept of accountability "can mean many different things to different people." ${ }^{38}$ More specifically, accountability "often serves as a conceptual umbrella that covers various other distinct concepts,

\footnotetext{
${ }^{29}$ Bovens (2007) P. 465.

${ }^{30}$ Ibid. P. 466.

31 Ibid. P. 464.

32 Beetham and Lord (1998) P. 3.

33 "We speak of formal legitimacy always when the decision making process can be formally/procedurally recognized as an expression of self-governance. A political system enjoys substantive legitimacy when it can boast wide social acceptance, i.e. the loyalty of its citizens" (Verhoeven (2005) P. 155). In a similar way, some scholars distinguish between procedural and substantive legitimacy (Majone (1996) P. 291-296).

${ }^{34}$ Arnull (2002) P. 3-4; see, also Weiler (1999) P. 80-81 ("an institution, system, or polity, in most but not all cases, must enjoy formal legitimacy to enjoy social legitimacy”).

35 Grimm (2010) P. 7.

36 Puntscher Riekmann (2005) P. 7.

${ }^{37}$ van Gerven (2005) P. 228.

${ }^{38}$ Bovens (2010) P. 946; see, also: Bovens (2007) P. 448.
} 
such as transparency, equity, democracy, efficiency, responsiveness, responsibility and integrity." 39

A recent trend in (European) scholarly literature seems to have been zooming in to the core of the term, drawing a distinction between it and other mentioned concepts, and hence defining it narrowly..$^{40}$ Bovens offers a succinct definition of accountability in a narrow sense: "a relationship between an actor and a forum, in which the actor has an obligation to explain and to justify his or her conduct, the forum can pose questions and pass judgments, and the actor may face consequences." ${ }^{41}$

This definition is applicable to any type of accountability, including political and judicial accountability and accountability to peers. In this light, political accountability is understood in institutional terms as meaning accountability of executive institutions, such as EU agencies, before representative institutions, which usually implies parliaments, although it includes both the Council and the European Parliament in the EU context (Article 10 TEU).

Following Bovens' definition, (political) accountability comprises three stages: (1) the information stage where an actor 'has an obligation to justify his or her conduct'; (2) the discussion stage where 'the forum can pose questions' and the actor 'has to explain and to justify his or her conduct'; and (3) the rectification stage where the forum passes its judgments and the actor faces consequences. ${ }^{42}$ Without information, discussion is futile; having information without a possibility of discussion can prevent the rectification of mistakes; accountability without sanctions is incomplete as the presence of a possibility to sanction "makes the difference between non committal provision of information and being held to account," ${ }^{43}$ although the rectification stage is not always included as a defining element of accountability. ${ }^{44}$

The Bovens' definition is a narrow view ${ }^{45}$ of accountability because it excludes ex ante processes, such as making appointments to relevant institutions. As Mulgan explains,

The scope of accountability follows from the fact that it is retrospective in operation. Accountability, in its core sense, involves inquiring into actions after they have occurred and

\footnotetext{
${ }^{39}$ Bovens (2007) P. 449.

${ }^{40}$ See, e.g., Mulgan (2003) and Bovens (2007).

${ }^{41}$ Bovens (2007) P. 450.

42 Some distinguish answerability (information and discussion stages) and enforcement (rectification) stages of accountability (Pelizzo and Stapenhurst (2012) P. 23). Others identify explanation and sanction stages (Weale (2011) P. 64).

${ }^{43}$ Bovens (2007) P. 451.

"If someone is holding them accountable, two things can happen: when they do something good, nothing happens. But when they screw up, all hell can break loose. Those whom we want to hold accountable have a clear understanding of what accountability means. Accountability means punishment” (Behn (2001) P. 3).

${ }^{44}$ Bovens (2007) P. 451.

45 “This is an admittedly limited understanding" (Curtin et al. (2010) P. 938).
} 
imposing remedies or sanctions for past breaches of rules and instructions. $<\ldots>$ Accountability is therefore to be distinguished from the various forward-looking controls, including laws and regulations, under which different institutions and their members are required to act. ${ }^{46}$

Here, control is understood as an overarching notion, which consists of ex ante, ongoing and expost elements, the latter being accountability.

\section{Investigating political accountability}

"An enormous variety of definitions and approaches to accountability" ${ }^{47}$ results in having no general framework of how political accountability should be investigated and assessed. While according to the narrow definition of accountability one would focus only on mechanisms ensuring the three stages of accountability, such as reporting on and discussing agencies' performance, some scholars also include appointment (hence ex ante) procedures in the scope of their investigations of political accountability. ${ }^{48}$ What should be included and what not seems to be determined by the goals and other specifics of individual studies, such as the type of accountability.

The specific focus of this study on the political accountability of EU agencies dictates the necessity to focus not only on the accountability mechanisms ensuring the three stages of accountability in the relationship between the EU representative institutions and EU agencies ex post, but also to consider ex ante processes by which political accountability mechanisms can be shaped and influenced. This is because the Council and the European Parliament are not only the political accountability forum holding EU agencies to account, but also the 'accountability principal' that creates EU agencies, delegates to them certain authority, and, most importantly from the perspective of this book, designs their accountability arrangements by secondary legislation. Since ex ante processes may predetermine and influence the quantity and quality of ex post processes, they are important to be considered. In addition, the distinction between ex ante, ongoing, and ex post actions in the sphere of political accountability is not always that easy to make. "An example of ex ante accountability is where the principal selects (or is involved in the selection of) the agents or where the consent of the principal is required in order for a decision of the agent to be final." ${ }^{9} 9$ The budgetary procedure is another illustration where the allocation of money for the year to come and the discussion of agencies' achievements and failures can be difficult to separate. Political accountability seems therefore to be able to take place before, during, and after an action of the executive.

\footnotetext{
${ }^{46}$ Mulgan (2003) P. 18-19.

${ }^{47}$ Schillemans (2010) P. 303.

${ }^{48}$ See, e.g., Verhey et al. (2008).

${ }^{49}$ Curtin (2007) P. 525.
} 
In the absence of a general framework on how to investigate political accountability, it is necessary to establish one. Following the definition of Bovens as discussed above, this study focuses on the political accountability between representative bodies and IRAs, which involves a relationship where the latter have an obligation to inform representative bodies about their actions, justify their decisions and choices, and where agencies may face consequences for their behavior. The processes of providing information, justifications, and facing consequences take place ex post, i.e., after the agency has acted and during scrutiny of the agencies' performance and financial accounts before the representatives bodies. Accountability obligations, such as obligations to inform and to justify behavior and performance, which the agency can be subject to are, however, established predominantly ex ante. This occurs usually upon the creation of the agency and the delegation of tasks to it and pursuant to the creation and delegation standards. In addition, when talking about the accountability actor 'independent agency', the actor's institutional and personal features stand out, which makes it necessary to distinguish between the political accountability of the institution called independent agency and the political accountability of persons heading the institution, for instance, members of management boards and executive directors. This implies the necessity to consider not only processes and obligations of an institutional character, but also those of a personal character when studying political accountability of an independent agency and probably other executive institutions for that matter. Upon these considerations, the following five dimensions, in which political accountability can be shaped and exercised and within which it is to be investigated, are identified:

(1) creation of and delegation to independent regulatory agencies by representative bodies;

(2) appointment and removal of unelected officials of independent regulatory agencies by representative bodies;

(3) statutory regulation of accountability aspects of the operation of agencies;

(4) financial oversight;

(5) parliamentary scrutiny for performance, including continuous supervision by parliamentary committees, parliamentary support institutions, and the possibility of investigations.

(1) Investigating the legal rules governing the creation of agencies and the institutional setting at the moment of the creation of agencies helps to understand the sets of accountability mechanisms agencies are subject to. For example, Chapter 2.2.1.1. spots a correlation between the legislative involvement of the European Parliament into the passage of EU agencies' founding regulations and the amount of accountability obligations EU agencies have. Such a finding helps to explain the presence or absence of accountability mechanisms. Furthermore, as the need for accountability arises due to an act of delegation, the analysis of delegation doctrines helps to determine in how much they require accountability mechanisms to be put in place for delegation to qualify as lawful. This can also facilitate our 
understanding of the existing accountability mechanisms: their presence or absence and design.

(2) Independent regulatory agencies and their decisions "become politically legitimate to the extent to which they are nested in institutions underwritten by the democratic authority of parliaments. ${ }^{~} 50$ In this light, to trace the accountability line from IRAs to the people it is necessary to investigate how representative bodies are involved in appointing and removing such agencies' top officials. The appointment and removal procedures facilitate tracing the personal (rather than institutional) accountability line.

(3) Agencies are usually subject to various accountability obligations, such as reporting and other substantive requirements to consider in their operation. While statutes and regulations can be strictly defined as ex ante mechanisms of control, they can be "very crucial in terms of determining to what extent there is a need for ex post accountability to the principal." ${ }^{51}$ Statutory obligations can decrease an agency's discretion and set up a frame of reference, which makes the check on the agency ex post more feasible against the standard laid down in advance. They may influence the scope of political accountability also by establishing a direct accountability link between agencies and the public (the 'fire-alarm' form of political oversight)..$^{52}$

(4) \& (5) Parliamentary scrutiny for performance and financial oversight are the processes where agencies' plans, decisions, financial accounts, results of their actions, and manners, in which they have acted, can be scrutinized. These two processes are where political accountability's three stages, i.e., information, discussion and rectification, can be exercised directly.

All in all, investigating political accountability with the help of these dimensions enables the study of accountability mechanisms ensuring the three stages of accountability in a broader institutional environment within which they can be shaped, influenced, and exercised. This in turn facilitates assessing political accountability.

\section{Assessing political accountability}

Having investigated accountability mechanisms in a broader institutional environment within which they can be shaped, influenced, and exercised, how can political accountability be assessed? Is accountability problematic or not? If so, where does the source of the problem lie and in reference to what is it problematic?

One way of assessing political accountability is mapping out accountability mechanisms with regard to the three stages of accountability. For instance, political accountability can

\footnotetext{
${ }^{50}$ Weale (2011) P. 66.

${ }^{51}$ Curtin (2007) P. 525.

${ }^{52}$ McCubbins and Schwarz (1984); Chapter 3.2.5.1. discusses the fire-alarm and police patrolling forms of congressional oversight.
} 
be evaluated as problematic if mechanisms ensuring one or more stages of accountability are missing. At the same time, the fact that a parliament has relevant mechanisms says little about their soundness and whether they are applied in practice. In this light, next to the assessment of accountability capacity, i.e., the presence or absence of accountability mechanisms ensuring the three stages of accountability, it is necessary to evaluate what I would call 'accountability quality'. The latter implies the degree to which accountability obligations and mechanisms are consciously designed to serve the purposes of accountability and whether accountability mechanisms are applied in practice.

\section{- Design of accountability obligations and mechanisms}

The design of accountability obligations and mechanisms predetermines their future application. ${ }^{53}$ "If you want to hold people accountable, you have to be able to specify what you expect them to do and not do" ${ }^{54}$ and how. "Failure to specify the terms of the bargain with some clarity at the beginning almost inevitably leads to trouble." 55 Here, two elements seem to be crucial: the specificity of accountability obligations and the interplay of accountability mechanisms.

The specificity of accountability obligations makes it clear for an agency what it is expected to do, which enables a check on the agency against the laid down standard in advance. As an example, if the legislator requests an agency to explain its actions and inactions in the agency's annual reports, then it can check whether the agency has done so ex post. This can be less feasible in a situation when the legislator obliges the agency 'to submit an annual report' only. Furthermore, accountability mechanisms should interplay and reinforce each other "to promote the overall objectives of the enterprise" 56 called accountability. For instance, the absence of a possibility to question an agency's representative may decrease the incentive to study its report. In other words, the absence of the discussion stage may influence the exercise of the information stage.

\section{- Practical application of accountability mechanisms}

At the same time, a perfectly designed (in terms of accountability) founding act of an agency is worthless if its practical application fails. An obligation to report about an agency's performance at a parliamentary committee's hearing is unlikely to ensure political accountability if no member of the committee is present at the hearing or if no questions have been asked. This is because a parliamentary hearing as a political accountability tool is meant to

\footnotetext{
${ }^{53}$ Accountability mechanisms imply powers with the help of which an accountability forum can hold an actor to account. Accountability obligations imply legal provisions, such as provisions to submit an annual report, which obliges accountability forum and/or actor to undertake certain actions with accountability purposes.

${ }^{54}$ Behn (2001) P. 7.

55 Smith (1971) P. 32.

${ }^{56}$ Oliver (2009) P. 29.
} 
make an inquiry into an agency's actions which requires the presence of people's representatives and a discussion.

Assessing political accountability therefore necessitates taking into account not only the presence of relevant mechanisms but also the quality of accountability obligations and mechanisms and their practical application:

\section{Political accountability =}

availability of accountability mechanisms ensuring the three stages of accountability+ their design

(specificity of accountability obligations and interplay of accountability mechanisms)

+ their practical application

Important to note, it is clearly difficult to assess in how much the formulation of accountability obligations actually impacts accountability or whether there is a direct causal link between the design of accountability provisions and existing accountability successes and failures. Moreover, such an assessment can be hindered given the lack of conceptual and empirical research about exact conditions under which legal provisions produce desired outcomes. ${ }^{57}$ What can be done, however, is to have a discussion on how the formulation of and interplay between accountability relevant provisions can contribute to or hinder accountability. The practical application of an accountability mechanism can be assessed by discussing which challenges political institutions face in applying accountability mechanisms and whether and how they attempt to address such challenges. As a whole, assessing political accountability with the help of these three elements helps to recognize the quantity (mechanisms) and quality of political accountability (design and practical application) and to identify more specifically the sources of problems. Knowing the source of a problem makes it more feasible to think of appropriate solutions.

\subsubsection{Challenges in Studying the Political Accountability of EU Agencies}

Studying the political accountability of EU agencies is a challenging task because it is a complex issue in at least two respects. Firstly, any delegation raises a classic 'principal-agent' question, namely whether and how the recipient of delegated powers can be held to account for the exercise of the delegated functions. Given the multi-level structure of the EU, the question of delegation and accountability becomes even more complicated as the multiplicity of levels implies a multiplicity of principals and actors and a multiplicity of delega-

\footnotetext{
${ }^{57}$ Veerman and Mulder (2010).

(Het is "eigenlijk niet bekend $\langle\ldots>$ onder welke condities wetten werken, in de zin van wat zij in de maatschappij teweeg brengen en in welke mate zij hun maatschapplijke doelen bereiken” (Ibid. P. 1)).
} 
tion and accountability chains, which carry certain implications for the accountability of EU agencies. Secondly, as EU agencies enjoy some degree of autonomy, the question of their political accountability involves a classic dilemma of accountability and independence, namely whether an agency can be held to account, if it is independent. This section discusses the mentioned challenges and how this book goes about addressing them.

\section{Political accountability of EU agencies: the 'principals-agent' question}

EU agencies have become the recipients of powers that have been or could have been exercised by respective national authorities, intergovernmental structures, including those of the Council, and by the Commission (see Chapter 2.1.2.3.). "To the extent that there was delegation, it entailed" both "a vertical transfer of powers (from the national to the EU level)" and "a horizontal one (from Community institutions to specialised agencies)." ${ }^{58}$ In addition, the creation of and delegation to EU agencies have occurred mostly by secondary legislation passed by the Council with an increasing involvement of the European Parliament (see Chapter 2.2.1.). The involvement of both institutions is likely to be the 'usual case' in the future given the expanded legislative remit of the European Parliament with the Lisbon Treaty (see Chapter 2.1.1.2.). This means that "despite its unquestionable relevance, the principal-agent model, in its standard form, is analytically inadequate as it does not take into consideration some of the peculiarities of the EU setting. The most important of these is the absence of a clearly defined 'principal'." 59 Given the diversity of levels (national and European) and of institutions (national authorities, the Commission and the Council) from which EU agencies' powers have been delegated, it is difficult to establish a single chain of delegation in its classic fashion. ${ }^{60}$ "At the EU level, there is quite often multiple $\langle\ldots\rangle$ principals involved in the establishment of non-majoritarian institutions" ${ }^{61}$ and delegation to them.

The multiplicity of principals implies a multiplicity of accountability channels, which would be arguably proportionate to the number of institutions involved in delegation. In addition to the involvement of the legislative institutions, i.e., the Council and the European Parliament, one could also expect that those who have given up their own task in favor of an EU agency, for instance, national authorities or the Commission, would want to

\footnotetext{
${ }^{58}$ Dehousse (2008) P. 793.

${ }^{59}$ Ibid. P. 790.

In addition, while the main concern in the P-A literature focuses on how political principals attempt to avoid 'agency drift', "that is, the idea that agents will pursue a political agenda that differs from that of its principal," in the EU multi-principal environment "what the principals fear most is the emergence of a variant of 'political drift', in which agencies are somehow 'captured' by one of their institutional rivals in the leadership contest" (Ibid. P. 796).

${ }^{60}$ Curtin (2005) P. 91.

${ }^{61}$ Ibid. P. 93.
} 
assume some control over the agency as compensation. The existing 'principals-agent' model characterizing EU multi-level governance will have implications for such questions related to the (political) accountability of EU agencies as to whom EU agencies should be/are accountable, for what, and how?

Investigating these questions is in turn interconnected with another important issue. It is the issue of what the EU is: an intergovernmental organization, a supranational polity or a regulatory regime. For the proponents of each of these views, the answer to the question of 'to whom EU agencies should be accountable' will differ. It will be to member states' governments from the intergovernmental perspective, to the EU institutions from the supranational perspective, and to agencies' management boards composed of technical experts from the regulatory perspective. ${ }^{62}$ Inquiries based on different perspectives "are likely to arrive at different assessments" of whether EU agencies are accountable or not. ${ }^{63}$

In addition, the effects of the multiplication of accountability channels are unknown. ${ }^{64}$ Papadopoulos pinpoints contradictory effects in this respect. The multiplicity of accountability forums may lead to redundancy which may have positive implications for accountability by increasing the chances of agencies being overseen, but also it may adversely affect accountability if accountability forums become indifferent shifting the responsibility from one to another. ${ }^{65}$ Here, the line can be rather thin between the accountability shortcomings of 'too many hands' or 'no hands at all'; 'the more accountability channels, the better' and 'the more accountability channels, the worse' can thus both hold true.

Where does this leave us? This leaves us with the fact that there is no genuine consensus as to what set of accountability obligations, including in relation to what institutions, an EU agency should be subject to in order to qualify as accountable or not. The absence of such a common agreement has further implications as to whether there is an accountability deficit or excess and how different institutions, for instance, the Council and the European Parliament, should be involved in holding EU agencies to account. For instance, does sending a report to one of the EU representative institutions or both make an agency more accountable or less, suffering from an accountability shortage or excess? The line of questioning can be extended even further, including issues like in how far the involvement of the Council or the European Parliament can be seen as an appropriate substitute for the involvement of the other from an accountability perspective, etc. Since the accountability (model) of EU agencies' is still in the making, the investigation of the political accountability of EU agencies in the following chapters becomes more of an empirical study of 'how EU agencies' political accountability has been arranged in existing laws and practices.' This study's normative assessment is strictly limited to the question of what the EU representa-

\footnotetext{
${ }^{62}$ Bovens et al. (2010) P. 27.

${ }^{63}$ Ibid. P. 29.

${ }^{64}$ Papadopoulos (2010) P. 1041.

${ }^{65}$ Ibid. P. 1041-1042.
} 
tive institutions should consider in adjusting the existing rules and practices. This book does not extend to such normative questions as 'whether and how the Council and the European Parliament should be involved (or not) holding EU agencies to account'. Nor does it address the question of whether EU agencies are accountable or not.

\section{The political accountability of EU agencies: the classic accountability-independence dilemma}

The issue of the political accountability of EU agencies also has an additional dimension which concerns the classic dilemma between the independence and accountability of agencies.

Executive institutions and agencies are the recipients of delegated powers with discretion because "principals can realise the benefits of delegation only by granting discretion to the agent." ${ }^{166}$ Moreover, legislators seek to delegate tasks "that frequently cannot be precisely specified in advance. ${ }^{\prime 67}$ Functional discretion thus accompanies delegation per definition. ${ }^{68}$

In seeking to achieve maximum benefits from granting functional discretion, an institutional innovation called the 'independent agency' has been invented. But from whom is the agency independent? "Independence is generally considered to be free of both political and industry interests. In the Community context this also refers to national interests." ${ }^{69}$

Independence can be promoted in three ways. ${ }^{70}$ Making an agency a separate legal entity (not part of a ministry or the Commission) ensures institutional independence. Making (re)appointment and removal procedures more difficult or conditional aims to promote the personal independence of agencies' top officials. A separate budget and autonomy in financial matters is sought to achieve financial independence. An agency's autonomy can be ensured by design (de jure) and developed in practice (de facto). ${ }^{71}$

Why should there be delegation to independent regulatory agencies? "The most often mentioned determinant $\langle\ldots\rangle$ is the need for credible commitments. Politicians seek to enhance the credibility of long-term political commitments, but are constrained in these efforts by their relatively short time horizon - that is, the period until the next elections." 72 IRAs can thus be used to enhance "the credibility of promises made, either between multiple principles, or vis-à-vis principals and their constituencies, given the underlying collec-

\footnotetext{
${ }^{66}$ Thatcher and Stone Sweet (2003) P. 4.

${ }^{67}$ Smith (1971) P. 39.

68 "If rules could be so formalized that officials would merely have to follow the rules mechanically there would be no problem," or much less problems (Smith (1971) P. 33).

${ }^{69}$ Vos (2005) P. 123.

${ }^{70}$ Scholten (forthcoming in 2014)

${ }^{71}$ For comprehensive studies on agencies' de jure and de facto autonomy, please, see: Yesilkagit and van Thiel (2008); Groenleer (2009).

${ }^{72}$ Koop (2011) P. 49.
} 
tive action problems." ${ }^{\prime 3}$ This seems to be especially relevant in the case of the European Union when a compromise between national and community interests or simply among member states has been reached and needs to be kept outside political turmoil in order to keep the policy stable and credible. ${ }^{74}$ In addition, the complexity of regulated issues requires (elected) representatives to use and to rely upon expert bodies. ${ }^{75}$ Yet, "the more complex the policy area, the greater is the need to loosen provisions for control and accountability," because it is important "to let agencies incorporate their knowledge and information into their decisions." "Because they are one step removed from election returns,"77 independent regulatory agencies can be expected "to develop and employ expertise in order to produce, or help principals produce appropriate public policy." ${ }^{\prime 7}$ Finally, delegating to independent bodies can also have rather a pragmatic reason of creating a possibility for people's representatives to avoid taking the blame for unpopular policy decisions. ${ }^{79}$

While delegation occurs because the delegating authority can benefit from it, "delegation is not costless." 80 "Any delegation of authority creates the risk that the agent may not faithfully pursue the interests of the principal." ${ }^{11}$ "The essence of delegation is to empower others to make their own decisions and to use their own judgment about how best to serve us. But, human nature being what it is, those who have been given such power tend to use it to favour themselves at the expense of their clients." ${ }^{22}$ This cost of delegation seems to be even higher as regards the so-called independent regulatory agencies because they can enjoy institutional, personal, and financial types of independence. The challenge is to maximize the benefit from delegation to an independent agency, while minimizing the risk of abuse of delegating powers by ensuring accountability. ${ }^{83}$ Thus, "there is to some extent an inevitable tension between the values of independence and of accountability." ${ }^{4}$

\footnotetext{
73 Thatcher and Stone Sweet (2003) P. 4.

74 "Both EU institutions and member states have used agency creation to demonstrate political will and decisiveness, especially in the wake of disasters and emergencies confronting the EU” (Groenleer (2009) P. 103). See, also, Tallberg (2002) P. 26.

75 "The policy choices involved are thought to be characterized by a high level of technical complexity and, at the same time, a broad agreement on the criteria for distinguishing desirable from undesirable outcomes. Hence 'good' decisions depend on expertise" (Scharpf (1999) P. 16).

${ }^{76}$ Koop (2011) P. 50.

77 Majone (1996) P. 41.

78 Thatcher and Stone Sweet (2003) P. 4.

${ }^{79}$ The discussed reasons concerning delegation to independent regulatory agencies are mentioned by, for instance: Majone (1996) P. 41; Pollack (2003) P. 20; Magnette (2005) P. 5; Tallberg (2009) P. 113, to name but a few.

80 Thatcher and Stone Sweet (2003) P. 11.

${ }^{81}$ Strøm (2006) P. 61.

${ }^{82}$ Mulgan (2003) P. 8.

${ }^{83}$ See, also, Self who advocates that "the tensions between the requirements of responsibility or 'accountability' and those of effective action can reasonably be described as the classic dilemma of public administration" (Self (1972) P. 277-278).

${ }^{84}$ Smith (1971) P. 4.
} 
Whereas the contradiction between the values of independence and accountability has been often pictured as having a causal relationship, namely 'independent, hence unaccountable', this study does not look at the political accountability of EU agencies in this way. This is because the accountability problems of IRAs, such as the poor quality of submitted reports, need not necessarily be caused by their independence. ${ }^{85}$

When talking about the causal link between independence and accountability the questions 'from whom an agency is independent' and 'to whom it renders (political) account' are important to consider. IRAs are usually made independent from the main executive institution, such as the minister, the president or the Commission in the EU setting. While agencies' distant position from the main executive implies having less or no accountability relationship between such agencies and the main executive, and hence limited accountability of the main executive before representative bodies, such as parliaments, for such agencies' actions, IRAs can be made accountable before representative bodies directly. In this way, the traditional channel (accountability of the main executive before the parliament) is replaced by a direct accountability link between IRAs and representative bodies. This book focuses primarily on such a link and whether the three stages of accountability are present in the relationship between IRAs and representative bodies. From this perspective, the fact that an agency is made independent from the main executive institution does not need to cause political accountability problems if the three stages of accountability can be ensured between such agencies and representative bodies.

\subsubsection{Method}

The research question in this study is how the political accountability of EU agencies is arranged and what the EU representative institutions should consider when adjusting the existing accountability arrangements in the course of the ongoing reform of the operation of EU agencies. This study addresses it in three steps. First, it investigates and assesses the political accountability of all $35 \mathrm{EU}$ agencies. Second, it studies the political accountability of US independent regulatory agencies to compare the EU experiences with those of the US in order to gain learning experiences. Third, in light of the comparative insights gained, it offers recommendations of what issues the EU representative institutions should consider when adjusting the political accountability arrangements of EU agencies in the ongoing reform of the operation of agencies.

The investigation of political accountability is done with the help of the five dimensions identified where political accountability can be shaped and exercised, namely (1) the creation of and delegation to independent regulatory agencies by representative bodies, (2) the appointment and removal of unelected agencies' officials by representative bodies, (3) statutory regulation of accountability relevant aspects, (4) financial oversight, and (5) parliamen-

${ }^{85}$ Scholten (2011). 
tary scrutiny (section 1.2.1.). As was mentioned before, these dimensions make it possible to understand accountability mechanisms within a broader institutional environment, which in turn facilitates assessing political accountability with the help of the proposed three elements (section 1.2.1.), namely the availability of accountability mechanisms, their design and practical application. The political accountability of US IRAs is studied in the same manner ${ }^{86}$ as that of EU agencies to facilitate the comparison, i.e., with the help of the five dimensions identified where political accountability can be shaped and exercised and the proposed formula for making the assessment. The findings of each case-study are then compared to offer recommendations for the EU.

\section{Comparative approach}

While the investigation and assessment of the political accountability of EU agencies can be done simply by studying relevant legal provisions and practices in the EU, the step of offering recommendations for adjustment especially, though not exclusively, can benefit from a comparative perspective. This is because comparison "helps us better appreciate and understand our own system" and it "allows us to critically assess a system, and to better see not only what" relevant legal provisions say but also what they do not say. ${ }^{87}$ Moreover, a learning component of a comparative approach is important for the younger EU jurisdiction. This brings us to the national level for the simple reason that the interrelationship between representative institutions and independent regulatory agencies cannot be found elsewhere.

Being often referred to as 'the birthplace of independent regulatory agencies' which exist there since $1889,{ }^{88}$ the US jurisdiction has been selected for comparison in this study. It is a prominent example of a jurisdiction facing similar trends and challenges in the field of how public authority has been delimited and exercised as the EU faces, yet having more than a century-long experience in dealing with those trends and addressing those challenges. The trends include the growing scope of delegation to the executive branch and cutting "the executive into smaller pieces." ${ }^{89}$ The seemingly unitary executive branch ${ }^{90}$ in the US comprises more than 300 institutions of various types, ${ }^{91}$ such as departments, executive

\footnotetext{
${ }^{86}$ It has to be noted that the established analytical framework is applied less consistently in parallel sections 2.2.3. and 3.2.3., 2.2.4. and 3.2.4., and 2.2.5. and 3.2.5. due to the differences in laws and procedures between the two systems and different focus that this study has in relation to the EU (an in depth investigation of the current laws and practices) and the US (learning purposes) jurisdictions.

${ }^{87}$ Heringa and Kiiver (2012) P. 1.

${ }^{88}$ See, e.g., Zwart (2003) P. 3.

${ }^{89}$ Verhey (2009) P. 67.

${ }^{90}$ Some also notice a transition from a unitary administration with diverse functions to single-purpose organisations (Christensen and Lægreid (2006) P. 4). In this light, Everson notes that specialized, single purpose commissions and agencies "are generally considered to be amongst the most efficient of modern administrative bodies" (Everson (1995) P. 180-181).

${ }^{91}$ Moe (2002) P. 243-254; see also Lewis and Selin (2012).
} 
agencies, and independent regulatory commissions, with various degrees of autonomy and to certain extent accountability. These executive institutions can be empowered with decision-making powers and annually pass approximately 4,000 rules, which directly affect the US society in a very similar way as the approximately 400 statutes that Congress passes every year. ${ }^{92}$ The proliferation of IRAs in the US occurred largely in 1930s during the 'New Deal' era, "Europe followed the same path half a century later."

One of the major implications of the growing scope of delegation to and the dispersion of the executive is the issue of the executive's political accountability. ${ }^{94}$ Holding to account, however, has become a challenging task considering the dispersion of the executive ${ }^{95}$ and the necessity to balance functional discretion, which is the raison d'être of delegation, ${ }^{96}$ with various mechanisms of control. As the US Congress is known for having more than a century-long experience with holding IRAs to account and an "awesome arsenal" 97 of accountability mechanisms, "many useful insights can be gained by looking at the US experience with regulatory agencies."

In addition to the mentioned advantages, the choice of the US can also be supported by the fact that it is difficult to think of an alternative jurisdiction. Although the most logical solution in EU-related comparative research is to turn to EU member states' experiences, given the focus of this study the EU member states seem to experience similar problems to those of the EU institutions, ${ }^{99}$ hence EU member states also may benefit from the US experience presented in this book. The national ministers of EU member states "seem accountable for an agency only insofar as they can actually influence the actions and decisions of

\footnotetext{
${ }^{92}$ Lecture of Prof. Strauss during the Amsterdam-Leyden-Columbia summer program in American Law, July 2010.

93 Yataganas (2001) P. 41.

${ }^{94}$ This implication has also boosted the quest for accountability which can be demonstrated by the amount of scholarly attention to the topic of accountability: in the last ten years only 17 international journals published 117 articles that feature the word accountability in their titles or as a key concept (Schillemans (2010) P. 303).

95 "One of the weightiest objections to a plurality in the Executive is that it tends to conceal faults and destroy responsibility. $\langle\ldots>$ It often becomes impossible, amidst mutual accusations, to determine on whom the blame or the punishment $\langle\ldots\rangle$ ought really to fall” (Hamilton 'The Federalist No. 70' printed in: Kesler and Rossiter (2003). P. 426).

96 Thatcher and Stone Sweet (2003) P. 4.

${ }_{97}$ Wilson (1989) P. 236.

${ }^{98}$ Geradin (2005) P. 242.

${ }^{99}$ Interestingly in this respect, a European Parliament's comparative study on agencies' governance chose to investigate EU member states' experiences arguing that US agencies are 'caught in the middle' between presidential and congressional influences whereas in contrast to the US "in the European context, agencies are usually controlled by ministerial bureaucracies with a political leadership accountable to parliament, roughly resembling the accountability lines between many EU agencies and the Commission Directorates General." "99 It concluded that a comparison with the US and "drawing meaningful lessons for the EU level (and especially for the role of the EP) has little added value" 99 (Best Practice in governance of agencies - A comparative study in view of identifying best practice for governing agencies carrying out activities on behalf of the European Union, Policy Department on Budgetary Affairs, European Parliament, 2008. P. 62).
} 
the agency concerned." ${ }^{100}$ Thus, if IRAs are created to be independent from ministerial control, parliamentary and hence democratic control becomes troublesome. ${ }^{101}$ It is a very similar situation to the one existing at the EU level where the Commission does not seem to carry responsibility for the agencies it does not control. ${ }^{102}$

Furthermore, this study does not intend to compare the US and the EU constitutional models which show as many differences as similarities. ${ }^{103}$ Needless to say, "the presidential system of government in the US differs fundamentally from $\langle\ldots\rangle$ the institutional arrangements of the EU." ${ }^{104}$ Interesting in this respect is that Judge and Earnshaw note a tendency "to select individual characteristics of the 'parliamentary model' and to proclaim that because the EU displays individual elements of this model it is necessarily evolving towards a 'parliamentary democracy." 105 However, the EU is not a parliamentary system, which makes the comparison of the EU with any national jurisdiction equally challenging. In any case, the comparison of two jurisdictions is not needed to get insights on a more specific topic from which we can learn, ${ }^{106}$ which is the political accountability of independent regulatory agencies. The comparison concerns how the two systems attempt to make

${ }^{100}$ Broeksteeg et al. (2008) P. 289 ("In most Member States involved in this research ministers seem accountable for an agency only insofar as they can actually influence the actions and decisions of the agency concerned." Moreover, "the extent to which ministers are considered to be accountable in daily practice is less clear." The research project included $11 \mathrm{EU}$ member states).

${ }^{101}$ Heringa and Verhey (2003) P. 160-162.

102 "The Commission is sometimes made accountable for what is beyond its responsibility" (Ramboll Evaluation, Volume I. P. 25).

${ }^{103}$ According to Geradin these two systems "do not rely on similar foundations," however, "the various points of convergence $\langle\ldots\rangle$ make it often helpful for Europeans and Americans to look at each other's regimes." He demonstrates some elements of convergence on a number of points such as: a) US federalism and the relationship between EU supranational institutions and national member states; b) the US separation of powers and the organization of EU main institutions in a comparable way to that doctrine; c) the bi-cameral Congress and the similar connection between the Council and European Parliament; and d) the US President and the Commission - both playing the role of executives that do not rely on a majority in parliament (Geradin (2005) P. 217).

${ }^{104}$ Best Practice in governance of agencies - A comparative study in view of identifying best practice for governing agencies carrying out activities on behalf of the European Union, Policy Department on Budgetary Affairs, European Parliament, 2008. P. 61-62.

105 Judge and Earnshaw (2008) P. 16.

See, also, Shackleton (2005) (arguing that the European Parliament is likely to develop into an institution similar to the US House of Representatives, rather than into a national parliament on the European model).

106 "The question to which any comparative study is devoted must be posed in purely functional terms; the problem must be stated without any reference to the concepts of one's own legal system. Thus, instead of asking, 'What formal requirements are there for sale contracts in foreign law?' it is better to ask, 'How does foreign law protect parties from surprise, of from being held to an agreement not seriously intended?' $<\ldots><$. .> To take another example: only in Germany does one meet with the concept of 'disappearance of enrichment' (Wegfall der Bereicherung, $\$ 818$ par. $3 \mathrm{BGB}$ ), yet all systems must resolve the conflict which arises when a person who is bound to restore a thing received under an invalid contract no longer has the thing to restore. One must never allow one's vision to be clouded by the concepts of one's own national system; always in comparative law one must focus on the concrete problem" (Zweigert and Kötz (1998) P. 34-35). 
political accountability work and what can be learned from that experience for one's own system.

All in all, taking into account more than a century-old experience that Congress has in holding US IRAs to account, which implies offering both good practices and possible mistakes, the comparison should be meaningful. As "the institution of agencies has been introduced in Europe after the American concept of agencies; it now seems wise also to consider the parallel methods of parliamentary control." 107

\subsubsection{Sources}

Being an academic comparative legal study, this book draws its conclusions on the basis of relevant legal texts of the selected jurisdictions, such as respective constitutions and treaties, agencies' founding acts and regulations, and other official relevant documentation issued by the EU and US (political) institutions and IRAs, and the case law. The analysis of official documents and legal sources is supplemented by the utilization of the existing relevant academic literature. At the same time, "it is nothing new that "law in the books" (legal texts) and "law in practice" are different." 108 The specific focus of this book on political accountability, which is not a strictly legal concept, makes it necessary to look outside the 'legal box'. The choice of literature sources is extended to include publications of other disciplines, such as political science and public administration.

At times, however, the existing legal provisions and academic literature lack necessary information, partly because the political accountability of EU agencies is an understudied subject. To fill up such a knowledge gap, but also to put some 'theoretical' findings in a broader perspective, a 'field research' has been undertaken. It included visiting various institutions and conducting semi-structured interviews. In total, I have visited and talked to (former) officials from seven US independent regulatory agencies ${ }^{109}$ and eight EU agencies, ${ }^{110}$ members and staff of the European Parliament, officials from the EU Commission, US congressional support agencies' specialists (Administrative Conference of the United

\footnotetext{
${ }^{107}$ Heringa and Verhey (2003) P. 167.

${ }_{108}$ Kreher (1997) P. 167.

${ }^{109}$ The Federal Energy Regulatory Commission (senior staff level), the Federal Maritime Commission (management board level), the Federal Trade Commission (management board level), The National Labor Relations Board (management board level), the Postal Regulatory Commission (senior staff level), the Securities and Exchange Commission (senior staff level), and the US Occupational Safety and Health Review Commission (chairman's office staff level).

110 The Community Plant Variety Office (director's level), the European Aviation Safety Agency (management board level), the European Centre for Disease Prevention and Control (director's office level), the European Chemicals Agency (management board level and senior staff level), the European Foundation for the Improvement of Living and Working Conditions (senior staff level), the EU Fundamental Rights Agency (director's staff office), the European Monitoring Centre for Drugs and Drug Addiction (director's office level), and the European Training Foundation (director's level).
} 
States, Congressional Research Service, and Government Accountability Office), and other (academic) experts in the field. ${ }^{111}$ In addition, I have had a chance to visit several congressional hearings and participate in the meetings of the Interinstitutional Working Group (IWG) on EU agencies, which have certainly given me more insights on how things work in reality. Due to the highly politicized environments in which the people, whom I have interviewed, are working, I do not disclose their names. ${ }^{112}$ The content of non-public meetings of the IWG on agencies is also not discussed.

The outcomes of the mentioned randomly selected interviews serve purely an illustrative purpose and hence offer only supportive material with respect to behaviors and trends occurring in the area of accountability in reality. In a few cases, facts gathered with the help of an interview is the only source of information. For this reason, the relevance of such information is significant, however, it should be treated with caution because these are all individual cases told by people who may be biased by personal or professional attachments and positive or negative experiences.

\subsubsection{Structure of the Book}

This book consists of five chapters. Chapter 1, which comes to its end with this section, has introduced the research focus and methodological considerations of this study. Chapters 2 and 3 are devoted to the selected jurisdictions, the EU and US respectively. To ease the comparison they are structured in the same way. The introductions of respective representative institutions and independent regulatory agencies are followed by the investigation of the five processes distinguished earlier in which political accountability can be shaped, influenced, and exercised. Each case-study concludes with an assessment of political accountability. The lack of studies on the political accountability of EU agencies justifies the choice of the so-called 'classic comparative structure' which implies first an investigation of the two selected jurisdictions separately and then drawing conclusions with the help of a comparative analysis. Chapter 4 provides the comparative analysis of political accountability in the two selected jurisdictions with the purpose of drawing lessons for the EU. Chapter 5 puts forward three recommendations in the field of the political accountability of agencies for the EU representative institutions to consider in the ongoing reform of the operation of EU agencies. In the concluding pages (Chapter 6), reflections on in how far the goals of this study have been achieved and prospects for further academic endeavours and practitioners are presented.

\footnotetext{
${ }^{111}$ Interviews and written communications have taken place from March through November 2011.

112 Because of political sensitivity of information the names of agencies are also not disclosed in some cases. References are made to the positions of respondents.
} 



\section{Chapter 2.}

\section{Holding EU agencies to Political Account}

The rapidly increasing number and powers of EU agencies have made the political accountability of EU agencies a salient political and legal issue. This Chapter analyzes how the political accountability of EU agencies is arranged. In doing so, it addresses the first part of the research question of this study. The findings serve both as a stand-alone assessment of the political accountability relationship between EU agencies and EU representative institutions as well as a basis for the comparison between the EU and US jurisdictions (Chapter 4).

The Chapter is divided into three parts. Section 2.1. introduces the institutions of the accountability relationship under investigation; the Council and the European Parliament (2.1.1.) and EU agencies (2.1.2.). It is followed by the investigation of the political accountability of EU agencies with the help of the five dimensions introduced in Chapter 1 (2.2.). These include the creation of and the delegation to EU agencies by representative bodies (2.2.1.), the appointment and removal of EU agencies' top officials by representative bodies (2.2.2.), accountability through statutory regulation (2.2.3.), financial oversight (2.2.4.) and the mechanism of scrutiny (2.2.5.). In light of the recent developments at the EU level, section 2.2.6. offers a succinct critical analysis of the 'Common Approach' on EU agencies which has been the result of a three-year negotiation between the EU main institutions within the Interinstitutional Working Group on EU agencies. Section 2.3. finally assesses the political accountability of EU agencies using the formula presented in Chapter 1. It implies evaluating the political accountability of EU agencies based on three criteria: the availability of accountability mechanisms, their design, and practical application.

\subsection{The EU Political Accountability Forum and Actor: Introducing the Council, the European Parliament, and EU Agencies}

This book focuses on the political accountability of EU agencies, implying representative institutions, typically parliaments, but including both the European Parliament and the Council in the EU context (Article $10 \mathrm{TEU}$ ), holding EU agencies to account. Before political accountability is going to be investigated and assessed, it is necessary to introduce the institutions under discussion, which is done in this section and divided into two respective parts. Section 2.1.1. briefly illustrates the Council and the European Parliament from the structural and functional perspectives and discusses potential implications of the institutional design of the EU representative institutions on the political accountability of EU agencies. The introduction of EU agencies follows (2.1.2.). It includes defining EU agen- 
cies and discussing their historical development, functions, and the issue of EU agencies within the EU institutional balance.

\subsubsection{The Council and the European Parliament}

The Lisbon Treaty has become the first treaty in the history of the EU integration to state that the functioning of the European Union is based on the principle of representative democracy (Article 10 TEU). Article 10 TEU specifies further that citizens are directly represented at the Union level in the European Parliament and member states are represented in the Council, whose members are democratically accountable either to their national parliaments or to their citizens. ${ }^{1}$ This section gives a brief introduction of the structural composition and functions of the Council and the European Parliament (2.1.1. and 2.1.2. accordingly) and discusses potential implications of the institutional design of the EU representative institutions for the process of holding EU agencies to account (2.1.3.).

\subsubsection{The Council and the European Parliament from a structural perspective}

\section{The Council}

The Council has always been one of the principal decision-making institutions of the European Union. While this book talks about the Council, it is necessary to point out that it is "not a monolithic body"; ${ }^{2}$ in reality it meets in different configurations depending on the policy area. ${ }^{3}$ For instance, ministers of finance gather within the Economic and Financial Affairs Council (Ecofin), while the Environment Council is made up of ministers of the environment, etc. Each of those configurations comprises 28 national ministers in relevant fields and has a different frequency of its meetings from once a month (for instance, in the fields of general affairs and economic and financial matters) to twice a year (for instance, in the field of culture and education $)^{4}$ which seems to depend on the degree of integration in respective fields. Therefore, it is true that if one visits "the seat of the Council of Ministers of the European Union in Brussels, $<\ldots>$ the chances are you will find no council of minis-

\footnotetext{
${ }^{1}$ Article $10 \mathrm{TEU}$ also lists the European Council as another representative institution of the member states. It is however excluded from the focus of this book because it is not directly involved in holding EU agencies to political account as the Council and the European Parliament usually are according to EU agencies' founding acts.

${ }^{2}$ Hayes-Renshaw (2006) P. 96.

${ }^{3}$ Article 16 (6) of the Treaty on European Union (Further: TEU) and Article 236 Treaty on the Functioning of the European Union (Further: TFEU); also, see, Article 2 (1) of Council's Rules of Procedure.

Ten compositions of the Council are: 1. General Affairs; 2. Foreign Affairs; 3. Economic and Financial Affairs; 4. Justice and Home Affairs; 5. Employment, Social Policy, Health and Consumer Affairs; 6. Competitiveness (internal market, industry, research and space); 7. Transport, Telecommunications and Energy; 8. Agriculture and Fisheries; 9. Environment; and 10. Education, Youth, Culture and Sport.

(Find at: http://www.consilium.europa.eu/council/council-configurations?lang=en (last check October 2012))

${ }^{4}$ Cini (2004) P. 150.
} 
ters there. The Council is more of a process than an institution. Groups of ministers from national governments meet for a day or two $\langle\ldots>$ the detailed work is done by the "permanent representatives"."5

Similar to how national ministers rely on national ministries at home, the Council relies greatly on the preparatory work of its senior policy committees, about 160 working parties, ${ }^{6}$ its secretariat, ${ }^{7}$ and, most importantly, the Permanent Representatives Committee (Coreper). ${ }^{8}$ Coreper, consisting of people delegated from the member states and their assistants working in more than 150 committees and working groups, ${ }^{9}$ provides crucial support for the Council. It should be thought "partly as a coordinator of Council business, partly as a fixer and trouble-shooter." ${ }^{10}$ Being "policy generalists and experts in the substantive questions of a file," ${ }^{11}$ Coreper's members do not enjoy formal voting or decision-making powers, except for voting in conciliation committees where Coreper's members "constitute the Council's almost permanent conciliation team." ${ }^{12}$ Nevertheless, Coreper seems to be the "de facto decision-making" place because this is "where, qualitatively speaking, many decisions are made." 13 It is the main place for negotiations, which, if they result in an agreement, lead to 'A' items on Council's provisional agenda. In this respect, one ambassador noted that "if we have to take it to the Council, there is a sense that we have failed." 14 When ministers come together for a few days meeting, their provisional agenda is divided into A and B items (Article 3(6) Council's Rules of Procedure) “examined in advance by

\footnotetext{
${ }^{5}$ 'Coreper, Europe's managing board', The Economist, August 6, 1998. Find at: http://www.economist.com/node/170753 (last check October 2012).

${ }^{6}$ Westlake and Galloway (2004) P. 217-222; Lewis refers to 200 working groups (Lewis (2005) P. 143).

7 "It facilitates the meetings taking place within the ambit of the Council - in other words the meetings of the various sectoral councils - but also of key committees and the myriad of sub-committees and working groups which prepare the decision-making of Coreper and ministerial councils. <...> while it lacks formal decisionmaking powers, its officials have eschewed 'noise' and still developed an important role in different areas of EU policy-making. To the extent to which the Council secretariat influences EU policymaking, it is a distinctly quiet influence" (Christiansen (2002) P. 81). The Secretariat does not articulate its own position. "The norm has been that its civil servants are impartial. They are expected to look for the common interest and facilitate the problemsolving process. As one senior official of the Council Secretariat remarked, 'I don't mind whether they decide to paint the room black or white, as long as the decision is taken in the correct way"' (Christiansen and Vanhoonacker (2008) P. 757).

${ }^{8}$ According to Article 19 (1) Council's Rules of procedure "Coreper shall be responsible for preparing the work of all meetings of the Council and for carrying out the tasks assigned to it by the Council."

9 This information is taken from the official web-page of the Council. Find at: http://www.consilium.europa.eu/showPage.aspx?id=427\&lang=en (last check 7 February 2011).

But also, the representatives of the Commission normally take part in the sessions of all levels within the Council (Hayes-Renshaw and Wallace (2006) P. 15).

${ }^{10}$ Bostock (2002) P. 215.

11 Ibid. 226.

12 Ibid. 220.

${ }^{13}$ Lewis (2006) P. 272, 281.

14 Ibid. P. 273.
} 
Coreper (Article 19 (2) Council's Rules of Procedure). "Items for which approval by the Council is possible without discussion shall be entered as A items"15 (Article 3(6) Council's Rules of Procedure). In fact, " 85 per cent of all issues on Council agendas were essentially agreed in advance of ministerial sessions" 16 where the preparatory bodies provide for 70 per cent of the legislative output of the Council. Coreper seems thus to be the Council of Ministers "in permanent session." 17

\section{The European Parliament}

There is no precedent of a parliament that is elected directly by the people of many different countries. In light of this, the European Parliament is a unique institution. ${ }^{18}$ It is in fact the only directly-elected institution of the European Union. It consists of 750 members, plus the President, representing the Union's citizens (Article 14 TEU). The elected members organize themselves in political groups "to better defend their positions." 19

Being a unique creature, its division into various parliamentary committees distinctly resembles national parliaments. Also, "like the US Congress, its real work done in committees, ${ }^{20}$ which prepare reports to be voted on in the plenary. As of this writing, there are 20 standing committees. ${ }^{21}$ The jurisdictions of European Parliament's committees are prescribed in its Rules of Procedure, which are normally negotiated upon each election, although standing committees can be also created upon the proposals of the Council of Presidents (the political groups' leaders within the European Parliament, Rule 183 of the European Parliament's Rules of Procedure).

Generally speaking, standing committees have legislative-, scrutiny-, and budget-related tasks. Concerning the legislative procedure, all proposals are referred to relevant committees without debate at the plenary. They are responsible for examination of the proposal and

\footnotetext{
${ }^{15}$ However, "this does not exclude the possibility for any member of the Council or of the Commission expressing an opinion at the time of the approval of these items" (Article 3(6) Council's Rules of Procedure).

${ }^{16}$ Hayes-Renshaw and Wallace (2006) P. 77.

"Not, really, that it makes the slightest difference to the conclusions of a meeting what Ministers say at it. Everything is decided, horse-traded off, by officials at Coreper, the Council [sic] of Permanent Representatives. The Ministers arrive on these scenes at the last minute, hot, tired, ill, or drunk (sometimes all of these together), read out their piece, and depart" (Clark (1994) P. 139).

${ }^{17}$ Busch and Puchala (1976) P. 235.

18 Priestley (2008).

${ }^{19}$ This information is taken from the official web-page of the institution. Find at: http://www.europarl.europa.eu/aboutparliament/en/0025729351/Organisation-and-work.html (last check April 2013).

${ }^{20}$ Corbett et al. (2011) P. 9.

Corbett et al. suggest that European Parliament's committees have more similarity with their counterparts from the US than from national parliaments in Europe considering their central roles "in the establishment of the position of the institution on the whole range of issues, legislative and non-legislative, that come before it." (Ibid. P. 170).

${ }^{21}$ The full list is to be found at: http://www.europarl.europa.eu/activities/committees/committeesList.do?language $=\mathrm{EN}$ (last check November 2012).
} 
only its amendments can be considered in plenary. ${ }^{22}$ The relevant committee appoints a rapporteur to prepare a report and follow his or her legislative proposal from the beginning until the conclusion of the procedure. Specialization is also relevant as regards scrutiny and budgetary tasks where similar practices of appointing individual members to be responsible for respective activities and at times individual agencies exist.

\subsubsection{The Council and the European Parliament from a functional perspective}

While the Council has always been one of the main decision-making institutions in the EU, over the last four decades its decision-making powers have experienced considerable changes. This is because "a system whereby ministers alone could adopt legislation suffered from a "democratic deficit,"”23 which was thought to be addressed by adding a parliamentary body, the European Parliament. The growth of parliamentary powers occurred to a large extent at the Council's expense, whose sole decisive role in the matters of legislation and the Union budget has evolved into becoming the co-decider.

\section{The Council + the European Parliament = the Union Legislator}

The Lisbon Treaty has become the first treaty to refer to the Council and the European Parliament as the Union Legislator (TFEU Protocol 2 Articles 4 and 7). And this is not surprising given the fact that the areas where consent of both institutions is required for secondary legislation to pass has expanded considerably - from 15 to 86 areas since the Maastricht Treaty (see Table 2.1. below). With the newly introduced 'ordinary legislative procedure', the name speaks for itself, which has replaced co-decision (Article 294 TFEU replacing Article 251 TEC), the legislative power has become almost equally shared ${ }^{24}$ between the Council and the European Parliament. While the Commission retains the power of legislative initiative, both the Council and the Parliament may influence the launching of a legislative proposal (Article 241 TFEU and Article 225 TFEU respectively). ${ }^{25}$ This institutional change implies that

Almost all European Union legislation now has to pass two tests to be enacted: acceptability to a qualified majority of national ministers meeting in the Council and acceptability

\footnotetext{
22 Shackleton (2006) P. 113.

${ }^{23}$ Corbett et al. (2011) P. 3.

24 "There are also a few "special legislative procedures", giving the final say to either the Council or the Parliament instead of co-decision, as well as a "consent procedure", where one institution, usually the Parliament, may either consent to or veto a decision of the other, and, in a few remaining cases, the simple consultation of Parliament, with the Council alone being the final legislator" (Ibid. P. 232).

${ }^{25}$ Moreover, "the Commission has always been prepared in principle to accept any EP proposal to which it had no major objections and, where possible, to accept EP amendments to Commission proposals" (Hayes-Renshaw and Wallace (2006) P. 223).
} 
to a majority of directly elected MEPs in the European Parliament. These two hurdles (or quality controls) mean that European legislation is subject to double scrutiny. ${ }^{26}$

\section{The Council + the European Parliament = the EU Budgetary Authority}

The Lisbon Treaty has also brought a crucial change to the budgetary power. ${ }^{27}$ The budgetary power used to be shared between the Council and the European Parliament unevenly. In the past, the budget consisted of two parts, i.e., compulsory and non-compulsory, with the 'compulsory expenditure' being determined by treaty obligations; as such, the Common Agricultural Policy held one of its biggest shares. The Council had a final say on these expenditures; but because they were determined by the treaty they were hardly revised during annual budgetary procedures. ${ }^{28}$ The final say for the non-compulsory part, which included, for instance, EU agencies as instruments of implementing individual policies, was given to the European Parliament. Since the Lisbon Treaty abolished the two-part division of the EU general budget, the Council and the European Parliament have become on par with respect to deciding on the EU general budget, thus, constituting two equal branches of the EU 'budgetary authority'. ${ }^{29}$

\section{The Council + the European Parliament = the EU Political Accountability Forum?}

In addition to the labels 'Union Legislator' and 'EU budgetary authority', the union between the Council and the European Parliament can also be called the 'EU Political Accountability Forum' when one considers their shared functions of political control over EU agencies. However, unlike their shared legislative and budgetary powers, which are formalized in the treaty, their political accountability powers over EU agencies are not regulated by the treaty. ${ }^{30}$ Moreover, the treaty reserves the function of political control for the European Parliament only (Article 14 (1) TEU). This includes the powers to conduct investiga-

\footnotetext{
${ }^{26}$ Corbett et al. (2011) P. 232-233.

${ }^{27}$ The European budgetary authority does not enjoy the power to lay down the revenue of the Union, where the member states have to agree on the respective Council's decision taken in accordance with the special legislative procedure (Article $311 \mathrm{TFEU})$.

${ }^{28}$ Corbett et al. (2011) P. 274.

${ }^{29}$ Council Regulation (EC, EURATOM) No 1605/2002 on the Financial Regulation applicable to the general budget of the European Communities.

30 The Lisbon Treaty mentions EU agencies only in a number of general provisions, such as Article 15 TFEU: "In order to promote good governance and ensure the participation of civil society, the Union institutions, bodies, offices and agencies shall conduct their work as openly as possible." Similar references to agencies can be found in Articles 9 (on democratic equality), 42 and 45 (on European Defence Agency) TEU and Articles 15 (mentioned before), 16 (on data protection), 24 (on right to communication, indirectly referring to any 'body'), 71 (on internal security), 123, 124, 127 and 130 (on monetary union), 228 (concerning the procedures of Ombudsman), 263, 265, 267 and 277 (on judicial review), 282 (on ECB), 287 (on the discharge by the Court of Auditors), 298 (on 'open, efficient and independent' European administration) and 325 (on anti-fraud) TFEU, and Protocols 3 (on the Court of Justice), 4 (on the ECB), 6 (on the seats), 10 (concerning the European Defence Agency), and 36 (on transitional provisions).
} 
tions by means of setting up temporary committees of inquiry (Article 226 TEU), to receive the report from the Commission and discuss it in the plenary and with the Commission (Articles 230 and $233 \mathrm{TEU}$ ), to hear the representatives from the Council and the European Council (Article 230 TEU), to table a motion of censure against the Commission (Article $234 \mathrm{TEU}$ ), and to give (or to refuse) the discharge on the implementation of the general budget (Article 319 TEU). The powers to conduct investigations and to give the discharge are the only treaty-based powers that the European Parliament has in relation to EU agencies. ${ }^{31}$ However, while the Treaty is silent on this matter, the Council and the European Parliament are involved in different ways in the appointment of and removal of agencies' top officials and in scrutinizing agencies' performance, which derive from agencies' founding acts and are investigated further in section 2.2. The powers that the Council and the European Parliament have been sharing in relation to holding EU agencies to account seem to indicate the development of another union between these institutions, namely the 'EU Political Accountability Forum'.

All in all, considering the representation functions and decisive powers that the Council and the European Parliament enjoy and share, the EU seems to have obtained what is called "a classic two chamber legislature: in which the Council represents the states and the European Parliament represents the citizens." 32

Table 2.1. The Council and the European Parliament (EP): evolution of shared legislative and budgetary powers

\begin{tabular}{|l|l|l|l|}
\hline Treaties & Evolution of shared functions ${ }^{33}$ & The European Parliament (the Assembly) $)^{34}$ \\
\hline & The Council & (Only supervisory \\
Treaty Establishing the & The Council harmonizes "the action of the High Authority and that of the & power over the \\
European Coal and Steel & $\begin{array}{l}\text { Governments" (Article 26) and consults the High Authority (the Commis- } \\
\text { Community (1951) }\end{array}$ & sion). & High Authority) \\
\hline
\end{tabular}

\footnotetext{
${ }^{31}$ Article 226 TFEU allows the European Parliament to set up a temporary committee of inquiry to investigate alleged contraventions and maladministration without specifying specific institutions which the Parliament may or may not investigate. Article 322 TFEU requires the European Parliament and the Council to adopt financial rules, including the checks on the responsibility of financial actors, in particular authorizing officers. Also, Article 287 TFEU requires the Court of Auditors examine agencies' expenditure. According to EU agencies' founding acts the agency's director is usually the authorizing officer accountable for the European Parliament in the course of the discharge procedure.

${ }^{32}$ Hix (1999) P. 72 see, also Lewis (2005) P. 147.

33 The sloping line of the European Parliament's column indicates growing and later more evenly sharing powers with the Council. The intensity of the grey colour for the last four lines indicates the expansion of areas for codecision (today - ordinary legislative procedure).

34 "Observing the European Parliament over the last 30 years was like witnessing, in a sort of fast-forward, an evolution that went through nearly all those very same steps taken centuries ago by the first parliamentary assemblies in European history on their way to asserting the peoples' power" (Juncker J-C., Prime Minister of Luxembourg, (2008) P. vii).
} 


\begin{tabular}{|c|c|c|c|}
\hline Tre & \multicolumn{3}{|l|}{ Evolution of shared functions ${ }^{33}$} \\
\hline & The Council & \multicolumn{2}{|c|}{ The European Parliament (the Assembly) ${ }^{34}$} \\
\hline $\begin{array}{l}\text { Treaty Establishing } \\
\text { European Economic } \\
\text { Community (1957) }\end{array}$ & \multicolumn{2}{|c|}{$\begin{array}{l}\text { The Council ensures coordination of general economic policies of } \\
\text { the member states and has the power to take decisions (Article } \\
\text { 145, 189), acting on the proposal of the Commission where the } \\
\text { Treaty so prescribes (Article 149). The Council is the exclusive } \\
\text { budgetary and discharge authority (Title II). }\end{array}$} & $\begin{array}{l}\text { The Assembly has advisory } \\
\text { authority (Article 137), in- } \\
\text { cluding on the budget; it is } \\
\text { informed about Council's } \\
\text { discharge decision. }\end{array}$ \\
\hline & $\begin{array}{l}\text { 1970: The budget is divided into compulsory and } \\
\text { non-compulsory parts; }{ }^{35} \text { the last word for the } \\
\text { adoption of compulsory part lies with the Council. } \\
\text { The discharge power is shared between the Coun- } \\
\text { cil and the EP (Articles 3, 6, 9). }\end{array}$ & \multicolumn{2}{|c|}{$\begin{array}{l}\text { 1970: The Assembly has the right to amend } \\
\text { and to reject the draft budget (Articles } 1,4,7 \text { ) } \\
\text { and to give (or not) discharge together with } \\
\text { the Council (Articles 9, 17, 25). 1975: the EP } \\
\text { becomes the discharge authority (Articles 9, } \\
\text { 17, 25). }\end{array}$} \\
\hline & & \multicolumn{2}{|c|}{$\begin{array}{l}\text { Cooperation procedure is introduced (Articles } \\
6-7) \text {. Assent procedure to approve enlarge- } \\
\text { ment and international treaties is introduced } \\
\text { (Articles 8-9). }\end{array}$} \\
\hline $\begin{array}{l}\text { Treaty Establishing the } \\
\text { European Community } \\
\text { and Treaty on European } \\
\text { Union (1992) }\end{array}$ & \multicolumn{3}{|c|}{$\begin{array}{l}\text { Introduction of the three pillars structure: cooperation and co-decision procedures with the EP are } \\
\text { introduced for the first pillar area (Articles } 189 \mathrm{~b} \text { and } 189 \mathrm{c} \text { TEC). Co-decision procedure applies to } \\
15 \text { legal bases. }{ }^{36} \text { The European Parliament has the right to invite the Commission to present a } \\
\text { legislative proposal (Article } 192 \text { TEC). }\end{array}$} \\
\hline $\begin{array}{l}\text { Treaty of Amsterdam } \\
\text { (1997) }\end{array}$ & \multicolumn{3}{|c|}{$\begin{array}{l}\text { Co-decision extended to } 32 \text { legal bases; }{ }^{37} \text { the EP has to be consulted on the issues falling within the } \\
\text { third pillar (point } 11 \text { on Title VI Article K11). }\end{array}$} \\
\hline Treaty of Nice (2001) & \multicolumn{3}{|l|}{ Co-decision extended to 37 legal bases. ${ }^{38}$} \\
\hline $\begin{array}{l}\text { Treaty on the Function- } \\
\text { ing of the European } \\
\text { Union (2009) }\end{array}$ & \multicolumn{3}{|c|}{$\begin{array}{l}\text { The three pillar structure and the distinction into compulsory and non-compulsory parts of the EU } \\
\text { general budget have been abolished. Co-decision extended to } 86 \text { legal bases }{ }^{39} \text { (ordinary legislative } \\
\text { procedure Articles } 289 \text { (1), 294), other legislative procedures remain possible, (e.g. consent and } \\
\text { consultation). The Council and the EP share the EU budgetary power equally (Articles } 310 \text { (1), } \\
\text { 314). The Council and the EP are called the 'Union Legislator' (Protocol } 2 \text { Articles } 4 \text { and 7). }\end{array}$} \\
\hline
\end{tabular}

${ }^{35}$ Compulsory expenditure is the expenditure that relates to expenditure necessarily resulting from the treaty or from acts adopted in accordance therewith (Article 2 of the 1975 budgetary treaty). (Originally introduced by the 1970 budgetary treaty: "L'Assemblée a le droit $<\ldots>$ de proposer au Conseil, <...>, des modifications au projet en ce qui concerne les dépenses découlant obligatoirement du traité ou des actes arrêtes en vertu de celui-ci” (Article 1)).

${ }^{36}$ Corbett et el. (2011) P. 232.

In addition, the areas where the cooperation and assent procedures apply extended.

${ }^{37}$ Shackleton (2006) P. 106.

${ }^{38}$ Ibid.

${ }^{39}$ Corbett et al. (2011) P. 248-250. 


\subsubsection{Implications of the institutional design of the EU representative institutions on the accountability of $E U$ agencies}

So far this section has discussed the Council and the European Parliament from structural and functional perspectives, which allowed the ways these institutions are organized and powers they enjoy and share to be illustrated. It was shown that while the Council has been the major decision-making institution since the first steps of the EU integration, the role of the European Parliament has been growing to address the concern of the weak democratic legitimacy in the EU decision-making processes. Yet, the ways in which such a concern has been addressed, as well as the realities in which the EU representative institutions function, are not without reservations. These involve the issues of somewhat troublesome legitimacy, accountability, and transparency of the Council and the European Parliament, the political accountability forum in discussion. Furthermore, the development of their interinstitutional relationship in the areas of shared powers may also influence the exercise of those powers. Consequently, the existing institutional design of EU representative institutions may have implications for the process of holding EU agencies to account. Such potential implications need to be taken into account for further discussions in this book and are therefore presented here in three sub-sections; on accountability (1), transparency (2) and interinstitutional relationship (3).

\section{(1) Troubling Accountability of the EU political accountability forum = Troubling}

\section{Accountability of EU agencies?}

While this book focuses on how the Council and the European Parliament hold EU agencies to account, it is important to note that the democratic accountability of the political forum under discussion is somewhat of a troublesome issue on its own. This section briefly sketches the existing debate and puts forward a suggestion that the troubling accountability of the political accountability forum under discussion may affect the accountability of those bodies that it holds to account.

As was mentioned before, to implement the treaties concluded between the members of the European Union, the Council was empowered with legislative functions. Such a construction suffered from the democratic deficit because it was the executive (national ministers) alone who enjoyed the legislative power. The creation and subsequent strengthening of the European Parliament occurred "in response to the argument that this would help to close the democratic deficit, and therefore the legitimacy deficit of the EU." ${ }^{40}$ In Weiler's words, the democratic deficit informed, animated, and mobilized the drive to change the powers of the European Parliament. ${ }^{41}$ It was thought that "the distinct constituencies repre-

\footnotetext{
${ }^{40}$ George and Bache (2001) P. 271.

${ }^{41}$ Weiler (1999) P. 77.
} 
sented by the Council, and the peoples of Europe in the case of the European Parliament lend a greater legitimacy than before to any joint decisions reached." ${ }^{2}$

However, "the creation of a parliamentary institution, called the Common Assembly [European Parliament's forerunner], was something of an afterthought, perceived as the least imperfect way to address the issue of accountability." ${ }^{43}$ While the European Parliament was thought to enhance the democratic mandate of the EU structures and decision making, the European Parliament's legitimacy and accountability have become debatable, too. How can the European Parliament represent and be held to account by the 'European citizen' if the latter does not exist? How can the European Parliament's actions be legitimate if its elections suffer from a low turnout?

The "no demos thesis" ${ }^{44}$ is based on the idea that "the peoples of Europe are not bound together in the same way as national communities with common histories and cultures." 45 "From the standpoint of national sovereignty, true democratization of European institutions is problematic because it breaks a link between democracy and the nation-state." 46 Thus, the European Parliament cannot represent the 'EU citizen' because the latter does not exist. The opponents of the argument extend the definition of 'demos' beyond the nation state. They question whether the existing national borders are shaped in accordance with the common histories and cultures of their peoples and whether the nation state "represents the 'final equilibrium' in identity formation." ${ }^{47}$ Also, "European history contains as many things that divide nations as potentially unite them." ${ }^{48}$ Nevertheless, the existence and possibility for the development of European identity remains a debatable issue.

The low turnout in European elections is another argument used against the legitimacy of the European Parliament's. Shackleton provides the data: the turnout for the 2009 elections was lower than 50 per cent in 18 member states. ${ }^{49}$ "And yet should this tendency be any surprise given the second order nature of the event?" ${ }^{50}$ It is not only that "most of the political issues that affect European citizens directly, such as health care, education and taxation, continue to be discussed and decided at national level," ${ }^{51}$ but also that decisions coming from 'Brussels' seem to have received a negative connotation. Even though "twothirds of respondents of the euro area countries believed that having the euro was a good

\footnotetext{
${ }^{42}$ Hayes-Renshaw and Wallace (2006) P. 214.

43 Shackleton (2006) P. 107.

${ }^{44}$ Weiler (1995) P. 224-231.

45 Shackleton (2006) P. 116-117.

${ }^{46}$ Lindseth (1999) P. 675.

${ }^{47}$ George and Bach (2001) P. 271.

${ }^{48}$ Ibid. P. 270.

${ }^{49}$ Shackleton (2006) P. 119.

${ }^{50}$ Ibid. P. 120.

${ }^{51}$ Ibid.
} 
thing for Europe," 52 because of "the collective character of decision in the EU" it makes it difficult for voters "to identify whom to reward or punish for particular policy outcomes when they participate in European elections." 53

The debate goes on not only about Parliament's legitimacy and accountability, but also about Council's accountability. While it has been designed to represent the member states of the European Union, "the Council, as an institution, equals more than the sum of its parts (the member states). National actors in the Council also act collectively, and many develop a shared sense of responsibility that the work of the Council should move forward and the legislative output of the Council <...> should be a success." ${ }^{54}$ Thus, "the Council of the EU is both an institution with collective EU functions and the creature of member governments." 55 The same applies to the Council's lower structures. While Coreper's members "operate $\langle\ldots\rangle$ in the framework of instructions from capitals," "decisions sometimes have to be made on the spot in the Conciliation Committee, without the chance to refer to capitals." ${ }^{56}$ This is because Coreper's objective is "maximizing agreement at its level and maximizing the chances of agreement in meetings of the Council." ${ }^{57}$ In this light, "members of Coreper describe themselves as being bound by a 'dual loyalty'. It is their responsibility faithfully to represent their member states; but it is also their responsibility to reach agreement." 58

Such 'dual loyalty' of the Council and its lower structures does not seem to be secured by 'dual accountability'. While individual ministers are accountable to their national parliaments, the collective accountability of the Council's decisions is missing. ${ }^{59}$ It is true that the Presidency of the Council ${ }^{60}$ can be invited to the European Parliament to respond to parliamentary questions and the Council may also present its views in writing (Article 230

\footnotetext{
52 Report of Eurobarometer 'The euro area, 2010. Public attitudes and perceptions. Summary', December 2010. Find at: http://ec.europa.eu/public_opinion/flash/fl_306_sum_en.pdf (last check September 2012).

Furthermore, "a large majority of Europeans believe that, as a consequence of the crisis, EU countries will have to work more closely together (84 per cent)"(Public Opinion in the European Union, Standard Eurobarometer 77, First Results, Spring 2012. P. 15, 19).

Find at: http://ec.europa.eu/public_opinion/archives/eb/eb77/eb77_first_en.pdf (last check September 2012).

${ }^{3}$ Shackleton (2006) P. 120.

54 Cini (2004) P. 151.

55 Wallace (2000) P. 16; Cini (2004) P. 163.

${ }^{56}$ Bostock (2002) P. 221-222.

${ }^{57}$ Ibid. 225.

${ }^{58}$ Ibid. P. 217.

59 "The secrecy of Council meetings makes it impossible for national parliaments (or the general public) to scrutinize the behaviour of their governments regardless of the decision-making mode. Despite a number of reforms regarding access to Council documents, decision-making (as well as in the Council's working groups and the Commité des Représentants Permanents) still takes place mainly behind closed doors. <...> being publicly accountable is not necessarily the same as acting in public" (Auel (2007) P. 499).

${ }^{60}$ Article 26 Council's Rules of Procedure prescribes representation of the Council by the Presidency or by a member of the pre-established group of three Member States before the European Parliament.
} 
TEU, Article 26 of Council's Rules of Procedure). However, the accountability line is not that explicit as the one of the Commission which "shall be responsible to the European Parliament" (Article 17 (8) TEU). Here, while some opine that "the rather ritualistic nature of these encounters should not detract from the fact that they are the most obvious manifestations of accountability on the part of the Council before the EP," ${ }^{61}$ others argue that "the European Parliament has no role to play of any significance in holding the Council of Ministers to account for its actions or inactions." ${ }^{2}$ Furthermore, as Lewis notes, "given Coreper's role in everyday decision-making, it is somewhat surprising that in all the discussions to address the EU's 'democratic deficit' since the early 1990s, Coreper's name has been virtually unmentioned." ${ }^{63}$ As a whole, "how can the public hold public authorities accountable if the public is not allowed to know what goes on within the public authorities, or if what goes on is obscure?" 4

The fact that legitimacy and accountability concerns exist in relation to the EU political accountability forum may have a spill-over effect on the next level of delegation, i.e., to EU agencies; the latter has often been discussed from 'problematic accountability' angles. ${ }^{65}$ Indeed, a weak or absent check over the actions of the Council and the European Parliament may influence all aspects of their work, including, for instance, the quantity and quality of their checks over EU agencies. If the check upon the accountability forum is absent or quite weak, there are little (if any) incentives for it to be involved in, for instance, accountability activities in relation to EU agencies and to make an effort to do its job properly. This may negatively affect the political accountability of EU agencies.

\section{(2) Holding to Account Requires Transparency of an Accountability Forum}

As transparency is a prerequisite to accountability, ${ }^{66}$ holding EU agencies to account requires transparency of operations inherent to accountability. In this light, the absence of transparency of the Council's structures and practices, on the one hand, makes one wonder in how much it can succeed in its role as a political accountability forum. On the other hand, the institutional characteristics of the European Parliament seem to make it a suitable transparent accountability forum for scrutinizing various institutions, including EU agencies.

\footnotetext{
${ }^{61}$ Hayes-Renshaw and Wallace (2006) P. 219.

${ }^{62}$ Curtin and Egeberg (2008) P. 653.

${ }^{63}$ Lewis (2006) P. 287.

Moreover, "the density and opacity of Coreper $\langle\ldots\rangle$, as well as the key role in the operations of the Council $<\ldots\rangle$ raise obvious concerns of oversight: Coreper's meetings are always held in private" (Lindseth et al. (2008) P. 33).

${ }^{64}$ Dyrberg (2002) P. 83.

${ }^{65}$ Schillemans (2011); Bovens et al. (2010).

66 "There can be no accountability without transparency; rather accountability presumes transparency as a precondition” (Verhey et al. (2008) P. 316).
} 
"How the Council operates in practice is perhaps the least documented" ${ }^{67}$ and "least accessible." ${ }^{68}$ Part of the explanation for the lack of transparency of the Council's practices "lies in the historical secrecy surrounding so many of the deliberations of the Council. We lack detailed and authoritative accounts over time of meetings, voting records and how business is actually transacted, leaving too much to be read into the resulting texts and anecdotes." ${ }^{69}$ Also, the practices of its preparatory bodies, which greatly influence the Council's decisions and negotiations, remain hidden from the public as well; ${ }^{70}$ "at [COREPER's] level, publicity does not exist." ${ }^{\prime 1}$

In an attempt to respond to this criticism, transparency requirements have been implemented starting with 'the 1993 code of conduct' (Council decision 93/731/EC) introducing public access to the European institutions' documents. In 2001 'the access regulation'72 (1049/2001) was implemented to allow public access to the documents of European Parliament, Council and Commission. Also, today the Council has an obligation to "meet in public when it deliberates and votes on a draft legislative act" (Article 16(8) of the TEU). ${ }^{73}$ Many decisions and agendas have become accessible online or can be requested. The Council's deliberations are transmitted online in all 24 official languages. ${ }^{74}$

It is difficult, however, to distinguish between the Council's negotiating and legislating modes, "since negotiation is so heavily concentrated on the details of legislative texts." 75 Therefore, the question becomes to what extent the nature of Council's work allows transparency. Its practices are based on political negotiations and package deals, which remain in the shadow of intergovernmental politics and diplomacy that, by definition, do not co-exist with open deliberation. "Openness is traditionally not much of an issue in the international relations field, where a diplomatic ethos and secrecy go hand in hand." ${ }^{\text {" A }}$ As Reishow and Wallace note,

\footnotetext{
${ }^{67}$ Cini (2004) P. 150.

${ }^{68}$ Lewis (2005) P. 143.

${ }^{69}$ Hayes-Renshaw and Wallace (2006) P. 3.

${ }^{70}$ One could state that the work of national ministries is not that transparent either. At the same time the main difference is the clarity of the accountability channel. At the national level, the relevant national minister is responsible for his or her ministry before the national parliament. In the EU, no clear line seems to exist between specific Coreper structures and the Council or its specific compositions and there is no collective accountability of the Council for Coreper's work.

${ }^{71}$ Lewis (2006) P. 284.

72 Westlake and Galloway (2004) P. 371.

${ }^{73}$ On other issues the Council decides whether to make its meeting and its documents public or not. For instance, Article 8 (2) Council's Rules of Procedure states “on a decision taken by the Council or by Coreper, acting by a qualified majority, the Council shall hold public debates on important issues affecting the interests of the European Union and its citizens." But it is at Council's (or Coreper's) discretion to decide on what those 'important issues' are.

${ }^{74}$ Brunmayr (2009) P. 2.

${ }^{75}$ Hayes-Renshaw and Wallace (2006) P. 54.

${ }^{76}$ Curtin et al. (2010) P. 936.
} 
This should not surprise us; the negotiation of such issues as fishing quotas or financial allocations from Community funds are technically legislative decisions, in that way they eventually appear as legal texts, but it is hard to imagine national representatives agreeing to resolve such potentially politically sensitive issues as these or, for example, negotiating mandates with third countries, in open session. ${ }^{77}$

Thus, the peculiarities of the Council as an institution for intergovernmental negotiations imply a lack of transparency. However, "openness of governmental practice is a necessary condition for accountability." ${ }^{78}$ While the Council's involvement in holding EU agencies to account is considered crucial considering the representative factor, it is questionable if the Council is a suitable candidate to carry out the job of an accountability forum, which is necessarily public. Without transparency of accountability practices it is impossible to judge whether, how often and of what quality, accountability processes take place. Moreover, the opacity of accountability practices seems to cut off "the ultimate principals, the citizens"79 from this process. One could agree that there can be accountability

Of a certain sort without transparency. $<\ldots>$ officeholders can be accountable to legislatures without full transparency in every possible dimension, for example, when security and intelligence services are scrutinized by legislative committees without full public disclosure of their activities and precisely who produced what information and at what time. ${ }^{80}$

There are, however, at least two important differences that make transparency an essential composite feature of political accountability at the EU level. First, while the absence of transparency in the mentioned example relates only to some aspects of the overall accountability relationship, i.e., security and intelligence, all other issues are supposedly open to the public. Nevertheless, the Council's accountability practices remain generally behind closed doors. Second, in the EU context, accountability becomes necessary not only as a value in its own right, but also as an instrument to promote the legitimacy of EU structures; accountability, requiring explanations and justifications to the people, can only be obtained in a transparent environment. "Confidential accountability, exercised behind closed doors, tends to be perceived as a farce, a caricature of accountability." ${ }^{\text {1 }}$

In contrast, while "effective monitoring of European negotiations is much impeded by the degree of secrecy that surrounds the Council," 82 the European Parliament seems to bring light into dark corridors of the Council's practices. "The Parliament has traditionally offered a contrast between its own way of operating and the often less transparent mecha-

\footnotetext{
${ }_{77}$ Hayes-Renshaw and Wallace (2006) P. 25; see, also, Westlake and Galloway (2004) P. 368.

${ }^{78}$ Curtin et al. (2010) P. 937.

${ }^{79}$ Auel (2007) P. 504.

${ }^{80}$ Hood (2010) P. 991.

${ }^{81}$ Auel (2007) P. 497.

${ }^{82}$ Hayes-Renshaw and Wallace (2006) P. 241.
} 
nisms of the Council." ${ }^{\prime 3}$ Its committees' meetings "shall normally meet in public" (Rule 103 Rules of Procedure) and relevant documents are available online. Individual citizens have the right to contact MEPs (Article 227 TFEU). In this light, the European Parliament seems to be a more suitable candidate for the position of a political accountability forum on the grounds of transparency, although its legitimacy may be less obvious than that of the Council.

As a whole, as transparency is a prerequisite to accountability, the process of holding EU agencies to account necessitates transparency of accountability procedures. This in its turn requires transparency of the accountability forum. Opacity in the process of holding to account makes it more difficult to judge whether relevant accountability procedures occur, if so, how often and of what quality they are, which makes the investigation of Council's accountability role in relation to EU agencies in this study quite a challenging task. Furthermore, the absence of transparency of political accountability processes seems to cut off the ultimate principal, the people, and hence the targeted audience for political accountability. Transparency of political accountability processes seems especially relevant in the EU context where accountability is an important instrument in promoting the EU's legitimacy.

\section{(3) The Correlation between Interinstitutional Development of Shared Functions and the}

\section{Exercise of Those Functions}

The European Parliament's legislative powers have evolved from having none to obtaining a co-decision role in 86 areas. What Table 2.1. above has shown, i.e., the sloping curve between two columns, is that the European Parliament has asserted its law-making, budgetary, and discharge powers at the Council's expense. Not surprisingly, such changes did not happen smoothly. In fact, if one looks at the development of the interinstitutional relationship in relation to budgetary and legislative powers, a path from conflict to cohabitation, and at times cooperation (which can be called as a path of ' 3 c's'), is noticeable. The stage of development of the interinstitutional relationship in relation to individual shared functions influences the way the shared functions can be exercised, which may also be relevant with respect to another shared function of the Council and the European Parliament, namely the political oversight over EU agencies.

The Council has always shown a 'natural' resistance in the process of sharing something it used to have on its own, especially because the European Parliament was often perceived as a weak institution due to its initial rather insignificant role. Hence, the Council had no choice but to get used to "shar[ing] its toys." ${ }^{84}$ As regards the budgetary power, the power that the Council and the European Parliament have been sharing the longest, the division into compulsory and non-compulsory parts, introduced by the budgetary treaty of 1970, gave the European Parliament the powers to have the last word on the non-compulsory

\footnotetext{
${ }^{83}$ Shackleton (2006) P. 113.

${ }^{84}$ Hayes-Renshaw and Wallace (2006) P. 210.
} 
part and to reject the budget as a whole, "a mighty weapon against the Council." ${ }^{\text {s5 }}$ Rejection of the budget in $1980^{86}$ and further difficult operation of budgetary decision making between 1980 and 1988, when the budgets for 1980, 1985 and 1988 were not adopted until five or six months of the subsequent financial year had passed, was mainly due to the conflict situation between the two institutions. ${ }^{87}$ Two institutions were drawing boundaries around each other's 'power territories'.

After the 'battle for the budget', the 'battle for legislative power' seemed to repeat the history. ${ }^{88}$ "The Council had enjoyed a legislative dominance for forty years and would be eager to find ways of maintaining its position. But the fact that legislation cannot be adopted against the will of the European Parliament gives the latter a bargaining position which it previously lacked." ${ }^{89}$ The European Parliament has long been 'a subordinate advisor' to the legislating Council, even when the cooperation procedure was established, the Council perceived the European Parliament that way. ${ }^{90}$ However, gradually the Council got used to working with the European Parliament and the fears that co-decision would produce deadlocks did not come true. ${ }^{91}$

Interdependence impacted the somewhat negative feelings between two institutions and resulted often in the resolution of those conflicts. The resolution of conflicts has been facilitated by making joint declarations and interinstitutional agreements, increasing the intensity of contacts and thus establishing a tighter relationship, especially when the co-decision procedure was established. Thus, the conflict stage was followed by co-habitation because both institutions realized their need of each other in order to exercise their own functions. Such a pragmatic attitude has even led to cooperation at times. ${ }^{92}$ Rejections of the EU budget seem "to be becoming a distant memory. The attitude is businesslike, the negotiation is real but loyal (the rhetoric of battle is naturally still there...), meetings are appearing

\footnotetext{
${ }^{85}$ Hayes-Renshaw and Wallace (2006). P. 209.

86 "One of the very first things the Parliament did following the first direct elections in June 1979 was to reject the European Community budget in its entirety and thereby plunge Europe into a political and potentially a financial crisis" (Priestley (2008) P. 6).

${ }^{87}$ European Union Public Finance, $4^{\text {th }}$ edition. European Commission, 2008. P. 23.

88 Priestley (2008).

${ }^{89}$ Corbett et al. (2011) P. 246.

${ }^{90}$ In Isoglucose (Cases 138 and 139/79), the CJEU overturned legislation passed by the Council without Parliament's opinion, which was required under the treaty provision at issue (consultation procedure). The Court stated that "such a power represents an essential factor in the institutional balance intended by the Treaty. Although limited, it reflects at Community level the fundamental democratic principle that the people should take part in the exercise of power through the intermediary of a representative assembly. Due consultation of the Parliament in the cases provided by the Treaty $\langle\ldots\rangle$ constitutes an essential formality, disregard of which means that the measure concerned is void" (point 33).

${ }^{91}$ Corbett et al. (2011) P. 246.

${ }^{92}$ Hayes-Renshaw and Wallace provide the data: in 1999-2004 in total 403 dossiers were concluded by codecision and no agreement was reached in 5 cases for the whole period from 1993-2004 (Hayes-Renshaw and Wallace (2006) P. 213).
} 
to become shorter." ${ }^{93}$ Cooperation between the two institutions takes place in their mutual 'power struggle' against the Commission. "Many times EP and Council limit the right of initiative of the Commission in advance in predefining future legal proposals by including review clauses and calendars for complementary new legislation." ${ }^{94}$ Another area for cooperation comes from the fact that their co-decided acts may be challenged before the Court of Justice of the European Union. Here, the Council and the EP defend their position jointly.

Holding EU agencies to account brings another challenge to the interinstitutional relationship between the Council and the European Parliament. Until recently, the Council used to create EU agencies and design their (accountability) obligations with hardly any influence from the European Parliament. A stronger legislative involvement of the European Parliament has led to its stronger involvement in creating agencies and holding them to account (see section 2.2.1.). The developing interinstitutional relationship between the Council and the European Parliament may help to explain the existing accountability obligations, or their absence, of EU agencies.

\subsubsection{EU Agencies}

There is a genuine consensus that the proliferation of EU agencies is one of the most important institutional developments at the EU level. ${ }^{95}$ The number of agencies has been growing rapidly since the 1990 s, and, as of this writing, there are $35 \mathrm{EU}$ agencies. ${ }^{96} \mathrm{EU}$ agencies are independent legal entities entrusted with different tasks from information gathering to decision making and supervision. They are considered to be an effective tool in implementing EU policies. ${ }^{97}$ What does their independent status imply and why have they been created? This section introduces EU agencies by defining EU agencies, including offering a list of EU agencies on which this study focuses (2.2.1), and by discussing their historical development and the reasons for their creation (2.2.2.), their functions (2.2.3.), and the issue of EU agencies within the EU institutional balance (2.2.4.).

\footnotetext{
93 Westlake and Galloway (2004) P. 108.

${ }_{94}$ Brunmayr (2009) P. 4.

${ }^{95}$ Nearly every academic and policy document recognizes this development, calling its at times an 'agency fever' (Christensen and Laegreid (2005) P. 8).

${ }^{96}$ This information is taken from the official web-page of EU agencies. Find at: http://europa.eu/agencies/regulatory_agencies_bodies/index_en.htm (last check April 2013).

${ }^{97}$ Joint Statement of the European Parliament, the Council of the EU and the European Commission on decentralised agencies, 19 July 2012. P. 1.
} 


\subsubsection{Defining EU agencies}

Defining 'an EU agency' is a challenging task. This is mainly due to the absence of an official definition and the existing variety of bodies that could be put under the umbrella of 'EU agencies'. Agencies are not explicitly recognized by the existing or any past treaties, and the term 'agency' is used as an omnibus term substituted by the terms such as 'institute', 'center', 'office' or 'authority' in the existing EU agencies' official titles. ${ }^{98}$ In this respect, the European Parliament's Budgetary Affairs unit that called the existing variety of bodies and their names an "administrative zoo" 99 seems to have a valid point.

Because of the difficulty of defining EU agencies, there is little consensus on how many EU agencies there actually are. Reports on the number of EU agencies vary greatly: various studies, evaluations and EU official documents refer to different numbers of EU agencies. For instance, while the Commission's brochure "EU agencies: Whatever you do, we work for you" (2007) offered an overview of 29 EU agencies, the Meta-study for the Commission (2008) evaluated 26 decentralized agencies, the Joint Statement of the European Parliament, the Council of the EU and the European Commission summarizing the results of the IWG on agencies (2012) referred to 31 agencies, and the official web-page of EU agencies (2013) listed 35 decentralized agencies.

What is an EU agency? The official web-page of EU agencies describes them as follows:

A number of specialised and decentralised EU agencies have been established to support the EU Member States and their citizens. These agencies are an answer to a desire for geographical devolution and the need to cope with new tasks of a legal, technical and/or scientific nature. They are bodies governed by European public law; they are distinct from the EU Institutions (Council, Parliament, Commission, etc.) and have their own legal personality. ${ }^{100}$

Furthermore, scholars include additional characteristics of EU agencies, such as: agencies are created by secondary legislation; they enjoy a new organizational mode ${ }^{101}$ and financial autonomy; and they are created on the basis of the EU or EC Treaties provision(s). ${ }^{102}$

\footnotetext{
98 The recently issued 'Common Approach' on EU agencies (discussed in section 2.2.6.) proposes harmonization of agencies' titles in the future using a standard term 'European Union agency for ...' ('Common Approach' attached to Joint Statement of the European Parliament, the Council of the EU and the European Commission on decentralized agencies, 19 July 2012).

99 'Best practice in governance of agencies - A comparative study in view of identifying best practice for governing agencies carrying out activities on behalf of the European Union', European Parliament - Budgetary Affairs, 2008. P. 5 .

${ }^{100}$ This information is taken from the official web-page of EU agencies. Find at: http://europa.eu/agencies/regulatory_agencies_bodies/index_en.htm (last check September 2011).

${ }^{101}$ Agencies share a similar organizational structure: a management board, executive director, and additional (scientific) committees reflecting their functional needs; exact names of such organs may differ. Some agencies that issue individual decisions also have boards of appeals, e.g., the OHIM.
} 


\section{Independence of EU agencies}

Independence is another distinctive feature of EU agencies. ${ }^{103}$ In its Communication proposing to establish a common framework for regulatory agencies, the Commission states,

It is particularly important that [agencies] should have genuine autonomy in their internal organisation and functioning if their contribution is to be effective and credible. The independence of their technical and/or scientific assessments is, in fact, their real raison d'être. The main advantage of using the agencies is that their decisions are based on purely technical evaluations of very high quality and are not influenced by political or contingent considerations. ${ }^{104}$

In the Draft Interinstitutional Agreement on the operation of the regulatory agencies, the Commission explained how independence should be assured:

The need for autonomy takes several forms: granting of legal personality, budgetary autonomy, collective responsibility and own powers of the administrative board, the independence of the director, of the members of the scientific committees and of the boards of appeal, etc." and "the director, the members of the scientific committees and of the boards of appeal shall also undertake to act independently of any external influence. To this end, they shall make a written declaration of commitment and a written declaration of interests every year. ${ }^{105}$

Barely any establishing act talks about from whom European agencies need to be independent. One can find various 'independence related' clauses in agencies' enabling regulations (see Appendix 1). The Cedefop's establishing regulation explains that this agency is independent of other departments of the Commission (Recital of Regulation (EC) No 337/1975). Thus, the (institutional) independence from the Commission seems to be implied here. In the case of EFSA "the independence of the Authority and its role in informing the public mean that it should be able to communicate autonomously in the fields falling within its competence, its purpose being to provide objective, reliable and easily understandable information" (Recital 54 Regulation (EC) 178/2002, as amended). Thus, being able to 'communicate objective data autonomously', a sort of functional-institutional independence, is what seems to be implied in this case. There is only one agency (FRA) whose enabling act states that "the composition of that Board should ensure the Agency's independence from both Community institutions and Member State governments" (Recital 20 of Regulation (EC) No 168/2007).

${ }^{102}$ Vos (2003) P. 118; Vos (2005) P. 122; Thatcher and Coen (2008) P. 814; Andoura and Timmerman (2008) P.5; Chiti (2009) P. 1396; Griller and Orator (2010) P. 7-10, to name but a few.

103 This section is largely based on: Scholten (2011).

${ }^{104}$ Communication from the Commission on the Operating framework for the European regulatory agencies, COM (2002) P. 5.

${ }^{105}$ Draft Interinstitutional Agreement on the operating framework for the European regulatory agencies, COM (2005) 59. P. 5-6. 
It seems that independence of agencies in the context of the EU indeed implies independence from both the Community institutions and the member states and hence from 'political' interference from the EU's and the member states' interests. There are some additional sources that support this idea. In one of its resolutions, the European Parliament proposed concentrating on issues such as agencies' "degree of independence from the Commission as it is often of particular interest to the legislator." ${ }^{106} \mathrm{~A}$ recent evaluation of decentralized agencies states that "agencies are meant to be autonomous from both the Commission and the Member States." ${ }^{107}$ And as a prominent scholar in the field of EU agencies opined, "independence is generally considered to be free of both political and industry interests. In the Community context this also refers to national interests." 108

In his study on the autonomy of EU agencies, Groenleer shows that autonomy of the existing EU agencies can differ greatly in design and in practice. ${ }^{109} \mathrm{He}$ points out that autonomy of design comprises the variations in: "(1) the sources of their funding and (2) the appointment of their director, as well as (3) the composition of the management board and (4) the mandate, objectives and tasks." ${ }^{110}$ His findings on the development of the actual autonomy of six EU agencies show considerable differences, particularly with respect to "whether they could (1) interpret their mission and role, (2) prioritise their objectives and tasks, (3) choose their clients or target audience, (4) determine their working methods, (5) draw their own conclusions or formulate their own opinions and recommendations, (6) allocate their budget and deploy their staff, and (7) enter into relations with other actors." 111 Thus, while generally speaking all EU agencies can be considered autonomous bodies, each individual agency may enjoy more or less autonomy by design and in reality.

\section{Decentralized, regulatory, and executive EU agencies}

In addition to the independent or autonomous label with which EU agencies have been described, they are also categorised by other terms, such as decentralized, regulatory or executive. For the sake of clarity, these terms will be defined here.

Various documents issued by the Commission in the first decade of the 2000s have usually referred to two types of agencies; executive and regulatory. The former, executive

\footnotetext{
${ }^{106}$ European Parliament Resolution of 21 October 2008 on a strategy for the future settlement of the institutional aspects of regulatory agencies, (2008/2103(INI)), Point 28.

107 The Ramboll evaluation, Volume I. P. 11.

108 Vos (2005) P. 123.

${ }^{109}$ Groenleer chooses to use the term 'autonomous' instead of 'independent' with regard to EU agencies because "an autonomous actor is granted a level of autonomy by other actors or will attempt to ascertain a degree of control over his or her own affairs, but this does not mean that he or she is completely free, without restrictions, independent" (Groenleer (2009) P. 29). See, also, Scholten (2011) (arguing that the term 'independent' is misleading).

${ }^{110}$ Groenleer (2009) P. 345.

111 Ibid. P. 346.
} 
agencies, are established by Council Regulation (EC) No 58/2003. These are the so-tospeak 'assistant' agencies of the Commission that created them on a temporary basis wherever necessary to implement and manage certain programs. For instance, the Education, Audiovisual and Culture Executive Agency was created to deal with management aspects, such as drawing up calls for proposals, selecting projects and signing project agreements, of 15 Community funded programs and actions in the fields of education and training, active citizenship, youth, audiovisual and culture. ${ }^{12}$ The Commission supervises them and may dissolve them. As of this writing, six executive agencies exist, ${ }^{113}$ but as these agencies are not deemed to be independent, they are not discussed in this study.

The label 'regulatory' is explained by the Commission as follows:

Regulatory activities do not necessary involve the adoption of legal acts. They may also involve measures of a more incentive nature, such as co-regulation, self-regulation, recommendations, referral to the scientific authority, networking and pooling good practice, evaluating the application and implementation of rules, etc. It therefore follows that a European "regulatory" agency does not necessarily have the power to enact binding legal norms. ${ }^{114}$

The regulatory agencies are the so-called independent EU agencies and thus form the main focus of this book.

Finally, the distinction between regulatory and decentralized agencies is not very clear. In the meta-study on decentralized agencies prepared for the Commission, the terms regulatory and decentralized are used as synonyms: ${ }^{15}$

Decentralized agencies are bodies created by the EU legislator, with legal personality, also known as "traditional agencies" or "satellite agencies" or "regulatory agencies" <...>. Agencies are "decentralised" in the way that they perform tasks which could otherwise be undertaken

\footnotetext{
112 This information is taken from the official web-page on EU agencies: http://europa.eu/agencies/executive_agencies/eacea/index_en.htm (last check September 2012).

113 These are: Education, Audiovisual and Culture Executive Agency (EACEA); European Research Council Executive Agency (ERC Executive Agency); Executive Agency for Competitiveness and Innovation (EACI); Executive Agency for Health and Consumers (EAHC); Research Executive Agency (REA); and Trans-European Transport Network Executive Agency (TEN-T EA). Find at: http://europa.eu/agencies/executive_agencies/index_en.htm (last check September 2012).

${ }^{114}$ Draft Interinstitutional Agreement on the operating framework for the European regulatory agencies COM (2005) 59. P. 4.

According to a senior official from the ECDC "in the network of the EU agencies' directors we call agencies regulatory if they apply the staff regulation and the financial regulation"(Senior official from the ECDC (interviewed in October 2011)).

${ }^{115}$ Meta-study on the decentralized agencies: cross-cutting analysis of the evaluation findings. Final Report 2008, evaluation for the European Commission. P. 93-94.
} 
by the Commission, but they are centralised in the sense that an agency is a central Community point of decision, contrary to a situation with one body in each Member State. ${ }^{116}$

However, the Committee of Budgets of the European Parliament seems to note the difference when it states that regulatory agencies are only one type of decentralized agency. ${ }^{117} \mathrm{It}$ labels only EU agencies of the former first pillar as regulatory while it lists EU agencies of the former second, e.g., the European Defence Agency, and third, e.g., Europol, pillars under the term 'decentralized'. ${ }^{118}$ In fact, the term 'decentralized' has also been used to indicate the spread of EU agencies across the Union. ${ }^{119}$

\section{EU agencies: the focus of this book}

Considering the absence of general terminology and criteria defining EU agencies and the intention of this book to provide as complete a picture as possible it examines all $35 \mathrm{EU}$ agencies listed on the official web-page of EU institutions and agencies (see Appendix 1 for more specific details regarding these agencies' accountability and independence features). ${ }^{120}$ Following the official web-page order, the $35 \mathrm{EU}$ agencies are:

1. Agency for the Cooperation of Energy Regulators (ACER)

2. Body of European Regulators for Electronic Communications (BEREC), the Office

3. Community Plant Variety Office (CPVO)

4. European Agency for Safety and Health at Work (EU-OSHA)

5. European Agency for the Management of Operational Cooperation at the External Borders (Frontex)

6. European Agency for the operational management of large-scale IT systems in the area of freedom, security and justice (IT Agency)

7. European Asylum Support Office (EASO)

8. European Aviation Safety Agency (EASA)

9. European Banking Authority (EBA)

10. European Centre for Disease Prevention and Control (ECDC)

\footnotetext{
116 Meta-study on the decentralized agencies: cross-cutting analysis of the evaluation findings. Final Report 2008, evaluation for the European Commission. P. 92.

117 Report on a strategy for the future settlement of the institutional aspects of Regulatory Agencies (2008/2103(INI)), Opinion of the Committee of Budgets, suggestion 14. P. 20.

${ }^{118}$ In 1993-2009, the Treaty of the European Union was based on the so-called "Temple" structure, which comprised of common provisions and objectives (the roof of the temple) and three pillars (the community pillar (pillar 1), the common foreign and security policy pillar (pillar 2), and the justice and home affairs pillar (pillar 3). Each of these pillars represented a different balance between supranational and intergovernmental principles (Kaczorowska (2013) P. 19-22.).

${ }^{119}$ See, e.g., Curtin (2009) P. 161.

${ }^{120}$ This information is taken from the official web-page of EU agencies. Find at: http://europa.eu/agencies/regulatory_agencies_bodies/index_en.htm (last check April 2013).
} 
11. European Centre for the Development of Vocational Training (Cedefop)

12. European Chemicals Agency (ECHA)

13. European Environment Agency (EEA)

14. European Fisheries Control Agency (EFCA)

15. European Food Safety Authority (EFSA)

16. European Foundation for the Improvement of Living and Working Conditions (Eurofound)

17. European GNSS Agency (GSA)

18. European Institute for Gender Equality (EIGE)

19. European Insurance and Occupational Pensions Authority (EIOPA)

20. European Maritime Safety Agency (EMSA)

21. European Medicines Agency (EMA)

22. European Monitoring Centre for Drugs and Drug Addiction (EMCDDA)

23. European Network and Information Security Agency (ENISA)

24. European Police College (CEPOL)

25. European Police Office (Europol)

26. European Railway Agency (ERA)

27. European Securities and Markets Authority (ESMA)

28. European Training Foundation (ETF)

29. European Union Agency for Fundamental Rights (FRA)

30. Office for Harmonization in the Internal Market (OHIM)

31. The European Union's Judicial Cooperation Unit (Eurojust)

32. Translation Centre for the Bodies of the European Union (CdT)

33. European Defence Agency (EDA)

34. European Union Institute for Security Studies (EUISS)

35. European Union Satellite Centre (EUSC).

These 35 EU agencies are bodies "governed by European public law; they are distinct from the EU Institutions (Council, Parliament, Commission, etc.) and have their own legal personality." "They enjoy a new organizational mode and autonomy ensured by such elements as "granting of legal personality, budgetary autonomy, collective responsibility and own powers of the administrative board, the independence of the director, of the members of the scientific committees and of the boards of appeal." ${ }^{22}$ They also qualify as 'regulatory' as they can be involved in "co-regulation, self-regulation, recommendations, referral to the scientific authority, networking and pooling good practice, evaluating the

\footnotetext{
${ }^{121}$ This is the official description of EU agencies taken from the official web-page of EU agencies. Find at: http://europa.eu/agencies/regulatory_agencies_bodies/index_en.htm (last check September 2012).

${ }^{122}$ Draft Interinstitutional Agreement on the operating framework for the European regulatory agencies COM (2005) 59. P. 5.
} 
application and implementation of rules." ${ }^{123}$ Furthermore, the majority were created initially or later by secondary legislation. While the European Defence Agency (EDA), the European Union Institute for Security Studies (EUISS) and the European Union Satellite Centre (EUSC) were created by Council Joint Actions and may have found a place in the Lisbon Treaty (TEU Articles 42 and 45 and Protocol 10 as regards the EDA), the official webpage explicitly qualifies them as 'agencies'. Therefore, for the sake of providing a complete picture of the political accountability of EU agencies, they are also included in the focus of this study.

\subsubsection{Historical development of EU agencies and the reasons for creation}

The EU agencies are fruits of the evolving EU polity, which can be described as a "sui generis political system;" it is something more than an international organization but something less than a nation state. ${ }^{124}$ "Policy making in the EU goes beyond mere cooperation between member states' politicians, $\langle\ldots\rangle$ there is not only integration of substantive policies, but also integration in institutional terms, among national administrations and supranational EU organizations." 125 The scope of power exercised at the EU level includes not only 'legislative' decision making ("who adopts what, when, and according to what procedure?" $\left.{ }^{126}\right)$ but also "executive action in one form or another from implementation and standard setting to operational decisions by both majoritarian and non-majoritarian actors." 127 The EU Commission has become the principal executive institution with farreaching non-legislative functions, including the adoption of the so-called 'delegated legislation' (Article 290 TFEU $^{128}$ ), to fill in the details of legislation, yet it is not the only executive institution at the EU level.

EU agencies have become a tool to address various challenges of the integration process and technological change; "to a large extent, the creation of European agencies must be seen as a response to $<\ldots$. functional needs," ${ }^{129}$ which seem to have come, roughly speaking, in three waves ${ }^{130}$ starting in the 1970 s. The fact that "the development of agencies did

\footnotetext{
${ }^{123}$ Draft Interinstitutional Agreement on the operating framework for the European regulatory agencies COM (2005) 59. P. 4.

124 Eising and Kohler-Koch (1999) P. 3.

125 Groenleer (2009) P. 96.

126 Curtin (2009) P. 3.

127 Ibid.

${ }^{128}$ Article 290 TFEU reads as follows: "a legislative act may delegate to the Commission the power to adopt nonlegislative acts of general application to supplement or amend certain non-essential elements of the legislative act. The objective, content, scope and duration of the delegation of power shall be explicitly defined in the legislative acts. The essential elements of an area shall be reserved for the legislative act and accordingly shall not be the subject of a delegation of power."

${ }^{129}$ Dehousse (1997) P. 255.

${ }^{130} \operatorname{Vos}(2003)$ P. 114-115.
} 
not start earlier, i.e. during the 1960 s, has sometimes been attributed $<\ldots>$ to a ruling of the European Court of Justice, which was given in the framework of the European Coal and Steel Community," ${ }^{131}$ the Meroni case, to be discussed in 2.2.1.2. "The change in the political climate over a period of years led to a gradual reinterpretation of the legal consequences of the Meroni judgment by the Commission and the Council, which in the mid1970s came up with the first proposals for Community-style agencies, no longer believing that this Court of Justice judgment posed a substantial obstacle." ${ }^{132}$

The first wave came in 1975 when the first two agencies, namely the European Centre for the Development of Vocational Training (Cedefop) and the European Foundation for the Improvement of Living and Working Conditions (Eurofound), were created "to establish, inter alia, action programmes on social and environmental policy." ${ }^{133}$ Cedefop was set up to "assist the Commission in encouraging, at the Community level, the promotion and development of vocational training and of in-service training" (Article 2 (1) Regulation No. 337/75). Eurofound was thought to "contribute to the planning and establishment of better living and working conditions through action designed to increase and disseminate knowledge likely to assist this development" (Article 2 (1) Regulation No. 1365/75).

With EU regulations expanding in number and technical detail after the EU faced another round of integration (the Single European Act and the Maastricht Treaty), it became necessary to create bodies that could provide technical expertise and support policy- and decision-making tasks of the Commission. "Delegating technical work to independent agencies would expand the EU's regulatory capacity while allowing the Commission to concentrate on its core competences, namely policy-making and long-term strategic planning." ${ }^{34}$ Here, EU agencies were established to provide and facilitate technical expertise and assistance as well as to ensure consistence in the implementation of Community policies and legislation. 1989 saw the creation of the first so-called 'Community' agency, i.e., the European Environmental Agency, and by the end of the 1990s, the so-to-speak second wave, ten new agencies appeared.

Finally, the $21^{\text {st }}$ century has witnessed further agency proliferation, the third wave, which seems to be partly a response to the 'transparency deficit' avalanche that fell upon the comitology system. ${ }^{135} \mathrm{EU}$ agencies are thought to enhance the transparency of EU decision

\footnotetext{
131 Kreher (1997) P. 228.

132 Ibid.; see, also Lauwaars (1979) P. 371-372.

${ }^{133}$ Lauwaars (1979) P. 368.

134 Kelemen (2002) P. 101.

135 "In exercising its implementing powers, the Commission is assisted by representatives of the Member States through committees, in accordance with the "comitology" procedure. The committees are forums for discussion consisting of representatives from Member States and are chaired by the Commission.” (http://europa.eu/legislation_summaries/glossary/comitology_en.htm (last visit December 2013)). National representatives can block Commission's initiatives through committees. The criticism on the operation of the comitology system has become considerable, because there has been a lack of information about the number of, membership to, and
} 
making by 'bringing the Union closer to its citizen' directly (by placing agencies all over the Union) and indirectly (by, for example, inviting various interested groups to participate in agencies' decision making). ${ }^{136}$ However, it is arguable whether EU agencies have reached these objectives. Toggenburg notes in this respect,

The image evoked by Commission President Barroso, who compared the agencies to satellites, certainly appears to be unfortunately chosen: Barroso should not be surprised if, from the citizens' perspective, what agencies mainly have in common with satellites is that they are neither visible nor well grounded. ${ }^{137}$

EU agencies have been thus created for various functional reasons, including to overcome the lack of technical knowledge (for instance, European Food Safety Agency and Office for Harmonization in the Internal Market), to promote cooperation (for instance, the earlier mentioned Cedefop) and to enhance credibility of commitment (for instance, European Aviation Safety Agency). ${ }^{138}$

At the same time, "while there may be functional benefits to be gained from creating EUlevel regulatory bodies," 139 their creation as well as designs are not determined only "by functional imperatives - indeed, sometimes such bodies may be designed to be ineffective. Rather than functional necessities, political considerations drive" the agencification process and "the fundamental choice of whether to create a centralised, EU-level body or instead to establish a looser network of national regulatory authorities." 140 "Since the beginning of the 1990s, it has become clear that Member State governments are unwilling to countenance any significant expansion of the Commission and instead prefer delegating new regulatory tasks to bodies outside the Commission hierarchy." ${ }^{141}$ In this light, agencies represent an attempt "to solve the traditional Community administrative deficit through instruments that may be politically acceptable both to the national governments and the supranational institution $\langle\ldots\rangle$ without implying a direct reinforcement of the Commission." ${ }^{142}$ Thus, a mixture of functional necessity with acceptability for relevant veto players involved in the creation of agencies seems to offer a more nuanced explanation of the proliferation of EU agencies.

In addition, scholars also mention a number of practical considerations in the process of the creation of agencies. Agencies offer greater staffing flexibility; they reduce the admin-

\footnotetext{
operation of the committees. It has also resulted from the fact that the directly elected European Parliament has had little information and weak powers in relation to committees' decision.

136 "The spread of agencies beyond Brussels and Luxembourg adds to the visibility of the Union and of course although not mentioned by the Commission - to options for political bargaining” (Schneider (2009) P. 33).

137 Toggenburg (2007) P. 3.

${ }_{138}$ Magnette (2005) P. 9.

${ }^{139}$ Kelemen and Tarrant (2011) P. 923.

${ }^{140}$ Kelemen and Tarrant (2011) P. 923.

${ }^{141}$ Ibid. P. 929.

${ }^{142}$ Chiti (2009) P. 1398.
} 
istration workload so that the Commission can concentrate on strategy policy, and insulate the resolution of technical regulatory issues from day-to-day political change. ${ }^{143}$ They "facilitate both European-wide cooperation between stakeholders" and "efficient and flexible implementation of EU legislation"; "offer cost-savings to industry and business"; "reduce transaction costs for national governments and thereby increase bureaucratic efficiency"; "and/or encourage the harmonisation of regulatory practices in the member states." 144

All in all, the creation and proliferation of EU agencies can be explained by "the quantitative expansion of EC jurisdiction" and "qualitative change within EC policy-making though both horizontal and vertical co-ordination and co-operation." ${ }^{145}$

\subsubsection{EU agencies' functions}

While agencies' tasks vary greatly from agency to agency, six types of functions that EU agencies may exercise can be distinguished. They can be created to gather information, enhance cooperation, provide service, advise, take decisions which affect third parties, and supervise the implementation of EU law. ${ }^{146}$

An agency with an information function is, for example, the European Centre for the Development of Vocational Training. It develops the vocational education and training policy by providing research and support in the form of publications, the creation of databases, the organization of workshops, and the dissemination of information for the general public. The European Union's Judicial Cooperation Unit is an illustrative example of an agency with cooperation tasks; its mission is to improve and stimulate the coordination of investigation and prosecution among the member states by "facilitating the execution of international mutual legal assistance and the implementation of extradition requests." ${ }^{147} \mathrm{~A}$ typical service-oriented agency is the Translation Centre for the Bodies of the European Union that provides translations of various documents, probably one of the most important administrative services for the bodies of a union with 24 official languages. Furthermore, the European Aviation Safety Agency assists the Commission with drafting rules in the

\footnotetext{
143 Vos (2003) P. 114-115.

144 Groenleer (2009) P. 100-101.

145 Kreher (1997) P. 241.

${ }^{146}$ It has to be noted that various classifications exist in relation to EU agencies' functions. See, e.g., Chiti distinguishing between agencies with production and dissemination of information, advisory, and assistant and administrative decision-making functions (Chiti (2009) P. 1395); Griller and Orator classifying agencies in ordinary agencies with information gathering and coordinating functions, agencies with pre-decision advisory and decisionmaking powers (Griller and Orator (2010) P. 3); and Lavrijssen and Ottow treating EU agencies as 'European supervisory authorities' since they are "involved in supervising and regulating markets or market parties, especially if they advise on the adoption of new European legislation and policies and monitor uniform application of EU law" (Lavrijssen and Ottow (2012) P. 423).

147 This information is taken from the official web-page of the agency. Find at: http://www.eurojust.europa.eu/mission.htm (last check May 2010).
} 
relevant area. Also, it has the power to issue certificates "for aeronautical products and organisations involved in their design, production and maintenance." 148 This makes EASA an agency with advisory and decision-making powers.

While EASA enjoys regulatory decision-making powers, the recently created EU financial agencies (EBA, ESMA and EIOPA) have been entrusted also with supervisory responsibilities, including the power to issue instructions to relevant financial institutions bypassing national supervisory authorities if the latter do not comply with the Commission's formal opinion or these agencies' decisions (Articles 17 and 18 of Regulations 1093/2010, $1094 / 2010$, and 1095/2010). What is more is that Regulation 513/2011 has made ESMA exclusively responsible for the registration and supervision, including the right to impose sanctions, of credit rating agencies in the EU. ESMA has received the powers to examine and take copies of any relevant records and material, ask for oral explanation, summon and hear persons, require telephone and data traffic records, and interview persons (Article 23 (b) of Regulation 513/2011), powers not available even to the European Parliament in its investigatory capacity. ESMA's sanctioning arsenal includes withdrawal of registrations, temporary prohibitions on issuing ratings, suspension of the use of ratings for regulatory purposes, and issuance of public notice (Article 24 of Regulation 513/2011).

Although some suggest that EU agencies do not seem 'powerful enough' in the sense that most do not formally enjoy policy-making discretion, ${ }^{149}$ "influence does not equal formal powers." ${ }^{50} \mathrm{EU}$ agencies' input into the EU policy-making process should not be underestimated. "Today, the tasks and competences of the various agencies are remarkably diverse and are having a growing impact on EU citizens and enterprises." ${ }^{151}$ EU agencies feed into policy making on the EU level by collecting and disseminating information, raising awareness on a given issue, contributing to soft coordination and providing expert advice. ${ }^{152}$ The European Parliament states, in this light, that "although at first the regulatory agencies appear to be 'micro-institutions', they nevertheless have a 'macro-impact' at the level of European governance." ${ }^{153}$ All in all, except for the existing decision-making agencies, EU agencies' involvement may be indirect (hence difficult to measure) but can be of direct significance.

Whose tasks do agencies exercise? In its various documents, "the Commission has presented itself as the principal that must evaluate the possibility of delegating a share of its

\footnotetext{
${ }^{148}$ This information is taken from the official web-page of EU agencies. Find at: http://europa.eu/agencies/community_agencies/easa/index_en.htm (last check May 2010).

${ }^{149}$ van Ooik, for example, concludes that the importance of EU agencies should not be exaggerated at the moment, at least before they have been delegated 'more intense responsibilities' (van Ooik (2005) P. 152).

${ }^{150}$ Christiansen (2002) P. 80.

${ }^{151}$ Saurer (2010) P. 619.

152 The Ramboll Evaluation, Volume I. P. 16.

${ }^{153}$ European Parliament resolution of 21 October 2008 on a strategy for the future settlement of the institutional aspects of Regulatory Agencies (2008/2103(INI)).
} 
powers to autonomous bodies, which will assist in completing its tasks and operating the internal market." ${ }^{54}$ From this view point, EU agencies are merely auxiliaries of the Commission. ${ }^{155}$ At the same time, EU agencies have been assigned tasks that have been previously exercised by national authorities, the Council or its "fragmentary and opaque structures." 156 Thus, nearly every EU agency has an institutional or procedural forerunner, such as:

Technical Assistance Units (in the case of the European Training Foundation), the comitology system (two scientific committees in the case of the EMEA), procedural mechanisms within the EP and within the Commission (in the case of the European Monitoring Centre for Drugs and Drug Addiction), or Community programmes (the CORINE programme in the case of the EEA $\langle\ldots\rangle$ ) or activities which were undertaken at an intergovernmental level. In two cases, the emergence of an agency took place alongside the decision to establish a new Community regime (Community plant variety protection and the Community trademark). ${ }^{157}$

In addition, some agencies, such as the recently created ACER (2009), constitute "an institutionalisation of the previously existing informal regulatory networks." 158 Thus, considering different levels where EU agencies' functions originate, "a partial "fusion” between the two orders of authorities" (national and European) has taken place. ${ }^{159}$ In the case of ESMA's exclusive supervisory and enforcement powers in relation to registration, supervision, and sanctioning of credit rating agencies, one can talk about the transfer of almost all respective powers from the national to the EU level.

Furthermore, Kelemen argues that the differences in the powers delegated to EU agencies interrelate with the political preferences of the key players, i.e., the Council and the Commission (and after the Maastricht Treaty also the European Parliament). ${ }^{160}$ According

\footnotetext{
154 Curtin (2009) P. 145.

155 Dehousse (2008) P. 792.

${ }^{156}$ Curtin (2009) P. 164.

${ }^{157}$ Kreher (1997) P. 233; see, also Vos (2000) P. 1113 (showing that agencies have been created to replace various committees of the Commission and arguing that the visibility of agencies facilitates holding the EU structures to account).

${ }^{158}$ Zinzani (2012) P. 156; see, also Levi-Faur (2011) on the discussion of how agencies replace networks.

${ }^{159}$ Chiti (2000) P. 342.

160 Kelemen (2002) P. 103.
}

"Member state governments were sensitive to the potential threat that European agencies posed to their national administrations. In order to secure the approval of resistant member states, the Commission proposed that the agencies operate as the hubs of networks of national administrative agencies, research centres, testing laboratories and other expert bodies. <...> When the EMEA in London receives an application for a Community Marketing Authorisation for a new medicinal product, the agency delegates the assessment of the product to two national testing authorities, a rapporteur and a co-rapporteur. The laboratories of these national authorities do the actual testing of the product, subject to EMEA testing requirements, and report their findings back to the EMEA in London" (Ibid. P. 103-104). 
to him, when there is an agreement that regulation of a policy requires delegation of powers, the option of an 'EU agency' is likely to be chosen when it suits the interests of all key institutions involved in the creation and delegation processes. This is particularly the case when it secures control over newly created structures for the member states, for instance by means of representation, as well as ensures oversight over agencies for the European Parliament, and furthermore takes into account that "the Commission is likely to resist the creation of agencies that strip it of authority in areas where it has well-established powers, and, given its role in policy initiation, it is well positioned to do so." ${ }^{161}$ Also, Kelemen and Tarrant argue that member states are more likely to delegate some tasks to networks of national authorities (rather than to EU agencies) when they want to "preserve control over the content of regulation applied within their jurisdiction and thus to influence its distributional impact." ${ }^{162}$ The degree of involvement of the member states and of the Commission in the operation of individual EU agencies seems to depend therefore on whether an EU agency has been given the functions that have been exercised or could have been exercised by national authorities or the Commission.

\subsubsection{EU agencies and the EU institutional balance}

The interrelations between EU different institutions and respect of each other's boundaries have become known as the principle of institutional balance defined by the Court of Justice of the European Union in Chernobyl as "a system for distributing powers among the different Community institutions, assigning to each institution its own role in the institutional structure of the Community and the accomplishment of the tasks entrusted to the Community." 163 While the principle does not derive from the treaty explicitly, the Court did link it to Article 7 TEC, which is a part of Article 13 TEU today, stating that each institution shall act within the limits of the powers conferred on it in the Treaties. Never addressed by the Court, yet widely discussed by academics, is the question of whether creating EU agencies upsets the institutional balance. The matter of EU agencies and the institutional balance is relevant for the question of the political accountability of agencies to be

\footnotetext{
${ }^{161}$ Kelemen (2002) P. 111; see, also: Kelemen and Tarrant (2011) P. 927-928.

162 Kelemen and Tarrant (2011) P. 930.

"If legislation potentially exposes state-owned entities to competition and there is a sufficiently large set of member states with state-owned entities, then the institutions selected as authoritative regulators are national regulatory authorities, typically organised into networks. In some sectors, we see multiple institutions created. The explanation for this is that lawmakers may succeed in dividing regulation in a sector into different types of issues, where distributional conflict is high with respect to one set of issues and low with respect to another. For instance, in the rail sector, regulation of access to national rail networks, which potentially has high distributional consequences, has been separated from safety regulation, which entails less distributional conflict. Access to rail networks in practice remains subject to national control, while safety regulation has been delegated to a European agency (the European Railway Agency)" (Ibid. P. 932).

${ }^{163}$ Case 70/88, European Parliament v Council (1990) ECR I-2041, at I-2072, para. 21.
} 
able to position EU agencies within the EU institutional constellation, which in turn may bring more clarity and perhaps even facilitate reaching a common understanding as to who should hold EU agencies to account. Yet, the complexity of the issue does not allow that.

The issue of institutional balance is complex in a number of respects. First, according to Jacqué it can be envisaged in two different ways:

From a legal point of view, institutional balance is a constitutional principle which must be respected by the institutions and the Member States; infringements may be condemned and sanctioned by the Court of Justice. From a political point of view, it can be envisaged as a means of describing the way the relationship between the institutions is organized. ${ }^{164}$

Especially considering the latter, the principle of institutional balance seems to be a rather dynamic concept as the balance of powers between the EU main institutions, especially between the Council and the European Parliament, has experienced significant changes in the last four decades ${ }^{165}$ (see Table 2.1. in section 2.1.1.2.). The dynamism makes it difficult to draw clear boundaries between the powers of the EU institutions. Second, the EU institutional architecture is not governed by the separation of powers doctrine. ${ }^{166}$ In addition, "institutional balance does not imply an equal allocation of power among the European institutions, but only that the relative position of each institution $\langle\ldots\rangle$ should be preserved." 167 Identifying the locus of the executive power is quite difficult, because it is shared among the Commission, Council and European Council, and "the legislative power is divided between the Commission, EP, and the Council." ${ }^{168}$ This may complicate the allocation of different natures of powers to specific EU institutions. The inability to do that may hinder spotting encroachment of one institution on the powers of another institution if EU institutions can exercise powers of a 'mixed nature'. Moreover, this mixture has been quite dynamic. Finally, scholars distinguish between two dimensions of the principle of institutional balance, i.e., vertical (balance between the EU institutions and member states) and horizontal (the balanced interaction among the EU institutions and actors), ${ }^{169}$ which may require establishing different sets of criteria to define the (im)balance. As a whole, "institutional balance remains at present a rather elusive concept of an uncertain scope." 170

\footnotetext{
164 Jacqué (2004) P. 383.

165 See, Craig (2003) for the historical evolution of the institutional balance

166 "Often, the parallel between institutional balance and the doctrine of separation of powers is drawn. However, one cannot but acknowledge that institutional balance fits uneasily within the contours usually ascribed to the doctrine of trias politica" (Lenaerts and Verhoeven (2002) P. 38).

${ }^{167}$ Majone (2009) P. 186-187.

${ }^{168}$ Craig (2005) P. 316, 329, 344.

${ }^{169}$ Zinzani (2012) P. 53; Lenaerts and Verhoeven (2002) P. 43; Dehousse (1997) P. 258.

${ }^{170}$ Lenaerts and Verhoeven (2002) P. 38.
} 
In relation to EU agencies, scholars have discussed the issue of institutional balance connecting it to the Meroni judgment, to be discussed in 2.2.1.2., ${ }^{171}$ more specifically to its restrictive holding concerning the nature of powers that can be delegated to EU agencies. As Vos explains, in Meroni, the Court justified its position about lawful delegation of 'clearly defined executive powers' (and not discretionary powers) by referring to the balance of powers characterizing the institutional structure of the Community. ${ }^{172}$ She argues that the prohibition against the delegation of discretionary powers "seems to lie in its understanding of democratic legitimacy in which the powers of any rule-making body ultimately should be traced back to the authority of a democratically elected parliament." ${ }^{173}$ Indeed, one of the EU agencies' founding acts states in its recital: "according to the case-law of the Court of Justice of the European Union, and in order to respect the principle of institutional balance, the power to adopt decisions of general application may not be conferred on an agency" (Recital 29 of Regulation 100/2013 amending the European Maritime Safety Agency's founding regulation). Yet, Vos is also quick to point out (in the same paragraph) that "many "discretionary" powers are at present generally delegated to the administration." 174

Does this mean that the institutional balance is upset? It depends. Following the Court's reasoning, two essential elements seem to prevent the distortion of the institutional balance. While the EU institutions can use assistant bodies, these assistants cannot enjoy discretionary powers, which is reserved for the EU institutions. Such assistants have to be supervised and be subject to obligations, such as reporting and giving reasons, imposed on the EU institutions by the treaty. If these elements are secured, the institutional balance seems fine. At the same time, the institutional balance may be upset given the increasing impact of the formally weak but informally strong EU agencies. ${ }^{175}$

In any case, if the institutional balance is disturbed, who is the winner and who is the loser? EU agencies have become the recipients of powers that have been or could have been exercised by national authorities, intergovernmental structures, including those of the Council, and/or by the Commission. These are thus among potential losers. To give a more specific answer, one would have to look at each individual EU agency to determine whose functions it has received and how the loss of the functions by that authority in favor of EU agency has been compensated, which would include analyzing controlling and supervising tasks that 'the loser' enjoys in relation to the EU agency. The winners will be those institu-

\footnotetext{
${ }^{171}$ At the same, time Chamon (2010) argues that Meroni's 'balance of power' should not be equalized with Chernobyls institutional balance and questions the application of the judgment in relation to the delegation to EU agencies.

172 Vos (2000) P. 1123.

173 Ibid.

174 Ibid.

175 "It may be legally and politically difficult for the Commission to ignore the agency's advice" (Kelemen and Tarrant (2011) P. 927), see, also other authors on this point in Chapter 1.1. (fn 14).
} 
tions that would gain some powers which they did not have in the first place, for instance, the European Parliament, if it receives strong scrutiny powers over EU agencies exercising tasks that belonged previously to national authorities which are clearly outside the grip of the European Parliament.

At the same time, considering the specifics of the creation of EU agencies that occurs with the participation of the main institutions of the EU and potential winners and losers, one might wonder if it is practically possible to spot an imbalance and to overturn it. Jacqué states that "any encroachment by one institution on the powers allotted to another institution is consequently prohibited. The same applies to any delegation of power from one of the institutions to an external body or to another institution insofar as this would alter the institutional balance." ${ }^{176}$ But the creation of and delegation to EU agencies is done in agreement with all main institutions. Normally, the Commission initiates a founding act and is included in further negotiations; the Council and the European Parliament share the decisive power to enact the legislative proposal, especially after the Lisbon Treaty. In a way, independent regulatory agencies may be seen "to be supportive of the principle of the balancing powers," 177 if institutional balance is understood as "the necessary frame within which different interests can discuss with each other in order to achieve solutions that are acceptable to all and do not unduly abridge the liberties of anyone." ${ }^{178}$ Furthermore, considering that the separation of powers is rather elastic in the EU (if applicable at all), the possibility of redistributing functions among the key players may hinder spotting any imbalance. Finally, as long as the key players and potential losers agree to create an agency, the Court is unlikely to be bothered with the question of imbalance or to overturn the action adopted by the key players. ${ }^{179}$

What about positioning EU agencies within the EU institutional constellation? The situation is crystal clear concerning the position of the executive agencies created and abol-

\footnotetext{
176 Jacqué (2004) P.385.

177 Everson (1995) P. 190.

${ }^{178}$ Lenaerts and Verhoeven (2002) P. 42-43.

${ }^{179}$ As of this writing, the only court ruling concerning the creation of an EU agency has been the challenge of the legal basis for passing ENISA's founding act. The UK challenged the founding regulation of ENISA arguing that the general Article 308 TEC was the only legal basis possible (and not sectoral Article 95 TEC); the Court upheld the applicability of Article 95 (Case C-217/04, United Kingdom of Great Britain and Northern Ireland v. European Parliament and Council of the European Union, 2 May 2006).

It is not surprising that the claim came from the UK. The House of Commons' European Scrutiny Committee seems to look quite closely at the EU decision making. For instance, it also monitored proposals where the former Article 308 TEC was cited as the legal basis. Its report concluded that the Committee was not convinced by what seems to be the general opinion on using the purposive interpretation of this provision (pass regulations necessary to attain Community objectives), rather than the literal approach (an action had to be relevant for the operation of the common market). (House of Commons European Scrutiny Committee, Article 308 of the EC Treaty, Twentyninth Report of Session 2006-07, 4 July 2007) Interestingly, the new Article 352 TFEU got rid of the troubling (for the House of Commons) 'common market' formulation, thus arguably converging the mentioned literal and purposive approaches of interpretation.
} 
ished by the Commission pursuant to Regulation Council Regulation (EC) No 58/2003. As they are the Commission's assistants, their position is below the Commission, which is responsible for them. The place of regulatory agencies is not necessarily there because they are thought to be independent from the Commission. ${ }^{180}$ Considering that agencies' founding acts are passed by the Council with an increasing involvement of the European Parliament and that these institutions enjoy supervisory functions in relation to EU agencies, there is a direct line between them and EU agencies. Given the origins of EU agencies' powers, they might be subordinate to the Commission and the member states, which may enjoy some powers of control over agencies, for instance, via agencies' management boards. Thus, being "a matter of secondary Community law," ${ }^{181}$ EU agencies can be placed below the EU institutions and they "operate outside the Commission and Council." 182 More specific coordinates are difficult to give. Moreover, the coordinates seem to be still under discussion given the ongoing political strategizing, even after a three-year negotiation within the Interinstitutional Working Group on EU agencies whose non-binding results are analyzed in section 2.2.6.

\section{Conclusion}

The intention of section 2.1. was to introduce the institutions subject to the accountability relationship under investigation. It was shown that, given their representative roles and functions, the Council and the European Parliament can be seen as the EU representative institutions, the Union Legislator, the EU budgetary authority and, arguably, also as the EU political accountability forum. While (and in part because) the latter is not formalized in the treaty, this book focuses specifically on Council's and Parliament's accountability powers in relation to EU agencies, the accountability actor also introduced by this section. This book investigates the political accountability of all $35 \mathrm{EU}$ agencies listed on the official web-page of the EU institutions and agencies. Considering their growing number, EU agencies seem to have become a popular tool of the Union Legislator in addressing the needs and challenges brought about by the quantitative and qualitative expansion of the EU jurisdiction and its multi-level structure. EU agencies have been created for both functional and political reasons. They are considered to be autonomous from both 'political' interference from the EU's and the member states' interests to be able to exercise their functions, which include information gathering, enhancing cooperation, providing service, advising, taking individual decisions, and supervising. Considering the complexity and dynamism of the concept of the institutional balance, it is difficult to give the exact coordinates of EU agencies within the EU institutional constellation, which may be partly due to

\footnotetext{
180 The Ramboll evaluation, Volume I. P. 11; Vos (2005) P. 123.

181 van Ooik (2005) P. 128.

${ }^{182}$ Craig (2003) P. 116.
} 
the fact that the EU main institutions' controlling powers over EU agencies, in turn impacting the position of agencies, are still in the making.

\subsection{Investigating the Political Accountability of EU Agencies}

This section investigates the political accountability of EU agencies with the help of five processes identified in Chapter 1 in which political accountability can be shaped and exercised. It starts with the discussion of legal rules allowing the creation of agencies and delegation to them (2.2.1.). Here, it is shown that in the absence of a treaty provision regulating the creation of EU agencies, delegation and accountability, these issues have been decided by the Union Legislator, which has certain implications for the political accountability of EU agencies. The appointment and removal of agencies' unelected officials by the EU representative institutions are analyzed next (2.2.2.). A great diversity of (re)appointment and removal formulas demonstrates how politically sensitive the questions of appointment and removal are for delimiting the roles and hence influences between the EU main institutions over the so-called 'independent' EU agencies. Furthermore, sub-section 2.2.3. analyzes accountability aspects of statutory regulation of the operation of agencies, namely reporting and evaluation of accountability obligations, and shows what shortcomings the existing accountability obligations face. The discussion of the financial oversight of EU agencies follows (2.2.4.) This sub-section demonstrates how well developed rules and practices concerning agencies' financial oversight are. The question of political scrutiny over EU agencies is analyzed after that in sub-section 2.2.5. This sub-section devotes its attention to the rules, practices, and challenges to the scrutiny tool and concludes that this tool is still developing. Finally, the recently released results of the Interinstitutional Working Group on EU agencies (July 2012) are critically assessed in sub-section 2.2.6. which pinpoints the issues where the progress has been made and matters that remain unresolved. As a whole, this section discusses the current issues of and challenges to the political accountability of EU agencies by offering a detailed analysis of relevant rules and, to a certain extent, existing practices. The findings of this section serve as the basis for assessing the political accountability of EU agencies in section 2.3.

\subsubsection{Creation of and Delegation to EU agencies: at the EU Legislator's Discretion}

The creation and delegation processes are determinant for political accountability, more specifically the availability and design of accountability obligations. It is when the legislator creates an agency and delegates to it certain powers that it faces the question of how the agency should be made accountable for the exercise of delegated powers. This section discusses the existing creation and delegation standards and the implications they have in relation to the organization of the political accountability of EU agencies (2.2.1.1. and 
2.2.1.2. respectively). It shows that the risks from creating agencies in the absence of a treaty provision that allows the creation and delegation to agencies is expanding 'Eurocracy' without there being functional needs necessarily and with accountability deficits.

\subsubsection{The legality of the creation of EU agencies}

"Once the Community institutions began to function, practice quite naturally gave birth to bodies for which no provision was made initially." ${ }^{183}$ Indeed, no treaty provision has ever authorized the creation of EU agencies; yet, $35 \mathrm{EU}$ agencies exist. This section discusses the legality of creating EU agencies in the absence of a relevant treaty provision and implications that the existing situation has on the organization of the political accountability of EU agencies.

\section{Upon what legal basis are EU agencies created?}

While no treaty provision has ever existed to allow creating EU agencies explicitly, the former and existing treaties have provided the so-called 'open clauses' which the Union Legislator has used to create EU agencies. These include, for instance, Article 308 TEC (now Article 352 TFEU), which states that the Council and the European Parliament may adopt appropriate measures if action by the Union should prove necessary. Also, a number of specific 'sectoral' provisions regulating specific policies have been used to establish EU agencies, such as Article 95 TEC (now Article 114 TFEU $^{184}$ ), which, according to the Court of Justice, can be used to adopt a measure aiming at the establishment and functioning of the internal market. ${ }^{185}$ Some scholars argue that "the legal basis for establishing an agency [is proposed to] be the same as that authorizing the corresponding policy rather than the general Article 308 EC. The logic of the proposal is clear - the agency is simply an instrument of policy implementation." ${ }^{186}$ Indeed, the majority of EU agencies have been created on the basis of sectoral provisions. Table 2.2. below provides the exact data.

\footnotetext{
${ }^{183}$ Report of the Working Party examining the problem of the enlargement of the powers of the European Parliament, Bull. Of the EC 1972, Supp. 4, P. 27 (in: Lauwaars (1979) P. 365).

184 "The European Parliament and the Council shall, acting in accordance with the ordinary legislative procedure and after consulting the Economic and Social Committee, adopt the measures for the approximation of the provisions laid down by law, regulation or administrative action in Member States which have as their object the establishment and functioning of the internal market."

${ }^{185}$ Case C-217/04, United Kingdom of Great Britain and Northern Ireland v European Parliament and Council of the European Union, 2006. See, also, Hofmann and Morini (2012) on the discussion of the flexibility of the term 'measures' under specific policy-related treaty provisions.

${ }^{186}$ Majone (2006) P. 197.
} 
Table 2.2. The legal basis for the creation of the existing EU agencies

\begin{tabular}{|c|c|}
\hline $\begin{array}{l}\text { Legal base used (Treaty); Articles } \\
\text { of another treaty replacing } \\
\text { relevant TEC provisions }\end{array}$ & Agency created (the year of creation) \\
\hline Article $13(\mathrm{TEC})^{187}$ & EIGE (2006) \\
\hline Article $37\left(\right.$ TEC) ${ }^{188}$ & EFCA (2005), EFSA (2002) \\
\hline Article 66 (TEC); & Frontex (2004); \\
\hline Articles 74 and 78 (TFEU) ${ }^{189}$ & IT-Agency (2011), EASO (2010) \\
\hline Article 71 (TEC) & ERA (2004) \\
\hline Article 80 (TEC) & EASA (2008), EMSA (2002) \\
\hline $\begin{array}{l}\text { Article } 95(\mathrm{TEC})^{190} \\
\text { Article } 114 \text { (TFEU) }\end{array}$ & $\begin{array}{l}\text { ACER (2009), BEREC (2009), ECHA (2006), EMSA (2004), EMA (2004), } \\
\text { EFSA (2002); } \\
\text { EBA (2010), ESMA (2010), EIOPA (2010) }\end{array}$ \\
\hline Article 150 (TEC) & ETF (2008) \\
\hline Article $152(\mathrm{TEC})^{191}$ & ECDC (2004), EMCDDA (2006), EMA (2004), EFSA (2002) \\
\hline Article 175 (TEC) & EEA (2009) \\
\hline Article 308 (TEC); & GSA (2004), FRA (2007); \\
\hline Article 235 (TEC); & CPVO (1994), EU-OSHA (1994), OHIM (1994), CdT (1994); \\
\hline Article 235 (EEC) & Cedefop (1975), Eurofound (1975) \\
\hline Article 14 (TEU) & EDA (2004), EUSC (2001), EUISS (2001) \\
\hline Articles 30 and 34 (TEU) & Europol (2009), Cepol (2005) \\
\hline Articles 31 and 34 (TEU) & Eurojust (2002) \\
\hline
\end{tabular}

Concerning the EU agencies of the former second and third pillars, they have been created by other legal instruments, such as Council Joint Decisions or intergovernmental conventions (in the case of Europol). With respect to the latter, some scholars have argued that when the legislative form of 'an intergovernmental convention' has been chosen to establish an EU agency, there is an additional accountability layer in relation to the creation decision - ratification by national legislatures - which increases democratic credentials of the agency. ${ }^{192}$ In all other cases a decision to create an agency has been a piece of secondary legislation that was passed by the Council alone or with the European Parliament. This has certain implications for the accountability of EU agencies.

\footnotetext{
187 Together with Article 141 (TEC).

188 Together with Articles 95, 133 and 152 in the case of EFSA.

189 Together with Articles 77, 79, 81, 85 and 88 (TFEU) in the case of IT-Agency.

190 Together with Article 152 (TEC) in the case of EMA; together with Articles 37, 133 and 152 in the case of EFSA.

191 Together with Article 95 (TEC) in the case of EMA; together with Articles 37, 95 and 133 in the case of EFSA.

192 Davies (2012) P. 331-333.
} 


\section{Implications of creating EU agencies without the explicit treaty authorization to do so}

The absence of an explicit treaty provision authorizing the Union Legislator to create EU agencies has several implications. First, it concerns the question of the legitimacy of EU agencies. The limits of the Union's competences are governed by the principle of conferral (Article $5 \mathrm{TEU}$ ). Strictly speaking, the absence of a treaty provision providing the possibility to create EU agencies can be interpreted as a prohibition to do so. In a similar way, the absence of any reference to EU agencies in the treaty articles on non-legislative acts (Articles 290 and especially 291) can be interpreted as a prohibition to empower agencies with legally-binding powers. While the decisions of the Commission, such as "approval or refusal of an EU-wide approval of a novel food," are "implementing decisions in the sense of Article 291 based on comitology," OHIM's acts on registering or refusing to give a European Trade Mark "do clearly not fall under this category;" "OHIM as such is not recognized by Article 288 TFEU as an actor that can adopt acts 'to exercise the Union's competences.'."193

The second implication concerns the potential lack of justifications for creating agencies and the lack of necessary accountability mechanisms. As the use of competences of the Union is governed by the principle of proportionality, the action of the Union Legislator to create EU agencies "should not exceed what is necessary to achieve the objectives of the Treaties" (Article 5 (4) TEU). Furthermore, Article 296 TFEU obliges reasons on which legal acts are based to be stated. The burden of proof to justify the creation of an EU agency thus rests upon the Union Legislator. Does it justify its decisions? According to the Ramboll evaluation of 26 EU agencies it does not: agencies' founding acts "did not sufficiently explain why new instruments had to be implemented through an agency, rather than something else." ${ }^{194}$ EU agencies' founding acts refer to various treaty provisions as the legal basis, but they seem to do that for procedural, rather than substantive purposes. While this can ensure procedural legitimacy of EU agencies that are created in accordance with the legislative procedures set by the Treaty, substantive legitimacy suffers from the lack of justification on the substance. ${ }^{195}$

Furthermore, as the Union Legislator uses generally formulated treaty provisions that were not designed specifically for creating EU agencies, such provisions clearly lack requirements relevant to regulate institutional questions, such as, for instance, an obligation upon the legislator to establish a certain accountability framework when creating another body. Here, the creation of and delegation to agencies seem to have been "made with the minimum of democratic control, leaving the Council [and subsequently the EP] virtually

\footnotetext{
193 Vos (forthcoming in 2014) P. 44.

194 "Alternatives to creating agencies were paid limited attention until impact assessments came into practice. The creation of agencies is now justified in a transparent way, although it is not yet fully evidence-based and still does not cover all relevant issues" (The Rambol Evaluation, Volume I. P. i-ii).

195 Using Majone’s terminology of procedural and substantive legitimacy (Majone (1996) P. 291-296).
} 
free to frame the control mechanisms, or lack thereof, of the agency to whom they are delegating power." 196

Third, there is no general framework prescribing the criteria of when an EU agency can be created. The absence of such criteria and the mentioned absence of a substantive justification hurdle upon the legislator makes it easy to expand "Eurocracy" ${ }^{197}$ without functional necessity and arguably good reasons. "The risk of remaining $\langle\ldots\rangle$ vague about when it is useful to create agencies is that in a relatively short period of time all kinds of different agencies could be created without a clear ratio." ${ }^{198}$ Indeed, the number of EU agencies has tripled since 2000 and some of existing EU agencies lack reasons for their creation. ${ }^{199}$ As an example, Eurofound and EU-OSHA seem to have a similar thematic focus. Also, there are two 'police agencies' (Cepol and Europol), which could have been merged considering the financial problems that Cepol experienced recently. In addition to its financial malpractices (see Chapter 2.2.4.2.), it had inefficient administration with 27 national board members and only 24 staff. As the high number of agencies may also influence the scope of accountability deficit, it seems reasonable "to create or maintain independent agencies only if there is a clear rationale to do so. The rationale should be clearly and comprehensively debated during the legislative process preceding the creation or evaluation of a particular agency." 200

Fourth, the absence of a relevant treaty provision has implications for the organization of the political accountability of EU agencies. Using different treaty provisions when creating agencies has impacted the legislative procedure according to which an agency's founding act would be passed, which has determined the composition of the legislative authority taking the final decision. While the Commission has normally been the initiator of the existing agencies' founding acts (except for the agencies created by Council Joint Actions), the legislating authority has varied. As the existing EU agencies have been created in three waves, i.e., 1975, 1990s, and the first decade of the 2000s, their founding acts have been passed in accordance with different treaties reflecting a different balance of power among the main EU institutions, especially the extent to which the legislative power has been shared between the Council and the European Parliament (see Table 2.1. in Chapter 2.1.1.2.). Depending on the legislative basis, it was either the Council alone or together with the consultative or co-legislating European Parliament that adopted the founding regulation. It is interesting to note that the ten agencies that were created in the second wave, in the 1990s, were created by the consultation procedure with a limited influence from the European Parliament and that,

\footnotetext{
${ }^{196}$ Davies (2012) P. 334.

${ }^{197}$ Kelemen and Tarrant (2011)P. 922.

198 Verhey (2005) P. 65.

199 The Rambol Evaluation, Volume I. P. i-ii.

${ }^{200}$ Heringa and Verhey (2003) P. 166.
} 
In two cases (the EMEA and the Community Plant Variety Office), the Council changed the legal principle on which the Commission had originally based the proposal. Using Article $100 \mathrm{~A}$, EC Treaty, as proposed by the Commission for the EMEA, would have required the co-operation procedure and thus more EP influence, and, additionally, qualified majority voting in the Council. ${ }^{201}$

The different sets of institutions involved in the passage of the existing agencies' founding acts have influenced agencies' accountability designs. A correlation between the European Parliament's legislative role and the amount of accountability obligations that individual agencies are subject to is noticeable. ${ }^{202}$ The correlation is the following: the stronger legislative position the European Parliament had to play, the more involvement in the further operation of agencies it obtained, and as the European Parliament's involvement is normally interconnected with accountability settings, the more accountability-related provisions have been included in agencies' founding acts. Let us look at two examples (see also section 2.2.2.2.).

The first example concerns a correlation between the legislative role of the European Parliament and the existence of provisions prescribing that agencies' directors are subject to hearings. There are three types of obligations to take part in hearings that EU agencies' directors can be subject to: upon their appointment, the extension of the term of office, and on performance of their duties. ${ }^{203}$ While hearings upon the appointment and extension of the term of office are held before the European Parliament, both the Council and the European Parliament may invite agencies' directors for performance hearings. In the founding

\footnotetext{
${ }^{201}$ Kreher (1997) P. 232.

202 The proposed correlation is based only on the analysis of the EP's formal involvement in passing the founding act and the role it plays in holding agencies' to account. It does not include other factors, such as the field in which the agency was created, interinstitutional relations between the Council and the European Parliament, which may be influencing factors as well.

${ }^{203} \mathrm{EU}$ agencies' founding acts use various formulations of what I call 'hearings on performance'. For instance, the Executive Director of EASA may be invited by the European Parliament and the Council to "report on the carrying out of his/her duties" (Article 38 (2) Regulation 216/2008 establishing the EASA). The Executive Director of ENISA may be asked by the European Parliament or the Council to come for a hearing which concerns "any subject related to the Agency's activities" (Article 7 (2) Regulation 460/2004 establishing ENISA). The Director of ETF “shall present the Foundation's annual activity report to the relevant committees of the European Parliament and preparatory bodies of the Council” (Article 13 (5) Regulation 1339/2008 establishing ETF). In the case of Europol it is the Presidency of the Council, the Chairperson of the management board and the Director of the agency who "shall appear before the European Parliament at its request to discuss matters relating to Europol taking into account the obligations of discretion and confidentiality" (Article 48 Council Decision 2009/371/JHA governing Europol which replaces the initial convention which created Europol). Finally, the chairpersons of the recently created financial agencies, the EBA, EIOPA, and ESMA, may be invited by the European Parliament and the Council "to make a statement, while fully respecting" their independence and they shall "answer any questions put by" the members of the Parliament (the Council is not specified in this sentence), "whenever so requested" (Article 50 (1) of Regulations 1093/2010, 1094/2010 and 1095/2010 establishing EBA, EIOPA and ESMA accordingly). One may wonder if different formulations result in the different scopes of such hearings before the EU representative institutions.
} 
regulations of 18 (out of 19) agencies, where the European Parliament acted as colegislator, regulatory agencies' directors have an obligation to come to a parliamentary hearing. At the same time, for agencies where the Parliament only provided its opinion at the time of creation, only four founding regulations (out of 13) included hearings of directors. These four cases include, for instance, the European Union Agency for Fundamental Rights, which can probably be explained by the fact that the European Parliament is thought to play a prominent role in promoting human rights. Hence, the European Parliament could not have been ignored here. The regulation establishing the FRA says that

Considering the significant role played by the European Parliament in the defence, mainstreaming and promotion of fundamental rights, it should be involved in the activities of the Agency, including the adoption of the Multiannual Framework for the Agency, and, given the exceptional nature and task of the Agency, the selection of the candidates proposed for the post of the Director of the Agency, [though interestingly] without setting a precedent for other Agencies (Recital 23 Regulation 168/2007 establishing FRA).

The founding act of Europol was modified in 2009 after having received a considerable amount of criticism on the lack of transparency of its operation. ${ }^{204}$ The introduction of the performance hearings may be one of the ways that were sought to address the criticisms.

${ }^{204}$ Curtin (2009) P. 261. 
Table 2.3. Correlation between the legislative role of the European Parliament in passing the EU agencies' founding acts and the presence of hearings obligations

\begin{tabular}{|c|c|c|}
\hline & $\begin{array}{l}\text { No hearings requirement } \\
\text { in agencies' founding acts }\end{array}$ & $\begin{array}{l}\text { Hearings provisions present in agencies' } \\
\text { founding acts }\end{array}$ \\
\hline The EP as co-legislator & 1 agency $^{205}$ & $\begin{array}{l}18 \text { agencies }^{206} \\
\text { (appointment hearings - } 17 \text { agencies; }^{207} \\
\text { extension hearings - } 5 \text { agencies; }{ }^{208} \\
\text { performance hearings - } 12 \text { agencies }^{209} \text { ) }\end{array}$ \\
\hline Opinion of the European Parliament & 9 agencies $^{210}$ & 4 agencies $^{211}$ \\
\hline $\begin{array}{l}\text { The EP did not play any role in passing } \\
\text { the establishing acts }\end{array}$ & $\begin{array}{l}3 \text { agencies of the former } \\
\text { second pillar }{ }^{212}\end{array}$ & none \\
\hline
\end{tabular}

Another example concerns the involvement of the European Parliament in the appointment process of the members of the management boards of agencies. Such involvements can include consulting the European Parliament by an appointing authority and designating independent experts to the management boards of EU agencies by the European Parliament itself. The independent experts which the Parliament designates are thought to be important to maintain an adequate relationship between the agency and the Parliament. ${ }^{213}$ Table 2.4. offers a more detailed calculation.

\footnotetext{
205 This is EEA. EMSA could belong to this category before the amending regulation of 2013, now it has hearings' provisions; the amendment regulation was passed with the European Parliament as co-legislator.

${ }^{206}$ These are: ACER, BEREC (the Office), IT-Agency, EASO, EASA, EBA, ECDC, ECHA, EFSA, EIGE, EIOPA, EMSA, EMA, EMCDDA, ENISA, ERA, ESMA, and ETF.

${ }^{207}$ ACER, BEREC (the Office), IT-Agency, EASO, EASA, EBA (in relation to chairperson), ECDC, ECHA, EFSA, EIGE, EIOPA (in relation to chairperson), EMSA, EMA, EMCDDA, ENISA, ESMA (in relation to chairperson), and ETF.

208 ACER, IT-Agency, EASO, EMSA and ETF. In the cases of EBA, EIOPA and ESMA the European Parliament has the power to confirm the decision to extend the term of office of the Chairman of the agency. Yet, since this does not oblige it to have extension hearings explicitly, these agencies are excluded from calculation.

${ }^{209}$ ACER, BEREC (the Office), IT-Agency, EASO, EASA, EBA, EIGE, EIOPA, ENISA, ERA, ESMA, and ETF. ${ }^{210}$ CdT, CPVO, Cedefop, EU-OSHA, EFCA, Eurofound, Eurojust, GSA, and OHIM.

The ETF and EMCDDA could belong to this category but their founding regulations were amended, including insertion of hearings' provisions; the amendment acts were passed with the European Parliament as co-legislator.

211 These include Frontex (performance hearings), FRA (appointment, extension and performance hearings), Cepol (performance hearings) and Europol (performance hearings).

212 EDA, EUISS and EUSC, all agencies of the former second pillar.

${ }^{213}$ Committee of Employment and Social Affairs' draft report on the proposal for a regulation of the European Parliament and of the Council establishing a European Training Foundation (recast) (2007/0163(COD)).
} 
Table 2.4. Correlation between the legislative role of the European Parliament in passing the EU agencies' founding acts and the Parliament's involvement in the appointment of the members of the management boards of EU agencies

\begin{tabular}{|c|c|c|}
\hline & $\begin{array}{l}\text { No designed members by the } \\
\text { EP on the boards }\end{array}$ & $\begin{array}{l}\text { There are persons who are designated by or } \\
\text { appointed in consultation with the EP }\end{array}$ \\
\hline The EP as co-legislator & 10 agencies $^{214}$ & 7 agencies $^{215}$ \\
\hline Opinion of the European Parliament & 13 agencies $^{216}$ & 2 agencies $^{217}$ \\
\hline $\begin{array}{l}\text { The EP did not play any role in the } \\
\text { passage of founding acts }\end{array}$ & 3 agencies $^{218}$ & none \\
\hline
\end{tabular}

As Table 2.4. demonstrates, the co-legislating European Parliament seems to have been more successful in being involved in appointing members of the management boards of agencies (seven out of 17 cases) than the advising European Parliament (two out of 15 cases). Moreover, in those cases where the Parliament played a co-legislative role, but has not become one of the appointing authorities of members of the management boards of agencies, it seems to have received other important powers. These include, for example, hearings provisions of two types of parliamentary hearings of agencies' directors, before a directors' appointment and on the performance of their functions (EIGE, ENISA, and ERA) and the power to remove the Chairperson of the agency (EBA, EIOPA, and ESMA). Moreover, in the case of ENISA, its director has almost a unique task to develop and maintain contact with the European Parliament and ensure a regular dialogue with its relevant committees (Article 7 (4(g))) Regulation (EC) No 460/2004).

In addition to the implications on agencies' accountability designs, the involvement of the European Parliament seems to have impacted the way in which agencies' founding acts have been passed. Curtin suggests that "depending on which legal basis is used, the process will be more or less open or more or less closed." ${ }^{219}$ She argues that the involvement of the European Parliament makes the discussion on the institutional design features of the proposed agency publicly available which "has been quite different with regard to agencies that have been proposed and adopted by the Council of Ministers in the newer policy areas of police cooperation and defence policy." 220

\footnotetext{
${ }^{214}$ BEREC (the Office), IT-Agency, EASO, EBA, EIGE, EIOPA, EMSA, ENISA, ERA and ESMA.

${ }^{215}$ ACER, ECDC, ECHA, EASA (the EP is informed about the appointees), EFSA (the EP is consulted), EMA and ETF.

${ }^{216}$ Cedefop, Cepol, CdT, CPVO, EFCA, EU-OSHA, Eurofound, Eurojust, Europol, FRA, Frontex, GSA, and OHIM.

${ }^{217}$ EEA and EMCDDA.

${ }^{218}$ EDA, EUISS and EUSC, all agencies of the former second pillar.

${ }^{219}$ Curtin (2009) P. 150.

${ }^{220}$ Ibid.
} 
The opening up of the negotiation process of agencies' founding acts can be important for various issues of the operation of EU agencies. The mentioned absence of reasoning of why agencies have been created is one of the questions that could be improved by increasing the transparency of the negotiation process. Another issue is the costs that agencies incur for the EU general budget and for national budgets as well. The costs of the operation of agencies are interconnected, for instance, with the location where EU agencies are placed. Clearly, renting premises in London would cost more than in Vilnius (see Table 2.5. below), yet, various package deals concluded behind closed doors may result in incurring unnecessary costs for the EU budget. As Table 2.5. shows, the building for the ETF is provided by the host government (Italy) for a symbolic rent of 1 Euro for the next 30 years. Yet, the costs of renovation were provided partly by the host country and partly by the EU where the ETF contributed 5,000,000 Euro to the original reconstruction of the premises. Furthermore, differences exist in relation to the same member state hosting several agencies. For instance, the Netherlands, the host country for the Europol and Eurojust, pays for the premises for the former (annual cost approximately 1,350,000 Euro) but not for the latter agency $(2,660,837$ Euro). The variety, and at times inconsistent conditions, of such package deals seem to indicate tough intergovernmental negotiations and prices that member states are willing to pay to get a piece of the 'EU cake'. Also, on the basis of Table 2.5., one can see how successful the British negotiators were as they attracted 15,008,013 Euro from the EU budget to the British economy only for EMA's rent or how eager the Greek government was to have EU agencies that it provided free buildings for them, including for the Greek office of Frontex whose headquarters are situated in Poland.

The issue of EU agencies' seats matters in relation to issues such as attracting competent personnel to bodies that are created with the purpose of being the experts. The famous discussion between the heads of various member states about the seat of the EFSA, which according to Italian Prime-Minister Berlusconi should have been placed in Parma "on account of its famous cured ham,"221 is a good illustration of how agencies' seats have been decided so far. In fact, this agency was placed in Parma, which, according to the Ramboll evaluation, is not an optimal location in relation to attracting experts. ${ }^{22}$ The remote location of ENISA is another example in this respect. MEP Jensen who once questioned the reasoning behind placing the ENISA on Crete (Greece) told,

I think that it was just because the Greek minister yielded a little bit more than other ministers. I did ask the question to the Council why it was put in Greece, because I knew several other courtiers could provide very good options for this agency with good infrastructure and

\footnotetext{
${ }^{221} \operatorname{Vos}$ (2003) P. 126-127.

222 "EFSA spends around one million euro a year just on transfers of visitors and staff from the airport to its headquarters, thus representing a significant budgetary burden.” It has also other issues to solve as regards international flights connections, etc. "Overall, the assessment of the evaluation team is that EFSA's location does pose some problems in terms of additional costs" (The Ramboll Evaluation, Volume 3. P. 98).
} 
good surroundings research-wise and company-wise. The Council said to me that they had chosen Greece because of the geographic spread. And then I asked the question again, because I said that Greece had already two agencies. It is a very small country, and there are countries that have no agencies. Why? And then they gave me an answer which basically said that 'you do not question the wisdom of the decisions of the European Council.' [She laughed]. So, this was decided by the heads of states, and you do not question that. I would like to question that. I think that we should have a far better process when deciding on the seat of agencies. ${ }^{223}$

While this is how it has been done before recently, the Lisbon Treaty has extended the colegislative role of the European Parliament to 86 areas (see Table 2.1. in Chapter 2.1.2.). From now on the European Parliament's involvement in creating new agencies or modifying the existing ones can be expected to be much more frequent, which seems to imply enhancing transparency in the creation process and accountability obligations of agencies given the spotted correlation between the strength of Parliament's legislative involvement and the amount of accountability obligations in agencies' founding acts.

Table 2.5. Costs of EU agencies' premises

\begin{tabular}{|c|c|c|}
\hline $\begin{array}{l}\text { EU member state } \\
\text { (year of accession) }\end{array}$ & $\begin{array}{l}\text { EU agencies (year of crea- } \\
\text { tion, city) }\end{array}$ & $\begin{array}{l}\text { Annual rental in Euros (support from hosting country } \\
\text { (yes/no; other relevant details) }^{224}\end{array}$ \\
\hline Austria (1995) & FRA (1997, Vienna) & $\begin{array}{l}732,000 \text { (yes }-1 / 3 \text { of the rent and if agencies' staff exceeds } \\
100 \text { members, the subsidy will become } 1 / 2 \text { of the rent) }\end{array}$ \\
\hline Belgium (1952) & $\begin{array}{l}\text { GSA (2004, Brussels) } \\
\text { EDA (Brussels) }\end{array}$ & $\begin{array}{l}557,674 \text { (no) } \\
\text { Self-funded; information in the EU general budget is absent }\end{array}$ \\
\hline Denmark (1973) & EEA (1990, Copenhagen) & $\begin{array}{l}\text { 2,080,000 (no; but } 10 \text { million Danish kroner in } 1995 \text { for } \\
\text { office furniture and other fittings) }\end{array}$ \\
\hline Estonia (2004) & $\begin{array}{l}\text { IT-Agency }(2012, \text { Tal- } \\
\text { linn })^{225}\end{array}$ & Not known at the moment of writing \\
\hline Finland (1995) & ECHA (2006, Helsinki) & $5,931,843($ no) \\
\hline
\end{tabular}

${ }^{223}$ MEP Jensen, member of the Interinstitutional Working Group on agencies (interviewed in August 2010). ${ }^{224}$ The Table relies on data provided in the Draft General Budget of the European Commission for the Financial Year 2012, Working Document part III, Bodies set up by the European Union and having legal personality, COM (2011) 300 - May 2011, European Commission. Since CPVO, OHIM, EDA, EUISS, EUSC are selffunded agencies, the mentioned document, hence also the table, does not provide the data on the costs of these agencies' premises and whether they receive financial support from their hosting countries.

225 "The seat of the Agency is in Tallinn, Estonia, while the operational management of the large-scale systems is carried out in Strasbourg, France with a backup site in Sankt Johann im Pongau, Austria" http://ec.europa.eu/dgs/home-affairs/what-we-do/policies/borders-and-visas/agency/index_en.htm (last check April 2013). 


\begin{tabular}{|c|c|c|}
\hline $\begin{array}{l}\text { EU member state } \\
\text { (year of accession) }\end{array}$ & $\begin{array}{l}\text { EU agencies (year of crea- } \\
\text { tion, city) }\end{array}$ & $\begin{array}{l}\text { Annual rental in Euros (support from hosting country } \\
\text { (yes/no; other relevant details) }\end{array}$ \\
\hline France & ESMA (2010, Paris) ; & $1,925,278$ (no) \\
\hline \multirow[t]{3}{*}{$(1952)$} & $\begin{array}{l}\text { ERA (2004, Valenciennes, } \\
\text { Lille); }\end{array}$ & $573,951($ no) \\
\hline & EUISS (2002, Paris) & Self-funded; information in the EU general budget is absent \\
\hline & CPVO (1994, Angers) & Self-funded; information in the EU general budget is absent \\
\hline \multirow[t]{2}{*}{ Germany (1952) } & $\begin{array}{l}\text { EIOPA (2010, Frankfurt am } \\
\text { Main); }\end{array}$ & $1,085,599$ (no); \\
\hline & EASA (2002, Cologne) & $6,217,000($ no) \\
\hline \multirow[t]{3}{*}{ Greece (1981) } & $\begin{array}{l}\text { ENISA (2004, Heraklion, } \\
\text { Athens); }\end{array}$ & 0 (yes - "contribution in kind"226) \\
\hline & $\begin{array}{l}\text { Cedefop (1975, Thessaloni- } \\
\text { ki, Brussels); }\end{array}$ & $\begin{array}{l}0 \text { (yes - around 2,300,000 +13,000 support for Brussels' } \\
\text { office; agency owns its premises which is valued at } \\
3,887,054 \text { ) }\end{array}$ \\
\hline & EAR (closed in 2008) & $\mathrm{n} / \mathrm{a}$ \\
\hline Ireland (1973) & Eurofound (1975, Dublin) & $\begin{array}{l}0 \text { (no; agency is the owner of its premises which is valued at } \\
1,965,470 \text {; its office in Brussels costs } 19,250 \text { ) }\end{array}$ \\
\hline \multirow[t]{2}{*}{$\begin{array}{l}\text { Italy } \\
(1952)\end{array}$} & EFSA (2002, Parma); & $\begin{array}{l}2,700,000 \text { (no, the agency owns its premises which is valued } \\
\text { at } 38,500,000)\end{array}$ \\
\hline & ETF (1990, Turin, Brussels) & $\begin{array}{l}\text { The building is provided by the host government for a } \\
\text { symbolic rent of } 1 \text { Euro for the next } 30 \text { years. The costs of } \\
\text { renovation were provided partly by the host country and by } \\
\text { the EU. The ETF contributed 5,000,000 to its original } \\
\text { reconstructing. Its office in Brussels costs 5,500. }\end{array}$ \\
\hline $\begin{array}{l}\text { Latvia } \\
(2004)\end{array}$ & BEREC (2009, Riga) & Not available at the moment of writing \\
\hline Lithuania (2004) & IEGE (2006, Vilnus) & $370,000(\mathrm{No})$ \\
\hline $\begin{array}{l}\text { Luxembourg } \\
(1952)\end{array}$ & CdT (1994, Luxembourg) & $1,025,390($ no) \\
\hline $\begin{array}{l}\text { Malta } \\
(2004)\end{array}$ & EASO (2010, Valletta) & 106,260 (yes - 415,987 for 2011-2013) \\
\hline \multirow[t]{2}{*}{$\begin{array}{l}\text { Netherlands } \\
\text { (1952) }\end{array}$} & Europol (1995, The Hague); & $\begin{array}{l}0 \text { (yes - provided by the Host State free of charge (annual } \\
\text { cost app. } 1,350,000 \text { ) }\end{array}$ \\
\hline & Eurojust (2002, The Hague) & $2,660,837$ \\
\hline Poland (2004) & $\begin{array}{l}\text { Frontex (2004, Warsaw, } \\
\text { Brussels and Piraeus in } \\
\text { Greece) }\end{array}$ & $\begin{array}{l}2,915,796 \text { (yes - in relation to its Greek office which is } \\
\text { provided by the Greek Government - Hellenic Coast } \\
\text { Guard) }\end{array}$ \\
\hline
\end{tabular}

\footnotetext{
${ }^{226}$ Draft General Budget of the European Commission for the Financial Year 2012, Working Document part III, Bodies set up by the European Union and having legal personality, COM (2011) 300 - May 2011, European Commission, P. 160.
} 


\begin{tabular}{|c|c|c|}
\hline $\begin{array}{l}\text { EU member state } \\
\text { (year of accession) }\end{array}$ & $\begin{array}{l}\text { EU agencies (year of crea- } \\
\text { tion, city) }\end{array}$ & $\begin{array}{l}\text { Annual rental in Euros (support from hosting country } \\
\text { (yes/no; other relevant details) }^{224}\end{array}$ \\
\hline Portugal (1986) & $\begin{array}{l}\text { EMSA (2002, Lisbon) } \\
\text { EMCDDA (1993, Lisbon) }\end{array}$ & $\begin{array}{l}2,295,000 \text { (no) } \\
889,255 \text { (yes in providing office furniture as well as "artistic } \\
\text { enhancement of reception areas, management and confer- } \\
\text { ence rooms") }\end{array}$ \\
\hline Slovenia (2004) & ACER (2009, Ljubljana) & $\begin{array}{l}0 \text { (yes - offered for free by the government of Slovenia for the } \\
\text { first two years) }\end{array}$ \\
\hline Spain & CFCA (2005, Vigo); & currently no rent, funded by Spain \\
\hline \multirow[t]{3}{*}{$(1986)$} & EUSC (2002, Madrid) & $\begin{array}{l}\text { Self-funded; information in the EU common budget is } \\
\text { absent }\end{array}$ \\
\hline & EU-OSHA (1994, Bilbao); & 665,000 (yes - host country support 200,000) \\
\hline & OHIM (1994, Alicante) & $\begin{array}{l}\text { Self-funded; information in the EU common budget is } \\
\text { absent }\end{array}$ \\
\hline Sweden (1995) & ECDC (2004, Stockholm) & $1,916,000(\mathrm{no})$ \\
\hline \multirow{3}{*}{$\begin{array}{l}\text { United Kingdom } \\
\text { (1973) }\end{array}$} & EBA (2010, London); & $3,160,500($ no) \\
\hline & Cepol (2005, Bramshill) & $\begin{array}{l}0 \text { (Currently for free by the UK National Police Improve- } \\
\text { ment Agency, negotiations are ongoing to introduce actual } \\
\text { costs for building maintenance) }\end{array}$ \\
\hline & EMA(1993, London) & $15,008,013$ (no) \\
\hline
\end{tabular}

\subsubsection{Delegation of powers to EU agencies: the Meroni safeguard?}

How does the treaty which does not explicitly allow the creation of agencies permit the delegation of various powers to them? The question of delegation is crucial when investigating political accountability, because the necessity of political accountability arises upon an act of delegation; in other words, if no delegation occurs, there is no need to hold someone to account. Delegation and political accountability are thus two sides of the same coin, and this section therefore addresses them together by discussing the legality of delegation to EU agencies and the merit of the existing delegation standard from an accountability perspective. This section argues that the existing delegation doctrine may be an insufficient safeguard against delegation of strong powers without accountability. As the EU delegation standard is governed by the Meroni doctrine, let us start with a brief introduction of it.

\section{The Meroni doctrine}

The Meroni doctrine was established in 1958 within the framework of the European Coal and Steal Community (ECSC). As the subsequent treaties after the ECSC neither explicitly allowed delegation, nor prohibited it, this doctrine "has stood for approaching 50 years as a 
constitutional limit to delegation"227 and remains valid today. Likewise the Lisbon Treaty does not address the issue of delegation to EU agencies, except indirectly by stating that the Court of Justice shall review the legality of acts of EU agencies intended to produce legal effects vis-à-vis third parties (Article 263 TFEU). If the review of such actions is foreseen, the possibility of delegation of certain powers seems to be implied. Thus, the Meroni doctrine remains to fill the treaty delegation lacuna. ${ }^{228}$ What is the Meroni doctrine?

The Meroni doctrine is best characterized by the word 'non-delegation', because it imposes a very strict limitation on the nature of delegated powers within the EU. In short, it allows for delegation of 'executive powers' only; such powers cannot have a policy-making discretion and they have to correspond to the powers that the delegating authority could exercise itself, including obligations, such as reporting, that the delegating institutions may be subject to by the treaties. The Court reached this conclusion in Meroni v. Co., Industrie Metallurgische S.p.A. v. High Authority.

The case concerned the Italian steel company Meroni, which refused to pay a sum of money to the Imported Ferrous Scrap Equalization Fund, a private company under Belgium law operating under the responsibility of the High Authority (predecessor of the European Commission). The Fund's task was administering a special obligatory ferrousscrap equalization system created by the High Authority with a view of keeping ferrous scrap prices low. ${ }^{229}$ The steel company challenged the legality of the bill it received and questioned the possibility for the High Authority to delegate powers, since the Treaty did not provide for delegation explicitly.

While the Meroni Court concluded that the delegation at stake was illegal, it addressed the possibility of delegation at the EU level, because the Treaty did not provide explicitly for that. Reading Article 53 of the ECSC Treaty the Court stated that the delegation was not excluded, and that the institutions might use assistant bodies having a distinct legal personality. In Meroni, the power of the High Authority "to authorize or itself make the financial arrangement mentioned in Article 53 of the Treaty" gave it the right "to entrust certain powers to such bodies subject to conditions to be determined by it and subject to its supervision." ${ }^{30}$ However, such delegation was allowed only if it was "necessary for the performance of the tasks set out in" respective articles and "compatible with" the treaty. ${ }^{231}$ Furthermore, the Court ruled that the delegating authority "could not confer upon the Authority receiving the delegation powers different from those which the delegating au-

\footnotetext{
227 Orator (2007) P. 34.

${ }^{228}$ In relation to the Commission, Craig argues that the Meroni principle has been indirectly reinforced by Article 290 TFEU which requires the Union Legislator to specify essential elements when delegating the Commission the authority to adopt non-legislative acts of general application (Craig (2012) P. 155).

${ }^{229}$ Griller and Orator (2010) P. 15-16.

${ }^{230}$ Case 9-56, Meroni \& Co., Industrie Metallurgiche, SpA v High Authority of the European Coal and Steel Community. P. 151.

231 Ibid.
} 
thority itself received under the Treaty." ${ }^{232}$ In Meroni, it was found that if the delegating authority would have exercised the delegated powers itself, when issuing decisions, it would have been bound by certain principles established by the Treaty, such as principles to state reasons and to publish an annual report. But as the agencies at stake received those powers without any further 'guidance' on how they should implement the delegated tasks, they were not bound by relevant treaty obligations, and hence received more extensive powers than the delegating authority enjoyed itself, which violated the Treaty.

While Meroni showed that delegation was in principle possible, the Court made it clear that not all kinds of powers are 'delegatable'. According to the Court, the consequences resulting from delegation may differ depending on the nature of powers that are delegated. Here, two categories of powers were distinguished: "clearly defined executive powers the exercise of which can $\langle\ldots\rangle$ be subject to strict review in the light of objective criteria determined by the delegating authority" and powers that involve discretion, which can "make possible the execution of actual $<\ldots>$ policy" ${ }^{233}$ (emphasis added). The Court accepted the delegation of the first kind of powers. ${ }^{234}$ The delegation of the second kind was considered to hinder the balance of powers which is the guarantee that the treaty preserves (see also section 2.1.2.4.); "to delegate a discretionary power, by entrusting it to bodies other than those which the treaty has established to effect and supervise the exercise of such power each within the limits of its own authority, would render that guarantee ineffective." 235

Although the Meroni ruling goes way back to the beginning of the EU integration (1956), in more recent judgments the Court of Justice confirmed its relevance to delegation: "the powers conferred on an institution include the right to delegate" 236 and "when the Community legislature wishes to delegate its power to amend aspects of the legislative act at issue, it must ensure that that power is clearly defined and that the exercise of the power is subject to strict review in the light of objective criteria." ${ }^{237}$ As a whole, delegation is allowed, even though it is not explicitly mentioned in the treaty, but upon a certain condition: the delegation is limited to clearly defined executive (and not discretionary) powers, which the authority could have exercised itself, supported with guidance and supervision.

\footnotetext{
${ }^{232}$ Case 9-56, Meroni \& Co., Industrie Metallurgiche, SpA v High Authority of the European Coal and Steel Community. P. 150.

233 Ibid. P. 152.

234 "A delegation of the first kind cannot appreciably alter the consequences involved in the exercise of the powers concerned, whereas a delegation of the second kind, since it replaces the choices of the delegator by the choices of the delegate, brings about an actual transfer of responsibility" (Ibid. P. 152).

235 Ibid. P. 152.

${ }^{236}$ Case C-301/02, P Carmine Salvatore Tralli v ECB, 2005, ECR I-4071. P. 42.

${ }^{237}$ Joined Cases C-154/04 and C-155/04 The Queen, on the application of Alliance for Natural Health and Others v Secretary of State for Health and National Assembly for Wales. P. 90.
} 


\section{The Meroni doctrine from an accountability perspective}

"Every decision to delegate essentially involves two choices - what powers to delegate and what institutional control mechanisms to craft." ${ }^{238}$ In the delegation cases before it, the Court of Justice also faced these issues: it addressed the issue of the nature of powers that can be delegated and of requirements that need to be imposed on the recipients of the delegated powers. However, while (or perhaps because) it imposed a rather strict standard in relation to the first question on the nature of powers, it left the second clearly complex question of how many limitations and standards should be crafted to pass the delegation test to be determined by the delegating authority. What does the current situation imply in terms of accountability?

Those who opine that the necessity and amount of accountability obligations should be proportionate to the presence and amount of discretion given to agencies can be relieved by the strictness of the delegation doctrine in relation to the nature of delegatable powers. EU agencies cannot enjoy discretion because it "brings about an actual transfer of responsibility" ${ }^{239}$ for making policy choices. And tasks that they exercise, for instance, "information gathering operations are purely managerial not political. They involve no discretion. Facts are facts." ${ }^{240}$ In this light, some have suggested that the importance of EU agencies "should not be exaggerated at the moment, at least before they have been delegated with more intense responsibilities." 241 Following this line of reasoning, it is not surprising that the question of accountability of the 'rather weak' EU agencies has become an underinvestigated issue.

At the same time, "to say that an agency only provides information, that is neither makes nor enforces policy, is in a certain sense incomprehensible in the conditions of modern politics," which is "a politics of information." 242 "Is there really no policy making dimension to the "information" that German brown coal burning is killing the forests of Sweden"?243 In other words, even information-gathering involves discretion, i.e., the making of choices of what to research and of what to report back to the delegating authority. ${ }^{244}$ One should not forget that the functions that EU agencies have been delegated also include advisory and decision-making powers where empirical research shows that the advice of

\footnotetext{
238 Tallberg (2002) P. 28.

${ }^{239}$ Case 9-56, Meroni \& Co., Industrie Metallurgiche, SpA v High Authority of the European Coal and Steel Community. P. 152.

240 Shapiro (1996) P. 24.

${ }^{241}$ van Ooik (2005) P. 152.

242 Shapiro (1996) P. 24.

243 Ibid. 24-25.

244 "The difference between policy making and policy administration can be difficult to be made. <...> Networks of regulators and network agencies, formally do not exercise decision-making powers. However, they produce information, data and proposals that eventually influence the content of the European policies formally adopted by the competent EU institutions" (Zinzani (2012) P. 242).
} 
some agencies becomes an official decision of the Commission without any changes. ${ }^{245} \mathrm{~A}$ senior official from ECHA stated in this respect, "We publish our technical assessments. If the Commission does not follow the advice (in the comitology decision), it is seen. $<\ldots>$ In theory - it can happen, perhaps, the comitology groups have national experts who have a different opinion; in practice - I do not see it happening." ${ }^{246}$ Thus, the question of the accountability of EU agencies may be not that insignificant after all.

Having restricted the nature of powers that can be delegated, the Court of Justice did not bother that much, however, with the second question about accountability obligations that the delegating authority has to establish for delegation to be lawful. The Meroni Court mentions here and there a few requirements that seem to hint at accountability obligations, such as supervision by the delegating authority, requirements to state reasons, and to publish annual reports on agencies' activities and such data as could be useful to governments or to any other parties concerned. ${ }^{247}$ Yet, it remains unclear who should hold agencies to account and with what mechanisms (in quantitative and qualitative terms) in order to pass the delegation test. The Court states that the delegating authority can delegate tasks which it has received under the treaty, including the conditions that the treaty imposes upon the delegating authority when it exercises those tasks, for instance, reporting and stating reasons requirements. Considering the origins of functions that EU agencies exercise, which come among other things from national authorities and the Commission (see section 2.1.2.3.), it is questionable if the Council and the European Parliament, which form the delegating authority, have received those functions under the treaty in the first place. The variety of origins of agencies' functions makes the question of who the supervisory authority should be unclear.

In any case, the absence of clear requirements regarding what accountability obligations an agency has to have makes it easy to pass the delegation test. This runs a risk of creating EU agencies that formally have 'executive' powers but actually carry out discretionary tasks, at least understood in a broad sense, ${ }^{248}$ which allows the delegation of strong powers without proper accountability being put in place. The existing situation could be problematic because "a system that extends discretion for managers without strengthening their accountability undermines political control." 249

\footnotetext{
${ }^{245}$ Dehousse (2008) P. 799.

${ }^{246}$ A senior official from ECHA (interviewed in September 2011).

${ }^{247}$ Case C-301/02 P Carmine Salvatore Tralli v. ECB [2005] ECR I-4071.

248 "If the term "policy-making" is understood in its wider sense, then there is a grey area between policy-making and a number of agency activities, i.e. collecting and disseminating harmonized information, raising awareness on a given issue, contributing to soft coordination, providing expert advice. $<\ldots>$ they feed into the making of EU policies or decisions rather than simply applying existing policies" (The Ramboll evaluation, Volume 1. P. 16).

${ }^{249}$ Christensen and Lægreid (2006) P. 369.
} 
"Is Meroni good law?" 250 It depends from what perspective this question is viewed. It has been criticized on the grounds of being too restrictive as it does not appreciate "the advantages of delegation in terms of decision-making efficiency" and prohibits 'real' regulatory agencies, which in the words of the opponents of Meroni doctrine leads to the creation of a "regulatory agency without regulatory powers." ${ }^{251}$ According to Majone, "the delegation of important policy-making powers to independent institutions is democratically justified only in the sphere of efficiency issues, where reliance on expertise and on a problemsolving style of decision-making is more important than reliance on direct political accountability." ${ }^{252}$ Griller and Orator also argue in favor of giving more discretion to EU agencies. They see a possibility of a more 'flexible' system "depending, first, on the kind of powers delegated, and, second, on the balancing of a variety of steering and control mechanisms." 253 They argue that some discretion can be given if supported by mechanisms available under the comitology procedures (Articles 290 TFEU), which include callback or veto mechanisms and joint decisions between the Commission and the agency, judicial scrutiny, and political accountability. ${ }^{254}$

It does indeed seem plausible to allow delegation when sound accountability mechanisms are ensured. However, before delegation of 'real regulatory powers' is allowed (if it has not been done already), it seems necessary to establish what sound accountability mechanisms are, who exercises them (e.g., national and/or European level and what institutions, see section 2.1.2.4.) and who determines the soundness of the accountability system (for instance, the CJEU, member states or the Union Legislator). ${ }^{255}$ In this regard, the Meroni doctrine is not that useful from an accountability perspective because it is not specific as to who should be the accountability authority for the agencies and what mechanisms are necessary to be present to pass the delegation test.

Concluding, the creation of and delegation to EU agencies are determinant processes in establishing the accountability of agencies. The investigation of these processes has shown that EU agencies are created at the Union Legislator's discretion and with hardly any restrictions imposed on it since there is no treaty provision or other law establishing explicit requirements as to when an EU agency should be created and what accountability obliga-

\footnotetext{
250 Orator (2007) P. 33; Griller and Orator (2006) P. 8.

${ }^{251}$ Majone (2005) P. 92-93.

252 Majone (1996) P. 296.

${ }^{253}$ Griller and Orator (2010) P. 27.

${ }^{254}$ Ibid. P. 27-29.

${ }^{255}$ Schneider warns in this respect that "it is especially important to rethink the continuance of traditional concepts like the Meroni doctrine, which was established fifty years ago at a rather different state of European integration, which are an important obstacle to a meaningful decentralization of administrative functions from the Commission to EU agencies. No less urgent is a solid legal concept for an acceptable scope of functions for decentralized EU agencies and for adequate accountability mechanisms. Otherwise the growth of this component of EU administrative law will continue to be rather uncontrolled and unsystematic" (Schneider (2009) P. 31).
} 
tions it has to be subject to. While the Meroni doctrine has been criticized for its restrictive appearance as to the nature of powers that can be delegated, it is not that explicit as to who and how should hold EU agencies to account, which can be explained by the facts that it bans 'real regulatory agencies' and was so far not applied in a case questioning delegation to an EU agency. Moreover, "if the distinction between instrumental and final powers tends to blur, then it should not be taken for granted that European agencies are actually in line with" the Meroni jurisprudence. ${ }^{256}$ The implication from the absence of any obligation upon the Union Legislator to give substantive reasons when creating agencies includes the possibility to expand 'Eurocracy' without functional needs and good reasons. This has arguably happened in recent years since the creation of EU agencies has not always been properly justified and agencies have been given similar remits. The absence of any requirement upon the Union Legislator to support delegation by certain accountability mechanisms leaves it to the Legislator to decide the quantity and quality of accountability requirements without necessarily justifying its decisions. The discussed differences in hearings obligations seem to illustrate the point.

\subsubsection{Appointment and Removal Procedures of EU agencies' Top Officials: a Playground for Political Influences}

The question of the appointment of agencies' heads is of utmost importance in tracing the personal accountability link between the people and independent regulatory agencies' officials. This is because while the heads of such agencies exercise public authority, they are not elected to do that. Hence, the involvement of representative bodies in appointment, reappointment, and removal procedures of agencies' unelected officials becomes necessary from democratic accountability and legitimacy perspectives. Inherent to the appointment power is the power of removal which is also important to look at from the accountability perspective because it provides a sanction for possible misbehavior. The importance of investigating these issues also comes from the fact that since EU agencies are barely mentioned in the treaty, hence, these procedures are not governed by it. This section discusses both the appointment and removal procedures of EU agencies' top officials (in sub-sections 2.2.2.1. and 2.2.2.2. respectively) and demonstrates a great diversity in appointment, reappointment, and removal procedures: 12 appointment and 5 removal formulas. The existing variety seems to indicate an ongoing political game between respective national and EU institutions over influences in relation to the so-called 'independent' EU agencies.

EU agencies usually comprise management boards, directors, ${ }^{257}$ and additional organs depending on the specifics of their work. ${ }^{258}$ The additional organs may include boards of

\footnotetext{
${ }^{256}$ Chiti (2009) P. 1406.

${ }^{257}$ Only in three cases of the recently created financial agencies (EBA, EIOPA and ESMA) the organizational structure differs. These agencies' management boards and directors operate under supervision of the boards of
} 
appeal (for agencies with decision-making powers) and scientific and technical departments appointed normally by agencies' management boards. As important decisions that EU agencies take are prepared under the supervision of agencies' directors and usually are adopted by their management boards, the following sections focus on the appointment and removal of management boards' members and directors of EU agencies.

\subsubsection{Appointing EU agencies' top officials}

\section{Composition of EU agencies' management boards}

Generally speaking, EU agencies' management boards coordinate agencies and their general course. Members of agencies' management boards gather a few times per year to approve (multi-annual) working plans and annual reports; send the budgetary requests to the EU budgetary authority, i.e., the Council and the European Parliament, and to the Commission; establish additional internal organs; adopt guidelines and other rules, including, for instance, internal rules of procedure for agencies' personnel and agencies' financial regulations. They may be involved in appointing and dismissing agency's staff and exercise disciplinary authority over them. Interestingly, in the case of the European Maritime Safety Agency the management board appoints an observer to follow the pre-selection procedure of the future director exercised by the Commission (Recital 42 Regulation 100/2013). ${ }^{259}$ Furthermore, in a few cases they may also exercise financial scrutiny, and hence are the budgetary and discharge authority for their agencies. Finally, management boards may have the power to propose changes in agencies' founding acts based upon evaluations prepared by independent persons (appointed by them). Given the functions agencies' management boards may have, their role is twofold. On the one hand, they are the deciding organ when

supervisors and chairpersons of these agencies (see Appendix 1 for specific details). The different organizational structure can be perhaps explained by the fact that these three agencies form part of a European System of Financial Supervision where they cooperate with each other and other relevant institutions and thus create a network of national and Union supervisory authorities to enhance harmonization, coherent application of relevant EU legislation and enhance supervision.

${ }^{258}$ There is no common terminology as regards EU agencies' management boards and the positions of agencies' directors. These organs can be called quite differently, i.e., management boards, administrative boards, administrative councils, management committees, and directors, executive directors, administrative managements, and presidents. I use the most frequently used terms, i.e., 'management board' and 'director', as generic terms.

259 "In order to ensure a fair and transparent procedure for the appointment of the Executive Director, the selection procedure to be followed should be in accordance with the Commission guidelines for the selection and nomination of Directors for agencies of the Union. These guidelines provide that nationals of any Member State can submit an application. For the same reasons, the Administrative Board should be represented by an observer in the pre-selection committee. The observer should be kept informed during the further stages of the selection procedure. At the time that the Administrative Board takes its decision on appointment, its members should be able to address questions to the Commission on the selection procedure." 
they adopt formal agencies' documents. On the other hand, they are 'merely' supervisory organs, ${ }^{260}$ as they gather only a few times per year to adopt already prepared documents. ${ }^{261}$

The composition of EU agencies' management boards is usually shared between the representatives of the EU member states ${ }^{262}$ and members appointed by the Commission. ${ }^{263}$ According to a member of European Aviation Safety Agency's management board (EASA), there are two reasons for all member states to be present on this agency's management board: (1) the political reason: "if something happens, let us say in the UK, a minister will be asked before the Parliament. He cannot say that it is all Cologne. He would say that we work with Cologne to address the issue;" and (2) the legal reason: member states (and not the EU) are members of the International Civil Aviation Organization (including the Chicago convention of 1944 on civil aviation) and carry out certain obligations some of which have been transferred to EASA. As the EU member states keep their legal responsibility internationally, they need to be able to oversee how EASA is exercising its delegated powers. $^{264}$

Expertise of the members of management boards is often prescribed, but not always. ${ }^{265}$ The European Food Safety Authority's founding regulation (EFSA), for instance, requires four of the members of its management board to have their background in organizations representing consumers and others to have 'interests' in the food chain (Article 25 (1) Regulation (EC) 178/2002). When the specialization or expertise is not prescribed, the raison d'être for creating 'expert independent' bodies may become questionable. In any case it seems that the profile of members should correspond to the roles that are supposed to play.

\footnotetext{
${ }^{260}$ In this respect Kelemen argues that agencies' management boards are similar oversight mechanisms to those that the Council has created in relation to the comitology system: "when the Council began delegating implementation powers to the Commission in the early 1960s, it established a system of oversight committees (comitology) as a means to monitor the Commission's exercise of its executive powers. $<\ldots>$ Given the Council's preference for minimising supranational bureaucratic drift, one would expect the Council to demand the establishment of similar mechanisms for ongoing intergovernmental oversight when creating any new EU level regulatory agencies outside the Commission hierarchy" (Kelemen (2002) P. 97).

261 "We do not really approve the budget, we do not really have a say." (Chairman of an EU agency's management board (interviewed in November 2011)).

262 What is interesting to point out here is that the situation with the appointing authority of member states' representatives differs. In some cases "each member state shall appoint a member of the Management Board" (Article 21 Regulation establishing Frontex 2007/2004). In other cases it is the Council that appoints member states' representatives on the basis of lists of candidates submitted by the member states (Article 4 (2) Regulation (EEC) No 337/75 establishing Cedefop).

263 The Commission's representation varies from agency to agency. The Commission can appoint from one to six representatives (CFCA and ECHA) of EU agencies' management boards.

${ }^{264}$ Member of EASA's management board (interviewed in November 2011).

${ }^{265}$ E.g., Cedefop (for the member states' representatives) and EEA (except for two designated persons from the European Parliament). In case of CPVO its founding regulation does not prescribe for members of its Administrative Boards to have any expertise in the area, though they "may be assisted by advisers or experts" (Article 37 (2) Council Regulation (EC) No 2100/94 establishing CPVO).
} 
A senior official from an EU agency mentioned in this respect: "the management board members are from the ministries of health, they are more familiar with the content and not management, and this is a problem. They should supervise agency on the governance issues and not the content which is decided in the scientific organs." ${ }^{266}$ It may be thus important to establish what the management boards are supposed to do - managing agencies which may necessitate more organizing and administrative skills for members of management boards or supervising agencies, including, for instance, their technical decisions, which may require more technical knowledge.

Agencies' management boards may also include persons designated by the European Parliament and stakeholders of relevant sectors, such as employers' and employees' organizations (EU-OSHA, Cedefop and Eurofound) and relevant industries (EMA, ERA and ENISA). Furthermore, some EU agencies' management boards, like the European Environment Agency, may have representatives of non-EU member states (Iceland, Liechtenstein, Norway, Switzerland, and Turkey). Other agencies, for instance, the European Monitoring Centre for Drugs and Drug Addiction, may also include observers from international organizations (World Health Organization). Moreover, one of the management board members of the European Union Agency for Fundamental Rights is appointed by the Council of Europe. Finally, the management board of the Translation Centre includes, among others, EU agencies' representatives that use its services. The three financial agencies, the EBA, EIOPA, and ESMA, include each other's non-voting representatives on their boards of regulators' which seem to be the counterparts of other agencies' management boards considering their composition. They are composed of the heads of relevant financial regulatory authorities. In the case of the EBA, a non-voting representative from the European Central Bank is also a member of this agency's board of regulators.

Considering the amount of interests that must be represented, agencies' management boards are quite 'densely populated'. The smallest (number-wise) management board consists of seven members (EBA, EIOPA and ESMA), although these agencies have also the boards of regulators with representatives of relevant national regulatory authorities and other non-voting members. Without these agencies the smallest management board would be that of the EFSA that has 14 members appointed by the Council, from a list drawn by the Commission, and one member appointed by the Commission. This agency does not have representatives of all Member States, which is typical for EU agencies, but a rotation system. ${ }^{267}$ One of the largest management boards is that of the European Agency for Safety and Health at Work (EU-OSHA) that has 84 members which include representatives of all the member states and various stakeholders, including representatives from employees' and

\footnotetext{
266 Senior official from an EU agency (interviewed in October 2011).

${ }^{267}$ The EIGE also employs a rotation system among the member states. Its board has 19 members, including one representative of the Commission.
} 
employers' organizations from each member state. ${ }^{268}$ In this respect, the Ramboll evaluation concluded that having all member states on agencies' boards may be "unnecessary, costly and ineffective." ${ }^{269}$ Indeed, one might wonder whether, for instance, the presence of Malta, a member state without railways, is necessary on the board of the railway agency (ERA). Transportation and accommodation for 84 members of EU-OSHA's management board for a minimum of two formally-required meetings could be indeed quite costly. The 'densely populated' management boards also show where efficiency problems may come from. To address the efficiency and effectiveness problems in future agencies the 'Common Approach' on EU Agencies (see section 2.2.6.) endorses 'a two-level governance structure' already used by a few agencies:

in addition to the Management Board, giving general orientations for the agency's activities, a small-sized Executive Board, with the presence of a Commission representative, should operate and be more closely involved in the monitoring of the agency's activities, with a view to reinforcing supervision of administrative and budgetary management, in particular on audit matters. ${ }^{270}$

Such multipartite representation from each member state, EU institutions and other bodies and countries seem to ensure that "all major stakeholders are involved and the account is taken of the diversity of interests and approaches" (Recital 12 Council Regulation (EC) No 1112/2005 establishing EU-OSHA). However, while various institutions, organizations and countries may be represented on agencies' management boards, they do not always enjoy voting rights which are "reserved to the representatives of public authorities who are answerable to the democratic control authorities" (Recital 23 of the Regulation (EC) No $881 / 2004$ establishing ERA). The representatives of public authorities answerable to the democratic control authorities are in the majority of cases representatives of the member states and of the Commission and in a few cases persons designated by the European Parliament. It is, however, not explicitly stated in agencies' founding acts how they answer to the democratic control authorities and what such authorities are in each case exactly. Since this book focuses on accountability, let us look at this issue a bit closer.

\footnotetext{
${ }^{268}$ In this respect, the size of a management board may be disproportionate to the size of the agency's staff. For instance, the EU-OSHA employs 64 staff while its management board includes 84 members (The Ramboll Evaluation. Volume I. P. 22).

${ }^{269}$ The Ramboll evaluation. Volume I. P. iii.

270 ‘Common Approach’ on EU agencies, Point 10.
} 


\section{EU agencies' management boards and accountability}

\section{Democratic Accountability of National Representatives}

National representatives usually come from respective national ministries and agencies at a (deputy) director level. In some cases, however, these national (deputy) directors are only formal members of EU agencies' management boards and are actually represented by other ministerial staff during management board meetings. ${ }^{271} \mathrm{It}$ is true that the formal democratic accountability link exists: a national civil servant participating at an EU agency's management board meeting $\rightarrow$ (deputy) director of a national ministry's department $\rightarrow$ other possible levels in national ministerial hierarchy $\rightarrow$ national minister $\rightarrow$ national parliament $\rightarrow$ people. But, "the longer the chain of delegation, the greater the potential for agency loss." ${ }^{272}$ A member of EASA's management board states in this respect,

The formal mandate derives from the mandate of the minister which is the only controllable source. Ministers give mandates to their subordinates (DGs) who give them then further, etc. As long as there are internal instructions and a reporting system, it is thus 'acceptable accountability'; it is indirectly to be detected from the minister. However, often members of the management board do not have any instructions. They get an e-mail and read some documents relevant to a management board meeting in the train. ${ }^{273}$

Ex ante instructions and ex post reporting requirements are regulated within national ministries and may be thus either written by those who actually participate in management boards meetings (national civil servants), or such obligations are absent. A member of European Chemicals Agency's management board (ECHA) states:

I know that some management board members undertake quite complex processes to coordinate their positions among various representatives from their country in different EU structures. Others act on their personal behalf. It depends on how the nomination process works in various countries and on coordination. In my case it is my decision to contact others to coordinate or not. ${ }^{274}$

Thus, not all members of EU agencies' boards may necessarily have instructions beforehand or reporting obligations ex post. In light of this it should not come as a surprise when a senior official from an EU agency suggests that "they are actually controlled by nobody." 275 The question of holding national representatives to account at the national level is also interrelated with the role that they are supposed to play. The perception of the members of

\footnotetext{
${ }^{271}$ Member of EASA's management board (interviewed in September 2011).

272 Strøm (2006) P. 67.

${ }^{273}$ Member of EASA's management board (interviewed in September 2011).

${ }^{274}$ Member of EASA's management board (interviewed in September 2011).

275 Senior official from an EU agency (interviewed in August 2011).
} 
agencies' management boards differs as to whether they should represent the positions of their states or act as independent experts in their own capacity. A senior official from the FRA states in this respect,

When I first visited a meeting, it was very refreshing how openly the people were speaking. I worked in a $\langle\ldots\rangle$ foreign ministry before, $<\ldots\rangle$ so I knew some positions of the member states. And what I heard from people coming from various member states was partly contrary to the official position of their member states. They are really independent experts. $\langle\ldots\rangle$ Those people are really independent and they do not take instructions or report to the member states, and if they do, it is an act of courtesy. ${ }^{276}$

Yet, in fact the founding act of the FRA differs in this respect from other agencies because it states that each Member States appoints "one independent person having high level responsibilities in an independent national human rights institution or other public or private sector" (Article 12 (1) Regulation (EC) No 168/2007), rather than its own 'representatives', as in the case of EMCDDA (Article 9 of Regulation (EC) No 1920/2006) and a great majority of EU agencies (see Appendix 1). Nevertheless, a member of another agency's management board states, "I do not think that there is a person who thinks that he or she operates within the mandate of his or her government." ${ }^{277}$ Also, a member of ECHA's management board reports that

[They] have been broadly discussing this issue. It is not the role to represent your country; it is rather to act as an individual governing the agency. You always have your own national position in your mind. We have to distinguish between bodies taking political decisions, like those people who sit in the committees in the Commission representing their member states. There has to be a coordination mechanism. A management board is a governing supervisory body. It gives instructions and advice; it is not a policy-making body. ${ }^{278}$

Furthermore, next to the question 'for what should national representatives be held to account?' there is an issue of 'how?' Upon what criteria can individual members' behavior be evaluated? A member of the ECHA's management board states that "there is a huge difference between those who have 10-15 pages documents prepared reflecting each agenda item and those who are, how to put in diplomatic terms, not prepared on that level." ${ }^{279}$ At the same time, however, the cases when "half of the board says never anything" 280 do exist, such cases are not necessarily without explanations.

\footnotetext{
276 Senior official from FRA (interviewed in August 2011).

277 Member of an EU agency's management board (interviewed in November 2011).

${ }^{278}$ Member of ECHA's management board (interviewed in September 2011).

${ }^{279}$ Ibid.

${ }^{280}$ Member of an EU agency's management board (interviewed in November 2011).
} 
"The reasons could be language barrier and the hierarchy of the size of EU states."281 The size of the country or the institution members represent may influence the members' active and involved attitude: in some agencies, such as the EASA, the representatives of the UK and France have been more active, and members from the Netherlands speak up more while members from Germany speak up less. ${ }^{282}$ The Commission's representatives have often been more active; they are well prepared as they are more familiar with the EU policies, ${ }^{283}$ yet not necessarily leading the boards. ${ }^{284}$ Some also suggest that

It is not always the importance of the country that makes someone speak, but it is more the personality. We had a member, for instance, from Cyprus couple of years ago. He always took the floor, although Cyprus does have even a [relevant] system itself. But he had an opinion and he expressed his opinion. Now we have someone from Cyprus, I have never heard the person saying one sentence, only yes or no if there is a vote. Of course, the big countries, such as France, the UK, Germany, in our system the Netherlands, <...> they express their views more than others, because they have a bigger share in our activities than other countries. But, for instance, Poland, which is an important country in our system, they have a representative whom you really have to put a pistol to his head [joking] before he speaks, although he has a very high position in Poland...different mentality. ${ }^{285}$

Thus, "as the management board consists of a large number of people, there are less and more active persons." 286 "Some speak only when something goes wrong." ${ }^{287}$ On the basis of members' silence "it would be unfair to say that some men do not know...they are from respected ministries...perhaps the perspectives of some countries are narrower $\langle\ldots\rangle$. Every country has pilots and airlines but not every country has an airplane industry. Only 10."288 In addition, "you have countries when you have whole ministries or agencies dealing with

\footnotetext{
${ }^{281}$ Member of EASA's management board (interviewed in November 2011).

282 Ibid.

283 Busuioc (2010) P. 86.

284 "They are not in lead, but of course their arguments are highly valued (because of their preparedness). But they are definitely not leading." (Senior official from FRA (interviewed in August 2011)) While others say that they "have been reluctant to draw conclusions to which the Commission was opposed. If they do not like something, we are unlikely to proceed. They are the most important member" (Member of an EU agency's management board (interviewed in November 2011)).

285 Director of an EU agency (interviewed in July 2011).

Interestingly, a management board's member of another EU agency also mentioned a member from Cyprus who was more active than representatives from some (bigger) member states. He referred to the importance of personality but also the position of the country, like Cyprus, that was "acceptable for all. If a discussion is stuck, he may come to the floor, sum up all what has been said and propose to do the following ...” (Member of an EU agency's management board (interviewed in September 2011)).

${ }^{286}$ Member of an EU agency's management board (interviewed in November 2011).

${ }^{287}$ Director of an EU agency (interviewed in July 2011).

${ }^{288}$ Member of EASA's management board (interviewed in November 2011).
} 
the area, you have countries when there are 2-3 people." 289 The silence of boards' members may also be seen as "the positive side because if all 27 members would express their opinion about each subject, the meetings would take forever." 290

\section{Democratic Accountability of the Members appointed or designated by the Commission and the European Parliament}

Similar to national representatives, it is also unclear whether and how the Commission's representatives render account internally (i.e., whether there are ex ante instructions and ex post checks); if this is regulated, it is likely to be done within individual DGs. Yet, as the Commission is accountable before the European Parliament (Article 17 (8) TEU), the European Parliament, as the 'democratic control authority', can supposedly question Commission representatives.

While the appointment and accountability procedures of the representatives from the member states and the Commission are made within these institutions, there is more transparency as to how the European Parliament designates independent experts to EU agencies' management boards. Take note of the difference in language: the founding regulation of the EMCDDA, for instance makes a clear distinction between appointees of different authorities. Its management board consists of "one representative from each Member State, two representatives from the Commission, two independent experts $\langle\ldots\rangle$ designated by the European Parliament" (emphasis added, Article 9 of Regulation (EC) No 1920/2006).

The Decision of the Conference of Presidents (the political groups' leaders within the European Parliament) of 5 March 1998 regulates the designation procedure. In short, no MEP can be designated to EU agencies, ${ }^{291}$ the designated persons are appointed by the President of the Parliament upon the decision of the Conference of Presidents that decides on the list drawn by the responsible committee. ${ }^{292}$ Following the innovation of Parliament's Environment Committee in 2004, permanent specialized committees hold nomination hearings of the candidates to agencies' management boards. ${ }^{293}$ The European Parliament opines that its designated persons are important to maintain an adequate relationship between the agency and the Parliament. ${ }^{294}$ These persons could act as intermediaries, passing on agencies' concerns to the MEPs. To this end, the designated persons may be asked to

\footnotetext{
289 Senior official of an EU agency (interviewed in October 2011).

${ }^{290}$ Director of an EU agency (interviewed in July 2011).

${ }^{291}$ Article 3 of Decision of the Conference of Presidents of 5 March 1998 'Rules on the Designation by the European Parliament of Members of the Management Boards of the Specialised Agencies and Bodies' referring to the decision of the meeting of the Conference of Presidents on 11 September 1997.

292 The responsible committee probably implies the committee under whose jurisdiction the agency falls thematically.

${ }^{293}$ Corbett et al. (2011) P. 304.

${ }^{294}$ Committee of Employment and Social Affairs' draft report on the proposal for a regulation of the European Parliament and of the Council establishing a European Training Foundation (recast) (2007/0163(COD)).
} 
exchange information and to submit a report. ${ }^{295}$ These functions are, however, suggested by the Commission to be inappropriate because the Parliament "must be free to exercise external political supervision over their activities, without feeling tied by the membership of the administrative board," ${ }^{296}$ although it is debatable whether the European Parliament has control over agencies' management boards at all. Such 'inappropriateness' exists, however, only in seven agencies. ${ }^{297}$ Except for a few other cases where the European Parliament needs to be informed (EASA) and consulted (EFSA) as regards the appointment of members of these agencies' management boards, it does not participate in the appointment of management boards' members of other EU agencies.

\section{'The issue of collective accountability of EU agencies' management boards}

Similar to how management boards' composition resembles that of the Council, these agencies' 'mini-Councils' cannot be held to account collectively. The Community Plant Variety Office (CPVO) is a very interesting example in this respect. The management board of the CPVO Administrative Council is composed of "one representative of each Member State and one representative of the Commission" (Article 37(1) Regulation 2100/94). There is no tenure and there are no removal provisions for the members of the Administrative Council. The Administrative Council's tasks include taking "all necessary steps $\langle\ldots\rangle$ to ensure the functioning of the Office in accordance $\langle\ldots\rangle$ with the rules established, or guidance issued, by the Administrative Council" (Article 42(1) Regulation 2100/94). ${ }^{298}$ The Administrative Council gives its opinion to the Council of Ministers that appoints the President of the Office based upon a list drawn up by the Commission. Together with the Commission the Administrative Council also receives the annual report from the President. Moreover, it "may deliver opinions to, and require information from the office and the Commission, where it considers that this is necessary" (Article 36(2) Regulation 2100/94) (emphasis added). Furthermore, since it is a self-funded agency, it is not required to give financial account before the Council and the European Parliament, but before the Administrative Council who is the budgetary and discharge authority for the agency (see section 2.2.4.3.).

\footnotetext{
${ }^{295}$ Decision of the Conference of Presidents of 5 March 1998 'Rules on the Designation by the European Parliament of Members of the Management Boards of the Specialised Agencies and Bodies'.

${ }^{296}$ Majone (2006) P. 198.

${ }^{297}$ ACER, ECDC, ECHA, EEA, EMA, EMCDDA, and ETF.

298 "The Administrative Council is the budgetary authority of the CPVO, it monitors the CPVO activities and the management of its President, adopts general guidelines on matters for which the Office is responsible, advises the CPVO management, submits to the European Commission proposals for amendment of Community legislation on Plant Variety Rights and may issue rules on working methods of the Office." This information is taken from the official web-page of the agency. Find at: http://www.cpvo.europa.eu/main/en/home/about-thecpvo/administrative-council (last check April 2013).
} 
Given the composition and its tasks, the mandate of the Administrative Council of the agency is twofold. It is the highest internal organ of the agency (its management board), and the political accountability forum since it examines the annual report, adopts the budget, gives the discharge and participates in the appointment of the agency's director. While the Administrative Council is responsible for ensuring the proper functioning of the agency and for holding it to account (especially since the involvement of the EU representative institutions is to a great extent precluded), the democratic accountability line of the Administrative Council for its collective decisions is absent.

\section{Appointment of EU agencies' directors}

While collective accountability of management boards does not exist, this could perhaps be at least partly explained by the importance of the role agencies' directors play in EU agencies. The management boards of EU agencies usually adopt annual plans and draft budgets; however such documents are usually prepared before their meetings by agencies' staff under the authority of executive directors who are responsible for the daily administration. Moreover, EU agencies' executive directors are normally agencies' official representatives and it is they who formally render financial account before the European Parliament in the course of the annual discharge procedure. For the three financial agencies, the EBA, EIOPA and ESMA, it is the chairperson who officially represents its agency, while the executive director is accountable for the implementation of the budget before the European Parliament. EU agencies' directors thus play more prominent roles than merely executing, they often run their agencies. ${ }^{299}$

The appointment of directors is usually shared among agencies' management boards, the Commission, the Council and the boards of supervisors (for the EBA, EIOPA and ESMA). The involvement of these actors and procedures vary greatly from agency to agency. In fact, there are 12 appointment formulas that apply to the appointment of EU agencies' directors. They will be briefly listed here.

(1) One of the most commonly used scenarios (17 out of 35 agencies $^{300}$ ) is that following an open call announced in the Official Journal, the Commission draws up a list of several candidates for the relevant management board to select a candidate. ${ }^{301}$ Such a scenario is likely to dominate in future agencies. ${ }^{302}$ (2) In the case of the FRA this procedure is

\footnotetext{
${ }^{299}$ Groenleer (2009) P. 122.

${ }^{300}$ EU-OSHA, Frontex, IT-Agency, EASA, ECDC, ECHA, EEA, EFCA, EFSA, GSA, EIGE, EMSA, EMA, EMCDDA, ENISA, ETF, and Cdt.

${ }^{301}$ Interestingly, in this respect the European Parliament stated that "the autonomy which is to be conferred on the agency in respect of technical matters falling within its remit does not relieve the Commission of its political responsibility for the agency's activities" and that "the way in which the role of the Commission in selecting and appointing the executive body, generally the director, is fulfilled must reflect this requirement for political responsibility and accountability” (Motion for a Resolution, B6-0000/2005, of 13.10.2005).

302 'Common Approach'. Point 16.
} 
supplemented by providing the opinions of the European Parliament and of the Council. (3) In case of ACER its Board of Regulators is consulted. (4) The Commission and management board can switch their roles, thus making the Commission the appointing authority, based upon the list drawn up by the management board (Cedefop and Eurofound). (5) Furthermore, CPVO's director is appointed by the Council based upon a list drawn up by the Commission and an opinion received from CPVO management board whereas $(\sigma)$ the director of OHIM is appointed by the Council based upon the list prepared by its management board. (7) The executive directors of EBA, EIOPA, and ESMA are appointed by their boards of supervisors upon European Parliament's confirmation. In addition to the directors, they have also chairpersons who are appointed by the boards of supervisors where the European Parliament can object to the decision. (8) Management boards of EU agencies of the former second pillar appoint their directors upon a proposal of the member states (ISS and EUSC) or (9) of the head of the agency who is the Secretary General of the CFSP Council (EDA). There are also cases where a director is appointed either by (10) a management board (BEREC (the Office), EASO and ERA) or (11) the Council (Europol) alone. (12) Eurojust's director and Cepol's director are appointed by their management boards (College in the case of Eurojust) based upon the list prepared by a selection board. As a final note, in 18 (out of 35) cases a parliamentary hearing is prescribed before the appointment of a director. ${ }^{303}$

Considering the important role agencies' directors play, some diversity concerning their appointment formulas can be explained by the institutional design of the autonomy of agencies: whether individual agencies are created to be independent from supranational institutions or member states. ${ }^{304}$ However, it is difficult to find such explanations in agencies' founding acts and it is doubtful that the institutional design of the autonomy of agencies requires 12 different appointment procedures.

Agencies' directors are normally appointed for a three to five year term which does not necessarily correspond to the term of the agency's management board members. While some founding acts specify relevant expertise for the candidates to the director's position, ${ }^{305}$ this is not always the case. ${ }^{306}$ The professional backgrounds of agencies' directors include EU institutions, national administrations, and university professors. ${ }^{307}$ There are no nation-

\footnotetext{
${ }^{303}$ ACER, BEREC (the Office), IT-Agency, EASO, EASA, EBA (in relation to chairperson), ECDC, ECHA, EFSA, EIGE, EIOPA (in relation to chairperson), EMSA, EMA, EMCDDA, ENISA, ESMA (in relation to chairperson), and ETF.

${ }^{304}$ Kreher (1997) P. 234-235.

${ }^{305}$ A typical clause being "the Executive Director shall be appointed by the Management Board on the grounds of merit and documented administrative and managerial skills, as well as competence and expertise relevant to the [relevant] sector" (e.g. Regulation (EC) No 460/2004 establishing the ENISA).

${ }^{306}$ CPVO, OSHA, ECDC, EEA, EFSA, EIGE, EMA, EMCDDA, OHIM, CdT, EDA, ISS, and Eurojust. As regards Cepol and Europol the task to establish the appointment procedure is delegated to the management board. ${ }^{307}$ Groenleer (2009) P. 123.
} 
ality-related restrictions, however, certain practices have emerged. Directors do not normally hold the nationality of the agency's host country, and, interestingly, the majority of the former and existing agencies' directors have held the nationality of a Northern European country. ${ }^{308}$

A director's terms of office can be renewed, although at times this is upon certain conditions. A founding regulation may include an evaluation clause which prescribes requirements for reappointment, but this is not always the case. ${ }^{309}$ In some cases, the founding act prescribes who has the power to propose the extension of the office, for instance, the Commission or the management board. Another peculiarity concerning the renewal of terms of office is that some agencies' directors can be reappointed for a shorter term than the initial appointment term (e.g., FRA, EDA, ISS, and EUSC).

The existing variety of (re)appointment formulas has led to a legislative proposal to make a more harmonized appointment procedure for the sake of clarity and comprehensibility. It was a proposed amendment to the founding regulations of the existing, at that point, 18 'community' agencies to harmonize the terms of office (making it five years) and appointment procedures of their directors. ${ }^{310}$ The proposal was initiated in 2005 and received amendments from the European Parliament. The amendments concerned including the parliamentary opinion before the appointment and extension of the term of directors and the removal of the Commission's responsibility for proposing the extension of director's office or making an evaluation. ${ }^{311}$ In response, the Commission stated that the purpose of making the procedure shorter and simpler was hindered by the Parliament's proposal of

\footnotetext{
${ }^{308}$ Groenleer (2009) P. 123.

${ }^{309}$ As an example, according to its founding regulation the CFCA's Executive Director can receive an extension of his or her term "on a proposal of the Commission" which is to "be approved by a two thirds majority of members of the Administrative Board” (Article 30 (4) of Council Regulation (EC) No 768/2005) while Article 12 (2) of the EIGE's founding regulation requires the Commission to evaluate the results achieved by the director in his or her first term of office, the way the results were achieved and the agency's duties and requirements in the coming years when making such a proposal (Regulation (EC) 1922/2006).

${ }^{310}$ Legislative Proposal to amend regulations of 18 EU agencies, COD/2005/0076: 13/05/2005 - Commission/Council: initial legislative document.

The Commission reasoned that the proposal was necessary due to the existing legal uncertainty coming from the term 'renewal of the term of office' which was thought to be replaced by the term 'extension'. The terminology seemed to matter in relation to the starting-up phase of the reappointment procedure, including the publication of the vacancy in the Official Journal and the selection procedure, when the term 'renewal' is used. The intention was to avoid a lengthy appointment procedure. According to the proposed legislation, directors would be appointed by their management boards on a proposal from the Commission whose evaluation would be necessary for the extension of the term for another five years. The evaluation would focus on three aspects: the results achieved in the first term of office, the way in which the results have been achieved, and the agency's duties and requirements in the coming years.

${ }^{311}$ Report on the proposal for a regulation of the European Parliament and of the Council amending Regulation (EEC) No 302/93 on the establishment of a European Monitoring Centre for Drugs and Drug Addiction as regards the Director's term of office (COM(2005) 0190 - C6-0145/2005 - 2005/0076(COD)).
} 
adding another step, i.e., a hearing before the Parliament. The removal of the Commission from the evaluation procedure was also unacceptable for the Commission as it called "into question the existing institutional balance." ${ }^{12}$ Nevertheless, this is another example of the European Parliament's attempt to strengthen its role in relation to EU agencies with the help of its stronger legislative power (see section 2.2.1.1.). In a larger picture, this example seems to demonstrate how, in the absence of specific treaty provisions, the EU main institutions draw the boundaries between each other to ascertain more control over the so-called independent EU agencies. ${ }^{313}$

\subsubsection{Removing agencies' top officials}

\section{EU agencies' management board members}

The members of management boards may a tenure, which varies from three to six years and the term can be renewable. "Whereas a longer term of office is argued to increase their independence from political influences and enhance the continuity of their activities, a shorter tenure is said to make it more difficult for organised interests (notably industry) to capture the board." ${ }^{14}$ Interestingly, the recently released 'Common Approach' on EU agencies proposes that all appointing authorities as regards EU agencies' management boards "should increase efforts to limit turnover of their representatives in the boards, in order to ensure continuity of the boards' work." 315 At the same time, founding acts of approximately one third of EU agencies do not specify any tenure, ${ }^{316}$ so even a 'for good behavior' restriction is not included. Moreover, no removal clauses exist in agencies' founding acts. Arguably respective appointing authorities replace their representatives and designated persons either on the expiration of their terms, if there are any, or for other reasons. ${ }^{317}$ The absence of removal clauses and procedures in agencies' founding acts may be an indication of a more 'external' role the management boards are supposed to play: "if you

\footnotetext{
${ }^{312}$ Commission response to text adopted in plenary SP(2006)0053 12/01/2006 (Codecision procedure - First reading, Proposals for amending the basic Regulations of 18 Agencies as regards the term of office of their Director).

313 Groenleer states in this respect that EFSA's management board considered a review of the appointment by the Commission "an attack on its independence". The chair of the management board sent even an open letter to the Secretary-General of the European Commission in which he called the proposal to in effect transfer the power to reappoint an executive director from the board to the Commission unacceptable (Groenleer (2009) P. 124).

314 Groenleer (2009) P. 120-121.

315 'Common Approach' on EU agencies, Point 10.

${ }^{316}$ BEREC (the Office), CPVO, EEA, EMCDDA, ENISA, OHIM, EDA, ISS, EUSC, Cepol, Europol, and Eurojust.

${ }^{317}$ In the decision of the Conference of Presidents of March 5, 1998 Article 7 mentions when the designated person can be removed: if he shall "fail the obligations of his office or violate the principles of impartiality or independence." (Rules on the Designation by the European Parliament of members of the management boards of the specialized agencies and bodies decision of the Conference of Presidents parliamentary decision). No information has been found on the removal procedures of other removal authorities.
} 
think about a company, there are executive and non-executive people. The board here is made of non-executives. I do not work here. In this sense, the board is an external organ. Technically, we are external." 318

\section{Removal of EU agencies' directors}

In contrast to the situation with the members of management boards, agencies' directors render personal accountability for their performance in various ways. First of all, founding acts of the great majority of agencies prescribe specific removal procedures, although there are several founding regulations that lack an explicit removal clause (see Table 2.6. below). Table 2.6. shows that there are five different procedures on how EU agencies' directors can be removed.

Removal of directors is often within the competence of agencies' management boards, but in a few cases it is within the competence of the Council (CPVO and OHIM) or the European Parliament. The latter applies in three cases of chairpersons of the recently created financial agencies (EBA, EIOPA and ESMA); these chairpersons may be seen as counterparts of other agencies' directors because they represent their agencies. In some cases, the removal proposal has to come from another institution, for instance, the Commission (EMA) or the management board (Europol). Interestingly, while the agency director is usually accountable before the European Parliament for the implementation of the budget, the European Parliament has no formal power to remove the director. While Cepol's director was removed for financial mismanagement-the first negative discharge decision in history, given by the European Parliament to an EU agency (see section 2.2.4.2.) — it was the management board who adopted that decision and not the European Parliament. ${ }^{319}$

In addition to (or in some cases instead of ${ }^{320}$ ) the explicit removal clauses in agencies' founding acts there are 'accountability' and 'disciplinary' clauses which can be arguably used for removal purposes. Moreover, in those founding acts where no explicit removal clause is prescribed, such clauses, if included, seem to be the only formal possibility to remove the director. The former, 'accountability clause', implies accountability of an agency's director before a specified body, often the management board. The latter, the 'disciplinary clause', is often formulated as follows: 'the management board (or the Council) exercises disciplinary authority over the agency director'. It has to be noted, however, that it is unclear "how to put it in practice." ${ }^{21}$ Some agencies' officials understand it as the power to fire the director, ${ }^{322}$ others suggest that "it can be considered as indirectly used when a direc-

\footnotetext{
${ }^{318}$ Member of an EU agency's management board (interviewed in November 2011).

319 'EU police agency Cepol criticised over accounts'. Find at: http://www.bbc.co.uk/news/world-europe11494209 (last check October 2010).

${ }^{320}$ BEREC (the Office), EU-OSHA, Cedefop, EEA, Eurofound, EMCDDA, Cepol, CdT, EDA, EUISS and EUSC.

321 Senior official from an EU agency (interviewed in October 2011); also see Busuioc (2010) P. 121.

322 Senior official from an EU agency (interviewed in August 2011).
} 
tor who has the right for the extension of his mandate does not get it." ${ }^{23}$ Thus, except for the explicit removal provisions, the implications of such accountability and disciplinary clauses remain speculative.

Table 2.6. Removal of EU agencies' directors: relevant statutory clauses

\begin{tabular}{ll}
\hline Removal-relevant clauses & Agencies' abbreviations \\
\hline Removal by the management board & $\begin{array}{l}\text { Frontex, IT-Agency, EASO, EASA, EBA, ECDC, ECHA, } \\
\text { EFCA, EFSA, GSA, EIGE, EIOPA, EMSA, ENISA, ERA, } \\
\text { ESMA, ETF, Eurojust (by the College) and FRA }\end{array}$ \\
$\begin{array}{l}\text { Removal by the management board upon the } \\
\text { consent of the Board of Regulators }\end{array}$ & $\begin{array}{l}\text { ACER } \\
\text { Removal by the management board upon the } \\
\text { proposal of the Commission }\end{array}$ \\
$\begin{array}{l}\text { Removal by the Council (taking into account } \\
\text { the opinion of the management board) }\end{array}$ & $\begin{array}{l}\text { CPVO, OHIM, (Europol) } \\
\text { Removal by the European Parliament }\end{array}$ \\
$\begin{array}{l}\text { EBA, EIOPA, ESMA (in relation to the chairpersons of these } \\
\text { agencies and following the decision of the Board of Supervisors } \\
\text { of these agencies) }\end{array}$ \\
$\begin{array}{l}\text { BEREC (the Office), EU-OSHA, Cedefop, EEA, Eurofound, } \\
\text { EMCDDA, Cepol, CdT, EDA, EUISS and EUSC }\end{array}$ \\
$\begin{array}{l}\text { No removal clause } \\
\text { ACER, CPVO, Frontex, EASO, EASA, EBA, ECDC, ECHA, } \\
\text { EFCA, GSA, EIGE, EIOPA, EMSA, ERA, ESMA, ETF, FRA } \\
\text { agement board or by the Council } \\
\text { and OHIM } \\
\text { BEREC (the Office), EU-OSHA, Frontex, IT-Agency, EASO, } \\
\text { Cedefop, EEA, Eurofound, EIGE, EMCDDA, Cepol, ETF, } \\
\text { FRA, CdT, EDA, EUISS and EUSC }\end{array}$ \\
\hline
\end{tabular}

Concluding, the appointment and removal procedures are crucial in investigating the political accountability of EU agencies because they make it possible to draw the personal accountability line between agencies' unelected officials and the people via representative bodies. This section has shown a great variety of (re)appointment and removal procedures existing in EU agencies' founding acts with different involvements of the EU representative institutions: 12 appointment and 5 removal formulas. The existing situation hinders transparency and clarity and has somewhat troubling characteristics, such as the absence of removal clauses, which could be seen as an accountability gap in the democratic accountability chain between EU agencies' top officials and the people. The ways in which appointment and removal procedures have been organized seem to indicate an ongoing political game between national and EU institutions with respect to asserting control over the so-

${ }^{323}$ Director of an EU agency (interviewed in August 2011). 
called independent 'independent' EU agencies. As the game is not over, it is difficult to arrive at a limited number of formulas governed by reason, rather than outcomes of individual political negotiations. While some degree of diversity could be explained by the necessities of the institutional design of the autonomy of agencies, it is doubtful that one needs 12 different appointment procedures and five different removal procedures in relation to EU agencies' directors.

As a final remark, what is interesting to notice is that the European Parliament's role with respect to appointing and removing agencies' directors has grown. In a way, it resembles the development of the Parliament's appointment role as regards the Commission: the initial 'zero role' in appointing Commissioners transformed into the investiture procedure. Likewise, initially the European Parliament did not participate in the appointment of directors, nor the members of management boards, whereas today it can be consulted in these procedures, may hold appointment hearings, ${ }^{324}$ can designate independent experts to management boards of a few agencies, has a confirmation role in appointing directors and may even remove the chairpersons of the three recently created financial agencies, counterparts of agencies' directors regarding their representative roles and tasks. This is another illustration of the identified correlation in section 2.2.1.1. between the growing legislative power of the European Parliament and enhancing the personal accountability of EU agencies' top officials before the EU representative institutions.

\subsubsection{Accountability through Statutory Regulation: Theory and Practice of Reporting and Review Clauses}

EU agencies are subjected to a number of accountability obligations. These derive from agencies' founding acts and additional secondary legislation, such as the Financial Regulation. ${ }^{325}$ This section focuses on the most important aspects of statutory regulation, in terms of political accountability, namely reporting (2.2.3.1.) and review (2.2.3.2.) clauses. It shows a great diversity of EU agencies' reporting and review obligations and shortcomings of such obligations in law and practice.

\footnotetext{
${ }^{324}$ Although the appointment hearing does not exist in relation to all EU agencies, it is interesting to note that in case of the Court of Auditors, the first institution where the European Parliament's consultative role in the appointment was introduced, the absence of the formal requirement to come to a hearing was supported by "the political calculation that any candidate who refused to attend a hearing would be highly unlikely to receive positive parliamentary support" (Judge and Earnshaw (2008) P. 213-214).

${ }^{325} \mathrm{EU}$ agencies are, among other things, subject to Regulation on public access (1041/2001). EU agencies are obliged to give "the fullest possible effect to the right of public access" (recital 4) to all documents in their possession, subject to the principles, conditions and limits of the Regulation. The aim of this act is to "enshrine the concept of openness" (recital 1) which "enable citizens to participate more closely in the decision-making and guarantees that the administration enjoys greater legitimacy and is more effective and more accountable to the citizen in a democratic way" (recital 2).
} 


\subsubsection{Reporting obligations: 'you get what you ask for'}

All EU agencies are regulated by their sui generis founding acts which on an agency-byagency basis prescribe individual standards for performance and accountability obligations, such as reporting obligations. The Financial Regulation ${ }^{326}$ imposes additional reporting obligations on EU agencies. This section discusses relevant laws and practices concerning agencies' reporting obligations and argues that the poor quality of existing reporting may be caused by very general formulations of reporting obligations. In this case, the legislator is getting what it asked for.

\section{Types of reporting obligations}

Every agency has some reporting obligations. The amount of institutions-recipients as well as the number and types of reports vary greatly from agency to agency, but every agency issues at least some kind of report and submits it to at least one of the following authorities: the Commission, the Council, and the European Parliament. The list of institutions can be extended in some cases with the European Economic and Social Committee and the Court of Auditors (mainly, for financial reports). The reports are published.

Founding acts and the Financial Regulation, two existing legal sources of reporting obligations, require different types of reports. The most 'common' (in the sense of applicability to almost all agencies) are annual working programs and annual reports of founding acts and annual activity reports of the Financial Regulation.

Annual reports are comprehensive documents which show what an agency has done throughout the preceding year, although reporting obligations are usually quite short on details concerning what needs to be reported and how. The annual report is a document which every agency prepares and nearly every agency has an obligation to submit its annual report to the Council and the European Parliament. The exceptions include CPVO that submits its annual report to its management board and the Commission; OHIM which submits its annual report to the European Parliament and the Commission; and EDA that submits its annual report to the Council only. Furthermore, in the cases of Eurojust, Cepol, Europol, EUISS and EUSC the report is submitted to the Council who forwards it to the European Parliament for information.

In addition to annual reports, there are (multi) annual working programs, ex ante plans which show what agencies are going to do in the coming year(s). Again, the majority of agencies have to send them to the European Parliament and the Council, but there are exceptions. ACER has to submit its working program to the European Parliament only. With respect to the EDA, EUISS, and EUSC, the working program is sent only to the

\footnotetext{
${ }^{326}$ Commission Regulation (EC, EURATOM) No 2343/2002 on the Framework Financial Regulation for agencies passed in accordance with Council Regulation (EC, EURATOM) No 1605/2002 on the Financial Regulation applicable to the general budget.
} 
Council. Cepol's working program requires the Council's approval. Europol's working program requires the Council's endorsement and is sent to the European Parliament for information. The European Parliament and the Council receive the working programs from the three financial agencies, the EBA, EIOPA and ESMA for their information. Furthermore, the working program of the FRA is adopted by the Council in consultation with the European Parliament upon a proposal from the Commission.

Unlike annual reports and working programs prescribed differently by individual agencies' founding acts, annual activity reports are required by and explained in detail in the Financial Regulation. This applies to all EU agencies financed from the EU general budget, thus excluding self-funded agencies discussed in section 2.2.4.3. Article 40 of the Commission Regulation No 2343/2002 reads as follows:

The authorising officer [normally an agency's director] shall report to the management board on the performance of his/her duties in the form of an annual activity report $\langle\ldots\rangle$ together with financial and management information. This report shall indicate the results of his/her operations by reference to the objectives set, the risks associated with these operations, the use made of the resources provided and the way the internal control system functions.

Such reports are often attached to agencies' annual budget requests submitted to the Commission, the Council and the European Parliament. In addition, EU agencies have to send reports "drawn up by its director summarising the number and type of internal audits conducted by the internal auditors, the recommendations made and the action taken on these recommendations" to the Commission and the 'discharge authority', which is normally, but not always (excluding self-funded agencies), the European Parliament (Article 72(5) Commission Regulation 2343/2002).

In addition to the three 'most common' types of reports, individual agencies may submit specific reports and information, which may include, among others, scientific opinions or risk assessments, which are interconnected with specific activities of individual agencies. As an example, the European Fisheries Control Agency has to submit assessments of joint deployment plans to the European Parliament, the Commission and the member states. An annual evaluation of the current and emerging threats to health in the Community is to be forwarded to the European Parliament, the Council and the Commission by the European Centre for Disease Prevention and Control (ECDC). Such additional reporting obligations can also be found in the founding acts of CPVO, EASO, EBA, ECHA, EFSA, EIOPA, EMCDDA, ESMA, Eurojust, and GSA.

\section{Reporting obligations: problematic instances}

While EU agencies can be subject to various reporting obligations, reporting obligations differ from agency to agency without clear reasons for the differences. Reports of the agencies of the former second and third pillars are normally submitted to the Council, but in 
some cases the European Parliament also receives a copy of an annual report for information forwarded to it by the Council. The CPVO and the OHIM are two agencies with similar decision-making tasks created in the same second wave of the creation of agencies (in 1994) but have quite different reporting obligations, the CPVO reports to its management board and the Commission, while the OHIM has an obligation to submit its annual report to the European Parliament and the Commission.

Furthermore, the existence of reports is one thing that is important for the accountability process. But the existence says little about their quality, which has been an issue of concern. The recent Ramboll evaluation of $26 \mathrm{EU}$ agencies concluded that monitoring and reporting issues are not at a satisfactory level. "Performance information relates to the agency's own responsibility in achieving its intended outputs, and results at a reasonable cost. $<\ldots>$ such information is scarce" 327 and "performance reporting is almost non-existent." 328 Roughly speaking, existing reports would list the actions that the agencies have undertaken, rather than assessing what the agencies have achieved, whether it has been necessary, efficient, and actually intended, and if so, why. ${ }^{329}$ In this light, "public administration remains descriptive and not analytical. You report what you have done but so what that you have done it." ${ }^{330}$ According to the Ramboll evaluation, necessary monitoring systems, which would link agency performance, outputs and resources have not been established or applied properly. The Court of Auditors' special report has also spotted similar shortcomings. ${ }^{331}$

One of the possible reasons for poor quality reporting could be the silence of agencies' founding acts about information expected to be in the annual report. A typical reporting obligation says no more than that an agency has to submit an annual report (see Table 2.7. below). In contrast, only in a few cases do EU agencies have more specific reporting obligations, such as the EASA (1) or ETF (2) have:

\section{(1) Article 57 of Regulation 216/2008 establishing EASA}

The annual general report shall describe the way in which the Agency has implemented its annual programme of work. It shall clearly indicate which of the mandates and tasks of the Agency have been added, changed or deleted in comparison with the previous year. The report shall outline the activities carried out by the Agency and evaluate the results thereof with respect to the objectives and timetable set, the risks associated with those activities, the use of resources and the general operations of the Agency.

\footnotetext{
327 The Ramboll evaluation, Volume I. P. 23.

328 Ibid.

${ }^{329}$ Agencies' reports "were in most cases descriptive and detailed. However, they provided little information on results apart from indicating the amount of activity." (The European Union's Agencies: Getting Results. The European Court of Auditors, Special Report No 5, 2008 (executive summary)).

${ }^{330}$ Director of an EU agency (interviewed in August 2011).

331 The European Union's Agencies: Getting Results. The European Court of Auditors, Special Report No 5, 2008. P. 21. The conclusions of this report are based upon the analysis of eight agencies.
} 
(2) Article 13(2)) Regulation 1339/2008 establishing ETF

The annual activity report shall contain financial and management information indicating the results of operations by reference to the annual work programme and to the objectives set, the risks associated with those operations, the use made of the resources provided and the way the internal control system has functioned.

If reporting is considered to be one of the most important accountability mechanisms that political institutions have in relation to agencies (and other executive bodies), such accountability obligations need to be formulated in the way that they promote the purposes of accountability. The legislator "has to have a clear idea what it wants in these reports" 332 and state it in respective legislation.

Table 2.7. Specificity of statutory obligations to submit annual reports in relation to EU agencies

\begin{tabular}{|c|c|}
\hline Specificity of obligations requiring annual reports & EU agencies \\
\hline $\begin{array}{l}\text { Merely a procedural obligation (such as "a management } \\
\text { board has to adopt the report and transmit it to the } \\
\text { European Parliament and the Council") }\end{array}$ & $\begin{array}{l}24 \text { EU agencies: BEREC (the Office), EBA, ESMA, } \\
\text { EIOPA, CPVO, FRA, ECDC, Cedefop, EEA, EFCA, } \\
\text { EFSA, Eurofound, GSA, EIGE, EMCDDA, ENISA, } \\
\text { OHIM, CdT, EDA, EUISS, EUSC, Cepol, Eurojust, } \\
\text { and Europol }\end{array}$ \\
\hline $\begin{array}{l}\text { An obligation that specifies the inclusion of certain } \\
\text { topics in light of the field of the agency's operation }\end{array}$ & 3 EU agencies: ACER, ECHA, and EMA \\
\hline $\begin{array}{l}\text { An obligation featuring analytical elements, such as } \\
\text { reporting expost results in light of ex ante plans }\end{array}$ & $\begin{array}{l}8 \text { EU agencies: EU-OSHA, EASA, EASO, IT-Agency, } \\
\text { EMSA, ERA, ETF, and FRA }\end{array}$ \\
\hline
\end{tabular}

The poor quality might also be a signal of another shortcoming, namely the absence of interested and knowledgeable readers. The Council and the European Parliament are probably the most targeted audience for EU agencies' reports. However, do they read agencies' reports? The empirical findings of Busuioc demonstrate mixed results in relation to the interest that MEPs have in relation to agencies, ${ }^{333}$ to be further discussed in section 2.2.5. Also, "it depends on the Council Presidency and the Council Secretariat and what business they have [as to] what takes priority for the current presidency" ${ }^{334}$ which in turn will impact the need for a hearing of an annual report and its discussion. There is, for example, an interesting practice of giving conclusions on the annual reports of Eurojust. These conclusions are to be commented on by the agency and followed up in the next year's report. ${ }^{335}$ However, in the absence of formal rules and transparency of the Council's work it is diffi-

\footnotetext{
332 Senior official from an EU agency (interviewed in August 2011).

333 Busuioc (2010) P. 108.

334 Ibid. P. 122.

335 Ibid. P. 124.
} 
cult to conclude whether this is the case with all EU agencies falling under the Council's supervision.

\subsubsection{The theory and practice of agencies' evaluation and review clauses}

A great number of EU agencies' founding acts foresee the possibility of evaluating and/or reviewing EU agencies. Yet, seven (out of 35) EU agencies do not include such clauses in their founding acts. ${ }^{336}$ The evaluation reports are important from an accountability perspective because the purposes of evaluations align with those of accountability: evaluations aim to assess existing practices and results with a view of improvement, rectification of mistakes, and reconsideration of the necessity and relevance of agencies and their individual programs. Furthermore, "evaluations can lead to changes in law, such as reducing or extending agencies' powers, adapting control mechanisms, changing the rules with respect to the composition of agencies etc." 337 This section discusses what evaluation and review clauses exist in agencies' founding acts and the Financial Regulation and it pinpoints the shortcomings of such clauses, including problems related to the practical application of reconsidering the need for EU agencies.

\section{Evaluation and Review clauses of EU agencies' founding acts: a statutory mess}

Generally speaking, EU agencies can have evaluation and/or review clauses in their founding acts. However, looking more specifically at the content of these provisions, a number of inconsistencies can be noticed.

First, it concerns the meaning of such clauses. On the one hand, there seems to be a distinction between an evaluation and a review clause, especially when some founding acts prescribe both clauses implying different procedures. This is the case with five agencies (BEREC (the Office)), EASO, EIGE, ETF and the FRA. For example, the EIGE evaluation and review clauses read as follows:

Article 20 of Regulation 1922/2006 establishing EIGE

Evaluation

By 18 January 2010, the Institute shall commission an independent external evaluation of its achievements on the basis of terms of reference issued by the Management Board in agreement with the Commission. The evaluation shall assess the impact of the Institute on the promotion of gender equality and shall include an analysis of the synergy effects. It shall, in particular, address the possible need to modify or extend the tasks of the Institute, including the financial implications of any such modification or extension of the tasks. Such evaluation shall also examine the appropriateness of the management structure in carrying out the Insti-

\footnotetext{
${ }^{336}$ CPVO, Cedefop, EEA, Eurofound, GSA, EMA and OHIM.

${ }^{337}$ Heringa and Verhey (2003) P. 165.
} 
tute's tasks. The evaluation shall take into account the views of the stakeholders, at both Community and national level.

\section{Article 21 Regulation 1922/2006 establishing EIGE}

Review Clause

The Management Board shall examine the conclusions of the evaluation mentioned in Article 20 and issue to the Commission such recommendations as may be necessary regarding changes in the Institute, its working practices and remit. The Commission shall forward the evaluation report and the recommendations to the European Parliament, the Council, the European Economic and Social Committee and the Committee of the Regions and make them public. After examination of the evaluation report and the recommendations, the Commission may submit any proposals which it deems necessary concerning this Regulation.

As one sees, the difference between the evaluation and review clauses is that the former requires an assessment of the agency's performance, while the latter provides for further actions to be undertaken on the basis of the assessment. Although there seem to be some differences, a great number of founding regulations do not distinguish them in the mentioned way and simply refer to the evaluation or review clause which may imply one or both formulations mentioned above. ${ }^{338}$ In fact, 11 EU agencies ${ }^{339}$ have only evaluation clauses and $12 \mathrm{EU}$ agencies ${ }^{340}$ have only review clauses.

Secondly, such clauses differ with respect to the specificity with which they are formulated. Some prescribe merely a possibility of the respective procedure while others go further and prescribe the substantive evaluation criteria. Thus, such clauses may be elaborate or quite short. The exceptionally elaborate review clauses exist only in three cases, the recently created financial agencies (the EBA, EIOPA, and ESMA). Such clauses are identical for the three agencies:

Article 81 Regulation 1093/2010 establishing EBA

Review

\footnotetext{
${ }^{338}$ E.g., Article 33 'Evaluation' of Regulation (EC) 2007/2004 establishing Frontex includes both types in one: “1. Within three years from the date of the Agency having taken up its responsibilities, and every five years thereafter, the Management Board shall commission an independent external evaluation on the implementation of this Regulation. 2. The evaluation shall examine how effectively the Agency fulfils its mission. It shall also assess the impact of the Agency and its working practices. The evaluation shall take into account the views of stakeholders, at both European and national level. 3. The Management Board shall receive the findings of the evaluation and issue recommendations regarding changes to this Regulation, the Agency and its working practices to the Commission, which shall forward them, together with its own opinion as well as appropriate proposals, to the Council. An action plan with a timetable shall be included, if appropriate. Both the findings and the recommendations of the evaluation shall be made public."

Regulation (EC) No 851/2004 establishing the ECDC contains similar text in Article 31, which is called 'Review Clause'.

${ }^{339}$ ACER, Frontex, IT-Agency, EASA, EFCA, EMSA, EMCDDA, Cepol, Europol, ERA, and Eurojust.

${ }^{340}$ EU-OSHA, EBA, ECDC, ECHA, EFSA, EIOPA, ENISA, ESMA, CdT, EDA, EUISS, and EUSC.
} 
1. By 2 January 2014, and every 3 years thereafter, the Commission shall publish a general report on the experience acquired as a result of the operation of the Authority and the procedures laid down in this Regulation. That report shall evaluate, inter alia:

(a) the convergence in supervisory practices reached by competent authorities:

(i) the convergence in functional independence of the competent authorities and in standards equivalent to corporate governance;

(ii) the impartiality, objectivity and autonomy of the Authority;

(b) the functioning of the colleges of supervisors;

(c) the progress achieved towards convergence in the fields of crisis prevention, management and resolution, including Union funding mechanisms;

(d) the role of the Authority as regards systemic risk;

(e) the application of the safeguard clause established in Article 38;

(f) the application of the binding mediation role established in Article 19.

2. The report referred to in paragraph 1 shall also examine whether:

(a) it is appropriate to continue separate supervision of banking, insurance, occupational pensions, securities and financial markets;

(b) it is appropriate to undertake prudential supervision and supervise the conduct of business separately or by the same supervisor;

(c) it is appropriate to simplify and reinforce the architecture of the ESFS in order to increase the coherence between the macro and the micro levels and between the ESAs;

(d) the evolution of the ESFS is consistent with that of the global evolution;

(e) there is sufficient diversity and excellence within the ESFS;

(f) accountability and transparency in relation to publication requirements are adequate;

(g) the resources of the Authority are adequate to carry out its responsibilities;

(h) it is appropriate for the seat of the Authority to be maintained or to move the ESAs to a single seat to enhance better coordination between them.

3. Concerning the issue of direct supervision of institutions or infrastructures of panEuropean reach and taking account of market developments, the Commission shall draw up an annual report on the appropriateness of entrusting the Authority with further supervisory responsibilities in this area.

4. The report and any accompanying proposals, as appropriate, shall be forwarded to the European Parliament and to the Council.

In contrast to that the review clause of EU-OSHA's founding regulation looks rather short, including the absence of specificity on the substance:

Article 23 Regulation 2062/94 establishing EU-OSHA

Review Clause

No later than five years after the entry into force of this Regulation, on the basis of a Commission report, accompanied as appropriate by a proposal, the Council, having consulted the European Parliament, shall review this Regulation and any new assignment for the Agency that proves necessary. 
From an accountability perspective the former more elaborate clause seems to be more valuable because the Union Legislator sets up a clearer standard against which to check the review report.

Thirdly, the existing evaluation and review clauses vary greatly with respect to the frequency of required evaluations and reviews. $15^{341}$ (out of 35) EU agencies are subject to the evaluation and/or review clauses with the periodicity of three years. An evaluation or review every four years has been prescribed in the cases of Europol, ETF and FRA. Eight agen$\operatorname{cies}^{342}$ have a five-year frequency of evaluations and/or reviews. EMCDDA is subject to an evaluation obligation every six years, whereas ENISA has had a sunset clause which stated that the agency was created for five years and its further existence depended on the evaluation. In addition to that, founding acts of 12 EU agencies ${ }^{343}$ specify only the initial evaluation and/or review period, without obliging periodical evaluations and/or reviews in the future, which is the case with other $16 \mathrm{EU}$ agencies ${ }^{344}$ whose subsequent evaluation/review frequency varies also from three to six years.

Finally, the differences concern the procedure of how evaluations and reviews should be made. The evaluations and reviews are usually done by external evaluators, which are initiated or undertaken (in case of reviews normally) by the Commission, ${ }^{345}$ by the management board ${ }^{346}$ by the agency's head or the chairman of the management board ${ }^{347}$ or by the management board and the Commission together (EIGE and FRA). In a few cases (EU-OSHA, ECHA, and EFSA), the formulation is less clear about the exact organ within the agency which initiates the procedure.

\section{Evaluations required by the Financial Regulation}

Another type of evaluation is required by the Financial Regulation. All agencies that are financed from the general budget have the general requirement of an evaluation of their specific programs. Thus, even if an agency does not have an evaluation obligation on its general performance in its founding act, it can be required to evaluate its individual programs. ${ }^{348}$ For example, on the web-page of Eurofound, that has no evaluation clause in its

${ }^{341}$ ACER, BEREC (the Office), Frontex, IT-Agency, EASO, EASA, EBA, ECDC, EFSA, EIGE, EIOPA, ESMA, Eurojust, CdT and EDA.

342 EU-OSHA, ECHA, EFCA, EMSA, Cepol, ERA, EUISS, and EUSC.

343 BEREC (the Office), EASO, ECDC, EIGE, CdT, EDA, ENISA, ETF, EU-OSHA, ERA, EUISS, and EUSC.

${ }^{344}$ ACER, Frontex, IT-Agency, EASA, EBA, EFSA, EIOPA, ESMA, Eurojust, Europol, FRA, ECHA, EFCA, EMSA, Cepol, and EMCDDA.

345 ACER, BEREC (the Office), IT-Agency, EBA, EIOPA, EMCDDA, ENISA, ERA, ESMA, ETF, and CdT.

${ }^{346}$ Frontex, EASO, EASA, ECDC, EFCA, EMSA, Cepol, Europol, and Eurojust.

${ }^{347}$ EDA, EUISS, and EUSC.

${ }^{348}$ Article 27 of Commission Regulation (EC, Euratom) No 2343/2002: "in order to improve decision-making, the Community body shall regularly carry out ex ante and ex post evaluations of programmes or activities. Such evaluations shall be applied to all programmes and activities which entail significant spending and evaluation results shall be sent to the management boards." 
founding regulation, a number of ex ante working plans and multiannual programs are put in conjunction with their ex post evaluations. ${ }^{349}$ The web-page explicitly refers to the Financial Regulation as the legal basis for such publications. However, this is not always the case. There are cases, like with the OHIM, in which there is neither a legal obligation to make general evaluations in the founding act, nor an evaluation obligation pursuant to the Financial Regulation, because such an agency is a self-funded agency. No overall evaluation has taken place since the creation of the OHIM, although internal efficiency has been evaluated by an external evaluator. ${ }^{350}$

Although evaluations made pursuant to the Financial Regulation may be seen as additional means and compensatory in those cases where agencies have no general evaluation obligations, they differ from general evaluations clauses in a number of aspects. As regards their scope, only programs 'which entail significant spending' need to be evaluated. There are also no frequency and content requirements. The Ramboll evaluation found out that about half of the 26 agencies it studied "state that they carry out activity evaluations. For the others, this type of evaluation seems to mainly take place in connection with the periodic overall evaluations." ${ }^{351}$ In this case the question becomes: if an agency does not have an obligation to perform a periodic general evaluation, are those agencies not being evaluated at all?

\section{Poor quality evaluations}

According to the Ramboll evaluation, the existing evaluation practices are in need of improvement. It points out that EU agencies are given a very short period of time (e.g. in some cases three years) before the first assessment of its existence. Some paradoxical situations occur, like the one with EIGE, whose evaluation was foreseen in 2010 after being formally established in 2006. However, it only became operational at the end of 2009 . Furthermore, there are also other points of attention concerning evaluations:

Both the requirements and the practice of overall evaluations differ considerably between agencies, both in terms of frequency, responsibility, coverage, and dissemination. There seems to be no logical explanation, or justification, for these variations. The only justified exception would seem to be agencies which are $100 \%$ financed by user fees, since public (EU) funds are not used to subsidise the agencies, and thus the need for accountability through evaluation is (slightly) smaller. It is the opinion of the evaluator that the transparency of the agency system would be improved if all agencies were subject to similar requirements. ${ }^{352}$

\footnotetext{
${ }^{349}$ This information is taken from the official web-page of the agency. Find at: http://www.eurofound.europa.eu/about/publicaccess/categories/general/index.htm (last check November 2012).

350 The Ramboll evaluation, Volume III. P. 251, 253.

351 The Ramboll evaluation, Volume II. P. 119.

352 Ibid. P. 121.
} 
All in all, "the bulk of evaluation efforts applies to periodic agency evaluations which fall short on concluding on results and impacts, and therefore add little value in terms of accountability" 353 (emphasis added).

\section{Reconsidering the existence of agencies}

Not many agencies' founding acts mention specifically that evaluations and reviews are meant among other things to reconsider an agency's existence. ${ }^{354}$ From a legal perspective, even in the absence of such a clause similar to how the Union Legislator creates EU agencies, it may at any time amend or repeal individual founding acts, for instance, when the agency has completed its task or has misbehaved or a particular program has become unnecessary. However, while the Union Legislator has amended agencies' founding acts on numerous occasions, only one agency has been closed so far. Abolishing agencies is an act the use of which seems to be restricted by intergovernmental politics.

It is true that the Union Legislator can always change the mandate and functions of EU agencies. It has done so on several occasions. The ETF, for example, has experienced considerable changes in its thematic and geographical scopes. Initially, it was created to support the implementation of the PHARE (pre-accession) program, but later its thematic remit expanded to all matters related to Human Capital Development. The FRA has legally succeeded the European Monitoring Centre on Racism and Xenophobia. As of this writing, only one agency, the European Agency for Reconstruction (EAR), was dissolved. The EAR's task was to assist EU programs in Kosovo re-building infrastructure destroyed by the war. Both its mandate and geographical area were later extended. The initial five-year term (2000-2004) was prolonged until 2008 with the additional task of assisting pre-accession. While its headquarters was in Thessaloniki (Greece), its operation centers were placed in Belgrade, Podgorica and Skopje. In 2008, it was closed on the grounds of 'needs satisfied'. ${ }^{355}$

There can be several explanations of why only one EU agency has been closed so far. The Ramboll evaluation concluded that many tasks that EU agencies perform are still relevant, although a merger of some agencies could have been considered. At the same time, it also pointed out that "the existence of established agencies is almost never reconsidered," 356 and that when many agencies have actually experienced the relevance problem in their existence, a "solution $\langle\ldots>$ has almost always been sought in terms of survival (continua-

\footnotetext{
353 The Ramboll evaluation, Volume I. P. 26.

${ }^{354}$ Article 25 of ETF's founding act is unique in this case: "Following its evaluation, the Commission shall present, where necessary, a proposal for the revision of this Regulation. If the Commission considers that the existence of the Foundation is no longer justified with regard to the objectives assigned to it, it may propose that this Regulation be repealed (Regulation 1339/2008).

355 The Ramboll evaluation, Volume III. P. 48-51.

356 The Ramboll evaluation, Volume II. P. 20.
} 
tion with a smaller size or extension of the mandate) rather than in terms of closure or merging." 357

While the European Parliament's view seems to support the reconsideration of the existence of an agency, the intergovernmental politics is likely to be the reason such revisions may have been prevented. MEP Jensen explained,

We have all the time been discussing the fact that an agency should not be an agency forever. If it is not needed anymore, it does not live up to the tasks, then we might consider changing the structure. That is then complicated by the fact that you place agencies in different countries. So, you would always find, the Spaniards - fighting for the agencies in Spain, the Greeks - fighting for the agencies in Greece. ${ }^{358}$

Concluding, while generally speaking EU agencies are subject to a number of accountability obligations, namely reporting, evaluation, and review clauses deriving from their founding acts and the Financial Regulation, such clauses differ from agency to agency, if included in individual founding acts at all. The differences exist with respect to institutions involved, terms used, specificity of substantive requirements and other procedural elements, such as frequency of evaluations. The reasons for the necessity of the existing differences are unclear. In addition, problems exist concerning the practical application of such clauses, which include poor quality of reports and evaluations, which may not serve the needs of accountability. Finally, while one of the purposes of reviewing agencies is to question their necessity and hence the possibility to dissolve an agency, intergovernmental politics (rather than functional necessity and other factors) seems to be the decisive factor in relation to the abolition of EU agencies placed in different EU member states. The existent diversity hinders legal certainty and any consistency of the institutional framework.

\subsubsection{Financial Oversight: a Well-established Accountability Venue}

Not only the number and diversity of EU agencies may cause one to be concerned about agencification in Europe but also their growing share in the EU general budget is a cause of concern. The majority of EU agencies are financed from the EU general budget and, as their number is growing, so is their share of the budget. "The Community contributions to the decentralised agencies <...> increased between 2000 and 2010 by about $610 \%$ from EUR 94700000 to EUR 578874 000."359 This section examines the issue of financial oversight of EU agencies, which takes place annually within the budgetary (allocation of money) and discharge (implementation of the budget) procedures. These procedures are

\footnotetext{
357 The Ramboll evaluation, Volume I. P. 20.

${ }^{358}$ MEP Jensen (interviewed in August 2010).

${ }^{359}$ European Parliament Resolution of 5 May 2010 on the 2008 discharge; performance, financial management and control of EU agencies (2010/2007(INI)).
} 
analyzed separately in sections 2.2 .4 .1 . and 2.2.4.2. respectively. Following that, the special case of political accountability of self-funded EU agencies is discussed (2.2.4.3.). This section shows that financial oversight over EU agencies is a well-established accountability venue governed by clear rules and established practices.

\subsubsection{Financial oversight over EU agencies: the annual budgetary procedure}

The annual budgetary procedure involves a number of steps where EU agencies interact with the three main EU institutions and it is governed by several principles influencing the financial accountability of EU agencies. This section therefore discusses the issues mentioned in two sub-sections: the steps of and the principles governing the annual budgetary procedure.

\section{Annual budgetary procedure: the steps}

The annual budgetary procedure ${ }^{360}$ begins with EU agencies sending their budgetary proposals to the Commission, which is to be done by 31 March of each year. ${ }^{361}$ Internally, it is normally the agency's director who prepares the draft, submits it to its management board which then sends its adopted version to the Commission. ${ }^{362}$ The Commission prepares a consolidated version of the EU general budget where it may put its estimations of agencies' budgets, thus modifying initial agencies' requests. ${ }^{363}$ While this does not usually happen with other EU institutions, where the principle of institutional autonomy prevails, ${ }^{364}$ some officials from EU agencies state in this respect:

of course before we sent our official [budgetary] proposal, there are contacts with the Commission. They inform us about the developments and the likeliness of the adoption of certain demands. So we are developing that also under the radar of cooperation with the Commission. It would not make sense $\langle\ldots\rangle$ to include figures in those draft budgets which the

\footnotetext{
360 "Amending budgets are subject to the same rules of procedure as the general budget" (European Union Public Finance, $4^{\text {th }}$ edition. European Commission, 2008. P. 222).

361 The questions related to their financial oversight are governed by Commission Regulation (EC, EURATOM) No 2343/2002 on the Framework Financial Regulation for agencies passed in accordance with Council Regulation (EC, EURATOM) No 1605/2002 on the Financial Regulation applicable to the general budget (the 'Financial Regulation'). The Commission Regulation has established common principles and procedures governing the establishment, implementation and control over agencies' finances and obliged agencies to issue their internal financial rules in accordance with it, which resulted normally in 'copying and pasting' of the Regulation into agencies' internal rules.

362 The internal practices may vary from agency to agency.

363 "If it disagrees with any of the estimates submitted by the other institutions, it may attach a dissenting opinion and its own recommendations, in accordance with Article 272(2) of the Treaty" (Article 314 (1) TFEU). (European Union Public Finance, $4^{\text {th }}$ edition. European Commission, 2008. P. 211).

${ }^{364}$ European Union Public Finance, $4^{\text {th }}$ edition. European Commission, 2008. P. 211.
} 
Commission deems totally unreal. ${ }^{365}[\mathrm{Or}$,$] budget is totally to be agreed with the Commis-$ sion. Sometimes the Commission does not want us to do something or wants us to look specifically at some issues. ${ }^{366}$

"Thus, there is definitely work being done on it within the Commission. So some changes can be made." 367 This implies that while EU agencies have formally been granted autonomous budgets, their financial autonomy may be subject to the Commission's influences.

The next step takes place when the draft budget goes to the EU budgetary authority, i.e., the Council and the European Parliament. This step seems to be especially relevant from an accountability perspective because the Council and the European Parliament not only receive financial numbers but also "appropriate supporting documents (Commission's working document on EU bodies has been enhanced along the years at the EP's request: 458 pages for budget 2011)." 368 Such supporting documents include the outcomes of various evaluations and special reports prepared, for example, by the Court of Auditors, to be discussed in section 2.2.4.2. The consideration of agencies' budgets can therefore imply more than 'simply' discussing financial numbers. As money translates into agencies' actions, it involves an annual check upon agencies' performance, their achievements and failures.

The discussions within and between the European Parliament and the Council are another important step from an accountability perspective. Here, EU agencies and their budgets seem to be treated quite differently by the two branches of the EU budgetary authority. As EU agencies' budgets used to be in the non-compulsory part of the EU general budget, where the European Parliament had a final say (see Chapter 2.1.1.2.), certain practices emerged between the European Parliament and EU agencies. MEP Haug who has been dealing with agencies' budgets since 2004 explained:

In the end of June the budgetary committee organises an annual meeting with agencies' directors. Before 2006, directors for all EU agencies that receive money from the EU general budget used to be invited. But with the proliferation of EU agencies the budget committee was 'crowded'. So in 2006 this practice was changed into inviting a trio of directors - a spokesman for all EU agencies and two spokesmen for the preceding and subsequent years. The three come to the budget committee and they discuss with us the horizontal things that need to be discussed which may involve specialised things for individual agencies. The rotation is determined by the agencies where the agency-coordinator is the one who delivers the

\footnotetext{
365 Senior official from an EU agency (interviewed in August 2011).

366 Director of an EU agency's representation in Brussels (interviewed in September 2011).

367 Senior official from an EU agency (interviewed in August 2011).

${ }^{368}$ Administrator of the Committee on Budgets of the European Parliament (e-mail of August 2010).

In the past the Commission did not provide enough information in this respect: "to mitigate the effects of endless budgetary discord, on 13 July 2007 the European Parliament, the Council and the Commission adopted a joint statement on decentralized agencies in which the Commission agreed to provide more information about agency budgets to the two branches of the budgetary authority" (Building Parliament: 50 Years of European Parliament History, 1958-2008, 2009. P. 216).
} 
leading spokesman. In case it is necessary, directors of other agencies may be invited as well. ${ }^{369}$

The situation differs with respect to the Council's involvement. "The Council is not involved in agencies' budgets. The budget committee of the Council is the committee consisting of representatives of all member states and the only task they seem to have is to save some euros for their finance ministers." ${ }^{770}$ The situation becomes quite odd, because "there is little coordination with the Council. And this is a problem. The national members of agencies' management boards adopting the budget have a different view than the Council when the latter cuts that budget. There is thus no coordination between national positions." ${ }^{371}$ The structural problem of the lack of coordination $<\ldots>$ makes the life of agencies more difficult. It undermines their value as Council's officials seem to not understand their necessity, even if agencies sit in their own states." ${ }^{772}$

Different views on the financial numbers may also exist between specialized permanent committees and their budgetary counterparts in the European Parliament. Here, in case of disagreement, the opinion of DG Budget and of the parliamentary budgetary committee would prevail over the positions of their sectoral counterparts; ${ }^{373}$ the budgetary committee oversees the whole budget and often lacks the financial means to satisfy all budgetary requests. What is important here is that respective budgetary organs of the European Parliament and of the Council communicate with their sectoral counterparts and agencies concerning such issues as relevance, necessity, achievements, and failures of individual programs and agencies. It is necessary in order to appropriate necessary sums to relevant programs in order to achieve intended targets, which may not be the case with respect to Council's policy of simply cutting five per cent of all agencies' budgets, ${ }^{374}$ irrespective of what they do and what their achievements or failures are.

In the European Parliament, according to MEP Haug "the issue of communication among specialized committees has become better." ${ }^{375}$ She points out the existing practice of holding annual meetings of budget rapporteurs from individual permanent specialized committees together with a general rapporteur on the whole budget where relevant issues can be discussed. The communication between specialized and budgetary structures is very important in defining what sums to allocate. The specialized committees check their pro-

\footnotetext{
${ }^{369}$ MEP Haug (interviewed in June 2011).

EU agencies' directors have organized a network to discuss common issues. (Senior official from ECDC (interviewed in October 2011)).

370 Ibid.

371 Senior official from an EU agency (interviewed in October 2011).

372 Ibid.

373 Administrator of European Parliament's Employment Committee (interviewed in October 2011).

374 Chairman of an EU agency's management board (interviewed in November 2011) and Senior official from an EU agency (interviewed in October 2011).

${ }^{375}$ MEP Haug (interviewed in June 2011).
} 
grams and allocation of the budget first and with more precision and expertise. This can also prevent financing overlapping programs exercised by different institutions. As specialized permanent committees are supposed to oversee 'their' agencies on a regular basis, they are arguably in the best position to determine the priorities and problem areas where more financing could be necessary ${ }^{376}$ or, conversely, less money should be given. That is why "should the relevant specialised committee choose to withhold endorsement of the agencies' annual report and work program, the Committee on Budgets will refuse $10 \%$ of the respective agencies' budgets." 377 The limit of a 10 per cent decrease can perhaps be explained by the fact that budget cuts' as a sanction measure may be counterproductive. ${ }^{378}$

Finally, the annual budgetary procedure continues with several trialogue meetings, i.e., between the representatives from the Commission, the Council and the European Parliament, and a possible conciliation procedure. The budgetary authority normally adopts the budget by the end of the year (Article 214 (9) TFEU). ${ }^{379}$ In addition to the finally approved money for each agency, the budgetary authority adopts an establishment plan for each agency, which is then to be adopted by agencies' management boards together with the budget. The establishment plan shows "the number of posts authorized for the next financial year, the number authorized for the preceding year and the number of posts actually filled. $<\ldots>$ no appointment may be made in excess of the limit set" with a few exceptions to certain grades of officials where the management board may modify the plan by 10 per cent (Article 32 Commission Regulation No 2343/2002).

\section{Principles governing the budgetary process}

The whole annual budgetary process is governed by a number of principles prescribed by the Commission's Regulation on EU agencies No 2343/2002. Considering the implica-

\footnotetext{
376 Therefore, "if you take the agencies in the field of transport, then it will be first of all the transport committee who looks into their budgets. In fact, if you take the budget of the transport committee is overseeing, then it is mainly the trans-European network or some programmes related to that and then the agencies. <...>the transport committee listens to the argument of the agencies; we ask them whether they will be able to fulfil the tasks" and, considering agencies' concerns, specialized committees give information to the Committee on Budgets (MEP Jensen (interviewed in August 2010)).

377 Busuioc (2010) P. 117.

378 "A fundamental problem here is that budgets play two roles - one that shapes the incentives of bureaucrats, one that provides a financial foundation for programmatic behavior - and these may work at cross-purposes. Suppose, for example, that a committee wants substantially higher levels of regulatory enforcement but the agency refuses $<\ldots>$ If the committee slashes the agency's budget as punishment, on the one hand, it is simultaneously denying the agency the very resources it needs to comply with the committee's wishes. There is no clear solution. The budget is simply not a very dependable control mechanism” (Moe (1987a) P. 487).

${ }^{379}$ If no agreement is reached before the start of the new financial year, the so-to-speak 'one-twelfth rule' applies meaning that all institutions continue to function on the budget which equals $1 / 12^{\text {th }}$ of their previous budget before any agreement is reached (Article 315 TFEU).
} 
tions such principles can have for the accountability and independence of EU agencies, it is important that they are discussed here briefly. ${ }^{380}$

According to the principle of specification, all appropriations are given to specific programs, subdivided into separate sections, if necessary. Each appropriation to a specific program has to be based upon a legal provision authorizing such action. Thus, no 'lump-sum' appropriations, meaning general sums of money without specified purposes, can be given. Furthermore, transfers from one article (an action or a sub-program) to another within one chapter (a more general program) in the budgets can be made by the director only upon informing the management board. Transfers from one chapter to another one can be made by the director only within a total of 10 per cent of the appropriations for the financial year. Beyond this limit, the director has to forward its request to the management board, which has one month to oppose the transfer. For the purposes of accountability, this principle seems to facilitate ex post control over expenditures and specific actions, because it reduces the discretion agencies would have in deciding how much money is to be allocated to individual programs, if lump-sum appropriations were allowed. At the same time, it clearly decreases the scope of the financial autonomy of agencies.

Although each and every estimate in the budgetary proposal has to be supported by a legal instrument, i.e., regulation, directive or decision, a few exceptions "introduce an element of flexibility at both institutional and legislative levels." 381 These are pilot actions to test the feasibility of certain actions, appropriations for preparatory actions in the field of application of the specific titles of the treaty and few more. ${ }^{382}$ "Parliament often initiates these activities, although not exclusively, thus breaching the Commissions monopoly of initiative"; hence, "the budgetary decision relating to these activities precedes and gives rise to the legislative decision, reversing the usual order." ${ }^{383}$ Such exceptions may not only give the Parliament the right of initiative, but also to some extent give the Parliament temporary control over specific agency actions and priorities.

Furthermore, the principle of universality requires that appropriations given to EU agencies should not be adjusted against specific revenues. Roughly speaking, all EU revenue comes in one box, and is then redistributed among different institutions and agencies, irrespective of where the revenue came from in the first place. However, earmarked appropriations, i.e., money given, for instance, from specific member states to individual agencies

\footnotetext{
380 The principles, which are not discussed in this section, are the principles of: annuality (the appropriations are given for one year lasting from 1 January to 31 December Article 7), equilibrium (revenue and payment should be in balance Article 15), the unit of account (usage of euro as single unit Article 17), and transparency (publication in the official journal within two months of the adoption of the general budget (Article 26)).

${ }^{381}$ European Union Public Finance, $4^{\text {th }}$ edition, European Commission, 2008. P. 231.

382 Ibid.

Corbett et al. specify that the total amount for such actions is restricted to 40 million euro for one financial year (Corbett et al. (2011) P. 283).

${ }^{383}$ European Union Public Finance, $4^{\text {th }}$ edition. European Commission, 2008. P. 231.
} 
for specific purposes, like local operations, remain possible pursuant to Article 19 Commission Regulation 2343/2002. Such a possibility of giving earmarked money could be a leverage of (temporary) control for the authorities giving that money over agencies' activities and action priorities.

The Financial Regulation's greatest achievement in terms of accountability seems to be the requirement for agencies' actions to be justified and reasoned with the help of the specified performance criteria. This is the principle of sound financial management. The principle comprises economy, efficiency and effectiveness elements. The principle of economy requires agencies to use their resources 'in due time, in appropriate quantity and quality and at the best price'. The principle of efficiency interlinks 'resources employed and results achieved'. And attaining specific objectives and achieving the intended results are required by the principle of effectiveness. These three elements are the standards to be followed in issuing agencies' annual documents which accompany the preliminary draft budgets and give information about agencies' actions and achievements. Also, the principle of sound financial management prescribes ex ante and ex post evaluations of programs and activities, although the scope of evaluations seems to be limited to the programs requiring 'significant spending'. The troubling aspect here is the fact that the compliance with the principle of sound financial management is still to be established. ${ }^{384}$

\subsubsection{Financial oversight over EU agencies: the annual discharge procedure}

The spending of the 'taxpayers' money' necessitates a check by representative institutions on whether various executive institutions have spent the allocated money prudently. This is done within the so-called discharge procedure which is the other financial accountability venue where the EU representative institutions can hold EU agencies to account. It is an annual procedure resulting in a Parliamentary decision of giving or refusing discharge of financial accounts. Here, "the Committee on Budgetary Control [responsible for the discharge procedures] and ultimately the Parliament are performing a work of political appraisal." 385 To understand the nature of this accountability mechanism this part first looks at the procedural elements of how discharge decisions are being taken and then at the im-

\footnotetext{
384 The European Union's Agencies: Getting Results. The European Court of Auditors, Special Report No 5, 2008. P. 19.

In its 2010 discharge decision the European Parliament demanded that "the EU agencies' management boards achieve maximum convergence between planning of tasks and of resources (both financial and human) through the introduction of activity-based budgeting and management (ABB/ABM)," and stressed that "the agencies are subject to the principle of sound financial management and budgetary discipline." (European Parliament Resolution of 5 May 2010 on the 2008 discharge; performance, financial management and control of EU agencies (2010/2007(INI)), Point 14).

${ }^{385}$ Handbook 2009 for new members of the Committee on Budgetary Control, Committee on Budgetary Control, DG for Internal Policies of the Union. Directorate for Budgetary Affairs. June 2009. DV1785742EN.Doc. P. 9.
} 
plications discharge decisions have for EU agencies. This sub-section shows that the power of discharge is an important accountability mechanism at the European Parliament's disposal. It provides all three stages of accountability before the European Parliament and establishes an additional layer of accountability where the Court of Auditors plays a role of a diagonal accountability forum. ${ }^{386}$

\section{Discharge procedure: the first steps and the role of the Court of Auditors}

The implementation of an agency's budget is usually the responsibility of the agency's director who is accountable before the European Parliament via the discharge procedure, although with a few exceptions discussed later in section 2.2.4.3. on the self-funded agencies. The agency director has to report to his or her management board "on the performance on his/her duties in the form of an annual activity report $\langle\ldots\rangle$ together with financial and management information" (Article 40 of Commission Regulation No 2343/2002). Agencies' provisional accounts and reports on budgetary and financial management are then sent to the Commission, which consolidates and sends them to the Court of Auditors by March, 31. By the same day EU agencies are obliged to send these reports to the European Parliament and the Council.

The European Court of Auditors plays a crucial role during the discharge procedure. It exercises an external audit of individual agencies' spending. ${ }^{387}$ Its tasks are to verify the lawfulness and proper manner of receiving the revenue and incurring the expenditure and to check the soundness of financial management. The Court of Auditors verifies agencies' accounts by issuing a statement of assurance as to the reliability of accounts and the legality and regularity of relevant transactions pursuant to Article 287 TFEU.

The role that the Court of Auditors plays within the discharge procedure can be viewed as an additional, 'diagonal'388 accountability forum within the financial oversight of EU agencies. This is because the relationship between the Court of Auditors and EU agencies involves all three stages of accountability. The Court of Auditors has extensive powers to request any information from agencies relating to the financial management. ${ }^{389}$ Agencies "shall afford the Court of Auditors all the facilities and give it all the information which the Court of Auditors considers necessary for the performance of its task" (Article 142 (1) Financial Regulation (EC) No 1605/2002). There is a possibility for discussion through several written contacts that occur between the Court of Auditors and agencies before the Court's annual report is published on October, 31 in the Official Journal and sent to all

\footnotetext{
386 This part is partly based on Scholten (2010).

387 "The Court of Auditors shall scrutinise the accounts of the Community body" (Article 91 Commission Regulation No 2343/2002).

388 Bovens (2007) P. 460.

389 "It shall make enquiries of any official responsible for a revenue or expenditure operation and to use any of the auditing procedures appropriate” to agencies (Article 140 (2) Financial Regulation (EC) No 1605/2002).
} 
institutions covered by that report. This involves sending Court's observations to each agency by June, 15, at which point agencies are provided with an opportunity to respond to these observations by September, 30. These responses are then sent to the Court and are included in its final reports on individual agencies, where the Court also attaches its opinions to agencies' responses. Thus, the Court's observations are added to with agencies' responses and published in the specific annual reports on agencies. In addition to the written contacts, the representatives of the Court of Auditors visit EU agencies:

[This happens] twice a year for approximately one week at a time. The first audit takes place in October-November and is focused primarily on the implementation of the current year's budgets as well as specific topics such as: procurement, management of contracts, HR issues, $\langle\ldots\rangle$. During the second audit, which is usually scheduled for February-March, the Court focuses on the closing of the previous financial year's accounts. ${ }^{390}$

Direct discussions with agencies' representatives allow misunderstandings to be addressed and overcome and may impact the Court's final opinions by explaining relevant issues and providing more evidence. ${ }^{391}$ Finally, the consequences facing the agencies are in the form of evaluations they receive in the Court's reports, one of the key documents upon which the discharge authority bases its discharge decision. Thus, financial accountability before the European Parliament has an additional internal layer of rendering account before the Court of Auditors.

The Court's report is very important and valuable for the agencies' financial accountability. It contains an assessment of the soundness of the financial management (Article 143 (3) Financial Regulation (EC) No 1605/2002), but also it may add any summary report or general observation which "it sees fit to make" (Article 143 (4) Financial Regulation (EC) No 1605/2002). In addition, the Court may issue special reports identifying some general problems that agencies may have and propose solutions to resolve those problems (Article 144 Financial Regulation (EC) No 1605/2002). Before the publication of a special report, contact is established with the agencies and institutions that are featured in the report. Prior to publication, the Court confidentially sends the observations due to be included in the final special report to the respective institutions and those bodies may respond to the observations. With respect to the EU agencies the special report, "The European Union's Agencies: Getting Results", ${ }^{392}$ was published by the Court of Auditors in 2008. It offers an analysis of the operation of eight EU agencies and proposes several recommendations on improving the soundness of agencies' financial management. The Court's annual specific reports on individual agencies and its somewhat $a d$ hoc special reports are important for the

\footnotetext{
390 Busuioc (2010) P. 143.

391 Ibid.

392 The European Union's Agencies: Getting Results. The European Court of Auditors, Special Report No 5, 2008.
} 
accountability system because they provide both an audit and analytical insights of various aspects of the operation of agencies with a view to improving existing practices.

In addition to such annual specific reports and Court's statements of assurance, there are other sources of information that the discharge authority, i.e., the European Parliament, takes into account when taking its decision. These are the financial analysis and the balance sheet from the Commission (Annex VI, Article 1 (1) of the Rules of Procedure of the European Parliament) and the recommendation issued by the Council. ${ }^{393}$ In addition, the European Parliament's Committee on Budgetary Control, responsible for discharge matters, considers it very important to have information from other parliamentary committees responsible for 'their' respective agencies. ${ }^{394}$ The Parliamentary Rules of Procedure provide for such practices (Annex VI, Article 1 (2) of the Rules of Procedure of the European Parliament). And indeed, some discharge decisions on individual agencies include opinions given by permanent specialized committees. This is valuable information considering the regular involvement of the permanent specialized committees in the oversight over agencies. Such information and interconnections between various parliamentary committees seem to be valuable in making a more complete assessment of agencies' performance and programs and in deciding whether to give the discharge or not.

\section{Discharge decision and its implications}

The discharge is a

"decision adopted by Parliament in plenary sitting on the basis of a report by the Committee on Budgetary Control consisting of a proposal for a decision, a proposal for the closure of the accounts and a motion for resolution containing a detailed assessment by the institution concerned during the period under review, together with (in case of a postponement of discharge) shortcomings which must be addressed within six months in order to avoid an outright refusal of discharge." 395

\footnotetext{
393 It is important to note that having different horizontal accountability forums, such as the Court of Auditors and the Commission, which also performs audits of agencies' programmes and accounts, may lead to undesired accountability overloads, which can be especially detrimental to the effective operation of smaller EU agencies Busuioc and Groenleer (forthcoming in 2014) P. 196).

${ }^{394}$ In the discharge decision for 2008 the Committee on Budgetary Control stressed "the importance of including an assessment of agencies' performance in the discharge process which is made available to the competent committee dealing with its respective agencies in the European Parliament", it has also called "on the Court of Auditors to look into the matter in its next reports on the agencies" (European Parliament Resolution of 5 May 2010 on the 2008 discharge: performance, financial management and control of the EU agencies (2010/2007(INI)), point 22). ${ }^{395}$ Corbett et al. (2011) P. 287.

See, also Article 185 Financial Regulation (EC) No 1605/2002. The Treaty provision on the discharge do not specify individual discharge decisions to agencies, but only giving the discharge to the Commission (TFEU Articles 317-319).
} 
It should be issued by April, 30 of the year $n$ (normally not later than May, 15 $5^{396}$ ) as regards the accounts of the financial year $n-2$. There are two kinds of decisions and two steps for issuing such decisions (Figure 2.1. below). If the discharge is not given immediately by April, 30 then it is postponed until October when the European Parliament will either grant the discharge, or refuse it (Annex VI, Articles 3-6 of the Rules of Procedure of the European Parliament).

Figure 2.1. The European Parliament giving discharge

\section{The European Parliament giving discharge to individual agencies}

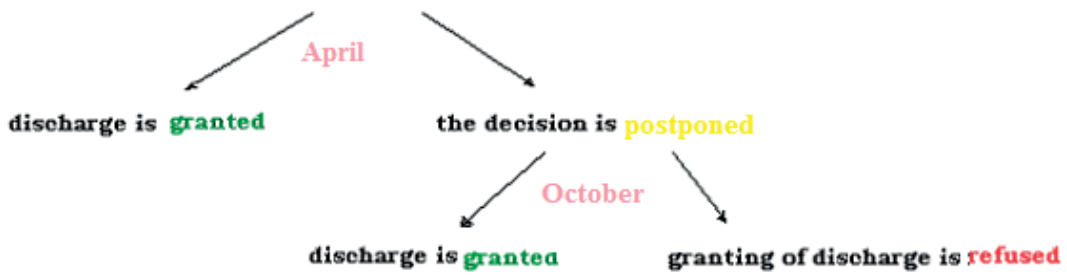

Postponing the discharge and threatening to refuse to give it are quite strong powers that the European Parliament has in relation EU agencies, also because these two options offer some additional possibilities. Firstly, "discharge is more than the necessary final act in adopting the Communities' accounts. It enables Parliament to lay down requirements for future conduct." 397 Such requirements can also be accompanied with deadlines. As MEP Jensen explains,

What is being asked for is more information, some clarifications, and then of course there is a limit to how far you can go before you give the discharge, and the promise that you would want to solve the problems mentioned, that promise from the responsible people that they would do some things to remedy problems that have been revealed" and "there has been harsh criticism. And we do follow up on this criticism. I can tell you that managers of the agencies do not find it nice to come and be exposed to this public criticism. So, our experience is that they actually do deal with it. ${ }^{398}$

Requests for more information and compliance with certain actions may create direct written or oral contacts between EU agencies and the European Parliament. Such contacts may not be formally prescribed by agencies' founding acts, for instance, when a founding act lacks a hearings obligation for the agency's director to come and report on the performance

\footnotetext{
${ }^{396}$ European Union Public Finance, $4^{\text {th }}$ edition. European Commission, 2008. P. 352.

${ }^{397}$ Corbett et al. (2007) P. 290.

${ }^{398}$ MEP Jensen (interviewed in August 2010).
} 
of agency. Such hearings exist only in 12 (out of 35) cases. ${ }^{399}$ In this sense, the Parliament may stretch its discharge competence to include missing information-providing and discussion possibilities in its relationship with EU agencies.

\section{Discharge resolution}

In addition to individual discharge decisions, the European Parliament also issues general resolutions on the issues related to the whole population of EU agencies. The European Parliament has used these resolutions with a number of purposes connected with financial matters and going beyond them. The European Parliament applauds agencies that are pioneers of certain practices and points fingers towards those who fail. ${ }^{400}$ It does not merely mention problematic issues, but it also outlines directions for further investigation by requesting the Court of Auditors and the Commission to prepare relevant information and reports which can be followed up in subsequent resolutions. ${ }^{401}$ It may even assume the initiator's role for possible future legislative proposals suggesting that the Commission should come up with relevant drafts to address existing troubling matters. These general discharge resolutions are a political weapon to push on those issues that the Parliament deems necessary to be pushed forward. ${ }^{402}$

\footnotetext{
${ }^{399}$ ACER, BEREC (the Office), IT-Agency, EASO, EASA, EBA, EIGE, EIOPA, ENISA, ERA, ESMA, and ETF.

${ }^{400}$ E.g., the European Parliament welcomed "CEDEFOP's intention to further reduce its carryovers by monitoring through standardised templates of budget execution (commitments, payments) and procurement progress" and considered "this measure to be a practice to be followed by the other Agencies" (European Parliament resolution of 10 May 2012 on discharge in respect of the implementation of the budget of the European Union Agencies for the financial year 2010: performance, financial management and control of European Union Agencies (2011/2232(DEC)), Point 12).

${ }^{401}$ E.g., the European Parliament called on the Commission to provide consolidated information "on the total annual funding per, in a comparable and transparent manner, as well as for the previous financial years to enable Parliament and the public to compare the Union's contribution to each Agency over time; this will also ensure clarity, transparency and public control over the spending of the Union's money.” At the same time it was concerned that "despite the Court of Auditors' information provided in its 2011 AWP and the persistent requests from Parliament, the Special Report on cost-benchmarking of the Agencies has not been delivered" (European Parliament resolution of 10 May 2012 on discharge in respect of the implementation of the budget of the European Union Agencies for the financial year 2010: performance, financial management and control of European Union Agencies (2011/2232(DEC)), Points 1-2, 84).

${ }^{402}$ E.g., the European Parliament called "on the Interinstitutional Working Group (IWG) to address the modalities for appointing Agencies' Directors in order to have an open, transparent and trusty recruitment procedure" and called "on the IWG to ensure that its Joint Statement mentions that the candidates selected for the post of Agencies' Directors undergo a public interview by Parliament's committees” (European Parliament resolution of 10 May 2012 on discharge in respect of the implementation of the budget of the European Union Agencies for the financial year 2010: performance, financial management and control of European Union Agencies (2011/2232(DEC)), Point 61).
} 


\section{Implications of a negative discharge decision}

While postponing decisions to give the discharge and general resolutions only shows the teeth of the European Parliament, April decisions on postponement are reconsidered in October. If an agency does not follow parliamentary recommendations, the European Parliament can 'bite', i.e., to refuse to give a discharge.

Formally speaking, the implications of a negative discharge decision are not prescribed anywhere. The postponement of the initial decision in April is clearly the first disapproval of an agency's performance. Article 147 (1) Financial Regulation (EC) No 1605/2002 states that agencies "shall take appropriate steps to act on the observations accompanying the European Parliament's discharge decision and on the comments accompanying the recommendation for discharge adopted by the Council." Non-compliance with the recommendations and requests contained in postponing decision would eventually lead to a refusal to grant the discharge. While "the most far-reaching consequence of the discharge procedure is the motion of censure against the Commission," 403 until recently it was unclear what it would mean in relation to an EU agency. The first refusal to give discharge to an agency was passed by the European Parliament in October 2010; the director of Cepol was removed by the governing board.

Both structural problems and maladministration have contributed to the initial postponement decision given to Cepol. Interestingly, the European Parliament referred to the discharge decision of the preceding year ${ }^{404}$ where it had already expressed its concerns about financial irregularities and where it called on the College to adopt certain rules, yet granting the discharge against a negative recommendation of the Committee on Budgetary Control. Already at that moment the European Anti-Fraud Office (OLAF) opened an internal investigation "in response to the findings of the Court of Auditors and the Internal Audit Service (IAS) that members of the College's staff had used public money for private purposes." ${ }^{405}$ In May 2010, the European Parliament postponed giving the discharge as it considered that Cepol's "replies to the Court of Auditors' remarks are $\langle\ldots\rangle$ inadequate and the remedial measures it puts forward are too vague and non-specific to enable the discharge authority adequately to determine whether the College is capable of improving in future." ${ }^{406}$ Cepol failed on the grounds of transparency, it did not launch an external evaluation suggested by the Court of Auditors, it had weaknesses in procurement procedures, and there were financial irregularities, i.e., the absence of "a budgetary commitment preceding

\footnotetext{
403 The discharge to the Commission was refused three times; in 1984, 1998 and 1999 for the 1982, 1996 and 1997 financial years respectively (the latter happened despite the resignation of the Santer Commission). (Building Parliament: 50 Years of European Parliamentary History, 1958-2008 (2009), P. 158).

${ }^{404}$ European Parliament's decision of 5 May 2010 on discharge in respect of the implementation of the budget of the European Police College for the financial year 2008 (C7-0198/2009 - 2009/2127(DEC)), Point 3 D.

${ }^{405}$ Ibid. Point 3, observation 18.

${ }^{406}$ Ibid. Point 3, observation 1.
} 
the legal commitment in nine cases covering a total of EUR $244200 . "{ }^{\prime 47}$ Annexed to the postponing discharge decision, there was an action plan proposed to be elaborated and adopted by the Cepol's governing board and the director.

As the Parliament did not find enough precision and accuracy in the elaboration of the proposed action plan, five months later the refusal followed, which was "approved by an overwhelming majority (618 in favour, none against, 7 abstentions)." ${ }^{408}$ Interestingly, Cepol's director, responsible for the implementation of 2008 budget, was removed by the governing board, although this was before the official refusal was given. It can be speculated that, as the decision was in preparation well in advance, the governing board anticipated or perhaps even knew about the refusal. Hence, while the European Parliament does not have a formal power to remove an agency's director, its negative discharge decision might have influenced the relevant authority to remove the director.

Finally, according to the Rules of Procedure of the European Parliament (Annex VI) another implication from the refusal to give the discharge can result in the case being brought before the Court of Justice:

On the basis of a report by the committee responsible for budgetary control, the President, acting on behalf of Parliament, may bring an action before the Court of Justice of the European Union against the institution concerned [including agencies], pursuant to Article 265 of the Treaty on the Functioning of the European Union, for failure to comply with the obligations deriving from the comments accompanying the discharge decision or the other resolutions concerning implementation of expenditure.

The agency "shall be required to take necessary measures to comply with the judgment of the Court of Justice" (Article 266 TFEU). If this also fails, clearly there are other mechanisms possible, for instance, passing secondary legislation abolishing an agency and reducing its functions and budgets, although these actions would require cooperation with the Council.

\subsubsection{The case of self-funded EU agencies}

Not all EU agencies follow the annual budgetary and discharge procedures as discussed in the previous sections. There are six EU agencies that are self-funded:

1. The Office for Harmonization in the Internal Market (OHIM);

2. The Community Plant Variety Office (CPVO);

\footnotetext{
${ }^{407}$ European Parliament's decision of 5 May 2010 on discharge in respect of the implementation of the budget of the European Police College for the financial year 2008 (C7-0198/2009 - 2009/2127(DEC)), Point 3, observation 16.

${ }^{408}$ Press Release 'European Police College: no budget discharge, funding for 2011 partly frozen'. Find at: http://www.europarl.europa.eu/nl/pressroom/content/20101006IPR85254 (last check October 2010).
} 


\section{The Translation Center $(\mathrm{CdT}) ;{ }^{409}$}

4. The European Union Institute for Security Studies (ISS);

5. The European Union Satellite Centre (EUSC);

6. The European Defence Agency (EDA). ${ }^{410}$

This section discusses the implications that self-funding has for the political accountability of EU agencies.

To understand how the financial oversight of EU self-funded agencies is organized, let us look at an example of the Office for Harmonization in the Internal Market (OHIM). The legal document that governs the financially-relevant procedures is Regulation No CB2-03411 issued by the Office's Budget Committee, which is similarly to the Administrative Board of the Office consists "of one representative from each Member State and one representative from the Commission, and their alternates." 412 The OHIM's financial regulation mirrors the Financial Regulation applicable to the EU institutions and agencies discussed earlier, except for the relationship between the agency and the EU budgetary authority, where the latter has no say in the adoption of annual budgets and giving discharge. The Budget Committee of the Office plays the role of the EU budgetary and discharge authorities. The President of the Office sends its draft to the OHIM's Budget Committee which adopts it together with the establishment plan (concerning the permanent and temporary posts); amendments are possible. The approved budget is sent to the Commission, presumably for it to be inserted in the EU general budget for information. The implementation of OHIM's budget is under the President's responsibility, and it is the OHIM's Budget Committee that gives the discharge by April, 30 of the year $n+2$ for the financial year $n$. The discharge decision may also be postponed for the specified causes which the President shall make every effort to eliminate. Furthermore, the OHIM's Budget Committee has an obligation to inform the European Parliament, the Council, the Commission, and the Court of Auditors about its discharge decisions. The Court of Auditors scrutinizes the

\footnotetext{
409 "The Translation Centre is subject to discharge from Parliament. However, the question of whether or not it receives funding from the [EU general] budget is the subject of a long-running dispute between the Commission and the Centre" (Agencies' Discharge, 2006. P. 10).

410 The revenue of these agencies comes from the services provided by them, such as registration fees and translation (OHIM, CPVO, CdT) and contributions from the member states (ISS, EUSC, EDA). In addition, there are partly self-funded agencies, such as the EASA, EBA, EIOPA, ESMA and temporarily ECHA, who operate only partly on the subsidy from the EU general budget. These agencies follow the annual budgetary and discharge procedures in a normal way, at least in relation to the sums received from the EU budget (see, Draft General Budget of the European Commission for the Financial Year 2012, Working Document part III, Bodies set up by the European Union and having legal personality, COM (2011) 300 - May 2011, European Commission).

${ }^{411}$ Regulation no CB-2-03 of the Budget Committee of the Office for Harmonization in the Internal Market. Find at: http://oami.europa.eu/en/office/admin/pdf/CB-2-03.pdf (last check November 2012).

412 This information is taken from the official web-page of the agency. Find at: http://oami.europa.eu/ows/rw/pages/OHIM/institutional/ABBC/BC.en.do (last check November 2012).
} 
Office's accounts 'as usual' but takes into account the financial rules applicable to this agency.

In other cases, for instance, the European Defence Agency (EDA), all these procedures are also carried out internally. The Head of the agency, who is the Secretary General/High Representative (SC/HR) of the Common Foreign and Security Policy Council, submits a draft budget to the Steering Board, composed of representatives of the member states and the Commission, which adopts the budget. Therefore, unlike the OHIM, this agency does not have a separate Budget Committee. ${ }^{413}$ The discharge to the Chief Executive of the agency and its Accounting Officer is also given by the Steering Board. Furthermore, there are no 'information requirements' as regards sending the adopted budgets or discharge decisions to the Commission or the European Parliament. In the other two agencies of the second-pillar (ISS and EUSC) the discharge decision is given by these agencies' administrative boards and is sent to the Council for information.

Making an agency self-funded can be based on the logic that some agencies 'sell their services', such as registrations of trade marks, which makes it easier, in practical terms, to let them operate the money they earn. Another reason could be the institutional design of financial autonomy. The fact that self-funded agencies regulate their budgets and discharge internally means that they are exempted from the annual budgetary and discharge procedures before the Council and the European Parliament in the manner discussed the previous sections. However, in the EU self-funding also implies having hardly any relationship with the EU representative institutions, especially with the European Parliament. The cases of CPVO and OHIM are very illustrative in this respect.

The CPVO does not even have to send its annual report to the Parliament, which the OHIM is obliged to do, or to the Council. The Council is involved only in the appointment of these agencies' directors and formally exercises the disciplinary authority over them. Concerning the latter a director of OHIM tells,

We have never been asked to come because we are outside the grip of the European Parliament. <...> I have no contacts with the European Parliament, other than we send our report for information. We have never got feedback. ${ }^{414}$

The CPVO does not even have to send its annual report to the Parliament, which the OHIM is obliged to do, also with respect to the Council. The Council is further involved only in the appointment of these agencies' directors and formally exercises the disciplinary authority over them. Concerning the latter a director of OHIM tells, "I have never been the

\footnotetext{
${ }^{413}$ Specific details, including special requirements for the chair of the meeting when the annual budget is approved, can be found in the Council Decision 2007/643/CFSP on the financial rules of the European Defence Agency and on the procurement rules and rules on financial contributions from the operational budget of the European Defence Agency.

${ }^{414}$ President of CPVO (interviewed in July 2011).
} 
subject of the Council's disciplinary authority. What does it mean? No one actually knows." ${ }^{15}$

Considering that not all stages of accountability are present in the relationship between CPVO and OHIM on the one hand and the EU representative institutions on the other hand, the political and hence democratic accountability of these agencies shows some serious gaps.

A Study of the Budgetary Support Unit of the European Parliament 'Agencies' Discharge' (12/12/2006) looked at the issue of self-funded agencies in detail and concluded that "parliamentary discharge should apply to all agencies carrying out activities on behalf of the Union, in all three pillars, irrespective of whether they are in direct receipt of funds from the Community budget." 416 "It is difficult to understand the involvement of the Court of Auditors without the involvement of the discharge authority" and "why agencies should send their accounts to the European Parliament if the European Parliament is not able to control those accounts." ${ }^{\circledR 17}$

The study supported its conclusion by stipulating the fact that "all agencies act on behalf of the European Union and in the Union's name. They should thus all be accountable for their actions and for the way they raise and spend money." 418

The reasons some EU agencies escape financial control in 'the usual way' are of both a legal and political nature, although the political reason seems to cause the legal one. Legally speaking, the language of the Financial Regulation makes the 'usual discharge procedure' applicable only to agencies 'that actually receive grants' from the general budget (Article 185 of the Financial Regulation 1605/2002). Thus, it excludes the self-funded agencies from its application. In this light, the mentioned parliamentary study is being creative by suggesting that the provision of the Financial Regulation could be interpreted broadly where 'the received funds' would include the pensions that self-funded agencies' personnel will get in the future from the EU general budget. ${ }^{419}$ Concerning the political reason, as national governments are "sensitive to the potential threat that European agencies posed to their national administrations, ${ }^{\$ 20}$ it could be argued that making the decision-making agencies self-funded is a way that national governments try to secure their control over the fees of OHIM and CPVO via agencies' management boards (dominated by national representatives). In this way, the respective national institutions may remain competitive.

Concluding, the financial oversight over EU agencies takes place within the annual budgetary and discharge procedures. The annual budgetary procedure involves more than

\footnotetext{
415 President of OHIM in: Busuioc (2010) P. 121.

${ }^{416}$ Agencies' Discharge P. 6.

417 Ibid. P. 21-22.

418 Ibid. P. 24.

419 Ibid. P. 18.

${ }^{420}$ Kelemen (2002) P. 103.
} 
merely a discussion of financial numbers. As money translates to the implementation of particular programs and policies, it is the place where agencies' achievements and failures can be discussed and face direct consequences, although the financial sanction may have counterproductive effects. The budgetary accountability mechanism is further strengthened by the existing principles that govern the budgetary process. The principles of specification, universality, and especially of sound financial management facilitate ex post control over agencies' finances and activities by decreasing the degree of financial autonomy and establishing standards against which agencies' performance can be checked. The discharge procedure is the accountability venue which allows the European Parliament not only to verify agencies' financial accounts but it also empowers the European Parliament with other possibilities, such as requesting more and better information, subjecting agencies to certain requests which will be followed up on and arguably the indirect power to remove an agency director (the case of Cepol). Thus, the discharge procedure may also provide the three stages of accountability between the European Parliament and EU agencies. The discharge procedure is further strengthened by the role that the Court of Auditors plays, i.e., diagonal accountability forum. All in all, this section has shown that the sphere of financial oversight is governed by clear laws and established practices, with the exception of six self-funded agencies. From an accountability perspective, making EU agencies self-funded makes their political accountability problematic when it implies not only excluding financial oversight, but also other checks by the EU representative institutions.

\subsubsection{Scrutinizing EU Agencies' Performance: an Accountability Venue in Development}

"What the Americans call "oversight" has always been a major function of parliaments. As the sheer size of administration has grown, and governments have assumed greater powers, so the importance of parliamentary oversight has grown to ensure democratic accountability." 221 The European Parliament "has a special responsibility to ensure scrutiny of the executive." ${ }^{422}$ Being partly an executive institution, the Council plays a less prominent role with respect to the traditionally parliamentary tool of scrutiny, although it does have scrutinizing tasks in relation to some EU agencies. This section discusses the tool of scrutiny in relation to EU agencies by devoting its attention to European Parliament's scrutinizing power while the Council is discussed where relevant. Being divided into two parts this section starts with the 'what, why and how' aspects of scrutiny (2.2.5.1.) and continues with the challenges that the tool of (parliamentary) scrutiny faces (2.2.5.2.). As a whole, it shows that scrutinizing EU agencies is an accountability tool in development with respect to both existing rules and practices.

\footnotetext{
421 Corbett et al. (2011) P. 312.

422 Ibid.
} 


\subsubsection{Scrutinizing EU agencies: what, why and how?}

The scrutiny of the executive in general and of EU agencies in particular implies obtaining information for a number of purposes. As the relation between the European Parliament and the Council on the one hand and EU agencies on the other hand can be put in 'principals - agent' terms, where the former creates the latter and delegates certain authority to agencies, the primary goal of scrutiny from this perspective becomes to check whether the agency executes its tasks faithfully and within the set boundaries. In addition, if EU agencies are thought to be 'effective tools of implementation of EU policies, ${ }^{423}$ another reason for scrutiny is to assess how relevant policies and specific programs are being implemented and whether they achieve the desired goals. While scrutiny aims at preventing abuse of power, it is also used, by means of making investigations, when illegal conduct happens. All in all, the goals of scrutiny can be aligned to those of accountability: democratic control, prevention of corruption and abuse of power, and enhancing government effectiveness. ${ }^{424}$

In light of the mentioned purposes of scrutiny, the European Parliament and the Council need to obtain different sorts of information, including intentions, results, and evaluations of various agencies' programs. Such information can be obtained within different processes. Concerning EU agencies, the European Parliament opines that it "should exercise 'ex ante scrutiny' in the form of hearings of the candidate(s) for the office of director," 425 continuous monitoring of agencies' activities with the help of its permanent specialized committees, ${ }^{426}$ and ex post scrutiny implying parliamentary investigations and concerning financial oversight of the discharge procedure, the latter discussed in the course of the financial oversight over EU agencies in section 2.2.4.2. Ex ante scrutiny may allow policy priorities of potential agencies' directors to be identified, which could be important in assessing agencies' achievements ex post, i.e., against the set intentions. Continuous patrolling of agencies' performance with the help of parliamentary permanent specialized committees seems necessary to spot irregularities occurring in agencies' 'daily' operation with a view to correcting them as soon as possible. Retrospective inquiries into somewhat special cases and events, such as crisis or (political) scandals, help to shed more light on such events and inform the public about their causes in order to prevent similar events in the future. This section discusses the mentioned three types of scrutiny over EU agencies and the roles played by the European Parliament and the Council.

\footnotetext{
${ }^{423}$ Joint Statement of the European Parliament, the Council of the EU and the European Commission on decentralised agencies (annexed with the Common Approach).

${ }^{424}$ Bovens (2007) P. 462-463.

${ }^{425}$ Motion for a Resolution, B6-0000/2005, of 13.10.2005 Point 5(e).

426 Ibid.
} 


\section{A. Ex ante scrutiny by the European Parliament and the Council}

"To maximize parliamentary control the European Parliament sought to establish the principle of 'prior authorization' whereby individual Commissioners-designate would appear before its committee to identify the Commission's policy priorities." ${ }^{427}$ Likewise, to "establish parliamentary control over the formation and operation of regulatory agencies," 428 the European Parliament's involvement in holding hearings of the prospective directors of the EU agencies has increased. As of this writing, such an obligation exists in the founding acts of $18 \mathrm{EU}$ agencies, ${ }^{429}$ created mostly by co-decision (see section 2.2 .1 .1 .). In addition, the European Parliament has suggested that candidates of management boards' members should be interviewed before their appointment. ${ }^{430}$ The European Parliament sees "this role of 'ex ante political scrutiny' as a natural complement to 'ex post' political scrutiny in the form of the discharge for the implementation of the budget." ${ }^{431}$ How does ex ante scrutiny take place and is it important from an accountability perspective?

\section{Ex ante hearing before the appointment of an agency's director: the procedure}

Parliamentary committees have developed the practice to organize a formal hearing of the candidate to head an EU agency. To give an example of such a procedure, this section discusses the file published by the European Parliament's Directorate for Information which explained what, at that time, was considered an 'unprecedented' procedure of appointment of the first director of the European Food Safety Authority (EFSA) in 2002. ${ }^{432}$ Pursuant to EFSA's founding regulation the Commission submitted a list of three candidates to the Authority's newly created management board. The management board interviewed all three candidates and selected one as its nominee. The European Parliament was informed about the nominee who was then invited for a parliamentary hearing at the Committee on the Environment, Public Health and Consumer Policy, the committee

\footnotetext{
${ }^{427}$ Judge and Earnshaw (2008) P. 205.

${ }^{428}$ European Parliament resolution of 21 October 2008 on a strategy for the future settlement of the institutional aspects of Regulatory Agencies (2008/2103(INI)), Point 15).

For instance, recital 24 ERA's founding regulation states that "effective control by the European Parliament should be ensured and, to this end, the European Parliament should have the possibility of hearing the Executive director of the Agency."

${ }^{429}$ ACER, BEREC (the Office), FRA, IT-Agency, EASO, EASA, EBA (in relation to chairperson), ECDC, ECHA, EFSA, EIGE, EIOPA (in relation to chairperson), EMSA, EMA, EMCDDA, ENISA, ESMA (in relation to chairperson), and ETF.

${ }^{430}$ European Parliament resolution of 21 October 2008 on a strategy for the future settlement of the institutional aspects of Regulatory Agencies (2008/2103(INI)), Point 4.

${ }^{431}$ European Parliament resolution on the communication from the Commission: 'The operating framework for the European regulatory agencies' (P5_TA(2004)0015), Point 17 (d)).

${ }^{432}$ Hearing of the nominee to be the first Director of the European Food Safety Authority (EFSA), file published by the European Parliament's Directorate for Information. P. 2 (Find at: http://www.europarl.europa.eu/meetdocs/committees/envi/20021022/470347EN.pdf (last check April 2013)).
} 
responsible for food safety issues. The format of the hearing was a 10 -minute opening statement by the nominee followed by two-hour questioning session by MEPs. The procedure went as follows.

Designated representatives of each of the political groups pose[d] the questions, and there [was] then $\langle\ldots\rangle$ a catch-the-eye system for additional questions if time permits. In order to permit as many members as possible to pose questions within the limited time available, each member posing a question [had] no more than one and a half minutes to do so, and the nominee [was] asked to reply immediately in not more than three minutes. All those posing questions [were] also allowed one follow-up question in no more than one minute, and the nominee [was] given a similar time to reply. 433

Although parliamentary committees prepare written questionnaires for the nominees to the ECB and the Commission in advance, in this case the relevant committee only "asked for the nominee's CV, original application form and declaration of lack of conflict of interests. The issues of concern to the committee [were] thus raised directly at the hearing, so that it retain[ed] as much spontaneity as possible, and test[ed] the ability of the nominee to think on his feet." ${ }^{334}$ However, this does not seem to have become general practice as the appointment of the second director of EFSA did include the written questionnaire and responses. ${ }^{435}$

After the hearing, the chairman of the parliamentary committee together with designated experts evaluated the performance of the nominee and sent its recommendation to the President of the European Parliament who then discussed it with the Conference of President's (the political groups' leaders within the Parliament) and sent the decision to the EFSA's management board. The management board had the final say.

\section{European Parliament's opinion}

The European Parliament does not have any selection role when scrutinizing candidates for directors' positions, its role is to question the only and hence 'almost decided' candidate and to issue a non-binding opinion. The candidate is 'almost decided' because the European Parliament does not question, for instance, all selected candidates from the list proposed by the Commission. The idea of the European Parliament "was to have a hearing of the people from the short list of the Commission. <...> but the Commission and the Council were fiercely against" due to the high posts of candidates in respective countries that would

\footnotetext{
${ }^{433}$ Hearing of the nominee to be the first Director of the European Food Safety Authority (EFSA), file published by the European Parliament's Directorate for Information. P. 2 (Find at: http://www.europarl.europa.eu/meetdocs/committees/envi/20021022/470347EN.pdf (last check April 2013)).

434 Ibid.

${ }^{435}$ Questionnaire prepared by Catherine Geslain-Laneelle, candidate for the post of EFSA director (Find at: http://www.europarl.europa.eu/comparl/envi/pdf/hearings/2006-02-23/geslain-laneelle_questionnaire.pdf (last check April 2013)).
} 
not be willing to disclose such information, especially if they would not be selected. ${ }^{436}$ This is because "in the Parliament everything is really public, therefore, it is a bit difficult for them." ${ }^{337}$ Therefore, the EU main institutions have agreed that

The Commission makes a short-list to be interviewed by the management board of an agency. Afterwards, the candidate should come to the respective committee before the board takes its final decision. Normally, I think that this one candidate is the next director. Sometimes a member state has to come up with a new candidate. It has never happened with an agency, not yet, partly because it is a new competence. ${ }^{438}$

Except for the three recently created (2010) agencies to regulate the financial sector (EBA, EIOPA, and ESMA), the European Parliament does not have any confirmation power. If the Parliament were to give a negative recommendation, the appointing authority does not have to reconsider its choice. Concerning the EBA, EIOPA and ESMA the European Parliament enjoys the so far nonexistent confirmation power in relation to these agencies' directors and it may object to the choice of the Board of Supervisors concerning the chairman of the agency. Given the functions and composition of the Board of Supervisors and the chairmen of these agencies, these organs seem to be the counterparts of other agencies' management boards and directors. At any rate, in all other cases, the appointing authority, which is always the management board in those cases where the appointment hearing is prescribed, has a final say; the Parliament's role is only consultative. ${ }^{439}$

A negative recommendation is suggested to give the agency "a bad start" with the Parliament and "would probably reduce its initial effectiveness." ${ }^{440}$ Corbett et al. have analyzed the Parliament's role in making ECB's appointments: the role is "only consultative, but is potentially crucial." ${ }^{441}$ As regards the appointment to the Court of Auditors, their examples show that an 'unfavorable opinion' of the Parliament could lead to different reactions from the member states: some would replace their candidates, others would not. ${ }^{442}$ Thus, "evidence up to now suggests that a negative opinion by Parliament is quite likely to lead to, but does not guarantee, the withdrawal of the candidate in question." 443

\footnotetext{
${ }^{436}$ MEP Haug, the head of the delegation of the European Parliament to the Interinstitutional Working Group on EU agencies (interviewed in June 2011).

${ }^{437}$ Ibid.

${ }^{438}$ Ibid.

${ }^{439}$ This is the reason the parliamentary recommendation does not take form of a plenary resolution but a decision of the President of the European Parliament (Hearing of the nominee to be the first Director of the European Food Safety Authority (EFSA), P. 2.).

${ }^{440}$ MEP Haug (interviewed in June 2011).

${ }^{441}$ Corbett et al (2011) P. 298.

${ }^{442}$ Ibid. P. 300.

${ }^{443}$ Ibid.
} 


\section{Ex ante scrutiny from an accountability perspective}

While the possibility to hear a candidate proposed to head an EU agency is a formally weak tool, this procedure may be valuable from an accountability perspective in at least in two respects. First, considering the fact that agencies' directors are accountable before the European Parliament within the discharge procedure, ex ante parliamentary hearings "provide an opportunity for the parliamentary committees to get insights into the personalities of" the candidates, "to hold the views on the priorities" with regard to the respective fields, and in case of approval "the hearings serve in this way to establish a working relationship between parliamentary committees" and their agencies "at the earliest moment possible." ${ }^{444}$ Such hearings "also serve as an initial benchmark for examining the subsequent performance of agencies' directors." ${ }^{445}$ In a way, this resembles the democratic accountability of people's elected representatives: they are elected on the basis of their ex ante intentions put in the election manifesto and are then held to account on the basis of whether and in how much the initial intentions have been realized.

Second, the importance of appointment hearings from an accountability point of view also comes from the fact that it brings transparency into the appointment process and thus reduces the chances of abuse of powers by the appointing authority. In case of the FRA, for instance, its founding act specifies explicitly that its director is "appointed by the Management Board in accordance with a cooperation (concertation) procedure" which includes "a list drawn up by the Commission after a call for candidates and a transparent selection procedure, applicants will be asked before an appointment is made to address the Council and the competent European Parliament Committee and to reply to questions" (Article 15 Regulation (EC) No 168/2007 (emphasis added)). The logic here seems to be the following: the more institutions that are included in the appointment procedure, the more transparent the procedure becomes. The 'cooperation procedure' also aims at including as many institutions and hence interests as possible to make the appointment decision as objective as possible, which could promote agencies' independence. Furthermore, an appointment hearing is not only important since it is a public event, but it may also put certain pressure on the selection authority to do its job properly and to come up with a candidate who will have to prove himself before the Parliament in public.

The importance of transparency in the appointing procedures may prevent the situations, such as a story told by an EU agency's director who was appointed without any interview,

\footnotetext{
${ }^{444}$ Investiture Procedure of the 2004-2009 Commission - Hearings of the Commissioners Designate (Find at: http://www.europarl.europa.eu/hearings/commission/2004_comm/structure_en.htm (last check November 2010)).

445 Ibid.
} 
I was appointed in 1996 which was on the basis of an advertisement, an announcement that there was a vacancy in the Official Journal. $\langle\ldots\rangle$ there were was a number of candidates, I do not know the number, but let us say 15-16. So, I applied, I sent my cv like other competitors. $<\ldots>$ I had no interview, neither with the Council, nor with the management board. It took more than a year before the decision was taken. The reason was that when I was appointed, there was still no decision taken about the seat of the [agency]. And they wanted in fact combine two decisions. $\langle\ldots\rangle$ So, I was not interviewed, neither were my colleagues who applied for the position. Most of the persons who applied were known in the circles. I was at that time a member of the management board myself. $<\ldots>$ The management board was to advise, so they knew me and a lot of other candidates. Then, I got a phone call from the [national] minister $<\ldots>$ and he said: 'you are appointed.' $<\ldots>$ There were 15 member states and I got six and another person got four votes. Then they got a second round and I had the absolute majority, I think nine to six. ${ }^{446}$

Ex ante interviews for the members of the management boards by the European Parliament seem less necessary than for agency directors. ${ }^{447}$ Only for those management boards that have balanced representation from the member states and other institutions, the Parliament's opinion could be useful to increase the transparency and objectivity of the selection and appointment procedures. However, unlike agencies' directors who are not supposed to serve any national or industry interest, the majority of existing agencies' management boards are designed in such a way so that the member states retain control over agencies via their representatives (see section 2.2.2.1.). Therefore, the involvement of the European Parliament is of questionable appropriateness here, because "each country puts forward its own nominees on the basis of domestic rather than European considerations, with Member States accepting each other's nominees on a consensus basis." ${ }^{448}$ Thus, parliamentary opinion is not desirable by design and would probably not matter, which could also influence the quality of ex ante hearing. More importantly, if the management board would be accountable before the Parliament for its collective managing of an agency, like the director normally is within the discharge procedure, ex ante scrutiny could make some sense. However, as this is not the case, why does the Parliament need to have ex ante scrutiny to establish the relationship 'at the earliest moment possible' and install 'the first benchmark' of an accountability relationship which does not exist? If transparency of the appointment and removal procedures of the members of EU agencies' management boards needs to be enhanced, this seems to be better done at the Council's or national level. Here, the involvement of national parliaments (and their committees on EU affairs, for example) could be an option to consider, although it has been said that "the involvement of national parliaments

\footnotetext{
${ }^{446}$ Director of an EU agency (interviewed in July 2011).

${ }^{447}$ European Parliament Resolution of 21 October 2008 on a strategy for the future settlement of the institutional aspects of Regulatory Agencies (2008/2103(INI)), Point 4.

${ }_{448}$ Corbett et al. (2007) P. 266.
} 
to approve each representative would be disproportionate, he is not that important after all." 449

\section{Council's ex ante appointment role}

No founding act of an EU agency prescribes ex ante hearings of the candidates to head EU agencies' before the Council. Hearing a director ex ante by the Council may still occur when the Council is the appointing authority (CPVO, OHIM, and Europol). In the absence of any formal rules and the lack of transparency of the Council's practices, it is difficult to judge whether such hearings occur and what questions are being asked. The example in the previous section shows that appointment hearings do not always take place. The necessity of Council's involvement in ex ante hearings may be questionable for two reasons. First, EU agencies' management boards are often involved in the selection and appointment of agencies' directors, so the inclusion of the Council could duplicate the involvement of the member states, which dominate agencies' management boards. This may unnecessarily complicate and prolong the appointment procedure. Second, a hearing at the Council is likely to imply a hearing at one of its preparatory bodies which are neither representative bodies, nor are bodies famous for their transparent operation. Conversely, a hearing at the European Parliament can offer both representation of the people and transparency of the procedure.

As a whole, while ex ante scrutiny of candidates for agencies' directors, formally prescribed by 18 EU agencies' founding acts, may be considered a weak tool of the European Parliament as the Parliament does not usually have any selection and confirmation powers, this procedure seems to be valuable from an accountability perspective in at least two respects. First, it facilitates the establishment of the initial benchmark between the European Parliament and an agency's director who is accountable before the Parliament in the course of the discharge procedure. Second, it increases the transparency of the appointment procedure: by holding a public hearing and by putting certain pressure on the selection authority to do its jobs properly because there is a public check of the candidate it proposed. The Council's role in ex ante scrutiny of candidates to head EU agencies seems to be limited to the three cases where it plays the appointment role. At the same time, due to the lack of transparency of Council's operation and of representative factors, if such hearings take place in the Council's lower structures, the value of the Council's ex ante scrutiny role from an accountability perspective is questionable.

\section{B. Continuous scrutiny by the European Parliament and the Council}

Continuous scrutiny is "the classic parliamentary power to force the executive to be available to the Parliament and to compel its 'responsiveness to parliamentary questions, its par-

${ }^{449}$ Chairman of an EU agency's management board (interviewed in November 2011). 
ticipation in debate and its public defense of its position." ${ }^{450}$ Various meetings allowing the questioning of agencies' representatives and discussing agencies' performance are the format of continuous scrutiny of EU agencies by the European Parliament and the Council. The continuous scrutiny is organized in different ways in the European Parliament and the Council and hence is addressed here in two respective sub-sections.

\section{Rules and practices of continuous scrutiny of the European Parliament}

Continuous scrutiny over EU agencies takes place within permanent specialized committees of the European Parliament. However, great differences exist as to the rules and practices that exist between individual committees and 'their' EU agencies.

First of all, there are differences concerning assigning individual agencies to permanent specialized committees' remits. The Rules of Procedure of the European Parliament (Annex VII) specify jurisdictions of each parliamentary permanent specialized committee. ${ }^{451}$ For instance, the Committee on Employment and Social Affairs is responsible for relations with four EU agencies (Cedefop, Eurofound, ETF, and OSHA). At the same time, the fact that the Rules of Procedure assign some agencies to individual committees seems to say little about the existence of any relationship. For instance, the Committee on Transport and Tourism does not have any agency under its jurisdiction prescribed in the Rules of Procedure, ${ }^{452}$ this committee is nonetheless responsible for the supervision of ERA, EASA and EMSA. ${ }^{453}$

\footnotetext{
${ }^{450}$ Judge and Earnshaw (2008) P. 217.

${ }^{451}$ Committee on Employment and Social Affairs for Cedefop, Eurofound, ETF, OSHA; Committee on the Environment, Public Health and Food Safety for EEA, ECHA, EMA, ECDC, EFSA; Committee on Agriculture and Rural Development for CPVO; Committee on Legal Affairs for OHIM; Committee on Civil Liberties, Justice and Home Affairs for EMCDDA, FRA, Europol, Eurojust, Cepol and other bodies and agencies in the same area (Annex VII EP's Rules of Procedures of 2010).

Two budgetary committees (committee on budgets responsible for Parliament's input in the annual budgetary procedure and on budgetary control responsible for discharge) include all agencies financed from the EU budget under their financial responsibility.

The Parliament's committee on Petitions has a general jurisdiction over all institutions and agencies concerning petitions received from natural and legal persons and EU citizens on matters related to the Union' fields of activity and which affect them directly (Article 227 TFEU). The jurisdiction of this committee also includes relations with the European Ombudsman, a separate body established by Article 228 TFEU to deal with cases of maladministration of the Union institutions and agencies. It can be seen as an assistant body in relation to the European Parliament which governs the office of Ombudsman in various ways - it elects the Ombudsman, receives its annual reports, may propose the removal to the Court of Justice and regulate other aspects by regulation initiated directly by the European Parliament to be adopted in accordance with a special legislative procedure.

${ }^{452}$ The Rules of Procedure of the European Parliament, Annex VII:

"XI. Committee on Transport and Tourism; Committee responsible for: 1 . matters relating to the development of a common policy for rail, road, inland waterway, maritime and air transport, in particular: (a) common rules applicable to transport within the European Union, (b) the establishment and development of trans-European networks in the area of transport infrastructure, (c) the provision of transport services and relations in the field of
} 
One could explain the absence of some agencies in permanent specialized committees' remits by the fact that the European Parliament lacks at times formal powers in relation to some EU agencies, i.e., the formal power to invite an agency's director to a hearing to report on the performance of the agency. Such an obligation exists only in the founding acts of $16 \mathrm{EU}$ agencies. ${ }^{454}$ In such a case, the formal assignment of agencies to their individual committees could be seen as an act of aggrandizement, i.e., the Parliament increasing its own powers. However, this is not necessarily true. For instance, ERA's founding act is one of a few regulations that states explicitly that "effective control by the European Parliament should be ensured and, to this end, the European Parliament should have the possibility of hearing the Executive Director of the Agency" (Recital 24 Regulation (EC) No 881/2004). Yet, as mentioned above, it is not included formally in Committee on Transport and Tourism's jurisdiction. The same applies to EASA whose director has hearings obligations in this agency's founding act, yet, this agency does not feature in the Rules of Procedure.

Conversely, the presence of some agencies in committees' remits in Annex VII, such as CPVO which officially falls under the jurisdictions of the Committee on Agriculture and Rural Development, does not ensure the presence of supervision. A President of CPVO states, "I have no contacts with the European Parliament, other than we send our report for information. We have never got any feedback." 455

Despite these remits, the Rules of Procedure of the European Parliament are silent as to how supervision over agencies should be organized. For instance, Rule 115, which governs questions for oral answer with debate, addresses the questioning of the Commission and of the Council only. Rules 116 and 117 on the question time and questions with written answer do not cover agencies either. Only Rule 126 deals with EU agencies specifically. It prescribes the procedure where in cases where the Parliament has the right to submit a request to a European Agency, any Member may submit a request in writing to the President of Parliament. The only document that exists in this respect is the 'Directions on cooperation between the committees with expertise relating to decentralized bodies of the Community of 14 July 1998', available only in French. It does not establish common rules, but rather outlines possibilities that committees could use in overseeing agencies. In the absence of general rules, it is not surprising that individual committees oversee their agencies in different ways, if they do it at all.

\footnotetext{
transport with third countries, (d) transport safety, (e) relations with international transport bodies and organisations; 2. postal services; 3 . tourism.”

${ }^{453}$ Appendix 2 offers the results of my e-mail inquiry directed to all permanent specialized committees of the European Parliament with the questions concerning their supervision over EU agencies and using the practice of liaison members (September 2011).

${ }^{454}$ ACER, BEREC (the Office), Cepol, FRA, Frontex, IT-Agency, EASO, EASA, EBA, EIGE, EIOPA, ENISA, ERA, ESMA, ETF, and Europol.

${ }^{455}$ President of CPVO (interviewed in July 2011).
} 
Parliamentary committees can employ the following practices: (1) agencies' directors can be invited to come to permanent specialized committees to report on the agency's activity and (2) they can be invited to speak with their liaison members, and (3) MEPs can visit their agencies. Yet, these practices do not exist in all committees and, where they do, they vary in application. Liaisons are appointed to be "responsible for maintaining contact with those agencies coming under their committee's purview." 456 Some committees appoint them from among their MEPs and other committees appoint members of the staff of parliamentary committees. ${ }^{457}$ The issues of how liaisons have to supervise agencies, including the frequency of the contact, are nowhere prescribed either. In her capacity as a liaison member for EFSA MEP Liotard has monthly contact with 'her' agency. ${ }^{458} \mathrm{MEP}$ Hassi is a liaison member for ECHA, with which she may have contact several times a year: "Normally I have visited ECHA once a year, last year twice." ${ }^{459}$ In her opinion, liaison members are necessary "to be able to follow how these agencies are implementing laws on which ENVI has been the lead committee in EP." 460 Finally, visits to agencies occur with different frequency: once every two years ${ }^{461}$ or every four years. ${ }^{462}$

Furthermore, MEPs may have informal contacts with their agencies. Thus, the EMA's founding regulation provides no hearings obligation on the performance of agency, but de facto annual hearings exist before the relevant committee. ${ }^{463}$ In some cases the Parliament formalizes its relation with specific agencies through an exchange of letters, for instance, the parliamentary committee on the Environment, Public Health and Food Safety with 'its' European Environmental Agency. ${ }^{464}$ While informal relations can be valuable for accountability, the problem is that the quality and the quantity of informal scrutiny may be unknown for the public, the 'ultimate principal'. Also, such relationships may be short-lived concerning the high turnover of MEPs after each election and frequent changes of MEPs on specialized committees. ${ }^{465}$ Finally, informality makes it difficult to judge on the content of such contacts. One interviewee noted that "there were never control or accountability

\footnotetext{
${ }^{456}$ Judge and Earnshaw (2008) P. 217.

${ }^{457}$ Administrator of European Parliament's Employment Committee (interviewed in September 2011); see, also, Appendix 2.

${ }^{458}$ MEP Liotard (her lecture at Maastricht University, 19 November 2010).

${ }^{459}$ MEP Hassi's response to my e-mail inquiry (see Appendix 2 which offers an overview of almost all committees' practices in relation to the appointment of liaisons to keep in touch with EU agencies).

${ }^{460}$ Ibid.

${ }^{461}$ Analytical Fiche Nr 32 'Parliament role', P. 12 (prepared for the work of the IWG on agencies. Find at: http://europa.eu/agencies/regulatory_agencies_bodies/index_en.htm (last check April 2013).

${ }_{462}$ Administrator of European Parliament's Employment Committee (interviewed in October 2011).

This respondent also points to the fact that there are "strict rules on who can go, three biggest political groups are always there and there is rotation for the rest."

463 Busuioc (2010) P. 105.

464 Analytical Fiche Nr 32, Parliament 's role, P. 11.

${ }^{465}$ Corbett et al. (2011) P. 51-52.
} 
checks, neither from the Council, nor from the Parliament;" 466 this sentiment was shared by a few other respondents. Often agencies' representatives have been invited to come to the European Parliament and the Council to provide technical assistance in the legislative process, rather than to be checked upon for their performance.

The lack of general rules and common practices may be explained by the fact that the task of scrutinizing EU agencies is a recent one that the European Parliament has assumed. Similar to how it has taken a few decades to establish and advance scrutinizing practices in relation to the Commission codified in a series of Framework Agreements, the most recent annexed to the Parliament's Rules of Procedure (Annex XIV), it seems that the existing (mostly informal) practices in relation to EU agencies are emerging in individual committees and are being taken over (or not) by other committees. In this light, the practice of appointing liaisons still needs to show whether it is a positive or negative development: "the advantage is that you have got at least one person who takes it seriously" whereas "the disadvantage might be that others feel that they do not have to take interest in it." ${ }^{667}$ In this respect, the European Parliament seems to need more time to figure these things out. ${ }^{468}$

\section{Continuous scrutiny by the Council}

The Council is also at times involved in the continuous oversight over EU agencies. For the agencies of the former second pillar it is the primary recipient of their annual reports, which are in some cases forwarded to the European Parliament for information. ${ }^{469}$ For the agencies of the former second and third pillars, the Council is often given extensive powers as regards supervision. For instance, according to its founding act the EDA "operate[s] under the authority and political supervision of the Council, to which it shall provide regular reports and from which it shall receive regular guidelines" (Article 4 Council Joint Action 2004/551/CFSP). The Political and Security Committee of the Council exercises 'political supervision' of the EUISS and EUSC. The recently introduced High Representative of the Union for Foreign Affairs and Security Policy (Article 27 TFEU) seems to have become the

\footnotetext{
466 Senior official from an EU agency (interviewed in August 2011).

${ }^{467}$ MEP Jensen (interviewed in June 2011).

An administrator from the European Parliament's Employment Committee notes in this respect that "if you have a liaison, you may have fewer possibilities to talk to other MEPs and others may be less interested, because they know that someone is dealing with that agency" (Administrator of European Parliament's Employment Committee (interviewed in September 2011)).

468 "You can say that we are still in the situation where the Parliament is young in many functions and the whole set up of agencies, the way we know it now and the way they are developing, is also something rather new. So there are still things to be developed and improved, but I think it is happening (MEP Jensen (interviewed in August 2010)).

${ }^{469}$ Here the European Parliament's involvement is very limited. (For instance, Article 20 of Eurojust's Rules of procedure specifies that "Eurojust shall maintain the necessary channels of communication with the European Parliament" (emphasis added). It seems to be at Eurojust's discretion to define what 'necessary' is (Eurojust's Rules of Procedure 2002/C 286/01).
} 
'liaison' from the Council with these agencies. Furthermore, the President of Eurojust reports to the Council "in writing every year on the activities and management, including budgetary management" (Article 32 Council Decision 2002/187/JHA). The Council then sends its written comments on the annual report which are then followed up in the following year's report. ${ }^{470}$ The Eurojust's President also submits "any report or any information on the operation of Eurojust which may be required of him by the Council" (Article 32 Council Decision 2002/187/JHA). In addition, the Council is often involved in the approval of all kinds of internal rules of these agencies: financial regulations (EDA, EUSC, and EUISS), rules of procedure (Eurojust and Europol), guidelines (EDA), priorities (Europol), rules on personal data files (Eurojust and Europol), and agency's staff regulations (EDA, EUSC, EUISS, and Europol).

As regards the former 'community' agencies the Council plays a somewhat special role in the operation of GSA which has to "develop coordination and consultation procedures on security-related matters with the Secretary-General of the Council (CFSP)" and "identify and inform the Council of possible measures that could be taken by the Council in the event of a threat to the security of the European Union or a Member State" (Article 2 (1(j(ix) and (x))) Council Regulation 1321/2004). This is probably interconnected with the specific area of this agency's operation. The Council may also exercise the disciplinary authority over directors of CPVO and of OHIM. In total, 15 EU agencies' founding acts ${ }^{471}$ prescribe a possibility for the Council to invite an agency's director to report on the performance of the agency. Interestingly, in the case of Europol, the Presidency of the Council may be invited to the European Parliament to discuss relevant matters. From this perspective, it seems that the Council plays both roles of the accountability relationship: an accountability forum in relation to Europol as an institution and an accountability actor rendering account for Europol before the European Parliament. ${ }^{472}$

The information about the Council's procedures and practices other than those prescribed in the founding acts of EU agencies discussed above is difficult to find. ${ }^{473}$ Thus, the questions of whether the Council's representatives visit agencies and how often agencies' representatives are invited to the Council (and what organ exactly) are unknown to the public. ${ }^{474}$ In the case of the FRA, for instance, "the Council has started more or less active

\footnotetext{
${ }^{470}$ Busuioc (2010) P. 124.

${ }^{471}$ ACER, Frontex, IT-Agency, EASO, EASA, EBA, GSA, EIOPA, ENISA, Cepol, ERA, ESMA, ETF, FRA and Europol.

472 "The Presidency of the Council, the Chairperson of the Management Board and the Director shall appear before the European Parliament at its request to discuss matters relating to Europol taking into account the obligations of discretion and confidentiality" (Article 48 Council Decision 2009/371/JHA).

${ }^{473}$ Council's Rules of Procedure do not prescribe any specific scrutiny procedure for EU agencies.

${ }^{474}$ E.g., since her appointment, Catherine Ashton, the High Representative of the Union for Foreign Affairs and Security Policy, has visited the EUSC several times. In this light, an introduction of the new post with clear responsibilities (as a liaison between 'the forum and the actor') may have positive effects on accountability. Yet, the
} 
interaction [with the agency] under the Swedish Presidency, when the director was firstly invited. $\langle\ldots\rangle$ They also asked us to deliver an opinion on a particular issue on the agenda." ${ }^{475}$ In the case of ECHA, when "chemicals come on the agenda, the work of the agency is also scrutinized. But there is no formal platform." ${ }^{476}$ One respondent stated, however, that "the Council has never been discussing the agency $<\ldots\rangle$ perhaps one time when the agency was set up, and another time when the first extension of the agency's functions was on the agenda." ${ }^{477}$ Similar to the situation with informal contacts between EU agencies and MEPs, the representatives of some agencies stated that they were invited to Council's working groups to give technical advice, rather than to be checked upon. ${ }^{478}$

The role of the Council in continuous scrutiny may be hindered by the fact that there is no continuous Council. The Council has different compositions of ministers who gather a few times a year (see Chapter 2.1.1.1.). Meetings with the Council are thus often "complemented or even replaced by meetings before lower Council structures." ${ }^{479}$ In the case of the FRA, for instance, the agency deals with a fundamental rights working party of the Council, which was the primary body where the mandate of the agency was established and negotiated. It used to be an ad hoc working group but at the end of 2009 it was made permanent by the decision of the Council. "It is now tasked with, let us quote from their mandate, following up the reports of the agency." ${ }^{480}$ At the same time, the nature of the role of the working party in relation to the agency is a bit unclear: "They are not really checking but more a cooperative body $<\ldots>$ their mandate is not drafted in a way that they are meant to check us. It is that they discuss the follow-ups of our reports." ${ }^{481}$ Such an involvement of the Council in scrutinizing agencies could be perhaps explained by the fact that by design agencies' management boards resemble the Council and in a way its supervision role. For instance, the disciplinary authority over EU agencies' directors and the involvement in the appointment and removal of directors are the competences which are often assigned to the Council or to the management board of the agency.

All in all, the scrutiny by the Council is likely to imply scrutiny by its lower structures, which are not famous for their transparent operation. ${ }^{482}$ Because of the lack of transparency

nature of such contacts remains unknown. This makes it difficult to judge in how much such visits were visits of an accountability nature (Official from the EUSC at the exhibition of European agencies 'EU Agencies - The way ahead', taken place on 31 January - 3 February 2011 in the European Parliament in Brussels).

475 Senior official from FRA (interviewed in August 2011).

${ }^{476}$ Member of ECHA's management board (interviewed in September 2011).

477 Chairman of an EU agency's management board (interviewed in November 2011).

${ }^{478}$ Senior official from an EU agency (interviewed in August 2011) and Director of an EU agency's representation in Brussels (interviewed in September 2011).

479 Ibid.

${ }^{480}$ Senior official from FRA (interviewed in August 2011).

481 Ibid.

${ }^{482}$ An EU agency official stated: "even for us the Council is very opaque. There is definitely room for improvement" (Senior official from an EU agency (interviewed in August 2011)). 
of such meetings and the absence of formal rules governing scrutiny in the Council, it becomes difficult to judge whether and how often scrutiny takes place and how much such interactions focus on checking agencies' performance rather than on asking for agencies' technical advice.

\section{The investigating European Parliament}

The European Parliament enjoys the sole power to make political investigations. The TFEU and the Rules of Procedure govern the procedural elements and the scope of possible investigatory committees which can be divided into two types: the committees of inquiry and special temporary committees. This section briefly discusses them in a comparative manner.

To begin with, the scope of the two types of investigatory committees differs. The scope of the committees of inquiry has become rather narrow which may have influenced the frequency of usage of this tool. ${ }^{483}$ Such committees can be established

to investigate alleged contraventions of Union law or alleged maladministration in the application of Union law which would appear to be the act of an institution or body [hence, including European agencies] of the European Union (Rule 185 (1), Article 226 TFEU), except where the alleged facts are being examined before a court and while the case is still subject to legal proceedings (Article 226 TFEU).

As for special temporary committees

On a proposal from the Conference of Presidents, Parliament may at any time set up special committees, whose powers, composition and term of office shall be defined at the same time as the decision to set them up is taken (Rule 184 of European Parliament's Rules of Procedure).

Thus, as long as there is an agreement of the Conference of Presidents (the political groups' leaders within the European Parliament) a special temporary committee may be set up to focus on the agreed topic. Unlike the committees of inquiry, special parliamentary committees can be set up with different purposes in mind, such as to scrutinize a particular institution or body, to follow-up and to monitor the implementation of parliamentary recommendations resulted from a committee of inquiry investigation, to contribute to the devel-

\footnotetext{
${ }^{483}$ Before this power was formalized in the Maastricht Treaty, the committees of inquiry could "enable a wideranging investigation of a particular issue, putting the public spotlight on it and placing it on the political agenda" (Corbett et al. (2011) P. 331). The new restriction could be seen as a sign for 'abandoning' this mechanism in the last two decades: there have been only three investigations (Investigations of the Community Transit System (1996-1997), of the BSE Crisis (1996-1997) and of the Crisis of the Equitable Life Assurance Society (20062007)) by the committees of inquiry since the introduction of these limitations, while eleven committees of inquiry had been used in a ten-year period before 1992. For the full list of these committees, see: Corbett et al. (2007) P. 303-304.
} 
opment of a legislative proposal, and to raise public and other institutions' awareness of particular issues. These purposes do not exclude one another. Since 1979 there have been 15 temporary committees, ${ }^{484}$ some of which were clearly devoted to one of the mentioned purposes while others had a mixed mandate.

Both types of investigatory committees are time-bound and have special procedures for their establishment. The committees of inquiry can be established upon the request of one quarter of the members of the Parliament supported by the majority of the Conference of Presidents to put the request for voting in the plenary (Article 185 Rules of the Procedure). ${ }^{485}$ Also, committees of inquiry "shall conclude their work within not more than 12 months. Parliament may twice decide to extend this period by three months" (Rule 185 (4) Rules of the Procedure). They cannot be re-established unless new facts appear and only after 12 months following the completion of its task or the submission of its report (Article 2(5) IIA $\left.^{486}\right)$. The time frame for special temporary committees is normally 12 months and it can be prolonged without limitation on its length. The only limitation of their operation is the rule that the Parliament cannot subsequently alter the power, composition and term of office of a special committee (Rule 184 Rules of the Procedure). The restrictive character of this rule can be undermined by the absence of a limitation for re-establishing a special committee which is the case with the committees of inquiry.

While the scope and the time limitation are less flexible in relation to the committees of inquiry in comparison to the special temporary committees, the committees of inquiry seem to give extra investigatory tools to the European Parliament. According to Article 3 IIA the European Parliament may invite relevant institutions and natural and legal persons and other relevant individuals who shall designate their officials for hearings to provide requested documents. This is an additional tool that the Parliament has when it resorts to the committees of inquiry, although it is not without reservations. For reasons of secrecy and of public and national security, which are not explicitly defined, some documents and

${ }^{484}$ Corbett et al. (2011) P. 167.

Information about the former special temporary committees can be found at: http://www.europarl.europa.eu/activities/archives/staticDisplay.do?language=EN\&id=156 (last check November 2012). See, Syrier (2013) for a comprehensive study on the conducted investigations by the European Parliament.

${ }^{485}$ There is an obligation to notify the public by publication of a notice in the Official Journal. Hearing and testimony shall take pace in public (Article 2(2) IIA, Annex IX). At the same time "witnesses and experts have the right to make a statement or provide testimony in camera" (Article 2(2)).

${ }^{486}$ According to Article 226 TFEU a regulation passed upon the initiative of the European Parliament and consent of the Commission and the Council shall determine the detailed provisions establishing such committees and their practices. Interestingly, the two main executive bodies of the EU have to consent on the procedures which are mostly designed to investigate their 'wrong doings'. Before the revision of existing practices is going to take place, the Interinstitutional Agreement of 1995 (IIA) codified in Annex IX of the Rules of Procedure of the European Parliament governs how committees of inquiry are set up. 
officials may be not be disclosed to or invited before the committees of inquiry. ${ }^{487}$ In this light, "many members felt that the powers of these committees remained too weak," 488 because "for example, they do not give the Parliament a general power of summons" 489 but only the power to invite EU and national officials as well as other individuals. There are also no sanctions for perjury. Thus, the concern of parliamentarians is not only about whether the invited persons show up but also about hearing 'the truth' and receiving all relevant information.

At the same time, Corbett et al. point towards some positive developments in practice. In the first two cases of the committees of inquiry after 1993 only one person refused the parliamentary initiation to come personally and instead sent a designated person on his behalf. ${ }^{490}$ And "although there were no sanctions for perjury, both committees went to considerable lengths to ensure that the evidence given by witnesses was widely publicized." 491 "All witnesses thereby became aware that they would be held to account by a much wider audience than the one to which they gave evidence." ${ }^{292}$ Yet, the third and last case until now of the committee of inquiry showed a different story where approximately twenty invited witnesses did not come. ${ }^{493}$ While "the close institutional ties between the Commission and the Parliament made non-attendance by a Commissioner virtually unthinkable," "the situation was much more different in relation to members of national governments." ${ }^{494}$ Finally, the committees of inquiry have "limited resources at their disposal," including both additional financial and expert support, especially in comparison to their national counterparts. ${ }^{495}$

Interestingly, the two types of investigatory committees may reinforce each other. The result of a committee of inquiry may be followed-up by a special temporary committee as to the implementation of parliamentary recommendations. The conclusion of the work of a committee of inquiry is a report submitted to the Parliament followed by a plenary debate at the request of the committee. The report is published and it contains recommendations addressed to relevant institutions and bodies or the member states (Rule 185 (10) Rules of the Procedure). A responsible parliamentary permanent specialized committee shall monitor the actions taken on the result of the investigation and, if appropriate, report on the

\footnotetext{
487 "Institutions or bodies of the European Communities shall not supply the temporary committee of inquiry with documents originating in a Member State without first informing the State concerned" (Article 3(6) IIA).

488 Corbett et al. (2011) P. 335.

${ }^{489}$ Corbett et al. (2007) P. 304.

${ }^{490}$ It was British Minister of Agriculture, Douglas Hogg (Corbett et al. (2011) P. 334).

491 Corbett et al. (2011) P. 334.

492 Shackleton (1998) P. 123.

${ }^{493}$ Report on the crisis of the Equitable Life Assurance Society (2007), the Equitable Life Committee of the European Parliament (A6-0203/2007 4). Part I, Point IV.

${ }^{494}$ Shackleton (1998) P. 119.

495 Ibid. P. 118.
} 
progress and "shall take any further steps which are deemed appropriate to ensure that the conclusions of the inquiry are acted upon in practice" (Rule 185 (11) Rules of the Procedure). In case of the BSE (mad cow) committee of inquiry, for example, a motion of censure was proposed to be used as a potential sanction against the Commission if it did not implement parliamentary recommendations within a reasonable time. ${ }^{496}$ For the purpose of monitoring the implementation of parliamentary recommendations. a special temporary committee was subsequently set up.

Finally, both types of committees may be used to attract public attention to a specific issue. The establishment of investigatory committees is announced via the Official Journal and often implies public hearings, especially in case of the committees of inquiry where this is an obligation (Article II A). In this light, Shackleton states, "one of the most striking features of [such] committees is the contrast between their lack of formal powers and the impact that they had outside the Parliament. $\langle\ldots\rangle$ committees generated significant press and media coverage across the whole European Union." ${ }^{997}$ Thus, scrutinizing agencies with the help of investigatory committees could raise public awareness and facilitate 'shaming and blaming' ${ }^{498}$ To this end, the refusals of some officials to accept the European Parliament's invitations could have a 'positive' effect by increasing media attention.

So far no committee of inquiry or special temporary committee has been established to scrutinize an EU agency's performance or specific event, not even in the case of maladministration in Cepol, discussed in section 2.2.4.2. In case of Cepol, the reasons for this could be the specific focus on financial mismanagement which was investigated by the Court of Auditors within the discharge procedure and by the European Anti-Fraud Office with respect to the more specific (criminal) responsibility of the director responsible for the implementation of 2008 budget. Also, the financial irregularity was quite small, 244,200 Euro. ${ }^{499}$ Considering the significance of the issues and events for which the past investigatory committees have been set up, such as the mad cow crisis involving actions of respective national authorities and the Commission, they seem to be used as a last resort measure in the cases of large-scale maladministration and significant events, which are unlikely to be caused by individual EU agencies, especially those whose formal powers are weak. In this light, Parliament's permanent committees are likely to be the place where nearly continuous oversight of somewhat special cases, such as the maladministration of Cepol, will be investigated.

\footnotetext{
${ }^{496}$ Resolution of the European Parliament of 19 February 1997 on the results of the Temporary Committee of Inquiry into BSE. the European Police College for the financial year 2008 (C7-0198/2009 - 2009/2127(DEC)), Point 3, observation 16.
} 
As a whole, the European Parliament has a possibility to investigate the EU executive by establishing special investigatory committees which can be of two types, the committees of inquiry and special temporary committees. The differences between these two types of investigatory committees include the width of their scope, time limitations and formal powers. The likelihood that the European Parliament will use this tool against EU agencies may be rather small for two reasons. First, such committees may not necessarily add extra powers to those that the European Parliament enjoys in relation to EU agencies already (hearings obligations). Second, EU agencies with formally weak powers are unlikely to cause such events as past investigatory committees have been focusing on. Therefore, scrutinizing EU agencies with the help of its permanent specialized committees is likely to be the main choice of the Parliament to oversee agencies on a daily basis and in somewhat special cases, such as Cepol's maladministration.

\subsubsection{Scrutinizing EU agencies: challenges}

While the previous section has discussed how the European Parliament and the Council can, and in part do, scrutinize EU agencies, this section points to two challenges that the tool of scrutiny faces. These are the great number of executive institutions to oversee intelligibly and the weak incentives of representative bodies to scrutinize the executive.

\section{(1) The great number of executive institutions to oversee intelligibly}

As an old debating jibe says, I can give you an answer, but not the intelligence to understand it. ${ }^{500}$ One of the biggest challenges for representative institutions worldwide seems to be how to oversee the actions of executive branch institutions and agencies, and to oversee them intelligibly. Hence, "effective parliamentary scrutiny depends not only on adequate information received in time, but also on the capacities of parliaments actually to deal with and process this information." 501

Generally speaking, the executive branch includes a great many entities regulating numerous and at times quite technical matters. As a consequence, the attention of the overseeing institution "will be naturally selective, as the time and attention at their disposal are clearly limited." 502 In this light, assigning agencies to permanent specialized committees according to their subject matters and appointing individual members to be responsible for individual agencies is not simply a matter of a more efficient organization of parliamentary activities. It is important also to promote specialization which facilitates the comprehension of information that the Parliament receives and hence holding EU agencies to account.

\footnotetext{
500 Priestley (2008) P. 145.

501 Auel (2007) P. 489, 500.

502 Schillemans (2011) P. 396.
} 
However, does the European Parliament have sufficient knowledge to scrutinize EU agencies?

First, the content of hearings often includes technical and scientific information. Parliamentarians are not necessarily experts in the fields they supervise. Also, a rather frequent turnover of MEPs in general, and in permanent specialized committees in particular, ${ }^{503}$ may adversely affect the cumulative knowledge of the European Parliament and its committees: "there are relatively few very long-serving MEPs." ${ }^{504}$ This is not surprising given the fact that the turnover of the members of the European Parliament members is 50 per cent. ${ }^{505}$ In addition, "traditionally committees have witnessed a relatively high turnover in membership from one Parliament to another $\langle\ldots\rangle$. Only a minority of MEPs stay in one committee for more than ten years. $<\ldots>$ There is doubtless less continuity in committee membership than in the US Congress." 506

Second, while MEPs can rely on their personal and other assistants, ${ }^{507}$ it is unclear whether they have necessary support with respect to both the number and expertise. Members are free to choose how many assistants to hire; however, generally there are two fulltime and one or more part-time assistants, ${ }^{508}$ but the number of assistants that are located in member states varies as salary scales vary greatly from member state to member state. Furthermore, "a number of members choose to have a stagiare on an internship for six months or for an academic year. <...> Assistants tend to be less well paid $<\ldots>$ than Parliament or Political Group staff, and there has tended to be a far higher turnover. <...> They tend to be younger (often recent university graduates), and take on the job as their first or second job." ${ }^{509}$ Concerning personal research requests, in 2011, the maximum monthly amount available for MEPs personal staff was 21,209 Euro per MEP where only "up to a quarter of this budget can be used for services from service providers chosen by the MEP, such as ordering an expert study on a particular subject." ${ }^{510}$ Also, the research capacity of Parliament's departments is restricted by budget limitations, which makes two to three studies possible per committee per year and a few (two to three a month) short notice paper

\footnotetext{
503 Corbett et al (2011) P. 51.

504 Ibid. P. 52.

505 Ibid. P. 51.

${ }^{506}$ Ibid. P. 147 (Corbett et al. note that also chairmanship of parliamentary committees is changing rather often, especially in comparison to the US Congress. (P. 151)).

${ }^{507}$ Personal "assistants are not the only knowledge support we have. Political groups have advisers to give knowledge support their MEPs in committees. For the Green group these advisers are very good experts on the substance of each committee. Also, the staff of the EP committees is helping us in our job and this expert help is very important for our work. We can also hire experts who work for us for a limited time in cases we need more knowledge support, e.g. in cases we act as rapporteurs" (MEP Hassi (e-mail from September 2011)).

${ }^{508}$ Corbett et al. (2011) P. 74.

${ }^{509}$ Ibid.

${ }^{510}$ Miller (2010) P. 5.
} 
policy reports by policy departments. ${ }^{511}$ In this light, some prominent scholars previously employed at the European Parliament conclude that parliamentary support is small in numbers and short on expertise:

Compared to the US Congress (but not to the national parliaments of the Member States) the full-time staff of Parliament's committees is small. Committees normally have between four and ten administrators. <...> They tend to be generalists rather than specialists, largely because there are too few of them to cover what is often a wide range of policy areas, but also because of language constraints. A French-speaking expert on a particular subject area may have to hand over to a German-speaking, but non-expert, colleague if the rapporteur he or she is meant to assist speaks only German. ${ }^{512}$

Furthermore, while there is a parliamentary library that supports "the European Parliament's legislative, control and representational functions by providing high-quality information services that are timely, objective and non-partisan," 513 it does not have a research service. It offers a 'library briefings' service. ${ }^{514}$ The support MEPs can get includes, for instance, "a three page long summary on what legislation and budget there is in relation to a particular issue. The library can give you information on where to find more information." 515 The staff of the library consists of 99 employees most of whom have a librarian degree. ${ }^{516}$ Moreover, as the turnover of MEPs is quite high, some MEPs are not even familiar with the possibilities that the library offers; "many MEPs do not know about it." 517

While in financial aspects the European Parliament replies on the specialized help of the European Court of Auditors ${ }^{518}$ (see section 2.2.4.2.), for its political scrutiny task it seems

\footnotetext{
511 Administrator of European Parliament's Employment Committee (interviewed in September 2011).

512 Corbett et al. (2007) P. 133.

${ }^{513}$ Parliamentary Library, research and archive services of Europe: description of the Parliamentary Library, Research and Archive Services of Europe + Israel, the United States of America, Council of Europe, European Parliament and Assembly of the WEU, compiled by Elisabeth Dietrich-Schulz, ECPRD Coordinator for Parliamentary Libraries, Research and Archives and Head librarian of the Austrian Parliament, 2008. P. 25.

${ }^{514}$ Ibid. P. 31.

${ }^{515}$ MEP Jensen (interviewed in June 2011).

516 Parliamentary Library, research and archive services of Europe: description of the Parliamentary Library, Research and Archive Services of Europe + Israel, the United States of America, Council of Europe, European Parliament and Assembly of the WEU, compiled by Elisabeth Dietrich-Schulz, ECPRD Coordinator for Parliamentary Libraries, Research and Archives and Head librarian of the Austrian Parliament, 2008. P. 31.

${ }^{517}$ MEP Jensen (interviewed in June 2011).

518 There is also the European Centre for Parliamentary Research and Documentation which is primarily established for inter-parliamentarian cooperation and exchange of information. Although it responds also to comparative requests, these are mostly done within the framework of the inter-parliamentary cooperation (See, its 26 publications at: https://ecprd.secure.europarl.europa.eu/ecprd/pub/publication.do?start=0 (last check December 2010)). Although Corbett et al. opine that "it cannot easily match the Commission and national governments in terms of providing an alternative, but equally detailed, viewpoint on controversial complex subjects" (Corbett et al. (2007) P. 287).
} 
to miss a similar support institution. This has led to the situation where the Parliament assigns the Court of Auditors, "the independent guardian of the financial interests of the citizens of the Union," ${ }^{519}$ to investigate and to issue reports on other than financial subjects. ${ }^{520}$ For the Court of Auditors, this means a shift of a part of its personnel from their central focus task on financial audits and executing requests in the areas where it may lack required expertise. Both issues may negatively affect the quality of such reports.

There is also the Parliament's secretariat that employs over 6,000 people, thus officially "outnumbering MEPs by more than eight to one." ${ }^{21}$ Yet, while the number is much higher compared to national parliaments in Europe, "the high ratio can only be understood in the light of two particular constraints imposed on Parliament by the Member States, namely that it must devote a very high level of resources to ensuring that parliamentary bodies can operate in all [24] EU official languages and that it is spread over three main places of work (with additional information offices in all Member States)." 522

In addition, the Parliament has internal departments that may provide legal advice (Legal Service) or conduct studies (DG IV). DG IV also includes a mechanism called STOA (Scientific and Technological Options Assessment). DG IV has an annual program of 750,000 Euro and may conduct research with the help of outside institutions. However, such a mechanism has been criticized for its ineffectiveness as the whole procedure of winning those tenders, including announcing calls for tenders and concluding relevant contracts and other related procedures, takes about half a year. If this is then added with a time for realization of the project "you are close to a total period of 12-18 months." 523

Furthermore, while it is necessary that the European Parliament does not get information only from the institutions it oversees, it is questionable whether it relies on necessary support to scrutinize the growing in number EU agencies (and also other institutions):

A major problem the EP faces is how to obtain relevant information for its legislative work. The Commission is, of course, a prime source $\langle\ldots\rangle$. Interest groups may offer advice and national governments may send memos to MEPs from their country. As a result, it is not so much advice per se that is lacking, but its independence. If all these possible sources have a

\footnotetext{
519 This information is taken from the official web-page of this institution. Find at: http://eca.europa.eu/portal/page/portal/aboutus/abouttheeca (last check December 2010).

${ }^{520}$ See, e.g., European Parliament's discharge resolution of 2010 where it asks the Court to investigate the issue of involvement of competent standing committees in the discharge of their agencies (European Parliament Resolution of 5 May 2010 on the 2008 discharge; performance, financial management and control of EU agencies (2010/2007(INI), Point 22)).

${ }^{521}$ Corbett et al. (2011) P. 218.

522 Ibid.

${ }^{523}$ Neunreither (2002) P. 52.
} 
tendency to be biased, is there a chance for the EP to have access to more objective and reliable advice? ${ }^{524}$

All in all, while MEPs have personal and other assistants and possibilities to outsource requests to study specific subjects, it is unclear whether they rely on an equally strong support to conduct political oversight as they do in relation to financial aspects where the Court of Auditors plays a 'diagonal accountability forum' role.

\section{(2) Lacking incentives to scrutinize}

"Effective scrutiny obviously depends to a large degree on the amount of information" parliaments receive. ${ }^{525}$ Although receiving information may look like a one-way process, it actually implies not only obtaining information, but also comprehending it. The interest in an agency and its business from the side overseeing institutions is, however, another point for concern. Apart from the potential lack of (technical) knowledge there might be low interest in an agency on the side of an overseeing institution. Such an interest depends on a number of factors, such as the relation of the agency to the constituency where the parliamentarian is (re)elected ${ }^{56}$ and the salience of the agency and the policy that the agency regulates. ${ }^{527}$ "You do not score with the electorate when you are dealing with agencies, so it is from this point of view not a very attractive job. It is interesting and it is necessary but you do not get votes for that." ${ }^{528}$ With respect to the salience of the agency an official from an EU agency explained,

The director has two meetings per year at ENVI committee (in January and October)" where the work program, past and future actions are discussed. "The content of hearings depends on the agency, how interesting and important it is. If the director is new, there is more interest, than if he is there for a while and everything is ok. If the MEPs are interested and agencies are in their political agendas, more interest is given to agencies. ${ }^{529}$

In the case of OHIM, the interest from parliamentarians was so low that the President of OHIM was not informed for two years that the oversight of his agency was transferred

\footnotetext{
524 Neunreither (2002) P. 51.

525 Auel (2007) P.489.

${ }^{526}$ A senior official from the Brussels' representation of Eurofound noticed that Irish MEPs used to be more involved in the agency than others. Yet, in the last six or seven years there has been more interest in agencies and hence a better relationship has emerged between the agency and the European Parliament, especially parliamentary committees' administrators because "they last longer" (Senior official from the Brussels' representation of Eurofound (interviewed in September 2011)).

${ }^{527}$ See, e.g., Busuioc (2010) P. 107, 109; Schillemans (2011) P. 396.

${ }^{528}$ Director of an EU agency (interviewed in July 2011).

${ }^{529}$ Senior official from an EU agency (interviewed in October 2011).
} 
from one parliamentary committee to another, because he was never asked to come to a meeting to any of those committees. ${ }^{530}$

It has to be noted that the interest varies greatly from committee to committee. "It depends on the agency, it depends on the specialized committee how far it is involved in agencies' work." ${ }^{531}$ MEP Jensen tells,

In transport committee there was a broad interest in agencies, whenever they came to the committee, it would not be like in the employment committee where you would have three persons sitting there, it would be actually the full committee present. ${ }^{532}$

An administrator from the employment committee seems to agree,

Once every year in January there is a presentation of all four agencies under our jurisdiction of their achievement, plans and budget estimates. Every director is given 10-15 min to make a presentation followed by questions; it can be very silent in the room." 533 "From approximately 50 MEPs in our committee, 10 are there. There is one week for them all to have committee meetings, too many issues to deal with. ${ }^{534}$

A senior official from an agency overseen by the employment committee shares the mentioned sentiment,

When we present our work programme, we are given eight minutes. That's it. What also happens is that our presentation is scheduled at the end of the committee meeting, so many MEPs leave. You get the President, Vice President and one or two rapporteurs. They complain that they are not informed, but they do not stay, they do not listen. ${ }^{535}$

Conversely, there are committees, such as the environmental committee, "who take their oversight seriously. $\langle\ldots\rangle$ They call their agencies regularly and ask to come and explain their decisions. It is more like the American system." 536 Interestingly, this committee assigns liaisons MEPs for each agency (see Appendix 2). A senior official from ECHA, an agency overseen by the environmental committee, states,

We are given 45 minutes to 1 hour to explain what we do" which is then followed by a 1.5-2 hour questions' session. "The European Parliament is very interested in chemicals $\langle\ldots\rangle$ they

${ }^{530}$ Busuioc (2010) P. 113.

This should not perhaps come as a surprise because the European Parliament has no formal power to oversee OHIM (according to OHIM's establishing regulation). Moreover, it is a self-funded agency which implies having no (financial) relationship with the European Parliament (see section 2.2.4.3.).

${ }^{531}$ MEP Haug (interviewed in June 2011).

532 MEP Jensen (interviewed in June 2011).

533 Administrator of European Parliament's Employment Committee (interviewed in September 2011).

534 Administrator of European Parliament's Employment Committee (interviewed in September 2011).

535 Director of an EU agency's representation in Brussels (interviewed in October 2011).

${ }^{536}$ MEP Jensen (interviewed in June 2011). 
have put a lot of effort in passing relevant regulation. They are very well prepared, know very well our field. They defend our resources and budget, ask why we do not regulate this or that, what we do to protect EU citizens and if we disseminate the information to, for example, NGOs. $<\ldots>90$ per cent of questions are relevant and precise, there seems to be a person who centralizes all questions. ${ }^{537}$

The chairman of ECHA's management board confirms,

The European Parliament has played an important role in adopting our legislation $(\mathrm{REACH})$, therefore many members are quite the experts and therefore such a hearing could be really a hard job to do. It is of high political relevance and influences the decision making. ${ }^{538}$

It seems that the involvement of parliamentary committees in their oversight over agencies may also be interrelated with its legislative power; when the Parliament is deeply involved in passing a policy regulation, like $\mathrm{REACH},{ }^{539}$ it is likely to be more interested in following up on the implementation of such a regulation.

Concluding, having discussed relevant rules and in part practices it can be concluded that the tool of scrutiny is in the process of development. In the absence of general rules on how scrutiny of EU agencies needs to be organized, various practices have emerged between individual agencies on the one hand and the European Parliament's individual committees or the Council and its lower structures on the other hand. The lack of general rules and at times transparency of such informal arrangements make it difficult to judge on the content and quality of such interactions. Furthermore, the scrutiny tool faces two challenges, which include the ability to oversee intelligibly a great number of agencies as well as other institutions and tasks and the weak incentives of representative bodies to scrutinize agencies. When the European Parliament faces certain challenges, the 'first thought response' becomes the necessity of increasing its formal powers to address relevant challenges. Having discussed the patchy organization of Parliament's scrutiny over the executive, however, it seems that utilizing the already existing competences and organizing them in a clearer, transparent, and a more effective way may be more important in the short-term. ${ }^{540}$ Also, the Council's role as agencies' overseer needs to be clarified, since political scrutiny requires transparency of relevant activities and involvement of representative bodies. Given the

\footnotetext{
${ }^{537}$ Senior official from ECHA (interviewed in September 2011).

${ }_{538}$ Chairman of ECHA's management board (interviewed in September 2011).

539 "REACH is the European Community Regulation on chemicals and their safe use (EC 1907/2006). It deals with the Registration, Evaluation, Authorisation and Restriction of Chemical substances" (This information is taken from the official web-page of the European Commission. Find at: http://ec.europa.eu/environment/chemicals/reach/reach_intro.htm (last check April 2013)).

${ }^{540}$ See, also Syrier (2013: 240-245) who argues for the necessity to strengthen European Parliament's investigation function not only formally but also in practice.
} 
institutional characteristics of the Council, such as the absence of a 'continuous Council' and the opacity of its internal procedures, it is questionable how closely the Council matches the profile of a political overseer.

\subsubsection{The 'Common Approach' on the Operation of EU Agencies: Going Forward or Standing Still?}

Since the White Paper on EU Governance, the Commission has issued a number of documents ${ }^{541}$ creating a platform for discussion of problematic issues concerning the existing EU agencies with the Council and the European Parliament. Such activism on the side of the Commission to deal with EU agencies might have been boosted by a "vigilant approach towards the EU agencies" taken by several national legislatures, which demonstrated how "the power of negative publicity as a form of sanctioning" may work "despite the lack of a formal retribution. Political oversight exercised by Member States legislatures focuse[d] on both the overall agency system and its day-to-day practices." ${ }^{542} \mathrm{In}$ its report on the European Aviation Safety Agency, for example, the British House of Commons concluded,

It is with dismay that we have learnt of the chaotic state of (EASA), which at this time is not able to fulfil its declared purpose. EASA is an accident waiting to happen-if its problems are left unchecked, we believe it has the potential to put aviation safety in the UK and the rest of Europe at risk at some point in the future. The United Kingdom cannot and must not transfer any further powers from the CAA to EASA until the Government is assured that the serious problems of governance, management and resources at EASA have been resolved. We welcome the Minister's assurances on this. ${ }^{543}$

\footnotetext{
${ }^{541}$ White Paper on European Governance (COM (2001) 428 final), Communication from the Commission 'The operating framework for the European Regulatory Agencies (COM (2002) 718 final), Draft Interinstitutional Agreement on the operating framework for the European regulatory agencies (COM (2005) 59 final), Communication from the Commission to the European Parliament and the Council 'European agencies - The way forward' (COM (2008) 135 final).

542 Sauerer (2010) P. 623.

Sauerer offers three examples in this respect:

(1) the German Bundestag's exploration of the whole system of EU agencies with questioning the legality of EU regulatory agencies by pointing to the principle of subsidiarity and the proposal for a moratorium on the further establishment of EU agencies from Bundesrat;

(2) the French National Assembly's inquiry into the whole system of agencies in 2006 who seemed to push the Commission to make an evaluation (i.e., the Ramboll evaluation published in 2009), and

(3) the British House of Commons' inquiry into the whole system of agencies and specifically the organization and work practice of the EASA by its Transport Committee who was not satisfied with the work of the agency (2006) (Sauerer (2010) P. 623-625).

${ }^{543}$ House of Commons, Transport Committee, The work of the Civil Aviation Authority: Government Response to the Committee's Thirteenth Report of Session 2005-06, Fifth Special Report of Session 2006-07, Ordered by The House of Commons to be printed March 7, 2007. P. 3.
} 
Following the last document in the chain of the Commission's proposals on EU agencies 'Communication 'European agencies: the way forward'544 the EU's three main institutions, i.e., the Council, the European Parliament and the Commission, have launched an Interinstitutional Working Group on agencies (IWG) whose three-year negotiations have resulted in the 'Common Approach' on EU agencies. ${ }^{545}$ While the official press release offers a long list of "a range of improvements", "the work on $<\ldots>$ decentralised agencies has not come to an end," says Jutta Haug, the German MEP (S\&D) representing the European Parliament in the talks. ${ }^{546}$ This section offers a succinct critical analysis of the 'Common Approach' and shows that while progress has been made on a number of issues, it is still eclipsed by several serious factors, especially the non-legally-binding character of the newly released document. ${ }^{547}$

\section{'Common Approach' on EU agencies: 'going forward'}

The idea of addressing the operation of EU regulatory agencies in a single document was boosted by the fact that so far the establishment of EU agencies was done on a case-by-case basis without a common vision, resulting in inconsistencies between very similar entities (see all earlier sections in this Chapter). In addition, the operation of EU regulatory agencies has faced a number of challenges, such as the efficiency of operation and the issues of accountability and transparency. ${ }^{548}$ In this light, the joint effort of the EU institutions to identify the existing problems and to try formulating a common vision towards EU agencies, their role and the way they ought to operate at the EU level is in itself already a big step forward. In what aspects has this joint effort succeeded?

Solid progress seems to have been made on the question of the establishment and closure of EU agencies. Making 'an objective impact assessment' before deciding to create a new agency seems to address the existing problem of the necessity and usefulness of agencies as a tool of implementation of EU policies. ${ }^{549}$ In addition, the decision about the seat for a future agency ought to be taken before the end of the legislative process $s^{50}$ in order to ease an agency's starting-up phase which has been often delayed due to long-lasting political

\footnotetext{
${ }^{544}$ Communication from the Commission to the European Parliament and the Council 'European agencies: the way forward' (COM (2008) 135 final).

${ }^{545}$ Joint Statement of the European Parliament, the Council of the EU and the European Commission on decentralised agencies (annexed with the 'Common Approach' on EU agencies).

${ }^{546}$ Press Release 'Breakthrough as EU institutions agree common approach on agencies' of 13 June 2012. Find at: http://europa.eu/rapid/press-release_IP-12-604_en.htm (last check April 2013).

${ }^{547}$ This sub-section is largely based on: Scholten (2012).

548 See, the Ramboll evaluation's conclusions.

549 'Common Approach' on EU agencies, point 2.

${ }^{550}$ Ibid. Point 6.
} 
negotiations among Member States. ${ }^{551}$ In choosing the seat of new agencies the priority should be given to the new Member States. ${ }^{552}$ Also, due consideration should be given to such factors as accessibility of the seat and the presence of appropriate facilities for the future staff of the agency. ${ }^{553}$

The introduction of sunset or review clauses, ${ }^{554}$ which should allow closing or merging agencies upon their performance results and the needs of the EU, is another breakthrough on the way to the effective and accountable operation of agencies. Such clauses could be used as measures of last resort upon the results of agencies' evaluations, which is another important point brought by the 'Common Approach'. Concerning evaluations, there are three developments that are important to pinpoint. First, according to the 'Common Approach', evaluations should be made periodically, every five years. This is in addition to internal audits assessing major risks made by the Commission's Internal Audit Service over a three-year cycle. ${ }^{555}$ Second, ex ante evaluations should be introduced for programs requiring significant budgets or upon specific requests from agencies' management boards. The ex post results should be assessed in light of ex ante evaluations. Third, follow-up action plans should be introduced and reported to the Commission. Such action plans are supposed to allow checking the implementation of findings brought by ex post evaluations. ${ }^{556}$

Furthermore, evaluations of agencies' directors should be uniformly applied, meaning that the prolongation of directors' terms should be made upon their good performance and the needs of agencies, which is not the case in all existing agencies. ${ }^{557}$ Additionally, the governance of agencies seems to be also improved by introducing small-size executive boards next to the remaining 'densely-populated' management boards with representatives from each Member State, the Commission and other possible entities, such as stakeholders and the European Parliament. Such small executive boards are supposed to monitor agencies' activities more closely. ${ }^{558}$

For monitoring agencies, programming and reporting activities are crucial. These issues have also received some positive reflections in the 'Common Approach'. ${ }^{559}$ Indicative templates with common elements for annual working programs and for annual reports, the latter becoming the only kind of reports agencies will issue, seem to be a good development

\footnotetext{
551 "The decision on the location of the agency is typically made two years after that of creating the agency and this has over time often involved a certain amount of "horse-trading" between Member States at Council meetings" (the Ramboll Evaluation, Volume 2. P. 65).

552 'Common Approach' on EU agencies, point 6.

${ }_{553}$ Ibid. Points 6-7.

554 Ibid. Point 4.

555 Ibid. Point 50.

556 Ibid. Points 60-63.

557 Ibid. Point 17.

558 'Common Approach' on EU agencies, point 10.

${ }^{559}$ Ibid. Points 27, 46-48.
} 
with respect to improving the quality of planning and of reporting on the basis of the existing best practices and to making comparisons between agencies and their achievements.

All in all, 'the way forward' is based upon: (1) justifying the rationale behind using agencies as tool for implementing EU policies, including addressing a number of problematic technical issues, such as agencies' seats and facilities for the staff; (2) connecting ex ante evaluations of programs with their ex post results with a possibility for follow-up reporting and knitting the performance indicators to agencies' existence; (3) improving the governance of agencies with the help of smaller executive boards and of directors' evaluations with respect to prolongation of directors' terms; and (4) harmonizing other practices, such as programming and reporting, upon the existing best examples for the sake of improvement of the quality of such practices.

\section{The 'Common Approach' on EU agencies: 'standing still'}

While the three-year negotiations have been fruitful in relation to the discussed aspects of the operation of EU agencies, these achievements seem to be eclipsed by the following political compromises.

The biggest concern for the future application of the 'Common Approach' stems from the fact that it is not a legally-binding document. ${ }^{560}$ It is a document of 'should' and 'could', rather than of 'must' and 'will be'.

The 'Common Approach' targets 'future decisions concerning EU agencies. ${ }^{561}$ Thus, it does not amend founding acts of the existing agencies, although this does not exclude a possibility of taking the 'Common Approach' into account when recasting existing agencies. But, as the existing agencies' founding acts may lack 'review clauses' (see section 2.2.3.2.), it is unclear when the new changes will affect such agencies. Even if the 'Common Approach' is applied to new agencies, the question becomes how many there are still to come if there are already 35 agencies and the EU competences are unlikely to expand drastically any time soon. Evidently, the existing agencies are unlikely to be closed or merged as no Member State wishes to lose what they have achieved after often long-lasting political negotiations (see section 2.2.1.1.).

Nevertheless, it is worth mentioning that the 'Common Approach' is just the beginning. On many occasions the Commission is given the task of launching, developing or advancing individual points of the 'Common Approach', such as issuing a roadmap for implementing the 'Common Approach'. ${ }^{562}$ This may result in new proposals and future

\footnotetext{
${ }^{560}$ Joint Statement of the European Parliament, the Council of the EU and the European Commission on decentralised agencies. P. 3.

561 Ibid.

562 'Common Approach', point 2.
} 
negotiations which are clearly not legally compelled by the just agreed intentions for the future.

Furthermore, a number of issues remain unresolved. For instance, it is stated that "the possibilities for securing democratic accountability for fully self-financed agencies (i.e. financed by their clients) should be explored, as they are Union bodies in charge of implementing EU policies but not subject to a discharge within the meaning of the TFEU."563 This language indicates that the democratic accountability of self-financed agencies remains unchanged because of a possible political disagreement. Another unresolved issue concerns the members of the management boards of the agencies and their representative role should they represent their Member States or act in their personal capacity?564

Last but not least, the position of EU agencies within the existing institutional setting remains unclear. On the one hand, EU agencies are often created to be "autonomous" bodies $^{565}$ from the Commission. On the other hand, the Commission's role seems to be strengthened ${ }^{566}$ by: (1) the expansion of the Commission's role during the start-up phase of an agency; ${ }^{567}$ (2) the extension of the administrative services provided by the Commission; ${ }^{568}$ (3) the subjection of agencies' international relations to discussions with the relevant Directorate Generals ("DGs") of the Commission; ${ }^{569}$ (4) the requirement to discuss agencies' annual and multi-annual plans with the Commission; ${ }^{570}$ and (5) the evaluation and audit practices done by the Commission and the obligation to inform relevant DGs about the results of such evaluations and about progress made in implementing relevant recommendations. ${ }^{571}$ In addition, the Commission maintains 'a red button' power; it can activate an 'alert/warning system'572 "if it has serious reasons for concern that an agency's Management Board is about to take decisions which may not comply with the mandate of the agency." ${ }^{573}$ All these new developments provide the Commission's representatives with

\footnotetext{
563 'Common Approach', point 58.

564 Ibid. Point 11.

565 Ibid. Point 16.

${ }^{566}$ Egeberg and Trondal (2011) argue that EU agencies find themselves closer to the Commission and take its opinion (rather than of national authorities or the Council) more in consideration.

567 Ibid. Point 3.

568 Ibid. Point 23.

569 Ibid. Point 25.

570 Ibid. Point 29.

571 Ibid. Points 50-52, 60-62.

572 "In these cases, the Commission will raise formally the question in the Management Board and request it to refrain from adopting the relevant decision. Should the Management Board set aside the request, the Commission will formally inform the European Parliament and the Council, with a view to allow the three institutions to react quickly. The Commission may request the Management Board to refrain from implementing the contentious decision while the representatives of the three institutions are still discussing the issue" (Ibid. Point 59).

573 Ibid. Point 59.
} 
more influence on agencies' management boards, which may jeopardize the autonomy given to agencies.

As a whole, the three-year negotiations seem not to be very fruitful given the fact that they have produced a non-legally-binding document targeting future decisions concerning EU agencies, a document using quite tentative language and leaving a number of issues unresolved or to be developed and discussed again.

Concluding, the fact that the EU institutions have made a joint effort to develop a common vision towards EU agencies and to address the challenges EU agencies are facing is clearly a considerable step forward with respect to improving the operation of EU agencies. While the 'Common Approach' seems to contain a number of positive developments, one should not be too enthusiastic about its achievements because they are not legally-binding. For now, it seems that while the EU main institutions realize what needs to be done, it remains to be seen whether the agreement has been merely a 'formality' in response to concerns about agencification in the EU expressed by several national legislatures or whether it will indeed alter the way in which agencies have been created and operate. The future negotiations will test the political will required to implement the intentions laid down in the 'Common Approach' consistently.

\section{Conclusion}

This section investigated the political accountability of EU agencies with regard to five dimensions where political accountability can be shaped and exercised. These included the creation of and delegation to EU agencies by EU representative institutions, the appointment and removal procedures of EU agencies' top officials by EU representative institutions, statutory regulation of accountability relevant aspects, financial oversight, and scrutiny of agencies' performance. This section discussed how the political accountability of EU agencies has been organized and in part exercised, relevant legal rules, and to a certain extent (informal) practices that reshape formal rules or fill up their gaps. The findings of this section serve the basis for assessing the political accountability of EU agencies in the following section 2.3.

To sum up the findings of this section, there is no treaty provision or any other legal framework that authorizes the creation of and delegation to EU agencies. Creating EU agencies based upon general treaty provisions runs the risk of (and has arguably resulted in) creating EU agencies with no apparent functional necessity and with questionable accountability. This is because general treaty provisions do not impose substantive obligations on the legislator to justify its decision to create an agency and to establish a certain accountability framework. With respect to an accountability framework, the Meroni doctrine governing delegation in the EU is not particularly useful because it is not very explicit as to who should hold EU agencies to account and how. 
Since no legal framework governing the accountability of agencies exists, it is not surprising that accountability arrangements vary so greatly from agency to agency. For instance, EU agencies' directors can be appointed in 12 different procedures and can be removed in five different ways. Similar procedures may receive different legal labels in agencies' founding acts, such as evaluation and review clauses. Moreover, founding acts may simply lack evaluation, review, and removal clauses. Also, reporting obligations vary greatly with respect to the institutions-recipients of agencies' reports and specificity of such obligations. In this respect, it was shown that $24 \mathrm{EU}$ agencies are obliged to submit 'an annual report' without any specification on what such an annual report should include. This could in part explain the existing poor quality reporting. Furthermore, whereas EU agencies' founding acts can prescribe three types of hearings obligations before the European Parliament and/or the Council, they are not generally applied. Only 18 (out of 35) founding acts prescribe appointment hearings for candidates to head EU agencies, 16 (out of 35) agencies' directors may be invited to report on the performance of the agency, and in six (out of 35) cases the founding acts provide a possibility to question an agency's director before the extension of the term of office. Here, a correlation between the growing legislative power and hence involvement of the European Parliament in passing agencies' founding acts and the growing number of agencies' accountability obligations, such as hearings obligations, was noticed.

Due to the lack of formal rules, parliamentary and Council's practices in the field of political scrutiny vary greatly between and within these institutions. This makes it difficult to conclude whether and how, in quantitative and qualitative terms, scrutiny of individual agencies takes place. Parliamentary committees may have developed the practices of appointing liaisons to maintain contacts with their agencies, of visiting agencies and of holding annual hearings where agencies' directors present their annual reports. Yet, the presence and application of such practices varies greatly from committee to committee. Concerning Council's scrutinizing practices, the lack of transparency of its operations hinders a thorough investigation of the issue.

Clear laws and established practices exist only in relation to EU agencies' financial oversight which takes place within the annual budgetary and discharge procedures. Its strengths lie not only in the regularity but also in a number of legal principles that govern the budgetary procedure and the availability of an expert support institution, the Court of Auditors, which plays a role of a diagonal accountability forum. The principles of specification, universality, and especially of sound financial management facilitate ex post control over agencies' finances and activities by decreasing the degree of financial discretion and establishing standards against which agencies' performance can be checked. At the same time, even here there are some exceptions. The political accountability of the six self-funded agencies seems troublesome as self-finding implies not only the absence of financial oversight, but also the 
absence of hardly any further relationship between such agencies and the EU representative institutions, especially the European Parliament.

The existing diversity seems to indicate an ongoing political game over who ascertains control over EU agencies. Such a political game seems to have not ended even after the operation of EU agencies was discussed by the EU main institutions within the Interinstitutional Working group on EU agencies. The results of the work of the mentioned group, the non-legally-binding 'Common Approach' on EU agencies, shows that while the main institutions have identified the existing problems, and the necessity to address them in the future, political negotiations remain the determinant factor in relation to the creation and operation of EU agencies, including how agencies' political accountability is arranged.

\subsection{Assessing the Political Accountability of EU Agencies}

Having introduced relevant institutions and having investigated the current issues of and challenges to the political accountability of EU agencies this concluding section of Chapter 2 assesses the political accountability of EU agencies. The assessment is done pursuant to the three criteria presented in Chapter 1 as the following formula: 'political accountability = availability of accountability mechanisms + their design (specificity of accountability obligations and interplay of accountability mechanisms) + their practical application'. This section discusses the political accountability of EU agencies in three respective parts and shows problematic areas concerning all three elements.

\subsubsection{Availability of Accountability Mechanisms: Harmful Implications of Diverse Accountability Obligations}

In order to hold EU agencies to political account the EU representative institutions need to have accountability mechanisms ensuring the three stages of political accountability. While the statement seems to be quite obvious, this section shows that this is not necessarily the case with EU agencies. Different EU agencies are subject to different sets of accountability obligations with different involvements of the Council and the European Parliament. This implies some EU agencies escaping accountability obligations that other (similar) agencies are subject to. Not being an accountability problem in itself excessive diversity is harmful for political accountability in several respects. This section attempts to explain the existing situation and questions the appropriateness of 'one size does not fit all' logic from an accountability perspective.

\section{The existing situation}

Generally speaking, the Union Legislator has made EU agencies subject to various accountability mechanisms ensuring the three stages of accountability. The European Parliament 
and the Council can receive various sorts of information from EU agencies - annual working programs and reports, information about their financial accounts and implementation of the budget, evaluations and special reports reflecting agencies' specific fields of work (see section 2.2.3.). The European Parliament and the Council may hold hearings and other meetings with EU agencies' representatives to discuss agencies' intentions, ongoing work and results (see sections 2.2.4. and 2.2.5). The EU agencies are subject to scrutiny by the Council and the European Parliament which may take place ex ante (appointment hearings), continuously (by parliamentary committees and Council's lower structures), and ex post (with the discharge procedure and during parliamentary investigations). Finally, the EU agencies may face sanctions of personal and of institutional character by way of the removal of agencies' directors, postponements or refusals in the course of the discharge procedure, cuts to agencies' budgets, and reconsiderations of agencies' mandates and existence. It is also possible to trace the personal democratic accountability chain of agencies' top officials through the involvements of the Council and the European Parliament in (re)appointment and removal procedures (see section 2.2.2.).

At the same time, the Union Legislator has not been consistent in inserting accountability relevant provisions into agencies' founding acts. There are $35 \mathrm{EU}$ agencies, where nearly each has a different set of accountability obligations (see Appendix 1). While reporting obligations are common to all EU agencies, the institutions-recipients of agencies' reports vary: for example, the self-funded Community Plant Variety Office (CPVO) is not legally obliged to send its report to the European Parliament and the Council, as is the case with nearly every EU agency. Furthermore, while the CPVO has to send its report to its management board and the Commission, the self-funded Office for Harmonization in the Internal Market (OHIM), an agency which is closely situated to the CPVO function- and type-wise, is obliged to submit its report to the European Parliament and the Commission. Both CPVO and OHIM were created in the same second wave of the creation of agencies (1994). Furthermore, great differences exist with respect to hearings obligations of agencies' directors. There are three types of hearings obligations: before the appointment of a candidate to head an EU agency, before the agency's director reappointment and on the performance of the agency. Out of $35 \mathrm{EU}$ agencies $18 \mathrm{EU}$ agencies have a hearings obligation of the first type, six EU agencies have a hearings obligation of the second type, and $16 \mathrm{EU}$ agencies have a hearings obligation of the third type (see Table 2.3. in section 2.2.1.1.). The list of such differences could go further but the point is clear: every EU agency is held to political account differently, which implies that some agencies escape accountability mechanisms that other (similar) agencies are subject to.

That some agencies are subject to more accountability obligations than others is in principle not an accountability problem, especially if a good reason is given. It seems logical to make accountability obligations of an agency proportionate to the powers the agency has. For instance, an information-gathering agency could have a fewer accountability obli- 
gations, than of a decision-making one. In fact, the existing EU agencies do differ in function, namely information-gathering, advisory, service-providing, cooperation, decisionmaking, and supervision, and also in type, for instance, the division of EU agencies according to the former three pillars, which has also affected agencies' accountability obligations. However, the existing excessive diversity in accountability practices does not necessarily correspond to the mentioned classifications. As an example, the director of the serviceproviding European Training Foundation (ETF) is subject to all three types of parliamentary hearings. At the same time, the director of the service-providing European Fisheries Control Agency (EFCA) has no hearings obligations before the European Parliament at all. Both agencies belonged to the 'former first pillar' group of agencies.

As there is no genuine consensus as to what minimum set of accountability mechanisms EU agencies should be subject to and what (minimum) involvement the Council and the European Parliament should have in relation to EU agencies, it is difficult to evaluate EU agencies as accountable or not. Even when looking at individual cases, it is hard to conclude whether, for instance, a missing parliamentary hearing mechanism makes an EU agency less accountable or not. It depends on, among other things, from what perspective one looks at the EU; intergovernmental, supranational or regulatory. ${ }^{574}$ It is thus difficult to judge whether, for instance, there is a problem of too many or too few hands when EU agencies are obliged to send their reports to one or both representative institutions. At the same time, it seems reasonable to expect that derogations from certain practices used in relation to similar agencies and diversity in general are based on certain logic. This seems essential for promoting legitimacy of EU structures and processes.

Furthermore, the randomness and at times lack of formal powers and rules concerning political accountability have led to informal and voluntary practices being established between the Council and the European Parliament on the one hand and the EU agencies on the other hand. These involve, for instance, informal meetings of EU agencies' representatives with representatives of the parliamentary budgetary committee which have been initiated by the European Parliament's budgetary committee. Clearly, informal practices may play an important role in holding EU agencies to account. Yet, informality runs certain risks.

Not only would such practices and contacts be unknown to the public, they would also usually survive only as long as the persons who have initiated them hold their positions. Concerning the European Parliament, for example, "there are relatively few very longserving MEPs;" 575 this is not surprising given the fact that the turnover of the members of the European Parliament members is 50 per cent; the committees see thus also frequent changes of their members. ${ }^{576}$ If MEPs change frequently, it seems challenging to establish

\footnotetext{
574 Bovens et al. (2010) P. 29.

575 Corbett et al. (2011) P. 52

${ }^{576}$ Ibid. P. 51; 147.
} 
and sustain customary practices unsupported by any formal rules. A black letter rule creates transparency of how oversight practices are organized and obliges respective institutions to undertake respective accountability actions. Inactions and changes of such rules would be more visible which may require giving relevant justifications. Also, transparency in holding to account facilitates achieving the greater purpose of accountability which is promoting the legitimacy of EU structures and processes. Needless to say, the more actors that are involved in holding EU agencies to account (the Council and the European Parliament and their internal sub-divisions), the more necessary it becomes to introduce rules to avoid accountability inconsistencies, shortages and excesses.

All in all, the existing situation can be characterized as excessively diverse where $35 \mathrm{EU}$ agencies have roughly speaking 35 accountability regimes, implying that some EU agencies escape accountability obligations that other (similar) agencies are subject to. The existing differences in accountability obligations do not necessarily correspond to the different types and functions of agencies. While the existing gaps of formal powers and rules concerning political accountability have led to informal practices being established, the latter should not be seen as an equal substitute to formal accountability mechanisms as informality lacks a binding force, transparency and an obligation for continuation.

\section{Explaining the existing diversity and the lack of justifications}

The processes of creation and historical development can help to explain the existing diversity of accountability obligations with the missing justification of why the differences (should) exist. As previously discussed (section 2.1.2.2.), EU agencies have been created partly for functional reasons and partly as a solution to the challenges brought by technological change and integration that became acceptable to the relevant veto players participating in the creation of EU agencies. EU agencies' founding acts are the results of highly politicized negotiations ${ }^{577}$ taking place within the three waves of creation of agencies (1975, the 1990s, and the first decade of 2000). It is a well-known fact that negotiations and political compromises do not "necessarily prioritize analytical clarity." 578 "The wording of the document with its long sentences and different elements here and there already shows that the negotiations have had difficulties and it is very difficult to make everybody happy." 579 A senior official from the ECDC added that when writing their founding regulation they checked different regulations and "tried to come up with a common ground, but then it was left to "the reality of political life and diplomatic negotiations." 580

\footnotetext{
577 Dehousse (2008) P. 803.

${ }^{578}$ Levi-Faur (2011) P. 816.

579 Senior official from FRA (interviewed in August 2011).

${ }^{580}$ Senior official from ECDC (interviewed in October 2011).
} 
In addition, the three waves in which the existing EU agencies were created involved different sets of actors, namely the EU institutions and the growing number of member states since 1975 . These negotiating parties may have enjoyed different powers, especially regarding the composition of the EU legislative authority. The European Parliament has been involved in different legislative capacities in passing the founding acts of the existing EU agencies, which seems to correspond to the amount of accountability obligations agencies have had in their founding acts. The following correlation has been noticed (section 2.2.1.1.): the stronger legislative position the European Parliament had to play, the more involvement in the further operation of agencies it obtained, and as the European Parliament's involvement is normally interconnected with accountability settings, more accountability-related provisions have been included in agencies' founding acts.

Furthermore, political negotiations have not been restrained by strict legal rules. The Union Legislator has faced hardly any 'creation and delegation standards' hurdles in the process of establishing accountability obligations for agencies, mostly because the treaties have not specifically provided for the creation of and delegation to EU agencies. Thus, the creation standard has been quite lenient by allowing EU agencies to be established based upon various treaty articles. While the delegation doctrine seems restrictive regarding the nature of 'delegatable' powers, it lacks specificity concerning the necessary accountability set of mechanisms that would make delegation lawful (see section 2.2.1.2.). As a final remark, the fact that the check upon the political accountability forum under discussion is arguably rather weak may also contribute to the lacking 'analytical clarity' of agencies' founding acts and at times missing accountability obligations in EU agencies' founding acts. As was discussed in section 2.1.1.3. the accountability of the European Parliament and the Council have been matters of debate. The non-existence of the European demos and the low turnout on the European elections hinder European Parliament's accountability whereas the Council's (and its powerful lower structures') collective accountability does not exist. Thus, the creation of and delegation to agencies seems to be "made with the minimum of democratic control, leaving the Council virtually free to frame the control mechanisms, or lack thereof, of the agency to whom they are delegating power." 581

What is also noticeable is that the existing differences in accountability mechanisms of different agencies seem to be smaller in relation to the power that the Council and the European Parliament have shared the longest. In the sphere of financial oversight, there are hardly any differences between agencies' accountability obligations and practices, except for the six self-funded agencies. From this perspective, the existing diversity of accountability obligations can be explained by the development of the interinstitutional relationship between the Council and the European Parliament. When the relationship between the Council and the European Parliament are at the cohabitation (and cooperation) stage (see

\footnotetext{
581 Davies (2012) P. 334.
} 
section 2.1.1.3.), like in the financial sphere, this implies that the roles of these institutions and the existing rules and practices are established. This in turn decreases the influence of political negotiations with regard to the established rules and practices when EU agencies are being set up. When the Council and the European Parliament are in a process of drawing the boundaries between each other's power territories, consistency and uniformity suffer.

In addition to the explanations of the existing differences, and at times missing accountability obligations explained by the institutional settings, within with EU agencies have been created, some argue that the different appointment formulas of agencies' top officials can be explained by the institutional design of the autonomy of agencies: whether individual agencies are created to be independent from supranational institutions or member states. ${ }^{582}$ The idea of making certain agencies more independent from supranational institutions and others from the member states is likely to be interrelated with the issue of where agencies' functions come from. Section 2.1.2.3. showed that the EU agencies often have "institutional or procedural forerunners" 583 at the EU and national levels. Following this line of reasoning, if an agency were to inherit tasks previously exercised by the member states' authorities, it would be likely to be made more independent from the EU institutions, and the other way around. This would then go hand-in-hand with accountability mechanisms that authorities loosing powers in favor of EU agencies would gain as compensation.

While this section has attempted to explain the existing excessive diversity of and at times missing accountability obligations, it does not wish to intimate that the existing situation should develop further in the same way. Generally, the necessity of diversity in accountability obligations is justified by the thesis that 'one size does not fit all'. EU agencies differ in function and type, so one accountability size may be an obstacle to creating tailored regulators to meet the needs of specific policy areas. The question becomes, however, in how much this thesis is relevant from a political accountability perspective.

While diversity in itself is not an accountability problem, it seems to have several harmful effects with respect to political accountability. First of all, diversity disperses the political forum and its accountability responsibilities, which increase the chances of having accountability deficits. The question of who holds EU agencies to political account does not have a straightforward answer, which "damages the consistency and the transparency of the institutional framework." 584 This makes identification of the institutions responsible for holding the executive to account (or not) a challenging task which makes it easier for the EU main institutions to shift the blame if something goes wrong. Also, the diverse accountability roles of the EU representative institutions complicate the already complex EU institutional

\footnotetext{
${ }^{582}$ Kreher (1997) P. 234-235.

583 Ibid. P. 233.

${ }^{584}$ Verhey (2005) P. 65.
} 
constellation and processes and makes the processes of holding EU agencies to account unclear for the outsiders and arguably also for the insiders coming from 28 different countries and rotating quite often, at least in case of the European Parliament. ${ }^{585}$

Secondly, diversity shadows accountability inconsistencies, shortages, and excesses. A general description of the accountability mechanisms available to the EU representative institutions hides individual nuances when one or more mechanisms do not apply in relation to individual agencies. As was mentioned before, whereas the great majority of EU agencies send their annual reports to the Council and the European Parliament, the CPVO submits it to the Commission and its management board. In this way, the diversity shadows accountability gaps in the democratic accountability chain between EU agencies and the people.

Thirdly, the existing diversity lacks justifications, except that "it has not always been prudence that has guided the hands of the legislators of Europe (with a laugh) when agencies have been decided." ${ }^{586}$ This hinders legitimacy of the EU structures and processes. A jurisdiction where the delegation to the EU main institutions is under fire as regards legitimacy and accountability deficits would be better off when the decisions of such institutions were backed-up by clear and good reasons for their actions or inactions and why derogations are necessary. This is because "it is doubtful that the exercise of public authority may be perceived as legitimate if it is not understood." 587

Concluding, in order to hold an agency to account accountability mechanisms ensuring the three stages of accountability should be there. While the European Parliament and the Council possess the necessary arsenal of mechanisms, it has not been used consistently in relation to individual EU agencies, which has resulted in some EU agencies escaping accountability obligations other (similar) agencies are subject to. The existing diversity is a result of political negotiations between the EU and national institutions that have taken place in the absence of strict formal creation and delegation rules and arguably checks upon the negotiating parties. Additionally, such negotiations have taken place at different times in history implying a different institutional power balance between the veto players, which has also impacted the diverse involvement of the EU main institutions in controlling EU agencies. While it is not an accountability problem as such, excessive diversity is harmful in relation to political accountability in several respects. It disperses the accountability forum and its responsibilities, which increases the chances of creating accountability deficits, shadows the existing shortages, excesses and other accountability problems, and hinders EU

\footnotetext{
585 "The varied role, structure, and profile of regulatory agencies make the system opaque and raise doubts about their accountability and legitimacy. The diverse roles of agencies fuel concerns that they might stray into areas that are more properly the domain of the policymaking branches of the EC-EU. The responsibilities of the other institutions toward agencies and of the Commission in particular suffer from the lack of a clear framework and defined lines of responsibility" (Schneider (2009) P. 33).

${ }^{586}$ MEP Jensen (interviewed in August 2010).

${ }^{587}$ Dyrberg (2002) P. 83.
} 
legitimacy by not justifying why the differences (should) exist. As a final remark, since every EU agency acts on behalf of and affects the EU citizens, it has to render account before the people directly or via the representative bodies. The fundamental character and essentiality of political accountability seem to limit the degree of possible diversity of accountability arrangements. Hence, from a political accountability perspective, 'a few reasoned sizes should be able to fit all'.

\subsection{2. 'Unconsciousness' of Design of Accountability Provisions}

The specificity of accountability obligations and interplay of accountability mechanisms have been identified as two essential elements ensuring the conscious design of accountability mechanisms, meaning that they are formulated and organized in such a way that they promote accountability (see Chapter 1.2.1). This section discusses the existing accountability provisions in light of these two criteria and shows 'unconsciousness' of the design of the existing accountability obligations and mechanisms. The existing short and unspecific reporting obligations and the missing interplay between accountability mechanisms, such as the absent of the formal power to question an agency's director about the submitted report, may hinder ensuring political accountability.

\section{Specificity of accountability obligations}

The specificity of accountability provisions makes it clear for an agency what it is expected to do which enables the check upon the agency against the standard laid down in advance. Yet, are accountability obligations that EU agencies are subject to always specific? The answer is negative.

The illustrative example comes from the reporting obligations of agencies' founding acts. A typical founding regulation obliges an EU agency to submit 'an annual report', which is the case with 24 (out of 35) EU agencies. ${ }^{588}$ And this is what all EU agencies do: they submit an annual report. However, the Ramboll evaluation of $26 \mathrm{EU}$ agencies concluded that the quality of reporting of EU agencies is inadequate ${ }^{589}$ and that "the bulk of evaluation efforts applies to periodic agency evaluations $\langle\ldots\rangle$ add little value in terms of accountability." 590 This leads to the question of whom to blame - EU agencies or the Union Legislator who has not been specific as to what essential elements an annual report should have in order to be qualified as a 'report of adequate quality'? The absence of specific rules of the game makes both the work of an agency and the ex post check by the political

\footnotetext{
${ }^{588}$ Berec (the Office), EBA, ESMA, EIOPA, CPVO, FRA, ECDC, Cedefop, EEA, EFCA, EFSA, Eurofound, GSA, EIGE, EMCDDA, ENISA, OHIM, CdT, EDA, EUISS, EUSC, Cepol, Eurojust, and Europol.

${ }^{589}$ The Ramboll evaluation, Volume I. P. 23.

590 The Ramboll evaluation, Volume II. P. 26.
} 
accountability forum more difficult. Clearly, it is not always possible to include all necessary details, yet, a certain degree of specificity seems necessary for accountability and it does exist in relation to some accountability obligations of EU agencies. For instance, the reporting obligations of eight EU agencies ${ }^{51}$ do include elements which promote analytical reporting. Also, the Financial Regulation specifies, among other things, that annual financial reports "shall indicate the results of his/her operations by reference to the objectives set, the risks associated with these operations, the use made of the resources provided and the way the internal control system functions" (Article 40, Commission Decision 2343/2002).

The provisions governing the extension of the terms of office of agencies' directors are another example of how accountability provisions can be specific but the specificity is used inconsistently. As an example, according to its founding regulation the CFCA's Executive Director can receive an extension of his or her term "on a proposal of the Commission" which is to "be approved by a two thirds majority of members of the Administrative Board" (Article 30 (4) of Council Regulation (EC) No 768/2005). In contrast to this provision, Article 12 (2) of the EIGE's founding regulation requires the Commission evaluating the results achieved by the director in his or her first term of office, the way the results were achieved and the agency's duties and requirements in the coming years when making such a proposal (Regulation (EC) 1922/2006). The latter provision is clearly more than a mere description of a procedure, but an example of a standard that makes it more feasible to evaluate a director's performance ex post.

\section{Interplay between accountability mechanisms}

Together with specificity, accountability provisions should interplay between each other in such a way that they promote accountability. An example of the absence of such interplay in EU agencies' founding acts is the obligation that agencies must submit an annual report to the European Parliament without an obligation that the agency must come to a parliamentary hearing to discuss the report. If it were possible to measure such accountability mechanisms quantitatively, the effect of such a reporting obligation would likely to be close to zero as hardly any MEP is likely to spend his or her time on a report where follow-up is precluded. ${ }^{592}$ Here, it should not come as a surprise that "relations between the decentral-

\footnotetext{
${ }^{591}$ EU-OSHA, EASA, EASO, IT-Agency, EMSA, ERA, ETF, and FRA.

${ }^{592}$ For instance, the European Parliament claimed the necessity of having more oversight powers in relation to Europol to avoid the practice of "discussing without anyone listening and making reports without anyone implementing" (Report of 26 March 2003 on the initiative by the Kingdom of Denmark with a view to adopting a Council Act amending the Council Act of 3 November 1998 adopting Rules on the confidentiality of Europol information (13875/2002 - C5-0553/2002 - 2002/0823(CNS)).
} 
ized European agencies and the European Parliament are inadequate. MEPs are often very poorly informed of the functions these agencies fulfil and what they actually do."593

The missing interplay between individual accountability mechanisms seems to be intertwined with the fact that EU agencies operate in a multi-principal environment. While EU agencies may be subject to accountability mechanisms to ensure all three stages of accountability, not all accountability obligations may exist in relation to the same representative institution, the Council or the European Parliament. An example could be the discharge procedure where the director is formally accountable before the European Parliament for the implementation of the budget. While making the implementation of an agency's budget the personal responsibility of an agency's director before the European Parliament, the sanction for failure that the European Parliament has is of an institutional character, i.e., refusal to give the discharge of financial accounts. The European Parliament cannot remove the director directly, although such a refusal (or may not) prompt the removal authority, such as a management board or the Council, to consider the removal.

In the discussed case of the discharge procedure, the multiplicity of accountability channels may hinder accountability because it results in disconnecting mechanisms ensuring three stages of accountability in the sense that they can be exercised by different institutions with conflicting interests, yet forming one accountability forum. Another example illustrating the same is, for instance, "the threat of reducing an agency's subsidy" from the European Parliament which "will not be credible unless it receives a positive echo from within the two branches of the budgetary authority." 594 If the conflict between two branches of the budgetary authority is significant, the threat is doomed. Thus, the issue of how unitary an accountability forum is and the degree of conflict between individual branches that constitute one accountability forum will affect the interplay between mechanisms ensuring the three stages of accountability and hence the overall accountability. This could be one of the effects of the multiplication of accountability channels in the EU which, according to Papadopoulos, so far remain unknown. ${ }^{595}$

Concluding, the formulation of accountability obligations predetermines their future application. In this light, it is not only important to have accountability obligations ensuring the three stages of accountability, but they also need to be designed in such a way that they promote accountability. The lack of specificity of accountability provisions, such as an obligation 'to submit an annual report', makes it unclear for the agency what it needs to report back and how, which may result in having reports of inadequate quality, and makes

\footnotetext{
${ }^{593}$ Draft Report on the proposal for a regulation of the European Parliament and of the Council establishing a European Training Foundation (recast), 2007/0163 (COD), 07.01.2008, Committee on Employment and Social Affairs, P. 6. (Interestingly, the empirical findings presented in section 2.2.5.2. show that this committee seems indeed to have an 'inadequate' relationship with its agencies).

${ }^{594}$ Dehousse (2008) P. 801.

595 Papadopoulos (2010) P. 1041; Papadopoulos (2007).
} 
the ex post check by the political overseer less feasible since there is no standard to check against. However, to evaluate the quality of agencies' reports as 'inadequate' requires a definition of what 'adequate' is in the first place. The lack of interplay between accountability mechanisms ensuring the three stages of accountability may hinder the exercise of some accountability mechanisms, such as studying the submitted reports, when the discussion stage is precluded. This in turn hinders ensuring the overall accountability.

\subsubsection{Practical Application of Accountability Provisions: Facing a Number of Challenges}

So far this section has focused on the legal side of ensuring political accountability. It has been argued that accountability mechanisms ensuring the three stages of accountability should be present and be designed in such a way that they serve the purposes of accountability. While these are clearly essential elements in ensuring political accountability, a perfectly designed (in terms of accountability) founding act, full of accountability mechanisms, is worthless if its practical application fails. This section discusses the practical side of ensuring political accountability and challenges the practical application of the existing accountability mechanisms.

\section{Challenges in ensuring the information and discussion stages of accountability}

The classic mechanism ensuring the information stage of accountability is reporting. EU agencies are subject to various reporting obligations. In addition to agencies' annual reports, the European Parliament and the Council can receive the results of various evaluations of agencies and their (individual) programs. While EU agencies are subject to various information-providing obligations, there is a sentiment that "MEPs are often very poorly informed of the functions these agencies fulfil and what they actually do." ${ }^{596}$ This is, however, not a general feeling as there are mixed cases as regards individual MEPs and individual permanent specialized committees concerning their levels of being informed, involved and interested in 'their' agencies. Hence, the information stage may be not always ensured.

In part, the existing situation could be explained by the way parliamentary committees organize their oversight, which in turn may depend on the formal powers that the European Parliament has in relation to individual EU agencies. Such formal powers derive from the reporting and hearings obligations of individual agencies' founding acts. Since the Rules of Procedure of the European Parliament are quite short on how the European Parliament holds EU agencies to account, divergent practices have emerged in different committees.

\footnotetext{
${ }^{596}$ Draft Report on the proposal for a regulation of the European Parliament and of the Council establishing a European Training Foundation (recast), 2007/0163 (COD), 07.01.2008, Committee on Employment and Social Affairs, P. 6.
} 
These include, for instance, appointing liaison persons among its members or support staff to monitor and communicate with individual agencies or making (regular) visits to agencies which are spread over the whole Union. Such practices do not exist in all parliamentary committees (see Appendix 2) and vary in how they are applied by individual members and committees. For instance, visits to agencies occur with different frequency: once every two years ${ }^{597}$ or every four years. ${ }^{598}$ As such practices are not formal, they might be short-lived given the 50 per cent turnover of MEPs in general and a relatively high turnover in the membership of permanent committees from one Parliament to another. ${ }^{599}$

The other part of the explanation of why the practical application of the information and discussion stages of accountability may fail lies with the challenges that the tool of scrutiny has. The Council and the European Parliament have too many agencies to oversee (in addition to their other tasks) and they need to oversee them intelligibly. Yet, "the fulltime staff of Parliament's committees is small," ${ }^{600}$ and there are other challenges, such as language constraints which may hinder thorough oversight. A French-speaking expert on a particular subject area may have to hand over to a German-speaking, but non-expert, colleague if the rapporteur he or she is meant to assist speaks only German." ${ }^{\circ 01}$ Furthermore, with respect to the Council's scrutinizing role it is unclear whether and how the Council scrutinizes EU agencies (see section 2.2.5.1.). Its practices most likely remain behind the closed doors of its lower structures. Moreover, one of my respondents noted that "the Council has never been discussing the agency; perhaps one time when the agency was set up, and another time when the first extension of the agency's functions was on the agenda." ${ }^{602}$ Also, empirical research showed that the attention to scrutinize an agency depends on the salience of the issues which the agency regulates and its inclusion on the agenda of the Council or its lower structures and the European Parliament. ${ }^{603}$

Interconnected with the salience of agencies, MEPs may lack the incentives to scrutinize agencies because "you do not score with the electorate when you are dealing with agencies, so it is from this point of view not a very attractive job." ${ }^{604}$ Uninterested and non-involved MEPs are likely to simply hear the presentation of an agency's director (if attending the

\footnotetext{
${ }^{597}$ Analytical Fiche Nr 32, 'Parliament role'. P. 12.

598 Administrator of European Parliament's Employment Committee (interviewed in October 2011).

This respondent also points towards the fact that there are "strict rules on who can go, three biggest political groups are always there and there is rotation for the rest."

${ }^{599}$ Corbett et al. (2011) P. 51.

To compare, in the US the turnover is higher than 80 per cent, especially in the House of Representatives (elected each two years) where it reaches almost 100 per cent. Find at: http://www.opensecrets.org/bigpicture/reelect.php (last check June 2012).

${ }^{600}$ Corbett et al. (2007) P. 133.

601 Ibid.

${ }^{602}$ Chairman of an EU agency's management board (interviewed in November 2011).

${ }^{603}$ Busuioc (2010) P. 113.

${ }^{604}$ Director of an EU agency (interviewed in July 2011).
} 
hearing at all) without further questioning. But a parliamentary hearing with hardly any MEPs present and no relevant questions is unlikely to be valuable to serve the purposes of political accountability. Furthermore, the involvement of parliamentary committees in the oversight over EU agencies may be interrelated with its legislative power; when the Parliament is closely involved in passing a policy regulation, like $\mathrm{REACH}$, it is more interested in following it up (see section 2.2.5.2.). Finally, the quality of oversight procedures may be influenced by arguably a weak check upon the Council and the European Parliament. The collective accountability of the Council is non-existent and the European Parliament's accountability is weakened by the low-turnout at its elections. Moreover, due to the distance and complexity of EU structures many people may not even be familiar with the existence of EU agencies ${ }^{605}$ to be able to hold the EU representative institutions to account for the lack of oversight over agencies.

\section{Challenges in ensuring the rectification stage}

Concerning the rectification stage, a number of sanctioning tools may encounter (practical) problems. There is no collective accountability of the management boards. The personal sanctions against individual members of management boards in the way of their removals are not prescribed in agencies' founding acts. Such appointment and removal procedures are regulated within national ministries and other appointing authorities where relevant guidelines and instructions do not necessarily exist or may be written by those national officials who in fact sit on the management boards of EU agencies. ${ }^{606}$ Also, it is difficult to assess the performance of individual members since their poor preparation for or low involvement in the meetings of agencies' management boards can be explained by the language barrier and importance for individual member states of the issue regulated by individual agencies. Moreover, any poor preparation for the meetings of the management boards and low involvement are not further reported to any EU or national institution. Finally, the sanctions of a personal nature against agencies' directors may be hindered by the fact that some founding acts lack removal clauses and while agencies' directors are accountable before the European Parliament for the implementation of the budget, the Parliament cannot remove them for malperformance. In addition, the practical significance of such ambiguous clauses as 'the Council or the management board exercises disciplinary authority over the director' is unclear (see section 2.2.2.2.).

With respect to the sanctions of an institutional nature, the use of financial sanctions may be hindered by the fact that slashing an agency's budget as punishment simultaneously denies the agency its resources to perform its functions and perhaps even to redress mistakes

\footnotetext{
605 Toggenburg (2007) P. 3.

${ }^{606}$ Member of EASA's management board (interviewed in September 2011).
} 
made. ${ }^{607}$ In this case, "the budget is simply not a very dependable" ${ }^{608}$ sanctioning mechanism. Furthermore, while the European Parliament enjoys the power to conduct investigations with the help of temporary committees of inquiry and temporary specialized committees, it seems to be of questionable application to EU agencies. Making investigations with the help of such committees, which need to be especially created and operate within the limits imposed by the treaty and the rules of procedure, does not necessarily increase the powers that the European Parliament may have in relation to EU agencies already, such as the power to invite an agency's director to report on the performance of the agency. Therefore, its scrutiny over EU agencies is likely to take place in its permanent specialized committees.

Finally, the reconsideration of the existence of agencies is among the institutional sanctions that are faced in practical application. According to the Ramboll evaluation "the existence of established agencies is almost never reconsidered." ${ }^{609}$ Whereas the necessity of some EU agencies has been questioned, "solutions have almost always been sought in terms of survival (continuation with a smaller size or extension of the mandate) rather than in terms of closure or merging." ${ }^{10}$ The intergovernmental politics seem to maintain the status-quo because the situation is "complicated by the fact that you place agencies in different countries. So, you would always find, the Spaniards - fighting for the agencies in Spain, the Greeks - fighting for the agencies in Greece." ${ }^{611}$ However, "are we supposed to have an agency because we made a promise to Greece?" 612

Concluding, while all three stages of accountability can be ensured by various information-providing, hearings and sanctioning mechanisms, the existing mechanisms may face a number of challenges to their practical application. The EU agencies' reports are not necessarily being read, followed-up, and discussed, which could be caused by the absence of any formal rules in the European Parliament and the Council on how the scrutiny of EU agencies needs to take place. MEPs may lack necessary formal powers to question agencies and support to oversee EU agencies intelligibly. Also, the overseeing institutions may lack incentives to scrutinize agencies, if it does not contribute to their (personal) interests or reelection and if inaction is unlikely to be noticed. The issue of salience of policies that agencies regulate may result in ad hoc (rather than regular) checks of a selective (rather than comprehensive) scope. Finally, the quantity and quality of information and discussion stages may be affected by practical obstacles of using sanctioning mechanisms, such as the absence of removal clauses and the unfeasibility of the closure of agencies.

\footnotetext{
${ }^{607}$ Moe (1987a) P. 487.

608 Ibid.

${ }^{609}$ The Ramboll evaluation, Volume II. P. 20.

${ }^{610}$ The Ramboll evaluation, Volume I. P. 20.

${ }^{611}$ MEP Jensen (interviewed in August 2010).

${ }^{612}$ MEP Jensen (interviewed in June 2011).
} 


\section{Conclusion}

The intention of this section was to assess the political accountability of EU agencies in order to identify the sources of potential problematic instances of the political accountability of EU agencies. The identification of the existing problems is in turn necessary to identify the areas where recommendations of how to adjust the political accountability of EU agencies can be proposed. This section evaluated the political accountability of EU agencies with respect to the three elements introduced in Chapter 1, namely the availability of accountability mechanisms, their design and practical application. The political accountability of EU agencies is assessed as problematic in relation to all three elements. Generally speaking, the European Parliament and the Council do enjoy various accountability mechanisms. Yet, looking into individual agencies' accountability obligations one sees that (similar) EU agencies may be subject to different sets of accountability obligations with no clear justifications of why the differences (should) exist. The design of accountability obligations, including short and general formulations of reporting provisions and at times missing interplay between accountability mechanisms, may hinder accountability. Finally, applying existing accountability mechanisms in practice may encounter a number of challenges, such as having to conduct random checks of agencies' performance and constraints on using certain sanctions, such as the closure of agencies.

Excessive diversity seems to dominate the existing situation, which implies having at the same time more and less (or no) interaction with the EU representative institutions, more complete and reduced sets of accountability mechanisms in relation to individual agencies, general and more specific formulations of accountability obligations, and the existence and absence of interest in holding agencies to account on the side of the overseeing institutions. While diversity is not an accountability problem in itself, the growing amount of agencies and a great variety of their accountability settings become incomprehensible, which makes fusion and uniformity necessary. This seems especially relevant for a polity governed by people of 28 nationalities and hence potentially 28 'accountability cultures'. More importantly, diversity has harmful effects for political accountability. It disperses the political forum and its accountability responsibilities, which increases the chances of having accountability deficits, shadows accountability inconsistencies, shortages, and excesses, and hinders the legitimacy of the EU structures and processes by providing no clear justifications of why diversity should exist.

The existing diverse accountability arrangements are explainable by the fact that EU agencies' founding acts are the result of more than 30 politicized negations occurring in three waves between numerous actors of national and EU levels sharing the legislative power differently. However, since every EU agency acts on the behalf of the EU citizens and affects the latter with its decisions, it has to render account before the people (via representative bodies). Here, from a political accountability perspective, the thesis 'one size does 
not fit all' seems to be of questionable applicability as the fundamental character of political accountability limits the degree of potential diversity of accountability arrangements. In any case, a complex EU system alleged to have a legitimacy deficit is likely to be better off when having a limited number of accountability models governed by reason. 


\section{Chapter 3.}

\section{Holding US Independent Regulatory Agencies to Political Account}

The US has been often referred to as the birthplace of independent regulatory agencies (IRAs), ${ }^{1}$ considering they exist there since 1889 . The US Congress has therefore more than a century-long experience with holding independent regulatory agencies to account. The aim of this chapter is to highlight how the political accountability of US agencies is organized, what challenges it faces, and what we may learn from it. The findings serve as a basis for the comparison between the EU and US jurisdictions (Chapter 4) and for offering policy recommendations for the EU representative institutions to consider in the ongoing reform of the operation of EU agencies (Chapter 5).

To ease the comparison this chapter is divided into the same three parts as Chapter 2 on the political accountability of EU agencies. ${ }^{2}$ Section 3.1 introduces the institutions of the accountability relationship under investigation; Congress (3.1.1.) and US independent regulatory agencies (3.1.2.). Section 3.2 investigates the accountability of US IRAs in light of the five dimensions introduced in Chapter 1, namely the creation of and the delegation to IRAs by Congress (3.2.1.), the appointment and removal of US IRAs' top officials by Congress (3.2.2.), accountability through statutory regulation of agencies' performance (3.2.3.), congressional power of the purse (3.2.4.), and oversight (3.2.5.). Section 3.3 finally assesses the political accountability of US IRAs using the formula presented in Chapter 1. It implies evaluating the political accountability of US IRAs with respect to three criteria: the availability of accountability mechanisms, their design, and practical application.

\subsection{The US Political Accountability Forum and Actor: Introducing the US Congress and US Independent Regulatory Agencies}

Before investigating and assessing the political accountability of US independent regulatory agencies, it is necessary to introduce the institutions of the accountability relationship under investigation. This is the intention of this section 3.1. It starts with a brief introduction

\footnotetext{
${ }^{1}$ See, e.g., Zwart (2003) P. 3.

${ }^{2}$ As was mentioned before, the established analytical framework is applied less consistently in parallel sections 2.2.3. and 3.2.3., 2.2.4. and 3.2.4., and 2.2.5. and 3.2.5. due to the differences in laws and procedures between the two systems and the different focuses that this study has in relation to the EU (an in-depth investigation of the current laws and practices) and the US (learning purposes) jurisdictions.
} 
of the US Congress, its structural divisions, functions, and implications of congressional internal divisions on the exercise of its powers (3.1.1.), and continues with defining US independent regulatory agencies, their historical roots, functions, and the issue of how they are embedded within the US constitutional system (3.1.2.).

\subsubsection{The US Congress}

The US Congress is a federal legislature that operates within the limits of the US Constitution, governed by three broad constitutional principles, namely the separation of powers, checks and balances, and federalism. The separation of powers implies institutional and personal ${ }^{3}$ independence of Congress from the other two branches distinguished by the Constitution, i.e., the executive (headed by the US President) and the judiciary (headed by the Supreme Court). The checks and balances and federalism relate to the functions that Congress enjoys - they are often shared with other branches (checks and balances) and are restricted to federal matters (federalism). As Justice Jackson put it, "while the Constitution diffuses power the better to secure liberty, it also contemplates that practice will integrate the dispersed powers into a workable government. It enjoins upon its branches separateness but interdependence, autonomy but reciprocity." ${ }^{4}$

While Congress is distinct from the other two branches, it is not as unitary as it may seem and as it is referred to in this book. Congress has several internal divisions which have certain implications for the way it exercises its powers, including holding US IRAs to account. This section therefore addresses congressional internal divisions (3.1.1.1.); its powers (3.1.1.2.); and the implications of congressional internal divisions on the strength and usage of its powers (3.1.1.3.). This section shows that Congress can be stronger and weaker in reality depending on the degree of political unity and cooperation between its internal divisions and with the executive branch.

\subsubsection{Congress from the structural perspective}

The first article of the US Constitution establishes the Congress of the United States, a federal legislature, as an institution distinct from the other two constitutional branches, i.e., the executive and judiciary. The same article also points to the first division of Congress. Congress consists of two chambers, the House of Representatives (also, known as 'the House') and the Senate, representing individualized proportionate districts and individual states respectively. The chambers not only have different representation but also the election systems and the number of their members are different. 100 Senators, two per state,

\footnotetext{
${ }^{3}$ This is with the exception of the double mandate of the Vice-President who is part of the executive branch and the President of the Senate, enjoying a decisive voting right in case of a tie in the Senate.

${ }^{4}$ Justice Jackson in Youngstown Sheet \& Tube Co. v. Sawyer, 343 U.S. 579, 635 (1952).
} 
are elected for six years in such a way that each two years one third of the chamber is replaced. The House comprises 435 voting members and (currently) six non-voting representatives of US special territories, such as the District of Columbia and Puerto Rico. The elections of the whole House take place every two years.

Congressional chambers can also be divided on political grounds. Two political parties, the Democrats and the Republicans, dominate the political arena of the US. This means that from time to time, including at present, different political majorities may constitute two chambers of Congress simultaneously.

Finally, "Congress in session is Congress on public exhibition, whilst Congress in its committee-room is Congress at work." The Senate and the House of Representatives are divided internally into committees. Each chamber has standing committees established by the internal rules of procedure (House Rule X and Senate Rule XXV). ${ }^{6}$ Standing committees can have two types of functions - drafting bills (legislative prerogative) and collecting information with the help of hearings and investigations (oversight function). Standing committees are permanent committees divided on jurisdictional basis. Thus, for instance, both chambers have appropriations and judicial committees, although the committee divisions in both houses do not necessarily correspond to each other's title or jurisdiction. ${ }^{7}$ Interestingly, the names of congressional committees may reflect the respective majorities sitting in both chambers. ${ }^{8}$ As of this writing, the Democratic Senate has a committee dealing with 'labor', while the Republican House has a standing committee dealing with 'workforce'. Furthermore, for the purpose of specific studies or investigations both chambers may establish temporary select (special) committees and joint committees, the latter comprising the members of both chambers. ${ }^{?}$

Considering the mentioned divisions, reference to 'Congress' and especially to 'its will' probably can never be associated with a unified vote by its 535 voting members. The discussed divisions of Congress are important as regards the 'congressional' relationship with independent regulatory agencies because they impact the strength and the use of various

\footnotetext{
${ }^{5}$ Wilson (1885) P. 79; see, also Shapiro (1996) P. 27.

${ }^{6}$ As of this writing, the Senate has 20 standing committees and the House - 21 (This information is taken from the official web-pages of the Senate and the House of Representatives. Find at: http://www.senate.gov/pagelayout/committees/d_three_sections_with_teasers/committees_home.htm; http://house.gov/committees/ (last check January 2012)).

${ }^{7}$ Committee jurisdiction implies "the subjects and functions assigned to a committee by rule, resolution, precedent, or practice, including legislative matters, oversight and investigations, and nominations of executive officers." (This information is taken from the official web-page of the Senate. Find at: http://www.senate.gov/reference/glossary_term/committee_jurisdiction.htm (last check February 2012)).

${ }^{8}$ It is important to note that political power division in committees also reflects the overall political division in the chamber. Thus, all standing committees have members of Congress that are Democrats and Republicans, but the chairpersons of standing committees are the representatives of the majority party in the chamber.

${ }^{8}$ CRS Report for Congress “Committee Types and Roles," by Heitshusen V., February 2011.

${ }^{9}$ Ibid.
} 
mechanisms that 'Congress' has, to be discussed after having introduced congressional powers.

\subsubsection{Congress from the functional perspective}

From the functional point of view, Congress is an institution that enjoys two kinds of powers: legislative and non-legislative powers deriving from the US Constitution and case law.

Article I $₫ 1$ of the US Constitution vests all legislative power in Congress, thus its main task is to make federal laws. The strength of congressional legislative power lies, first of all, in the fact that Congress is the only institution that can initiate and amend legislative proposals. Both chambers are on the equal footing in this respect. ${ }^{10}$ Furthermore, Congress can pass bills overriding the President's veto by a two-thirds vote of both chambers (Article I $\$$ 7 of the US Constitution). The scope of congressional legislative power is broad. Creating a federation of several states, each afraid of losing its powers, the Framers of the Constitution modelled the federal level as a 'government of limited powers'. This implied that the federal government was there only to regulate the explicitly listed federal matters (Article I $₫ 8$ and 9, Amendment X of the US Constitution). At the same time, Article I $₫ 8$ of the US Constitution offers a number of open clauses, which have led to stretching the boundaries of what these federal issues can include. ${ }^{11}$ For instance, according to the 'necessary and proper' clause Congress may make such laws as it deems necessary and proper to exercise its powers and the powers of the government established by the Constitution, namely the President and the Supreme Court. As will be shown later, this clause allows Congress to create IRAs and regulate their operation. With the help of such open clauses, which expand federal jurisdiction to issues that are not specifically given to the federal level by the Constitution, the federal government of 'limited powers' has thus gradually developed into the government of broad powers.

Together with its broad legislative power, Congress enjoys three non-legislative powers, i.e., where Congress does not (necessarily) pass a law. These are appointment, removal, and oversight powers. Without the Senate's consent the President cannot appoint any 'officer of the United States', implying judges, heads of departments, and agency heads (Article II \$2). It can impeach the President, the Vice-President and all civil officers, including the heads of IRAs, for 'conviction of treason, bribery, or other high crimes and misdemeanors' (Article II $\$ 4)$. Article III $₫ 1$ states that judges serve for life but 'during good behavior', which implies the possibility of impeachment if they should 'misbehave'. Although not stipulated

\footnotetext{
${ }^{10}$ The only exception are the so-called 'money bills', such as budgetary proposals, which can only originate in the House (Article I $\$ 7$ US Constitution).

The most prominent cases are Heart of Atlanta Motel Inc. v. US (379 US 241 (1964)) where the Interstate Commerce Clause, one of the enumerated powers, expanded to include the discrimination of the black people in public places, and South Dakota v. Dole (483 US 203 (1987)) where the Supreme Court upheld indirect regulation of the minimum drinking age with the help of the congressional power of the purse.
} 
in the Constitution explicitly Congress enjoys the power to oversee the executive branch, including IRAs (McGrain v. Daugherty 273 US 135 (1927)).

\subsubsection{Implications of congressional internal divisions on its powers}

The strength and the use of powers that Congress has are influenced by the three divisions of Congress, which need to be taken into account for further discussions in this book. In this light, the intention of this part is to give a more nuanced picture of Congress by discussing its powers in light of congressional divisions, i.e., two chambers, political interests, and congressional committees.

To begin with, the division of Congress into two chambers can have an important implication on the function that the Senate and the House perform jointly, namely the legislative power. These chambers represent different interests; however, for any bill to become the law, the agreement between them is crucial (Article I $\$ 7$ US Constitution).

Such an agreement depends greatly on the political majorities that these chambers may have. The US political landscape is divided into two major political camps, the Democrats and the Republicans. Hence, having different parties in the majority in two chambers may make the legislative process more difficult whereas if the same party is in control of both chambers, the legislative process can go more smoothly. Furthermore, the political color of the incumbent of the White House matters for the legislative function of Congress, because any bill ends up at the President's table and he has the possibility of vetoing it. Finally, since two thirds majority in both chambers of Congress is required to override President's veto (Article I $₫ 7$ US Constitution), the chances to override the veto will depend on how high political majorities in both chambers of Congress are.

The implication of the division into two parties on congressional powers has become known as the 'separation of parties and not powers' theory:

American political institutions were founded upon the Madisonian assumption of vigorous, self-sustaining political competition between the legislative and executive branches. Congress and the President would check and balance each other; officeholders would defend the distinct interests of their different institutions; ambition would counteract ambition. That is not how American democracy turned out. $<\ldots>$ the degree and kind of competition between the legislative and executive branches will vary significantly and may all but disappear, depending on whether party control of the House, Senate, and Presidency is divided or unified. ${ }^{12}$

Levinson and Pildes show that "party-line voting in both the House and the Senate has become the norm;" "from the late 1950s through 1992, the President's own party in Con-

\footnotetext{
${ }^{12}$ Levinson and Pildes (2006) P. 2312.

Interestingly, since 1832 government has been more often unified (about 60 per cent of the time) and "sustained periods of divided government are a relatively recent phenomenon” (Ibid. P. 2330-2331).
} 
gress voted in favor of legislation he supported almost three-quarters of the time; the opposing party supported him half of the time or less."13 "Empirical studies confirm [as well] that presidential vetoes all but disappear during periods of unified government." ${ }^{14}$ Furthermore, Epstein and O'Halloran show that not only the quantity but also the quality of legislation matters when talking about the 'divided-government argument'. Their findings indicate that "Congress delegates less and constrains more under the divided government." 15 They also claim that the choice of delegating to an executive agency is used "relatively more often under unified government, while independent agencies and commissions are used more often under divided control." ${ }^{16}$ If under the unified government independent regulatory commissions have been the recipients of the laws delegating authority in 17 per cent of the cases, under the divided government - the number reached 36 per cent. ${ }^{17}$

The political majorities thus affect the legislative function of Congress. However, the intensity of congressional oversight over the executive can be also expected to depend on this factor. The congressional chamber that has the same political majority as the majority of the members of an independent agency's management board is thus likely to be more favorable to the independent agency than the chamber with a different party in control. The same applies to the appointment process which would depend on the parties sitting in the Senate and in the White House - the more support there is in the Senate, the easier it could be for the President to confirm his nominees.

The 'separation of parties, not powers' theory shows therefore how different Congress can be in reality in relation to the executive branch and that the difference depends on the respective political majorities of the two chambers and of the two branches. Congressional checks upon the executive, including impeachments, oversight, and investigations of the behavior of the executive, the Senate's check upon the proposed appointees by the President, discretion given to the executive, and the rigidness of statutory regulation are all issues relevant for accountability. They all, however, seem to depend on whether the government is unified or divided..$^{18}$ In this light, with respect to accountability of IRAs, "we should worry much less when government is divided than when it is unified." ${ }^{19}$

\footnotetext{
${ }^{13}$ Levinson and Pildes (2006) P. 2333.

${ }^{14}$ Ibid. P. 2340.

${ }^{15}$ Epstein and O’Halloran (1999) P. 11.

${ }^{16}$ Ibid. P. 154-155.

${ }^{17}$ Ibid. P. 156.

18 "The Watergate investigations were carried out by an opposition controlled Congress," the War Power Resolution "was passed by a Democratic Congress over President Nixon's veto, "conflicts between Congress and the President over "executive privilege" also track divided party control" (Levinson and Pildes (2006) P. 2345).

Also, they point out that the enactment of the Administrative Procedure Act, 'the constitution for agencies' operation (to be discussed in Chapter 6.3.2.), by the Democratic Congress was likely boosted by the assumed (but, as it turned out, incorrect) anticipation of the imminent loss of the presidency to the Republicans (Ibid. P. 2362).

${ }^{19}$ Ibid. P. 2359.
} 
Furthermore, "whatever is to be done must be done by or through the Committee." ${ }^{20}$ In addition to the implications of congressional divisions into chambers and political parties on congressional powers, Congress's internal division into various committees is another important factor to take into consideration. This is because congressional standing committees enjoy powers on their own, including in relation to IRAs. Standing committees can have two types of functions - drafting bills (law-making) and collecting information with the help of hearings and investigations (oversight).

"The power in Congress is not distributed evenly, the influence of individual committees and their chairmen can be strong with respect to their ability to stop a legislative proposal at the committee stage." 21 This has resulted in calling congressional committees the 'little legislators' ${ }^{22}$ Thus, every independent agency is overseen only by a few committees (or subcommittees), although by at least four: "the House and Senate committees that authorize the agency and shape the legislation it enforces and the House and Senate appropriations committees that determine the size of its staff and budget. An agency head needs support from both kinds of committees," even though agencies often get "inconsistent signals from them: "Do more!" is heard from the legislative committee, "Spend less!" from the appropriations committee." ${ }^{23}$ In this light, having studied the Federal Trade Commission's activities in a given period of time, Weingast and Moran concluded that "congressional institutions play important roles in agency decisions. It is not the entire Congress that seems of most interest but rather the specific committees." ${ }^{24}$ In any way, "the extent of active oversight varies depending upon the agenda of the committee themselves and the politics of the day;" "the amount of oversight also varies depending upon the character of the work of the agency." 25

Year after year, IRAs develop close ties with 'their' committees. This relationship, characterized by both formal and informal contacts, plays a very important role affecting all

\footnotetext{
${ }^{20}$ Wilson (1885) P. 82.

${ }^{21}$ Beermann (2006) P. 141.

When a bill is initiated, it is referred to one or more committee(s) of appropriate jurisdiction in that chamber of Congress. The bill is normally prepared and discussed first in the sub-committee, which will first investigate the issue, hold numerous hearings where various experts may be heard and questioned, and finally make a draft. Unless the sub-committee supports a particular draft, the proposal will reach the floor of the whole committee, which may lead to additional investigations and hearings. The same procedure follows here - only if the committee agrees on the proposal will it reach the floor of the whole chamber. As one sees the decision of a particular subcommittee and committee has far-reaching consequences, if one of them does not support the bill, the proposal dies at that stage. If adopted by one chamber, the bill goes to the other chamber and the same process takes place. 22 Wilson (1885) P. 103 (borrowing "Senator Hoar's apt name for the Committees").

"Power in Congress has rested in the committees or, increasingly, subcommittees" (Dodd and Oppenheimer (1977) P. 21-53).

23 Wilson (1989) P. 256.

24 Weingast and Moran (1983) P. 793.

${ }^{25}$ Lewis and Selin (2012) P. 120.
} 
aspects of agency operation. Strauss points out in this respect that these relationships are particularly important also because congressmen and committee staff "tend to be longerlived than Presidents and their appointees." 26 Since individual congressional committees enjoy a significant scope of authority within their jurisdictions, including the elaboration of legislative proposals, the approval of bills that will go to the floor of the whole chamber, and the scrutiny of governmental programs and institutions and (independent) agencies, individual agencies' relationships with 'Congress' implies rather their relationships with a few congressional committees.

\subsubsection{US Independent Regulatory Agencies}

The US is often referred to as the birthplace of independent regulatory agencies, which have existed there since $1889 .{ }^{27}$ In the absence of a general definition one can count today at least 16 'independent regulatory commissions' (using the US terminology) whose strong powers make them no different than US executive agencies and departments (ministries in the European tradition). Whereas from the functional perspective there is little difference between executive and IRAs, the latter has the label 'independent' which distinguishes them from the rest of President's administration and gives them a special place within the governmental structure which impacts their accountability arrangements. This section introduces US IRAs in the following way. It starts with defining independent regulatory agencies (3.1.2.1.), continues with their historical roots (3.1.2.2.) and functions (3.1.2.3.), and concludes by addressing the question of the place of IRAs within the US constitutional system (3.1.2.4.).

\subsubsection{Defining US independent regulatory agencies}

The US Constitution establishes the top-level government institutions - Congress, the President, and the Supreme Court (Articles I, II, and III of the Constitution correspondingly). Already in 1789, two years after the creation of the Constitution and one year after its ratification, the necessity to establish executive departments arose. Thus, the first three Departments (of Foreign Affairs, of War, and of Treasury) appeared and the system of federal courts began its process of formation. Although the Constitution provides the basis for the creation of the latter (Article III $\$ 1$ ), it is silent with respect to the creation of executive departments and IRAs. ${ }^{28}$ Nevertheless, the 'implied powers' of Congress ${ }^{29}$ recognized

\footnotetext{
${ }^{26}$ Strauss (1984) P. 592.

${ }^{27}$ See, e.g., Zwart (2003) P. 3.

${ }^{28}$ The main text of the US Constitution contains only two references to executive departments. The first is in the 'opinion clause': the President "may require the opinion, in writing, of the principal officer in each of the executive departments, upon any subject relating to the duties of their respective offices" (Article II $₫ 2$, cl 1). The second is in the Appointments Clause in Article II, $\$ 2 \mathrm{cl} 2$, allowing "inferior officers to be appointed by "the
} 
by the Supreme Court and later the 'common sense of governmental necessities'30 seemed to justify various institutional innovations of Congress when it shapes the executive branch.

The institutional landscape of the US federal executive branch is diverse. As of this writing, there are 15 executive departments (e.g., the Department of Justice), ${ }^{31}$ around 200 bureaus spread around the executive departments (e.g., the Food and Drug Administration within the Department of Health and Human Services), approximately 60 executive independent agencies ${ }^{32}$ (e.g., National Aeronautics and Space Administration (NASA)), 16 independent regulatory commissions (e.g., the Securities and Exchange Commission), 23 government corporations (e.g., US Postal Service) and a few other agencies and entities (e.g., Smithsonian Institution). ${ }^{33}$ Although their names differ, they all could be put under the umbrella of 'agencies' which is broadly defined by the Administrative Procedure Act (5 USC \$\$551 - 59 and 701 - 706): agency "means each authority of the Government of the United States, whether or not it is within or subject to review by another agency, but does not include (A) the Congress; (B) the courts of the United States; (C) the governments of the territories or possessions of the United States; (D) the government of the District of Columbia" (US Code $\$ 551(1)) .{ }^{34}$

While the executive departments, the bureaus within them, the independent executive agencies and independent regulatory commissions may exercise similar regulatory functions, i.e., they all can have powers to make rules and adjudicate cases (to be discussed shortly in sub-section 3.1.2.3.), only the former three are directly subordinated to the President. ${ }^{35}$ In his interactions with independent regulatory commissions the President is restricted in a number of ways. ${ }^{36}$

It is the President who appoints the heads of both executive and independent agencies (Article II $₫ 2$ of the US Constitution), yet, he is restricted by (statutory) bipartisanship requirements when appointing the heads of IRAs. This implies that not more than a majority of independent regulatory agencies' management boards, for instance, a maximum three

President alone, Courts of Law, or Heads of Departments," but there is no definition of the term. Amendment XXV (since 1967) also has a reference to the executive departments.

${ }^{29}$ McCulloch v. Maryland (17 US 316 (1819)), discussed in section 3.2.1.1.

${ }^{30}$ Hampton, Jr., \& Co. v. U.S. 276 US 406 (1928), discussed in section 3.2.1.2.

31 This information is taken from the official web-page from the US government. Find at: http://www.usa.gov/Agencies/Federal/Executive.shtml (last check October 2011).

32 Independence here implies being "less 'governmental' than a standard bureau within a department." (see, Moe (2002) P. 250) These agencies are headed by single administrators, rather than multi-member boards, and are removable at President's will.

${ }^{33}$ Moe (2002) P. 243-254; see, also, Lewis and Selin (2012) for a comprehensive study on US executive agencies.

34 "Agency is a term and concept that defined and employed generically to refer to all Executive branch entities.

$<\ldots>$ Thus, the Department of the Treasury, Peace Corps, Federal Bureau of Investigation, Office of Comptroller of the Currency, $\langle\ldots\rangle$, are all agencies of the government" (Moe (2002) P. 243).

${ }^{35}$ Lewis and Selin (2012) P. 49.

${ }^{36}$ See, e.g., Verkuil (1988) P. 259. 
out of five, can come from the same political party. Also, the officials heading IRAs have staggered terms of office, implying that one vacancy appears each year for the President to fill in. That IRAs have multi-member management boards is another distinctive feature of these agencies, because executive agencies and departments are headed by a single official. ${ }^{37}$ This is important from the agency's independence point of view because it makes it more difficult to influence the policy course of an independent agency as one needs to convince several members instead of a single head of an executive agency. In addition, the President's power of removal of the heads of IRAs typically is restricted by the presence of a so-called 'for cause' clause. This means that the President cannot remove commissioners at will, as he can with respect to the heads of executive departments and agencies. ${ }^{38}$ These statutory requirements are deemed to ensure agencies' independence by distancing them from the President. The appointment and removal procedures are further discussed in section 3.2.2.

Furthermore, the President's tool to control the executive branch by issuing executive orders has a limited impact with respect to IRAs. Executive orders are management directives that the Presidents use to direct subordinate executive officers and departments in exercising their executive functions. As an example, to enhance effective management of the executive branch, Executive order 12,866 requires all executive agencies and departments to submit proposed and final rules to a White House office for review, do cost-benefit analyses for economically significant rules and to prepare annual regulatory plans to be published in the 'Unified Agenda of Federal Regulatory and Deregulatory Actions' ${ }^{39}$ Scholars point out that there has been an increased presidential control in federal agency rulemaking in the last 20 years. ${ }^{40}$ In addition to the congressional oversight over the executive branch, Presidents seem to develop their own oversight over the executive branch with the help of, among other things, executive orders. Executive orders, however, remain optional for IRAs to follow. ${ }^{41}$

\footnotetext{
${ }^{37}$ It should be noted that two agencies are headed by single heads who have for-cause protection from removal, the Social Security Administration and the Office of Special Counsel.

${ }^{38}$ The idea behind this is that "one who holds his office only during the pleasure of another cannot be depended upon to maintain an attitude of independence against the latter's will.” (Humphrey's Ex'r v. U.S. 295 U.S. 602, $629(1935))$.

${ }^{39}$ Interestingly, the Order provides that the independent regulatory agencies do not have to comply with the rule review requirements but are supposed to publish their plans in the Unified Agenda, E.O. 12,866\$4.

${ }^{40}$ Lubbers (2006) P. 20.

${ }^{41}$ In part this is because Presidents lack the power to fire these agency heads without cause. And it has never been determined whether disobedience of an executive order could constitute such cause. As Strauss states "both President Carter and President Reagan were advised that they had authority to include the independents in their executive orders promoting economic analysis of proposed rules as an element of regulatory reform." In 1981 Vice President Bush sent a letter asking them to comply voluntarily with some sections of an executive order "to demonstrate to the American people the willingness of all components of the Federal Government to respond to their concerns ..." Several agencies did comply. But as one can see the influence is very limited (Strauss (1984) P. 592-593).
} 
In addition, the President's Office of Management and Budget (OMB), responsible for the preparation of the annual budget draft, may have limited control over IRAs' budget proposals and hence functions, to be discussed in section 3.2.4.

Finally, it is the office of the Attorney General, who is the head of the Department of Justice, that represents the federal government in the courts, and, in the absence of statutory exemptions, this also applies to IRAs. ${ }^{42}$ However, some IRAs enjoy such exemptions, and thus self-representation in courts (see Appendix 3).

The issues discussed demonstrate that IRAs are designed to be distant from the President whose control is restricted by the following features: a multi-member management board; political criteria for appointment with no more than a majority of the same political party; and restrictions on the presidential removal power. In addition, Presidential executive orders, OMB's budgetary approval, and representation in courts by the Department of Justice have limited application to IRAs. It is thus the distance from the President which is thought to provide insulation from politics and to make these institutions 'independent'.

Since no general definition of 'independent regulatory agency' exists, different numbers of US IRAs exist. ${ }^{43}$ This book gives a comprehensive overview of 16 agencies (see Appendix 3 for more specific details regarding these agencies' accountability and independence relevant features). These are:

- $\quad$ the Board of Governors of the Federal Reserve System (the Fed)

- $\quad$ the Commodity Futures Trading Commission (the CFTC)

- the Consumer Product Safety Commission (CPSC)

- the Federal Communications Commission (the FCC)

- the Federal Deposit Insurance Corporation (the FDIC)

- the Federal Energy Regulatory Commission (the FERC)

- the Federal Housing Finance Agency (the FHFA)

- the Federal Maritime Commission (the FMC)

- the Federal Mine Safety and Health Review Commission (the FMSHRC)

- $\quad$ the Federal Trade Commission (the FTC)

- $\quad$ the United States International Trade Commission (the USITC)

- the Nuclear Regulatory Commission (the NRC)

\footnotetext{
42 This is provided by law (28 USC $\$ 516$ ), although with a reservation: “Except as otherwise authorized by law, the conduct of litigation in which the United States, an agency, or officer thereof is a party, or is interested, and securing evidence therefore, is reserved to officers of the Department of Justice, under the direction of the Attorney General" (emphasis added).

In addition, a number of aspects of independent regulatory agencies' work are usually regulated by the President's administration for both independent and executive agencies. These issues include agencies' property, contracts, employment practices, allowances, and schemes, and the protection of national secrets (Strauss (1984) P. 587).

${ }^{43}$ See, e.g., Breger and Edles (2000) and the list provided by Justice Breyer in Appendix D of Free Enterprise Fund et al. v Public Company Accounting Oversight Board et al. (561 US _ (2010)).
} 
- the Occupational Safety and Health Review Commission (the OSHRC)

- the Postal Regulatory Commission (the PRC)

- the Securities and Exchange Commission (the SEC).

The choice was made based upon the following three considerations. First, except for the USITC, this list is provided by law (44 U.S.C. 3502). ${ }^{44}$ While the law is open-ended, including also "any other similar agency designated by statute as a Federal independent regulatory agency or commission", the Administrative Conference of the United States, an independent advisory (not regulatory) agency discussed in section 3.2.5., has established regular non-public meetings of the representatives of these 16 independent regulatory agencies to discuss their operation concerns. Third, with a few exceptions these agencies feature typical characteristics distinguished as the essential elements of agencies' independence: multi-member management boards, bipartisan criteria for appointment and the removal 'for cause' restriction. ${ }^{45}$

\subsubsection{Historical development of US independent regulatory agencies}

US independent regulatory agencies trace their roots back to the creation of the Interstate Commerce Commission (ICC), which was established in 1887 after the discussion of 150

\footnotetext{
${ }^{44}$ The only definition of the term 'independent regulatory agency' in the U.S. Code appears in 44 U.S.C. 3502, the codified Paperwork Reduction Act. The definition specifies 'independent regulatory agency' by listing 16 agencies: the Board of Governors of the Federal Reserve System, Commodity Futures Trading Commission, Consumer Product Safety Commission, Federal Communications Commission, Federal Deposit Insurance Corporation, Federal Energy Regulatory Commission, Federal Housing Finance Agency, Federal Maritime Commission, Federal Mine Safety and Health Review Commission, Federal Trade Commission, Interstate Commerce, National Labor Relations Board, Nuclear Regulatory Commission, the Occupational Safety and Health Review Commission, Postal Regulatory Commission, Securities and Exchange Commission 'and any other similar agency designated by statute as a Federal independent regulatory agency or commission.”

The Interstate Commerce Commission is no longer in existence; and the United States International Trade Commission is separately identified as an independent regulatory agency in 19 U.S.C. 1330.

${ }^{45}$ Miller (1986) P. 51; Pierce et al. (1999) P. 95.

Although some scholars refer to the restricted President's removal power as the main feature distinguishing independent regulatory agencies from the executive ones, it is not the only criteria. Leadership by multi-member management boards and political criteria for appointment seem to be equally important in this respect.

As Appendix 3 demonstrates, some of these distinctive elements do not necessarily have 'statutory protection'. The NLRB, e.g., does not have a bi-partisanship requirement for the appointment of its commissioners; however, this has been done in practice anyway (Chairman of NLRB (interviewed in April 2011)). Nor do the SEC commissioners actually benefit from a statutory for-cause protection provision-although the Supreme Court assumed that such protection existed in Free Enterprise Fund v Public Company Accounting Oversight Board, 561 U.S. , 130 S. Ct 3138 (2010). This hints at the importance of these elements more from a political rather than legal perspective. (the numbers of US independent regulatory commissions may clearly differ depending on the criteria taken to define independence (see, e.g., Breger and Edles (2000)).
} 
legislative proposals of various committees. ${ }^{46}$ While the need for federal regulation of the railway sector, which had developed into an interstate activity and thus an activity to be regulated on the federal level (Article I $₫ 8$ of the US Constitution), had become clear, the method of regulation was a debatable issue in Congress for 20 years prior to the creation of the ICC. ${ }^{47}$ One of the alternatives to the creation of an independent body was to assign the Department of Justice and the courts a role in enforcing a new statute, which would provide exact terms for regulation of the sector. Yet, the views in support of creating a federal commission to regulate the railways sector prevailed. What were the reasons for creating the ICC?

Initially, the ICC's creation was boosted by regulatory concerns and the need to acquire expertise in the new field of railroad services. "The commission would provide flexible and expert administration of railroad regulation" 48 enforcing the standards laid down in relevant statutes. The previous practices of passing penal laws and enforcing them in courts was not effective because of the 'complexity of the railroad business'; therefore, the conclusion was that a body of experts should deal with those problems. ${ }^{49}$ In effect, Congress was seeking the assistance of the ICC in formulating legislative policy towards the new issues involving railroads. The ICC would have the necessary expertise and information about what laws were needed simply because it would be involved in regulation of the sector on a daily basis. Such expertise was also necessary for the courts. The Commission would provide a judicial service for the courts though without powers of issuing final judgments; this was later changed and the present day independent regulatory agencies are normally act as 'courts of first instance' and 'courts of first appeal' in cases concerning the enforcement of statutes they administer. At the same time, as at the time of the creation of the ICC, and still today, the expert findings of these bodies are valuable for the courts in making their final judgments.

Created to address the mentioned regulatory and expertise concerns the ICC was not independent from the very beginning. It was only two years later, in 1889, when the authority of the Secretary of the Interior over it, including regulation of salaries and receiving its reports, was abolished. ${ }^{50}$ In his comprehensive study of the legislative history of the ICC,

\footnotetext{
${ }^{46}$ Cushman (1941) P. 41.

47 Ibid. P. 19.

It is not completely correct to think that the model of independent regulatory agencies originates in the US. Creating the first independent regulatory agency in 1887 US Congress did, among others, consider the relevant British experience.

48 Ibid. P. 45.

${ }^{49}$ The House debate of 1886 illustrates this point: "How much better this is than to fix in advance by inflexible law the whole body of rules to govern the most complex business known to our civilization and the most extensive, involving the largest amount of property and the greatest number of individual interests in the world. It is well to have five wise, able, experienced men of reputation, commanding general confidence, clothed with a limited discretion in applying and enforcing a law that touches every man and every interest so closely" (Ibid. P. 45-46).

${ }^{50}$ Breger and Edles (2000) P. 1128-1129.
} 
Cushman noticed the absence of any discussions on the independence of the commission in Congress. ${ }^{51}$ Although the statute making the ICC independent in 1889 was enacted by the Democratic Congress two days before the Republican President Harrison took office, Breger and Edles state that this change was unlikely to have been prompted by partisan considerations. ${ }^{52}$ In any case, the elimination of control of the executive department seems to have become the first step on the way to placing the creation of agencies some distance from the President. The second step came in 1934 when the statutory restriction of the President's removal power, i.e., only 'for cause', over the heads of IRAs was upheld by the Supreme Court in Humphrey's, to be discussed in section 3.2.2. Interestingly, the removal of Mr. Humphrey, a Commissioner of the Federal Trade Commission "on the ground that his policy with regard to the work of the commission was not in harmony with the President's policy evoked no protest in either house of Congress and practically no comment. The President was apparently doing in this situation what Congress assumed that he would and should do." 53 Thus, some scholars suggest that "the American independent agencies were rendered quasi-independent of the President not by Congressional design but by Supreme Court opinion." ${ }^{54}$ All in all, with or without any intention, independent regulatory agencies have been put at a distance from the President to insulate them from the control of one political party. ${ }^{55}$

The ICC has become the prototype for further independent agency's movement and continued with the creation of the Federal Reserve Board (1913), the Federal Trade Commission (1914) and the US Shipping Board (1916). ${ }^{56}$ Some independent regulatory agencies, including the very first one, the ICC, were later abolished (the ICC - in 1995), though some of the ICC's functions were succeeded by the Surface Transportation Board, while other IRAs appeared, also as a result of reorganization of an executive department.

Today, there are at least 16 independent regulatory commissions (listed in 3.1.2.1. and Appendix 3) created, roughly speaking, in three waves: the mentioned first agencies were created at the end of the $19^{\text {th }}$ to the beginning of the $20^{\text {th }}$ centuries, the 'New Deal' regulators were created in 1930s, and a number of agencies were created in the 1970s. The Federal Maritime Commission was established in 1960 after a series of reorganizations, and, in response to the 2008 housing market crisis, the Federal Housing Finance Agency succeeded the Financial Housing Finance Board and some other agencies.

\footnotetext{
51 Cushman (1941) P. 61.

"The word independence does not appear in the legislative debates and the problem itself escaped any direct consideration" (Ibid.).

52 Breger and Edles (2000) P. 1130-1131.

53 Cushman (1941) P. 226.

${ }^{54}$ Shapiro (2005) P. 352-353.

${ }^{55}$ Morrison (1988) P. 253; Verkuil (1988) P. 259.

${ }^{56}$ The Shipping Board has seen several reorganizations, and in 1961 its regulatory functions have been succeeded by the Federal Maritime Commission, an independent regulatory commission.
} 


\subsubsection{Functions of US independent regulatory agencies}

Appendix 3 lists briefly the areas that IRAs are created to regulate. For instance, the Federal Trade Commission was set up to prevent unfair methods of competition, and the Securities and Exchange Commission to protect investors, maintain fair, orderly, and efficient markets, and facilitate capital formation. How can IRAs enforce their statutory goals?

Generally speaking, there are two types of functions that Congress delegates to IRAs. These are rulemaking and adjudication. "Agencies resort to rulemaking as they carry out general policy. They employ adjudication when their administrative action affects individual rights." ${ }^{57}$ As an example, the requirement of the Security and Exchange Commission that companies that sell securities should disclose specified information and register with the SEC could be a rule whereas “the Nuclear Regulatory Commission's decision to assess a $\$ 2$ million penalty against an electric utility for rule violations in running a nuclear power plant" ${ }^{8}$ is an illustrative example of an adjudication decision. To be more specific:

Rule making is agency action which regulates the future conduct of either group of persons or a single person; it is essentially legislative in nature, not only because it operates in the future but also because it is primarily concerned with policy considerations. The object of the rule making proceeding is the implementation or prescription of law or policy for the future, rather than the evaluation of a respondent's past conduct. ${ }^{59}$

Rules are made pursuant to the well-known 'notice-and-comment procedure' regulated by the US Administrative Procedure Act. In short, it implies the following steps: (1) an agency publishes a draft rule, (2) interested persons have a possibility to react by the means of submitting "written data, views, or arguments", and (3) the agency publishes the final rule, which includes agencies' reflections upon the received comments. ${ }^{60}$ Conversely, adjudication implies

The determination of past and present rights and liabilities. Normally, there is involved a decision as to whether past conduct was unlawful, so that the proceeding $\langle\ldots\rangle$ may result in disciplinary action. Or, it may involve the determination of a person's right to benefits under existing law so that the issues relate to whether he is within the established category of persons entitled to such benefits. ${ }^{61}$

Thus, adjudication means formulation of an order, i.e., "final disposition, whether affirmative, negative, injunctive, or declaratory in form, of an agency in a matter other than rule making but including licensing” (5 USC $\$ 551$ (6), (7)). Depending on statutory re-

\footnotetext{
${ }^{57}$ Custos (2006) P. 618.

${ }^{58}$ Strauss (2002) P. 199.

${ }^{59}$ Clark (2008) P. 14 (Attorney General's Manual on the Administrative Procedure Act).

${ }^{60}$ Lubbers (2006) P. 60; for a comprehensive study on rulemaking, see: Lubbers (2006).

${ }^{61}$ Clark (2008) P. 14 (Attorney General's Manual on the Administrative Procedure Act).
} 
quirements, these decisions can be given with or without hearings of the concerned parties. ${ }^{62}$ It is important to note that any enabling statute may add additional functions and specify which procedure an agency has to follow; in the absence of an explicit statutory requirement of which function to perform agencies are free to choose how they enforce their statutory goals - by rulemaking or by adjudication. ${ }^{63}$

Additional functions that agencies may have include research and investigations. The former function, i.e., research and publicity, implies an agency investigating existing problems in order to offer solutions. Such research and publications of its findings could help consumers, industry but also the government to improve existing situation. As an example, the Administrative Conference of the United States, not a regulatory agency, is "an independent federal agency dedicated to improving the administrative process through consensus-driven applied research, providing nonpartisan expert advice and recommendations for improvement of federal agency procedures." ${ }^{64}$ Concerning the latter, i.e., investigation, an agency, such as the SEC, may require regulated parties to submit periodic reports to ensure that its rules are followed. To deal with unsatisfactory reports or public complaints about operations of one or another company, such agencies can be empowered with investigative powers, including requesting additional documentation and inspecting premises. This may lead to further enforcement actions, such as administrative enforcement actions heard by Administrative Law Judges, or bringing law suits against private parties before the court. ${ }^{65}$

Interestingly, the primary initial function of independent regulatory commissions was adjudication; ${ }^{66}$ some scholars argue that this was the key rationale behind making IRAs multi-member boards, because they were supposed to act as appellate courts. However, gradually the rulemaking function has become more important at most agencies. ${ }^{67}$ In light of this development of agencies' functions, i.e., from adjudication to rulemaking, some scholars question whether the multi-member board structure is an appropriate form for agencies that primarily engage in rulemaking activities. ${ }^{68}$ This also leads to the question to what extent the type of agency matters with respect to the functions they may perform. However, neither rulemaking nor adjudication are "unique to independent agencies; execu-

\footnotetext{
${ }^{62}$ For a comprehensive study on adjudications, see: Asimow (2002).

${ }^{63}$ Lubbers (2006) P. 127.

${ }^{64}$ Guide for members, Administrative Conference of the United States, 2011. Find at: http://www.acus.gov/wpcontent/uploads/downloads/2011/05/Guide_5-9.pdf (last check February 2012).

${ }^{65}$ Asimow and Levin (2009) P. 5-7.

${ }^{66}$ Custos (2006) P. 628-629.

${ }^{67}$ There are, however, some independent regulatory agencies that remain almost 'purely' adjudicatory bodies. They are, e.g., the US Occupational Safety and Health Review Commission or the National Labor Relations Board, the latter issued its last rule in 1989, although at the moment of writing the NLRB is involved in the rulemaking activity again (Lubbers (2010) P. 412).

${ }^{68}$ Verkuil (1988) P. 267.
} 
tive agencies and departments employ them as well." ${ }^{\circ 9}$ All agencies, independent and otherwise, can perform rulemaking, adjudicatory, and other functions prescribed by law.

\subsubsection{The place of IRAs within the US constitutional system}

The creation of IRAs gave rise to numerous discussions about the place of such agencies within the US constitutional system governed by the principle of separation of powers. Indeed, while IRAs execute the law, their place within the executive is not clear since the President has limited control over them. In addition, the execution of law by these agencies implies making rules and adjudicating, the functions resembling the powers of the main three branches of the federal government. The question of the place of IRAs is directly interrelated with the question of agencies' legitimacy and accountability. If the President's grip upon these agencies is limited, then the President cannot be held to account for their actions in the same way as he is responsible for his executive agencies and departments, and therefore independent regulatory commissions do not seem to sit very comfortably in the executive branch. This in turn puts pressure on the legitimacy of such agencies' existence and decisions and their accountability. Is there a place within the US constitutional system to accommodate these 'strangers'? Is there another way (not via the President) to hold IRAs to account?

The answers to the questions depend greatly on how one interprets the US Constitution and understands the US constitutional setting - in a 'unitary executive' or 'functionalist' way.

According to unitarism (or the theory of a unitary executive), all agencies should be under the head of the executive. The supporters of this view argue that the President alone has the executive power and therefore should control all federal officers that exercise such power. "According to this view, the Constitution creates a unitary executive to ensure energetic enforcement of the law and to promote accountability by making it crystal clear who is to blame for maladministration." ${ }^{\prime 0}$ The proponents of this theory base their arguments upon the "vesting clause ${ }^{71}$ and the 'take-care clause ${ }^{72}$ of Article II of the US Constitution. ${ }^{73}$ Uni- $^{7}$ tarists view the federal bureaucracy as a pyramid, with the President at the top. All executive bodies have to be subordinated to the President; otherwise, he is not able to perform

\footnotetext{
${ }^{69}$ Verkuil (1988) P. 263.

${ }^{70}$ Calabresi and Yoo (2008) P. 3.

71 "The executive power shall be vested in a President of the United States of America" (Article II $₫ 1$ of the US Constitution).

72 The President has the duty to "take care that laws be faithfully executed" (Article II $₫ 3$ of the US Constitution).

${ }^{73}$ Calabresi and Yoo (2008) P. 4; Calabresi and Rhodes (1992) P. 1153 - 1216.
} 
his constitutionally assigned functions. For the supporters of this theory, IRAs are thus unconstitutional and should not exist. ${ }^{74}$

The other theory is functionalism. Strauss, the most prominent advocate of this approach, argues that the separation of powers doctrine is relevant only when we are talking about the 'apex of the governmental structure', and what is below that level should be analysed in terms of separation of functions and checks and balances. ${ }^{75}$ The separation of powers doctrine "has to do with the general tendency of certain governmental structures to result in (or prevent) tyrannical government." ${ }^{\prime 6}$ Each agency does not substitute any of the three constitutional branches, they are inferior departments of the government and they are controlled by all three branches, which are secured by the checks and balances system. Thus, proponents of this view see the federal bureaucracy as a trapezium consisting of two levels with the three constitutional branches on top and all other inferior institutions, including IRAs, below.

What this discussion suggests is that while "all will agree that the Constitution creates a unitary chief executive officer, the President, $<\ldots>$ disagreement arises over what his function entails." 77 What does the executive power imply? And should the President be the decider or the overseer in exercising his constitutional duty of 'taking care that the laws are faithfully executed'? ${ }^{78}$ If the heads of IRAs are there to execute the law, as is the President, to what extent does it matter if the President has a limited power over the removal of officials heading these agencies? While the Constitution gives the authority to shape the executive branch to Congress, the Constitution does not give the removal power, except for the impeachment, to any branch. It does not state that the President has to have the power to remove all executive officers in order to be able to execute its constitutional tasks. Looking back to the creation of the first executive departments, the law gave the removal power to the President. Yet, as Fisher argues, "agreement on the President's power to remove department heads did not include a freedom to remove every official in the executive branch. During debate on the Treasury Department and the office of the Comptroller, Madison intervened to protect that individual from presidential removal $\langle\ldots$.$\rangle because of the mixed$ nature of this position." 79 This seems to be the position adopted by the Supreme Court in Humphrey's, the landmark case institutionalizing IRAs (see, also, section 3.2.2.):

The language of the act, the legislative reports, and the general purposes of the legislation as reflected by the debates, all combine to demonstrate the congressional intent to create a body

\footnotetext{
${ }^{74}$ That these bodies should be abolished is one of the outcomes of the ongoing discussions about obliging independent regulatory agencies to implement President's executive orders concerning the cost and benefit analysis.

75 Struass (1984) P. 578.

${ }^{76}$ Ibid. P. 622.

77 Strauss (2007) P. 696.

${ }^{78}$ Ibid.

${ }^{79}$ Fisher (2010) P. 575.
} 
of experts who shall gain experience by length of service; a body which shall be independent of executive authority, except in its selection, and free to exercise its judgement without the leave or hindrance of any other official or any department of the government ${ }^{80}$ (emphasis added).

Interestingly, the Supreme Court has always found a way to accommodate independent regulatory agencies within the US constitutional system. In 1928 in Hampton, it did so indirectly by referring to the ICC as an illustrative example of how Congress legitimately delegated the power to make rates to be exacted by interstate carriers for the passenger and merchandise traffic. ${ }^{81}$ In 1989, in Mistretta, the Court followed the functionalist approach and upheld putting an independent commission, the Sentencing Commission, within the judicial branch:

In adopting this flexible understanding of separation of powers, we simply have recognized Madison's teaching that the greatest security against tyranny - the accumulation of excessive authority in a single Branch - lies not in a hermetic division among the Branches, but in a carefully crafted system of checked and balanced power within each Branch. $<\ldots>$ Congress may delegate to the Judicial Branch nonadjudicatory functions that do not trench upon the prerogatives of another Branch and that are appropriate to the central mission of the Judici$\operatorname{ary}^{82}$

Finally, in the most recent case, Free Enterprise Fund et al. v Public Company Accounting Oversight Board et al. (2010), the Supreme Court ruled that, for the purpose of the Appointments Clause, an independent regulatory commission at stake, i.e., the Securities and Exchange Commission, was "a freestanding component of the executive branch, not subordinate to or contained within any other such component." ${ }^{\prime 3}$ This sentence was, however, supplemented with the footnote with the help of which the Supreme Court tried to avoid any conclusive statements with respect to the application of the Opinions Clause upon IRAs, which the Presidents have refrained from invoking for political reasons. ${ }^{84}$

\footnotetext{
${ }^{80}$ Humphrey’s Ex’r v. U.S. 295 U.S. 602, 625-626 (1935).

81 "If such a power is to be exercised at all, it can only be satisfactorily done by a board or commission, constantly in session, whose time is exclusively given to the subject, and who, after investigation of the facts, can fix rates with reference to the peculiar circumstances of each road, and each particular kind of business, and who can change or modify these rates to suit the ever-varying conditions of traffic. $<\ldots>$ Our Legislature has gone a step further than most others, and vested our commission with full power to determine what rates are equal and reasonable in each particular case. Whether this was wise or not is not for us to say; but in doing so we cannot see that they have transcended their constitutional authority." (J.W. Hampton, Jr., \& Co. v. U.S. 276 U.S. 394, 408-409, (U.S.1928)).

${ }^{82}$ Mistretta v. U.S. 488 U.S. 361, 381-382, 388 (1989).

${ }^{83}$ Free Enterprise Fund et al. v Public Company Accounting Oversight Board et al. 561 US _ (2010). P. 31.

84 "We express no view on whether the Commission is thus an "executive department" under the Opinions Clause" (Ibid.).
} 
Thus, within the executive branch or outside, IRAs do exist, and "location does not minimize independence status." ${ }^{55}$ The Supreme Court has always managed to fit them into the US constitutional system. With respect to the place and accountability of IRAs, the functionalists' view seems to provide an explanation: IRAs are held to account by all three branches. Clearly, the President can exercise less control over independent regulatory commissions than over executive departments and agencies, but whether this should be considered unconstitutional depends on whether one adheres to functionalist or unitary theory. The Supreme Court seems to have chosen to adhere to the functionalist approach.

\section{Conclusion}

The intention of section 3.1. was to introduce US Congress and US independent regulatory agencies, the institutions of the accountability relationship under investigation. As this section has shown, the US Congress enjoys a number of formally strong legislative and non-legislative powers, yet its divisions into chambers, political parties and committees can affect the strength and the actual usage of these powers. In light of Woodrow Wilson's words that "government is not a machine, but a living thing," ${ }^{\prime 6}$ Congress is a 'living' institution. This is important to take into account when discussing various accountability mechanisms that Congress has in relation to IRAs, the other institution introduced by this chapter. It was pointed out that the concept of 'agency' is broadly defined and used in the US. Basically each of the mentioned 300 institutions of the executive branch is an 'agency'. However, what makes an agency 'independent' is that it has a multi-member management board whose members can be appointed and removed upon specific statutory requirements. Such requirements include the statutory 'removal for cause' restriction which makes the heads of IRAs removable only for the specified cause by the President and not at his will, which is the case in relation to the heads of other executive agencies. This difference has led to the debate about the place of IRAs within the constitutional system of the US, their legitimacy and accountability. While the debate is likely to persist, it is how Congress holds IRAs to account that is investigated and assessed in the following two sections.

The Opinions Clause reads as follows: "The President $<\ldots>$ may require the Opinion in writing, of the principal Officer in each of the executive Department, upon any subject relating to the Duties of their respective Offices" (Article II $\$ 2$ US Constitution).

${ }^{85}$ Fisher (2010) P. 584.

86 Wilson (1908) P. 56. 


\subsection{Investigating the Political Accountability of US Independent Regulatory Agencies}

Now that the relevant US institutions have been introduced, this section investigates the political accountability of US IRAs. This is done with the help of five dimensions introduced in Chapter 1. This section starts with the discussion of the legal rules governing the creation of and delegation to IRAs (3.2.1.). This sub-section shows that US IRAs are created at Congress's will and discusses implications that the existing situation has for the political accountability of IRAs. The appointment and removal procedures of IRAs' top officials are analyzed next (3.2.2.). This sub-section shows that IRAs' appointment and removal procedures are influenced by political realities in relation to both the existing statutory safeguards promoting agencies' independence and whether such safeguards are adhered to in practice. Sub-section 3.2.3. focuses on various accountability obligations that IRAs are subject to. This sub-section argues that while there are some concerns as to the number and the necessity of some accountability obligations, statutory regulation establishes a frame of reference which makes the ex post check of agencies' performance more feasible. Financial oversight over IRAs, including the case of self-funded IRAs, is discussed in 3.2.4. This subsection demonstrates that the annual appropriations process is 'The accountability venue' given both the strong formal congressional powers and regular interactions between congressional committees and IRAs that can ensure the three stages of accountability. Finally, sub-section 3.2.5. analyzes congressional oversight. This sub-section explains the strength of this tool and also pinpoints the challenges to the congressional oversight function. All in all, this section demonstrates the "awesome arsenal" of strong formal weapons that Congress "can use against agencies: legislation, appropriations, hearings, investigations, personal interventions, and "friendly advice" that is ignored at an executive's peril." ${ }^{\text {" Th }}$ The findings of this section serve as the basis for assessing the political accountability of US IRAs in section 3.3.

\subsubsection{Creation of and Delegation to Independent Regulatory Agencies: at Congress's Will}

When creating and delegating to IRAs, Congress faces the question of their political accountability. Considering the importance of these processes from an accountability perspective, this section analyzes the creation and delegation doctrines and discusses their implications on the political accountability of IRAs. It shows that, in the absence of a specific constitutional or statutory basis, the creation of IRAs and the scope of their authority depend on Congress's will, which is influenced by political circumstances. The existing situation has influenced the accountability of such agencies by reducing the President's respon-

${ }^{87}$ Wilson (1989) P. 236. 
sibility for them and hence the democratic accountability channels of such agencies before the people.

\subsubsection{The constitutionality of creation}

IRAs exist even though the US constitution does not explicitly allow their creation. At the same time, there is no constitutional provision that explicitly gives the power to Congress (or any other branch for that matter ${ }^{88}$ ) to shape the executive branch. The absence of any constitutional provision authorizing Congress to create executive institutions has led to the question whether their creation was constitutional. This question was answered positively in 1819 in McCulloch v. Maryland (17 U.S. 316 (1819)).

In this case, the creation of a national bank was challenged. The state of Maryland, the initial complainant, argued that as there was no constitutional provision authorizing Congress to create a national bank, Congress exceeded its powers and, thus, the act was unconstitutional. The Supreme Court ruled that while the power to establish the bank could not be found among the enumerated powers of Congress, it was an implied power of Congress. The creation of the bank was "necessary and proper for carrying into execution the foregoing powers", more specifically, "the power to lay and collect taxes, to borrow money; to regulate commerce, and to raise and support armies and navies" (Article I $\$ 8$ of the US Constitution). Thus, the absence of an explicit provision to establish various institutions, including IRAs, does not make the creation of agencies unconstitutional as long as they can be necessary and proper for carrying into Execution the foregoing Powers of Congress.

\section{The breadth of the creation standard}

The 'creation standard' formulated in McCulloch v. Maryland allowing Congress to shape the executive branch seems very broad. It gives a wide discretion to Congress to create various agencies without being obliged to justify how one or another institution and its type is in fact 'necessary and proper' for carrying out the constitutional functions of the three branches. In light of the discussion of functions of US IRAs, it was noticed that, from the functional perspective, independent and executive agencies cannot be distinguished as they can be empowered with the execution of the same rulemaking and adjudicatory powers. The US Congress does not offer any explanation for the choice of the type of agency and the type of functions it empowers the agency with:

\footnotetext{
${ }^{88}$ Even if the President were to create an agency, he might face various problems, such as the lack of funds. "Teddy Roosevelt created a stir by appointing extralegal, unsalaried commissions to study social and economic issues. When he asked Congress for $\$ 25,000$ to publish a commission study, Congress retaliated by prohibiting the appointment of commissions that lacked legislative authority. Although Roosevelt protested $<\ldots>$ and threatened to ignore the proscription, he had to seek private funds to publish the study" (Fisher (2007) P. 47).
} 
Congress has followed no consistent principle in assigning regulatory functions to independent agencies rather than to other units in the national government. There seems to be nothing about the regulatory job which makes it imperative that it be handled by the same kind of administrative body. ${ }^{89}$

It is important to note that the US Constitution does not impose any reasoning requirements upon Congress to justify how one or another law regulating the issues that are not explicitly mentioned in the Constitution fall within the federal competence. Interestingly, in December 2010, the House of Representatives amended its Rules of Procedures by introducing an obligation to make statements with any submission of a bill or a joint resolution. Such statements should say "as specifically as practicable the power or powers granted to Congress in the Constitution to enact the bill and joint resolution" (Rule XII, clause 7 as amended). ${ }^{90}$ "The idea was to demonstrate that a new $<\ldots>$ majority respected the enduring restraints of the Constitution." ${ }^{11}$ However, "over nine months, the House has passed laws about a variety of modern issues that the Founders didn't mention - abortion, charter schools and lasers"; for justification Congress has often turned to "broad clauses about "commerce," the "general welfare," and the need for "necessary and proper" laws."

\section{Implications for the political accountability of IRAs}

The absence of any constitutional or legal framework establishing criteria governing when IRAs can be set up, and with what accountability obligations, leaves these issues to Congress to decide. Hence, "the simplest answer to the question why regulatory agencies exercising executive power are independent of the executive branch is that Congress so ordained it." ${ }^{93}$ Furthermore, given the influence of the party politics on congressional powers (see section 3.1.1.3), the issues of the creation of IRAs and the scope of their authority are determined by political circumstances at the moment when the bill passes Congress. As Strauss explains,

Congress has employed many different forms of governmental authority in allocating the day-to-day work of government. $\langle\ldots\rangle$ The diversity is characteristic of our pragmatic ways with government, reflecting the circumstances of the particular regulatory regime, the temper of presidential/congressional relations at the time, or the perceived success or failure of an existing agency performing like functions, more than any grand scheme of government. ${ }^{94}$

\footnotetext{
${ }^{89}$ Cushman (1941) P. 10.

${ }^{90}$ Resolution 'Adopting rules for the One Hundred Twelfth Congress'. Find at: http://www.gop.gov/resources/library/documents/rules/112-hres5-conference-print.pdf (last check April 2012).

${ }^{91}$ Fahrenthold (2011).

92 Ibid.

93 Peters (1988) P. 290.

${ }^{94}$ Strauss (1984) P. 583-585.
} 
According to Epstein and O'Halloran, US IRAs receive public authority more often under the divided than unified government. ${ }^{95}$ The reason for that is that the type of agency has implications for agency's political accountability. Congress has used various statutory clauses, including the removal 'for cause' restriction, to limit President's influence over IRAs to safeguard their independence (see sections 3.1.2.1. and 3.1.2.4.). That Congress was able to restrict the President's grip over some agencies is also the result of the absence of a constitutional provision explicitly regulating the power of removal of officers of the United States, except for the impeachment procedure, and the Supreme Court's deference in this respect (see Humphrey's, discussed in section 3.2.2.2.). The existing situation has two implications for the accountability of IRAs.

First, in relation to Congress, IRAs can be held to account in the same way as other institutions of the executive branch. But the accountability of IRAs in relation to the President is limited by the 'for cause' restriction on President's removal power. The fact that the President cannot remove the heads of IRAs at will has affected his ability to hold IRAs to account for the performance of their functions. Hence, he cannot fully be responsible before the people for such agencies' actions.

Second, from the democratic accountability perspective, there seems to be a gap in the democratic accountability line from IRAs to the people for executing the law. Since the accountability of IRAs before the people via the President is limited, he cannot (fully) render account before the people for the execution of laws by such agencies. Congress has no responsibility to execute the law, but to pass statutes and oversee the executive for which it renders account before the people via the elections. Since IRAs fall (at least partly) outside the scope of the President's accountability for executing the law before the people and Congress has 'merely' an overseeing responsibility, the execution of laws by IRAs for which the President does not render account seems to escape democratic control by the people. The people can only sanction Congress for a failure to oversee (a failure in) executing the laws by IRAs. However, since Congress does not have a constitutional obligation to execute laws, it cannot be held to account for not doing that.

\subsubsection{The US non-delegation doctrine}

"As a good government is an empire of laws, the first question is, how shall the laws be made?" 96 The US Constitution is quite explicit in this respect. Its very first article reads as follows: "all legislative power herein granted shall be vested in a Congress of the United States." However, from the outset, Congress has used its legislative power to delegate certain tasks to various institutions. In 1892, the Supreme Court declared that the fact that "congress cannot delegate legislative power to the President is a principle universally recog-

\footnotetext{
${ }^{95}$ Epstein and O’Halloran (1999) P. 154-156.

${ }_{96}^{6}$ Words of John Adams (1776) cited by Schoenbrod (Schoenbrod (1993) P. 3).
} 
nized as vital to the integrity and maintenance of the system of government ordained by the constitution." ${ }^{\prime 7}$ The 'universally recognized principle', which the Court referred to, derives most likely from Locke's philosophy:

The power of the legislative, being derived from the people by a positive voluntary grant and institution, can be no other than what that positive grant conveyed, which being only to make laws, and not to make legislators, the legislative can have no power to transfer their authority of making laws and place it in other hands. ${ }^{98}$

Creating (independent) agencies, especially those who have powers to issue rules, therefore, leads to the question of whether Congress 'makes legislators'.

The discussion on the delegation of public authority to (independent) agencies can be sub-divided into three principal questions: (1) is delegation constitutional and, if so, (2) upon what conditions and (3) with respect to what powers? This section addresses these questions by discussing five landmark cases concerning the constitutionality of delegation and its scope. Generally speaking, the constitutionality of delegation was upheld already in 1825 in Wayman. The litigation in Hampton (1928) resulted in the formulation of a more explicit legal standard of delegation, which was later reaffirmed in Whitman (2001). There are only two cases in US history, i.e., Panama Refining Co. v. Ryan (1935) and Schechter Poultry $v$. US (1935), where the delegation standard did not stand up to judicial scrutiny. While the former three cases demonstrate the breadth of the non-delegation standard, the latter two cases help to understand its limits. This section shows that the 'non-delegation' standard is vaguely formulated, which makes it a 'myth' rather than a restriction imposed on Congress's delegation authority. From an accountability point of view, the delegation doctrine can be criticized on the fact that it is not elaborate as to how much accountability Congress has to establish to pass the delegation test.

\section{(1) Is delegation constitutional?}

Whether the delegation of public authority is constitutional was already answered by the Supreme Court in 1825 in Wayman (23 US 1 (1825)). In this case, Congress gave the power to the courts to determine judicial procedure. The delegation of arguably legislative powers was questioned. The Supreme Court, however, upheld the delegation with the help of making a distinction between "important subjects, which must be entirely regulated by the legislature itself," and details where "a general provision may be made, and power given to those who are to act under such general provisions, to fill up the details." ${ }^{\text {"9 }}$ The delegation of the latter, i.e., 'the power to fill up the details', was thus upheld to be constitutional.

\footnotetext{
${ }^{97}$ Marshall Field \& Co. v. Clark 143 U.S. 649, 692. (1892).

${ }^{98}$ Locke J. Second Treatise of Civil Government, Chapter IX, Of the Extent of Legislative Power, Sect. 141, 1690.

99 "The line has not been exactly drawn which separates those important subjects, which must be entirely regulated by the legislature itself, from those of less interest, in which a general provision may be made, and power given to
} 


\section{(2) Upon what conditions can Congress delegate?}

While in Wayman the Court did give a hint on a condition for delegation, i.e., 'there should be a general provision to act upon', the delegation standard was more explicitly formulated in Hampton. ${ }^{100}$ In this case, Congress delegated the authority to modify the rates of custom duties within certain limits to the President, who, upon investigation, could proclaim an increase or decrease of an import duty. The investigation was prescribed to be performed with the assistance of the United States Tariff Commission (today, the United States International Trade Commission, an independent regulatory agency), which was to give reasonable public notice and opportunity to parties to be heard. The issue before the Supreme Court became whether this 'flexible tariff provision' was constitutional as, in the view of the complainant, the President was delegated with legislative authority, which belongs to Congress. The Supreme Court upheld the statute and formulated the delegation standard.

The Supreme Court showed its understanding of the necessity of delegation:

Because of the difficulty in practically determining what that difference is, Congress seems to have doubted that the information in its possession was such as to enable it to make the adjustment accurately, and also to have apprehended that with changing conditions the difference might vary in such a way that some readjustments would be necessary to give effect to the principle on which the statute proceeds. ${ }^{101}$

To avoid such a difficulty, Congress let the tariffs be adjusted from time to time by another institution. In the Court's opinion, Congress cannot always predict future conditions, and thus, for the implementation policy to be effective, the legislature may leave certain decisions to the executive (and, presumably, to IRAs). The Court argued that in this case legislative power as such was not delegated, because "the power has already been exercised legislatively" by Congress. ${ }^{102}$ Interestingly, the Court referred to the Interstate Commerce Commission as an illustrative example of how Congress legitimately delegated the power to set rates. The Court stated that first Congress legislates that rates shall be 'just and reasonable' and then it prescribes how the ICC should enforce it. ${ }^{103}$

those who are to act under such general provisions to fill up the details" (Wayman v. Southard 23 U.S. 1, 43, (1825)).

${ }^{100}$ J.W. Hampton, Jr., \& Co. v. U.S. 276 U.S. 394 (1928).

${ }^{101}$ Ibid. at 404-405.

102 "The true distinction, therefore, is, between the delegation of power to make the law, which necessarily involves a discretion as to what it shall be, and conferring an authority or discretion as to its execution, to be exercised under and in pursuance of the law. The first cannot be done; to the latter no valid objection can be made" (Ibid. at 407).

103 "If such a power is to be exercised at all, it can only be satisfactorily done by a board or commission, constantly in session, whose time is exclusively given to the subject, and who, after investigation of the facts, can fix rates with reference to the peculiar circumstances of each road, and each particular kind of business, and who can change or modify these rates to suit the ever-varying conditions of traffic. $\langle\ldots>$ Our Legislature has gone a step further than 
The Court concluded that "if Congress shall lay down by legislative act an intelligible principle to which the person or body authorized to fix such rates is directed to conform, such legislative action is not a forbidden delegation of legislative power" ${ }^{104}$ (emphasis added). The 'intelligible principle' became the standard, which, if met, authorizes Congress to delegate public authority. However, the standard was not formulated very precisely, which led to further litigation almost immediately.

\section{The limits of the non-delegation doctrine}

Seven years later, in 1935, the Court decided two cases, which remain the only two cases to invalidate delegation; these are Panama Refining and Schechter Poultry. ${ }^{105}$ This was the time of the New Deal regulations, where the power of President F.D. Roosevelt was expanding quite remarkably. Even though the Supreme Court realized the necessity of and the importance of prompt and effective regulation established by numerous governmental programs to deal with the post-crisis years, both cases overturned the delegation. In these cases, the Supreme Court applied the recently (at that time) created delegation standard, which helps to see what the Supreme Court meant by it.

In Panama Refining, the President was delegated with the authority to prohibit "the transportation in interstate and foreign commerce of petroleum and the products thereof produced or withdrawn from storage in excess of the amount permitted to be produced or withdrawn from storage by any State law or valid regulation." ${ }^{106}$ The claimant argued that this provision, which authorized the President to pass a prohibitory law, was an unconstitutional delegation of the legislative power.

The Court started its analysis by reaffirming that "the question whether that transportation shall be prohibited by law is obviously of legislative policy." 107 To permit this delegation, the Court went looking for the intelligible principle, "whether the Congress has declared a policy with respect to that subject" and "whether the Congress has set up a standard for the President's action." 108 The Court found the provision itself very 'brief and un-

\footnotetext{
most others, and vested our commission with full power to determine what rates are equal and reasonable in each particular case. Whether this was wise or not is not for us to say; but in doing so we cannot see that they have transcended their constitutional authority" (Ibid. at 408-409).

104 Ibid. at 409.

${ }^{105}$ Many prominent US scholars point to the fact that after these two cases the Supreme Court consistently upheld the New Deal legislation and further delegations. They mention the 'Court-packing plan' (an initiative to add more justices to the Supreme Court to have a favorable to the President majority) which President Roosevelt proposed during the 1936 elections' campaign, which resulted in his re-election. (Schoenbrod (1993), Levinson and Pildes (2006), Fisher (2011)) Also, Epstein and O'Halloran note that "it was during the New Deal that that non-delegation doctrine made a [its?] bloody last stand $\langle\ldots>$ (the "switch in time that saved nine")" (Epstein and O’Halloran (1999) P. 20).

${ }^{106}$ Panama Refining Co. v. Ryan 293 U.S. 388, 405 (1935).

${ }^{107}$ Ibid. at 415.

108 Ibid.
} 
ambiguous', where Congress declared no policy and left it to the President's discretion to determine the policy and lay down the prohibition. ${ }^{109}$ Examining other provisions of the statute, the Court did not find any other policy goals, prohibitions or limitations of the power delegated to the President. "The Congress left the matter to the President without standard or rule, to be dealt with as he pleased." 110

The Supreme Court concluded that while "there are limits of delegation which there is no constitutional authority to transcend," 111 the provision at stake in this case went beyond those limits as Congress did not declare any policy, did not establish any standard and did not lay down any rule for the President's action.

Schechter Poultry v. US ${ }^{112}$ was decided shortly after Panama Refining. Here, the National Industrial Recovery Act, which authorized the President to approve codes of fair conduct for a trade or industry, was challenged. The President was authorized to issue such codes of fair competition on a complaint or on his own motion. The Supreme Court again went looking for the 'intelligible principle' or some limitations of the delegated authority. Interestingly, it referred again to the ICC as an illustrative example of delegation with the intelligible principle. ${ }^{113}$ Instead, it found a "virtually unfettered" discretion given to the President: "the approval of a code by the President is conditioned", however, in fact "the President in approving a code may impose his own conditions, adding to or taken from what is proposed, as 'in his discretion; he thinks necessary 'to effectuate the policy' declared by the act." 114 The Court concluded that the particular provisions of the Act do not

Undertake to prescribe rules of conduct to be applied to particular states of fact determined by appropriate administrative procedure. Instead of prescribing rules of conduct, it authorizes the making of codes to prescribe them. For that legislative undertaking, section 3 sets up no

\footnotetext{
109 "It establishes no criterion to govern the President's course. It does not require any finding by the President as a condition of his action. The Congress in section 9(c) thus declares no policy as to the transportation of the excess production. So far as this section is concerned, it gives to the President an unlimited authority to determine the policy and to lay down the prohibition, or not to lay it down, as he may see fit. And disobedience to his order is made a crime punishable by fine and imprisonment" (Panama Refining Co. v. Ryan 293 U.S. 388, 415 (1935)).

${ }^{110}$ Ibid. at 418 .

${ }^{111}$ Ibid. at 430 .

112 A.L.A. Schechter Poultry Corporation v. U.S. 295 U.S. 495 (1935).

113 "That administrative agency, in dealing with particular cases, is required to act upon notice and hearing, and its orders must be supported by findings of fact which in turn are sustained by evidence. $<\ldots>$ When the Commission is authorized to issue, for the construction, extension, or abandonment of lines, a certificate of 'public convenience and necessity,' or to permit the acquisition by one carrier of the control of another, if that is found to be 'in the public interest,' we have pointed out that these provisions are not left without standards to guide determination" (Ibid. at 539-540).

114 Ibid. at 523 .
} 
standards $\langle\ldots\rangle$. The discretion of the President in approving or prescribing codes, and thus enacting laws for the government, $<\ldots>$ is virtually unfettered. ${ }^{115}$

Thus, how specific should Congress be when laying down an intelligible principle? In the two discussed cases of 1935, the Court stated that the provisions of delegated authority should not be 'brief and ambiguous', Congress has 'to declare a policy with respect to' to the regulated matter, Congress has to 'set up a standard or a rule' for action, and the discretion should not be 'unfettered' but limited. The intelligible principle, therefore, seems to imply that, when conferring a certain task upon an agency, Congress has to prescribe how the agency has to enforce its will, implying the imposition of procedural and substantive requirements for the agency to follow, and thus to limit the agency's discretion. In this way, the Supreme Court seems to hint at the necessity to hold agencies to account which is more feasible when standards exist against which agencies' performance can be checked ex post. Yet, it is unclear what such minimum set of standards should entail. Furthermore, the prescribed requirements limiting an agency's discretion seem to make the powers that are delegated to an agency, non-legislative. However, the line remains thin between which powers are legislative, and thus prohibited to be delegated, and which powers are nonlegislative, and hence delegatable.

\section{(3) What powers are allowed to be delegated?}

What powers are 'delegatable' remains the issue for debate in the literature as well as among the Supreme Court Justices. Concerning the latter, Whitman ${ }^{116}$ (2001) is an interesting case to consider. In this case Congress empowered the Environmental Protection Agency (EPA), an 'executive independent agency'117, to promulgate and revise air quality standards from time to time, to be more precise, and "to establish uniform national standards at a level that is requisite to protect public health from the adverse effects of the pollutant in the ambient air." 118 The question became whether the delegation of arguably legislative power was constitutional.

To determine whether the statute delegated legislative power, the Supreme Court moved to determine what authority the statute conferred upon the agency. The statute authorized the EPA to set up standards "the attainment and maintenance of which <...> are requisite to protect the public health" with "an adequate margin of safety". ${ }^{119}$ The court of appeals determined that to be that this provision "failed to state intelligibly how much is

\footnotetext{
115 Ibid. at 541-542.

116 Whitman v. American Trucking Associations 531 U.S. 457 (2001).

117 This agency is headed by a single official and the President's grip over this agency is not restricted as it is the case with IRAs.

118 Whitman v. American Trucking Associations 531 U.S. 457, 473 (2001).

${ }^{119}$ Ibid. at 457.
} 
too much", ${ }^{120}$ i.e., what constitutes the 'requisite' level, thus delegating the legislative power to the agency and violating the intelligible principle. The Supreme Court disagreed. ${ }^{121}$

It referred to other statutes by virtue of which agencies were delegated with authority to determine 'necessary' or 'imminent' standards; in these cases the Court did not require Congress to specify what 'necessary' or 'imminent' should be, as 'a certain degree of discretion, and thus of lawmaking, inheres in most executive and judicial action'. Similarly here, to quote a section at issue, "which to repeat we interpret as requiring the EPA to set air quality standards at the level that is "requisite" that is, not lower or higher than is necessary - to protect the public health with an adequate margin of safety, fits comfortably within the scope of discretion permitted by our precedent." 122 The Court concluded that Congress did not delegate legislative power, but rather, as the Court called it, 'decisionmaking authority' to the EPA, and the delegation was done in accordance with the intelligible principle.

In Whitman, and also other judgments, the Supreme Court refers to various labels, such as administrative, decisionmaking, ratemaking or the power to 'fill up the details', of powers that are constitutionally 'delegatable'. However, what is now the difference between the legislative powers and those labels which the Court puts under the umbrella of nonlegislative powers? There are quite different views on this matter among the Supreme Court Justices. In this light, Justice Stevens, with whom Justice Souter joined in his dissent, expressed an interesting and somewhat revolutionary idea in Whitman. He wrote:

The Court has two choices. We could choose to articulate our ultimate disposition of this issue by frankly acknowledging that the power delegated to the EPA is "legislative" $<\ldots>$. Alternatively, we could pretend, as the Court does, that the authority delegated to the EPA is somehow not "legislative power." $<\ldots>$ It seems clear that an executive agency's exercise of rulemaking authority pursuant to a valid delegation from Congress is "legislative." As long as the delegation provides a sufficiently intelligible principle, there is nothing inherently unconstitutional about it. ${ }^{123}$

\footnotetext{
120 Whitman v. American Trucking Associations 531 U.S. 457, 472 (2001).

121 "In a delegation challenge, the constitutional question is whether the statute has delegated legislative power to the agency. Article I, $₫ 1$, of the Constitution vests “[a]ll legislative Powers herein granted $\langle\ldots>$ in a Congress of the United States." This text permits no delegation of those powers, $\langle\ldots\rangle$, and so we repeatedly have said that when Congress confers decisionmaking authority upon agencies Congress must "lay down by legislative act an intelligible principle to which the person or body authorized to [act] is directed to conform” J.W. Hampton, Jr., \& Co. v. United States, <...>." (Ibid. at 472-473).

"While Congress need not provide any direction to the EPA regarding the manner in which it is to define [standard, M.S.] $<\ldots>$ it must provide substantial guidance on setting fair standards that affect the entire national economy. But even in sweeping regulatory schemes we have never demanded, as the Court of Appeals did here, that statutes provide a "determinate criterion" for saying "how much [of the regulated harm] is too much" (Ibid. at 475).

122 Whitman v. American Trucking Associations 531 U.S. 457, 475-76 (2001).

${ }^{123}$ Ibid. at $487-490$.
} 
For now, this remains a minority opinion. As a whole, the line seems to be thin between legislative and non-legislative powers and hence what can be constitutionally delegated and what not.

\section{The 'myth' of the non-delegation doctrine}

The delegation of public authority to IRAs is governed by the 'non-delegation' doctrine based on the obligation for Congress to lay down the intelligible principle. The standard is not specifically formulated; it is unclear 'how much is enough', in other words how many limitations and standards should be there to pass the test. Because of that the existence and proper functioning of the non-delegation doctrine has been questioned in the US scholarly literature.

Schoenbrod, one of the most prominent critics of the weakness of the US nondelegation doctrine, argues that "since the early part of this century, the Court has said in essence that a statute may be vague so long as it is either not too vague or no vaguer than necessary." 124 Davis claimed that

The [US] non-delegation doctrine is almost a complete failure. It has not prevented the delegation of legislative power. Nor has it accomplished its later purpose of assuring that delegated power will be guided by meaningful standards. More importantly, it has failed to provide needed protection against unnecessary and uncontrolled discretionary power. The time has come for the courts to acknowledge that the non-delegation doctrine is unsatisfactory and to invent better ways to protect against arbitrary administrative power. ${ }^{125}$

"It remains a source of continuing controversy whether the non-delegation doctrine still exists, and, if it does, whether courts can and should enforce it by invalidating improper delegations." ${ }^{26}$ It is vague and it allows passing general laws by which Congress shifts the blame and making hard choices to agencies. ${ }^{127}$ It does not mean that no less critical opin-

\footnotetext{
${ }^{124}$ Schoenbrod (1985) P. 1224.

${ }^{125}$ Davis (1969) P. 713.

${ }^{126}$ Asimow and Levin (2009) P. 374.

127 Schoenbrod (1993).
}

He argues that there is a distinction between 'rules statutes' and 'goal statutes' where the former involves a permissible delegation, and the latter - not. "Imagine a national statute that limits air pollution from any power plant to a certain rate of emission. It would be a rules statute because it demarcates permissible from impermissible conduct. Congress is telling the private parties what they may or may not do. In contrast, a statute that empowers an agency to set controls on power plants in order to reduce the total of emissions from all power plants to a certain level would be a goals statute because it does not specify a rule of conduct for plants but rather provides only a goal, leaving to the delegate the balancing of interests necessary for determining how the burden of achieving that goal would be allocated. $\langle\ldots\rangle$ A rules statute requires the legislature to assume more responsibility and hence to be more accountable for the bearing of that responsibility than does a goals statute. In a rules statute, the legislature allocates rights and duties in the very course of indicating the kind of conduct that is permitted or not permitted. In a goals statute, the legislature does not go that far; it indicates legislative hopes and requires a delegate to allocate rights and duties corresponding to those hopes. Given the political nature of the legislative process, a goals 
ions exist. For instance, Stewart holds that, "While the courts might in some cases more carefully limit broad legislative delegations through statutory construction, any large-scale enforcement of the non-delegation doctrine would clearly be unwise." 128 According to him, when the subject of regulation is new, politically and economically volatile, and when the costs of legislative specification are too high, a broad non-delegation doctrine is necessary.

From an accountability perspective, the non-delegation doctrine can be criticized for being not specific as to how many procedural and substantive standards are necessary to pass the delegation test. The intelligible principle implies limiting agencies' discretion by procedural and substantive restrictions, yet, such restrictions do not automatically imply accountability; the latter can be ensured only by a combination of obligations promoting the three stages of accountability. In this way, by requiring the imposition of standards limiting agencies' discretion, the Supreme Court seems to reduce the scope of potential harm, rather than impose an obligation on Congress to establish an accountability framework for delegation to be lawful. Whereas in relation to executive agencies and departments the absence of such an obligation upon Congress can be less relevant since the President can be held to account for their actions, the situation seems different with the IRAs whose accountability before the President is limited. Here, it becomes less clear how IRAs render account before the people for the execution of laws for which the President cannot be held (fully) to account.

Concluding, while the US Constitution does not explicitly allow IRAs to be created, they do exist. They can be created at Congress's will, influenced by political circumstances, within the broadly formulated creation and delegation standards established by the $\mathrm{Su}$ preme Court. The creation standard does not impose any reasoning obligation upon Congress to justify its decision to create an executive institution and which type such an institution will have. The non-delegation doctrine requires Congress to limit agencies' discretion when it delegates a 'non-legislative' task to agencies. Yet, the Supreme Court has been vague in relation to both the definition of 'non-legislative' tasks and the (minimum) amount of restrictions limiting agencies' discretion necessary to pass the delegation test. The existing broad standards allow Congress to create IRAs whose accountability is limited before the President, but not before Congress.

statute is likely to express popular hopes that are inherently contradictory and leave the delegate with the unhappy job of dealing with the people's disappointments and conflicts. In a goals statute, the legislature therefore tends to do only half a job - to distribute benefits without taking responsibility for the costs. The bill for the benefits comes later and on the agency's letterhead. The agency gets the blame while Congress gets only the praise" (Schoenbrod (1985) P. 1253-1254).

${ }^{128}$ Stewart (1975) P. 1695. 


\subsubsection{The Law and Politics of Appointing and Removing IRAs' Commissioners}

The appointment and removal of the heads of IRAs are important to consider from a political accountability point of view because these procedures allow a personal accountability link to be established between the unelected officials of IRAs and the elected people's representatives. In addition, the power of removal can be used as a sanctioning tool for misbehavior. This section introduces both the appointment and removal procedures of the heads of IRAs (in sub-sections 3.2.2.1. and 3.2.2.2. respectively). It shows that IRAs' top officials are appointed according to the same constitutionally prescribed procedure as heads of executive agencies and departments and can be removed by the President, although only 'for cause' and not at his will, which is the case with executive agencies' top officials. At the same time, whereas personal independence of agencies' top officials is thought to be ensured by inserting relevant statutory safeguards, politics determines whether such safeguards are adhered to in practice. Moreover, the 'for cause' restriction on the President's removal power does not take all political influences away from IRAs. Rather, it shifts the origin of such influences from one political institution, the President, to another, Congress. In the end, we must conclude that even IRAs are not free from political influence.

\subsubsection{Appointing IRAs' top officials}

The appointment of heads of IRAs is a procedure in which the power of Congress and the President is shared. According to the US Constitution, the President enjoys the powers to nominate and appoint but only upon the advice and consent of the Senate. At the same time, Congress has influenced the President's appointment power by imposing various statutory requirements that potential appointees must have. Such statutory requirements are of direct importance when discussing IRAs because agencies' independence is thought to be achieved by such statutory clauses, which may not, however, be followed in reality. This section discusses the appointment procedure first as prescribed by law and then as influenced by political realities. It shows that the existing statutory safeguards in the appointment procedure aimed at ensuring the personal independence of agencies' top officials have been created upon political considerations, but also that politics determine whether such statutory requirements are adhered to in reality.

\section{The appointment process: constitutional procedure and legal restrictions}

Following the US Constitution, there is only one way in which the 'Officers of the United States', which include the heads of IRAs, can be appointed: ${ }^{129}$ the President shall nominate,

\footnotetext{
${ }^{129}$ Buckley v. Valeo 424 U.S. 1 (1976)) establishes the criteria to define 'officers of the United States', whereas Morrison v. Olson 487 U.S. 654 (1988) specifies the elements defining 'inferior officers' of the US government whose appointment can be delegated by statute to the President, a head of a Department, or court of law.
} 
and by and with the advice and consent of the Senate, shall appoint (Article II $₫ 2$ ). The officials heading IRAs are thus appointed according to the same constitutionally prescribed procedure as the heads of executive departments and agencies. The US Constitution also introduces the so-called 'ineligibility' and 'incompatibility' clauses. ${ }^{130}$ These imply that members of Congress may not be represented on agencies' boards, unless they participate only in advisory or ceremonial roles. ${ }^{131}$

Beyond these constitutional provisions, Congress has used its legislative power to limit the President's appointment power in various ways. Justice Brandeis, dissenting in Myers (see section 3.2.2.2.), offered ten pages of examples of various statutory requirements in this respect:

Congress has, from time to time, restricted the President's selection by the requirement of citizenship. It has limited the power of nomination by providing that the office may be held only by a resident of the United States; of a state; of a particular state; of a particular district; of a particular territory; of the District of Columbia; of a particular foreign country. It has limited the power of nomination further by prescribing specific professional attainments, or occupational experience, $<\ldots>$ the requirement of age; of sex; of races; of property; and of habitual temperance in the use of intoxicating liquors. Congress has imposed like restrictions on the power of nomination by requiring political representation; or that the selection be made on a nonpartisan basis. It has required, in some cases, that the representation be industrial; in others, that it be geographic. ${ }^{132}$

Some of these congressional 'appointment innovations' were overturned by the Supreme Court, ${ }^{133}$ while three of such clauses have led to creating IRAs. First, a bipartisanship re-

\footnotetext{
130 "No Senator or Representative shall, during the time, for which he was elected, be appointed to any civil office under the authority of the United States, which shall have been created, or the emoluments whereof shall have been increased during such time" and "no person holding any office under the United States, shall be a member of either House during his continuance in office" (Article I $\$ 6$ of the Constitution).

${ }^{131}$ Dellinger (2000) P. 550.

132 Myers v. U.S. 272 U.S. 52, 264-275 (1926).

"As an extreme example, consider the following language from a bill in 1916: Provided further, That of the vacancies created in the Judge Advocate's Department by this act, one such vacancy, not below the rank of Major, shall be filled by the appointment of a person from civil life, not less than forty-five nor more than fifty years of age, who shall have been for ten years a Judge of the Supreme Court of the Philippine Islands, shall have served for two years as a Captain in the regular or volunteer army, and shall be proficient in the Spanish language and laws. According to the New York Times, there was only one person that fit this description and he lived in the district of James Hay, the Chairman of the House Committee on Military Affairs, who also served on the conference committee reconciling House and Senate differences on the bill" (Lewis and Selin (2012) P. 100).

${ }^{133}$ In United States v. Ferreira, the Court ruled that as regards 'officers' "holding offices under the government, the power of appointment is in the President, by and with the advice and consent of the senate; and Congress could not by law, designate the persons to fill these offices" (U.S. v. Ferreira 54 U.S. 40, 51 (1851)). Thus, Congress may not pass 'appointing' laws.

In Metropolitan Washington Airports Authority v. Citizens for Abatement of Aircraft Noise, the Supreme Court declared unconstitutional an attempt of Congress to appoint its members to the boards with executive functions.
} 
quirement, i.e., not more than a majority of members of the management board, for instance, not more than three out of five members, can come from the same political party. IRAs, in this way, differ from executive agencies and departments because they are headed by multi-member boards and not by single heads which is thought necessary to strengthen their independence. Second, staggered terms of office, i.e., each of the members of the management board "serves a term so calculated that the term of only one member expires each year." 134 As a result, each new President has to deal with the appointees of his predecessor, and it can take some years before his own appointees will gain control. Third, the statutory requirement of removal 'for cause', ${ }^{135}$ to be discussed in the subsequent section, which restricts the ability of the President to remove members of IRAs' management boards at his will as he does it with the heads of executive agencies. ${ }^{136}$ It is interesting to note that not all IRAs have the mentioned three clauses in their enabling acts (see Appendix 3), however, they be applied to them in practice. ${ }^{137}$ In any case, while the idea behind the existing restrictions is to ensure independence of the members of IRAs' management boards from the political influence from the President, this 'theory' does not always stand up to political realities which may 'reshape' the existing constitutional and legal rules.

This 'innovative governmental experiment', in Justice's White words, was the Board of Reviews with the jurisdiction of transportation questions, with nine congressmen on the board appointed by Directors of the Metropolitan Washington Airports Authority (MWAA), which was created by a compact between Virginia and the District of Columbia, with a variety of powers, including the authority to veto decisions made by MWAA's directors (Metropolitan Washington Airports Authority v. Citizens for Abatement of Aircraft Noise, Inc. 501 U.S. 252, 252 (1991)).

In Buckley $v$. Valeo, the Court ruled out the possibility of inventing another appointment procedure even though the agency, the Federal Elections Commission, was empowered "with extraordinary authority reposed in Congress to regulate elections", which, as was argued, would allow Congress to put this case "on a different footing than if Congress had exercised its legislative authority in another field." (Buckley v. Valeo 424 U.S. at 131. The invention here was that eight commissioners were appointed in the following way: two by the president pro tempore of the Senate on recommendation of the majority and minority leaders of the Senate; two by the Speaker of the House on recommendation of the majority and minority leaders of the House; two by the President; and the remaining two were ex officio members (Secretary of the Senate and Clerk of the House) without the voting right. The first three groups of two had then to be confirmed by both chambers of Congress and each of the three appointing authorities was forbidden to choose both candidates from the same political party.

134 Strauss (2002) P. 98.

${ }^{135}$ Removal provisions that imply removal for 'inefficiency', 'neglect of duty', and 'malfeasance in office' have evolved into a collective term often referred to in the American legal scholarship as removal 'for cause'. Similarly, this book uses this term. This clause was first included in the statute establishing the first independent commission, the ICC, and later copied into other IRAs' enabling statutes or simply applied by convention without an explicit statutory provision (see Appendix 3 for US individual independent regulatory agencies' specifics).

${ }^{136}$ In 1822 President Monroe strongly disagreed with statutory restrictions to the President's appointment power, he considered them unconstitutional. Interestingly, a number of Presidents found a way around such restrictions by requesting an undated resignation as a condition to appointment (e.g., President Wilson in relation to D.J. Lewis, an appointee to the Tariff Commission (Cushman (1941) P. 463) and Presidents Harding and Coolidge (Bernstein (1955) P. 132).

${ }^{137}$ Chairman of NLRB (interviewed in April 2011). 
Political realities of the appointment process of IRAs' top officials

Following the US Constitution, it is the Senate that has a decisive say with respect to the nominees of the President. In the case when a political majority favorable to the President sits in the Senate, the appointment process may see little, if any, political resistance. In this way, the President can easily get the desired candidates appointed. However, the Senate does not always hold the same political color as the incumbent of the White House. Also, the majority in the Senate may not be big enough, ${ }^{138}$ which means that the appointment process would go less smoothly, if resulting in the appointment of the President's desired candidate at all. ${ }^{139}$

With respect to the appointment procedure, independence of the members of IRAs' management boards is thought to be achieved by heading such agencies with multimember boards where not more than a majority, for instance not more than three out of five members, can be from the same political party and where individual members are appointed on an annual basis forcing the President to work with the appointees of his predecessor. These safeguards can, however, be circumvented in practice.

Concerning the multi-membership of IRAs' management boards, the President may play with his nomination power. Without a nominee proposed by the President, there is no one for the Senate to confirm. Although in the case of an appointment to a single-headed agency the absence of a nomination can lead to a court decision requiring him to do so, ${ }^{140}$ an independent agency is headed by several commissioners, and in this case the President's inaction does not necessarily affect the agency's operation. Fisher states that President Carter 'deliberately kept' the board of the Interstate Commerce Commission, the first independent agency, which was statutorily authorized to have eleven commissioners, to seven by not filling all the vacancies. ${ }^{141}$

\footnotetext{
${ }^{138}$ While a majority vote is necessary to support the nomination, unless there is a three-fifth support, a filibuster is possible to block the motion to vote. Filibuster is an "informal term for any attempt to block or delay Senate action on a bill or other matter by debating it at length, by offering numerous procedural motions, or by any other delaying or obstructive actions" (This information is taken from the official web-page of this institution. Find at: http://www.senate.gov/reference/glossary_term/filibuster.htm (last check February 2012)).

Any Senator can initiate a filibuster. 60 members are needed to break through it.

${ }^{139}$ Fisher states that at least for the last 30 years Democratic majorities in the Senate often 'showed little interest in acting on nominations' of Republican Presidents and vice versa (Fisher (2007) P. 26-27).

${ }^{140}$ In Minnesota Chippewa Tribe v. Carlucci (358 F.Supp. 973 (D.D.D.C.1973)), President Nixon's refusal to nominate and appoint members of the National Advisory Council on Indian Education was overturned by a district judge who ruled that the President inaction meant that the Council could not function. "Although the President clearly has discretion to choose whom to appoint to the Council, he apparently has no discretion to decide if the Council should or should not be constituted" (at 975 -976).

${ }^{141}$ Fisher (1998) P. 9.
} 
Also, the President has some means to bypass the Senate by making recess appointments to the multi-member boards which may give him a favorable majority. ${ }^{142}$ According to the US Constitution, "the President shall have Power to fill up all Vacancies that may happen during the Recess of the Senate, by granting Commissions which shall expire at the End of their next Session” (Article II \$2). At the same time, "like a driver who avoids traffic on the main road by speeding down residential side streets, Presidents who take this route trade one set of problems for another." ${ }^{143}$ These possibilities are a temporary solution. ${ }^{144}$ Furthermore, Congress may control such appointments using its power of the purse. In 1863, Senator Fessenden wrote that "it may not be in our power to prevent the [recess] appointment, but it is in our power to prevent the payment; and when payment is prevented, I think that will probably put an end to the habit of making such appointments."145 Later, however, Congress passed a law allowing for some exceptions (5 USC $\$ 5503$ ). The President may make a temporary appointment when a commissioner resigns, dies, gets sick, and in other prescribed cases. ${ }^{146}$ In general, the maximum of 210 days is stipulated as tenure for such temporary appointees (5 USC $\$ \$ 3345-48$ ).

With respect to the multi-member as well as staggered terms requirements, the $\mathrm{Na}$ tional Labor Relations Board is an interesting example to consider. ${ }^{147}$ In the last decade, this independent agency has seen various compositions of its multi-member board of five members: it had one member for about one month and two members (a Democrat and a Republican) for 27 months. This shows that the President and the Senate may not necessarily fill the vacancies which appear on an annual basis (as the theory tells us) but can wait until two or more vacancies ${ }^{148}$ are available to appoint two or more candidates at the same

\footnotetext{
${ }^{142}$ As of this writing, there has been a new development in relation to the President's recess appointment power. The Court of Appeals for the District of Columbia issued a decision that President Obama violated the Constitution when he appointed three Members of the National Labor Relations Board (Canning v. NLRB, 705 F.3d 490 D.C. Cir. (2013)). This ruling has far-reaching implications on the ability of the President to make recess appointments. On June 242013 the Supreme Court accepted the NLRB's petition for certiorari, N.L.R.B. v. Canning 133 S.Ct. 2861, meaning the Supreme Court will review the case.

${ }^{143}$ Kalt (2011) P. 2.

144 "A recess appointment expires at the end of the Senate's next session or when an individual $<\ldots>$ is nominated, confirmed, and permanently appointed to the position whichever occurs first. In practice, this means that a recess appointment could last for almost two years," depending at what period in Senate's session the appointment has been made (at the end of the previous session or in the middle) (CRS Report for Congress 'Recess Appointments: Frequently Asked Questions', by Hogue H., 2010 P. 4).

${ }^{145}$ Fisher (2007), P. 39; Fisher (2011) P. 62. Currently, it is regulated by 5 USC $₫ 5503$.

${ }^{146}$ Dellinger states that "reasonableness of a given interim appointment should be measures not by a per se rule but by a variety of pragmatic factors," such as "the difficulty of finding suitable candidates, "the specific functions being performed by the [interim officer], the manner in which the vacancy was created (death, long-planned resignation)," etc. (Dellinger (2000) P. 554).

${ }_{147}$ This agency constitutes a special case because the field it regulates is highly politicized (Scher (1960)).

${ }^{148}$ Although it is difficult to determine in how much this situation relates to the contemporary practices, but in 1955 Bernstein mentioned the fact that "in most commissions the average tenure of the commissioners was about
} 
time so that both institutions/parties are able to agree. Such package deals may also imply having no confirmation hearings at the Senate. ${ }^{149}$

Yet, confirmation hearings may also be important for accountability purposes. Confirmation hearings are the point where the nominees to head IRAs, agencies over which the elected branches would have eventually less control, confront political accountability ex ante. What the nominee says during the appointment hearing can be followed-up later on whether he fulfills the commitments made. Yet, politics can take over this important function that the Senate's confirmation hearings can provide, although this probably applies to the appointments made to all agencies. As a FMC commissioner explains, for the confirmation hearing "you prepare like for your PhD exam, try to learn everything, but then it depends; some candidates have worked in the Senate, their hearings would be like a family reunion. $<\ldots>$ highly politicized appointees would have tough questions." 150

It is important to note that the fact that the US Constitution gives the Senate an advisory and consent role with respect to the President's appointees, not only gives the Senate the power of confirmation but also of consultation before the President nominates. The decisions to hold hearings and to take a floor vote are "entirely within the prerogatives of the Senate as a separate branch of government. The best method of ensuring committee and floor action is for the President and the White House to work closely with the Senate during the pre-nomination process, meeting with Senators from both parties." 151 "Any effort by a President to monopolize the choice of nominees would result in Senate retaliation, not just against nominees but against other presidential objectives and priorities." 152

The Senate may thus also use this opportunity to raise related and unrelated issues as trade-offs for its consent. ${ }^{153}$

There are also a few other peculiarities with respect to making appointments to IRAs. First, the President's willingness to push forward the desired candidate could be not as strong with respect to IRAs, agencies that are distant from the President, as with respect to executive agencies. ${ }^{154}$ This could give more say to the Senate and its individual committees. ${ }^{155}$ Kovacic notes also that

half the length of a full term. Thus a president in office for two terms, and perhaps even one term, might look forward to appointing a majority and sometimes all the members of a commission" (Bernstein (1955) P. 107).

${ }^{149}$ One Member of the NLRB who has served for more than a decade on the Board has always been appointed in a list with other candidates without having been invited to attend a confirmation hearing at the Senate (interviewed in April 2011). On the politics of the appointments to the NLRB see, also: Moe (1987b).

Note that the President has very little say in the nomination of the members from the 'other' party. Those are dictated by the Senators from that party.

${ }^{150}$ Commissioner from FMC (interviewed in May 2011).

${ }^{151}$ Fisher (2007) P. 35.

152 Fisher (2011) P. 61.

153 Beermann (2006) P. 110-111.

${ }^{154}$ Bernstein wrote in this respect, "the president may be more willing to come to terms with vigorously pressed political considerations in the appointment of commissioners than in the appointments of other governmental 
Because the executive branch has limited responsibility for the operation of independent commissions, Presidents have little incentive to find candidates of consistently high quality. Often presidents do not treat appointments to regulatory commissions as seriously as they treat appointments to cabinet departments. $\langle\ldots\rangle$ The multi-member structure of the Commission reduces the urgency to make every appointment count and the limited role and powers of non-chairman commissioners probably make such positions unattractive to many individuals whose skills would strengthen the agency. ${ }^{156}$

This seems to have resulted in a difficulty attracting experts into the field and hence a poor quality of the (FTC) commissioners. ${ }^{157}$ Furthermore, "too often, the appointments to the commissions have been made for other reasons than fitness to perform the duties of the office." ${ }^{58}$ Therefore, the initial idea behind creating independent expert bodies seems to be

officials. The lack of direct answerability of commissioners to the president allows him the dubious luxury of nominating individuals whom he could not tolerate if he were held immediately responsible for their administrative and political acts. $\langle\ldots\rangle$ single commissioners are not very important or at least not as important as the heads of agencies and departments responsible directly to the president" (Bernstein (1955) P. 112-113).

${ }^{155}$ In her New York Times article Stolberg compared the appointment hearings for the nominations to the Chairman of the Fed and to a Justice of the Supreme Court, scheduled in the same week. She observed that while the lawmakers, the media and the public have been focusing on Judge Alito for the Supreme Court, the "Fed choice is blip on some Senators' radar." However, "as Federal Reserve chairman, Mr. Bernanke, considered one of the nation's pre-eminent monetary economists, would arguably be the most powerful economic figure in the world, his every remark having the power to move markets. Unlike Judge Alito, Mr. Bernanke would not be receiving a lifetime appointment; the term of a Fed chairman is just four years. But Mr. Bernanke is also being appointed to a 14-year term as a member of the Fed's board of governors, and under Fed rules would be eligible for reappointment as chairman for the life of that term. Mr. Greenspan, who served one partial term and one full term as a Fed governor, was chairman for 18 years. That is long enough to have an extraordinary impact, and Fed chairmen often do." Yet, she noted that a number of Senators have missed Mr. Bernanke's appointment hearings or did not know that they were over. If the appointments made to the Fed are barely noticeable, even in the Senate, more influence from individual committees and members can be expected" (Stolberg (2006)).

156 Kovacic (1997) P. 944-945, 951.

${ }^{157}$ Kovacic (1997) refers to a survey made by the Congressional Research Service in 1977 in which the commissioners serving at the FTC and FMC received the most negative evaluations. The participants of the survey (lawyers, administrative law judges and the members of the Administrative Conference of the United States) were asked to state "how many current commissioners: (1) have the necessary training and experience to be federal regulators; (2) have a record of fair and impartial decisionmaking; (3) should the President reappoint based on the record of their accomplishments; and (4) are generally effective” (Kovacic (1997) P. 933-934).

See, also Swire who points out to the decline of expertise and impartiality of IRAs and argues that they should be incorporated into the executive branch (Swire (1985)).

${ }^{158}$ Task Force Report on Regulatory Commissions, Appendix N of the Hoover Commission report, United States Commission on Organization of the Executive Branch of the Government, Washington, 25, DC, 1949. P. 19-25 in: Salomon L. (ed.) The Independent Federal Regulatory Agencies, The Reference Shelf, Vol. 31, No. 2, The H.W. Wilson Company, 1959. P. 57. 
jeopardized by the poor quality of "political appointees. Usually they are politically active lawyers, either young ones or older ones on the way out." 159

Finally, politics also play a great role in appointing the chairmen of multi-member agencies: since 1950s the Presidents appoint the chairmen of IRAs' management boards (regulated by agencies' enabling acts, see Appendix 3) instead of the earlier practice of internal appointments within the board. "By nominating commissioners and by designating or recommending chairmen of the commissions, the presidents of both parties have been able to exercise a measure of control over their behavior."160 "Chairmen are recruited and selected with an assumption that they, as chairmen, will constitute part of an administration. Chairmen accept appointment with that understanding." 161 All in all, US IRAs seem to become not "as independent as they once were." 162

\subsubsection{Removing IRAs' top officials}

The US Constitution is not elaborate on the matter of which branch of government has the power to remove public officials, except for impeachment (Article II $\$ 4$ ). With respect to other, 'ordinary' cases of removal, such as neglect of duties or disagreements with the President and Congress, the US Constitution is silent. This section discusses the removal procedure of the heads of IRAs with the help of relevant case law, which is in fact especially relevant when talking about IRAs since it is the statutory restriction 'for cause' (and not at President's will as is the case with the heads of executive agencies) which promotes agencies' independence. Whereas this requirement aims to distance IRAs from the President in order to ensure insulation from political interference for agencies, ${ }^{163}$ it does not mean that it is independent of Congress, ${ }^{164}$ another political body with a number of controls in relation to such agencies. It thus merely shifts the origin of political influence.

\footnotetext{
159 Shepherd (1979); see, also Bernstein (1955) P. 106 (pointing to the fact that there have been mostly lawyers on the boards of independent commissions).

Aldo, Kovacic notes that "with notable exceptions, appointments to the FTC have been made with too little interest in the skills and experience pertinent to the problems of competition and monopoly, and too much attention to service to political party" (Kovacic (1997) P. 932, referring to the Hoover Commission's Committee on Independent Regulatory Commissions).

${ }^{160}$ Bernstein (1955) P. 109.

161 Welborn (1977) P. 141.

His study of seven independent regulatory commissions showed that chairmen have a substantial impact on "what the commissions do and how they do it," including their regulatory decisions (Ibid. P. 136-137).

162 Morrison (1988) P. 256.

163 Ibid. P. 253; Verkuil (1988) P. 259.

${ }^{164}$ Shapiro (1996) P. 8; see, also Strauss (1984) P. 592.
} 
Who has the power to remove officers of the United States? - clarification from the case law There are three principal Supreme Court judgments relevant with respect to the procedure for the removal of heads of IRAs. The first case, Myers $v$. U.S. (272 US 52 (1926)), established the President's removal power and that he was apparently able to remove all executive officers that he appointed upon advice and with consent of the Senate. Ironically, Chief Justice Taft, a former President, wrote the judgment with far-reaching implications. Nine years later, however, in Humphrey's Executor v. U.S. (295 US 602 (1935)) the Supreme Court unanimously limited the breadth of the scope of Myers, and thereby recognized the legitimacy of IRAs. The Wiener v. U.S. (357 US 349 (1958)) case became another confirmation of the Humphrey's conclusion with a clearer formulation of the standard.

The majority opinion in Myers established the removal power of the President over all officers appointed by him with the consent of the Senate. In this case, both the appointment and removal of first-class postmasters, as Mr. Myers was, were statutorily shared between the President and the Senate. Therefore, Mr. Myers challenged his dismissal, which was exercised solely by the President. The Court based its judgment on two major arguments. First, it referred to the establishment of some of the first departments, where the removal provisions authorized the President alone to remove the heads of those departments, even though they were appointed with the consent of the Senate. Second, the Court proposed the following explanation. The US Constitution vests all executive power in the President, who has to "take care that the laws be faithfully executed" (Article II \$3). Clearly, the President is not able to exercise all his executive power and to look after the faithful execution of laws alone, thus he needs assistants. As each officer is an alter ego of the President, the President can be held accountable for his assistants. ${ }^{165}$ Therefore, the President should be able to remove those officers for whom he can be held responsible.

Humphrey's, a case decided nine years later, became a historically important case to institutionalize IRAs. The Supreme Court ruled that the President could not remove a member of the Federal Trade Commission (FTC) for other than the specified statutory causes, because the FTC was created to be separate from any executive department and not to be accountable before the President. ${ }^{166}$ Without really defining what it meant, the Court labelled the functions of the FTC as 'quasi-legislative' and 'quasi-judicial' and not political or executive in nature, where the President had authority to act and control. This was distinct from Myers, where a postmaster exercised 'purely executive' functions. Thus, the conclusion

\footnotetext{
165 "Each head of a department is and must be the President's alter ego in the matters of that department where the President is required by law to exercise authority" (Myers v. U.S., 272 U.S. 52, 133, (1926)).

166 "The language of the act, the legislative reports, and the general purposes of the legislation as reflected by the debates, all combine to demonstrate the congressional intent to create a body of experts who shall gain experience by length of service; a body which shall be independent of executive authority, except in its selection, and free to exercise its judgement without the leave or hindrance of any other official or any department of the government" (Humphrey’s Ex'r v. U.S., 295 U.S. 602, 625-626 (1935)).
} 
became that "illimitable power of removal is not possessed by the President in respect of officers of the character of those just named."167

As a result, the Supreme Court established that the President can remove at his will those officers who exercise purely executive tasks whereas the removal of officers charged with 'quasi-legislative' and 'quasi-judicial' tasks may be done on the grounds listed in the respective acts. This conclusion was later stated more clearly in Wiener where President Eisenhower removed a member of the War Claims Commission for political reasons. The Court ruled that "the most reliable factor for drawing an inference regarding the President's power of removal in our case is the nature of the function that Congress vested in"168 a commission. In that case, the War Claims Commission was an adjudicating body, so the President could not exercise the power to remove the commissioner even though the act establishing this commission was completely silent on the matter of removals.

\section{Implications from the removal 'for cause' clause}

The idea behind the statutory clause 'removal for cause' is to distance some agencies from the President. This is necessary in order to insulate such agencies from the political influence of one party. However, "while public discussion of agency "independence" usually focuses on allegations of improper White House influence, the most powerful and persistent "political" influence over <...> [IRAs] clearly originates with the congressional appropriations and oversight committees and with other important members of the legislature." ${ }^{169}$ What this implies is that the 'for cause' removal seems to have shifted the axis of political influence from the President to Congress where "independent agencies are seen as the arms of Congress." 170

As Justice Sutherland stated in Humphrey's, "one who holds his office only during the pleasure of another cannot be depended upon to maintain an attitude of independence against the latter's will." ${ }^{171}$ Whereas Congress has no constitutional power of removal, with the exception of impeachment, it enjoys a number of possibilities to influence IRAs. These include the possibility of changing the structure of agencies, which allows creating new positions, prohibiting payments to existing positions, and legislating some commissioners out of office. In 1930, for example, Congress 'reorganized' the Federal Trade Commission by terminating the terms of the commissioners in office by law. This led to the appointment of a whole new board. Cushman held the view that in case of a 'for cause' removal provision, this remains the only legal way for Congress to change the board completely. ${ }^{172}$

\footnotetext{
${ }^{167}$ Humphrey's Ex'r v. U.S., 295 U.S. 602, 629 (1935).

168 Wiener v. U.S., 357 U.S. 349, 353 (1958).

${ }^{169}$ Wiley (1988) P. 282.

${ }^{170}$ Pierce et al. (1999) P. 103.

${ }^{171}$ Humphrey's Ex'r v. U.S., 295 U.S. 602, 629 (1935).

${ }^{172}$ Cushman (1941) P. 450 (referring to Act of June 17, 1930, 46 Stat. at L. 590, 696).
} 
Furthermore, in 1940, in order to get rid of D.J. Saposs, the chief economist of the National Labor Relations Board, Congress attached a rider ${ }^{173}$ forbidding the board to keep the position. ${ }^{174}$ Therefore, Congress's legislative powers, including the power of the purse, create more feasible ways for the removal of the heads of IRAs but also for scrutinizing them, which gives Congress, and its individual committees, the power to influence IRAs. And it is so that "once an officer is appointed, it is only the authority that can remove him, and not the authority that appointed him, that he must fear and, in the performance of his functions, obey." 175 The restriction 'for cause' results therefore in insulating IRAs from political influence of the President, but not that of Congress.

Concluding, the appointment of the heads of IRAs is exercised by the constitutionally prescribed appointment procedure: the President nominates candidates who are appointed upon the Senate's consent. They are appointed in accordance with the same constitutionally prescribed appointment procedure as the heads of executive agencies, except for several statutory safeguards that have been established with a view to ensuring the independence of some agencies. The idea behind heading some agencies by multi-member boards whose members are appointed on a bipartisan basis, have staggered terms of office and can be removed only 'for cause' was to create agencies independent from political influence. However, similarly to how political considerations gave birth to the mentioned safeguards ensuring independence of some agencies, they also determine in how far such safeguards will be applied in practice. For instance, each vacancy is not filled in immediately and the removal 'for cause' restriction shifts the origin of political influences from one political institution, the President, to the other, Congress, which enjoys various possibilities to influence IRAs. It seems therefore highly questionable whether US IRAs can be actually made independent from political influences, if that is what the distance from the President is needed for.

\subsubsection{Accountability through Statutory regulation of Agencies' Performance: Learning and Cautionary Experiences}

This section discussed various accountability obligations to which US IRAs are subject. These include: reporting obligations (3.2.3.1.) and substantive and procedural requirements regulating the operation of agencies (3.2.3.2.). This section shows that the existing statutory obligations are valuable from an accountability perspective because they create a frame of reference making it more feasible to hold agencies to account against the standard laid down in advance and allow Congress to share its oversight responsibility with the affected parties and its support bodies. At the same time, the downside of the existing statu-

\footnotetext{
${ }^{173}$ Appropriations riders are discussed in section 3.2.4.2.

${ }^{174}$ Cushman (1941) P. 675.

175 Bowsher v. Synar, 478 U.S. 714, 726 (1986).
} 
tory regulation is the great number of obligations that agencies are subject to and the ineffectiveness of some statutes.

\subsubsection{Reporting obligations}

Reports are one of the most important sources of information that Congress receives on a regular basis. They are "a constant reminder that Congress is interested in agency activity and that all such activity takes place under Congress's watchful eye." ${ }^{176}$ Reporting obligations derive from different legal sources, such as agencies' enabling acts and additional legislation of general application, and may require a study to be made about a particular problem, alert Congress about a planned activity, provide information about institutions' activities and summarize an institution's activities on a regular basis. ${ }^{177}$ Hence, reporting obligations differ as to their specificity, the type of information they require, and the intervals within which reports need to be submitted. This in turn means that reports can have a different value in terms of accountability.

\section{Types of reports that IRAs submit to Congress}

US IRAs are required to submit a great variety of reports to Congress. These include annual performance reports, annual budget requests, multi-annual strategic plans, summaries of economically significant regulations, weekly summaries of decisions, to name but a few. Appendix 3 provides more details in relation to each of the 16 IRAs, yet, even there a complete picture of all reporting obligations that each individual agency is subject to is difficult to provide since reporting obligations originate from a great many statutory sources. For this reason this section gives only one relevant example, from an accountability perspective. It is an extract (see Box 1 below) from the Government Performance and Results Act of 2010, codified in 31 USC, which requires federal agencies to develop strategic plans for their performance in the future. Agencies are obliged to submit long-run strategic plans and follow-up annual performance reports reflecting on how well the targets set have been met and explain the reasons of possible failures. This allows Congress to assess agencies' performance against the targets agencies have set in advance.

\footnotetext{
176 Beermann (2006) P. 106.

${ }_{177}$ CRS Report for Congress "Congressional Oversight Manual” by Kaiser F.M., Oleszek W.J., Tatelman T.B., 2011. P. 95.
} 
Box 1. US reporting obligations: an extract from the Government Performance and Results Act of 2010

\section{USC $\$ 1115$ - Federal Government and agency performance plans}

(a) Federal Government Performance Plans. - In carrying out the provisions of section 1105 (a)(28), the Director of the Office of Management and Budget shall coordinate with agencies to develop the Federal Government performance plan. In addition to the submission of such plan with each budget of the United States Government, the Director of the Office of Management and Budget shall ensure that all information required by this subsection is concurrently made available on the website provided under section 1122 and updated periodically, but no less than annually. The Federal Government performance plan shall(1) establish Federal Government performance goals to define the level of performance to be achieved during the year in which the plan is submitted and the next fiscal year for each of the Federal Government priority goals required under section 1120 (a) of this title;

(2) identify the agencies, organizations, program activities, regulations, tax expenditures, policies, and other activities contributing to each Federal Government performance goal during the current fiscal year;

(3) for each Federal Government performance goal, identify a lead Government official who shall be responsible for coordinating the efforts to achieve the goal;

(4) establish common Federal Government performance indicators with quarterly targets to be used in measuring or assessing-

(A) overall progress toward each Federal Government performance goal; and

(B) the individual contribution of each agency, organization, program activity, regulation, tax expenditure, policy, and other activity identified under paragraph (2);

(5) establish clearly defined quarterly milestones; and

(6) identify major management challenges that are Governmentwide or crosscutting in nature and describe plans to address such challenges, including relevant performance goals, performance indicators, and milestones.

(b) Agency Performance Plans. - Not later than the first Monday in February of each year, the head of each agency shall make available on a public website of the agency, and notify the President and the Congress of its availability, a performance plan covering each program activity set forth in the budget of such agency.

Such plan shall-

(1) establish performance goals to define the level of performance to be achieved during the year in which the plan is submitted and the next fiscal year;

(2) express such goals in an objective, quantifiable, and measurable form unless authorized to be in an alternative form under subsection (c);

(3) describe how the performance goals contribute to-

(A) the general goals and objectives established in the agency's strategic plan required by section 306 (a)(2) of title 5; and

(B) any of the Federal Government performance goals established in the Federal Government performance plan required by subsection (a)(1);

(4) identify among the performance goals those which are designated as agency priority goals as required by section 1120 (b) of this title, if applicable;

(5) provide a description of how the performance goals are to be achieved, including-

(A) the operation processes, training, skills and technology, and the human, capital, information, and other resources and strategies required to meet those performance goals;

(B) clearly defined milestones;

(C) an identification of the organizations, program activities, regulations, policies, and other activities that contribute to each performance goal, both within and external to the agency;

(D) a description of how the agency is working with other agencies to achieve its performance goals as well as relevant Federal Government performance goals; and 
(E) an identification of the agency officials responsible for the achievement of each performance goal, who shall be known as goal leaders;

(6) establish a balanced set of performance indicators to be used in measuring or assessing progress toward each performance goal, including, as appropriate, customer service, efficiency, output, and outcome indicators;

(7) provide a basis for comparing actual program results with the established performance goals;

(8) a description of how the agency will ensure the accuracy and reliability of the data used to measure progress towards its performance goals, including an identification of-

(A) the means to be used to verify and validate measured values;

(B) the sources for the data;

(C) the level of accuracy required for the intended use of the data;

(D) any limitations to the data at the required level of accuracy; and

(E) how the agency will compensate for such limitations if needed to reach the required level of accuracy;

(9) describe major management challenges the agency faces and identify-

(A) planned actions to address such challenges;

(B) performance goals, performance indicators, and milestones to measure progress toward resolving such challenges; and

(C) the agency official responsible for resolving such challenges; and

(10) identify low-priority program activities based on an analysis of their contribution to the mission and goals of the agency and include an evidence-based justification for designating a program activity as low priority.

(c) Alternative Form.- If an agency, in consultation with the Director of the Office of Management and Budget, determines that it is not feasible to express the performance goals for a particular program activity in an objective, quantifiable, and measurable form, the Director of the Office of Management and Budget may authorize an alternative form. Such alternative form shall-

(1) include separate descriptive statements of-

(A)

(i) a minimally effective program; and

(ii) a successful program; or

(B) such alternative as authorized by the Director of the Office of Management and Budget, with sufficient precision and in such terms that would allow for an accurate, independent determination of whether the program activity's performance meets the criteria of the description; or

(2) state why it is infeasible or impractical to express a performance goal in any form for the program activity.

(d) Treatment of Program Activities.- For the purpose of complying with this section, an agency may aggregate, disaggregate, or consolidate program activities, except that any aggregation or consolidation may not omit or minimize the significance of any program activity constituting a major function or operation for the agency.

(e) Appendix.- An agency may submit with an annual performance plan an appendix covering any portion of the plan that-

(1) is specifically authorized under criteria established by an Executive order to be kept secret in the interest of national defense or foreign policy; and

(2) is properly classified pursuant to such Executive order. <...>

\section{USC $\$ 1116$ - Agency performance reporting}

(a) The head of each agency shall make available on a public website of the agency and to the Office of Management and Budget an update on agency performance.

(b) 
(1) Each update shall compare actual performance achieved with the performance goals established in the agency performance plan under section 1115 (b) and shall occur no less than 150 days after the end of each fiscal year, with more frequent updates of actual performance on indicators that provide data of significant value to the Government, Congress, or program partners at a reasonable level of administrative burden.

(2) If performance goals are specified in an alternative form under section 1115 (c), the results shall be described in relation to such specifications, including whether the performance failed to meet the criteria of a minimally effective or successful program.

(c) Each update shall-

(1) review the success of achieving the performance goals and include actual results for the 5 preceding fiscal years;

(2) evaluate the performance plan for the current fiscal year relative to the performance achieved toward the performance goals during the period covered by the update;

(3) explain and describe where a performance goal has not been met (including when a program activity's performance is determined not to have met the criteria of a successful program activity under sec-

tion 1115 (c)(1)(A)(ii) or a corresponding level of achievement if another alternative form is used) -

(A) why the goal was not met;

(B) those plans and schedules for achieving the established performance goal; and

(C) if the performance goal is impractical or infeasible, why that is the case and what action is recommended;

(4) describe the use and assess the effectiveness in achieving performance goals of any waiver under section 9703 [1] of this title;

(5) include a review of the performance goals and evaluation of the performance plan relative to the agency's strategic human capital management;

(6) describe how the agency ensures the accuracy and reliability of the data used to measure progress towards its performance goals, including an identification of-

(A) the means used to verify and validate measured values;

(B) the sources for the data;

(C) the level of accuracy required for the intended use of the data;

(D) any limitations to the data at the required level of accuracy; and

(E) how the agency has compensated for such limitations if needed to reach the required level of accuracy; and

(7) include the summary findings of those program evaluations completed during the period covered by the update.

(d) If an agency performance update includes any program activity or information that is specifically authorized under criteria established by an Executive Order to be kept secret in the interest of national defense or foreign policy and is properly classified pursuant to such Executive Order, the head of the agency shall make such information available in the classified appendix provided under section 1115 (e).

(e) The functions and activities of this section shall be considered to be inherently governmental functions. The drafting of agency performance updates under this section shall be performed only by Federal employees.

(f) Each fiscal year, the Office of Management and Budget shall determine whether the agency programs or activities meet performance goals and objectives outlined in the agency performance plans and submit a report on unmet goals to-

(1) the head of the agency;

(2) the Committee on Homeland Security and Governmental Affairs of the Senate;

(3) the Committee on Oversight and Governmental Reform of the House of Representatives; and

(4) the Government Accountability Office.

(g) If an agency's programs or activities have not met performance goals as determined by the Office of 
Management and Budget for 1 fiscal year, the head of the agency shall submit a performance improvement plan to the Office of Management and Budget to increase program effectiveness for each unmet goal with measurable milestones. The agency shall designate a senior official who shall oversee the performance improvement strategies for each unmet goal.

(h)

(1) If the Office of Management and Budget determines that agency programs or activities have unmet performance goals for 2 consecutive fiscal years, the head of the agency shall-

(A) submit to Congress a description of the actions the Administration will take to improve performance, including proposed statutory changes or planned executive actions; and

(B) describe any additional funding the agency will obligate to achieve the goal, if such an action is determined appropriate in consultation with the Director of the Office of Management and Budget, for an amount determined appropriate by the Director.

(2) In providing additional funding described under paragraph (1)(B), the head of the agency shall use any reprogramming or transfer authority available to the agency. If after exercising such authority additional funding is necessary to achieve the level determined appropriate by the Director of the Office of Management and Budget, the head of the agency shall submit a request to Congress for additional reprogramming or transfer authority.

(i) If an agency's programs or activities have not met performance goals as determined by the Office of Management and Budget for 3 consecutive fiscal years, the Director of the Office of Management and Budget shall submit recommendations to Congress on actions to improve performance not later than 60 days after that determination, including -

(1) reauthorization proposals for each program or activity that has not met performance goals;

(2) proposed statutory changes necessary for the program activities to achieve the proposed level of performance on each performance goal; and

(3) planned executive actions or identification of the program for termination or reduction in the President's budget.

\section{Reporting obligations as an accountability mechanism}

Three elements valuable from an accountability perspective stand out when analyzing reporting obligations in the US: (1) their specificity; (2) the involvement of other institutions in overseeing agencies and their reporting; and (3) the presence of analytical, rather than merely descriptive, reporting. The latter seems to be achieved by inserting requirements to state reasons, to align ex ante plans to ex post results, and to provide recommendations for improvement. These elements can be illustrated with the example given in Box 1. The specificity of reporting obligations can be seen in, for instance, sections 1115 (b) and 1116 (c), which state what the requested reports need to include. Section 1115 (a) imposes an obligation on another institution, namely the Office of Management and Budget, to enforce the reporting obligation on agencies. Furthermore, section 1116 (c (3(A))) requires agencies to explain their performance failures. As Shapiro explains,

Giving reasons requirements are a form of internal improvement for administrators. A decisionmaker required to give reasons will be more likely to weigh pros and cons carefully before reaching a decision than will a decisionmaker able to proceed by simple fiat. <... Such re- 
quirements are a mild self-enforcing mechanism for controlling discretion." ${ }^{178}$ And also, "giving reasons requirements are an obvious vehicle for transparency. ${ }^{179}$

Finally, ex post reports (section 1116) need to be written on the basis of indicators presented in ex ante plans (section 1115). Connecting ex post results with ex ante plans makes the assessment of agencies' performance and results more feasible.

While the US reporting obligations seem to have valuable elements from an accountability point of view, the down side of the existing situation is their great number. As Pray points out, "reporting requirements have a history nearly as long as that of Congress itself." ${ }^{180}$ Several attempts to study the number of reports have been undertaken by a congressional support agency, the Government Accountability Office discussed in section 3.2.5.1, however, "there is no system for tracking reporting requirements or for determining whether reports were actually submitted in accordance with the statutes." ${ }^{181}$ In 1991, the Wall Street Journal estimated the number to be approximately 3000 reports, with an annual cost of $\$ 350$ million. ${ }^{182}$ For illustrative purposes, Box 2 gives an example of the number of reporting requirements that can originate from only one statute. This is an extract from an act that establishes the Postal Regulatory Commission and regulates the postal system in the US in general. This extract also shows how Congress guides agencies' actions, prescribing what and how IRAs and other relevant institutions, including congressional support agencies, need to consider in their work and report back.

It is important to note that IRAs may receive tasks from several statutes. The Federal Trade Commission, for instance, enforces about 50 statutes, ${ }^{183}$ which could result in a potential 50 reporting obligations, if each of them has at least one reporting requirement. Taking into account the more than 300 existing institutions of the executive branch, and that each of them is likely to enforce several statutes, the finding that there is a difficulty in counting the number of reports that Congress receives each year does not seem surprising.

\footnotetext{
178 Shapiro (1992) P. 180-181.

179 Ibid. P. 220.

180 Pray (2005) P. 304.

${ }^{181}$ Ibid. P. 299, referring to H.R. Rep. NO. 96-1268, at 1 (1980).

A CRS report refers to approximately 4,000 reports that reach Congress annually (CRS Report for Congress “Congressional Oversight Manual” by Kaiser F.M., Oleszek W.J., Tatelman T.B., 2011. P. 95).

The Congressional report of 1993 stated that in 1973 the estimated number of report requirements was 1,000, by 1980 it grew by half, and in 1992 it grew by 242 per cent, to 3, 627. (Organization of the Congress, Final Report of the Joint Committee on the Organization of Congress, December, 1993. Find at: http://democrats.rules.house.gov/archives/jcoc2.htm (last checked February 2012)).

${ }^{182}$ Pray (2005) P. 300.

${ }^{183}$ Commissioner from FTC (interviewed in April 2011).
} 
Box 2. Reporting requirements - an extract from the Postal Regulatory Commission's founding act

39 USC 501 note.

SEC. 701. ASSESSMENTS OF RATEMAKING, CLASSIFICATION, AND OTHER PROVISIONS.

(a) IN GENERAL.-The Postal Regulatory Commission shall, at least every 5 years, submit a report to the President and Congress concerning - (1) the operation of the amendments made by this Act; and (2) recommendations for any legislation or other measures necessary to improve the effectiveness or efficiency of the postal laws of the United States.

SEC. 702. REPORT ON UNIVERSAL POSTAL SERVICE AND THE POSTAL MONOPOLY. (a) REPORT BY THE POSTAL REGULATORY COMMISSION.- (1) IN GENERAL.-Not later than 24 months after the date of enactment of this Act, the Postal Regulatory Commission shall submit a report to the President and Congress on universal postal service and the postal monopoly in the United States (in this section referred to as "universal service and the postal monopoly"), including the monopoly on the delivery of mail and on access to mailboxes. (2) CONTENTS.-The report under this subsection shall include- (A) a comprehensive review of the history and development of universal service and the postal monopoly, including how the scope and standards of universal service and the postal monopoly have evolved over time for the Nation and its urban and rural areas; (B) the scope and standards of universal service and the postal monopoly provided under current law (including sections 101 and 403 of title 39, United States Code), and current rules, regulations, policy statements, and practices of the Postal Service; (C) a description of any geographic areas, populations, communities (including both urban and rural communities), organizations, or other groups or entities not currently covered by universal service or that are covered but that are receiving services deficient in scope or quality or both; and (D) the scope and standards of universal service and the postal monopoly likely to be required in the future in order to meet the needs and expectations of the United States public, including all types of mail users, based on discussion of such assumptions, alternative sets of assumptions, and analyses as the Postal Service considers plausible.

(b) RECOMMENDED CHANGES TO UNIVERSAL SERVICE AND THE MONOPOLY.-The Postal Regulatory Commission shall include in the report under subsection (a), and in all reports submitted under section 701 of this Act- (1) any recommended changes to universal service and the postal monopoly as the Commission considers appropriate, including changes that the Commission may implement under current law and changes that would require changes to current law, with estimated effects of the recommendations on the service, financial condition, rates, and security of mail provided by the Postal Service; (2) with respect to each recommended change described under paragraph (1) - (A) an estimate of the costs of the Postal Service attributable to the obligation to provide universal service under current law; and (B) an analysis of the likely benefit of the current postal monopoly to the ability of the Postal Service to sustain the current scope and standards of universal service, including estimates of the financial benefit of the postal monopoly to the extent practicable, under current law; and (3) such additional topics and recommendations as the Commission considers appropriate, with estimated effects of the recommendations on the service, financial condition, rates, and the security of mail provided by the Postal Service.

(c) CONSULTATION.-In preparing the report required by this section, the Postal Regulatory Commission - (1) shall solicit written comments from the Postal Service and consult with the Postal Service and other Federal agencies, users of the mails, enterprises in the private sector engaged in the delivery of the mail, and the general public; and (2) shall address in the report any written comments received under this section. $<\ldots>$

SEC. 704. REPORT ON POSTAL WORKPLACE SAFETY AND WORKPLACERELATED INJURIES.

(a) REPORT BY THE INSPECTOR GENERAL.- (1) IN GENERAL.-Not later than 6 months after the enactment of this Act, the Inspector General of the United States Postal Service shall submit a report to 
Congress and the Postal Service that - (A) details and assesses any progress the Postal Service has made in improving workplace safety and reducing workplace-related injuries nationwide; and (B) identifies opportunities for improvement that remain with respect to such improvements and reductions. (2) CONTENTS.The report under this subsection shall also- (A) discuss any injury reduction goals established by the Postal Service; (B) describe the actions that the Postal Service has taken to improve workplace safety and reduce workplace related injuries, and assess how successful the Postal Service has been in meeting its injury reduction goal; and (C) identify areas where the Postal Service has failed to meet its injury reduction goals, explain the reasons why these goals were not met, and identify opportunities for making further progress in meeting these goals.

(b) REPORT BY THE POSTAL SERVICE.- (1) REPORT TO CONGRESS.-Not later than 6 months after receiving the report under subsection (a), the Postal Service shall submit a report to Congress detailing how it plans to improve workplace safety and reduce workplace-related injuries nationwide, including goals and metrics. (2) PROBLEM AREAS.-The report under this subsection shall also include plans, developed in consultation with the Inspector General and employee representatives, including representatives of each postal labor union and management association, for addressing the problem areas identified by the Inspector General in the report under subsection $(\mathrm{a})(2)(\mathrm{C})$.

SEC. 705. STUDY ON RECYCLED PAPER.

(a) IN GENERAL.-Within 12 months after the date of enactment of this Act, the Government Accountability Office shall study and submit to the Congress, the Board of Governors of the Postal Service, and to the Postal Regulatory Commission a report concerning - (1) a description and analysis of the accomplishments of the Postal Service in each of the preceding 5 years involving recycling activities, including efforts by the Postal Service to recycle undeliverable and discarded mail and other materials and its public affairs efforts to promote the increased recycling of paper products; and (2) additional opportunities that may be available for the United States Postal Service to engage in recycling initiatives, including consultation with the paper recycling industry and encouraging mailers to increase both the recycling of paper products and the use of recycled paper, and the projected costs and revenues of undertaking such opportunities.

(b) RECOMMENDATIONS.- - The report shall include recommendations for any administrative or legislative actions that may be appropriate.

\section{SEC. 706. GREATER DIVERSITY IN POSTAL SERVICE EXECUTIVE AND ADMINISTRA- TIVE SCHEDULE MANAGEMENT POSITIONS.}

(a) IN GENERAL.-The Board of Governors shall study and, within 1 year after the date of the enactment of this Act, submit to the President and Congress a report concerning the extent to which women and minorities are represented in supervisory and management positions within the United States Postal Service. Any data included in the report shall be presented in the aggregate and by pay level.

(b) PERFORMANCE EVALUATIONS.-The United States Postal Service shall, as soon as is practicable, take such measures as may be necessary to incorporate the affirmative action and equal opportunity criteria contained in 4313(5) of title 5, United States Code, into the performance appraisals of senior supervisory or managerial employees.

SEC. 707. CONTRACTS WITH WOMEN, MINORITIES, AND SMALL BUSINESSES.

The Board of Governors shall study and, within 1 year after the date of the enactment of this Act, submit to the President and the Congress a report concerning the number and value of contracts and subcontracts the Postal Service has entered into with women, minorities, and small businesses.

SEC. 708. RATES FOR PERIODICALS.

(a) IN GENERAL.-The United States Postal Service, acting jointly with the Postal Regulatory Commission, shall study and submit to the President and Congress a report concerning- (1) the quality, accuracy, and completeness of the information used by the Postal Service in determining the direct and indirect postal costs attributable to periodicals; and (2) any opportunities that might exist for improving efficiencies in the 
collection, handling, transportation, or delivery of periodicals by the Postal Service, including any pricing incentives for mailers that might be appropriate.

(b) RECOMMENDATIONS.-The report shall include recommendations for any administrative action or legislation that might be appropriate.

\section{SEC. 709. ASSESSMENT OF CERTAIN RATE DEFICIENCIES.}

(a) IN GENERAL.-Within 12 months after the date of the enactment of this Act, the Office of Inspector General of the United States Postal Service shall study and submit to the President, the Congress, and the United States Postal Service, a report concerning the administration of section 3626(k) of title 39, United States Code.

(b) SPECIFIC REQUIREMENTS.-The study and report shall specifically address the adequacy and fairness of the process by which assessments under section 3626(k) of title 39, United States Code, are determined and appealable, including - (1) whether the Postal Regulatory Commission or any other body outside the Postal Service should be assigned a role; and (2) whether a statute of limitations should be established for the commencement of proceedings by the Postal Service thereunder.

SEC. 710. ASSESSMENT OF FUTURE BUSINESS MODEL OF THE POSTAL SERVICE.

(a) GOVERNMENT ACCOUNTABILITY OFFICE MANDATE.-The Comptroller General of the United States shall prepare and submit to the President and Congress a report that builds upon the work of the 2002 President's Commission on the United States Postal Service by evaluating in-depth various options and strategies for the long-term structural and operational reforms of the United States Postal Service. The final report required by this section shall be submitted within 5 years of the date of enactment of this Act. (b) PROTECTION OF UNIVERSAL SERVICE.-The Government Accountability Office may include such recommendations as it considers appropriate with respect to how the Postal Service's business model can be maintained or transformed in an orderly manner that will minimize adverse effects on all interested parties and assure continued availability of affordable, universal postal service throughout the United States. The Government Accountability Office shall not consider any strategy or other course of action that would pose a significant risk to the continued availability of affordable, universal postal service throughout the United States.

(c) ELEMENTS OF REPORT.- (1) TOPICS TO ADDRESS.-The report shall address at least the following: (A) Specification of nature and bases of one or more sets of reasonable assumptions about the development of the postal services market, to the extent that such assumptions may be necessary or appropriate for each strategy identified by the Government Accountability Office. (B) Specification of the nature and bases of one or more sets of reasonable assumptions about the development of the regulatory framework for postal services, to the extent that such assumptions may be necessary or appropriate for each strategy identified by the Government Accountability Office. (C) Qualitative and, to the extent possible, quantitative effects that each strategy identified by the Government Accountability Office may have on universal service generally, the Postal Service, mailers, postal employees, private companies that provide delivery services, and the general public. (D) Financial effects that each strategy identified by the Government Accountability Office may have on the Postal Service, postal employees, the Treasury of the United States, and other affected parties, including the American mailing consumer. (E) Feasible and appropriate procedural steps and timetables for implementing each strategy identified by the Government Accountability Office. (F) Such additional topics as the Comptroller General shall consider necessary and appropriate. (2) MATTERS TO CONSIDER.-For each strategy identified, the Government Accountability Office shall assess how each business model might- (A) address the human-capital challenges facing the Postal Service, including how employee-management relations within the Postal Service may be improved; (B) optimize the postal infrastructure, including the best methods for providing retail services that ensure convenience and access to customers; (C) ensure the safety and security of the mail and of postal employees; (D) minimize areas of inefficiency or waste and improve operations involved in the collection, processing, or delivery of mail; and 
(E) impact other matters that the Comptroller General determines are relevant to evaluating a viable longterm business model for the Postal Service. (3) EXPERIENCES OF OTHER COUNTRIES.-In preparing the report required by subsection (a), the Government Accountability Office shall comprehensively and quantitatively investigate the experiences of other industrialized countries that have transformed the national post office. The Government Accountability Office shall undertake such original research as it deems necessary. In each case, the Government Accountability Office shall describe as fully as possible the costs and benefits of transformation of the national post office on all affected parties and shall identify any lessons that foreign experience may imply for each strategy identified by the research organization.

(d) OUTSIDE EXPERTS.- - In preparing its study, the Government Accountability Office may retain the services of additional experts and consultants.

(e) CONSULTATION.-In preparing its report, the Government Accountability Office shall consult fully with the Postal Service, the Postal Regulatory Commission, other Federal agencies, postal employee unions and management associations, mailers, private companies that provide delivery services, and the general public.

The Government Accountability Office shall include with its final report a copy of all formal written comments received under this subsection.

(f) AUTHORIZATION OF APPROPRIATIONS.-There are authorized to be appropriated from the Postal Service Fund such sums as may be necessary to carry out this section.

SEC. 711. PROVISIONS RELATING TO COOPERATIVE MAILINGS.

(a) STUDY.- (1) IN GENERAL.-The Postal Regulatory Commission shall examine section E670.5.3 of the Domestic Mail Manual to determine whether it contains adequate safeguards to protect against- (A) abuses of rates for nonprofit mail; and (B) deception of consumers. (2) REPORT.-The Commission shall report the results of its examination to the Postal Service, along with any recommendations that the Commission determines appropriate. (b) FAILURE TO ACT.- If the Postal Service fails to act on the recommendations of the Commission, the Commission may take such action as it determines necessary to prevent abuse of rates or deception of consumers.

Furthermore, once enacted, reporting requirements remain in place "virtually indefinitely." ${ }^{184}$ This has led to several concerns about the necessity and usefulness of some of them. The latter point was supported by a study of a congressional support agency, the Congressional Research Service discussed in section 3.2.5.1., which concluded that "in a sample of several hundred reports, one-third were 'no longer serving a useful purpose'." 185 While Congress has been undertaking cyclical attempts to reduce the amount of useless, duplicative reports, in the meantime newly enacted acts have been introducing new reporting provisions, making it an everlasting exercise.

\footnotetext{
184 Pray (2005) P. 304.

185 Ibid. P. 301.
} 


\subsubsection{Substantive and procedural statutory requirements regulating agencies' performance}

US IRAs are subject to numerous procedural and substantive statutory requirements ${ }^{186}$ to follow in their operation. These standards are important for political accountability in several respects. First, they make it more feasible to check agencies' performance ex post against the standard laid down in advance. Secondly, such standards impact the scope of political oversight by decreasing agencies' discretion and allowing affected parties directly holding agencies to account. In this way, Congress shares its oversight with the people directly but also with its support institutions when it requires them to oversee agencies. In the words of McCubbins and Schwarz, Congress employs a 'fire-alarm' form of oversight when it establishes various rules and procedures "that enable individual citizens and organized interest groups to examine administrative decisions (sometimes in prospect), to charge executive agencies with violating congressional goals, and to seek remedies from agencies, courts, and Congress itself." 187 This part first introduces eight of the most relevant statutes from an accountability perspective (1-8) which is followed by giving two examples of how the existing statutes do not necessarily serve the purposes they are created for. Finally, the discussion of additional statutory clauses, namely deadline hammers and sunsets and the possibility of agencies' closure, concludes this section.

\section{(1) Administrative Procedure Act}

The Administrative Procedure Act enacted in 1946 and codified in Title 5 of the United States $\operatorname{Code}^{188}(\$ \$ 551$ - 59 and 701 - 706) regulates two internal agency procedures, rulemaking and adjudication, and the issues of judicial review of agency action. The 'notice and comment' procedure of informal rulemaking mentioned earlier (section 3.1.2.3.), but also other types of rulemaking and adjudication, are the issues regulated by the APA. In this way, the APA lays down the basic rules of agency functioning. In addition, "a person suffering legal wrong because of agency action, or adversely affected or aggrieved by agency action within the meaning of a relevant statute, is entitled to judicial review thereof" ( $\$ 702)$. All in all, the APA "established the fundamental relationship between regulatory agencies

\footnotetext{
${ }^{186}$ Among other things, there is a solid body of laws promoting transparency of governmental operation. These include: the Federal Register Act (44 USC $\$ \$ 1501-1511$ ) which requires agencies to publish their proposed and final rules; the Freedom of Information Act (5 USC $\$ 552$ ), which obliges agencies to disclose information about themselves and any material they hold upon request; the Information Quality Act (44 USCA $₫ 3516$ Note), according to which agencies have to issue various guidelines to facilitate comprehension of the disseminated information; and under the E-Government Act (44 USC $\$ 41$ ) agencies have to provide all kinds of information online. ${ }^{187}$ McCubbins and Schwarz (1984) P. 166. (see also section 3.2.5.).

188 The United States Code is a codified consolidation of US federal laws, published each six years by the House of Representatives' Office of the Law Revision Counsel. It is available online at: http://www.law.cornell.edu/uscode/ (last check February 2012).
} 
and those whom they regulate - between government, on the one hand, and private citizens, business, and the economy, on the other hand." 189

\section{(2) The Paperwork Reduction Act}

According to this Act (44 USC $\$ \$ 3501-3521$ ), agencies are required to show how they have minimized the paperwork burden on various groups, including individuals and small businesses. ${ }^{190}$ The Office of Information and Regulatory Affairs (OIRA), created by this Act within the President's Office of Management and Budget (OMB), is responsible for reviewing agency information-collection requirements. The Act covers IRAs, however, they may overrule disapprovals of the OMB by a majority vote (44 USC $\$ 3507$ (f)).

\section{(3) The Federal Advisory Committee Act}

Advisory bodies play an important role in agency decision making. They normally consist of technical experts, representatives of other agencies or affected interest groups, and their role in the process of preparing rules is quite important. The Act (5 USC App. 2) establishes a framework for the creation and operation of advisory committees by agencies. It sets up the requirements for when advisory committees can be created and terminated, how they may operate, and requires that Congress and the public have to be informed about such establishments (\$2). It makes the Administrator of the General Services Administration responsible for all matters relating to advisory committees” (\$7).

\section{(4) The Negotiated Rulemaking Act}

Codified in the APA, this Act (5 USC $\$ \$ 561-570$ ) prescribes the so-called 'reg-neg' procedure, which means that agencies involve interested groups in the drafting of rules. As Lubbers explains,

The essence of the procedure is that in certain situations it is possible to bring together representatives of the agency and the various affected interest groups to negotiate the text of a proposed rule. If they do achieve consensus, the resulting rule is likely to be easier to implement and the likelihood of subsequent litigation is diminished. Even in the absence of consensus $<\ldots\rangle$ the process may be valuable as a means of better informing the regulatory agency of the issues and concerns of the affected interests. ${ }^{191}$

\footnotetext{
189 Shepherd (1996) P. 1558.

190 The law imposes obligations to "minimize the paperwork burden for individuals, small businesses, educational and nonprofit institutions, Federal contractors, State, local and tribal governments, and other persons resulting from the collection of information by or for the Federal Government; <.. improve the quality and use of Federal information to strengthen decisionmaking, accountability, and openness in Government and society; minimize the cost to the Federal Government of the creation, collection, maintenance, use, dissemination, and disposition of information" (\$3501).

${ }^{191}$ Lubbers (2006) P. 172.
} 


\section{(5) The Government in the Sunshine Act}

This Act, embedded into the codified APA ( $\$ 552 \mathrm{~b}$ ), requires multi-member agencies to hold their meetings in public (with limited exceptions to hold meetings behind closed doors) and give advance notice published in the Federal Register about these meetings. "It is based on the policy that: public is entitled to the fullest practicable information regarding the decisionmaking process of the Federal Government." 192

\section{(6) The National Environmental Policy Act}

Pursuant to this Act (42 USC $\$ \$ 4321-4347$ ), all federal agencies are required to "identify and develop methods and procedures which will insure that presently unquantified environmental amenities and values may be given appropriate consideration in decisionmaking" and "include in every recommendation or report on proposals for legislation and other major Federal actions significantly affecting the quality of the human environment, a detailed statement $\langle\ldots\rangle$ on (i) the environmental impact of the proposed action, (ii) any adverse environmental effects which cannot be avoided should the proposal be implemented, (iii) alternatives to the proposed action” (42 USC $\$ \$ 4332$ (2 (B)(C))).

\section{(7) The Regulatory Flexibility Act}

Similar to the previous example, this Act (5 USC $\$ \$$ 601-612) is another example of a statute that requires agencies to "give special attention to certain values during the decisionmaking process." ${ }^{193}$ It requires agencies to consider the potential impact of the proposed rules on small businesses and other small entities with a view to minimizing any significant economic impact on them. For rules with such an impact, the agency must prepare initial regulatory flexibility analysis $(\$ 603)$. This analysis shall describe the impact on small entities and must be published in the Federal Register along with the notice of a proposed rule. After the comment procedure, the agency has to prepare and publish a final regulatory analysis responding to the comments received (\$604). The Act also contains provisions requiring agencies to publish and review the rules that have a significant economic impact on small entities (within 10 years, \$610). Further, the Act provides the requirement of annual reporting on agencies' compliance with the Act. The report has to be prepared by the Chief Counsel for Advocacy of the Small Business Administration and is submitted to the President and Congress (5 USC $\$ 612$ (a)).

\section{(8) Congressional Review Act}

The Congressional Review Act (5 USC $\$ \$ 801-808$ ) obliges all agencies to submit their rules, before they can take effect, to Congress and a congressional support agency, the Government Accountability Office discussed in section 3.2.5.1., for review, upon which rules

\footnotetext{
192 Berg et al. (2007) P. xxxi.

${ }^{193}$ Lubbers (2006) P. 149.
} 
can be disapproved. Upon the submission of any rule, an agency has to submit a statement specifying whether the submitted rule falls under the category of 'major rules. ${ }^{194}$ Such rules are delayed in entering into force for (at least) 60 days. Other rules also have to be submitted to Congress and GAO, but they enter into force as proposed by the agency, even though Congress can still review them and disapprove. Congress has 60 days to review submitted ('major') rules and decide whether it will issue a joint resolution of disapproval, which may be vetoed by the President or enacted over his veto. If the joint resolution of disapproval passes, any rule "shall be treated as though such rule had never taken effect" ( $\$$ 801(f)).

\section{Statutory regulation: the 'warnings'}

Now that a handful of examples have been discussed, it is important to note that not all statutes may serve the purposes for which they were created. Two examples will be discussed here, namely the Government in the Sunshine Act and the Congressional Review Act.

\section{Government in the Sunshine Act?}

The Government in the Sunshine Act has been heavily criticized by US academics ${ }^{195}$ and the commissioners of IRAs because it negates the value of any discussion between the commissioners beforehand since this statute requires multi-member agencies to hold their meetings in public and publish the notice about such meetings in advance. "The Sunshine Act forestalls all spontaneous discussion by more than two members of the Commission about most matters of agency business." ${ }^{196}$ While the act has opened agencies' meetings to public scrutiny, it has done so at costs of the principle of collegiality, ${ }^{197}$ which is suggested to be "the cornerstone of the decisional process at multimember agencies." 198 The openmeeting requirement

Is a barrier to the substantive exchange of ideas among commissioners, hampering our abilities to obtain the benefit of each others' views, input or comments, and hampering efforts to

\footnotetext{
194 The term "major rule" means "any rule that the Administrator of the Office of Information and Regulatory Affairs of the Office of Management and Budget finds has resulted in or is likely to result in - (A) an annual effect on the economy of $\$ 100,000,000$ or more; (B) a major increase in costs or prices for consumers, individual industries, Federal, State, or local government agencies, or geographic regions; or (C) significant adverse effects on competition, employment, investment, productivity, innovation, or on the ability of United States-based enterprises to compete with foreign-based enterprises in domestic and export markets” (5 USC $\$ 804$ (2)).

195 Pierce et al. (1999) P. 479-480; A Report by Federal Trade Commission Chairman William Kovacic 'The Federal Trade Commission at 100: Into Our $2^{\text {nd }}$ Century: The Continuing Pursuit of Better Practices, January 2009. P. 27, to name but a few.

${ }^{196}$ A Report by Federal Trade Commission Chairman William Kovacic 'The Federal Trade Commission at 100: Into Our $2^{\text {nd }}$ Century: The Continuing Pursuit of Better Practices, January 2009. P. 27.

${ }^{197}$ Pierce et al. (1999) P. 479-480.

198 Berg et al. (2007) P. 219-220.
} 
maximize consensus on the complex issues before us. Due to prohibition of private collective deliberations, we rely on written communications, staff, or one-on-one meetings with each other. These indirect methods of communicating clearly do not foster frank, open discussion, and they are less efficient. ${ }^{199}$

A commissioner from an independent agency characterized this act as "a pain in the neck." ${ }^{200}$ This statute has led commissioners to bypass its requirements in a legal way by discussing issues in groups of two and by e-mails, because the commissioners wish to discuss and to negotiate among each other first before facing the public eye. ${ }^{201}$ All in all, while the statute strives for openness, what it seems to have achieved in reality is less openness and less efficiency.

\section{Congressional Review Act and 'underground' legislative vetoes}

Another example is the Congressional Review Act, an arguably unworkable statute that has been applied only once since its enactment (1996). ${ }^{202}$ As its critics state, the statute will raise the costs of rulemaking further while not increasing political accountability for the regulatory system as it requires the preparation of reports for each of the submitted rules, reports that are unlikely to be studied by legislators. ${ }^{203}$ Its 'unworkability' lies in the fact that in order to overturn an agency's decision it requires the passage of a new law within a limited time.

The CRA was passed in delayed response to INS v. Chadha (462 U.S. 919 (1983)), which declared legislative vetoes unconstitutional. A legislative veto is a provision that

\footnotetext{
${ }^{199}$ A Letter from Michael L. Powell, Chairman, and Michael J. Copps, Commissioner, Federal Communications Commission, to the Honorable Ted Stevens, Chairman, Senate Committee on Commerce, Science and Transportation, February 2, 2005, printed in: Berg et al. (2007) P. 344-346.

${ }^{200}$ Commissioner from NLRB (interviewed in April 2011).

201 Ibid.

202 Lubbers (2006) P. 190-192.
}

This exceptional case happened in March 2001 when "the congressional leadership, supported by the Bush administration, used this mechanism to overturn $\langle\ldots\rangle$ controversial ergonomic regulations.” (Ibid. P. 191) The rule entered into force four days before President Clinton left office. President Bush used the Republican-controlled Congress to overturn this measure. As Lubbers states, it was an exceptional case because normally the enactment of disapproval requires the signature of the same President, whose OMB has already cleared the rule or a very rare veto override. He concludes that the number of rules overturned pursuant to the CRA is likely to be low.

${ }^{203}$ Cohen and Strauss (1997) P. 105, 109.

According to Cohen and Strauss "this review process is nothing more than another procedural hurdle for an agency to jump, further increasing the costs and uncertainties of rulemaking, with little, if any, added benefit" (Ibid. P. 106).

Interestingly, some members of Congress argue that there should be even stricter rules for the annulment of agencies' decisions. Recently, there has been a legislative proposal to enact "the Executive In Need of Scrutiny (REINS) Act (H.R. 10 and S. 299, 112th Congress)" that, if adopted, would require "the enactment of a joint resolution of approval before any "major rule" could take effect" (CRS Report for Congress "REINS Act: Number and Types of "Major Rules" in Recent Years, by Copeland C. and Carey M., 2011). 
Congress still sometimes inserts into its legislative acts prescribing the following procedure. An agency takes a decision and sends it to the relevant committee in Congress. Congress has a certain period of time to review the decision. There are two possible outcomes of the review: either Congress reviews but does not undertake any action, in this case upon the expiration of the prescribed period of time the decision enters into force, or Congress issues a one-chamber, two-chamber or even sometimes committee resolution of disapproval, in which case the decision is annulled. ${ }^{204}$

The Supreme Court declared legislative vetoes unconstitutional because their use was against the constitutionally prescribed procedure requiring the agreement of both chambers ('bicameralism') and presentment of the bill to the President (Article I $₫ 7$ ). The majority opinion pointed out that although legislative vetoes are 'convenient shortcuts' and they make it obviously easier to undertake an action by one or two chambers without submission to the President,

It is crystal clear from the records of the Convention, contemporaneous writings and debates, that the Framers ranked other values higher than efficiency. $\langle\ldots\rangle$ The choices we discern as having been made in the Constitutional Convention impose burdens on governmental processes that often seem clumsy, inefficient, even unworkable, but those hard choices were consciously made by men who had lived under a form of government that permitted arbitrary governmental acts to go unchecked. ${ }^{205}$

Interestingly, in his dissent Justice White pointed out the significance of legislative vetoes as an accountability mechanism of Congress:

It has become a central means by which Congress secures the accountability of executive and independent agencies. Without the legislative veto, Congress is faced with a Hobson's choice: either to refrain from delegating the necessary authority, leaving itself with a hopeless task of writing laws with the requisite specificity to cover endless special circumstances across the entire policy landscape, or in the alternative, to abdicate its law-making function to the executive branch and independent agencies. To choose the former leaves major national problems unresolved; to opt for the latter risks unaccountable policymaking by those not elected to fill that role. ${ }^{206}$

According to his dissent, legislative vetoes presented an important compromise between Congress and the executive to include such provisions in return for the broad delegation of powers conferred on the latter. ${ }^{207}$

\footnotetext{
204 Fisher (1993) P. 273.

${ }^{205}$ I.N.S. v. Chadha 462 U.S. 919, 959 (1983).

206 Ibid. at 968.

207 "When President Hoover requested authority to reorganize the government in 1929, he coupled his request that the "Congress be willing to delegate its authority over the problem (subject to defined principles) to the Executive" with a proposal for legislative review. He proposed that the Executive "should act upon approval of a
} 
Whereas legislative vetoes were declared unconstitutional in 1983, since then Congress enacted 400 new legislative vetoes. ${ }^{208}$ It seems that even if declared unconstitutional because they are 'convenient shortcuts' legislative vetoes remain in practice, while the procedurally difficult to apply CRA has been used only once since its adoption. Interestingly, Fisher states that by replacing "the one-house veto in the executive reorganization statute with a joint resolution of approval," the position of the President "was actually worsened. The President now had to obtain the approval of both houses within a specified number of days in order to reorganize executive agencies" whereas before such a plan "automatically became effective within a fixed number of days unless one house acted to disapprove."209

All in all, while statutory regulation is important in decreasing agencies' discretion and setting up a frame of reference for the future check upon agencies, it may also have counterproductive effects. It may incur additional costs on the operation of agencies without necessarily bringing desired benefits.

\section{Additional accountability obligations}

In addition to obliging agencies to follow the mentioned statutory procedural and substantive requirements, Congress can impose immediate sanctions for agencies' non- or slow performance. According to Pierce et al. the response of Congress on the Environmental Protection Agency's mismanagement was the imposition of strict deadlines or schedules to govern EPA's rulemaking. ${ }^{210}$ It was estimated that Congress introduced about 600 deadlines in various environmental statutes between 1970 and $1983 .{ }^{211}$ Normally the enforcement of deadlines can be done only by the courts upon litigation. However, Lubbers points out some other mechanisms that Congress uses in this respect. Thus, Congress imposes not only deadlines but also attaches sanctions, so-called 'hammers', in case of an agency's failure

joint committee of Congress or with the reservation of power of revision by Congress within some limited period adequate for its consideration." Congress followed President Hoover's suggestion and authorized reorganization subject to legislative review. Although the reorganization authority reenacted in 1933 did not contain a legislative veto provision, the provision returned during the Roosevelt Administration and has since been renewed numerous times. Over the years, the provision was used extensively. Presidents submitted 115 reorganization plans to Congress of which 23 were disapproved by Congress pursuant to legislative veto provisions" (I.N.S. v. Chadha 462 U.S. 919, 968-969 (1983)).

Fisher gives a number of examples showing that although presidents saw the necessity of this compromise, they still tried to resist. Thus, for example, President Carter treated legislative vetoes as 'report-and-wait' provisions meaning that "the administration would report to Congress on pending actions, wait a specified number of days, take into consideration the congressional response, and then act in the way the administration decided was best. It would not regard any committee veto, simple resolution [passed by either House], or concurrent resolution [passed by both Houses] these types of resolution as legally binding" (Fisher (1993) P. 285).

${ }^{208}$ CRS Report for Congress "Legislative Vetoes After Chadha", by L. Fisher, 2005. P. 2; CRS Report for Congress “Congressional Oversight Manual” by Kaiser F.M., Oleszek W.J., Tatelman T.B., 2011. P. 104.

${ }^{209}$ Fisher (1993) P. 286.

210 Pierce et al. (2009) P. 49; see, also Magill (1995).

${ }^{211}$ Lubbers (2006) P. 15. 
to meet the deadline. For example, if an agency does not issue a particular rule within a certain period of time, the hammer would fall: the draft rule would enter into force. Another example of the hammer was when Congress gave the Department of Health and Human Services and the Food and Drug Administration 18 months to issue regulations for food imports registration; the hammer in this case, if the deadline was not met, was that importers could have registered in the manner they wished. ${ }^{212}$

Closely related to this mechanism are the deadlines on the programs or specific functions of agencies. Such provisions, which stipulate for how long the program will be in operation, are generally known as 'sunsets'. ${ }^{213}$ Upon the expiration of the deadline, Congress has to reconsider whether the program should be reauthorized. The reasons for Congress to include sunsets include the necessity to test the effectiveness of a program, the appropriateness of allocated finances or the compliance of an agency with a particular delegated function. The accountability value of this mechanism is that Congress obliges itself to review the necessity of federal programs and agencies in the future. However, although the idea behind this was "that democracy needed an alarm clock," 214

"The trouble with sunset clauses is usually they're not enforced, because Congress is either too busy — or, more accurately — too neglectful," said Rep. Jim Cooper (D-Tenn.). He said he still believes in the theory: A "sunset clause is a very appropriate remedy. But it's got to be enforced to mean anything." 215

Congress seems to push back many laws' expiration dates, "often with minimum debate," which has led Fahrenthold to conclude that "the sunset clause has become something unintended: democracy's snooze button."216

At the same time, even without such clauses "what Congress gives, it can (if it chooses) take away. ${ }^{217}$ By its legislative acts it can always modify agency structure, add new functions, oblige an agency to consider additional criteria in its decisions, and abolish an agency. ${ }^{218}$ For example, when the FTC pursued "an unprecedented collection of ambitious antitrust and consumer protection measures" in the 1970s, "Congress eventually narrowed down the FTC's jurisdiction, threatened to terminate major Commission programs, and administered political battering that diminished the agency's effectiveness." 219 Pierce et al.

\footnotetext{
${ }^{212}$ Lubbers (2006) P. 16.

${ }^{213}$ Lifland (1980) P. 209-230.

${ }^{214}$ Fahrenthold (2012).

215 Ibid.

216 Ibid.

${ }^{217}$ Cann (2006) P. 73.

218 "Once created, federal agencies are durable but not immortal. Historically, periods of national upheaval such as wars, economic crises, and public scandals have also been periods of agency reorganization and termination" (Lewis and Selin (2012) P. 95).

${ }^{219}$ Kovacic (1997) P. 923.
} 
also show that the response of Congress on "what it perceived as the mismanagement of the Environmental Protection Agency (EPA)" was the adoption of "detailed substantive criteria to limit how EPA implemented its regulatory responsibilities." ${ }^{220}$ Finally, created by a legislative act, an independent agency may also be abolished by one. The abolition of an agency may be explained by functional needs and agency malpractices. The dissolution of the Civil Aviation Board (CAB) occurred at a time of de-regulation. Although in part the abolition of the $\mathrm{CAB}$ was due to economic reasons, maladministration also played a role there. ${ }^{221}$ Using the power of the purse Congress may 'temporarily' abolish an agency. This is what happened to the Administrative Conference of the United States, an independent advisory agency discussed in section 3.2.5.2., which did not function from 1995 until 2010 because Congress defunded the agency.

Concluding, a number of statutory obligations and possibilities that affect the accountability of IRAs have been discussed in this section. IRAs have to submit various reports to Congress and follow various substantive and procedural requirements in their operation. In addition, Congress has established a review process over agencies' rules with the help of the CRA. Furthermore, Congress can insert deadlines, and sunsets, and appropriation riders on agencies' specific actions to reconsider in the future. Finally, even without deadlines and sunsets Congress can always modify agencies' functional scope and abolish an agency due to functional needs and poor performance.

This section has shown both the existing statutory regulation's value from an accountability perspective and its sometimes troublesome experience. For instance, reporting obligations of US IRAs are formulated in such a way that they promote accountability. They are specific, involve other institutions to check upon agencies and require analytical reporting by prescribing requirements to state reasons and report about ex post results in light of ex ante plans. Furthermore, subjecting agencies to various procedural and substantive requirements influences the scope of political oversight. Specific statutory obligations and procedural and substantive requirements make the ex post check by Congress more feasible because they create a frame of reference to check against. Also, such statutory requirements shift a certain degree of political oversight to congressional support agencies and the affected parties by allowing them directly to hold agencies to account (the fire-alarm oversight). At the same time, this section has shown that not all statutory provisions may serve the purposes they are created for and their great number may hinder both the effective operation of agencies and the feasibility for Congress to have a proper check upon agencies.

\footnotetext{
220 Pierce et al. (2009) P. 49.

${ }^{221}$ Derthick and Quirk (1985) P. 43-44.
} 


\subsubsection{The Annual Appropriations Process: 'The Accountability Venue'}

The power of the purse is often referred to as the most important power of Congress. ${ }^{222}$ The ability to determine the budget of executive institutions allows Congress to control the executive's performance: “approval or disapproval of a commission's work may be tangibly expressed in the Congressional treatment of its budget." ${ }^{23}$ Most importantly from the perspective of this book, the annual appropriations process is where Congress can hold (independent) agencies to account for the spent 'taxpayers' money, sanction and reward agencies for their achievements and failures.

Since the annual appropriations process is a web of complex processes and relationships between the executive, (independent) agencies, and the legislative branch, this section starts with a brief introduction of the steps of this process (3.2.4.1). Various interrelations between IRAs, the President's Office of Management and Budget, and Congress, including special tools of financial control, i.e., appropriations riders and earmarks, are discussed thereafter in sub-section 3.2.4.2. The case of self-funded independent regulatory agencies follows in sub-section 3.2.4.3. As a whole, this section shows that existing numerous formal and informal interrelations as well as strong Congressional formal powers make the annual appropriations process 'The accountability venue' that Congress has in relation to the executive institutions.

\subsubsection{Annual appropriations process: the steps}

The legal basis for the congressional power of the purse derives from a number of constitutional provisions: Article I $₫ 8$ prescribes the power to lay and collect taxes and to borrow money, and Article I $\$ 9$, the so-called 'appropriation clause', states that "no money shall be drawn from the treasury, but in consequence of appropriations made by law." "Thus, unless Congress passes laws to impose taxes, authorizes borrowing or appropriates funds, the executive branch can neither take money from the citizenry nor spend money on behalf of the government." 224 Laws imposing taxes, authorizing borrowing and appropriation bills mean that Congress is in charge of the federal finances, and this in turn puts Congress in a superior position with respect to the other branches and agencies.

\footnotetext{
222 Cushman (1941), Strauss (2002), Beermann (2006), Pierce et al. (2009), Feld (2009), to name but a few.

${ }^{223}$ Cushman (1941) P. 449.

${ }^{224}$ Feld (2009) P. 487.

There are also a number of statutes that supplement the constitutional rules: "appropriations shall be applied only to the objects for which the appropriations were made except as otherwise provided by law" (31 USC $\$ 1301$ (a)); "an officer or employee of the United States Government or of the District of Columbia government may not $<\ldots>$ make or authorize an expenditure or obligation exceeding an amount available in an appropriation" (31 USC $\$ 1341$ ); and "an official or agent of the Government receiving money for the Government from any source shall deposit the money in the Treasury” (31 USC $\$ 3302$ ).
} 
Generally speaking, the budget process can be put in three key steps. First, there is a process of initiation of the federal budget pursuant to the Budget and Accounting Act of 1921 (31 USC). Some refer to the statute as an act that somewhat diminished the power of Congress, because it enhanced the role of the President in preparation of the unified annual budget. ${ }^{225}$ However, as a practical matter, in case of a disagreement between Congress and the President over particular programs and their funding, "Congress will win if it uses its power over the allocation of funds." 226 From a legal point of view, the President merely proposes a budget plan, which can and normally will be modified by Congress.

Second, there is a process of passing a concurrent budget resolution pursuant to the Congress Budget and Impoundment Control Act of 1974 (31 USC). The resolution does not have legal force, and therefore it does not have to be signed by the President. The resolution is "a general budget blueprint for the authorizing and appropriations committees,"227 which indicates the priorities of the whole Congress acting together on how the money should be spent. The resolution does not specify particular programs; rather it allocates the money among different functional categories, and different committees accordingly. After it is passed, the committees have to live within the set boundaries. Each committee thus receives a particular share and allocates it among its programs and sub-committees.

Third, the process of giving and receiving 'real' money is done by the appropriation bills. These should not be confused with the so-called 'authorizations'. "Authorization bills establish, continue, or modify agencies and programs;" 228 they normally determine 'ideal' expenditure estimates for the enacted programs, sometimes including dollar amounts or ceilings. ${ }^{229}$ However, they do not give the addressees the money as such. The appropriation bills are the legislative acts that actually "provide funding for the agencies and programs authorized." ${ }^{230}$ Although the difference between the two seems to become less and less clear, (as opposed to the practice in the $19^{\text {th }}$ century), ${ }^{231}$ they can still be very well distinguished from each other by the language they use: “...hereby authorized to be appropriated" or “...hereby appropriated." 32

\footnotetext{
${ }^{225}$ Beermann (2006) P.85.

226 Ibid.

${ }^{227}$ Organization of the Congress, Final Report of the Joint Committee on the Organization of Congress, December, 1993. Find at: http://democrats.rules.house.gov/archives/jcoc2.htm (last checked February 2012).

${ }^{228}$ CRS Report for Congress “The Congressional Appropriations Process: An Introduction” by Streeter S., December 2010. P. 22.

229 "Authorization is $\langle\ldots\rangle$ a political action which allows individual members of Congress to stand before TV cameras and say that they have authorized all those programs. Authorization does not imply appropriation or giving actually those amounts of money that are stated in law" (Former Official from SEC (interviewed in May 2011)).

${ }^{230}$ Organization of the Congress, Final Report of the Joint Committee on the Organization of Congress, December, 1993.

231 Ibid.

232 Ibid.
} 
The recent development with the Securities and Exchange Commission (SEC) is an illustrative example with respect to drawing the distinction between authorized and appropriated money. In 2010, Congress amended SEC's founding act, namely the Securities and Exchange Act of 1934 (Section 35), by strengthening SEC's authority, which implied also increasing the budget of the agency, as recognized when Congress inserted new authorization levels into its amendment. The SEC was authorized to receive - $\$ 1.3$ billion for fiscal 2011; $\$ 1.5$ billion for fiscal 2012, \$1.75 billion for fiscal 2013, \$2 billion for fiscal 2014, and $\$ 2.25$ billion for fiscal 2015 . However, as the agency is not self-funded in the sense of 'self-budgeting', these amounts in the authorization act do not mean that the SEC will automatically get the prescribed amounts of money. The act passed Congress when it had a Democratic majority. After the House election of November 2010 the Republican majority, which did not share the same pro-regulatory sentiment as its predecessor, appropriated less money to the SEC. In fact, the SEC's spending authority was \$ 1.1 billion in 2011 (instead of $\$ 1.3$ billion authorized) ${ }^{233}$ and $\$ 1.3$ billion in 2012 (instead of 1.5 billion authorized). ${ }^{234}$ Thus, even though this agency's remit has been expanded with more powers and programs, the execution of those programs depends on the money given each year. The annual appropriations do not have to correspond to the dollar amounts prescribed by Congress in its authorization acts. Moreover, "the division between an authorization and an appropriation applies to congressional consideration. If unauthorized appropriations or legislation remain in an appropriations measure as enacted, either because no one raised a point of order or the House or Senate waived the rules, the provision will have the force of law." 35 Thus, contrary to the SEC's example, some agencies may receive annual appropriations even though their programs may not have been formally (re)authorized.

Table 3.1. shows the steps of the annual appropriations process, with a short description of the procedure as well as deadlines and relevant legal provisions.

\footnotetext{
233 In Brief FY 2012 Congressional Justification prepared by the SEC, February 2011.

${ }^{234}$ In Brief FY 2013 Congressional Justification prepared by the SEC, February 2012.

${ }^{235}$ CRS Report for Congress “The Congressional Appropriations Process: An Introduction” by Streeter S., December 2010. P. 24.
} 
Table 3.1. The annual appropriations process in the US

\begin{tabular}{|c|c|c|c|c|c|}
\hline 岕 & Initiative -> & $\begin{array}{l}\text { Crafting } \\
\text { the resolution }->\end{array}$ & $\begin{array}{l}\text { Concurring } \\
\text { Budget } \\
\text { Resolution -> }\end{array}$ & $\begin{array}{l}\text { Allocation among } \\
\text { committees }->\end{array}$ & $\begin{array}{l}\text { Appropriation } \\
\text { bills }\end{array}$ \\
\hline 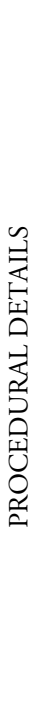 & $\begin{array}{l}\text { The President } \\
\text { initiates a budget } \\
\text { proposal which } \\
\text { is then submit- } \\
\text { ted by the } \\
\text { Congressional } \\
\text { Budget Office } \\
(\mathrm{CBO}) \text { to the } \\
\text { Budget Com- } \\
\text { mittees of both } \\
\text { houses. }\end{array}$ & $\begin{array}{l}\text { Each congressional } \\
\text { committee submits } \\
\text { proposals on all } \\
\text { budget matters within } \\
\text { their jurisdiction to } \\
\text { the respective } \\
\text { House/Senate Budget } \\
\text { Committee. } \\
\text { (The Budget Commit- } \\
\text { tees consult respective } \\
\text { legislative committees } \\
\text { during preparation, } \\
\text { consideration, and } \\
\text { enforcement of the } \\
\text { resolution.) }\end{array}$ & $\begin{array}{l}\text { Both cham- } \\
\text { bers agree on } \\
\text { a budget } \\
\text { resolution. }\end{array}$ & $\begin{array}{l}\text { Each committee receives its } \\
\text { share and allocates the } \\
\text { money among its programs } \\
\text { and sub-committees. } \\
\text { The House may begin with } \\
\text { the appropriation bills, } \\
\text { which are then sent to the } \\
\text { relevant Senate committees. } \\
\text { (It is the House that tradi- } \\
\text { tionally starts consideration } \\
\text { on all appropriation bills). } \\
\text { The money allocated within } \\
\text { the House Appropriations } \\
\text { Committee is divided } \\
\text { between discretionary and } \\
\text { mandatory programs and } \\
\text { other categories (pursuant } \\
\text { to a certain act). }\end{array}$ & $\begin{array}{l}\text { House Appro- } \\
\text { priations Com- } \\
\text { mittee report the } \\
\text { last appropria- } \\
\text { tion bill and } \\
\text { later completes } \\
\text { the action on } \\
\text { annual appropri- } \\
\text { ation bills } \\
\text { Several appro- } \\
\text { priation bills } \\
\text { packed together } \\
\text { are often passed } \\
\text { as omnibus } \\
\text { appropriation } \\
\text { bills. }\end{array}$ \\
\hline 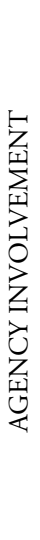 & $\begin{array}{l}\text { With limited } \\
\text { exceptions, } \\
\text { agencies first } \\
\text { submit their } \\
\text { proposals to the } \\
\text { Office of Man- } \\
\text { agement and } \\
\text { Budget (OMB) } \\
\text { for review. The } \\
\text { completed } \\
\text { review of the } \\
\text { OMB is submit- } \\
\text { ted to the } \\
\text { President. }\end{array}$ & $\begin{array}{l}\text { In preparing the } \\
\text { resolution the Com- } \\
\text { mittees on Budget } \\
\text { hold hearings where } \\
\text { they receive testimony } \\
\text { from the members of } \\
\text { relevant committees as } \\
\text { well as appropriate } \\
\text { agencies. }\end{array}$ & & $\begin{array}{l}\text { Here again agencies may } \\
\text { negotiate or be asked to } \\
\text { attend hearings about } \\
\text { various programs and their } \\
\text { funding. }\end{array}$ & \\
\hline
\end{tabular}




\begin{tabular}{|c|c|c|c|c|c|}
\hline 资 & $\begin{array}{l}\text { First Monday in } \\
\text { February for the } \\
\text { President and } \\
\text { February } 15 \text { for } \\
\text { the CBO }\end{array}$ & $\begin{array}{l}\text { Within six weeks of } \\
\text { the President's sub- } \\
\text { mission }\end{array}$ & April 15 & May 15 & $\begin{array}{l}\text { June } 10 \text { and } 30 \\
\text { October } 1-\text { the } \\
\text { fiscal year } \\
\text { begins. }\end{array}$ \\
\hline 点 & $\begin{array}{l}\text { Budget and } \\
\text { Accounting Act } \\
\text { of } 1921 \\
\text { (31 USC 1105) } \\
\text { and The Con- } \\
\text { gressional } \\
\text { Budget Act as } \\
\text { amended (Sec- } \\
\text { tion 300) }\end{array}$ & $\begin{array}{l}\text { The Congressional } \\
\text { Budget Act as amend- } \\
\text { ed (Section 300, } 301 \\
\text { (e)) }\end{array}$ & $\begin{array}{l}\text { The Congres- } \\
\text { sional Budget } \\
\text { Act as } \\
\text { amended } \\
\text { (Section 300) }\end{array}$ & $\begin{array}{l}\text { The Congressional Budget } \\
\text { Act as amended (Section } \\
300,302,303)\end{array}$ & $\begin{array}{l}\text { The Congres- } \\
\text { sional Budget } \\
\text { Act as amended } \\
\text { (Section 300) }\end{array}$ \\
\hline
\end{tabular}

\subsubsection{Annual appropriations process: formal and informal relationships and tools}

During the annual appropriations process agencies may interact with both the executive and legislative branches' institutions. This section discusses various relationships of IRAs with the President's Office of Management and Budget (OMB) and with various congressional committees to which they belong, by jurisdiction and the appropriations committees. In addition, Congress has two special tools of financial control, i.e., appropriation riders and earmarks, discussed hereafter.

\section{IRAs and the $O M B$}

The annual appropriations process starts with all institutions sending their budget drafts to the President's OMB, which must prepare a 'consolidated version' for Congress. In relation to the executive branch institutions, OMB looks at the submitted proposals and discusses them, thus approving or modifying the requested amounts. The role of the OMB in relation to the draft budget submissions from IRAs, however, varies greatly.

The situation with the submissions of budget proposals of IRAs to the OMB differs from agency to agency. Breger and Edles observe that before 1939 all independent agencies submitted their proposals directly to Congress even when the OMB was already in place (since 1921). In 1939, the Reorganization Act changed the situation by obliging agencies to submit their drafts to the OMB. However, in the 1970s Congress explicitly started to in-

\footnotetext{
${ }^{236}$ The deadline of September 30 is clearly not always met in practice and if the disagreement between the two chambers of Congress and /or with the President continues too long, the government can be shut down (e.g., in 2013).
} 
clude every now and then provisions allowing individual agencies to submit their budgets, legislative proposals, or views on legislation directly to Congress. ${ }^{237}$

Today, there are thus IRAs that are exempted from OMB clearance, ${ }^{238}$ those that submit their budgets for OMB's approval and those that submit their budget drafts to the $\mathrm{OMB}$ and simultaneously to Congress to let Congress know about their wishes directly. ${ }^{239}$ The reasons for such a diverse situation are unclear, but their roots could be traced to the practices established prior to and after the 1939 Reorganization Act and could perhaps be connected with personal interrelationships between the President and the commissioners of IRAs.

\section{IRAs and congressional committees}

Having prepared its budget proposal, which is basically a strategic plan for the year to come, agency representatives start to prepare for their (regular) visits to Congress. They can be invited to attend hearings in the respective congressional sub-committees and committees. They have to be prepared to answer and to provide all required information on all kinds of questions concerning the programs they supervise, their effectiveness, and expectations. Recalling Table 3.1. above, the same issue can be debated several times - during consideration of the budget resolution and the defence of the appropriation bill ${ }^{240}$ which takes place before appropriations and the 'jurisdictionally relevant' committees, which play an important role here:

The Appropriations Committee is probably one of the best committees at oversight. Having departments and agencies come before the Committee year after year in order to justify their budgets, brings forward a lot of information. $\langle\ldots\rangle$ we traditionally have about 10,000 witnesses appear before the Appropriations Committee through its thirteen subcommittees. That

\footnotetext{
${ }^{237}$ Breger and Edles (2000) P. 1151-1153.

${ }^{238}$ With respect to several independent and executive agencies in the financial field there is law that exempts them from sending their draft budgets to the OMB. "No officer or agency of the United States shall have any authority to require the Securities and Exchange Commission, the Board of Governors of the Federal Reserve System, the Federal Deposit Insurance Corporation, the Comptroller of the Currency, the Director of the Office of Thrift Supervision, the Director of the Federal Housing Finance Agency, or the National Credit Union Administration to submit legislative recommendations, or testimony, or comments on legislation, to any officer or agency of the United States for approval, comments, or review, prior to the submission of such recommendations, testimony, or comments to the Congress if such recommendations, testimony, or comments to the Congress include a statement indicating that the views expressed therein are those of the agency submitting them and do not necessarily represent the views of the President” (12 USC \$250).

${ }^{239} \mathrm{My}$ empirical research findings show that some agencies have to have a final approval of the OMB and even defend their OMB-set budget in Congress (the OSHRC and the FMC). In the case of the FERC, which is statutorily 'an independent agency within the Department of Energy', it receives its budget formally from this executive department, the Department of Energy. Furthermore, there are agencies that submit their budgets to the OMB but also 'let Congress know' about their desires (the FTC).

${ }^{240}$ Organization of the Congress, Final Report of the Joint Committee on the Organization of Congress, December, 1993. Find at: http://democrats.rules.house.gov/archives/jcoc2.htm (last checked February 2012).
} 
amounts to about 700 hearings days over a two year period. We publish approximately one 100,000 pages of hearing transcripts in any given Congress. We're one of the largest job orders in the Government Printing Office." 241

Furthermore, each jurisdictionally relevant committee, "knowing that it will receive a fixed amount of the total to be included in a budget resolution, has an incentive to scrutinize existing programs to make room for new programs or expanded funding of ongoing projects or to assess whether programs have outlived their usefulness." ${ }^{42}$ Thus, year after year, agencies have to defend their budgets and programs before these committees and their subcommittees; this leads to developing close relations with 'their' committees. Individual congressional committees have a good overview over 'their' agencies and may have more influence over them, also because IRAs' budgets are not often the subject for debate outside the relevant committees:

while debates over general spending levels and major programs such as the Defense budget are common in the two chambers, regulatory agency budgets are a small part of overall national expenditures. $<\ldots>$ In 2001, for example, the EPA regulatory budget was about $\$ 7.3$ billion; the Securities and Exchange Commission, about \$ 438 million; the Federal Trade Commission, about \$ 147 million. In comparison, that year's defense budget was $\$ 296.3$ billion, the total national budget for the year was $\$ 1.856$ billion. ${ }^{243}$

In comparison, the budget of the Netherlands was around 100 billion Euro ${ }^{244}$ and the EU15 budget of 2001 was approximately 95 billion Euro. ${ }^{245}$

\section{Informal procedures}

Informal procedures during the annual appropriations process are as important as formal ones, if not more so. The 'informalism' in this relationship can be brought down to two aspects.

First, any statute, be it a statute creating an agency or a statute appropriating funds to it, is supported by a committee report. Such reports normally explain the bills and what relevant institutions, such as IRAs, are deemed to do, the aim of the legislation, the choices made, the money agencies are supposed to spend on what programs, etc. These reports do

\footnotetext{
${ }^{241}$ Kedzior D. (former staff member of the House Appropriations Committee) in: The committee print of "Congressional Oversight: A "How-to" Series of Workshops, sponsored by the Speaker and the Chairman, House Rules Committee, organized and conducted by the CRS, 1999. P. 155.

${ }^{242}$ CRS Report for Congress "Congressional Oversight Manual" by Kaiser F.M., Oleszek W.J., Tatelman T.B., 2011. P. 17.

${ }^{243}$ Strauss (2002) P. 79.

244 This information is taken from the official web-page of the Dutch Statistical Bureau. Find at: http://www.cbs.nl/nl-NL/menu/themas/overheid-politiek/cijfers/extra/belasting-animatie.htm (last check February 2012).

${ }^{245}$ EU Budget 2007: Financial Report, 2008. P. 75.
} 
not have the legal force of law but are followed with great precision by agencies. Should an agency decide not to follow what the report prescribes it to do and how much money to spend, it will face a decrease of its funds or other sanctions. According to Shapiro,

If the committees do not get what they want in year one the result will be extremely uncomfortable budget hearings and perhaps an extremely uncomfortable budget for the agency in year two and, by about year three, amendments the agency does not want to the legislation that defines its structure and missions. Keeping Congress happy is as important as keeping the President happy to most agencies and is more important to the independent agencies. ${ }^{246}$

Second, if a change of the appropriated funding throughout the year is required, it does not go via the formal law-making procedure. Previously, the practice was that the appropriation bills included 'line item' detailed prescription of allocation of certain funding to particular actions. In case of a change, a new act or amendment to the appropriation bill was to be passed. Later, however, with the growth of government under F.D. Roosevelt, Congress began another practice by enacting broad, 'lump-sum' appropriations, relying on the informal non-binding 'reprogramming' agreements with agencies. ${ }^{247}$ Thus, if an agency needs to reallocate money from the implementation of one program to another, it seeks an informal authorization from the relevant committee. The reasons for such a change were speeding up the appropriations process, making less costly preparations of annual appropriations bills (than would have been the case if they were detailed), and enhancing the flexibility that was favored by both Congress and agencies in the implementation of appropriation bills provisions. Being authorized by Congress to do so, agency decisions to reallocate funds from one activity to another are not judicially reviewable. ${ }^{248}$ What also strengthens congres-

\footnotetext{
246 Shapiro (1996) P. 28.

247 Stith (1988) P. 643.
}

On the one hand, some scholars hold the view that these 'informal reprogramming agreements' are unconstitutional. Indeed, they are supplementary to the legislative acts and are not passed by the constitutionally prescribed legislative procedure. They are, however, authoritative, allowing agencies to redirect the funds. According to Stith (Stith (1988) P. 648)), however, Congress must make laws by statutes, and reallocation of funding seems to be a law-making activity, therefore, these informal agreements should not be treated as authoritative. The current situation with the informal relationship "illuminates an arena where Congress itself speaks authoritatively to the executive branch [and IRAs] through committees and committee report language, though without the force of law" (Roberts (2001) P. 564).

On the other hand, other scholars, such as Fisher, argue that "nonstatutory controls meet the needs of both branches. Neither Congress nor the agencies are always certain of the specifics to be included in a statute. When judgments and predictions are wrong, the statute has to be rewritten. Putting guidelines and details in nonstatutory sources adds valuable flexibility to the legislative and administrative process" (Fisher (2007) P. 99).

248 "The allocation of funds from a lump-sum appropriation is another administrative decision traditionally regarded as committed to agency discretion. After all, the very point of a lump-sum appropriation is to give an agency the capacity to adapt to changing circumstances and meet its statutory responsibilities in what it sees as the most effective or desirable way" (Lincoln v. Vigil, 508 U.S. 182, 192 (1993)). 
sional power of the purse is that the President cannot oblige agencies to reallocate funds otherwise than as prescribed by law. ${ }^{249}$

\section{Additional tools of financial control}

There are also two additional tools that the members of Congress can use in relation to agencies' budgets. They can either prohibit allocation of the budget to a specific program or explicitly direct agencies to implement one or another program, even if the agency does not have an explicit authorization to do that. These are appropriations riders and earmarks.

Appropriations riders take the form of a statutory provision inserted into appropriation bills that "single out a specific regulatory activity and prohibit the expenditure of funds for carrying out that regulatory activity or plan." ${ }^{250}$ Often they are temporary measures. Such provisions can be added on the floor by an individual member. In this light, Congress (or more likely its individual members) acts very cleverly, as these provisions are exempted from the all previous stages of discussion and negotiation and the riders are more likely to pass in a general appropriation bill than in the shape of separate statute, as the likelihood that the President will overturn the whole appropriation bill 'just' because of a 'tiny' rider is much smaller.

Beermann gives a number of examples when Congress has used this tool. Thus, for instance, he refers to the ergonomics policy of President Clinton as an example where Congress was not willing to allocate any funds for its exercise; the relevant appropriation bill stated the following: "none of the funds made available in this Act may be used by the Occupational Safety and Health Administration directly or through section 23(g) of the Occupational Safety and Health Act to promulgate or issue any proposed or final standard or guideline regarding ergonomic protection."251

Appropriations riders may also be used for some other purposes. They may be, for instance, attached as hammers to the deadlines (discussed in section 3.2.3.2.). Thus, these 'deadlines hammers' mean that unless an agency enforces certain rules by a specific deadline, the money for certain programs will be withheld. As was previously mentioned, Congress may use appropriations riders also as a tool for the removal of unsatisfactory officials (see section 3.2.2.2.).

Although this mechanism is undoubtedly an effective tool for Congress to make agencies follow its commands, there are issues to take into account. Some scholars express their concerns about the interference or even the pressure of Congress on the President, and his

\footnotetext{
${ }^{249}$ This issue was addressed in Train v. City of New York 420 U.S. 35 (1975) where the Supreme Court rejected the attempt of the President to allocate the funding of the program otherwise than it was prescribed to be allocated by law.

${ }^{250}$ Beermann (2006) P. 85.

${ }^{251}$ Ibid. P. 86 (citing Omnibus Consolidated Rescissions and Appropriations Act of 1996, Pub. L. No. 104-34, $\$$ 102, 110 Stat. 1321 (1996)).
} 
veto power as President, if he agrees with the entire bill, except riders, is likely to accept the bill. ${ }^{252}$ Others state that because this can be added on the floor by individual members at any time, many members of Congress may not even be aware of their presence, thus, "they often fly below the political radar." ${ }^{253}$ In his comprehensive article on appropriations riders, Devins argues that while they are sometimes necessary, "the appropriations process is not the proper vehicle for substantive policymaking." ${ }^{254}$ However, some scholars defend this tool because the use of riders "allows Congress to control important aspects of the execution of the law in ways that appear to impinge on the discretion of executive branch officials." 255

Earmarks are another method for Congress to allocate funds for very specific programs, but these have the opposite effect to appropriations riders. The earmarked money is given to agencies to run some parallel programs that are not directly or explicitly mandated to agencies as such, but are not explicitly forbidden either. The earmarks are generally created by the committees to which agencies are assigned or from which agencies receive their money. Beermann gives an example of earmarks in the area of endangered species where Congress made the relevant agency take steps to protect species that it would not have taken otherwise. ${ }^{256}$ Thus, Congress may guide agencies' functional course and even direct agencies' focus towards activities which they would not otherwise undertake.

Earmarks are also not without criticism. Many members of Congress use this possibility to get money from the federal budget for their constituencies (e.g., for road building, new federal research labs, etc.) that otherwise, as they claim, would be ignored by federal agencies. Because of the cumulatively adverse effect of earmarks on the federal budget deficit, their implementation and considerations about how to make their usage more difficult have been debated in Congress more and more often. ${ }^{257}$

\subsubsection{The case of self-funded IRAs}

Whereas the majority of IRAs are financed from the US federal budget, there are three (out of 16) US IRAs that are self-funded in the sense of self-budgeting, namely the Board of Governors of the Federal Reserve System (the Fed), the Federal Deposit Insurance Corporation (the FDIC), and the Federal Housing Finance Agency (the FHFA). Since there is no

\footnotetext{
252 Beermann (2006) P. 88.

${ }^{253}$ Ibid.

${ }^{254}$ Devins (1987) P. 456.

${ }^{255}$ Beermann (2006) P. 86-87.

256 Ibid. P. 89.

257 Ibid.
}

Interestingly, in 2010 the House introduced stricter rules against using earmarks, which accounted "for \$15.9 billion of federal spending in the fiscal year that ends September 30, less than 1 percent of the federal budget that Congress controls directly. That [wa]s down from an earmark total of \$29 billion in fiscal 2006” (Sullivan (2010)). 
constitutional or other provision establishing the criteria of when an independent or selffunded agency should be created, it is up to Congress to decide when an agency will be made self-funded. Self-funded agencies are financed directly from the money they receive either for services they provide, or other sources. For instance, the Fed's income includes interest income on securities and the sale of US Treasury securities. The self-funded independent regulatory agencies should not be confused with other IRAs which receive fees for their services but remain subject to congressional financial oversight, such as the Securities and Exchange Commission (SEC) or the Federal Energy Regulatory Commission (FERC):

The SEC "self-funds" 100\% of its annual appropriated budget," "under a 1996 amendment to Section 31(a) of the Securities Exchange Act, the money comes entirely from "transaction fees and assessments that are designed to recover the costs to the Government of' the entire SEC budget. Under this provision, the SEC adjusts its fee levels up or down several times each year to fully cover its budget. ${ }^{258}$

However, while this agency does not require the 'tax dollars', it still needs to go through the annual appropriations process before Congress requesting appropriations annually.

The idea behind making an agency actually self-funding is to promote its independence and the credibility of political compromises in the given field of regulation, such as the financial field. The fact that an independent agency is dependent on Congress for finance implies that Congress decides how much money the agency receives but also for what programs, because at the end of the day money translates into agency activities. The agency has thus less functional discretion because it is dependent on Congress for finance. Conversely, a self-funded agency governs its budget and hence activities on its own. As was mentioned earlier, the Fed is one of three self-funded IRAs, which escapes financial oversight from Congress. This makes it the master of its own money, not dependent on political majorities in Congress, and hence the master of its policy. As for its financial accountability, "the financial statements of the Federal Reserve Banks and the Board of Governors are audited annually by an independent outside auditor." 259

The main accountability implication of having a self-funded agency for Congress is that Congress misses one of its most important weapons in checking upon a self-funded agency, namely its financial oversight tool. Also, such a construction may increase the risk of 'inappropriate closeness to its related industry'. ${ }^{260}$ Making an agency self-funded does not, however, mean that Congress loses any possibility to hold it to account. A self-funded agency

\footnotetext{
${ }^{258}$ Crimmins S. Bad reasons to De-fund the SEC, Securities and Regulation Report, 02.07.2011, BNA. P. 1-2.

${ }^{259}$ This information is taken from the official web-page of the agency. Find at: http://www.federalreserve.gov/faqs/about_12798.htm (last check January 2012).

${ }^{260}$ Strauss (2002) P. 80.
} 
Would always remain subject to Congressional oversight. If Congress is concerned, it can call hearings to demand explanations, and if still not satisfied Congress can legislate to correct any perceived problems. The [self-funded] banking agencies remain keenly aware that they must use their self-budgeting power prudently, or Congress will modify it or take it away entirely. ${ }^{261}$

These are the arguments of the proponents of the reform to make the SEC a truly selffunded independent agency. ${ }^{262}$ The argument in rebuttal is that the regularity of the annual appropriations procedure and the interactions it provides is something else than having individual (ad hoc) inquiries into the agency's activities in the course of congressional oversight, to be discussed in section 3.2.5. Therefore, if Congress wants to keep the financial oversight option available and decrease the risk of industry influence, it chooses to have agencies' fees collected in one place (the Department of Treasury), and then, irrespective of who put how much money in the 'treasury box', distribute the funding in the course of the annual appropriations process. ${ }^{263}$

Concluding, taking into account the amount and nature of interactions that Congress can have with IRAs during its financial oversight it is not surprising that "the annual appropriations process is widely regarded as the principal venue for the oversight activities in Congress." 264 The appropriations process takes place regularly, once a year, allowing for numerous formal and informal interactions between Congressional appropriations and authorization committees and (independent) agencies. It involves the discussion of finances but also agencies' performance, because money translates into agencies' activities. This venue provides rewarding and sanctioning possibilities, including the possibilities of giving more or less money or allowing an agency do more or less with the help of earmarks and appropriation riders. Furthermore, the enhanced strength of congressional financial oversight over independent regulatory agencies also comes from the fact that IRAs are more distant from the President, hence they may miss the latter's protection and may escape the check of the President's OMB. Also, the fact that the budgets of IRAs are quite small may result in increasing the role of a few congressional committees with respect to 'their' agencies' budgets, because the floor debates tend to target the 'bigger fishes', such as the budget of the Department of Defense. Finally, the fact that the discussion of money involves the

\footnotetext{
${ }^{261}$ The testimony of Stephen J. Crimmins (K\&L Gates partner and a SEC's former senior officer) before the House of Representatives Committee on Government Oversight and Reform, Subcommittee on Government Organization, Efficiency and Financial Management and Subcommittee on TARP and Financial Services Joint Hearing "Financial Management, Work Force and Operation at the SEC: Who's Watching Wall Street's Watchdog?”, March 10, 2011. P. 5.

262 Ibid.

263 Strauss (2002) P. 80.

${ }^{264}$ Keith R. (CRS specialist) in: The committee print of "Congressional Oversight: A "How-to" Series of Workshops, sponsored by the Speaker and the Chairman, House Rules Committee, organized and conducted by the CRS, 1999. P. 145.
} 
discussion of agencies' actions can affect the scope of agencies' functional discretion, which is more protected when agencies are truly self-funded because the self-funded agencies escape congressional financial oversight. Making an agency self-funded does not, however, imply having no accountability relationship with it, as Congress can always scrutinize its performance using another strong power of congressional oversight.

\subsubsection{Congressional Oversight: Strengths and Challenges}

"Quite as important as lawmaking is vigilant oversight of administration." ${ }^{265}$ Oversight is "the review, monitoring, and supervision of the executive and the implementation of public policy." 266 This power allows Congress to gather information in order to exercise its continuous supervision of the implementation of statutory programs and also to conduct special investigations. This section discusses congressional oversight in two parts. First, it focuses on the 'what, why and how' issues of oversight (3.2.5.1.) and then pinpoints the challenges that this congressional tool faces (3.2.5.2.). This section shows that the strengths of congressional oversight are based on strong formal powers, wide scope, and solid support that Congress can rely on. The greatest challenge is, however, the weak incentives of the people's representatives to be involved in this time- and resource-consuming activity, which does not necessarily bring individual political benefits.

\subsubsection{Congressional oversight: what, why, and how}

This section introduces the congressional power to oversee the executive. It does it in three sections. First it defines oversight and its processes (1). Second, it discusses the purposes that congressional oversight pursues (2). The third part focuses on the issue of 'how', which involves the discussion of congressional oversight's legal basis and limits, tools to obtain information and support upon which Congress can rely in scrutinizing the executive (3). As a whole, this section shows that the strengths of congressional oversight lie with the broad scope of this power, strong formal powers, and a solid expert support upon which Congress relies and to whom Congress can shift to a certain degree its oversight responsibility.

\section{(1) What is congressional oversight?}

Gathering information in the course of the annual appropriations, or of a more periodic reauthorization process, is an oversight activity as well as a congressional investigation into a particular program, agency or event. Congressional oversight can be thus defined broadly and narrowly. In addition, various forms of congressional oversight can be distinguished. In

\footnotetext{
265 Wilson (1885) P. 297.

${ }^{266}$ Organization of the Congress, Final Report of the Joint Committee on the Organization of Congress, December, 1993. Find at: http://democrats.rules.house.gov/archives/jcoc2.htm (last checked February 2012).
} 
their landmark article, McCubbins and Schwarz discuss two forms of congressional oversight - fire-alarm and police-patrol oversight. ${ }^{267}$ Whereas the narrow and broad understandings of oversight help to define the processes where congressional oversight can take place, its two forms help to capture the ways Congress can oversee the executive. Here, the two definitions and forms of congressional oversight are introduced.

Oversight in a broad sense should be understood as gathering information, which includes written as well as oral means of obtaining information, that can take place within various processes, such as the annual appropriations process, reauthorizations, and, occasionally, impeachment. ${ }^{268}$ A confirmation hearing of a potential head of an agency at the Senate can be seen as an oversight activity, too. Here, the Senate can scrutinize the President's choice and follow-up later on whether the nominee fulfills the commitments made during the confirmation hearing. Also, the introduction, processing, and passage of a piece of legislation may involve consultations with agencies that produce oversight. ${ }^{269}$ Within all these processes agencies' representatives may be requested to provide (more and better) information about their activities, results and failures and justify their choices and decisions. Congressional oversight in a broad sense is thus (continuous) supervision over the executive taking place within various processes and serving the ends of those processes. With respect to IRAs, congressional oversight becomes the only possible continuous supervision because presidential oversight is rather limited.

Oversight can also be understood in a narrow sense, which implies investigative oversight. Individual members, congressional committees and sub-committees, staff or outside personnel under contract, and congressional support agencies may conduct investigations into specific agencies, their programs or (tragic) events and (political) scandals, such as the Watergate Committee investigation into Nixon's administration in the 1970s. Such investigations take place on an ad hoc basis and their main purpose is "to bring the relevant facts to light." ${ }^{270}$ In this case the primary objectives of investigative oversight are to obtain information and to prepare a report with a view of finding out what has happened with that particular institution, program or event to inform the public about it. The consequences for the guilty may take place afterwards within other processes, such as the removal of relevant officials, financial sanctions and (criminal) proceedings in courts.

In addition to the broad and narrow understandings of congressional oversight, McCubbins and Schwarz identify two specific types of congressional oversight: policecontrol and fire-alarm.

\footnotetext{
${ }^{267}$ McCubbins and Schwartz (1984).

${ }^{268}$ CRS Report for Congress "Congressional Oversight Manual” by Kaiser F.M., Oleszek W.J., Tatelman T.B., 2011.P. 16-23.

${ }^{269}$ Aberbach (1990) P. 220.

270 Pray (2005) P. 307.
} 
The police-patrol oversight implies that Congress examines an executive agency's activities on its own initiative. Its aim is to detect and remedy any violation of legislative goals and, by its random check, to discourage such violations. How does Congress do that? It can study various documents and studies, conduct field observations, and hold hearings to question officials and potential affected parties. ${ }^{271}$

The fire-alarm oversight implies "establishing a system of rules, procedures, and informal practices that enable individual citizens and organized interest groups to examine administrative decisions (sometimes in prospect), to charge executive agencies with violating congressional goals, and to seek remedies from agencies, courts, and Congress itself." 272 The statutes regulating agencies' performance discussed in section 3.2.3.2 contain provisions that enable interested parties to participate in agencies' decision-making processes and the affected parties to see remedies in courts. Here, "instead of sniffing for fires, Congress places fire-alarm boxes on street corners, builds neighborhood fire houses, and sometimes dispatches its own hook-and-ladder in response to an alarm." 273

McCubbins and Schwarz wrote their article in 1984 in response to the prevailing view at that moment that Congress had neglected its oversight function which was understood as conducting police-patrolling oversight. Indeed, if one thinks about the difficulties the police-patrolling form of oversight faces, Congress faces a hopeless task of overseeing a huge administration with an incredible amount of programs and institutions. The police-patrol form of oversight is time- and resource-consuming. Members of Congress "spend time examining a great many executive-branch actions that do not violate legislative goals or harm any potential supporters." 274 Placing various fire-alarm boxes could also be time- and resource-consuming but they have a greater potential to spot the fire. If in case of policepatrol oversight only a sample of activities is possible to be examined, the fire-alarm increases the number of overseeing eyes and shifts to a certain extent its oversight responsibility to the potential interested or affected parties. In this way, it may ensure that while it may seem that "no one controls [an agency], yet it is clearly under control." ${ }^{275}$ In employing both forms of oversight Congress decreases the degree of unchecked actions and increases the range of possibilities for both the public and 'the powerful' to be informed and in check. ${ }^{276}$

\footnotetext{
${ }^{271}$ McCubbins and Schwarz (1984) P. 166.

272 Ibid.

273 Ibid.

${ }^{274}$ Ibid. P. 168.

275 Moe (1987b) P. 291.

${ }^{276}$ Mulgan (2003) P. 1.
} 


\section{(2) What purposes does congressional oversight pursue?}

The mission of congressional oversight is to gather information and "to see whether or not the law as intended is being carried out or whether a great many of these laws are being repealed or revamped by those who administer them." ${ }^{277}$ As L. Hamilton, Member of US Congress (1966-1999) stated,

You all know that the legislative process requires a lot of compromises to be made. Language often gets fuzzy as a result of those compromises. And when that happens the direction of the bureaucracy is less clear and less precise. What that means is that the bureaucracy has a lot of leeway in determining the nature of the program. So you need oversight for a number of reasons. ${ }^{278}$

To be more specific, congressional oversight is necessary: (1) to ensure the compliance with its laws and intent; (2) to find out and assess agency performance; (3) to improve the efficiency of agencies' programs and activities; (4) to investigate illegal and incorrect actions and abuse of power and fraud; (5) to determine financial priorities and whether the designed programs reflect public interest and contemporary needs; (6) to make new necessary laws and review agency rules. ${ }^{279}$ Oversight pursues the same goals to those of accountability: democratic control, prevention of corruption and abuse of power, and enhancing government effectiveness. ${ }^{280}$

\section{(3) How can congressional oversight be performed?}

The question of 'how' in relation to congressional oversight involves the discussion of three issues: (A) the legal basis and limits of this congressional power; (B) congressional tools to obtain information; and (C) congressional support in overseeing the executive. This section discusses these issues in the mentioned order.

\section{A. The legal basis and limits of congressional oversight}

The power to conduct oversight over the executive does not derive from the US Constitution directly. Rather, in discussing congressional oversight's legal basis, limits and organization four principal Supreme Court judgments and the Legislative Reorganization Act of 1946 (as amended in 1970) need to be considered.

\footnotetext{
277 The words of Speaker Sam Rayburn when launching a fully-fledged investigation of the independent regulatory agencies in 1957 (Cary (1967) P. 41).

${ }^{278}$ Hamilton L. (member of Congress (1965-1999)) in: The committee print of "Congressional Oversight: A "How-to" Series of Workshops, sponsored by the Speaker and the Chairman, House Rules Committee, organized and conducted by the CRS, 1999. P. 13.

${ }^{279}$ CRS Report for Congress "Congressional Oversight Manual" by Kaiser F.M., Oleszek W.J., Tatelman T.B., 2011. P. 1-3.

${ }^{280}$ Bovens (2007) P. 462-463.
} 
Although congressional oversight began to take place shortly after the adoption of the Constitution, ${ }^{281}$ McGrain v. Daugherty (1928) has become the landmark case institutionalizing congressional oversight power. In this case, the Supreme Court ruled that

A legislative body cannot legislate wisely or effectively in the absence of information respecting the conditions which the legislation is intended to affect or change; and where the legislative body does not itself possess the requisite information - which not infrequently is true recourse must be had to others who do possess it. ${ }^{282}$

The case involved a Senate's investigation of the former attorney general. The official resigned for failure to prosecute cases that arose from a scandal. In the course of investigation the brother of the former attorney general was requested to appear before Congress. His failure to do so led to his temporary imprisonment. The Supreme Court ruled that Congress's actions were constitutional, arguing that these activities were clearly necessary to exercise congressional legislative power and the power of the purse, even though Congress made no mention of its legislative intent there. Thus, even in the absence of the explicit constitutional provision to conduct investigations, this power was interpreted as an implied power to the law-making function of Congress.

After that decision, the Legislative Reorganization Act of 1946 became the first public law that required both chambers of Congress to exercise 'continuous watchfulness' of the administration of laws and programs under their jurisdiction. This is when congressional continuous supervision "really" began. ${ }^{283}$ This Act also organized both chambers in a similar committee structure, ${ }^{284}$ authorized the creation of permanent professional and clerical staff for committees for the first time in history, ${ }^{285}$ and established a support institution, currently known as the Congressional Research Service, to be discussed shortly in this section. The Act was amended in 1970 (84 Stat. 1156 (1970)) and the oversight function was given a more precise formulation: "each standing committee of the Senate and the House of Representatives shall review and study, on a continuing basis, the application, admin-

\footnotetext{
281 The first major investigation was ordered by the House in 1792 (a committee to inquire into the expedition of Major General St. Clair, whose troops experienced disastrous losses to the Indians) and the power of contempt was exercised already in 1796 (the House ordered the Sergeant at Arms to arrest to suspects they wanted to question) (Fisher (2007) P. 156-157).

${ }^{282}$ McGrain v. Daugherty 273 U.S. 135, 175 (1927).

${ }^{283}$ Hamilton L. (Member of US Congress (1965-1999)) in: The committee print of "Congressional Oversight: A "How-to" Series of Workshops, sponsored by the Speaker and the Chairman, House Rules Committee, organized and conducted by the CRS, 1999. P. 12.

${ }^{284}$ As some scholars suggest: if a legislature "is to be a significant political factor, then it must have specialized committees of limited membership and considerable scope of power" (LaPalombara (1974) P. 311).

${ }^{285}$ CRS Report for Congress "Congressional Oversight Manual” by Kaiser F.M., Oleszek W.J., Tatelman T.B., 2011. P. 7.
} 
istration, and execution of those laws, or parts of laws, the subject matter of which is within the jurisdiction of that committee" (2 USC $190 \mathrm{~d}$ ).

The scope of congressional oversight inquiries is very broad, roughly speaking, Congress may ask IRAs' officials for more information and explanation at any time and on any occasion. But it is not unlimited; "neither house is invested with 'general' power to inquire into private affairs and compel disclosures, but only with such limited power of inquiry as is shown to exist when the rule of constitutional interpretation just stated is rightly applied." 286 Similar to how the oversight function originates from the case law, its limits have also been formulated by the courts. There are three principal cases, establishing the legal constraints of congressional oversight, to discuss.

In Watkins (1957), ${ }^{287}$ the Supreme Court held that the investigative power of congressional committees is restricted to the matters falling within their jurisdictions; "there is no general authority to expose the private affairs of individuals without justification in terms of the functions of the Congress $<\ldots>$ nor is the Congress a law enforcement or trial agency. $<\ldots>$ No inquiry is an end in itself; it must be related to, and in furtherance of, a legitimate task of the Congress." 288 In this case, Mr. Watkins was convicted after he refused to answer questions, which, he asserted, were beyond the authority of the relevant congressional committee. More specifically, he refused to tell whether he knew if the other mentioned persons were members of the Communist Party. The Court stated that congressional committees are "restricted to the missions delegated to them, i.e., to acquire certain data to be used by the House or the Senate in coping with a problem that falls within its legislative sphere." ${ }^{289}$ The topic of investigation was communist infiltration in labour, whereas the persons mentioned to Mr. Watkins were not connected with labour. The Court also stated that "the petitioner was not accorded a fair opportunity to determine whether he was within his rights in refusing to answer, and his conviction is necessarily invalid under the Due Process Clause of the Fifth Amendment." 290

In Barenblatt (1959), ${ }^{291}$ the Supreme Court ruled that congressional investigation oversight is subject to the limits of the Bill of Rights and of the exclusive areas reserved to other branches by the Constitution. In this case, Mr. Barenblatt was convicted after he refused to answer the question whether he was and had ever been a member of the Communist Party. The Court looked at a balance between the congressional inquiry into individual political relationships and the right of freedom of association (the First Amendment to the US Constitution). It established that it was hardly debatable that Congress enjoyed the power to

\footnotetext{
${ }^{286}$ McGrain v. Daugherty 273 U.S. 135, 174, 175 (1927).

287 Watkins v. US 354 US 178 (1957).

${ }^{288}$ Ibid. at 187.

${ }^{289}$ Ibid. at 206.

${ }^{290}$ Ibid. at 215.

${ }^{291}$ Barenblatt v. US 360 US 109 (1959).
} 
legislate in the field of Communist activity, which implied Congress having a valid legislative purpose. Also, the Court recognized "the close nexus between the Communist Party and violent overthrow of government." ${ }^{292}$ Therefore, the balance between the constitutional right to free association and the power of Congress to investigate on matters of national security was struck in favor of the latter.

In Eastland (1975), ${ }^{293}$ the Supreme Court stated, perhaps more explicitly than in Barenblatt, that Congress may use its oversight function to inquire into the areas where it may legislate. In this case, a bank was required to provide the relevant congressional committee all documents related to the account of its client, the United States Servicemen's Fund, Inc. (USSF). The USSF was a non-profit membership corporation that, among other things, established 'coffeehouses' near domestic military installations and aided the publication of 'underground' newspapers for distribution on American military installations throughout the world, which became "the focus of dissent and expressions of opposition within the military toward the war in (Southeast Asia)". ${ }^{294}$ The subpoena was issued to the bank rather than to the USSF, and the information requested by the committee would disclose private contributors to the USSF. Thus, the USSF claimed the violation of the First Amendment's rights, namely freedom of speech and assembly. ${ }^{295}$ However, as the Court held, the congressional committee was given broad authority "to make complete and continuing study and investigation of $\langle\ldots\rangle$ the administration, operation, and enforcement of the Internal Security Act of 1950" and "the resolution specifically directed inquiry concerning 'infiltration by persons who are or may be under the domination of $<\ldots>$ foreign government'." 296 Thus, the Court concluded that the request of the committee fell within the 'legitimate legislative sphere' where Congress could legislate.

All in all, while "the scope of the power of inquiry, $\langle\ldots\rangle$ is as penetrating and farreaching as the potential power to enact and appropriate under the Constitution," 297 there are some limits. Each congressional committee may request information on the topic, which falls within its jurisdiction. The human rights and freedoms which the US Constitution guarantees and the exclusive areas belonging to other branches can also limit the scope

\footnotetext{
292 Barenblatt v. US 360 US 109, 128 (1959).

293 Eastland v. United States Servicemen’s Fund et al. 421 US 491 (1975).

294 Ibid. at 494 .

295 "Congress shall make no law <...> abridging the freedom of speech, or of the press; or the right of the people peaceably to assemble, and to petition the government for a redress of grievances” (Amendment I, US Constitution).

${ }^{296}$ Eastland v. United States Servicemen's Fund et al. 421 US 491, 493 (1975).

${ }^{297}$ Barenblatt v. US 360 US 109, 111 (1959).

"The power of the Congress to conduct investigations is inherent in the legislative process. That power is broad. It encompasses inquiries concerning the administration of existing laws as well as proposed or possibly needed statutes. It includes surveys of defects in our social, economic or political system for the purpose of enabling the Congress to remedy them. It comprehends probes into departments of the Federal Government to expose corruption, inefficiency or waste" (Watkins v. U.S. 354 U.S. 178, 187, (1957)).
} 
of the congressional oversight function. Finally, there should be a connection between the request for information and the legislative purpose and the power of Congress, meaning that Congress should be able to legislate on that issue. Yet, even with these limits congressional oversight is considered to be a very strong congressional weapon, whose strength lies, among other things, in the strength and variety of tools that Congress has to obtain information discussed next.

\section{(B) Congressional tools to obtain information}

While individual members may conduct oversight activities, ${ }^{298}$ most commonly "oversight is $\langle\ldots\rangle$ considered a committee activity." ${ }^{299}$ The Rules of Procedure of both congressional chambers specify general topics (and not individual agencies) on which each committee can propose legislation and can have oversight functions. Interestingly, House Rule X requires specifically that each of its standing committees which has more than 20 members has to establish an oversight sub-committee. Furthermore, according to the same Rule each standing committee in the House has to issue regular ex ante plans of its oversight activities and report on the realisation of such plans ex post. The reason oversight is usually done by congressional committees can probably be best explained by the fact that congressional committees normally enjoy the powers to request relevant individuals to come to congressional hearings and necessary documentation to be disclosed to Congress. These are the congressional weapons to subpoena witnesses and to hold them in contempt. ${ }^{300}$

"In aid of the legislative function" 301 and within the scope of its jurisdiction or upon the explicit authorization, ${ }^{302}$ the relevant standing or special committees may issue subpoe-

\footnotetext{
298 The initiation of an oversight hearing or investigation may also start with complaints and requests about agencies' federal programs received by individual members of Congress from the constituencies they represent (the socalled casework).

${ }^{299}$ CRS Report for Congress "Congressional Oversight Manual” by Kaiser F.M., Oleszek W.J., Tatelman T.B., 2011.P. 13.

300 "Individual members have no authority to issue compulsory process or conduct official hearings" (CRS Report for Congress "Congressional Oversight Manual” by Kaiser F.M., Oleszek W.J., Tatelman T.B., 2011. P. 13).

Also, there are various quorum requirements, especially for the perjury purposes, however, they vary greatly from committee to committee: "Both the House and the Senate have adopted rules permitting a reduced quorum for taking testimony and receiving evidence. House hearings may be conducted if at least two members are present; most Senate committees permit hearings with only one member in attendance. Although most committees have adopted the minimum quorum requirement, some have not, while others require a higher quorum for sworn rather than unsworn testimony. For perjury purposes, the quorum requirement must be met at the time the allegedly perjured testimony is given, not at the beginning of the session. Reduced quorum requirement rules do not apply to authorizations for the issuance of subpoenas. Senate rules require a one-third quorum of a committee or subcommittee while the House requires a quorum of a majority of the members, unless a committee delegates authority for issuance to its chairman (Ibid. P. 30)." These are regulated by Senate Rule XXVI(7)(a)(1) and House Rule XI(2)(m)(3).

${ }^{301}$ Kilbourn v. Thompson 103 US 168, 204 (1880).

302 McGrain v. Daugherty 273 U.S. 135, 174, 175 (1927).
} 
nas. ${ }^{303}$ The congressional standing committees are authorized to do so according to Senate Rule XXVI and House Rule XI (2) (m). Having received a congressional subpoena, an individual has to testify before the body that requested it that and has only limited grounds for objections. False and 'I don't remember' statements may lead to perjury prosecution. According to the Fifth Amendment to the Constitution, ${ }^{304}$ witnesses may invoke the privilege against self-incrimination, although committees may also require testimony in some circumstances by granting "use immunity" from prosecution--meaning that any statements made in the hearing may not be introduced into evidence against witnesses in an ensuing criminal prosecution. Also, the executive privilege may be raised against disclosure of certain data, however, this seems to be relevant for the President and his administration, rather than for IRAs that are distant from the President. Strauss writes in this respect that a commissioner, "who had previously been an important official in the White House, remarked that being in an independent regulatory commission meant "having to appear naked in front of Congress," without the political protection a connection to the White House could bring." 305

An effective supportive tool to obtain information, especially in difficult cases when parties are not willing to disclose, derives from the contempt power or a threat to use it. There are three types of such power. ${ }^{306}$ First, the inherent contempt power allows Congress to bring the requested individual to the Sergeant-at-Arms, to question that individual and imprison him until he complies with the congressional will, but the imprisonment may last for a maximum of the length of the congressional session, i.e., before next adjournment. Second, statutory criminal contempt allows Congress to punish a person who did not comply with the subpoena or refused to answer the questions with a fine or up to one year of imprisonment. Finally, civil contempt is available for the Senate and means that the district court may issue an order to compel a person refusing or threatening to refuse to comply with the Senate's subpoena.

In addition to, or perhaps even thanks to the strong formal powers, informal contacts also play an important role in the oversight relationship between agencies and Congress. Informal consultations, negotiations, and hearings, including staff depositions, ${ }^{307}$ take place during various processes and interactions between Congress and agencies. At times these interactions can be quite intense. A former Chairman of the Securities and Exchange Commission, W.L. Cary, wrote in his book:

\footnotetext{
${ }^{303}$ A catalogue of all legal rules applicable to the congressional investigations and the rights of the witnesses can be found in: Hirschberg et al. (1984).

${ }^{304}$ It reads as follows: "no person $<\ldots>$ shall be compelled in any criminal case to be a witness against himself."

305 Strauss (2002) P. 82.

${ }^{306}$ CRS Report for Congress "Congressional Oversight Manual” by Kaiser F.M., Oleszek W.J., Tatelman T.B., 2011. P. 32-34; Fisher (2007) P. 160.

307 These are informal interviews conducted by congressional staff with agencies' officials serving mostly preparatory purposes for an investigation.
} 
Congress has been more than willing to exercise its budgetary authority [and oversight within this process] over $\langle\ldots\rangle$ regulatory commissions during the Kennedy and Johnson administrations. Indeed, that is one reason why any chairman of an agency must spend a very substantial part of his time on Capitol Hill. In my own case, our sub-committee chairman, the late Albert Thomas, made the remark, "I recall the first year Mr. Cary was here I thought he was in the office with us over here all the time... ${ }^{308}$

According to a former FTC commissioner,

The FTC's procedural rules permit FTC officials, pursuant to a vote of the Commission, to give confidential briefings to the chairs of committees and subcommittees about pending law enforcement matters, including investigations of mergers. Members of Congress routinely request and receive such briefings. ${ }^{309}$

While informal contacts are important, the success of an informal request may be interconnected with the fact that they are backed-up by strong formal powerful weapons to request the needed information and impose sanctions if it is not provided. As the Supreme Court stated in McGrain, "experience has taught that mere requests for information are often unavailing, and also that information which is volunteered is not always accurate or complete. So some means of compulsion are essential to obtain what is needed." ${ }^{10}$

\section{(C) Congressional support}

"There is no evident reason why Congress should respond to the complexity of issues by creating a large, expert bureaucracy without also creating a large, expert congressional staff - one sufficiently large and expert, not only to help decide complex issues, but to help oversee a large, expert bureaucracy." ${ }^{111}$ As was mentioned earlier, the Legislative Reorganization Act of 1946 authorized for the first time in history permanent staff for congressional committees. The executive branch grew further. Requesting all the necessary information but also studying all the received reports from the growing administration led to the further growth of congressional permanent staff and personal assistants for the members of Congress as well as the need of support agencies because the success of congressional oversight, especially in getting and analyzing all the information, was seen to depend greatly on how well equipped Congress was. This section gives an overview of the relevant support bodies that Congress can rely on in exercising its oversight function. These include the staff of Congress, offices of Inspectors General placed in agencies, and four support agencies, i.e., the Government Accountability Office, the Congressional Research Service, the Congressional Budget Office, and the Administrative Conference of the United States.

\footnotetext{
${ }^{308}$ Cary (1967) P. 36.

${ }^{309}$ Kovacic (2011) P. 298; see, also, Kovacic (1988).

${ }^{310}$ McGrain v. Daugherty 273 U.S. 135, 175 (1927).

${ }^{311}$ McCubbins and Schwarz (1984) P.169.
} 


\section{Congressional staff}

US Congress employs approximately 17,000 staff. Interestingly, "between 1977 and 2009, the number of House staff grew from 8,831 to 9,808 , or $11.06 \%$. In the Senate, the number of staff has grown steadily, from 3,380 in 1977 to 6,099 in 2010 , or $80.44 \%$." 312 The staff of Congress includes both personal assistants of its members and the staff working for both parties in congressional committees, leadership offices, and administrative support. Congressional committees have on average 68 and 46 employees in the House and the Senate respectively. ${ }^{313}$

The members of the House personal allowances range from $\$ 1,356,975$ to $\$ 1,671,596$ (per year) which is calculated based on three elements: personnel, official office expenses, and official mail. ${ }^{314}$ Whereas the 'personnel's element' is the same for all members, other components vary depending on the distance between member's districts and the capital. In 2010 , each member of the House could spend $\$ 944,671$ per annum ${ }^{315}$ on personal assistants and could employ up to 18 permanent employees. On average, the members of the House have around 16 assistants, ${ }^{316}$ eight Washington DC-based staff and eight districtbased personnel; they are usually generalists, rather than experts in specific fields. ${ }^{317}$

"Senators have three allowances available to them for personnel and official office expenses." 318 These are the administrative and clerical assistance allowance, the legislative assistance allowances, and the official office expense allowance. Whereas the legislative assistance allowance is the same for all senators, the other two depend on a number of factors, including states' population. In 2011, it varied from $\$ 3,149,536$ to $\$ 4,967,505$ (per year). ${ }^{319}$ Senators do not have a limitation on a number of personal assistants they can hire, but on average a Senate office, including their Washington DC, and their constituencies' offices, has 35 staff members ${ }^{320}$ specializing in more specific issues. ${ }^{321}$ The bigger the state (in population) they represent, the more assistants Senators normally have.

312 CRS Report for Congress "House of Representatives and Senate Staff Levels in Member, Committee, Leadership, and Other Offices, 1977-2010", by Petersen R., Reynolds P., and Wilhelm A., 2010. P. 4.

For comparison, in 1947, e.g., there were fewer than 500 aides on House and Senate committees and about 2,000 House and Senate personal aids (Strauss (2002) P. 27).

313 CRS Report for Congress “Congressional Staff: Duties and Functions”, by Pontius J.S. and Bullock F.M., 2003. P. 2.

${ }^{314}$ CRS Report for Congress “Congressional Salaries and Allowances”, by Brudnick I., 2011. P. 3.

${ }^{315}$ Ibid.

${ }^{316}$ CRS Report for Congress “Congressional Staff: Duties and Functions”, by Pontius J.S. and Bullock F.M., 2003. P. 1; also, see CRS Report for Congress "House of Representatives and Senate Staff Levels in Member, Committee, Leadership, and Other Offices, 1977-2010", by Petersen R., Reynolds P., and Wilhelm A., 2010. P. 7.

317 Official from FERC who worked previously as personal staff for the members of the House and the Senate (interviewed in May 2011).

318 CRS Report for Congress “Congressional Salaries and Allowances”, by Brudnick I., 2011. P. 7.

319 Ibid.

${ }^{320}$ CRS Report for Congress “Congressional Staff: Duties and Functions”, by Pontius J.S. and Bullock F.M., 2003. P. 1. 


\section{Inspectors General (IGs)}

Since 1978 offices of Inspectors General have been placed in all major agencies and departments, including independent regulatory agencies, although a few smaller agencies can be supervised by one Inspector General. These offices pursue three principal goals: (1) conduct and supervise audits and investigations of relevant agency's programs and operations; (2) provide leadership and coordination and recommend policies for activities designed to promote the economy, efficiency, and effectiveness and the prevention and detection of fraud and abuse in such programs and operations; and (3) keep the head of the establishment and Congress fully and currently informed about problems and deficiencies relating to such programs and the necessity for and progress of corrective action (5 USC App. \$2).

To be able to achieve the purposes they are created for, IGs have been granted vast authority, including the powers (1) to have access to all records, reports, audits, reviews, documents, papers, recommendations, or other material available to the applicable establishment, (2) to make such investigations and reports relating to the administration of the programs and operations of the applicable establishment as are, in the judgment of the Inspector General, necessary or desirable, (3) to request such information or assistance as may be necessary for carrying out the duties and responsibilities provided by this Act from any Federal, State, or local governmental agency or unit thereof, and (4) to require by subpoena the production of all information, documents, reports, answers, records, accounts, papers, and other data (5 USC App. \$6).

IGs report to the Attorney General (Head of the Department of Justice), agencies' heads, Congress, and the public. ${ }^{322}$ IGs can be appointed either by the President with the consent of the Senate (for larger agencies), the President alone, and by the heads of agencies. Their independence is ensured in several ways, including hiring their own staff, determining their activities, having the authority to issue subpoenas, and notifying Congress (and not only the head of the agency which they oversee) about their budget plans. They are appointed on the basis of their professionalism regardless of their political affiliation and the relevant removing authority has to notify Congress about the intention to remove an IG. Only in a few institutions, including the Fed, the heads of agencies may prevent or halt an IG investigation. However, there are limited grounds for that, such as a matter of national security, and Congress should be notified about such cases.

\footnotetext{
${ }^{321}$ Official from FERC who worked previously as a personal assistant to a member of the House and a member of the Senate (interviewed in May 2011).

${ }^{322}$ CRS Report for Congress "Congressional Oversight Manual” by Kaiser F.M., Oleszek W.J., Tatelman T.B., 2011. P. 89.
} 


\section{Government Accountability Office (GAO)}

The GAO was established in 1921 as the General Accounting Office by the Budget and Accounting Act. Its name (but not its acronym) changed to the Government Accountability Office in $2004 .{ }^{323} \mathrm{GAO}$, or the 'congressional watchdog' as it is called on its official web-page, supports "the Congress in meeting its constitutional responsibilities" and helps to "improve the performance and ensure the accountability of the federal government for the benefit of the American people". ${ }^{324}$ The Comptroller General heads GAO and is appointed for 15 years by the President from a list of three candidates drawn up by the leadership of both chambers and is removable by Congress. ${ }^{325}$ Strauss observes that the two aspects mentioned determine GAO's special liaison with Congress. As Comptroller General Walker stated, "we are in the legislative branch of the government, and therefore, our primary client is the Congress of the United States. Our beneficiary client is the American people." 326

GAO's tasks derive from statutes ${ }^{327}$ and congressional committees' requests, and some research can be done upon the initiative of its head, the Comptroller General. The GAO's work is focused on: (1) auditing agency operations on whether the funds are spent effectively; (2) investigating allegations of illegal activities; (3) reporting how well programs meet their objectives; (4) performing policy analyses; and (5) issuing legal opinions, including reports on agency rules. ${ }^{328}$

The GAO produces around 800 reports a year. ${ }^{329}$ In addition, the staff of the GAO is often invited to congressional hearings to provide their expert advice; in 2011, the GAO

\footnotetext{
323 This information is taken from the official web-page of the agency. Find at: http://www.gao.gov/about/namechange.html (last check September 2013).

324 This information is taken from the official web-page of the agency. Find at: http://www.gao.gov/about/index.html (last check February 2012).

325 While the constitutionality of the appointment procedure was brought before the court, the Supreme Court did not overturn this procedure (Bowsher v. Synar (478 U.S. 714 (1986)).

326 Walker D. (Comptroller General of the United States (1998-2008)) in: The committee print of "Congressional Oversight: A "How-to" Series of Workshops, sponsored by the Speaker and the Chairman, House Rules Committee, organized and conducted by the CRS, 1999. P. 93.

${ }^{327}$ For instance, the discussed statute establishing the Postal Regulatory Commission and regulating the postal service system of the US (see section 3.2.3.1.). In Section 710 of that act Congress requires the Comptroller General of the United States to "prepare and submit to the President and Congress a report that builds upon the work of the 2002 President's Commission on the United States Postal Service by evaluating in-depth various options and strategies for the long-term structural and operational reforms of the United States Postal Service. The final report required by this section shall be submitted within 5 years of the date of enactment of this Act."

328 This information is taken from the official web-page of the agency. Find at: http://www.gao.gov/about/index.html (last check February 2012).

${ }^{329}$ Some of its reports become 'best-sellers'. Thus, the online version of GAO's report on "Opportunities to Reduce Potential Duplication in Government Programs, Save Tax Dollars, and Enhance Revenue” had 90,277 visits in the first week after its release. This report identified the areas where multiple agencies have overlapping tasks that cost $\$ 6.5$ billion in 2010 (Dinan (2011)).
} 
staff testified at 174 hearings. ${ }^{330}$ "The average tenure for a GAO person is over 20 years," which facilitates "deep institutional memory." ${ }^{311}$ The GAO's opinion plays an important role as its disapprovals of agencies' spending of their funds (lawfulness or correctness) may lead to legal consequences that will make that agency reluctant to spend that money. ${ }^{332} \mathrm{It}$ employs 2,957 staff, ${ }^{333}$ over 50 per cent of its employees hold a PhD or Master's degree, ${ }^{334}$ and its 2012 budget was approximately $\$ 534$ million. ${ }^{335}$

\section{Congressional Research Service (CRS)}

This institution traces its roots back to 1914 when Congress established the first department within the Library of Congress to provide it with the work of research assistance. By the Legislative Reorganization Act amendment of 1970 the CRS received its current name and expanded its functions. Its main task is to provide research assistance upon requests of individual members and committees, on an $a d$ hoc and on a more continuous basis. Also, it conducts policy analyses and issues various reports ${ }^{336}$ and organizes seminars and training for members of Congress as well as their foreign counterparts. ${ }^{337}$ In 2010, for instance, CRS completed 670,000 responses to congressional requests, "CRS actively maintained and regularly updated more than 2,200 key products in major policy areas by the close of FY2010 and created 585 new reports. More than 6,000 titles were available at year's end." 338 The difference between the CRS and the GAO is that the CRS serves to satisfy the information needs of Congress, including the analysis on all subjects of legislative activity,

\footnotetext{
${ }^{330}$ Performance and Accountability report of FY 2011, Government Accountability Office. P. 33.

331 Walker D. (Comptroller General of the United States (1998-2008)) in: The committee print of "Congressional Oversight: A "How-to" Series of Workshops, sponsored by the Speaker and the Chairman, House Rules Committee, organized and conducted by the CRS, 1999. P. 96.

332 Strauss (2002) P. 86.

333 This information is taken from the official web-page of the agency. Find at: http://www.gao.gov/about/gglance.html (last check April 2013).

"Congressional mandates more than doubled in number from 75 in fiscal year 2007 to 160 in fiscal year 2008, and this upward trend appears to be continuing in fiscal year 2009” (Ibid.).

334 Walker D. (Comptroller General of the United States (1998-2008)) in: The committee print of "Congressional Oversight: A "How-to" Series of Workshops, sponsored by the Speaker and the Chairman, House Rules Committee, organized and conducted by the CRS, 1999. P. 95.

335 This information is taken from the official web-page of the agency. Find at: http://www.gao.gov/about/gglance.html (last check April 2013).

${ }^{336}$ For instance, CRS Report for Congress "Congressional Oversight Manual” which has been widely used in this section.

337 "CRS responds to more than 600,000 client requests annually. More significantly, it produced more than 1,000 general distribution written products and 2,000 custom written products during Fiscal Year 1992, and conducts seminars, institute, or other briefing programs attended by nearly 12,000 congressional staff, in addition to nearly 4,000 in-person briefings and consultations" (Organization of the Congress, Final Report of the Joint Committee on the Organization of Congress, December, 1993).

${ }^{338}$ Annual Report of the Congressional Research Service of the Library of Congress for Fiscal Year 2010, March 2011.
} 
while the latter, the GAO, deals more with the 'field work', including making investigations and policy recommendations. The CRS has more than 600 staff and it received \$107 million appropriated by Congress in 2012. ${ }^{339}$

\section{Congressional Budget Office (CBO)}

The Congressional Budget and Impoundment Act of 1974 established this institution. CBO's mandate is to provide Congress with "objective, nonpartisan, and timely analyses to aid in economic and budgetary decisions on the wide array of programs covered by the federal budget and the information and estimates required for the Congressional budget process." ${ }^{340}$ It mainly assists the congressional committees on the budget, created by the same Act, in the annual appropriations procedure and in making future economic projections. Other congressional committees may also make research requests, so as to prepare various analytical reports on the budget and economic policy, for instance, the cost and benefit analysis or estimations of expenditures for the (proposed) programs and bills.

In 2010, CBO completed approximately 650 federal cost estimates. ${ }^{341}$ In 2010, CBO issued 33 studies and reports, 12 briefs, 12 Monthly Budget Reviews, 35 letters, 14 presentations, and 2 background papers - along with 2 other publications and numerous supplemental data. ${ }^{342}$ Annual reports about unauthorized appropriations and expiring authorizations are one of the most interesting reports that the CBO issues. These reports aim to bring the attention of members of Congress to the money given to the programs whose authorization has expired ${ }^{343}$ (see section 3.2.4.1.). Given their expertise CBO's officials are also regularly invited to testify before Congress on specific topics.

The director of the CBO is appointed by the Speaker of the House and the President pro tempore of the Senate, the staff of the $\mathrm{CBO}$ is treated as employees of the House. ${ }^{344}$

\footnotetext{
${ }^{339}$ Annual Report of the Congressional Research Service of the Library of Congress for Fiscal Year 2012, March 2013. P. 28.

${ }_{340}$ This information is taken from the official web-page of the office. Find at: http://www.cbo.gov/aboutcbo/ (last check January 2012).

${ }^{341}$ This information is taken from the official web-page of the office. Find at: http://www.cbo.gov/aboutcbo/factsheet.cfm (last check January 2012).

${ }^{342}$ Ibid.

${ }^{343}$ In FY 2012, for example, Congress has given $\$ 261$ billion to the programs whose authorization of appropriations expired. It was $\$ 30$ billion less than in 2010 as several programs have been reauthorized. CBO Report Unauthorized Appropriations and Expiring Authorizations, 2012. P. 7 (This information is taken from the official webpage of the office. Find at: http://cbo.gov/ftpdocs/126xx/doc12673/01-13-UAEA_House.pdf (last check January 2012)).

${ }^{344}$ Interestingly, "for purposes of pay and employment benefits, all staff are treated as employees of the House of Representatives." (This information is taken from the official web-page of the office. Find at: http://www.cbo.gov/aboutcbo/organization/ (last check January 2012)).
} 
There are about 235 people working for the CBO, most of which have advanced degrees mostly in economics, ${ }^{345}$ and its FY2012 budget was $\$ 44$ million. ${ }^{346}$

\section{Administrative Conference of the United States (ACUS)}

The ACUS is "an independent federal agency dedicated to improving the administrative process through consensus-driven applied research, providing nonpartisan expert advice and recommendations for improvement of federal agency procedures." ${ }^{347}$ It was created in 1964 and was in operation until 1995 when Congress defunded it. Since 2010, the Conference has been revived. To accomplish its mission this institution conducts research, formulates recommendations, spreads agency best practices, promotes exchange of information and sponsors events and publications. It focuses on the topics of general administrative law and specific agencies' problems. For example, the Government in the Sunshine Act, discussed in section 3.2.3.2., has been one of its focuses where the Conference has provided a platform for exchange of information between IRAs' officials to identify existing problems and to discuss possible solutions. One of the tasks of the agency is to provide recommendations to Congress, the President, agencies or the courts, depending on the matter at stake. Although recommendations do not have any binding force, they have been used to improve legislation and existing practices. While the Conference has a small staff on its own (18 people $\mathrm{e}^{348}$ ), formally it consists of members from academia, federal agencies and the private sector, divided into several thematic committees, such as a committee on regulation or committee collaborative government. ${ }^{349}$ Its FY 2012 budget was approximately $\$ 3$ million. ${ }^{350}$

All in all, next to its 17,000 staff Congress relies on the support of almost 4,000 support staff at the annual cost of approximately $\$ 690$ million employed by congressional support agencies. The primary responsibility of the biggest agency, GAO, is to audit agencies' expenditure and to investigate maladministration and inefficiency in the operation of agencies. The $\mathrm{CBO}$ provides advice and analysis in the course of the budget process and the

\footnotetext{
345 This information is taken from the official web-page of the office. Find at: http://www.cbo.gov/about/ourorganization (last check April 2013).

346 This information is taken from the official web-page of the office. Find at: http://www.cbo.gov/publication/42990 (last check April 2013).

${ }^{347}$ Guide for members, Administrative Conference of the United States, 2011. Find at: http://www.acus.gov/wpcontent/uploads/downloads/2011/05/Guide_5-9.pdf (last check February 2012).

${ }^{348}$ FY 2013 OMB Budget Justification, ACUS, January 30, 2012. P. 3. Find at: http://www.acus.gov/sites/default/files/documents/ACUS\%202013\%20Congressional\%20Budget\%20Justification.pdf (last check April 2013).

${ }^{349}$ Guide for members, Administrative Conference of the United States, 2011. Find at: http://www.acus.gov/wpcontent/uploads/downloads/2011/05/Guide_5-9.pdf (last check February 2012).

${ }^{350}$ FY 2013 OMB Budget Justification, ACUS, January 30, 2012. P. 3 Find at: http://www.acus.gov/sites/default/files/documents/ACUS\%202013\%20Congressional\%20Budget\%20Justification.pdf (last check April 2013).
} 
impact of (new) legislation on the budget. IGs play a role of internal auditors but also are Congress's 'eyes and ears' about possible problems within agencies and specific programs agencies administer. The ACUS provides recommendations to Congress on how to address the challenges to the administrative process which IRAs are part of. Finally, CRS's staff is a 'quick response' service to research inquiries of individual members and committees on a wide range of issues, including the operation of Congress itself.

\subsubsection{The challenges to congressional oversight}

As was mentioned earlier, to address the challenge of overseeing a high number of executive institutions intelligibly, Congress has come up with two solutions: (1) enhancing its oversight capacity by increasing congressional staff and organizing its members in committees specializing in specific issues; and (2) sharing its oversight responsibility with its expert support agencies and directly with the people (the fire-alarm form of oversight). At the same time, the biggest challenge to its oversight functions seems to be the weak incentives of people's representatives to scrutinize the executive. This section discusses this issue.

Since the statutes of 1946 and of 1970 have required the oversight to be done by Congress, the internal rules of proceedings of both chambers started to address oversight issues as well, obliging its members to engage in this "very unglamorous work" where "most members see very little political benefit." ${ }^{351}$ This is because continuing oversight, which the law requires, is a time- and resource- consuming task that rarely attracts media attention, which is clearly one of the biggest incentives that members respond to. Since the task may be not politically attractive, it seems necessary to create additional measures.

Such measures include creating sub-committees on oversight in each standing committee and introducing self-enforcing rules to increase incentives to scrutinize the executive. House Rule $\mathrm{X}$ is a good illustration in this respect, it requires, among other things, that "not later than February 15 of the first session of a Congress, each standing committee shall, in a meeting that is open to the public and with a quorum present, adopt its oversight plan for that Congress" (2 (d (1))); such a plan has to be submitted to relevant committees. In addition, follow-up reports have to be submitted later, such follow-up reports need to assess what has actually been done in light of the initial oversight plans (House Rule X (2 (d (2))).

While this was "a way of getting committees overseeing other committees as to whether they were doing their jobs," 352 the establishment of new rules immediately resulted in complaints about the unpalatability of showing the minority party the oversight plans for the

\footnotetext{
${ }^{351}$ Hamilton L. (Member of the US Congress 1965-1999) in: The committee print of "Congressional Oversight: A "How-to" Series of Workshops, sponsored by the Speaker and the Chairman, House Rules Committee, organized and conducted by the CRS, 1999. P. 14.

352 Wolfensberger D. (Former Staff Director of the House Rules Committee) in: The committee print of "Congressional Oversight: A "How-to" Series of Workshops, sponsored by the Speaker and the Chairman, House Rules Committee, organized and conducted by the CRS, 1999. P. 62-63.
} 
next two years. In light of the 'separation of parties, not powers' theory, the content of oversight plans will depend on the political majorities sitting in the House and in the White House or on individual agencies' management boards. In this light, "no set of rules, no matter how artfully drafted and well intentioned, will produce effective oversight if the will is not there." ${ }^{353}$ And to get the members interested in conducting oversight is a big problem. ${ }^{354}$

According to L. Hamilton, Member of the US Congress 1965-1999, for congressional oversight to be successful both political will and good organization are required. More specifically, he lists the following elements: (1) bipartisan effort; (2) regularity; ${ }^{355}$ (3) comprehensive scope (not only those cases which make it to the headlines of newspapers); (4) continuity and expertise of both members and congressional staff (oversight should be done by members, not only by staff); 356 (5) oversight without micromanaging of agencies' internal activities; (6) documentation and feedback; ${ }^{357}$ (7) reasonable number of reports from agencies; ${ }^{358}$ and finally (8) "great public accountability," where Congress has to provide clear reports for the public to see the importance of oversight. ${ }^{359}$

Concluding, at the heart of congressional oversight lies gathering information with a view to monitoring the execution of laws, investigation abuse of power, and enhancing the efficiency of the operation and programs of agencies. "Oversight occurs in virtually any congressional activity and through a wide variety of channels, organizations, and structures." ${ }^{360}$ Although the scope of oversight is limited by the human rights and freedoms guaranteed by the Constitution, the scope of legislative power of Congress and jurisdictions of congressional committees when the latter conducts oversight, it is still quite broad. Furthermore, the strengths of the tool include formal strong tools to obtain information, such as the power to subpoena witnesses and to hold them in contempt, and congressional support institutions, which take a certain burden to conduct oversight on their shoulders.

\footnotetext{
353 Wolfensberger D. (Former Staff Director of the House Rules Committee) in: The committee print of "Congressional Oversight: A "How-to" Series of Workshops, sponsored by the Speaker and the Chairman, House Rules Committee, organized and conducted by the CRS, 1999. P. 66.

${ }^{354}$ Hamilton L. (Member of the US Congress 1965-1999) in: The committee print of "Congressional Oversight: A "How-to" Series of Workshops, sponsored by the Speaker and the Chairman, House Rules Committee, organized and conducted by the CRS, 1999. P. 24.

355 "Agencies get very nervous when someone from Congress starts poking around, and that is to the overall good. Federal bureaucracies do not stay on their toes unless they expect review and oversight by Congress” (Ibid. P. 12).

356 "If you have large turnover of staff on a committee, if you have large turnover of chairmen, that harms the institutional continuity and expertise to essential to the job of oversight" (Ibid.).

357 "The more you can get things in writing the better off you are. $<\ldots>$ It is one thing to ask agencies to improve their performance, but it requires staff and members to make sure that changes have taken place” (Ibid.).

358 "In general, the quality of oversight is much more important than the quantity of that review" (Ibid.).

359 Ibid. P. 16-20.

${ }^{360}$ CRS Report for Congress "Congressional Oversight Manual” by Kaiser F.M., Oleszek W.J., Tatelman T.B., 2011. P. 1.
} 
Sharing its oversight responsibilities with its expert assistant bodies seems to be one of the ways Congress has thought to address the challenges of oversight, which include the great number of executive institutions to oversee intelligibly and the weak incentives of the people's representatives to conduct oversight. The other solutions include allowing people to participate directly in agencies' decision-making processes and to seek redress in courts and in Congress (fire-alarm oversight) and introducing self-enforcing measures to promote oversight activities among the members of Congress. The latter seems especially necessary because, while the law obliges congressional committees to review and study the application, administration, and execution of laws on a continuing basis, regular oversight is timeand resource- consuming with no necessarily political benefit for the members of Congress.

\section{Conclusion}

This section has investigated the political accountability of US IRAs with the help of the five dimensions introduced in Chapter 1 in order to be able to assess it in the following section 3.3. These five dimensions included the creation of and delegation to US IRAs, the appointment and removal procedures of US these agencies' top officials, statutory regulation of accountability relevant aspects, the annual appropriations procedure, and congressional oversight. This section showed how the political accountability of IRAs has been organized and in part exercised, constitutional and legal rules establishing and influencing the political accountability processes, and practical concerns that reshape the existing law or fill up its gaps.

To sum up the findings of this section, IRAs are nowhere mentioned in the Constitution. In light of the broadly formulated creation and delegation doctrines by the Supreme Court, it is up to Congress, influenced by party politics, to decide when to create an independent agency and with what powers. This has influenced the political accountability of IRAs because creating an independent agency in the US implies creating an agency which will be distant from the President. Hence, IRAs render political account mainly before Congress. Agencies' independence from the President is thought to be ensured by inserting various statutory clauses to ensure personal independence of the members of IRAs' management boards from the President. Such clauses include creating IRAs headed by multimember boards whose members are appointed on a bipartisan basis, have staggered terms of office and can be removed only 'for cause'. However, similar to how political considerations gave birth to the mentioned safeguards to ensure independence of some agencies, politics also determine whether such safeguards will be applied in practice.

With respect to such various possibilities, this section has discussed a number of accountability obligations that Congress has imposed on (independent) agencies. IRAs have to submit various reports to Congress, exercise their functions in accordance with various statutory substantive and procedural requirements, submit their rules for review to Con- 
gress, meet statutory deadlines, and be subject to evaluations of their programs under sunset clauses. Needless to say, Congress can always modify agencies' functional scope and abolish an agency upon functional needs and poor performance. The number of detailed of accountability obligations that IRAs can be subject to are quite high, perhaps at times too high, which may hinder the effective operation of agencies and in fact holding them to account if the number of reports is so high that it becomes impossible for the Members of Congress are able to study them properly. At the same time, it was shown that such obligations promote the accountability of agencies in a number of ways. Specific statutory obligations and procedural and substantive requirements make congressional checks of agencies' performance more feasible because they create a frame of reference to check against. Also, such statutory requirements contribute to sharing to a certain extent congressional oversight responsibility with the affected parties and congressional support institutions by allowing them to hold agencies to account directly (the fire-alarm oversight).

The fire-alarm form of oversight strengthens the congressional oversight tool by increasing the number of programs and executive institutions being checked. Additionally, the strengths of the oversight tool lie in its broad scope and formal strong tools to obtain information, such as the power to subpoena witnesses and to hold them in contempt. The biggest challenge to oversight however is the weak incentives of the people's representatives to be engaged in such a time- and resource- consuming enterprise on a regular basis because it does not guarantee a political benefit for individual members of Congress. At the same time, regular checks upon agencies take place within the annual appropriations process which can be considered to be 'The accountability venue' allowing Congress to hold the executive institutions to account. Except for three self-funded agencies, financial oversight takes place regularly, once a year, and provides a venue for discussing and checking not only the financial figures but also agencies' performance, because money translates into agencies' activities.

All in all, the relationship between Congress and IRAs can be characterized as fullyfledged, given various interactions that can exist between them. Such interactions are all designed by Congress itself with hardly any restrictions imposed by the Constitution, as IRAs are not mentioned there, or designed by the Supreme Court, when interpreting the existing constitutional gaps.

\subsection{Assessing the Political Accountability of US Independent Regulatory Agencies}

Following the introduction of the US relevant institutions and the investigation of the political accountability of US independent regulatory agencies, this concluding section of Chapter 3 is devoted to the assessment of the political accountability of US IRAs. This is done on the basis of the three criteria ensuring political accountability introduced in Chapter 1 as the following formula: 'political accountability = availability of accountability mecha- 
nisms + their design (specificity of accountability obligations and interplay of accountability mechanisms) + their practical application'. This section is divided into three respective parts and assesses the political accountability of US IRAs as being partly problematic.

\subsubsection{The Availability of Accountability Mechanisms: a Solid Arsenal Applicable to All}

The availability of accountability mechanisms allowing all three stages of accountability to take place is necessary to ensure the political accountability of IRAs before Congress. This section discusses the US Congress's accountability capacity in relation to the US IRAs and shows an impressive arsenal of accountability mechanisms that the US Congress enjoys with respect to all US independent (and in fact also 'dependent') agencies in a very similar way. This section explains the existing uniform approach of the organization of political accountability of US IRAs and pinpoints the benefits of such an organization of political accountability.

\section{Accountability capacity of Congress}

The information and discussion stages of accountability of IRAs before Congress can be ensured within various processes falling under the umbrella of congressional oversight. As the Oversight Manual for the members of Congress explains, "oversight occurs in virtually any congressional activity and through a wide variety of channels, organizations, and structures." ${ }^{361}$ It takes place during legislative, appropriations and investigation procedures as well as when the Senate holds a confirmation hearing of a potential candidate to head an independent agency. Congressional oversight can thus take place ex ante (confirmation hearings), continuously (during legislative and oversight activities taken by congressional standing committees on a regular basis) and ex post (congressional investigations into particular events).

Congressional oversight implies obtaining information with a view to checking the performance of the executive, which is essential for political accountability. To this end, Congress enjoys various strong tools to obtain information. First, (independent) agencies are subject to numerous reporting obligations. In fact, the number of reports from all executive institutions that reach Congress annually is not that easily counted. ${ }^{362}$ Second, Congress has strong formal powers to subpoena witnesses and to hold them in contempt if a congressional invitation to come to a hearing or to provide documents is ignored. In addition to the formal powers, or perhaps because of their availability, Congress can be involved in

\footnotetext{
${ }^{361}$ CRS Report for Congress "Congressional Oversight Manual” by Kaiser F.M., Oleszek W.J., Tatelman T.B., 2011. P. 1.

362 Pray (2005).
} 
official and informal contacts with the officials from IRAs to obtain more and perhaps better information and to discuss it with them. Third, Congress has established a number of support agencies which assist Congress in its oversight function in two ways: (1) providing more and better (explanatory) information about certain policy issues, agencies and technical matters and (2) overseeing (independent) agencies directly and reporting their findings to Congress. For instance, individual members of Congress and congressional committees may request the Congressional Research Service to give short briefings and prepare reports on the major policy issues as well as on how Congress works whereas the Government Accountability Office may be requested to test the effectiveness of specific agencies' programs and report its findings to Congress.

Furthermore, the strength of oversight lies in its broad scope. "The scope of the power of inquiry, $\langle\ldots\rangle$ is as penetrating and far-reaching as the potential power to enact and appropriate under the Constitution." 363 Depending on the process within which congressional oversight takes place the scope of oversight can differ, from making general inquiries into agencies' performance to investigating specific events and programs, which may have produced adverse effects. For instance, the annual appropriations procedure will focus on how agencies have spent the 'taxpayers' money and what they have achieved with a view to deciding whether relevant programs should receive further funding. During a confirmation hearing, Senators will scrutinize the policy plans of a candidate to head an independent agency; such information can be used in the future against which the actual performance of the appointee can be checked. Furthermore, various statutory obligations, which agencies have to follow in their operation, may influence the scope of oversight. Such procedural and substantive requirements create a frame of reference to check agencies' performance against the standards laid down. For instance, in light of the National Environmental Policy Act Congress can investigate whether an agency has identified and developed "methods and procedures which will insure that presently unquantified environmental amenities and values may be given appropriate consideration in decisionmaking"' and if it prepared a relevant detailed statement on the environmental impact of its actions (42 USC \$\$ 4332 (2 (B) $(\mathrm{C}))$ ).

With respect to the rectification stage, Congress enjoys sanctioning tools of an institutional and personal nature. The former, institutional sanctions, include the possibilities to reorganize and to abolish agencies, to appropriate more or less money to agencies' programs, and to "make life of an agency miserable" by obliging it to come and testify each

\footnotetext{
363 Barenblatt v. US 360 US 109, 111 (1959).

"The power of the Congress to conduct investigations is inherent in the legislative process. That power is broad. It encompasses inquiries concerning the administration of existing laws as well as proposed or possibly needed statutes. It includes surveys of defects in our social, economic or political system for the purpose of enabling the Congress to remedy them. It comprehends probes into departments of the Federal Government to expose corruption, inefficiency or waste" (Watkins v. U.S. 354 U.S. 178, (1957)).
} 
week. ${ }^{364}$ This is difficult because "you have to prepare for hearings. You sit in a conference room and imitate hearings; some play senators and they ask you questions $<\ldots>$ a lot of staff is involved in the preparation of such hearings." 365

There is also a 'menu with US specialties' of sanctions, which includes the Congressional Review Act (CRA), legislative vetoes, deadline hammers, appropriations riders, and earmarks. Pursuant to the CRA, each and every rule has to be submitted to Congress for review. Thus, Congress enjoys the authority to annul any rule, although via the constitutionally prescribed legislative process involving the President. Moreover, Congress may impose deadlines for agencies' actions and also attach sanctions, the so-called 'hammers', in case of an agency's failure to meet a deadline. An example of such a deadline hammer is when Congress gave the Department of Health and Human Services and the Food and Drug Administration 18 months to issue regulations for food imports registration; the hammer in this case was that if the deadline was not met, importers could have registered in the manner they wished, for which these agencies were responsible. ${ }^{366}$ Finally, individual members of Congress may also use appropriation riders as a sanction targeting specific programs that they dislike, and the earmarked appropriations could be used to put an agency on the 'right' track.

The sanctions of a personal nature include various possibilities to remove agencies' officials. First, the US Constitution gives the power to Congress to remove any officer of the United States, which includes heads of IRAs, for the specified crimes via the impeachment procedure (Article II $₫ 4$ of the US Constitution). Second, using its legislative power Congress may 'legislate out' unfavored officials by restructuring agencies. In 1930, it simply legislated some commissioners out of office. This is how it 'reorganized' the Federal Trade Commission. It terminated their terms by law, which led to the appointment of a whole new board. ${ }^{367}$ Abolishing specific positions can be also done with the help of its power of the purse. In 1940, in order to get rid of D.J. Saposs, the chief economist of the National Labor Relations Board, Congress attached a rider forbidding the board to maintain the office; without money there is no post. ${ }^{368}$

While congressional accountability capacity has so far been discussed more in general terms, it is important to note that a few differences in accountability obligations may exist between individual IRAs. The most striking difference concerns the three self-funded IRAs, i.e., the Fed, the FDIC and the FHFA, regulating the financial sector, which escape the financial oversight by Congress. Also, it seems quite self-evident that differences exist, for instance, with respect to the topical spectrum of reporting obligations. The Federal Mari-

\footnotetext{
${ }^{364}$ Commissioner from FTC (interviewed in April 2011).

365 Ibid.

${ }^{366}$ Lubbers (2006) P. 16

${ }^{367}$ Cushman (1941) P. 450 (referring to Act of June 17, 1930, 46 Stat. at L. 590, 696).

368 Ibid. P. 675.
} 
time Commission (FMC) and the Federal Communications Commission (FCC) are required to report on regulatory activity in the maritime and communications sectors respectively. However, at most the members of Congress enjoy a quite uniform set of accountability instruments to hold (independent) agencies to account. In fact, all executive institutions render account before Congress in a very similar way.

\section{Explaining the uniform approach and its advantages}

The uniform approach in organizing the political accountability of US IRAs seems to be best explained by the characteristics of the US constitutional system and the meaning of the concept of independence with respect to agencies in the US context.

The US constitutional system is governed by the separation of powers doctrine. The US Constitution draws rather clear boundaries between the functions of the three branches, although introducing the checks and balances upon each other, such as congressional oversight of the executive. Similar to how congressional oversight began to take place shortly after the adoption of the Constitution, ${ }^{369}$ the formal separation of powers has been steady since the adoption of the US Constitution at the end of 18th century.

It is not to say that no development has affected the balance of powers between the 'separated, yet interdependent branches.' ${ }^{370}$ The development of political parties has affected the checks and balances between the branches greatly. For instance, "empirical studies confirm that presidential vetoes all but disappear during periods of unified government." 371 The quantity and quality of congressional oversight over the executive is also likely to depend on the political majorities sitting in Congress, or its individual chambers, and the White House. While politics can affect the degree of congressional check, the formal powers that Congress has in relation to overseeing the executive, remain steady. Thus, all executive institutions are subject to a very similar set of accountability obligations in relation to Congress, with a few derogations, such as self-funded agencies, which Congress prescribes by law.

The meaning of the concept of independence in the US context can also help to understand why Congress enjoys similar accountability mechanisms in relation to IRAs as to other executive institutions. Independence of US agencies is thought to be achieved by limiting the political influence from the President upon IRAs. Thus, the political accountability of such agencies is organized in a different way in relation to the President, but not in

\footnotetext{
${ }^{369}$ The first major investigation was ordered by the House in 1792 (a committee to inquire into the expedition of Major General St. Clair, whose troops experienced disastrous losses to the Indians) and the power of contempt was exercised already in 1796 (the House ordered the Sergeant at Arms to arrest to suspects they wanted to question) (Fisher (2007) P. 156-157).

${ }^{370}$ Justice Jackson in Youngstown Sheet \& Tube Co. v. Sawyer, 343 U.S. 579, 635 (1952).

${ }^{371}$ Levinson and Pildes (2006) P. 2340.
} 
relation to Congress, which is, however, also a political institution with various tools to influence the independence of agencies.

The biggest advantage of a uniform approach in organizing the political accountability of IRAs before Congress seems to be clarity on how such agencies can be held to account by Congress and hence before the people. This is further strengthened by the presence of general rules and practices. For instance, the Legislative Reorganization Act of 1946 (as amended in 1970) establishes continuous oversight and committee structure of Congress. The Rules of Procedure of the House require committees to issue oversight plans. All agencies can be subject to congressional oversight at any time and, roughly speaking, on any subject of their activity, although within jurisdictions of relevant congressional committees and other limits established by the case law. At the same time, the organization of political accountability of US IRAs shows that uniformity does not imply rigidness. The case of selffunded agencies is a derogation from the general practice because such agencies escape financial oversight by Congress. In fact, the creation of IRAs in itself is a derogation from the 'usual way' that the executive branch institutions render account before the people, which includes two channels, the President and Congress.

Concluding, the US Congress enjoys a solid arsenal of accountability mechanisms, which ensure the three stages of accountability, in relation to US IRAs. In fact, hardly any differences exist between accountability obligations of individual IRAs and other executive institutions in relation to Congress. ${ }^{372}$ The existing uniform approach in the organization of political accountability of IRAs seems to be best explained by the separation of powers and the checks and balances doctrines governing the US constitutional system and the meaning of the concept of independence in the US context. The uniform approach brings advantages of creating a clear system of how Congress can hold agencies to account where uniformity does not imply rigidness as some flexibility may exist, for instance, in the case of self-funded agencies.

\subsubsection{The 'Consciousness' of Design of Accountability Mechanisms}

The design of accountability mechanisms and obligations matters in ensuring political accountability because it predetermines their future functioning. This element can be further subdivided into two parts: the specificity of accountability obligations and interplay of accountability mechanisms. The specificity is necessary in order to make it clear what the legislator expects agencies to $\mathrm{do}^{373}$ and how. This creates a frame of reference that facilitates holding the agencies to account against the standard laid down in advance. The interplay among accountability mechanisms ensures that individual stages of accountability can rein-

\footnotetext{
${ }^{372}$ Clearly from the President's perspective the political accountability of IRAs can be seen as a special case because the President's check over such agencies is limited.

373 Behn (2001) P. 7.
} 
force each other and, in this way, promote the overall accountability. This section discusses accountability obligations of US IRAs in light of the two elements mentioned. The analysis of these elements reveals both valuable learning and somewhat cautionary experience.

\section{Specificity of accountability obligations: the example of reporting obligations}

Concerning the specificity of accountability obligations, the US Congress seems to be very specific when it formulates accountability obligations. The prominent case in point is the reporting obligations that IRAs can be subject to. Here, Congress seems to be very detailed as to what information should be reported and how; the type of information required to be reported and intervals. ${ }^{374}$ Congress may require the agency to conduct a study to be made about a particular problem, to alert it or other institutions about a planned activity, or to provide information about institutions' programs and summarize an agency's activities on a regular basis. ${ }^{375}$ Especially valuable from an accountability perspective are the requests of Congress to provide analytical information. This is ensured by inserting reasons requirements and obligations to report ex post results in light with ex ante plans. Furthermore, Congress's specificity of reporting obligations includes involving other institutions, such as Inspectors General and the Government Accountability Office, in two roles: ensuring agencies' compliance with the reporting obligations and helping such institutions prepare their own reports on the specified topics.

At the same time, there is also a somewhat troublesome aspect of US reporting obligations--their great number. ${ }^{376}$ The great number of reports involves time and human resources in IRAs and Congress to prepare and to check those reports. If the reports are not read by the members of Congress, their necessity should be questioned. In this light, the fire-alarm form of oversight becomes important. If reports are available to a broader public and congressional support agencies, the chances of reports being read and of the members of Congress being informed about possible irregularities via interest groups and lobbyist increase.

\footnotetext{
${ }^{374}$ See, for instance, a part of the enabling act of the Postal Regulatory Commission (PRC) where reporting obligations take several pages (section 3.2.3.1.).

${ }^{375}$ CRS Report for Congress "Congressional Oversight Manual” by Kaiser F.M., Oleszek W.J., Tatelman T.B., 2011. P. 95.

${ }^{376}$ A Wall Street Journal estimation of 1991 was approximately 3,000 reports, at an annual cost of \$ 350 million (Pray (2005) P. 300). A Congressional Research Service’s report refers to approximately 4,000 reports that reach Congress annually (CRS Report for Congress 'Congressional Oversight Manual' by Kaiser F.M., Oleszek W.J., Tatelman T.B., 2011. P. 95).
} 


\section{Interplay between accountability mechanisms}

With respect to the interplay of accountability mechanisms the US case shows a good example. All three stages of political accountability of US independent regulatory commissions can take place before the US Congress or, more specifically, before relevant specialized and appropriations committees. Congressional standing committees receive reports and other information from 'their' agencies. Committees can request additional information and organize hearings with agencies' officials as frequently as they wish. Finally, committees are also in charge of initiating the sanctions because the legislative and oversight powers of standing committees and at times individual chairmen or members of Congress are quite strong. Thus, all three stages of accountability can take place before individual committees.

At the same time, while the tools to ensure the information and discussion stages of accountability are available to individual congressional committees, most of the sanctioning possibilities can be exercised only in cooperation with other institutions, such as the other chamber of Congress or the President. This is because sanctions, such as reducing the budget or legislating an official out of office, require the passage of a bill. Individual committees on their own can only provide 'shaming and blaming' hearings and give informal disapprovals of agencies' actions and reallocation of finances from one program to another. Hence, the exercise of the rectification stage seems to be dependent on cooperation with other institutions. Following the 'separation of parties, not powers' theory the degree of cooperation will be influenced by the political majorities sitting in the respective institutions.

Concluding, the political accountability of US IRAs offers illustrative examples with respect to how the design of accountability obligations can promote accountability. The example of reporting obligations shows that Congress can be very specific as to what information agencies have to report back, how, and how often. The number of reports is, however, so great that it may hinder the check upon agencies since it makes it rather challenging for the members of Congress to study all the submitted reports properly. Concerning the consciousness of design of accountability mechanisms, there is interplay between mechanisms ensuring individuals stages of accountability before the same congressional committees. It has to be taken into consideration, however, that a number of sanctioning tools, such as appropriations bills, can be used only when other institutions, the other congressional chamber and the President, cooperate; the latter is influenced by political majorities sitting in respective institutions.

\subsubsection{The Practical Application of Accountability Mechanisms: Challenges and Solutions}

In addition to the availability of accountability mechanisms and their design, it is important that accountability mechanisms are applied in practice. This section discusses what 
challenges of practical application accountability mechanisms ensuring individual challenges of accountability of US IRAs face and whether and, if so, how Congress has attempted to address such challenges.

As the previous sections showed, Congress receives numerous reports from agencies and about agencies and can question agencies' officials at any time. In practice, however, it is unrealistic to expect the members of Congress to study (properly) all those thousands of reports and to understand all the technical details that such reports may include. Also, while congressional hearings can take place as often as Congress wishes, they may not take place and they may not necessarily be valuable for accountability considering their substance.

Congress has found the ways to deal with the great amount of (technical) information that it receives from agencies. It has divided its chambers into standing committees specializing in specific fields and has increased its staff which can offer necessary expertise. In total it employs 17,000 staff working for both chambers. Congress has expanded its oversight capacity by establishing a number of support institutions who may have the task to hold agencies to account directly. As Kiewiet and McCubbins note ironically, "The response of Congress to delegating problems, $\langle\ldots\rangle$, was to delegate responsibility for addressing these problems to another agency." 377 In addition to individual Inspectors General placed in individual agencies, almost 4,000 support staff are employed in congressional support bodies, including the Government Accountability Office, Congressional Budget Office, Congressional Research Service and the Administrative Conference of the United States. By establishing a direct link between agencies and the public it has also increased the chances that reports and generally agencies' actions are going to be checked.

At the same time, having the mentioned support possibilities does not completely resolve the problem of congressional oversight by the elected members themselves being selective and ad hoc, rather than general and continuous. Congressional oversight is a timeand resource- consuming activity which does not necessarily bring individual political benefit. This impacts the incentives of the members to be involved in continuing oversight activities. In light of the 'separation of parties, not power' theory, congressional check upon the executive is influenced by political majorities sitting on Capitol Hill and in the White House or the management boards of IRAs. Several examples can illustrate this point.

First, this concerns confirmation hearings at the Senate which may be important for oversight purposes since the information that a nominee reveals sets up a frame of reference to check against later. Also, some suggest that "when the Senate really scrutinizes the President's picks, by contrast, it can hold him accountable." ${ }^{378}$ Yet, such hearings can be skipped for political reasons or "be like a family reunion" for those appointees who have previously

\footnotetext{
377 Kiewiet and McCubbins (1991) P. 19.

${ }^{378}$ Kalt (2011) P. 3.
} 
worked in the Senate. ${ }^{379}$ Furthermore, congressional hearings can be unproductive "if members simply come into the room and read prepared questions and are not prepared to follow up with tough questions in light of the initial responses from the witness." 380

Second, a remarkable attempt to address the challenge of weak incentives of the members to conduct oversight has been a self-enforcing rule (House Rule X) to submit oversight plans and follow-up reports. Yet, establishing such a rule immediately resulted in complaints about the unpalatability of showing the minority party the oversight plans for the next two years. ${ }^{381}$ But whether or not such plans are announced, the quantity and quality of oversight will clearly depend on political majorities sitting on Capitol Hill and in the White House or IRAs' management boards (see Chapter 3.1.1.3.).

Third, while Congress occasionally inserts sunset clauses obliging itself to review the necessity of federal programs and financing in the future, they are usually not enforced, "because Congress is either too busy — or, more accurately — too neglectful," said Rep. Jim Cooper (D-Tenn.)." 382

All in all, "no set of rules, no matter how artfully drafted and well intentioned, will produce effective oversight if the will is not there." ${ }^{383}$ And the will of Congress is greatly influenced by political and personal gains of its members.

Concluding, while Congress has addressed the challenge of overseeing intelligibly the high number of agencies by increasing its own support and sharing its oversight responsibility with its expert support bodies and the public, it seems to have been less successful in being able to make its own members adhere to their own oversight responsibilities. Political and personal gains of the members of Congress will influence the quantity and quality of congressional checks upon the executive.

\section{Conclusion}

The intention of this section was to assess the political accountability of US independent regulatory agencies with a view to making a comparison with the EU and in light of comparative insights to offer policy recommendations to the EU representative institutions on how the political accountability of EU agencies could be adjusted. To this end, the political

\footnotetext{
${ }^{379}$ Commissioner from FMC (interviewed in May 2011).

${ }^{380}$ Hamilton L. (Member of the US Congress 1965-1999) in: The committee print of "Congressional Oversight: A "How-to" Series of Workshops, sponsored by the Speaker and the Chairman, House Rules Committee, organized and conducted by the CRS, 1999. P. 15.

381 Wolfensberger D. (Former Staff Director of the House Rules Committee) in: The committee print of "Congressional Oversight: A "How-to" Series of Workshops, sponsored by the Speaker and the Chairman, House Rules Committee, organized and conducted by the CRS, 1999. P. 62-63.

382 Fahrenthold (2012).

383 Wolfensberger D. (Former Staff Director of the House Rules Committee) in: The committee print of "Congressional Oversight: A "How-to" Series of Workshops, sponsored by the Speaker and the Chairman, House Rules Committee, organized and conducted by the CRS, 1999. P. 66.
} 
accountability of US IRAs was evaluated with regard to the three elements introduced in Chapter 1 . These are the availability of accountability mechanisms, their design and practical application. In light of these three elements the political accountability of US IRAs can be assessed as partly problematic.

The accountability system of US IRAs is organized in a quite uniform way which makes it clear how Congress can hold IRAs to account. In fact, Congress enjoys very strong powers which can ensure all three stages of accountability. Furthermore, accountability obligations are designed in such a way that they can promote accountability purposes. This section discussed the specificity of reporting obligations, which promotes analytical reporting, and a good interplay of accountability mechanisms ensuring individual stages of accountability before the same congressional committees. While the assessment of the US systems reveals some cautionary aspects, such as the great amount of (technical) information to deal with for the elected representatives, it also shows the solutions which Congress employed to address the challenges to its oversight function. Concerning the mentioned example Congress has increased its staff, created expert support bodies and established a direct accountability line between the agencies and the public. At the same time, not all challenges to political accountability can be addressed successfully. By introducing the self-enforcing rules obliging its members to report on oversight plans and results Congress seems to realize the necessity to render account before the public for the exercise of its oversight functions, yet, the politics make it quite challenging to adhere to its responsibilities. Following the 'separation of parties, not powers theory' the usage of all those strong powers that Congress has in relation to holding the executive to account depends on the political majorities sitting in its chambers and the executive, including IRAs. Thus, following Madison's legacy of first ensuring that the government will control the governed and then obliging the government to control itself, ${ }^{384}$ the greatest challenges to the political accountability of US IRAs seemed to lie largely in the second step.

${ }^{384}$ Madison J. 'The Federalist No. 51' printed in: Kesler and Rossiter (2003). P. 319. 


\section{Chapter 4. \\ The Political Accountability of IRAs in the EU and the US Compared}

Having investigated two systems separately, Chapter 4 offers a comparative analysis of the political accountability of independent regulatory agencies (IRAs) in the EU and the US with the purpose of learning from the US experience how the political accountability of EU agencies could be adjusted. It comes in three parts corresponding to the three elements of the formula introduced in Chapter 1 regarding how political accountability can be assessed: the availability of accountability mechanisms, their design, and practical application. The comparative analysis in this chapter shows that the US experience offers valuable lessons to consider for the Council and the European Parliament, sends warning signals in relation to some experiences that would be better avoided, and demonstrates similar concerns that indicate the fundamental character of certain questions in the field of the political accountability of independent regulatory agencies.

\subsection{The Availability of Accountability Mechanisms: Diversity vs. Uniformity}

For an accountability forum to be able to hold an actor to account, the availability of accountability mechanisms ensuring the three stages of accountability, i.e., information, discussion, and rectification, is necessary. This section compares accountability mechanisms, or 'accountability capacity', of the EU and the US representative institutions and shows that, in principle, the general arsenal of accountability mechanisms of the Council and the European Parliament is not considerably smaller than that of the US Congress. While individual accountability mechanisms may differ in their strength, the most striking difference between the EU and the US here lies in the approach that the legislators have applied to the use of accountability mechanisms in relation to individual agencies. It has been more uniformly applied in the case of the US, whereas an excessive diversity characterizes the case of the EU. This section starts by giving a brief comparative overview of accountability mechanisms available for the representative institutions in both jurisdictions (4.1.1.), it continues by explaining the similarities and differences of both jurisdictions' approaches in relation to the political accountability of IRAs (4.1.2), and it concludes by discussing the advantages of a more uniform approach in organizing the political accountability of EU agencies (4.1.3.). 


\subsubsection{Similar Accountability Mechanisms}

Generally speaking, the representative institutions in the EU and the US enjoy very similar accountability mechanisms of an institutional and personal nature. The former includes reporting, possibilities to scrutinize agencies' performance and finance, making investigations into specific events, and sanctioning tools of an institutional character, such as the modification of agencies' functions, budgets, and organizational structures. To ensure the personal accountability line of the 'unelected officials' heading IRAs to the people, the EU and US representative institutions can be involved in appointing and removing agencies' top-level officials. In this light, the available accountability mechanisms of the EU representative institutions are very similar to those of the US Congress. It is, however, not to say that accountability mechanisms are identical with respect to their strength.

The most noticeable example of the differences in strength of accountability mechanisms lies in the field of parliamentary scrutiny, where the European Parliament's formal power to scrutinize agencies' top-level officials for their performance is much weaker than that of the US Congress. It would not be a gross exaggeration to state that congressional committees may question agencies at any time on any matter within their jurisdiction, formally and informally, upon a statutory requirement or without any. US IRAs, in a way, are in a 'more difficult' situation than US executive agencies and departments, because they have no political protection from the President. A commissioner, "who had previously been an important official in the White House, remarked that being in an independent regulatory commission meant "having to appear naked in front of Congress," without the political protection a connection to the White House could bring."

At the same time, there are only 16 (out of 35) EU agencies whose founding acts provide formal hearing obligations for their directors before the European Parliament to report on their agencies' performance. Although both the European Parliament and Congress can establish special committees to investigate specific agencies and their actions, the European Parliament lacks the powers Congress has to subpoena witnesses and to hold them in contempt. Thus, the European Parliament's scrutiny tool is at least formally less strong and may not apply to some EU agencies. The difference in strength could also be demonstrated by the Senate's consent and the European Parliament's advisory roles (except for the three financial agencies) in the appointment procedures of agencies' top officials.

The difference in strength between accountability mechanisms is not always in favor of the US. For instance, while the sphere of financial oversight is an important accountability venue in both jurisdictions, also considering the strength of powers that the representative institutions have in this respect, the European Parliament's power to give discharge is something that the US Congress (or its individual chambers) lacks. ${ }^{2}$ Having a separate (from the

\footnotetext{
1 Strauss (2002) P. 82.

2 "Little attention is given to how agencies actually spend the appropriated money" (Fisher (2011) P. 190).
} 
annual budgetary) procedure may increase the number, regularity, and spectrum of interactions and checks between the European Parliament and its specialized committees and EU agencies. Also, the power of the final say over agencies' financial accounts gives an additional leverage to the European Parliament, which may at times imply an indirect power of removal, such as arguably in the case of Cepol (see Chapter 2.2.4.2.).

The only mechanism that makes the difference between accountability arsenals of the two jurisdictions is the possibility to review and annul agencies' decisions. The EU representative institutions do not have a European version of the Congressional Review Act which allows Congress to be informed about all, and especially major, decisions that agencies take, and if necessary to annul them. The reason for the absence of an annulment possibility in the EU could be interconnected with the fact that only seven EU agencies (CPVO, EASA, EBA, ECHA, EIOPA, ESMA, and OHIM) have decision-making powers. Whereas in practice recommendations of advisory agencies, such as EFSA and EMA, may be rubber-stamped by the Commission, formally speaking, it is the Commission that takes the decision and hence bears responsibility for it. At the same time, while Congress has the opportunity to annul agencies' decisions, it has used it only once since the CRA entered into force (1996). It seems to use rather legislative vetoes informally, even if they were declared unconstitutional. Such informal contacts resemble in a way the relationship between the EU Commission and EU agencies where EU agencies have to inform the Commission about their decisions before their publication ${ }^{3}$ and where the Commission does not have to follow the advice given by an agency which is in a way an 'act of annulment'.

All in all, while differences exist concerning the strength of accountability mechanisms and the EU representative institutions do not have the power to annual agencies' decisions, the accountability instruments that the political accountability forums have in the EU and the US are quite similar.

\subsubsection{Similar Mechanisms but Different Approaches}

While, generally speaking, the representative institutions in the EU and the US enjoy similar accountability mechanisms, looking more specifically at the individual IRAs' accountability obligations in two jurisdictions, one faces a striking difference between the EU and the US, which can be succinctly put as 'diversity vs. uniformity'.

In the EU, the existing $35 \mathrm{EU}$ agencies have, roughly speaking, 35 accountability regimes. The most remarkable example here concerns the self-funded Community Plant Variety Office (CPVO), which is not legally obliged to send its report to the European Parliament, as is the case with nearly every EU agency, including the self-funded Office for Harmonization in the Internal Market (OHIM), an agency that is similar to the CPVO in type and function. Also, both CPVO and OHIM were created in the same second wave of

\footnotetext{
${ }^{3}$ Official from the European Commission (interviewed in October 2011).
} 
the creation of EU agencies (in 1994). Furthermore, there are 12 different procedures of how EU agencies' directors can be appointed. Big differences exist also with respect to the obligation for the potential agency's director to appear before the European Parliament for questions, which applies only in 18 out of 35 cases (see Chapter 2.2.1.1.). The practices related to parliamentary scrutiny over agencies' performance, such as appointing liaisons and visiting agencies, also vary greatly from parliamentary committee to parliamentary committee. The financial oversight is probably the most harmonized procedure, although self-funded agencies are excluded. Appendix 1 presents the individual accountability arrangements of all $35 \mathrm{EU}$ agencies.

Conversely, all US independent (and also 'dependent') agencies are subject to the congressional watchful eye in a very similar way. The mentioned mechanisms, such as reporting, scrutinizing agencies' performance and expenditure, making investigations, and being involved in appointment and removal, apply to a large extent to all agencies. Certainly, a few differences may exist between various agencies. As an example, the Federal Maritime Commission and the Federal Communications Commission would be required to report on regulatory activity in the maritime and communications sectors respectively. Or, the self-funding option has been used in three (out of 16) cases of IRAs regulating the financial sector. But these differences seem to correspond more to agencies' specific fields of work rather than being somewhat random insertions. A 'basic set of accountability instruments' exists for the members of Congress. Everybody seems to render account in a very similar way.

\section{Explaining the difference in the approach}

That one jurisdiction uses a more uniform approach in relation to the political accountability of IRAs, and the other one a diverse approach, could be explained by differences in legislative style, and this alone does not necessarily mean that IRAs are more or less accountable in one or the other jurisdiction. However, it seems that the main reason for the EU's diverse approach lies in something other than the preference for another legislative style.

\section{The role of the evolving institutional balance in the EU}

The evolving institutional balance in the EU seems to account for the existing diversity with respect to the diverse organization of the political accountability of EU agencies. Most of the EU agencies' founding acts have been negotiated at different times in history, i.e., in three waves (1975, 1990s and 2000s), meaning with a different power balance between the key actors participating in the creation of agencies. Negotiations have taken place between and within different institutions, i.e., the Council comprising representatives of an increasing number of member states since the first of the EU agencies were established in 1975, the Commission, and the European Parliament. Note also the evolving legislative and 
budgetary role of the European Parliament (see Table 2.1.), its involvement in negotiating agencies' founding acts, and further involvement in holding agencies to account has seen considerable changes in the last few decades - from having no say to having the colegislative power. The fact that the EU governing structures have been evolving themselves seems to have considerably influenced the patchy architecture of the political accountability of EU agencies, which is not regulated at the treaty level.

Conversely, the US Constitution regulates the functional boundaries between the three branches and the constitutional separation of powers exists largely unchanged since the $18^{\text {th }}$ century. It is true that different developments in US constitutional law may have impacted the constitutionally prescribed separation of powers. A prominent example is the development of political parties, not foreseen by the Founding Fathers of the US Constitution. In this respect, the 'separation of parties and not powers' theory explains the differences of how congressional formal powers can be used differently depending on the political majorities sitting in Congress and the White House or on the management boards of IRAs. While the politics may affect the application of Congressional powers, the distribution of formal powers among the US federal institutions has remained quite stable since the adoption of the US Constitution. Furthermore, the creation of IRAs has changed the President's accountability role since in Humphrey's (1934) the Supreme Court upheld the 'for cause' removal restriction, meaning that the President cannot remove the heads of IRAs at his discretion as he can with all other agencies of the executive branch. While IRAs have thus become 'freestanding components of the executive branch, ${ }^{34}$ in relation to Congress their accountability has been organized in the same way as that of other executive institutions.

\section{The absence of strict legal rules governing the creation of and delegation to agencies}

What also seems to add to the diverse outcomes of highly politicized negotiations with respect to EU agencies is the absence of any strict legal boundaries regulating the creation of and delegation to EU agencies. However, this factor seems effective only in combination with the evolving principle of institutional balance.

IRAs exist in both jurisdictions despite the absence of an explicit constitutional (the US) or treaty (the EU) provision allowing the creation of and delegation to (independent) agencies. The courts in the EU and the US did not overturn the creation of agencies, instead they formulated creation and delegation standards which seem to follow the same logic (see Table 4.1. below):

- permission to create assistants entrusted with powers that the delegating authorities could exercise themselves;

- restrictions upon the nature of delegatable powers, i.e., prohibition to delegate the power to make important policy-making choices;

\footnotetext{
${ }^{4}$ Free Enterprise Fund et al. v Public Company Accounting Oversight Board et al. 561 US _ (2010).
} 
- $\quad$ and prescriptions of establishing some kind of guidance and supervision by the delegating authority over the recipients of the delegated powers.

Similar to the EU's broad creation and delegation standards the US Congress can create IRAs, roughly speaking, as long as it is 'necessary and proper' and the legislature can empower agencies with non-legislative tasks to fill in the details.

Table 4.1. Creation and Delegation Standards in the EU and the US compared

\begin{tabular}{|c|c|c|}
\hline & $\mathrm{EU}$ & US \\
\hline $\begin{array}{l}\text { Creation stand- } \\
\text { ards }\end{array}$ & $\begin{array}{l}\text { The power to authorize or to make certain } \\
\text { arrangements itself gives the delegating } \\
\text { authority the right to entrust certain } \\
\text { powers to such bodies subject to condi- } \\
\text { tions to be determined by it and subject to } \\
\text { its supervision. }\end{array}$ & $\begin{array}{l}\text { Congress may create institutions that are 'neces- } \\
\text { sary and proper for carrying into execution the } \\
\text { enumerated powers' given to Congress in the } \\
\text { Constitution. }\end{array}$ \\
\hline $\begin{array}{l}\text { 'Delegatable' } \\
\text { Powers }\end{array}$ & Executive, involving no discretion ${ }^{7}$ & $\begin{array}{l}\text { Non-legislative powers, the power to 'fill up the } \\
\text { details's }\end{array}$ \\
\hline $\begin{array}{l}\text { Delegation } \\
\text { standards }\end{array}$ & $\begin{array}{l}\text { Subject to strict review in light of objective } \\
\text { criteria determined by the delegating } \\
\text { authority. }\end{array}$ & $\begin{array}{l}\text { Upon 'intelligible principle }{ }^{\prime 10} \text { which establishes } \\
\text { certain guidance for agencies. Congress needs to } \\
\text { set a standard for agency action and to declare a } \\
\text { policy with respect to the regulated matter. }\end{array}$ \\
\hline
\end{tabular}

${ }^{5}$ Case 9-56, Meroni \& Co., Industrie Metallurgiche, SpA v High Authority of the European Coal and Steel Community. P. 151, discussed in Chapter 2.2.1.2. See, also, Case C-301/02, P Carmine Salvatore Tralli v ECB, 2005, ECR I-4071. P. 42 ("the powers conferred on an institution include the right to delegate").

${ }^{6}$ McCulloch v. Maryland (17 US 316 (1819)), discussed in Chapter 3.2.1.1.

See, also, Humphrey's Executor v. U.S. 295 U.S. 602, 629 (1935) ("The authority of Congress, in creating quasi legislative or quasi judicial agencies, to require them to act in discharge of their duties independently of executive control cannot well be doubted").

7 "Since it replaces the choices of the delegator by the choices of the delegate", delegation of discretionary power is not allowed, because it "brings about an actual transfer of responsibility" (Case 9-56, Meroni \& Co., Industrie Metallurgiche, SpA v High Authority of the European Coal and Steel Community. P. 152).

8 "Congress may certainly delegate $\langle\ldots>$ powers which the legislature may rightfully exercise itself. $<\ldots>$ The line has not been exactly drawn which separates those important subjects, which must be entirely regulated by the legislature itself, from those of less interest, in which a general provision may be made, and power given to those who are to act under such general provisions to fill up the details" (emphasis added). (Wayman v. Southard, 23 US (10 Wheat) 1, 43 (1825)), discussed in Chapter 3.2.1.2.

${ }^{9}$ Case 9-56, Meroni \& Co., Industrie Metallurgiche, SpA v High Authority of the European Coal and Steel Community. P. 152.

${ }^{10}$ Hampton, Jr., \& Co. v. U.S. 276 U.S. 394 (1928), reaffirmed in Whitman v. American Trucking Associations 531 U.S. 457 (2001), discussed in Chapter 3.2.1.2. 
While the creation and delegation standards encounter interesting similarities, the two jurisdictions illustrate different ${ }^{11}$ results, i.e., diversity vs. uniformity, in organizing the political accountability of IRAs. The reason for the identified difference seems to lie in the fact that the factor of the absence of strict legal rules is influenced by another condition, i.e., the evolving institutional balance. While both jurisdictions feature the absence of strict standards in relation to the creation and delegation standards, which implies flexibility for negotiation processes as regards the creation and operation of agencies, the degree of flexibility seems to be higher when other variables, i.e., the interinstitutional power balance between the key players, have not been constant. It is therefore the combination of the absence of strict rules and the 'living' institutional balance that seem to explain the existing variety of accountability obligations in the field of the political accountability of EU agencies. Since the European Parliament has become more uniformly involved in the EU legislative process after the most recent treaty reform of 2009, one could expect the creation of a more general framework of the accountability of EU agencies. In this light, the recently released 'Common Approach' on EU agencies could become such a framework, although due to its non-binding nature its credibility yet needs to be established in future negotiations.

\section{Implications of the absence of strict legal rules governing the creation of and delegation to agencies}

If more uniformity can be expected because the institutional balance among the EU institutions is likely to remain steady, at least in the short-term, does the absence of strict creation and delegation standards affect the political accountability of agencies? It seems it does. Both jurisdictions seem to feature the same effect in this respect: legislators can misuse the flexibility caused by the absence of strict creation and delegation standards and cultivate (independent) agencies with no functional necessity and questionable accountability. IRAs are created in both jurisdictions without being based on constitutional or treaty provisions or other guidance as to when IRAs should be created. Also, the legislature has used justifications of a procedural rather than a substantive nature (in the EU), if giving them at all (in the US).

In this light, on the basis of the comparison of the EU and US independent regulatory agencies, it can be observed that there seems to be no common rationale as to why an independent regulatory agency needs to be created. While both jurisdictions have independent institutions to conduct monetary policy; the European Central Bank (although it is not an EU agency) and the Federal Reserve in the US, in other policy areas the US and EU have

\footnotetext{
${ }^{11}$ Although from the perspective of the theory of the unitary executive, since accountability arrangements of US IRAs differ from those of the executive branch in relation to the US President, the result could be considered to be the same as in the EU, i.e., diversity in the organization of political accountability of independent and other agencies, though with a much lower degree of diversity.
} 
created different types of agencies. For instance, the US Environmental Protection Agency ${ }^{12}$ and the Food and Drug Administration are executive, and not independent, agencies in the US, while the European Environment Agency ${ }^{13}$ and the European Food and Safety Authority are IRAs in the EU. In part, the difference in policy areas delegated to independent bodies in different jurisdictions could be explained by the areas delegated to the federal or supranational level. However, as was shown earlier, in the US, the choice between delegating to executive agency is used "relatively more often under unified government, while independent agencies and commissions are used more often under divided control." ${ }^{14}$ And in the EU, the creation of a number of existing agencies is ill-reasoned (see Chapter 2.2.1.1.). Moreover, EU agencies' founding regulations use the words 'independent' and 'autonomous' interchangeably while some founding acts (also in the US) do not even have these terms in their texts (see Appendix 1 and 3). In this light, the delegation of public authority in regulatory areas other than the financial sector to independent regulatory agencies, agencies whose political accountability is organized in a different way than that of the principal executive institutions (the Commission and the President), seems to be of questionable functional necessity. ${ }^{15}$ Without strict legal rules it is always up to the legislature to decide when to create an independent regulatory agency and with what accountability obligations, even if the legislature's choice may lack good (functional) reasons.

Interestingly, the existing delegation standards are criticized in both the EU and the US for their ineffectiveness. "The [US] non-delegation doctrine is almost a complete failure. It has not prevented the delegation of legislative power."16 "It remains a source of continuing controversy whether the non-delegation doctrine still exists, and, if it does, whether courts can and should enforce it by invalidating improper delegations." ${ }^{17}$ It is vague and it allows general laws to be passed by which Congress shifts the blame and hard choices to agencies. ${ }^{18}$ Concerning the EU, a great many scholars have pointed out a thin line between the delegatable 'executive' and prohibited for delegation 'discretionary' powers (see Chapters 1 and 2). In this light, "if the distinction between instrumental and final powers tends to blur,

\footnotetext{
${ }^{12}$ It is a free-standing executive agency. It is executive because it has one head who serves at the will of the President. It is free-standing, because it is not subordinated to any executive department (ministry).

${ }^{13}$ In its founding act the EEA has a somewhat controversial 'independence clause' however: "the Agency should be granted legal autonomy while maintaining close links with the Community institutions and the Member States" (Recital 11 of its Founding Regulation (EC) No 401/2009).

${ }^{14}$ Epstein and O’Halloran (1999) P. 154-155.

Unified government implies the majorities in Congress and the White House's political colour correspond to each other, whereas divided government implies different parties sitting in Congress and in the White House.

${ }^{15}$ Although even in relation to the regulation of the financial sector some scholars argue that the creation of independent central banks in the US and the EU cannot be merely explained by functional economic requirements. "In both cases, these structures have political roots" (Jabco (2005) P. 12).

${ }^{16}$ Davis (1968-1969) P. 713.

${ }^{17}$ Asimow and Levin (2009) P. 374.

${ }^{18}$ Schoenbrod (1993).
} 
then it should not be taken for granted that European agencies are actually in line with" the Meroni jurisprudence. ${ }^{19}$ Therefore, stricter delegation standards, which include clearer requirements on what accountability elements need to be established to pass the creation and delegation tests, seem to be necessary to keep the dispersion of the executive branch within reasonable limits and upon good reasons and to prevent an accountability deficit. Here, the advantages of having a more uniform approach in organizing the political accountability of EU agencies seem to stand out.

\subsubsection{Diversity vs. Uniformity}

The fact that EU agencies' accountability obligations differ from agency to agency does not automatically imply having problematic accountability; diversity is not an accountability problem in itself. Yet, how much diversity does political accountability allow? The classic argument defending diversity in relation to (EU) agencies is that agencies are different in many respects, especially in the functions they perform. The proponents of such a view would argue that it is necessary to look into the specifics of each and every situation when creating an agency and designing its accountability obligations. While in both the EU and the US independent regulatory agencies are sui generis bodies, as they are created on a caseby-case basis, the striking difference exists in how much their accountability provisions are sui generis. In light of the US example, it seems that the fundamental character of political accountability implies that every agency has to render account before representative institutions and, in this way, before the people. This clearly limits the variety of accountability models.

Furthermore, the growing number of EU agencies, each having its own original accountability settings, hinders the establishment of any systematic understanding of EU agencies. This in turn puts the already complex EU structures and processes beyond the understanding of not only outsiders, including the 'ultimate principal', the people, but also arguably of the insiders, given, for instance, the high turnover of MEPs after each election. As Hamilton noted over two centuries ago, "one of the weightiest objections to a plurality in the Executive $\langle\ldots\rangle$ is that it tends to conceal faults and destroy responsibility. $<\ldots\rangle$ It often becomes impossible, amidst mutual accusations, to determine on whom the blame or the punishment of a pernicious measure $<\ldots$. $>$ ought really to fall. ${ }^{20}$ Likewise, diversity of accountability arrangements disperses the political accountability forum and hence on whom the blame or the punishment for not holding to account ought really to fall.

Also, diversity may increase disparity in law and in the application of accountability mechanisms. The example of the reporting obligations of CPVO and OHIM mentioned earlier is an illustration of inserting different accountability obligations into the founding

\footnotetext{
${ }^{19}$ Chiti (2009) P. 1406.

${ }^{20}$ Hamilton 'The Federalist No. 70' printed in: Kesler and Rossiter (2003). P. 426.
} 
acts establishing two functionally very similar agencies created in the same wave of the creation of EU agencies with unclear reasons for such differences. Concerning the disparity in application, individual parliamentary committees of the European Parliament have established different oversight practices, such as appointing liaison members to be responsible for contact with individual agencies or allotting different time limits for directors' presentations, in relation to agencies falling within their remits. In relation to the latter, different levels and scope of discussions can be expected between agencies' representatives and members of the European Parliament after a 10-15 minute presentation with hardly any members present in the employment committee and after a 90-120 minute presentation before the environment committee. ${ }^{21}$

Additionally, from a very practical angle, a more uniform approach may save the legislator's time in drafting agencies' founding acts if a template is available. While elaborating a template seems to have been proposed by the Commission in its Draft Interinstitutional Agreement on Agencies in 2005 and such ideas are present in the recently released 'Common Approach' of EU agencies, the latter document also shows how difficult it is to come up with a set of common principles acceptable to the key players, and it remains to be seen in how much its stated intentions will actually be followed in further agencification in the EU.

The advantages of organizing the political accountability of EU agencies in a more uniform way include clarity of the whole system and accountability roles of the accountability forum. Clarity is an important characteristic in a Union of 28 different nationalities (and hence different cultures to hold to account) and where continuity of accountability practices is contested by a great number of parties involved, i.e., the European Parliament and the Council and their internal subdivisions, and by the high turnover of MEPs after each election. In addition, making EU agencies subject to similar accountability obligations may facilitate decreasing disparities in law and in application.

It is important to stress that uniformity does not automatically imply rigidness. In this light, it is important to distinguish between two levels of uniformity: uniformity of accountability powers and responsibilities at the institutional level (who holds to account whom and with the help of which mechanisms) and uniformity of quantity and intensity of accountability obligations in individual cases (for instance, the number of reporting obligations individual agencies are subject to). The flexibility at the level of quantity and intensity of accountability obligations correspondent to, for instance, the scope of agencies' functions

\footnotetext{
${ }^{21}$ Administrator of European Parliament's Employment Committee (interviewed in September 2011) and Senior official from ECHA (interviewed in September 2011).

Clearly, the length of individual presentations may be influenced by other factors, such as technical details of a subject matter or number of new developments in the field. However, if annual presentations are always short and are given before a very few MEPs, this could be an indication of the lacking interest on the side of the overseeing authority to be involved in checking an agency; further empirical research is necessary in this respect.
} 
would not hurt the clarity of the accountability system at the institutional level (who holds the agency to account and how). Here, a streamlining approach, including a few reasoned templates of political accountability, would allow for both clarity and flexibility. Furthermore, the clarity of the system based on reasons behind existing differences may promote transparency of accountability practices, also because it would make a comparative analysis of different agencies more feasible. A clear and transparent system of political accountability of agencies governed by reason is essential in promoting both formal and social legitimacy of the EU.

Concluding, the comparative analysis of the accountability capacity of the EU and US representative institutions has shown a quite similar arsenal of accountability mechanisms which may, however, differ in their availability in relation to individual agencies and in their formal strength. While the sets of accountability mechanisms are similar, the striking difference lies in different approaches according to which the mechanisms have been used in relation to individual agencies: with an excessive diversity in the EU as compared to great uniformity in the US. This section has argued that the EU could benefit from introducing a more uniform approach, in which a few accountability models could be created with clear reasons behind the differences. For the EU, such a flexible uniform approach governed by reason seems to be essential as it promotes clarity, comprehensibility, and transparency of the political accountability of EU agencies and hence facilitates the legitimacy of the EU. As a final remark, that a system is considered to be uniform says very little about its soundness. The design of an accountability system and practical application of the rules of the game, the issues discussed in the following two sections, are also essential to ensure political accountability.

\subsection{The Design of Accountability Mechanisms: Specificity and Interplay}

In addition to the accountability capacity, the second important element ensuring political accountability is the design of an accountability system. This includes formulating accountability obligations and establishing interplay between different accountability mechanisms in such a way that they promote the purposes of accountability. The formulation of accountability obligations predetermines their future application. In this light, the specificity element stands out because it makes it clear for an agency what it is expected to do, which in turn enhances the feasibility to check agencies against the standards laid down in prospect. Furthermore, accountability mechanisms need to interplay with each other "to promote the overall objectives of the enterprise" 22 called accountability. This section compares the political accountability of EU and US agencies with respect to the specificity of accountability obligations and the interplay between accountability mechanisms. It argues

22 Oliver (2009) P.29. 
that the Union Legislator should be more specific when formulating EU agencies' accountability obligations and it should consider the issue of interplay between different accountability mechanisms once a political agreement on the accountability roles of the EU main institutions is reached.

\subsubsection{Specificity of Accountability Obligations: Balancing between Too Few and Too Many Details and Obligations}

The US example is extremely valuable with respect to the amount and the specificity of accountability obligations offering lessons in both respects - learning and warning. The prominent case in point concerns reporting obligations. Here, the US Congress can be very specific as to what information should be reported and how, i.e., the type of information required to be reported and the intervals. ${ }^{23}$ The degree of specificity is so high that reporting obligations can take several pages. In section 3.2.3.1., an example was given with an extract of reporting obligations from the enabling act of the Postal Regulatory Commission. The fact that the extract was a few pages long says something about the amount and specificity of reporting obligations in the US.

Furthermore, US IRAs can receive their reporting obligations from additional statutes with which they have to comply. As was mentioned earlier, statutes, like the Congressional Review Act (CRA), are another source of reporting obligations where agencies have to provide Congress additional reports. In the case of CRA, agencies need to report about each rule they make. In addition, agencies may be required to implement programs established other than by their enabling statutes. For instance, according to a Commissioner from the Federal Trade Commission, this agency implements approximately 50 statutes. ${ }^{24}$ If each of these statutes contains at least one reporting obligation, this would imply that Congress would receive 50 reports only from one independent agency. Recalling the existing 16 IRAs which are included in the approximately 300 institutions falling under the executive branch umbrella, Congress seems to receive a great many reports, perhaps even too many to be able to handle all of them properly.

Congress may require a study to be made about a particular problem, alert federal institutions about a planned activity; provide information about an institution's activities and summarize an institution's activities on a regular basis. ${ }^{25}$ This shows that reports differ. What seems to be neglected in the scholarly literature so far, where general reporting obligations are often taken 'for granted' as being accountability mechanisms, is that not every report can be (equally) valuable in terms of accountability. In this light, one needs to take

\footnotetext{
${ }^{23}$ See, e.g., a part of the enabling act of the Postal Regulatory Commission where reporting obligations take several pages, section 3.2.3.1.

${ }^{24}$ Commissioner from the FTC (interviewed in April 2011).

${ }^{25}$ CRS Report for Congress 'Congressional Oversight Manual' (2011) P. 95.
} 
some elements into account, such as 'giving reasons' requirements, which enhance the accountability value of reports. If a decisionmaker is required to give reasons, he "will be more likely to weigh pros and cons carefully before reaching a decision than will a decisionmaker able to proceed by simple fiat." ${ }^{26}$ Another element could be a requirement to connect ex post results with ex ante plans that are announced officially in advance. In the enabling act of the US Postal Regulatory Commission, the US Congress requests the Postal Service to submit reports "detailing how it plans to improve workplace safety and reduce workplace-related injuries nationwide, including goals and metrics" (39 USC 501 note). This creates a frame of reference for the overseeing institution to assess the performance against the announced intentions.

The mentioned elements seem to be valuable for the Union Legislator to consider because EU agencies' reporting and evaluation obligations focus merely on the fact of the submission of a relevant document to the specified institutions. ${ }^{27}$ In other words, EU agencies' reporting obligations are of a mere procedural nature, focusing on the question of 'who receives the report', instead of introducing obligations of what such a report needs to tell. This is most likely caused by the ongoing political struggle among the EU main institutions over EU agencies and who gets what powers of control over EU agencies. Furthermore, in contrast to the detailed reporting obligations in the US, a typical reporting obligation of an EU agency would not take longer than one line of an agency's founding regulation requiring the submission of an annual report. Only in eight $\operatorname{cases}^{28}$ do reporting obli-

\footnotetext{
${ }^{26}$ Shapiro (1992) P. 180-181.

${ }^{27}$ A typical reporting obligation would say that "the Management Board shall adopt the annual report on the Agency's activities" and list the institutions recipients of the agency's reports.

In contrast to the great majority of founding acts, Regulation (EC) No 1339/2008 establishing the European Training Foundation has a separate article with the heading 'Annual Activity Report' with quite precise reporting obligations: "1. The Director shall report to the Governing Board on the performance of his/her duties in the form of an annual activity report. 2. The annual activity report shall contain financial and management information indicating the results of operations by reference to the annual work programme and to the objectives set, the risks associated with those operations, the use made of the resources provided and the way the internal control system has functioned. 3. The Governing Board shall draft an analysis and an assessment of the draft annual activity report on the previous financial year. 4. The Governing Board shall adopt the annual activity report and forward it together with its analysis and an assessment to the competent bodies of the European Parliament, the Council, the Commission, the Court of Auditors and the European Economic and Social Committee by 15 June of the following year at the latest. This report shall also be forwarded to the Member States and, for information, to the partner countries. 5. The Director shall present the Foundation's annual activity report to the relevant committees of the European Parliament and preparatory bodies of the Council" (Article 13).

Also, in contrast to agencies' founding regulations the Financial Regulation, namely Article 40 of Commission Regulation No 2343/2002, is more specific with respect to the information that needs to be reported: "the authorising officer [normally an agency's director] shall report to the management board on the performance of his/her duties in the form of an annual activity report $\langle\ldots\rangle$ together with financial and management information. This report shall indicate the results of his/her operations by reference to the objectives set, the risks associated with these operations, the use made of the resources provided and the way the internal control system functions."

${ }^{28}$ EU-OSHA, EASA, EASO, IT-Agency, EMSA, ERA, ETF, and FRA.
} 
gations include analytical elements, such as reporting ex post results in light of ex ante plans. For instance, the European Agency for Safety and Health at Work's founding act states that a report "shall in particular compare the results obtained with the objectives of the annual work programme." ${ }^{29}$ Considering the existing situation, it is not surprising that an evaluation of $26 \mathrm{EU}$ agencies concluded that "performance reporting is almost non-existent" 30 and the existing evaluations "add little value in terms of accountability." 31 The existing situation is, by the way, also criticized by agencies' top officials: "public administration remains descriptive and not analytical. You report what you have done but so what that you have done it." ${ }^{32}$ All in all, it is the specificity, including the connection of ex ante plans and ex post results and reasoning requirements, which seems to create a frame of reference that makes it more feasible to check an agency's action against the standard laid down in prospect and that seems to turn a mere reporting obligation into a valuable accountability mechanism.

While the specificity of reporting obligations is a valuable lesson to consider, there is also a somewhat troublesome side in the mentioned US experience in relation to reports. It is the great number of reporting obligations. The heavy load of reports requires a considerable amount of time and human resources in both Congress and IRAs to prepare reports and study them. This may cause problems with its practical application, such as the impossibility to study all submitted reports properly which questions in turn their necessity. ${ }^{33}$ In this respect, the Union Legislator can be complimented for the existing amount of EU agencies' reporting obligations, which generally includes annual performance reports, annual budgetary requests and annual reports of financial accounts (in the course of the discharge procedure), periodical audits and evaluations and, in individual cases, additional reports, such as reports on emerging risks in the food sector for the European Food Safety Agency.

Considering what has been said, the comparison teaches us the following lessons. First, not every report may serve accountability purposes to the same extent. Hence, perhaps not every report can play the role of an accountability mechanism. Second, the Union Legislator could address the existing poor reporting and evaluation quality by being more specific in its reporting provisions. What seems to be essential to consider from an accountability perspective is including the reason-giving requirements and connecting ex ante plans with

\footnotetext{
${ }^{29}$ Article 10(2) of Regulation (EC) No 2062/94.

30 The Ramboll evaluation, Volume I. P. 23.

${ }^{31}$ Ibid. P. 26.

32 Director of an EU agency (interviewed in August 2011).

${ }^{33}$ Although it can be argued that reports, even if they remain unread, can be valuable in terms of accountability because they serve as a soft mechanism of encouraging agencies to perform responsibly as in the end agencies would need to report what they have done which is available for the public eye. Also, if reports are available to a broader public (the 'fire-alarm' oversight discussed in Chapter 3.2.5.1.) and parliamentary support agencies, the chances of reports being read and of the members of Congress being informed via interest groups and lobbyist increase.
} 
ex post results. Specificity seems valuable from the accountability perspective as it makes it more feasible for the overseeing institution to check upon the agency against the laid down standard. Roughly speaking, whether an agency has performed well depends on what well is. If the legislator does not specify what an agency needs to take into account while implementing its tasks and what it needs to report back, the agency cannot be expected to do more than it is asked for. Making accountability obligations specific seems especially relevant for a Union of 28 nationalities with diverse mentalities and ways of how to conduct 'accountability business'. At the same time, one should also be cautious about the necessity of a balanced amount of details and accountability obligations in general. Recalling one scholar's example,

[An analogy to accountability obligations] might be chemicals that are put into the community pool to control the spread of illness. If you don't put enough chemicals, they will not be effective. If you put too much, the pool will be an unpleasant place to swim. If you put the wrong kinds of chemicals, you may cause other illnesses. Most people trust that there is a professional at the helm who knows precisely the right kind of chemicals but in reality, it is probably the 17-year-old lifeguard hired for the summer. ${ }^{34}$

Hence, the third lesson is that there should be a balance between too many and too few details and the amount of accountability obligations for accountability to function properly. Both extremes can produce negative results - impossibility to use and to comply with accountability and other obligations if the number is too high and impossibility to check if the number is too low.

\subsubsection{Interplay between Accountability Mechanisms: Something for Future Consideration in the EU}

The interplay between accountability mechanisms is necessary for the overall accountability to work. This means that mechanisms ensuring individual stages of accountability, i.e., information, discussion, and rectification, should be seen as 'team players' whose individual actions influence each other and contribute to the achievement of the final goal, i.e., holding an agency to account. For example, a reporting mechanism ensuring the information stage may not function properly if an overseeing institution has no possibility to follow-up and discuss the report with an agency. An obligation to submit a report may be thus reinforced when it is accompanied by an obligation to come to a hearing to present the report because the latter increases the chances of the report being read, which also increases incentives to prepare a report of good quality. The EU and the US seem to demonstrate divergent results in relation to the interplay between accountability mechanisms.

\footnotetext{
34 Williams (2009) P. 3.
} 
In the EU, the interplay between various accountability mechanisms is not always ensured. A prominent case in point concerns a disconnection between the information and discussion stages before the European Parliament. The European Parliament receives reports from almost every EU agency, yet, it has the formal power to question the agency director about his or her performance only in 16 (out of 35) cases. Considering the potential lack of time and incentives of MEPs to scrutinize EU agencies the likelihood of the report being read by busy MEPs is very small, especially if no possibility exists to follow it up. In this light, it seems that the reporting accountability mechanism can be reinforced by tailoring it to a mechanism providing a possibility for discussion.

Contrary to the EU case, reports submitted to Congress can always be followed up during congressional oversight hearings which no independent agency, even a self-funded one, can escape. Individual congressional committees seem to enjoy mechanisms ensuring the three stages of accountability; information with the help of submitted reports, discussion in the course of hearings, and rectification in the way of 'blaming and shaming' hearings, proposals to change enabling legislation, which originate in specialized committees, and negative directives concerning finance and positions, including using appropriation riders and earmarks, tools to cancel or mandate financing of specific activities respectively.

Furthermore, in ensuring a proper interplay between accountability mechanisms, it also seems logical to assess the number of accountability mechanisms to avoid possible shortages or excesses. For the EU, it seems important to consider the question of how to avoid unnecessary duplication of accountability obligations before the EU main institutions that could be caused by the multi-principal characteristics of the EU institutional environment in which EU agencies operate. Since the effects of multi-principal environments are not known yet, ${ }^{35}$ it is not clear whether "the multiplicity of control channels makes agencies more accountable." ${ }^{36}$ In this light, the question of interplay between various accountability mechanisms has not (yet) made it to the agenda of the EU main institutions, which is probably because the negotiations related to the creation and operation of EU agencies seem to have focused so far on drawing the boundaries between the main institutions' powers. With the European Parliament's increased legislative power, more clarity on the issue of 'who does what' in relation to holding agencies to account could come (see Chapter 2.1.1.3.). Once this point is reached, the matter of interplay could receive more serious consideration.

To get some intuitive insights in this respect, the sphere of financial oversight is an illustrative example of how interplay seems to work in both jurisdictions. IRAs send their budget requests to the representative institutions. The latter may request additional (more explanatory) information and justifications on the financial numbers as well as specific actions where the money has been spent or is intended to be spent. On the basis of a com-

\footnotetext{
35 Papadopoulos (2010) P. 1041.

${ }^{36}$ Dehousse (2008) P. 800.
} 
bination of factors, including political priorities but also agencies' achievements and failures, agencies may be sanctioned or rewarded by receiving less or more money. The financial oversight procedures are further strengthened by the existing well-established rules and practices and involvement of expert assistants, such as the Court of Auditors and Congressional Budget Office and the Government Accountability Office, which may fulfil the role of a diagonal accountability forum.

Considering the existing advantages that the financial oversight in both the EU and the US can offer, which include established rules and practices, regularity and support the representative institutions can rely on, the fact that the political institutions could link agencies' political accountability for performance to the financial oversight procedures may become a central place to hold agencies to account for both performance and finance. ${ }^{37}$ For such a system to work properly, however, interconnections between specialized parliamentary committees overseeing agencies' programs and their budgetary counterparts would need to be enhanced. This is necessary in order to ensure the allocating of money on the basis of the content of respective policies and agencies' work, which is likely to be better assessed by specialized parliamentary committees, and not on the basis of purely financial indicators disconnected from the policy objectives and results. To this end, future investigation seems necessary to explore the possibilities for further specialization in (parliamentary) committees and new ways for interaction between specialized and budgetary committees, especially the ways in which the budgetary decisions are taken by them.

Concluding, the comparative analysis of the political accountability designs of EU and the US agencies has shown considerable differences where the US experience offers valuable lessons for what could be considered for the EU and what should be avoided. What is important to consider for the Union Legislator is the specificity of accountability obligations. Specificity creates a frame of reference which makes it feasible to check an agency's action against the laid down standard in prospect. In addition, reasoning requirements and alignment of ex ante plans next to ex post results seem necessary to turn a mere reporting obligation into a valuable accountability instrument. The US example also teaches the importance of being more cautious about having an excess of accountability obligations. A balance between too many and too few obligations and details needs to be found in order to avoid negative repercussions that can be caused by both extremes. Finally, the interplay of accountability mechanisms is another point for the EU to take into account in the future when the EU main institutions have established their accountability responsibilities in relation to EU agencies. Accountability mechanisms ensuring individual stages of accountability should be seen as 'team players' and reinforce each other in order to ensure the overall accountability, where the sphere of financial oversight gives an illustrative example of how such an interplay exists in both jurisdictions. As a final note, the existing differences

\footnotetext{
37 The 'budget-linked' accountability using Heringa and Verhey's terminology (Heringa and Verhey (2003) P.
} $165)$. 
between the discussed aspects of the design of accountability systems can be to a certain extent explained by the age difference between relevant institutions and the length of experience that they have had in overseeing IRAs. While this makes a true comparison a bit unfair, it does stress the importance of the more than a century-long congressional experience in dealing with IRAs from which lessons can be learned.

\subsection{The Practical Application of Accountability Mechanisms: Partial Relevance of the US Experiences}

Perfectly designed accountability mechanisms and obligations would be worthless if they were not applied in practice. The third element ensuring political accountability is the necessity of their practical application. In this respect the representative institutions in the EU and the US face quite common challenges in the application of accountability mechanisms. These include the three challenges of oversight, namely the number of institutions to oversee; knowledge and information asymmetry between agencies and their overseers; and the weak incentives for politicians to be involved in oversight. In addition to these, some sanctioning tools, such as the tool of reconsideration of the existence of agencies, may be difficult to apply in practice. This section compares the ways in which the EU and the US representative institutions attempt to address the mentioned challenges and shows that the US experience can be only partially applied in the EU case. The most valuable lessons in this respect seem to be introducing self-enforcing measures to promote people's representatives' commitments to stick to their accountability tasks and using whenever necessary sunsets to ensure the review of agencies' programs and their existence in the future.

\subsubsection{Addressing the Challenges to Parliamentary Oversight}

The ability of political institutions to oversee IRAs depends to a large extent on the amount and quality of support they have. In both systems, the people's representatives have their support staff, although the extent of such support differs considerably. It is much higher in the US. The staff of Congress amounts to 17,000 people and includes both personal assistants of its members and the staff working for both parties in congressional committees, leadership offices and administrative support. Senators (100 members elected for six-year terms) may have up to 35 personal assistants specializing in specific issues whereas this number is lower for the members of the House of Representatives (435 members elected for two-year terms) who have normally up to 18 more generalist assistants. ${ }^{38}$ In contrast, the members of the European Parliament (750 members elected for four-year terms) have on average three personal assistants and there are from four to ten administrators on its

\footnotetext{
${ }^{38}$ Official from FERC who worked previously as a personal assistant to a member of the House and a member of the Senate (interviewed in May 2011).
} 
permanent committees. Furthermore, the European Parliament's secretariat employs 6,000 people the majority of which are linguists of the 24 official languages of the EU.

Along with the oversight exercised by Congress itself, Congress can rely on its support agencies in conducting oversight. The Government Accountability Office, Congressional Budget Office, Congressional Research Office, and the Administrative Conference of the United States contribute to the accumulation of governmental knowledge about agencies and the programs they exercise and increase the range and variety of oversight over agencies' performance. This makes it not only feasible to oversee more bodies and programs than individual members could have done on their own or with the help of personal assistants only, but also, to have qualitative oversight, considering the expertise these bodies can offer. For instance, the GAO employs 2,957 staff, ${ }^{39}$ and over 50 per cent of its employees hold a PhD or Master's degree, ${ }^{40}$ while most of CBO's staff has advanced degrees (in economics). ${ }^{41}$ In addition, Inspectors General are placed in individual agencies to oversee their activities and report to Congress. In total, about 4,000 people are working for congressional support agencies which costs approximately \$ 690 million per year (see section 3.2.5.1.). In contrast, the Library of the European Parliament employs 99 people mostly with a librarian degree $^{42}$ and the only comparable support institution the European Parliament has is the Court of Auditors in the field of financial oversight that has approximately 800 staff, including a large number of translators and administrators. ${ }^{43}$

While the mentioned numbers speak clearly in favor of the US Congress, the European Parliament may not be necessarily as comparatively weak as the statistics make it appear. Whereas the US Congress has decided to "respond to the complexity of issues by creating a large, expert bureaucracy $<\ldots>$ to help oversee a large, expert bureaucracy," ${ }^{44}$ the European Parliament seems to have employed a different strategy. It outsources research projects to outside institutions for which it has an annual budget of 750,000 Euro. ${ }^{45}$ The only down-

\footnotetext{
${ }^{39}$ This information is taken from the official web-page of the agency. Find at: http://www.gao.gov/about/gglance.html (last check April 2013).

"Congressional mandates more than doubled in number from 75 in fiscal year 2007 to 160 in fiscal year 2008, and this upward trend appears to be continuing in fiscal year 2009” (Ibid.).

${ }^{40}$ Walker D. (Comptroller General of the United States (1998-2008)) in: The committee print of "Congressional Oversight: A "How-to" Series of Workshops, sponsored by the Speaker and the Chairman, House Rules Committee, organized and conducted by the CRS, 1999. P. 95.

${ }^{41}$ This information is taken from the official web-page of the office. Find at: http://www.cbo.gov/about/ourorganization (last check April 2013).

42 Parliamentary Library, research and archive services of Europe: description of the Parliamentary Library, Research and Archive Services of Europe + Israel, the United States of America, Council of Europe, European Parliament and Assembly of the WEU, compiled by Elisabeth Dietrich-Schulz, ECPRD Coordinator for Parliamentary Libraries, Research and Archives and Head librarian of the Austrian Parliament, 2008. P. 31.

${ }^{43}$ This information is taken from the official web-page of the Court of Auditors. Find at: http://europa.eu/abouteu/institutions-bodies/court-auditors/index_en.htm (last check 20 January 2013).

${ }^{44}$ McCubbins and Schwarz (1984) P.169.

${ }^{45}$ Neunreither (2002) P. 52.
} 
side of the existing system seems to be the duration of the whole procedure of announcing projects and choosing relevant institutions, which together with the research work can take up to 18 months (see Chapter 2.2.5.). In addition, another concern for the European Parliament is not so much that it lacks information as such, which comes by the way from a great many sources, including the institutions it oversees, but rather that it needs reliable and objective information, which necessitates having other sources than the institutions it oversees.

In this respect, the strategy the US Congress has employed seems to have two advantages: more rapid help with parliamentarians' inquiries and more objective information from institutions working for Congress. In fact, such advantages seem to be appreciated by the European Parliament in the field of financial oversight where it relies heavily on the support of the Court of Auditors that can respond promptly to parliamentary research inquiries and offer expert objective advice. ${ }^{46}$ Adopting the US approach would come, however, at the cost of expanding 'Eurocracy' which is unlikely to be welcomed by the member states whose national parliaments have even less support. ${ }^{47}$ Nevertheless, it seems that the lesson that can be derived from the comparison of congressional and European Parliament's oversight support possibilities is that the quantity and quality of support to the overseeing institutions should be in a certain way proportionate to the size of the executive branch. This may be difficult to establish, however, considering a great dispersion of the locus of the executive power. ${ }^{48}$

It is, however, not only by increasing its own support staff that the US Congress addresses the challenges to its oversight function. Another interesting tactic that it has employed has been what McCubbins and Schwarz call the 'fire-alarm' form of oversight. "Instead of sniffing for fires, Congress places fire-alarm boxes on street corners, builds neighbourhood fire houses, and sometimes dispatches its own hook-and-ladder in response to an

${ }^{46}$ Concerning the EU agencies, the Court of Auditors has prepared several reports requested by the European Parliament, including, for instance, the report 'The European Union’s Agencies: Getting Results' (2008).

${ }^{47}$ Corbett et al. (2007) P. 133.

${ }^{48}$ With respect to the size of the executive in the EU and the US, the numbers are quite difficult to find as the executive branches include an incredible variety of institutions some of which may be excluded from the official data to lower the size of the EU and US federal bureaucracy. To get some indication, the size of the US executive seems to be approximately 2.65 million civilian employees of the federal government in the US. The size of the EU executive amounts to approximately 55,000 employees, where according to the official web-page 33,000 are employed by the Commission. At the same time, one should not forget that many national civil servants work for and within the EU structures which may make it impossible to come up with the exact number of the EU bureaucracy.

(The mentioned numbers are based on several internet sources:

http://voices.washingtonpost.com/federal-eye/2010/09/how_many_federal_workers_are_t.html (last check February 2013)

http://openeuropeblog.blogspot.nl/2007/01/how-many-people-work-for-eu.html (last check February 2013)

http://ec.europa.eu/civil_service/about/figures/index_en.htm (last check February 2013)

http://www.bbc.co.uk/news/world-europe-13978019 (last check February 2013)). 
alarm." ${ }^{49}$ The vast array of statutes regulating agencies' performance, such as the Administrative Procedure Act, is an illustrative example of such 'fire-alarms'. These statutes allow for the judicial review of administrative decisions but also for the participation of interested parties in agencies' decision making. In this way, the US Congress seems to share its oversight function with the public directly by allowing the public to be involved in rule making and checking upon agencies.

In the EU, this practice has been used already in relation to the decision-making agencies, such as Community Plant Variety Office, where affected parties applying for relevant licenses and permits can challenge agencies' decisions before agencies' boards of appeal and then the Court of Justice of the European Union. Also, a few agencies' management boards include representatives of various organizations representing the citizens, such as representatives of employers' and employees' organizations in the European Centre for the Development of Vocational Training. However, such representatives do not enjoy any voting rights. In any case, sharing the oversight over EU agencies with the public more widely may be complicated by the fact that EU agencies remain unfamiliar 'satellites' which are "neither visible nor well grounded" 50 and the majority of them do not have strong formal powers which may obviate the need for public participation in agencies' decision making in the 'US-like style', i.e., to be able to comment on the proposed rules or challenge them before the courts. Hence, the possibility of sharing oversight over EU agencies with the public may only partly be applicable in the case of the EU at this moment. ${ }^{51}$

Another challenge in holding IRAs to account is the weak incentives of people's representatives to be involved in this "very unglamorous work" where "most members see very little political benefit." ${ }^{2}$ This is because oversight is a very time- and resource- consuming activity which does not always attract media attention, one of the biggest incentives that oversight can offer people's elected representatives. In this light, the existing chaotic organization of oversight activities in the European Parliament is one of the points for concern. Some committees hold hearings with agencies' directors for 10 minutes, while other committees have hearings for 90 minutes. Some committees oversee agencies, even those which are not explicitly prescribed in their remits by the Rules of Procedure of the Parliament,

\footnotetext{
${ }^{49}$ McCubbins and Schwarz (1984) P. 166.

50 Toggenburg (2007) P. 3.

51 This is not to say that the operation of EU agencies would not benefit from introducing of a European version of the APA, which could establish in a more coherent way such procedures as public participation and judicial review of agencies' binding but also perhaps advisory decisions. A European APA could "steer the development of EU administrative law in a direction that fosters a transparent and fair exercise of regulatory governance" (Meuwese et al. (2009) P. 31). In fact, as of this writing, a European APA is under consideration at the EU level (see, European Parliament's Resolution of 15 January 2013 with recommendations to the Commission on a Law of Administrative Procedure of the European Union (2012/2024 (INI)).

52 Hamilton L. (Member of the US Congress 1965-1999) in: The committee print of "Congressional Oversight: A "How-to" Series of Workshops, sponsored by the Speaker and the Chairman, House Rules Committee, organized and conducted by the CRS, 1999. P. 14.
} 
while others may have no relation with the agencies formally assigned to them in the Rules of Procedure. In this respect, appointing liaison members in European Parliament's committees, which again is not a practice used by every committee, could be a solution to address this challenge as "the advantage is that you have got at least one person who takes it seriously." ${ }^{53}$ Yet, "the disadvantage might be that others feel that they do not have to take interest in it." ${ }^{\prime 4}$ Also, assigning individual MEPs may come at the cost of political representation in holding to account.

In this respect, the discussed US House Rule $\mathrm{X}$ is valuable to consider. It obliges the House committees to prepare oversight plans and deliver reports on how those plans have been realized. Such a rule obliges members to carry out oversight officially which increases transparency and gives an opportunity for a public check that in turn could promote compliance with the rule. The idea is that an official announcement of oversight plans and then ex post results would increase transparency which would serve as a safeguard against random checks and inaction. While in the US the introduction of this new rule in 2010 immediately resulted in complaints about the unwillingness of showing the minority party oversight plans for the next two years, ${ }^{55}$ in the European Parliament the reaction is unlikely to be the same. There is a multi-party system in the EU and no direct line between the political parties sitting in the European Parliament and the executive branch institutions similar to the one that exists in the US, especially if the implications of the 'separation of parties, not powers' theory are considered. ${ }^{56}$ While the political majorities sitting in congressional chambers and the White House may affect the degree and nature of congressional oversight over the executive in the US, the European Parliament's appetite to oversee the EU executive, which is disconnected from the parliamentary parties in majority, seems to be only increasing with the expansion of its legislative and budgetary powers and desire to ascertain more control over EU decision making to which the EU agencies contribute.

What could also be a solution in addressing the challenge of weak incentives is introducing feedback obligations. In this way, agencies' overseers would be obliged to give written feedback on the information received. Feedback obligations could be thus another selfenforcing mechanism to address the discussed challenge and improve the information and discussion stages, which are not only about sending the information or making a presenta-

\footnotetext{
${ }^{53}$ MEP Jensen (interviewed in June 2011).

${ }^{54}$ Ibid.

An administrator from the European Parliament's Employment Committee noted in this respect that "if you have a liaison, you may have fewer possibilities to talk to other MEPs and others may be less interested, because they know that someone is dealing with that agency" (Administrator of European Parliament's Employment Committee (interviewed in September 2011)).

55 Wolfensberger D. (Former Staff Director of the House Rules Committee) in: The committee print of "Congressional Oversight: A "How-to" Series of Workshops, sponsored by the Speaker and the Chairman, House Rules Committee, organized and conducted by the CRS, 1999. P. 62-63.

${ }^{56}$ Levinson and Pildes (2006) P. 2312.
} 
tion before the relevant parliamentary committee, but also about comprehending information and asking relevant questions by representative bodies. The example of the annual report of the European Training Foundation, where its governing board gives its assessment of annual activities of the agency attached to the agency's annual activity reports, is interesting in this respect.

\subsubsection{Addressing the Challenges to Using Sanctioning Tools}

Another challenge in practical application comes from the fact that some sanctioning tools may be difficult to apply in practice. One such example concerns the financial sanction of slashing an agency's budget as punishment. The problem resulting from this is that this sanction simultaneously denies the agency its resources to perform its functions and perhaps even to redress the mistakes made. ${ }^{57}$

The sanctioning tool of reconsidering an agency's existence may also be ineffective. This seems to be especially the case in the EU where EU agencies are placed in different member states, hence the abolition of an agency would mean the hosting member state would lose its 'piece of the EU cake' which it had received probably after tense political negotiations (see Chapter 2.2.1.1.). In a way, such a sanction may be seen more as a punishment against the hosting member state rather than against the agency, and is unlikely to be used upon considering the solidarity among the member states.

The US has a different story in this respect. The US Congress does occasionally abolish IRAs if necessary. For instance, for functional reasons the Civil Aviation Board and the Interstate Commerce Commission were closed. The Administrative Conference of the United States, an independent advisory agency, was temporarily inactive (from 1996 until 2010) because its funding was frozen. Needless to say that Congress can always reorganize the executive branch institutions, which may imply turning an executive agency into an independent one or the other way around. While to pass an act of abolition may be politically and legally difficult considering the need of both chambers of Congress and the President to agree or two third majorities in Congress to bypass the veto of the President, the US does not face the problem of intergovernmental politics behind agencies' seats. All US independent regulatory commissions have their main office in Washington, DC.

While the EU and US demonstrate some differences in this respect, what could be learned from the US, and it seems to have recently found its place in the 'Common Approach' on EU agencies discussed earlier, is the possibility to use sunsets, i.e., legal provisions stipulating the length of life of an agency or specific program, whenever necessary. Although Congress fails to enforce sunset provisions, ${ }^{58}$ they are important to test the effec-

\footnotetext{
${ }^{57}$ Moe (1987a) P. 487.

58 “" The trouble with sunset clauses is usually they're not enforced, because Congress is either too busy - or, more accurately — too neglectful," said Rep. Jim Cooper (D-Tenn.). He said he still believes in the theory: A
} 
tiveness of a program, the appropriateness of allocated finances or the compliance of an agency with a particular delegated function and a deadline. An additional value of this mechanism is that the legislator obliges itself to review the necessity of federal programs and agencies in the future. By inserting an expiry date on (the financing of) a program with the help of a sunset the Union Legislator could increase the feasibility of using the reconsideration and financial sanctions.

Concluding, the US experience in addressing the discussed challenges includes the following issues: (1) matching the growth and expertise of the executive by increasing expert support, (2) sharing the oversight duty with other institutions and the public, (3) establishing formal rules governing oversight practices, including self-enforcing measures to address the challenge of weak incentives of politicians to "do the nitty-gritty work" 59 of oversight, and (4) using sunsets whenever necessary to ensure future review of specific agencies' programs, finance or an agency's existence as a whole. The most valuable lessons for the EU seem to be the last two options, namely introducing self-enforcing measures to address the challenge of the weak incentives of politicians to scrutinize the executive on a continuous basis and inserting sunsets to ensure the review of specific agencies' programs, finance, and agency's existence, whenever necessary. ${ }^{60}$ Both measures aim at increasing the selfcommitment of the political forum to its accountability and legislative actions.

As a final remark, the difficulty in using sanctions against agencies may also come from the fact that political accountability forums are not unitary institutions. For instance, "the threat of reducing an agency's subsidy" from the European Parliament or the House of Representatives "will not be credible unless it receives a positive echo from within the two branches of the budgetary authority." ${ }^{61}$ If the conflict between two branches of the budgetary authority is significant, the threat fails. The issue of how unitary the accountability forum is and the degree of conflict between individual branches that constitute one accountability forum will affect the process of holding to account. In the US, the degree and nature of congressional oversight upon the executive branch seems to depend on the political majorities sitting in congressional chambers and the White House. ${ }^{62}$ In the EU, this

\footnotetext{
“sunset clause is a very appropriate remedy. But it's got to be enforced to mean anything"” (Fahrenthold (2012)). This indicates that sunsets should be used in reasonable amounts.

${ }_{59}$ Wolfensberger D. (Former Staff Director of the House Rules Committee) in: The committee print of "Congressional Oversight: A "How-to" Series of Workshops, sponsored by the Speaker and the Chairman, House Rules Committee, organized and conducted by the CRS, 1999. P. 66.

${ }^{60}$ Clearly, inserting too many sunsets may make this tool ineffective if representative bodies are not able to cope with the workload of reviewing all those agencies and programs subject to sunsets.

${ }^{61}$ Dehousse (2008) P. 801.

62 "The degree and kind of competition between the legislative and executive branches will vary significantly and may all but disappear, depending on whether party control of the House, Senate, and Presidency is divided or unified" (Levinson and Pildes (2006) P. 2312).

In this light, Epstein and O'Halloran show that the choice of delegating to an executive agency is used "relatively more often under unified government, while independent agencies and commissions are used more often under
} 
disunity of the political accountability forum comprising the Council and the European Parliament is caused by the multi-principal and multi-level characteristics of the EU institutional landscape. The Council and the European Parliament represent different, and at times conflicting, interests, especially with respect to the question of asserting control over EU agencies.

\section{Conclusion}

This chapter compared the political accountability systems of EU and US independent regulatory agencies with a view to offering policy recommendations for the Union Legislator to consider in the ongoing reform of the operation of EU agencies, which are addressed in the following Chapter 5. It was shown that the accountability capacity of the EU representative institutions is not necessarily smaller than that of the US Congress, although some differences exist in relation to the existing accountability mechanisms and their strength. For instance, the European Parliament lacks the Congressional powers to subpoena witnesses and to hold them in contempt, while Congress (or its individual chambers) does not have the European Parliament's power to give discharge. The striking difference between the two jurisdictions seems to lie in the approach that the representative institutions have employed in relation to individual agencies - with great uniformity in the US and excessive diversity in the EU. For instance, while congressional committees can question agencies' representatives at any time within the subject-matters of their jurisdictions, the European Parliament and/or the Council have the formal power to do that only in 16 out of 35 agencies. It was argued that the EU could benefit from having a more uniform approach, i.e., introducing a limited number of accountability models corresponding to different categories of EU agencies which have been established based upon clear reasons. Such an approach could offer a clear, reasoned and hence transparent, yet flexible system, which is essential for promoting the legitimacy of the EU.

The comparative analysis has shown that it is not a perfect accountability world on the other side of the Atlantic, yet there are a few things for the EU to consider. The learning experience includes the matters of specificity of accountability obligations and their formulation to facilitate the purposes of accountability; enhancing parliamentary oversight ability by introducing relevant self-enforcing rules to promote representative bodies' compliance; and committing itself to evaluating agencies' existence periodically by inserting sunsets in enabling acts, though in a proportionate manner.

In addition, both jurisdictions demonstrate the importance of financial oversight, which seems to be an accountability venue in its own right ensuring all three stages of accountabil-

divided control." If under the unified government independent regulatory commissions have been the recipients of the laws delegating authority in 17 per cent of the cases, under the divided government - the number reached 36 per cent (Epstein and O’Halloran (1999) P. 11, 154-156). 
ity and providing an opportunity to discuss not only financial numbers but also agencies' actions as, at the end of the day, money translates into agencies' activities. From this, it may be necessary to investigate in the future whether the financial oversight procedures could play a central role in holding IRAs to political account.

Furthermore, the US experience sends a warning signal about placing too many accountability obligations to be complied with which could hinder the accountability system by incurring unnecessary costs (human, financial and time) and to use obligations such as reporting.

Finally, the US example demonstrates similar concerns to those that exist in the EU. These include, for instance, the existence of lenient creation and delegation standards allowing the legislator to create various institutions within the executive branch without necessarily functional needs and a sound accountability system in place.

All in all, while the US experience in the area of political accountability of IRAs seems more advanced and hence valuable for the EU, it does not provide solutions to all problems, which seems to indicate the fundamental nature of some existing concerns and increases the necessity to explore such concerns in the future. 


\section{Chapter 5.}

\section{The Political Accountability of EU Agencies: 'The Way Forward'}

The previous chapter offered a comparative analysis of the political accountability of EU and US independent regulatory agencies with a view to learning from the US long-standing experience for the EU jurisdiction. It is now time to use the comparative insights to offer the EU representative institutions recommendations on how they should adjust existing accountability arrangements in the course of the ongoing reform of the operation of EU agencies, thus addressing the second part of the research question. In light of the comparative analysis, Chapter 5 puts forward three recommendations and explains them in the three sub-sections, which offer illustrative examples of how these recommendations could be put in legislative terms. The three recommendations are:

1. The issues concerning the creation of, delegation to, and accountability of EU agencies should be regulated at the treaty level.

2. The Union Legislator should establish a legally-binding accountability framework for EU agencies based on a streamlining approach.

3. The EU representative institutions should render account for holding EU agencies to political account by introducing relevant self-enforcement measures and adhering to them.

\subsection{The Necessity of a Treaty Provision}

The number of EU agencies, including the strength of their powers, has been increasing in the last two decades. Scholars have more and more been pointing out that the formally 'executive' but actually 'discretionary policy-making' powers have already been delegated to EU agencies. This raises the question of whether agencies remain in line with the Meroni doctrine that governs the delegation of powers in the EU. In addition, the relevance of the Meroni doctrine with respect to delegating to EU agencies is at times questioned because so far ${ }^{1}$ it has not been applied in relation to an EU agency. ${ }^{2}$ In addition to the existing debate

\footnotetext{
${ }^{1}$ In this respect it is interesting to see what the CJEU decides with respect to the action brought recently by the UK against the Council and the European Parliament concerning the powers delegated to the European Securities and Markets Authority which according to the claimants has received "a large measure of discretion" (Case C270/12 Action brought on 1 June 2012 - United Kingdom of Great Britain and Northern Ireland v Council of the European Union, European Parliament).
} 
about the legitimacy of EU agencies and the lawfulness of the delegation of various powers to them, their accountability has become one of the matters for concern. Since no formal or political agreement exists in relation to the accountability responsibilities of the EU institutions in relation to EU agencies, it is unclear if and when EU agencies are accountable or not.

Given the fact that EU agencies have become a popular instrument for the implementation of EU policies, and the growing number of agencies suggests this being the case, the time for guessing about the solutions to the mentioned serious issues, such as whether EU agencies fall within the Meroni doctrine and whether they are accountable or not, should end by regulating them in the Treaty. Moreover, considering the principles of conferral and proportionality, which govern the limits of the Union's competences (Article 5 TEU) and the institutional balance between the EU main institutions (Article 13(1) TEU), the only way to ensure the legitimacy of EU agencies is by means of introducing a treaty provision regulating the creation of, delegation to, and accountability of EU agencies. ${ }^{3}$ An explicit treaty provision could also resolve the existing inconsistency in the treaties, which address agencies "in hidden ways" 4 in, for instance, articles on transparency and judicial review (see Chapter 2.1.1.2.). Agencies are, however, 'forgotten' in Articles 290 and 291 which codify the authors of non-legislative acts of the Union, acts that have been passed also by EU agencies. ${ }^{5}$ This implies that "the categorization of norms as introduced by the Lisbon Treaty is incomplete" and that "the continuing pluralisation of the EU Executive through agencification may lead to a blurring of responsibilities and holding certain actors to account." 7

This study has used a comparative approach to assess the existing state of affairs in the field of the political accountability of EU agencies taking the US jurisdiction into account. In relation to getting inspiration for formulating the respective treaty provision, however, the US experience does not offer any example. This is because no constitutional or other provision establishing a framework allowing the creation of and delegation to IRAs exists in the US. In the case of the US, such a framework might be unnecessary as the creation of

\footnotetext{
${ }^{2}$ Chamon (2010).

${ }^{3}$ Interestingly, some prominent experts in the field, e.g., Vos, have also argued for the necessity of a "more coherent approach" in relation to such issues related to EU agencies' operation as control, transparency, review and languages which is to be achieved by establishing a "legal basis for the creation of agencies, the delegation of powers to these agencies and judicial review be introduced in the Treaty" (Vos (2003) P. 142).

${ }^{4}$ Hofmann and Morini (2012) P. 34.

5 "For example, binding legal acts on the registration or refusal of a European Trade Mark adopted by the OHIM are clearly an act of executive nature and comparable with Commission decisions on the approval or refusal of an EU-wide approval of a novel food" (Vos (forthcoming in 2014) P. 44).

${ }^{6}$ Ibid.

${ }^{7}$ Hofmann and Morini (2012) P. 35.
} 
US IRAs has been constitutionalized by other means, including the case law and statutes like the Administrative Procedure Act. ${ }^{8}$

While the absence of the necessity to establish such a framework may be true for the US, the EU situation seems to differ in this respect. The legitimacy of the EU structures in general and of the EU agencies in particular cannot be taken 'for granted' as is the case in the US. Because the democratic credentials of the Union Legislator continue to be a matter of debate, the alleged democratic deficit of the EU structures seems to be exacerbated by the extension of the delegation chain to IRAs created by the Union Legislator. Consequently, the Union Legislator's power to extend the delegation chain to EU agencies should be formally established, and where the only way to do that is by means of regulating the issue at the treaty level. Allowing the Union Legislator to create EU agencies and delegate specified powers to them will formally legitimize EU agencies by means of the ratification of the relevant treaty amendment by the 28 national parliaments or directly by the people in case of a referendum.

Furthermore, the formal and also social legitimacy could be further promoted by including (1) a reasoning obligation or criteria when an EU agency is to be created and (2) an accountability safeguard, implying the specification of the responsibilities of the EU and perhaps national institutions in relation to EU agencies.

The first point, including a reasoning requirement, is based on the assumption that giving reasons requirements promotes legitimacy because they require an explanation of the actions taken by the governing structures to the governed;" "government action is in error until proved to be good." ${ }^{10}$ Whereas the founding acts of the existing agencies do refer to various treaty provisions to justify their lawfulness, only the lawfulness of procedural aspects rather than the substantive proof of the necessity of creating agencies seems to have been addressed. "The regulations which established the agencies always include justifications, but these documents do not always unravel the reasons for establishing new policy instruments from that of having these instruments managed through an agency." 11 To legitimize the existence of EU agencies the reasons of how the establishment of an EU agency contributes to the implementation of a particular EU policy or action have to be given. For that, however, a 'giving reasons' obligation needs to be imposed first on the institutions which can

\footnotetext{
${ }^{8}$ Although even in the US some argue that the US delegation doctrine laid down by the Supreme Court is "almost a complete failure. It has not prevented the delegation of legislative power. Nor has it accomplished its later purpose of assuring that delegated power will be guided by meaningful standards" (Davis (1969) P. 713); see, also, Schoenbrod (1993), Schoenbrod (1985)).

9 "It is doubtful that the exercise of public authority may be perceived as legitimate if it is not understood" (Dyrberg (2002) P. 83).

${ }^{10}$ Epstein (2006) P. 211.

11 The Ramboll Evaluation, Volume II. P. 17.
} 
create agencies because the voters cannot know "whether the actions of elected representatives - their agents - are in their best interest." 12

Concerning the second point, i.e., the inclusion of an accountability safeguard, as of this writing, $35 \mathrm{EU}$ agencies operate in, roughly speaking 35, accountability regimes, which hinders the clarity and comprehensibility of the system, if the word 'system' is appropriate here at all. As this study has shown, in 16 (out of 35) cases the European Parliament and/or the Council have the power to question an agency's director about the performance of the agency and in 18 (out of 35) cases the European Parliament has the power to question the candidate director to head an agency. These examples lead to at least two questions. First, in accordance with which treaty provision does the European Parliament have the power to question officials of entities other than those that are specifically provided in the treaty, e.g., Article 230 TFEU (in relation to the Commission and the Council)? Second, why are all officials of the same rank or level, for instance, agencies' directors, not subject to the hearings obligations before the European Parliament in the same way? In light of the existing diversity, a treaty provision is crucial to establish clear roles and accountability responsibilities of the EU and perhaps national institutions in relation to EU agencies. This is also important in order to understand the implications of provisions of secondary legislation, such as "the Agency should be accountable to the European Parliament, the Council and the Commission, where appropriate" (Recital 24 of Regulation (EU) No 713/2009 establishing the Agency for the Cooperation of Energy Regulators). Finally, given the fundamental character of political accountability, it is questionable how much diversity political accountability should allow if every agency has to render account before the EU representative institutions and, in this way, before the people.

\section{What such a treaty provision should say?}

Since the US does not offer any example in this respect, one would need to investigate other jurisdictions, including the EU member states, to get inspiration. For instance, Verhey refers to an act which exists in the Netherlands, where

An agency can only be created if: a. there is a need for independent assessment based on specific expertise; $b$. it concerns the execution of legislation without discretionary powers and a large amount of individual decisions have to be made; or c. it concerns the carrying out of administrative tasks in which the participation of civil society is deemed to be necessary. Although these criteria are perhaps not always easy to apply in practice, they do provide at least some indication. ${ }^{13}$

\footnotetext{
12 Kiewiet and McCubbins (1991) P. 25-26.

13 Verhey (2005) P.65.
} 
In light of the two elements discussed that could promote the legitimacy of EU agencies and keeping the Dutch example in mind, a treaty provision regulating the creation of, delegation to and accountability of EU agencies could be formulated as follows:

Article X of the Treaty on the Functioning of the European Union.

1. The Union Legislator shall have the power to create EU agencies in accordance with the ordinary legislative procedure. The action taken under this paragraph can be taken only upon stating clear reasons for the necessity of an agency in light of the specific objectives laid down in this treaty.

2. EU agencies shall be delegated with executive powers involving no policy-making discretion. Respecting Article 10 TEU (that the functioning of the Union is founded on representative democracy), the Council and the European Parliament shall have the means to hold the EU agencies to account.

3. Specific details with respect to specific criteria on when an EU agency can be created and how it is held to account shall be established by the Union Legislator in a framework for the creation and operation of EU agencies. ${ }^{14}$ Such a framework shall be established by $\mathrm{X}$ date in accordance with the ordinary legislative procedure.

4. The national parliaments shall be regularly informed about the progress made under paragraph 3 and via national representatives in the Council participate in the elaboration of the relevant framework.

The proposed treaty provision is only an illustrative example of what issues such a provision should address. These issues include:

- the conferral of the power to create agencies in order to respect the principle of conferral laid down in Article 5 TEU (point 1);

- the restrictions on the Union Legislator concerning the powers that EU agencies could have (point 2), taking into account the principles of proportionality (Article 5 TEU) and of the institutional balance (Article 13 (2) TEU);

- the prevention of delegation without accountability before the EU representative institutions taking into account the principle of representative democracy laid down in Article 10 TEU (point 2);

- the delegation of the power to establish a framework for the creation and operation of EU agencies to the Union Legislator using the ordinary legislative procedure so that both representative institutions who have to hold EU agencies to account could participate in establishing such a framework (point 3); and

- elements to ensure compliance by, for instance, introducing the check upon the Union Legislator from other representative institutions, namely the national parliaments (point 4).

The elaboration of such a treaty provision is a challenging task, yet no alternative exists. Without an explicit treaty provision EU agencies "lack a clear position within, first, the

\footnotetext{
14 The mentioned act from the Netherlands could be taken for inspiration here.
} 
separation of powers between the EU and the Member States as well as, second, between EU institutions, most notably the Commission, Council and the European Parliament." 15 In this light, while the proposed European APA can certainly promote EU's legitimacy by harmonising EU administrative law procedures and thus making it more transparent and clear for the citizen, it does not seem to solve the 'agency legitimacy' problem, at least when looked at from the following two perspectives. First, legitimizing EU agencies in a 'US style', i.e., by court rulings and secondary legislation, does not solve the problem of establishing EU agencies by the EU institutions with questionable democratic credentials. Second, the proposed $\mathrm{draft}^{16}$ does not address the issue of the treaty-based balance of power, including the power to hold to account, between the EU main institutions, which is altered by the creation of agencies. In favor of a treaty provision introducing an obligatory reasoning requirement and clear accountability responsibilities of the political accountability forum is also the fact that the Council and the European Parliament acting in legislative capacity may be hesitant to tighten the existing flexibility. This can be demonstrated by the non-legally-binding outcome of the Interinstitutional working group on agencies, i.e., the 'Common Approach', the negotiations for which took place from 2009 until 2012.

Concluding, the first recommendation that this study puts forward is that the issues concerning the creation of, delegation to and accountability of EU agencies should be regulated at the treaty level. Furthermore, the formal and also social legitimacy could be promoted by including a reasoning obligation upon the Union Legislator when it creates and delegates to agencies and by establishing clear responsibilities of the EU and perhaps national institutions for holding EU agencies to account. This recommendation is directed towards "the Government of any Member State, the European Parliament or the Commission" that have the power to "submit to the Council proposals for the amendment of the Treaties" (Article 48 TEU).

\subsection{The Necessity of a Legally-binding Framework Based on a Streamlining Approach (S, M, and L models)}

Without awaiting a formal obligation to do that, i.e., the earlier proposed treaty provision, the Union Legislator should establish an accountability framework for EU agencies. ${ }^{17}$ Such a framework needs to take a legally-binding shape at least for two reasons.

\footnotetext{
${ }^{15}$ Hofmann and Morini (2012) P. 34.

${ }^{16}$ European Parliament's Resolution of 15 January 2013 with recommendations to the Commission on a Law of Administrative Procedure of the European Union (2012/2024 (INI)).

${ }^{17}$ Such an accountability framework could be part of a more general framework for the creation and operation of EU agencies. Yet, in light of the central topic of this book (political accountability), this section focuses primarily on accountability aspects of EU agencies' operation.
} 
First, the political accountability of EU agencies is a politically sensitive issue because it implies drawing the boundaries between the EU main institutions' powers in relation to who can control agencies. The non-binding results of the interinstitutional working group on agencies, i.e., the 'Common Approach' on agencies, demonstrate how difficult it is to elaborate a common position, especially a legally-binding one. To recall briefly, the 'Common Approach' is annexed to the Joint Statement of the European Parliament, the Council of the EU and the European Commission on decentralised agencies published in July 2012 as the result of a three year negotiation between the EU main institutions on various issues of EU agencies' creation and operation. The 'Common Approach' is an important step taken by the EU main institutions because they realize what needs to be done. Such issues include, for instance, justifying the rationale behind using agencies as tool for implementing EU policies, connecting ex ante evaluations of programs with their ex post results with a possibility for follow-up reporting, improving the governance of agencies with the help of smaller executive boards, and harmonizing other practices, such as programming and reporting. Yet, its non-legally-binding character implies that future political negotiations remain the determinant factor in organizing the political accountability of agencies. This means that diversity in holding to account continues to be the case. To decrease the negative influence of political negotiations upon a more uniform organization of the political accountability of EU agencies seems possible by establishing a legally-binding accountability framework.

Second, considering the fundamental character and hence the importance of political accountability, it should not be part of political negotiations when establishing individual agencies in the first place. Every EU agency must render account before the EU citizens. This means that there has to be at least a minimum set of accountability mechanisms that the EU representative institutions should enjoy, which will make the accountability line from EU agencies to the EU citizens clearer. At this moment determining who holds EU agencies to account and how becomes a rather challenging exercise when 35 agencies are held to account in more than 30 different accountability regimes. Even though it is not an accountability problem, the existing diversity of accountability arrangements of EU agencies disperses the political accountability forum and its responsibilities, which in turn hinders, if not breaks in some cases, the accountability line to the ultimate principal, the people. The only way to secure the accountability line between EU agencies and the EU citizens via the EU representative institutions is to have a legally-binding document establishing at least a minimum set of accountability mechanisms available to them.

To organise political accountability of EU agencies in a clear and transparent way, it is essential to lay down specific responsibilities of the EU representative institutions and, to the extent necessary, responsibilities of the Commission, in a legally-binding document. At the same time, differences between EU agencies, such as the nature and amount of tasks they may have, cannot be ignored when designing their accountability obligations. There- 
fore, when organizing the political accountability of EU agencies, both clarity and flexibility need to be considered. To this end, a streamlining approach should be used. It implies creating a reasonable number of accountability models that establish clear (more uniform) accountability responsibilities of the EU representative institutions with a few justified derogations and allow flexibility with respect to the quantity and intensity of accountability obligations. ${ }^{18}$

Furthermore, when designing accountability models, proper consideration has to be given to two elements that facilitate ensuring political accountability. These include formulating accountability obligations in the way that they serve the purposes of accountability and establishing interplay between individual accountability mechanisms so that the overall accountability could be achieved. The mentioned elements are further discussed in three sub-sections which offer illustrative examples of (1) a streamlining approach, (2) the formulation of accountability obligations, and (3) the interplay between accountability mechanisms.

\section{(1) The streamlining approach}

The streamlining approach can be achieved by creating a few accountability models with a different set or intensity of the accountability mechanisms included, for instance, $S$ (small), M (medium), and L (large) sizes (summarized in Table 5.1. below). Each model would include a set of accountability mechanisms that can ensure the three stages of accountability before the EU representative institutions, yet allow some agencies to be under a stricter or more lenient supervision than others. What might such sets of accountability mechanisms look like? To begin with, one could first create an average set of accountability mechanisms, for instance, an ' $M$ ' reference accountability model, which would be applicable by default and which could be made lighter ('S) or heavier (' $L$ ) whenever necessary but based upon clear reasons for such derogations.

To ensure the three stages of accountability, the ' $M$ ' reference accountability model could include the following mechanisms:

1. an obligation to submit an annual activity report to the Council and the European Parliament;

2. hearings obligations of an agency's director with respect to the performance of the director's duties before the European Parliament and the Council;

\footnotetext{
${ }^{18}$ In Chapter 4.1.3, two levels of uniformity were distinguished: uniformity of accountability powers and responsibilities at the institutional level (who holds to account whom and with the help of which mechanisms) and uniformity of quantity and intensity of accountability obligations in individual cases (for instance, the number of reporting obligations individual agencies are subject to). The flexibility at the level of quantity and intensity of accountability obligations correspondent to, for instance, the scope of agencies' functions would not hurt the clarity of the accountability system at the institutional level (who holds the agency to account and how).
} 
3. financial scrutiny in the course of annual budgetary and discharge procedures before the European Parliament and the Council;

4. periodical external evaluations whose results should be sent to the Council and the European Parliament;

5. periodical obligatory review of the agency's existence and its individual programs (sunsets) by the Council and the European Parliament;

6. appointment of the agency director by the agency's management board based upon an open call announced by the Commission and the Commission's short list, a possibility to question the candidate to head the agency by the European Parliament;

7. the presence of all member states' representatives on the agency's management board and the presence of one or more representatives from the Commission; inserting a requirement for the members of the management board to meet at least four times a year;

8. removal of the director by the management board.

This illustrative set of accountability mechanisms includes mechanisms of an institutional (1-5) and personal (6-8) nature and is based on the mechanisms that apply to many existing EU agencies. Furthermore, the proposed set aims at establishing accountability mechanisms ensuring all three stages of accountability before the representative institutions. The Council and the Parliament receive information from and about agencies, i.e., annual activity reports and the results of external evaluations. They can discuss the information by inviting the agency's director to the hearing. The rectification stage can be ensured by inserting sunset clauses with respect to agencies' individual programs and an agency's existence as a whole. In addition, the budgetary and discharge procedures ensure the three stages of accountability as regards agencies' financial performance. Furthermore, the Council and the European Parliament participate in the appointment and removal of the agency's top officials by having the possibility to invite a candidate to the director's post to the hearing before the appointment (for the European Parliament), and by appointing and removing its representatives to agencies' management boards (for the Council). The Council may be seen as indirectly involved in the removal of the director which can be done by the agency's management board dominated by the national representatives.

The lighter version of the reference model, for instance, an 'S' size accountability model, could be made by modifying the mentioned elements in the following way:

1. an obligation to submit activity reports to the Council and the European Parliament could be done less frequently, for instance, on a biannual basis;

2. remains the same;

3. financial scrutiny could be done biannually (in such a case the modification of the treaty will be necessary) or the agency could be made self-funded in which case the EU representative institutions loose the power of financial oversight;

4. periodical external evaluations could be done less frequently than in the ' $M$ ' model; 
5. remains the same or periodical obligatory review of the agency and its individual programs (sunsets) by the Council and the European Parliament is made less frequent;

6. remains the same;

7. the presence of all member states' representatives on the agency's management board and one or more representatives from the Commission; inserting a requirement for the members of the management board to meet at least twice a year;

8. remains the same.

The 'S' model offers a lighter set of accountability obligations by making, for instance, reporting, evaluation, financial oversight or meetings of the management board less frequent or decreasing the amount of accountability mechanisms by, for instance, excluding financial oversight.

Finally, a tighter political supervision, i.e., a size ' $L$ ', could be achieved in the following way:

1. an obligation to submit annual activity reports could be supplemented by the requirement to submit special reports. As an example, an agency could be required to prepare special reports which offer the analysis of specific developments or the impact of the agency's existence and decisions on the respective policy or the interested parties. Also, the Council and the European Parliament could be involved in making multi-annual planning for such agencies by, for instance, having the power to comment on the relevant proposals;

2. hearings obligations of the agency director before the Council and the European Parliament with respect to the performance of the director's duties; these could be supplemented by adding the possibility of questioning the chairman of the agency's management board;

3. remains the same;

4. remains the same;

5. remains the same or the review should be done upon (more) specific criteria laid down in the founding act of an agency;

6. the appointment of the agency director could be done by the Council in consultation with the agency's management board upon an open call announced by the Commission and the Commission's short list; a possibility to question the candidate to head the agency by the European Parliament before the director's appointment and prolongation of the term of office;

7. the presence of all member states' representatives on the agency's management board, one or more representatives from the Commission, one or more independent persons designated by the European Parliament and relevant stakeholders; inserting a requirement for the members of the management board to meet at least four times a year; 
8. removal of the director by the Council upon the proposal of the agency's management board and/or upon consultation with the European Parliament.

The ' $L$ ' model enhances supervision by (1) imposing additional accountability obligations, such as special reports, criteria for reconsideration of agencies' programs and additional hearings; (2) involving the representative institutions directly in (a) making appointments of an agency's 'chief executive', the director, (b) removing the director, and (c) in planning activities, for instance, making multi-annual working programs; and (3) increasing the range of overseers by allowing the European Parliament and stakeholders to be present at the management board's meetings.

The reasons for making individual EU agencies subject to $S, M$, or L accountability mechanisms could be interconnected with such factors, as the powers agencies have, the sensitivity of the issues they regulate, and/or the source of powers from which agencies have received their powers; to name but a few. For instance, a single purpose information gathering agency, like the information gathering European Institute for Gender Equality which employs approximately 30 people and operates with a budget of 7.5 million Euro (in 2010), ${ }^{19}$ could be an example of an agency that could use the ' $S$ ' model. The multi-tasked agency like the European Aviation Safety Agency that enjoys from advisory to decisionmaking powers, employs approximately 600 staff and operates with a 132 million Euro budget (in 2010), ${ }^{20}$ could be a suitable candidate for the ' $L$ ' model.

\footnotetext{
${ }^{19}$ Draft General Budget of the European Commission for the Financial Year 2012, Working Document part III, Bodies set up by the European Union and having legal personality, COM (2011) 300 - May 2011, European Commission. P. 217-218.

${ }^{20}$ Ibid. P. 115, 121.
} 
Table 5.1. Political Accountability Models: S, M, and L sizes

\begin{tabular}{|c|c|c|c|}
\hline & $S$ & M & $\mathrm{L}$ \\
\hline Obligation to submit a performance report & biannual & annual & Annual + special reports \\
\hline $\begin{array}{l}\text { Hearings obligations with respect to the } \\
\text { performance of the director's duties }\end{array}$ & + & + & + \\
\hline $\begin{array}{l}\text { Financial scrutiny in the course of annual } \\
\text { budgetary and discharge procedures }\end{array}$ & $\begin{array}{l}\text { Biannual / } \\
\text { self-funded }\end{array}$ & Annual & Annual \\
\hline Periodical external evaluations & $\begin{array}{l}\text { Less frequent } \\
\text { than in the } M \\
\text { model }\end{array}$ & + & + \\
\hline $\begin{array}{l}\text { Periodical obligatory review of the agency's } \\
\text { existence and its individual programs (sun- } \\
\text { sets) by the Council and the European Par- } \\
\text { liament }\end{array}$ & $\begin{array}{l}+ \text { (Less fre- } \\
\text { quent than in } \\
\text { the } M \text { model })\end{array}$ & + & $\begin{array}{l}+(\text { Upon (more) specific criteria } \\
\text { laid down in the founding act of } \\
\text { an agency) }\end{array}$ \\
\hline $\begin{array}{l}\text { Appointment of the agency director by the } \\
\text { agency's management board based upon an } \\
\text { open call announced by the Commission and } \\
\text { the Commission's short list; a hearing before } \\
\text { the European Parliament upon appointment. }\end{array}$ & + & + & $\begin{array}{l}\text { The appointment could be made } \\
\text { by the Council in consultation } \\
\text { with the agency's management } \\
\text { board. A hearing upon the } \\
\text { extension of the term of office of } \\
\text { the director before the EP could } \\
\text { be added. }\end{array}$ \\
\hline $\begin{array}{l}\text { Presence of all member states' representatives } \\
\text { on the agency's management board and of } \\
\text { one or more representatives from the Com- } \\
\text { mission; inserting a requirement for the } \\
\text { members of the management board to meet } \\
\text { at least four times a year. }\end{array}$ & $\begin{array}{l}\text { The require- } \\
\text { ment to hold } \\
\text { meetings of the } \\
\text { members of the } \\
\text { management } \\
\text { board could be } \\
\text { made at least } \\
\text { twice times a } \\
\text { year. }\end{array}$ & + & $\begin{array}{l}\text { The composition of the man- } \\
\text { agement board may also include } \\
\text { one or more independent persons } \\
\text { designated by the European } \\
\text { Parliament and relevant stake- } \\
\text { holders. }\end{array}$ \\
\hline $\begin{array}{l}\text { Removal of the director by the management } \\
\text { board. }\end{array}$ & + & + & $\begin{array}{l}\text { Removal of the director may be } \\
\text { done by the Council upon the } \\
\text { proposal of the agency's man- } \\
\text { agement board and/or upon } \\
\text { consultation with the European } \\
\text { Parliament. }\end{array}$ \\
\hline
\end{tabular}

It has to be taken into account that these examples aim at giving an indication to the reader about how such accountability models could be introduced and differ from each other. Further investigation is necessary to make a reference model and to determine on which points the reference model could be made lighter and heavier, while preventing undesired accountability gaps and overloads, including with other types of accountability. In design- 
ing such accountability models one would need to consider such elements as the amount of accountability mechanisms, periodicity of using individual mechanisms, the number of institutions involved, and the character of their involvements. The variety of models could clearly be greater to include, for instance, ' $X S^{\prime}$ ' (extra-small) and ' $X L$ ' (extra-large) sizes, though the variety should be within reasonable limits in order to sustain the clarity of the system, which is the very purpose of undertaking the proposed exercise. ${ }^{21}$ Also, subjecting smaller agencies to lighter packages may prevent unnecessary accountability overload and introduce more efficiency in their operation, the lack of which was one of the problems revealed during the evaluation of the existing EU agencies. ${ }^{22}$

It is needless to say that the models could be designed in another way. As with the past classification of EU agencies corresponding to the pillar structure of the community areas of jurisdiction, the EU representative institutions could be involved differently in holding agencies to account depending on the sector that agencies regulate. For instance, if an agency, like the CPVO, has assumed the tasks previously exercised by national authorities, for instance, registering plant varieties, only the Council and national authorities would hold the EU agency to account. The same could apply to the EU service providing agencies, such as the EFCA that coordinates joint inspections of fishery vessels in the EU waters. The European Parliament (and perhaps also the Council) would hold those EU agencies to account whose actions contribute to the EU legislative process, for instance, the EASA's legislative drafts. Irrespective of the choice of the approach, what is essential is creating a reasonable number of accountability models that make clear who holds what agencies to political account and why differences exist.

\section{(2) The formulation of accountability obligations}

In addition to the question of who holds EU agencies to account, including the powers of the relevant institutions, it is important to address the issue of 'how' agencies should be held to account. Here, the formulation of accountability obligations plays an important role. The comparative analysis has revealed the importance of the specificity element in holding an agency to account; the legislator has to be specific as to what agencies are supposed to do and against what standard the agency will be held to account, including both procedural and substantive requirements. It has been argued that reporting obligations could serve the purposes of accountability better if they included reasoning requirements and requests to analyse ex ante intentions against ex post results. The comparative analysis also showed that the amount of reports should be kept within reasonable limits to save the time and personnel's efforts on both the agencies' and overseers' sides of the accountability

\footnotetext{
${ }^{21}$ In a way, the previously used pillar affiliation for EU agencies offered some clarity in this respect. For instance, if an agency belonged to the former second pillar, the Council's supervision was automatically implied.

22 The Rambol evaluation, Volume I. P. v, 8.
} 
relationship. To this end, an annual activity report could be based on the analysis of ex ante working programs, results of periodical evaluations and reports that agencies prepare in the course of financial oversight. Taking into account the mentioned elements, the reporting obligation of the European Training Foundation (Article 13 of Regulation (EC) No 1339/2008) and the US experience, such a reporting obligation could be formulated in the following way:

Article X of an EU agency's founding act. Annual Activity Report

1. The Director shall prepare an (bi)annual performance report and submit it to the management board that after having discussed it and attached its reflection on the agency's annual performance sends it to the Council, the European Parliament, the Commission, the Court of Auditors and the European Economic and Social Committee by 15 June of the following year at the latest. This report shall also be forwarded to the Member States' respective authorities and, for information, to the partner countries or stakeholders present at the management board.

2. The annual activity report shall contain financial and management information providing an analysis of the ex post achievements by reference to the ex ante announced plans (annual work programme) and to the objectives set, the risks associated with those activities, the use made of the resources provided and the way the internal control system has functioned. It should also identify the problems and challenges the agency has faced in implementing its tasks, give reasons for possible failures or negative effects of the agency's operation, and offer a plan of action of how the agency aims to redress those problems and address those challenges. Such plans of actions should be followed up in the subsequent reports.

3. The Director shall present the agency's annual activity report to the relevant committees of the European Parliament and the relevant structures of the Council who are invited to give their feedback in writing. Such feedback should be addressed by the agency in the subsequent activity reports.

4. Together with the agencies' programmes the content of annual activity reports should be subject to the periodical external evolutions.

5. In those agencies where stakeholders attend the meetings of the agency's management board, the annual activity report should include a section of the stakeholders' reflections on the agency's plans and achievements. This section should also include a brief reflection on whether the potential problems and challenges could have been better addressed in another way and give reasons for that.

6. If an agency is subject to special reporting obligations, such obligations should also be made more specific as to what issues the agency needs to study and report about in an analyt- 
ical way, how often, to what institutions, and how the recipients of such reports should use this information.

While further investigation is needed into the issue of what elements should be present in order to make a reporting obligation (and in fact other accountability provisions) be valuable in terms of accountability, this illustration offers an example of necessary elements that should be taken into account in order to make a reporting obligation valuable in terms of accountability. The given example includes both the procedural and substantive elements with respect to the reporting mechanism. It establishes a frame of reference against which the EU representative institutions can check the agency's performance and report. It aims at promoting analytical reporting by inserting reasoning requirements. By including ex ante and ex post elements of reporting but also the feedback and follow-up elements, the proposed reporting obligation creates a dialogue between the agency and its overseers. The feedback possibility imposes thus an obligation on the accountability forum to check agencies' reports and hence actions. By inviting the stakeholders to comment on the agency's performance and report, the Union Legislator shares in a way its overseeing responsibility with the interested and most importantly expert parties involved and affected by the agency's actions. All in all, the mentioned elements can make a reporting obligation ensuring both the information and discussion stage of accountability and ensuring them at a more valuable level in terms of accountability. The latter is achieved by enhancing the quality of information provided (ensuring the flow of and discussing analytical rather than descriptive information) and the participation of the relevant institutions (e.g., feedback and follow-up options).

\section{(3) Interplay between accountability mechanisms}

When creating accountability models, the question of interplay between individual accountability mechanisms needs to be considered. Depending on the criteria for differentiation between accountability models, different possibilities of interplay may be required. This will depend on, for instance, the answer to the question of whether the EU representative institutions together (as a unitary accountability forum) or individually should enjoy accountability mechanisms ensuring the three stages of accountability. Taking the existing situation into account, two examples where the interplay between accountability mechanisms is missing and how it could be facilitated will be discussed.

The first example concerns the discharge procedure where the agency's director is personally accountable before the European Parliament for the implementation of the budget. While the European Parliament is supposed to hold an agency's director to account, it enjoys only mechanisms ensuring the information and discussion stages of accountability. This means that the European Parliament lacks a sanctioning tool against the director (not the agency). The missing sanctioning possibility of a personal nature may be crucial, espe- 
cially for those who opine that the rectification stage is an essential element without which accountability cannot be ensured. ${ }^{23}$ To remedy the situation, the power to remove the agency's director for the failure to implement the budget could be given to the European Parliament. ${ }^{24}$

Another example concerns the necessity of introducing hearings obligations on the agencies' performance in those cases where the Council and the European Parliament receive agencies' reports. If the European Parliament and the Council receive a report from an agency but do not have the formal power to question the agency's officials, the chances that such reports will be read may be quite small. Consequently, the information stage may also be jeopardized as the quality of reporting may decrease if an agency's officials know in advance that the reports are unlikely to be read.

Concluding, taking into consideration the necessity of establishing a clear accountability line between the EU agencies and the people via the EU representative institutions, yet allowing differentiating between agencies upon clear reasons, the second recommendation becomes: the Union Legislator should establish a legally-binding accountability framework for $E U$ agencies based on a streamlining approach. In designing a reasonable amount of accountability models the Union Legislator should carefully consider the formulation of accountability obligations and the interplay between individual accountability mechanisms to make them serve the accountability purposes.

\subsection{The Necessity to Render Account for Holding EU Agencies to Account}

The previous sections have discussed the necessity to establish binding rules, i.e., treaty provisions and a piece of secondary legislation governing the creation of, delegation to, and accountability of EU agencies. They both emphasized the importance of including substantive (next to procedural) requirements upon the Council and the European Parliament when they legislate on EU agencies and when they oversee them. Such substantive requirements included reasoning, analytical, feedback, and follow-up elements which can promote accountability dialogue between the agency and its overseers and perhaps extend it to stakeholders and citizens. Imposing reasoning obligations upon the Union Legislator when it creates agencies and including feedback elements when the EU representative institutions hold EU agencies to account are both needed for the same reason. The reason is the neces-

\footnotetext{
${ }^{23}$ Bovens (2007) P. 451.

${ }^{24}$ With respect to the new removal powers of the European Parliament in relation to the chairpersons of the recently created financial agencies (EBA, EIOPA and ESMA), the missing interplay between accountability mechanisms ensuring the three stages of accountability is still present. This is because similarly to other EU agencies' directors these chairpersons represent their agencies, yet unlike other EU agencies' directors they are not responsible for the implementation of the budget, responsibility given to the executive directors of the mentioned agencies; the latter are removable by the Boards of Supervisors of these agencies.
} 
sity to subject the Council and the European Parliament acting in legislative and overseeing capacities to render account for their actions.

While the political accountability relationship implies the relationship between the (EU) representative institutions on the one hand and the agencies on the other hand, in a larger picture it is important for the democratic accountability chain: representative institutions rendering account for their actions, which include creating agencies and holding them to account and justifying these actions to the ultimate principal, the people. The necessity of rendering account before the people for creating agencies, delegating them public authority and holding them to account can be also stressed by the fact that these actions are not authorized at the treaty level explicitly. Although the representative institutions are the principals and accountability forum in relation to agencies, they are also the agent and the accountability actor in relation to the people. The necessity to subject the Council and the European Parliament to render account for its oversight function also comes from the challenge to oversight discussed earlier, which includes the weak incentives to scrutinize agencies.

"One can control the behaviour of an agent either through explicit formal rules and incentives or through informal norms and habits." ${ }^{25}$ In facing the choice between formal rules and informal norms, formality seems to be a more advantageous option in the case of political accountability and the EU. Firstly, clarity and transparency are pre-requisites to democratic accountability. The quantity and quality of accountability actions undertaken by the representative institutions need to be known to the general public, which is more likely to be achieved by introducing formal rules and making accountability proceedings open to the public eye. Secondly, the more institutions and their internal structures are involved in accountability practices, the more sensible it becomes to introduce common rules. A formal rule has more chances to prevent undesirable disparities and inconsistencies in law and at least to a certain extent in the application of accountability mechanisms. Inconsistencies can be expected also because the Union consists of people of 28 nationalities (and hence potential 28 cultures to hold to account). Furthermore, the obstacle to ensuring the continuity of tradition comes from the fact that the turnover of MEPs after each election is quite high. As a final note, the disadvantages of formal rules, which include inflexibility and inability to adapt to specific cases and to give prompt reactions, could be lessened by introducing a set of minimum formal procedures, for instance, the requirement to hold biannual hearings of agencies' directors on the performance of the agency and implementation of the budget. Such a set of minimum formal procedures constituting the relationship between EU agencies and their political overseers would not preclude the establishment of other (informal) practices, for instance, appointing (or not) a liaison person responsible for main-

\footnotetext{
${ }^{25}$ Fukuyama (2013) P. 14.
} 
taining contacts with individual agencies among the elected members or staff of individual parliamentary committees. ${ }^{26}$

What formal rules and incentives could be established to promote the EU representative institutions' accountability for holding EU agencies to account? Next to the possible treaty provisions and obligations introduced in secondary legislation discussed in two previous sections, the rules of procedure of the EU overseeing institutions, which so far hardly mention the EU agencies, should include relevant elements. This will make the organization of accountability procedures that the EU representative institutions can employ in relation to EU agencies clear and transparent. In fact, Article 232 TFEU requires the European Parliament to adopt its rules of procedure which are "Parliament's internal organisational and operational rules."

The US House Rule X provides a nice model for how the European Parliament could amend its Rules of Procedure. Taking also the existing informal practices established in accordance with the 'Directions on cooperation between the committees with expertise relating to decentralized bodies of the Community of 14 July 1998,' an oversight rule in the Rules of Procedure of the European Parliament could be the following:

Rule X. Oversight over EU agencies: holding EU agencies to account (1) and rendering account for holding EU agencies to account (2).

1. Every standing committee of the European Parliament shall oversee agencies falling within its jurisdiction. Annex VII to the Rules of Procedure of the European Parliament specifies the jurisdiction of every standing committee, including the exact agencies that fall within that jurisdiction.

1.1. Standing committees involved in the oversight of EU agencies are invited to appoint liaisons among its staff who are responsible for the information exchange and requests between the European Parliament and individual agencies. If applicable, the names of such persons should be made public on the website of the European Parliament and its respective committees.

1.2. In accordance with the hearings obligations laid down in agencies' founding acts every standing committee shall hold hearings to discuss agencies' draft (multi) annual working programmes, (bi)annual activity reports, and financial requests and reports. The permanent rapporteurs on agencies and other representatives of the committees on Budgets and on Budget-

\footnotetext{
${ }^{26}$ Concerning the question of appointing liaisons at the parliamentary committee level, it should be kept in mind that a link with a particular MEP could lead to individual controls and pressures and disinterest from the side of other MEPs in the agency at stake. Also, this may come at the cost of political representation in holding agencies to account. Given the high turnout of MEPs after each election, parliamentary committees' staff would be better fitted to maintain contacts with individual agencies on a continuous basis, also including the issue of reassigning agencies to other committees. The oversight function should be a responsibility of all members of the parliamentary committees.
} 
ary Control are invited to participate in these meetings. The standing committees are invited to give written feedback to agencies' (annual) reports and follow-up on the feedback points from the previous reports.

1.3. Concerning agencies' budgetary requests, every standing committee should issue a preliminary opinion on the draft budget and if necessary propose amendments, including withholding of certain funds, on the basis of the assessment of agencies' activity programs and policy priorities. Before the Committee on Budgets adopts its recommendation for the first reading budget, the general rapporteur and the rapporteur on agencies shall communicate their positions to the respective specialized committees, including justifications of their decisions.

1.4. Every standing committee shall ensure transparency within the European Parliament on all issues as related agencies. If a committee receives information from the representatives of an agency, it plans visits and hearings, such information should be known for all members by means of being included in the relevant committee's agenda announced in advance or should be spread around among all committees, including the Committee on Institutional Affairs on the basis of a list of documents transmitted at regular intervals.

2. Not later than a certain date, every standing committee of the European Parliament shall announce its oversight plans, supported by justifications, for the coming two years. Such plans should be distributed among the members of the European Parliament.

2.1. No later than a certain date, every standing committee shall submit to the specific committee a (semi)annual report on the activities of that committee. Such report shall include: (A) a summary of the announced oversight plans for the coming two years; (B) separate sections summarizing the oversight activities of that committee, including the responsible MEPs for exercising such activities; $(\mathrm{C})$ a summary of the actions taken and recommendations made with respect to the oversight plans specified in subdivision (A); (D) a summary of any additional oversight activities undertaken by that committee, supported by reasons why such activities have been necessary, and any recommendations made or actions taken thereon; (E) points for the future follow-up and reflections on such points from the previous reports.

2.2. Standing committees may send their delegations to individual agencies to oversee agencies' activities. Such delegations should issue a brief statement about their plans ex ante and announce the results of the visit ex post. The ex post report should include potential points of attention for the further follow-up.

2.3. Reports and plans mentioned in this section shall be made public by publication in the Official Journal and made available on the website of the European Parliament and its respective committees by a certain date.

The importance of such a rule is twofold. First, it establishes a clear oversight strategy of the European Parliament by formalizing some of the existing practices and informal guidelines. 
The strategy becomes clear for both the frequently changing members of the Parliament and the public who knows what actions the Parliament takes and what it could expect, such as, for instance, reports about oversight activities. Concerning the latter point, the given example puts emphasis not only on what the European Parliament's members could do but also on how they should render account for what they do, namely for the oversight actions. Announcing oversight plans in advance and then submitting the actual oversight activities in reference to the announced plans is one of the incentives that could address the challenge of weak incentives of MEPs to conduct oversight. To prevent the absence of many MEPs at committees' hearings of agencies' directors, for instance, paragraph 1.2. could include a quorum requirement. As an example, such a hearing can take place only when the majority of the committee's members are present.

The Council's Rules of Procedure could be adjusted in a similar way. However, it will first be necessary to establish the exact internal structures, the counterparts of parliamentary standing committees in the Council, which oversee EU agencies. Also, it is essential to introduce transparency rules ${ }^{27}$ in order to make accountability procedures, their nature and amount, known to the public.

Concluding, since the EU representative institutions with questionable democratic legitimacy are the agent and accountability actor in relation to the EU people and the representative bodies may lack incentives to be engaged in scrutinizing agencies, the third recommendation that this study puts forward is that the EU representative institutions should render account for holding EU agencies to political account by introducing relevant self-enforcing rules and adhering to them.

\section{Conclusion}

Based upon comparative insights, this chapter offered three recommendations for the EU representative institutions to consider in the ongoing reform of the operation of EU agencies. While the proposed recommendations include a wide range of issues, what binds them all together is the request to the EU institutions to address the existing problems in a transparent way and with reasons and clarity. The political accountability of EU agencies is not only about obliging the agencies to render account; it also implies that representative institutions must assume their responsibilities of establishing a sound accountability system, applying relevant accountability rules, and rendering account for that. The latter is especially relevant in the case of the EU whose democratic legitimacy remains a matter of debate. Now, the trick becomes to create such a sound accountability system for the EU agencies and to determine what a sound accountability system (in the EU) means.

\footnotetext{
${ }^{27}$ For instance, the Rules of Procedure of the Council requiring the Council "to meet in public when it deliberates and votes on a draft legislative act" (Article 7) could extend to Council's scrutinizing tasks.
} 


\section{Chapter 6. Reflections and Prospects}

The growing scope of delegation to EU agencies has put pressure on the EU's democratic credentials making the issue of the political accountability of EU agencies a salient political and legal issue. Holding to account is a challenging task, especially when the locus of the executive power has become dispersed and has moved beyond the nation state border. The research question which this study sought to address was: how is the political accountability of EU agencies arranged and what should the EU representative institutions consider when adjusting the existing accountability arrangements in the course of the ongoing reform of the operation of EU agencies? In this light, this study pursued two goals. First, it aimed at filling up the existing lack of knowledge on the current state of play concerning the political accountability arrangements of EU agencies. Second, it also intended to offer policy recommendations concerning the political accountability of agencies for the EU representative institutions to consider in the ongoing reform of the operation of EU agencies. Behind the pursuit of the two goals mentioned lies a greater purpose of this research project: to contribute to the existing academic and practitioners' debates on the implications of the everexpanding delegation of public authority to executive institutions with various degrees of autonomy. This concluding part reflects on in how far the goals of this research project have been achieved (1) and what implications the results of this study carry for further academic endeavors and practitioners (2).

\section{(1) Achievement of the study goal}

- Analytical contribution

In order to analyze the political accountability of EU agencies, including from a comparative perspective, this study faced the question of how political accountability was to be investigated and assessed given the absence of a relevant general framework. Following the definition of Bovens, the principal-agent characteristic of the relationship between representative institutions and IRAs, and the institutional and personal features of the accountability actor at stake, i.e., the independent agency, this study established an investigation framework of five dimensions in which political accountability can be shaped and exercised. These are: (1) the creation of and delegation to IRAs by representative bodies, (2) the appointment and removal of agencies' top officials by representative bodies (3) statutory regulation of accountability aspects of the operation of agencies, (4) financial oversight, and (5) (parliamentary) scrutiny. These five dimensions harbor aspects of an institutional (1, 3-5) 
and personal (2); ex ante (1-3) and ex post (2, 4, 5) nature, which enabled a comprehensive investigation of political accountability in a broader institutional environment (see Chapter 1).

Upon the findings gathered in the mentioned five dimensions political accountability was assessed and then compared on the basis of a proposed formula, namely political accountability = the availability of accountability mechanisms + design of accountability mechanisms and obligations + practical application of accountability mechanisms. The formula includes the elements which allow assessing both accountability capacity (accountability mechanisms) and accountability quality (design and practical application) and identifying more specifically the sources of problems. The latter makes it more feasible to think of appropriate solutions.

- Investigating and assessing the political accountability of all 35 EU agencies In pursuing the first goal, i.e., to fill up the existing lack of knowledge on the current state of play concerning the political accountability arrangements of EU agencies, the following steps were undertaken. The political accountability of EU agencies was first investigated on the basis of the mentioned five dimensions. Having studied the founding acts of all $35 \mathrm{EU}$ agencies, this made it possible to offer a complete overview of the existing statutory accountability arrangements. The analysis of the political accountability of EU agencies was further done with the help of the existing multi-disciplinary literature, official reports and studies, and semi-structured interviews which the author conducted with top-level officials from EU agencies and (political institutions); the latter was used as supportive material.

The investigation of the political accountability of EU agencies showed that, in the absence of any legal framework governing the creation of agencies and the accountability of agencies, EU agencies were created without necessarily functional necessity and with accountability gaps with regard to the EU representative institutions. For instance, EU agencies' founding acts might simply lack evaluation, review, and removal clauses. Whereas there were three types of hearings obligations for agencies' directors before the European Parliament and/or the Council, they were not generally applied. Only 18 (out of 35) founding acts prescribe appointment hearings for candidates to head EU agencies, 16 (out of 35) agencies' directors could be invited to report on the performance of the agency, and in six (out of 35) cases the founding acts provide a possibility to question an agency's director before the extension of his/her term of office. Here, a correlation between the growing legislative power and hence involvement of the European Parliament in passing agencies' founding acts and the growing number of agencies' accountability obligations, such as hearings obligations, was noticed.

Furthermore, while some parliamentary committees of the European Parliament might have developed practices of appointing liaisons to maintain contacts with their agencies, other parliamentary committees did not oversee EU agencies, even if specific agencies fell 
under their jurisdiction as prescribed by the Rules of Procedure. Here, the presence of hardly any formal rules, at both EU representative institutions, concerning how representative bodies should scrutinize agencies as well as the lack of transparency of the operation of the Council made it difficult to conclude whether and how, in quantitative and qualitative terms, scrutiny of all EU agencies took place. The sphere of financial oversight over EU agencies seemed to be the most harmonized accountability venue, although even here derogations existed, i.e., six self-funded agencies. Since making agencies self-funded implied having hardly any relationship with the EU representative institutions, especially the European Parliament, their political accountability showed serious shortcomings.

All in all, it was concluded that the EU main institutions seemed to be involved in a political game in relation to who ascertains control over EU agencies, which resulted in the existing diverse accountability arrangements. That political negotiations were likely to persist, being the determinant factor in relation to the creation and operation of EU agencies was argued on the basis of the fact that the Interinstitutional Working group's negotiations concerning the operation of EU agencies resulted in the non-legally-binding 'Common Approach' on EU agencies.

The findings of the discussed dimensions served as a basis for assessing political accountability according to the proposed formula (the availability of accountability mechanisms, design of accountability mechanisms and obligations, and their practical application). Regarding these three elements the political accountability of EU agencies was assessed as problematic with respect to all three elements. Generally speaking, the European Parliament and the Council enjoy various accountability mechanisms ensuring the three stages of accountability. Yet, in individual cases (similar) EU agencies might have been subject to different sets of accountability obligations with no clear justifications of why the differences (should) exist. Furthermore, the design of accountability obligations, including short and general formulations of reporting provisions and at times lacking interplay between accountability mechanisms, may hinder accountability. Finally, the practical application of the existing accountability mechanisms encountered a number of challenges, including random checks of agencies' performance and practical constraints to using such sanctioning tools, as the closure of agencies. It was shown that excessive diversity accompanied by a lack of reasoning dominated the current state of affairs and it was argued that considering the complexity of the EU structures and a fundamental character of the concept of accountability the existing roughly speaking 35 accountability models as regards EU agencies were of questionable necessity. A limited number of accountability models could create a system that would be clear, transparent and reasoned, yet allowing flexibility. This in turn could enhance the legitimacy of the EU structures and processes.

Looking back at the findings of Chapter 2, which devoted its attention to the political accountability of EU agencies, the task to fill up the knowledge gap in the field of the political accountability of $35 \mathrm{EU}$ agencies seems to be fulfilled to a great extent. The obstacle to 
attaining the goal completely stems from the difficulty in investigating and assessing the accountability role of the Council. Due to the lack of formal rules and transparency of its internal operations in relation to EU agencies it was rather difficult to investigate whether accountability processes take place, how often, and of what quality.

- Investigating and assessing the political accountability of US independent regulatory agencies

This study then took a 'comparative turn'. The investigation of the US system of political accountability of IRAs was an intermediary step towards making a comparison with a view to accomplishing the second goal, i.e., formulating policy recommendations for the EU representative institutions in the field of the political accountability of EU agencies. This is because comparison allows one to appreciate and understand one's system better, assessing it critically, and realizing not only what relevant legal provisions say, but also what they do not say. ${ }^{1}$

In Chapter 3, the political accountability of 16 US independent regulatory agencies was first investigated with regard to the five dimensions mentioned. It was shown that the relationship between Congress and US independent regulatory agencies could be characterized as fully-fledged as it involved various interactions all designed by Congress itself with hardly any restrictions imposed by the Constitution, as IRAs are not mentioned there, or by the Supreme Court, when interpreting the existing constitutional gaps.

This fully-fledged relationship implied a catalogue of ways in which Congress could be involved in governing IRAs. In fact, it was pointed out that hardly any differences existed between how Congress could hold independent and other agencies of the executive branch to account. The latter was explained by the meaning of the concept of 'independence' in the US context which implied a distance from the political influence of the President, rather than of Congress. At the same time, it was shown that limiting the President's control over IRAs merely shifted the origin of political influence from one political institution, the President, to the other one, Congress. Hence, politics influenced US independent regulatory agencies in a number of respects. Following the theory of 'separation of parties, not powers', the decisions concerning the creation of IRAs and delegation to them, the degree of oversight conducted by congressional chambers over IRAs and other issues, such as how the appointment and removal of IRAs' top level officials were made, seemed to depend on the political majorities sitting in Congress and the White House or IRAs' management boards.

Despite the fact that politics might influence Congress's ability to use its accountability instruments, various mechanisms were analyzed concerning how Congress could hold IRAs to account. These included oversight hearings supported by formally strong powers to

\footnotetext{
${ }^{1}$ Heringa and Kiiver (2012) P. 1.
} 
subpoena witnesses and to hold them in contempt and various 'fire-alarms' implying a solid body of statutory regulation which allowed Congress, its support bodies, and the interested parties to check upon agencies. The creation of expert congressional support agencies enhanced the scope of congressional oversight capacity which seemed to be especially relevant in addressing the challenge to oversee intelligibly the high number of executive institutions. Yet, the greatest challenge of congressional oversight remained the weak incentives of the elected politicians to conduct continuous oversight. Given the regularity of the annual appropriations process but also its possibility to ensure all three stages of accountability, it was argued to be 'The accountability tool' that Congress had at its disposal.

Using the formula mentioned earlier, the political accountability of US IRAs was assessed as partly problematic. It was shown that political accountability was organized in a clear way because US IRAs were subject to very similar accountability obligations which were designed in such a way that they could promote accountability. For instance, reporting obligations could be very specific and promoted accountability by requiring analytical reporting with the help of inserting the requirement to give reasons and obligations to report results in light of initial plans. Furthermore, while the assessment of the system of political accountability of US IRAs revealed some troubling moments, such as the great number of reports which may incur unnecessary costs upon the operation of agencies without bringing the desired results and may hinder accountability, it has also shown the solutions which Congress has employed to address those issues. Concerning the mentioned example about the high number of reports, Congress's solution was to increase its staff, to create expert support bodies and to establish a direct accountability line between the agencies and the public to increase the chances of reports being read and the agencies being checked upon. At the same time, while Congress can hold IRAs to account with the help of its "awesome arsenal" 2 of strong accountability mechanisms, it does not necessarily do it (properly) since the usage of that arsenal depends on the political majorities sitting on Capitol Hill and in the White House or individual IRAs' management boards. It was concluded that following Madison's legacy of first ensuring the government to control the governed and then of obliging the government to control itself, the greatest challenge to the political accountability of US IRAs seemed to lie largely in the second step.

\section{- Making a comparative analysis and offering recommendations}

It is through comparison that the task of offering policy recommendations of what the EU representative institutions should consider when adjusting the accountability arrangements of EU agencies, i.e., the second goal of the research project, was fulfilled. Chapter 4 offered a comparative analysis of the political accountability systems of IRAs in the EU and the US. Based upon comparative insights, Chapter 5 put three policy recommendations forward for

\footnotetext{
2 Wilson (1989) P. 236.
} 
the EU representative institutions to consider in the ongoing reform of the operation of EU agencies.

The comparative analysis has been valuable in several respects. First, it helped to appreciate what the EU representative institutions have. It was shown that the accountability capacity of the EU representative institutions is quite similar to that of the US Congress. Generally, the representative institutions in both studied jurisdictions enjoy possibilities to scrutinize agencies' performance and finance with the help of reports and hearings, make investigations into specific events, and sanction agencies by, for instance, modifying agencies' functions, budgets, and organizational structures. To ensure the personal accountability line of the 'unelected officials' heading IRAs to the people, the EU and US representative institutions can be involved in appointing and removing agencies' top-level officials. This is not to say, however, that individual accountability mechanisms do not differ in their strength; for they do. For instance, the European Parliament lacks congressional powers to subpoena witnesses and to hold them in contempt while congressional chambers do not have the European Parliament's power to give a discharge. ${ }^{3}$ Despite that, the most striking difference concerns the approach that the legislator uses in relation to organizing the political accountability of individual agencies: with great uniformity in the US and great diversity in the EU. Here, it was argued a more uniform yet flexible approach to ensure clarity, justification and differentiation among agencies was necessary. This is essential for promoting the EU's legitimacy.

Second, the comparative analysis offered lessons (for the EU) to consider and identified issues to be alarmed about. The learning experience included, for instance, the matters of specificity of accountability obligations and their formulation to facilitate the purposes of accountability. The warning signal concerned imposing too many accountability obligations upon agencies, such as the number of reports, which could hinder accountability by making it difficult to comply with all obligations on the side of the agencies and, on the side of Congress, to study properly all the received reports.

Third, the comparison highlighted several similarities which demonstrate the necessity for further exploration. This concerns, for instance, the importance of holding agencies to account and the advantages that the annual budgetary procedure offers to hold agencies to account. Its advantages included regularity in the discussion of agencies' performance since at the end of the day the money translated into agencies' activities. This indicated the possibility of making annual financial oversight procedures a central venue to exercise political

\footnotetext{
${ }^{3}$ In a way, differences regarding the absence of comparable mechanisms and legal instruments between the two systems have made it less feasible to apply consistently the established analytical framework for the investigation of political accountability of agencies (mostly, in parallel sections 2.2.3. and 3.2.3, 2.2.4 and 3.2.4, and 2.2.5. and 3.2.5).
} 
accountability. ${ }^{4}$ Both jurisdictions also demonstrated similar concerns, such as the existence of lenient creation and delegation standards allowing the legislator to create various institutions within the executive branch without necessarily functional needs but with accountability shortages. Here, both jurisdictions face the challenge that incentives are weak for the representative bodies to scrutinize agencies' performance on a continuing basis. Such similar concerns hint at the difficulty to formulate straightforward solutions to address these challenges, which in turn emphasizes the necessity to explore such concerns in the future.

With respect to the policy recommendations, this study argued for the necessity of (1) a treaty provision regulating the possibilities to create EU agencies and delegate to them certain powers supported by an obligation to set up an accountability framework of EU agencies in a secondary legislative act; (2) a legally-binding accountability framework (a secondary legislative act) based on a streamlining approach; and (3) self-enforcing rules for the EU representative institutions to render account for holding EU agencies to account. These measures are essential to legitimize EU agencies, organize their political accountability in a clear yet flexible way, and promote the EU representative institutions' accountability responsibilities. The Union Legislator was thus invited to adjust the existing political accountability arrangements of EU agencies based on good reasons and in a transparent way which could contribute to reducing the alleged EU legitimacy deficit. It was argued that the political accountability of EU agencies was not only about obliging agencies to render account, it also implied representative institutions assuming their responsibilities of establishing proper accountability mechanisms, applying relevant accountability rules and rendering account for that.

All in all, with the help of its own analytical framework this study investigated and assessed the political accountability of all 35 EU agencies, it discussed and attempted to explain the existing accountability arrangements and sources of accountability problems, and upon comparative insights with the US, and it offered three policy recommendations for the EU representative institutions to take into consideration when adjusting the existing accountability arrangements of EU agencies. Nevertheless, the study faced a difficulty in investigating the Council's accountability role in relation to EU agencies, which together with its results carry implications for future academic endeavors and practitioners.

\section{(2) Implications for the future}

While this research project has advanced our understanding of the political accountability of IRAs in general and of EU agencies in particular, its findings also indicate a necessity for further investigations that could be undertaken by academics and practitioners in at least two directions. These include extending the debate of political accountability of IRAs and

\footnotetext{
${ }^{4}$ The 'budget-linked' accountability using Heringa and Verhey's terminology (Heringa and Verhey (2003) P. $165)$.
} 
developing the ways that can contribute to ensuring the political accountability of the executive. Both directions require shifting the focus of research attention. In the former case the shift is from investigating IRAs to comparative inquiries of political accountability of different types of executive institutions and to institutions playing the role of a political accountability forum. As for the latter case, the shift is about studying not only the accountability capacity, i.e., what mechanisms accountability forums have, but also accountability quality, i.e., the consciousness of design and practical application of accountability mechanisms.

\section{- Extending the debate on the political accountability of IRAs}

With respect to the extension of the debate on political accountability of IRAs, it seems necessary to engage in comparative inquiries on similarities and differences that exist between (political) accountability arrangements and problems of independent and other types of executive institutions. In the EU setting, an interesting question for further investigation could be whether a task which is proposed to be delegated to an agency would be performed with more and/or better (political) accountability than if it was given to the Commission or a network of regulators. ${ }^{5}$ Studies comparing accountability arrangements of different types of executive institutions could further our understanding of the ways political accountability can be organized and exercised, the problems that those different ways may encounter and the solutions that exist. Such comparative insights could also contribute to addressing questions as to how much diversity (political) accountability should have given the fundamental character of the value of accountability. Finally, comparing accountability arrangements of independent and other executive institutions could prove or disprove the starting thesis that this study took as a given that independence does not necessarily cause accountability problems (see Chapter 1.2.2.).

Another dimension to extending the debate on the political accountability of IRAs was prompted by the obstacle that this study faced, namely the lack of formal rules and transparency of the Council's internal operations in relation to EU agencies. The necessity to involve the Council in overseeing EU agencies from a representative perspective seems logical. Yet, the Council's institutional characteristics, namely the absence of a 'continuous Council of Ministers', because the ministers gather only a few times a year, and the lack of formal rules concerning Council's oversight over EU agencies and the transparency of its operations, hindered connecting the processes of political accountability within its lower structures with the ultimate principal, the people. In addition, discussing the composition of the EU political accountability forum in Chapter 2.1., it was suggested that a weak check upon the political accountability forum may hinder the ability of representative bodies to

\footnotetext{
${ }^{5}$ I am grateful to Francis Jacobs (former employee of the European Parliament and, as of this writing, Head of European Parliament's Office in Dublin) for his question in this respect during the Montesquieu Institute workshop on the political accountability of EU and US independent agencies which took place at the Faculty of Law, Maastricht University on 3 February 2012.
} 
hold executive institutions to account. In this respect, representation, transparency of operations, organization of relevant procedures and a strong accountability link from the accountability forum to the people stand out as important characteristics that a political accountability forum needs to have to be able to exercise the tasks of a political overseer. However, are there more essential characteristics? In this light, future studies are necessary to identify such essential characteristics of political accountability forums which could be tested with a view to their ability to perform the duties of a political overseer.

Interconnected with the question of characteristics is the issue of the 'unitary' structure of an accountability forum. It may deserve more attention in future research projects, especially in relation to the EU multi-principal environment whose effects on accountability (of agencies) are unknown. The degree of how unitary the accountability forum is will affect accountability. If the accountability forum comprises several parts with conflicting interests, yet shares the powers necessary to hold agencies to account, (political) accountability may be problematic when the individual stages of accountability can be ensured only before separate parts of the accountability forum. Studying the implications of the degree of 'unity' of the accountability forum on accountability seems especially relevant if one considers building multi-level accountability structures, such as making EU agencies accountable before both EU and national levels.

\section{- Developing the ways to ensure (political) accountability of the executive}

Concerning the second issue, namely developing the ways that can contribute to ensuring political accountability, this project has made a first step in that direction, which is proposing a formula comprised of three elements necessary to ensure accountability, namely the availability of accountability mechanisms, their design, and practical application. Those who deal with holding EU agencies to account directly may find this formula useful when they design or adjust relevant accountability arrangements, as this formula combines the essential elements that contribute to ensuring accountability, i.e., accountability capacity (the availability of accountability mechanisms) and quality (the design of accountability mechanisms and obligations and their practical application). In addition to its usefulness at the design stage, it can be used as an assessment tool, like in this book, also when comparing political accountability systems. Yet, being only a first step, it necessitates further tests and possible adjustments.

Another implication of having a tool for designing and assessing political accountability is the possibility to build a model. In this light, the formula as well as the policy recommendations for the EU representative institutions mentioned earlier hint at important questions necessary to be addressed: What set of accountability mechanisms is needed to be able to hold (independent) agencies to account? How exactly should accountability obligations be formulated to serve the purposes of accountability? and What might be the concrete solutions to address challenges to the application of accountability mechanisms? To 
this end, further investigation in the direction of building a sound accountability system is necessary. This in turn requires such questions to be addressed as what a sound accountability system is and who may determine its soundness, the latter implying the classic debate of 'elected representatives vs. unelected judges'.

Furthermore, building an accountability model is likely to necessitate an investigation of the roles of different institutions in accountability processes, especially within the multiprincipal and multi-level EU setting. This will touch upon such issues as what sets of institutions one needs to establish to be able to hold various agencies to account, which in turn also requires other types of accountability to be considered. While political accountability of independent and other agencies is essential in ensuring the democratic accountability link between the unelected officials heading IRAs and the people governed by them, it is not enough to ensure the accountability of agencies, especially if one considers the challenges that political oversight faces. ${ }^{6}$ A fully-fledged accountability of (independent) agencies seems only possible to be established by combining political accountability with other types of accountability, such as by courts and peers. The questions for further investigation become how many types of accountability and how much of each type of accountability should be present to result in fully-fledged accountability of various executive actors and when accountability can be considered to be fully-fledged. In searching for a fully-fledged accountability, an additional important point of future research attention should be given to the quality and intensity of various types of accountability to prevent undesired effects, such as accountability gaps and excesses.

If attempts are made to build an accountability model, a comparative method can be recommended based on the experience of this study. A comparative analysis is valuable in three respects. It offers lessons of what rules and practices could be considered from different jurisdictions; it sends warnings of what should be better avoided; and it spots concerns of a fundamental nature when different jurisdictions show the same problematic instances. The latter seems to imply difficulties with providing solutions and stresses the need to look for them. For this reason, such concerns of a fundamental nature deserve to receive special attention in future research projects.

As a whole, having analysed the political accountability arrangements of EU and US independent regulatory agencies, this book has shown that excessive diversity of rules and practices governing the political accountability of EU agencies is a matter for serious concern. The absence of a coherent framework for the accountability of EU agencies hinders the EU's legitimacy, transparency of EU structures and processes, legal certainty, and accountability deficits. With respect to the rules, the US experience offers a valuable lesson by demonstrating the possibility of having both flexibility in relation to the type and functions

\footnotetext{
${ }^{6}$ Since different accountability forums apply different sets of criteria when holding to account, "the more forums a specific regulatory regime or actor is required to answer to, the more aspects of its conduct are subject to scrutiny as well and the higher the exposure to consequences or sanctions" (Curtin and Senden (2011) P. 183).
} 
of agencies and uniformity in relation to the organisation of agencies' political accountability. At the same time, the US example is also illustrative regarding the difference between de jure accountability capacity, which is very strong as regards the US Congress, and de facto weak incentives of people's representatives to hold the executive to account continuously. Such incentives depend largely on representatives' political and personal gains. Promoting incentives of representative bodies in holding agencies to account, a challenge identified in both studied jurisdictions, seems to be one of the fundamental concerns that deserves special research attention in the future. Hence, the question of 'how to oblige the government to control itself is one of the greatest difficulties that lie ahead. 



\section{REFERENCE LIST}

\section{A. Table of Text and Periodical Citations}

Aberbach, Joel D. Keeping a Watchful Eye: The Politics of Congressional Oversight. Washington, DC: The Brookings Institution, 1990.

Andoura, Sami, and Timmerman, Peter. "Governance of the EU: The Reform Debate on European Agencies Reignited,” Working Paper No. 19, European Policy Institutes Network, 2008. http://www.ceps.eu/files/book/1736.pdf (accessed January 2014).

Arnull, Anthony. "Introduction: The European Union's Accountability and Legitimacy Deficit." In Accountability and Legitimacy in the European Union, edited by Anthony Arnull, and Daniel Wincott, 1-11. Oxford: Oxford University Press, 2002.

Asimow, Michael, (ed.) A Guide to Federal Agency Adjudication. Chicago: American Bar Association 2002.

Asimow, Michael, and Levin, Ronald M. State and Federal Administrative law. 3rd ed. St. Paul: West Publishing, 2009.

Auel, Katrin. "Democratic Accountability and National Parliaments: Redefining the Impact of Parliamentary Scrutiny in EU Affairs.” European Law Journal 13, no. 4 (2007): 487 - 504.

Beermann, Jack M. “Congressional Administration” San Diego Law Review 43, no. 61 (2006): 61 - 158.

Beetham, David, and Lord, Christopher. Legitimacy and the EU. London: Longman, 1998.

Behn, Robert D. Rethinking Democratic Accountability. Washington DC: The Brooklings Institute, 2001.

Berg, Richard K., Klitzman, Stephen, and Edles, Gary. An Interpretive Guide to the Government in the Sunshine Act. 2nd ed. Chicago: American Bar Association, 2007.

Bernstein, Marver. Regulating Business by Independent Commission, Princeton: Princeton University Press, 1955.

Bostock, David. “Coreper Revisited.” Journal of Common Market Studies 40, no. 2 (2002): 215 - 234.

Bovens, Mark. "Two Concepts of Accountability: Accountability as a Virtue and as a Mechanism." West European Politics 33, no. 5 (2010): 946 - 967.

Bovens, Mark. "Analysing and Assessing Public Accountability: A Conceptual Framework.” European Law Journal 13, no. 4 (2007): 447 - 468.

Bovens, Mark, Curtin, Deirdre, and 't Hart, Paul. "The Quest for Legitimacy and Accountability in EU Governance." In The Real World of EU Accountability, What Deficit?, edited by Mark Boven, Deirdre Curtin and Paul 't Hart, 9 - 30. Oxford: Oxford University Press, 2010.

Bovens, Mark, Schillemans, Thomas, and 't Hart, Paul. "Does Public Accountability Work? An Assessment Tool." Public Administration 86, no. 1 (2008): 225 - 242.

Breger, Marshall, and Edles, Gary. "Established by Practice: The Theory and Operation of Independent Federal Agencies." Administrative Law Review 52, no. 4 (2000): 1111-1294.

Broeksteeg, Hansko, Van den Driessche, Ilse, and Verhey, Luc. "Political Accountability in the EU Member States: Different Concepts and Practical Implications." In Political Accountability in Europe: Which Way Forward?: A Traditional Concept of Parliamentary Democracy in an EU Context, edited by Luc Verhey, Hansko Broeksteeg and Ilse van den Driessche, 271 - 298. Groningen: Europa Law Publishing, 2008.

Brunmayr, Hans. "The EU Institutions Beyond the Lisbon Treaty - a Perspective From the Council." In The EU institutions beyond Lisbon Future Challenges, edited by Michael Shackleton and Sophie Vanhoonacker, 1 - 9. Maastricht: Maastricht Monnet Lecture Series One, 2009.

Busch, Peter, and Puchala, Donald. "Interests, Influence, and Integration: Political Structure in the European Communities." Comparative Political Studies 9, no. 3 (1976): 235 - 254.

Busuioc, Madalina. The Accountability of European Agencies: Legal Provisions and Ongoing Practices. Delft: Eburon, 2010. 
Busuioc, Madalina, and Groenleer, Martijn. "The Theory and Practice of EU Agency Autonomy and Accountability: Early Day Expectations, Today's Realities and Future Perspectives.” In European Agencies in between Institutions and Member States, edited by Michelle Everson, Cosimo Monda, and Ellen Vos eds., 175-200. Alphen aan de Rijn: Wolters Kluwer, forthcoming 2014.

Busuioc, Madalina, Groenleer, Martijn, and Trondal, Jarle eds. The agency phenomenon in the European Union: Emergence, institutionalisation and everyday decision-making. Manchester: Manchester University Press, 2012.

Calabresi, Steven G., and Rhodes, Kevin H. "The Structural Constitution: Unitary Executive, Plural Judiciary." Harvard Law Review 105, no. 6 (1992): 1153 - 1216.

Calabresi, Steven G., and Yoo, Christopher S. The Unitary Executive: Presidential Power from Washington to Bush. New Haven, CT: Yale University Press, 2008.

Cann, Steven J. Administrative Law, $4^{\text {th }}$ ed. Thousand Oaks, CA: Sage Publications, 2006.

Cary, William L. Politics and the Regulatory Agencies. New York: McGraw-Hill Book Company, 1967.

Chamon, Merijn. "EU Agencies: Does the Meroni Doctrine Make Sense?" Maastricht Journal of European and Comparative Law 17, no. 3 (2010): 281 - 305.

Chiti, Eduoardo. "An Important Part of the EU's Institutional Machinery: Features, Problems and Perspectives of European Agencies.” Common Market Law Review 46, no. 5 (2009): 1395 - 1442.

Chiti, Eduoardo. "The Emergence of A Community Administration: The Case of European Agencies." Common Market Law Review 37, no. 2 (2000): 309 - 343.

Christensen, Tom, and Lægreid, Per. "Rebalancing the State: Reregulation and the Reassertion of the Centre." In Autonomy and Regulation: Coping with Agencies in the Modern State, edited by Tom Christensen and Per Lægreid, 359 - 380. Cheltenham, MA: Edward Elgar Publishing, 2006.

Christensen, Tom, and Lægreid, Per. "Regulatory Reforms and Agencification.” Paper presented at the ECPR Conference, Budapest 8-10 September 2005.

Christiansen, Thomas. "Out of the shadows: The general secretariat of the Council of Ministers." The Journal of Legislative Studies 8, no. 4 (2002): 80 -97.

Christiansen, Thomas, and Vanhoonacker, Sophie. "At a critical juncture? Change and Continuity in the Institutional Development of the Council Secretariat.” West European Politics 31, no. 4 (2008), 751 -770.

Cini, Michelle, and Perez-Solorzano Borragan, Nieves. European Union Politics. Oxford: Oxford University Press, 2004.

Clark, Alan. Diaries: In Power 1983-1992. London: Phoenix, 1994.

Clark, Tom C. “Attorney General's Manual on the Administrative Procedure Act (1947).” In Federal Administrative Procedure Sourcebook, edited by William Funk, Jeffrey S. Lubbers and Charles Pou Jr., 39 - 177. Chicago: American Bar Association, 2008.

Cohen, Daniel, and Strauss, Peter L. "Congressional Review of Agency Regulations." Administrative Law Review 49, no. 1 (1997): 95 - 110.

Coreper, Europe's Managing Board. The Economist, August 6, 1998. http://www.economist.com/node/170753 (accessed October, 20 2012).

Corbett, Richard, Jacobs, Francis, and Shackleton, Michael. The European Parliament, $8^{\text {th }}$ ed. London: John Harper Publishing, 2011.

Corbett, Richard, Jacobs, Francis, and Shackleton, Michael. The European Parliament, $7^{\text {th }}$ ed. London: John Harper Publishing, 2007.

Craig, Paul. EU Administrative Law, 2 $2^{\text {nd }}$ ed. Oxford: Oxford University Press, 2012.

Craig, Paul. "The Locus and Accountability of the Executive in the European Union." In The Executive and Public Law: Power and Accountability in Comparative Perspective, edited by Paul Craig and Adam Tomkins, 315 355. Oxford: Oxford University Press, 2005.

Craig, Paul. “The Community Political Order." Indiana Journal of Global Legal Studies 10, no. 1 (2003): 79 - 124. 
Crimmins, Stephen J. "Bad reasons to Defund the SEC.” Securities Regulation and Law Report 02.07.2011, Bureau of National Affairs Inc, http://www.maastrichtuniversity.nl/web/file?uuid=04efe4b3-df894e76991aee73afc26868\&owner=f6791e56-38f8-45c8-8d62-71bfb741ef82 (accessed October, 2012).

Curtin, Deirdre. Executive Power of the European Union: Law, Practices, and the Living Constitution. Oxford: Oxford University Press, 2009.

Curtin, Deirdre. "Holding (Quasi-) Autonomous EU Administrative Actors to Public Account." European Law Journal 13, no. 4 (2007), 523 - 541.

Curtin, Deirdre. "Delegation to EU Non-majoritarian Agencies and Emerging Practices of Public Accountability." In Regulation through Agencies in the EU: A New Paradigm of European Governance, edited by Damien Geradin, Rudolphe Muňoz and Nicholas Petit, 87 - 117. Cheltham: Edward Elgar, 2005.

Curtin, Deirdre, and Dehousse, Renaud. "European Union Agencies: Tipping the Balance?” In The Agency Phenomenon in the European Union: Emergence, Institutionalisation and everyday Decision-making, edited Madalina Busuioc, Martijn Groenleer, and Jarle Trondal, 193-205. Manchester: Manchester University Press, 2012.

Curtin, Deirdre, and Egeberg, Morten. “Tradition and Innovation: Europe's Accumulated Executive Order.” West European Politics 31, no. 4 (2008): 639 - 661.

Curtin, Deirdre, Mair, Peter, and Papadopoulos, Yannis. "Positioning Accountability in European Governance: An Introduction.” West European Politics 33, no. 5 (2010): 929 - 945.

Curtin, Deirdre, and Senden, Linda. "Public Accountability of Transnational Private Regulation: Chimera or Reality?" Journal of Law and Society 38, no. 1 (2011): 163-188.

Curtin, Deirdre, and Wessel, Ramses, eds. Good Governance and the European Union: Reflections on Concepts, Institutions and Substance, vol. 49. Cambridge: Intersentia, 2005.

Cushman, Robert. The Independent Regulatory Commissions. New York: Oxford University Press, 1941.

Custos, Dominique. "The Rulemaking Power of Independent Regulatory Agencies." The American Journal of Comparative Law 54 (2006): 615 - 639.

Davies, Bleddyn. "Delegation and Accountability of Criminal Agencies after Lisbon: An Examination of Europol." In The Treaty of Lisbon and the Future of European Law and Policy, edited by Martin Trybus and Luca Rubini, 325 - 340. Cheltenham: Edward Elgar, 2012.

Davis, Kenneth C. “A New Approach to Delegation.” University of Chicago Law Review 36, no. 713 (1969): 729 735.

Dehousse, Renaud. "Delegation of powers in the European Union: The Need for a Multi-principals Model." West European Politics 31, no. 4 (2008): 789 - 8005.

Dehousse, Renaud. "Regulation by networks in the European Community: The Role of European Agencies." Journal of European Public Policy 4, no. 2 (1997): 246 - 261.

Dellinger, Walter. "Appendix: The Constitutional Separation of Powers Between the President and Congress." Law and Contemporary Problems 63, no. 1 (2000): 513 - 571.

Derthick, Martha, and Quirk, Paul. The Politics of Deregulation. Washington, DC: The Brookings Institution, 1985.

Devins, Neal. "Regulation of Government Agencies Through Limitation Riders." Duke Law Journal 36, no. 3 (1987): 456 - 500.

Dinan, Stephen. "GAO's report on waste suddenly a Hill must-read.” The Washington Times, March 15, 2011. http://www.washingtontimes.com/news/2011/mar/15/gaos-report-on-waste-suddenly-a-hill-must-read/?page=all (accessed January, 2012).

Dodd, Lawrence, and Oppenheimer, Bruce, eds. Congress Reconsidered. New York: Praeger Publishers, 1977.

Dyrberg, Peter. "Accountability and Legitimacy: What is the Contribution of Transparency?" In Accountability and Legitimacy in the European Union, edited by Antony Arnull and Daniel Wincott, 81 - 96. Oxford: Oxford University Press, 2002.

Egeberg, Morten, and Trondal, Jarle. "EU-level Agencies: New Executive Centre Formation or Vehicles for National Control?” Journal of European Public Policy 18, no. 6 (2011): 868 -887. 
Eising, Rainer, and Kohler-Koch, Beate. "Introduction: Network governance in the European Union." In The Transformation of Governance in the European Union, edited by Beate Kohler-Koch and Rainer Eising, 3 14. London: Routledge, 1999.

Epstein, Richard. "Why Parties and Powers Both Matter: A Separationist Response to Levinson and Pildes." Harvard Law Review Forum 119, no. 202 (2006): 210 - 219.

Epstein, David, and O'Halloran, Sharyn. Delegating Powers. Cambridge: Cambridge University Press, 1999.

EU Police Agency Cepol Criticised over Accounts. BBC, October 7, 2010, http://www.bbc.co.uk/news/worldeurope-11494209 (accessed October, 2010).

Everson, Michelle. “Independent Agencies: Hierarchy Beaters?” European Law Journal 1, no. 2 (1995): 180 - 204.

Everson, Michelle, Monda, Cosimo and Vos, Ellen eds. European Agencies in between Institutions and Member States. Alphen aan de Rijn: Wolters Kluwer, forthcoming 2014.

Fahrenthold, David. "In Congress, Sunset Clauses are Commonly Passed but Rarely Followed Through.” The Washington Post, December 15, 2012. http://articles.washingtonpost.com/2012-12-15/politics/35847138_1_expiration-dates-sunset-clauses-tax-cuts (accessed April, 2013).

Fahrenthold, David. “Congress Finds, and Lists, Meaning the Constitution.” The Washington Post, September 14, 2011. http://articles.washingtonpost.com/2011-09-16/politics/35273320_1_constitution-day-laserpointers-constitutional-authority-statement (accessed April, 2013).

Feld, Alan. “The Shrunken Power of the Purse.” Boston University Law Review 89, no. 2 (2009): 487 - 499.

Fisher, Louis. Defending Congress and the Constitution. Lawrence: University Press of Kansas, 2011.

Fisher, Louis. "The Unitary Executive and Inherent Executive Power." Journal of Constitutional Law 12, no. 2 (2010) $569-591$.

Fisher, Louis. Constitutional Conflicts between Congress and the President. Lawrence: University Press of Kansas, 2007.

Fisher, Louis. The Politics of Shared Power, Congress and the Executive, 4th ed. College Station, TX: Texas A\&M University Press, 1998.

Fisher, Louis. "The Legislative Veto: Invalidated, It survives." Law and Contemporary Problems 56, no. 4 (1993): $273-292$.

Fukuyama, Francis. "What is Governance?" Governance: An International Journal of Policy 26, no. 3 (2013): 347 368.

George, Stephen. and Bache, Ian. Politics of the European Union. Oxford: Oxford University Press, 2001.

Gerardin, Damien. "The Development of European Regulatory Agencies: What the EU Should Learn from American Experience." Columbia Journal of European Law 11, no. 1 (2005): 1-52.

Geradin, Damien, Muňoz, Rudolph, and Petit, Nicholas. Regulation through Agencies in the EU, A New Paradigm of European Governance. Cheltenham: Edward Elgar, 2005.

Griller, Stefan, and Orator, Andreas. "Everything Under Control? The "Way Forward" for European Agencies in the Footsteps of the Meroni Doctrine." European Law Review 35, no. 1 (2010): 3 - 35.

Griller, Stefan, and Orator, Andreas. "Meroni Revisited: Empowering European Agencies between Efficiency and Legitimacy.” Working Paper 04/D40, New Modes of Governance Project, 2006. http://www.eunewgov.org/database/DELIV/D04D40_WP_Meroni_Revisited.pdf (accessed January, 2014).

Grimm D. "The Achievement of Constitutionalism and its Prospects in a Changed World." In The Twilight of Constitutionalism?, edited by Petra Dobner and Martin Loughlin, 3 - 22. Oxford: Oxford University Press, 2010.

Groenleer, Martijn. The Autonomy of European Union Agencies: A Comparative Study of Institutional Development. Delft: Eburon, 2009.

Hamilton L. in: The committee print of "Congressional Oversight: A "How-to" Series of Workshops, sponsored by the Speaker and the Chairman, House Rules Committee, organized and conducted by the CRS, 1999.

Hamilton, Alexander. “The Federalist No. 70: The Executive Department Further Considered.” In: The Federalist Papers, edited by Charles Kessler, and Clinton Rossiter, 422-423. New York: Signet Classics, 2003. 
Hayes-Renshaw, Fiona. "The Council of Ministers." In The Institutions of the European Union, $2^{\text {nd }}$ ed., edited by John Peterson and Michael Shackleton, 60 - 80. Oxford: Oxford University Press, 2006.

Hayes-Renshaw, Fiona, and Wallace, Helen. The Council of Ministers, $2^{\text {nd }}$ ed. Hampshire, UK: Palgrave MacMillan, 2006.

Heringa, Aalt W., and Kiiver, Phillipp. Constitutions Compared: An Introduction to Comparative Constitutional Law. Cambridge: Intersentia, 2012.

Heringa, Aalt W., and Verhey, Luc. "Independent Agencies and Political Control." In Agencies in European and Comparative Law, edited by Luc Verhey and Tom Zwart, 155 - 170. Cambridge: Intersentia, 2003.

Hirschberg, D. Jeffrey, Pickholz, Marvin G., and Silbey, Franklin. Congressional Oversight Investigations. New York: Practicing Law Institute, 1984.

Hix, Simon, and Bjørn Høyland. The Political System of the European Union, $2^{\text {nd }}$ ed. Hampshire, UK: Palgrave Macmillan, 2005.

Hofmann, Herwig C.H., and Morini, Alessandro. "The Pluralisation of EU Executive-Constitutional Aspects of "Agencification". Working Paper Series 2012-01, University of Luxembourg Law, 2012. http://papers.ssrn.com/sol3/papers.cfm?abstract_id=2031499 (accessed January, 2014)

Hood, Christopher. “Accountability and Transparency: Siamese Twins, Matching Parts, Awkward Couple?” West European Politics 33, no. 5 (2010): 989 - 1009.

Jabco, N. "The Politics of Central Banking in the United States and in the European Union." Working Paper 19b/D04, New Modes of Governance Project, 2005. http://www.eu-newgov.org/database/DELIV/D19bD04_Politics_of_Central_Banking_US_and_EU.PDF (accessed January 2014).

Jacqué, Jean-Paul. “The Principle of Institutional Balance.” Common Market Law Review 41, no. (2004): 383 391.

Judge, David, and Earnshaw, David. The European Parliament, $2^{\text {nd }}$ ed. Hampshire, UK: Palgrave Macmillan, 2008.

Juncker J-C. "Preface." In Six Battles that Shaped Europe's Parliament, edited by Julian Priestley, vii - viii. London: John Harper Publishing, 2008.

Kaczorowska, Alina. European Union law, $3^{\text {rd }}$ ed. London: Routledge, 2013.

Kalt, Brian C. "Politics and the Federal Appointments Process." Harvard Law and Policy Review 5 (Online), Apr. 5, 2011. http://digitalcommons.law.msu.edu/cgi/viewcontent.cgi?article=1467\&context=facpubs (accessed January, 2014).

Kedzior D. in: The committee print of "Congressional Oversight: A "How-to" Series of Workshops, sponsored by the Speaker and the Chairman, House Rules Committee, organized and conducted by the CRS, 1999.

Keith R. in: The committee print of "Congressional Oversight: A "How-to" Series of Workshops, sponsored by the Speaker and the Chairman, House Rules Committee, organized and conducted by the CRS, 1999.

Kelemen, Daniel. “The Politics of 'Eurocratic' Structure and the New European Agencies." West European Politics 25, no. 4 (2002): 93 - 118.

Kelemen, Daniel, and Tarrant, Aandrew D. "The Political Foundations of the Eurocracy." West European Politics 34, no. 5 (2011): 922 - 947.

Kiewiet, D. Roderick, and McCubbins, Mathew. The Logic of Delegation: Congressional Parties and the Appropriations Process. Chicago: the University of Chicago Press, 1991.

Kochler-Koch, Beate, and Rittberger, Berthold. "Review Article: The 'Governance Turn'.” EU Studies Journal of Common Market Studies 44, no. Supplement s1, (2006): 27-49.

Koop, Christel. "Measuring and Explaining Accountability: A Comparative Study of Independent Agencies." PhD, diss. European University Institute, 2011.

Kovacic, William. "Competition Agencies, independence, and the political process." In Competition Policy and The Economic Approach, edited by Josef Drexl, Wolfgang Kerber, Rupprecht Podszun, 291 - 311. Cheltham: Edward Elgar Publishing, 2011.

Kovacic, William. "The Quality of Appointments and the Capability of the Federal Trade Commission." Administrative Law Review 49, no. 4 (1997): 915 - 961. 
Kovacic, William. “Congress and the Federal Trade Commission.” Antitrust Law Journal 57, no. 3 (1988): 869 908.

Kreher, Alexander. "Agencies in the European Community - a step towards administrative integration in Europe." Journal of European Public Policy 4, no. 2 (1997): 225 - 245.

LaPalombara, Joseph. Politics Within Nations. Englewood Cliffs, NJ: Prentice Hall, 1974.

Lauwaars, Richard H. “Auxiliary Organs and Agencies in the E.E.C.” Common Market Law Review 16, no. 3 (1979): 365 - 387.

Lavrijssen, Saskia, and Ottow, Annetje. "Independent Supervisory Authorities: A Fragile Concept." Legal Issues of Economic Integration 39, no. 4 (2012): 419-446.

Lenaerts, Koen, and Verhoeven, Amaryllis. "Institutional Balance as a Guarantee for Democracy in EU Governance." In Good Governance in Europe's Integrated Market, edited by Christian Joerges and Renaud Dehousse, 35 - 88. Oxford: Oxford University Press, 2002.

Levi-Faur, David. "Regulatory networks and regulatory Agencification: Towards a Single European Regulatory Space.” Journal of European Public Policy 18, no. 6 (2011): 810 - 829.

Levinson, Daryl, and Pildes, Richard. "Separation of Parties, not Powers" Harvard Law Review 119, no. 8 (2006): 2312 - 2386.

Lewis, David E., and Selin, Jennifer L. Sourcebook of United States Executive Agencies, Administrative Conference of the United States, $1^{\text {st }}$ ed. Administrative Conference of the United States, Office of the Chairman: Washington DC, 2012.

Lewis, Jeffrey. "National Interests: Committee of Permanent Representatives." In The Institutions of the European Union, $2^{\text {nd }}$ ed., edited by John Peterson and Michael Shackleton, 315 - 337. Oxford: Oxford University Press, 2006.

Lewis, Jeffrey. "Is the Council Becoming an Upper Chamber?" In With US or Against US? European Trends in American Perspective, Vol. 7, edited by Nicholas Jabco and Craig Parsons, 143 - 172. Oxford: Oxford University Press, 2005.

Lifland, William. "Sunset Review - Effective Oversight Tool or New Political Football?" Administrative Law Review 32, no. 2 (1980): 209-230.

Lindseth, Peter. "Democratic Legitimacy and the Administrative Character of Supranationalism: The Example of the European Community." Columbia Law Review 99, no. 3 (1999): 628 - 738.

Lindseth, Peter, Aman, Alfred, and Raul, Alan, eds. Administrative Law of the European Union: Oversight. Chicago: American Bar Association, 2008.

Locke, John. 1960 Second Treatise of Civil Government. Chapter X, Of the Extent of Legislative Power, Sect. 141, 1690. http://oregonstate.edu/instruct/phl302/texts/locke/locke2/locke2nd-c.html\#Sect.\%20141 (accessed February, 2012).

Lubbers, Jeffrey. “The Potential of Rulemaking by the NLRB." 5 Florida International Law University Law Review 5, no. 2 (2010): $411-436$.

Lubbers, Jeffrey. A Guide to Federal Agency Rulemaking. Chicago: American Bar Association, 2006.

Madison, James. "The Federalist No. 51: The Structure of the Government Must Furnish the Proper Checks and Balances Between the Different Departments." In: The Federalist Papers, edited by Charles Kessler, and Clinton Rossiter, 317 - 322. New York: Signet Classics, 2003.

Magill, Elizabeth. “Congressional Control over Agency Rulemaking: The Nutrition Labeling and Education Act's Hammer Provisions.” Food and Drug Law Journal 50 (1995): 149 - 190.

Magnette, Paul. "The Politics of Regulation in the European Union." In Regulation through Agencies in the EU: A New Paradigm of European Governance, edited by Damien Geradin, Rudolphe Muňoz and Nicholas Petit, 3 - 22. Cheltham: Edward Elgar, 2005.

Majone, Giandomenico. Europe as the Would-be World Power: The EU at Fifty. Cambridge: Cambridge University Press, 2009. 
Majone, Giandomenico, and Keleman, Daniel. "Managing Europeanization: The European Agencies." In The Institutions of the European Union, $2^{\text {nd }}$ ed., edited by John Peterson and Michael Shackleton, $219-240$. Oxford: Oxford University Press, 2006.

Majone, Giandomenico. Dilemmas of European Integration: The ambiguities and pitfalls of integration by stealth. Oxford: Oxford University Press, 2005.

Majone, Giandomenico. Regulating Europe. London: Routledge, 1996.

McCubbins, Mathew, and Schwartz, Thomas. "Congressional oversight overlooked: Police Patrols versus Fire Alarms.” American Journal of Political Science 28, no. 1, (1984): 165 - 179.

Mény, Yves. Building Parliament: 50 Years of European Parliamentary History, 1958-2008. Florence: European University Institute, 2009.

Meuwese, Anne, Schuurmans, Ymre, and Voermans, Wim. "Towards a European Administrative Procedure Act." Review of European Administrative Law 2, no. 2 (2009): 3-35.

Miller, Geoffrey. "Independent Agencies.” The Supreme Court Review 1986 (1986): 41-97.

Miller, Vaughne. "European Parliament Members' Expenses and Allowances." House of Commons Library SN/IA/5388, International Affairs and Defence, 2010. http://www.parliament.uk/briefingpapers/SN05388.pdf (accessed January, 2014).

Moe, Ronald. "United States." In Distributed Public Governance: Agencies, Authorities and Other Autonomous Bodies, OECD, 243 - 266. Paris: OECD, 2002.

Moe, Terry (a). An Assessment of the Positive Theory of Congressional Dominance, 12 Legislative Studies Quarterly 12, no. 4 (1987): 475-520.

Moe, Terry (b). "Interests, Institutions, and Positive Theory: The Politics of the NLRB." Studies in American Political Development 2 (1987): 236 - 299.

Morrison, Alan. "How Independent are Independent Regulatory Agencies?" Duke Law Journal 37, no. 2 (1988): $252-256$.

Mulgan, Richard. Holding Power to Account: Accountability in Modern Democracies. Hampshire, UK: Palgrave Macmillan, 2003.

Neunreither, Karlheinz. "Elected Legislators and their Unelected Assistants in the European Parliament." The Journal of Legislative Studies 8, no. 4 (2002), 40 - 60.

Oliver, Dawn. "Executive Accountability: A Key Concept." In Political Accountability and European Integration, edited by Luc Verhey, Phillipp Kiiver, and Sandor Loeffen, 9 - 32. Gronigen: Europa Law Publishing, 2009.

Orator, Andreas. "Empowering European agencies: Perspectives and limits of European democratic legitimacy.” In Perspectives and Limits of Democracy, edited by Harald Eberhard, Konrad Lachmayer, Gregor Ribarov, and Gerhard Thallinger C, 23-40. Baden-Baden: Nomos, 2007.

Papadopoulos, Yannis. “Accountability and Multi-level Governance: More Accountability, Less Democracy?” West European Politics 33, no. 5 (2010): 1030 - 1049.

Papadopoulos Yannis. "Problems of Democratic Accountability in Network and Multilevel Governance." European Law Journal 13, no. 4 (2007): 469 - 486.

Pelizzo, Riccardo, and Stapenhurst, Frederick. Parliamentary Oversight Tools: A Comparative analysis. London: Routledge, 2012.

Peters, Aulana. “Independent Agencies: Government’s Scourge or Salvation?” Duke Law Journal 27, no. 2 (1988): 286-299.

Pierce, Richard, Shapiro, Sidney, and Verkuil, Paul, eds. Administrative Law and Process, $5^{\text {th }}$ ed. New York: Foundation Press, 2009.

Pierce, Richard, Shapiro, Sidney, and Verkuil, Paul, eds. Administrative Law and Process, $3^{\text {rd }}$ ed. New York: Foundation Press, 1999.

Pollack, Mark. The Engines of European Integration: Delegation, Agency, and Agenda Setting in the EU. Oxford: Oxford University Press, 2003. 
Pray, Jonathan. "Congressional Reporting Requirements: Testing the Limits of the Oversight Power." University of Colorado Law Review 76, no. 1 (2005): 297 - 326.

Priestley, Julian. Six Battles that Shaped Europe's Parliament. London: John Harper Publishing, 2008.

Puntscher Riekmann, Sonja. "In Search of Lost Norms: Is Accountability the solution to the legitimacy problems of the European Union?" Working Paper No. 21, EIF 2005. http://eif.univie.ac.at/downloads/workingpapers/wp21.pdf (accessed January, 2014).

Roberts, John. “Are Congressional Committees Constitutional?: Radical Textualism, Separation of Powers, and the Enactment Process" Case Western Reserve Law Review 52, no. 2 (2001): 489 - 572.

Saurer, Johannes. "Supranational Governance and Networked Accountability Structures: Member States Oversight of EU Agencies." In Comparative Administrative Law, edited by Susan Rose-Ackerman and Peter Lindseth, 618-631. Cheltenham, MA: Edward Elgar, 2010.

Scharpf, Fritz. Governing in Europe: Effective and Democratic? Oxford: Oxford University Press, 1999.

Scher, Seymour. "Congressional Committee Members as Independent Agency Overseers: A Case Study." The American Political Science Review 54 , no. 4 (1960): 911-920.

Schillemans, Thomas. "Does Horizontal Accountability Work? Evaluating Potential Remedies for the Accountability Deficit of Agencies." Administration and Society 43, no. 4 (2011): 387 - 416.

Schillemans, Thomas. "Redundant Accountability: The Joint Impact of Horizontal and Vertical Accountability on Autonomous Agencies.” Public Administration Quarterly 34, no. 3 (2010): 300 - 337.

Schneider, Jens-Peter. "A Common Framework for Decentralized EU Agencies and the Meroni Doctrine." Administrative Law Review 61 (2009): 29 - 45.

Schoenbrod, David. Power Without Responsibility. New Haven: Yale University Press, 1993.

Schoenbrod, David. “The Delegation Doctrine: Could the Court Give It Substance?” Michigan Law Review 83, no. 5 (1985): 1223 - 1290 .

Scholten, Miroslava. “Accountability vs. Independence: Proving the Negative Correlation.” Maastricht Journal of European and Comparative Law, forthcoming in 2014.

Scholten, Miroslava. “The Newly Released 'Common Approach' on EU Agencies: Going Forward or Standing Still?” Columbia Journal of European Law 19, no. 1 (2012). http://www.cjel.net/wp-content/uploads/2013/02/Scholten-edited-and-rev1.pdf (accessed April, 2013).

Scholten, Miroslava. "Independent, hence unaccountable? The need for a broader debate on accountability of the executive." Review of European Administrative Law 4, no. 1 (2011): 5-44.

Scholten, Miroslava. "What if the European Parliament Says 'No'?: The Strength of European Parliament's Discharge Power.” Working Paper Series, November 2010. http://papers.ssrn.com/sol3/papers.cfm?abstract_id=1909450 (accessed April, 2013).

Self, Peter. Administrative Theories and Politics. London: Allen and Unwin, 1972.

Shackleton, Michael. "The European Parliament." In The Institutions of the European Union, $2^{\text {nd }}$ ed., edited by John Peterson and Michael Shackleton, 104-124. Oxford: Oxford University Press, 2006.

Shackleton, Michael. "Parliamentary Government or Division of Powers: Is the Destination Still Unknown?" In With US or Against US? European Trends in American Perspective, Vol. 7, edited by Nicholas Jabco and Craig Parsons, 123-142. Oxford University Press, 2005.

Shackleton, Michael. “The European Parliament's New Committees of Inquiry: Tiger or Paper Tiger?” 36 Journal of Common Market Studies 36, no. 1 (1998): 115 - 130.

Shapiro, Martin. “The Emergence of Global Administrative Law: "Deliberative," "Independent” Technocracy v. Democratic Politics: Will the Globe Echo the EU?” Law and Contemporary Problems 68 (2005): 341-356.

Shapiro, Martin. "Independent Agencies: US and EU.” Jean Monnet Chair Papers 34 (1996).

Shapiro, Martin. "The Giving Reasons Requirement” University of Chicago Legal Forum 1992 (1992): 179-221.

Shepherd, George. Fierce Compromise: The Administrative Procedure Act Emerges from New Deal Politics, Northwestern University Law Review 90, no. 4 (1996): 1557 - 1683.

Shepherd, William. The Economics of Industrial Organization. Englewood: Prentice-Hall, 1979. 
Smith, Bruce. "Accountability and Independence in the Contract State." In The Dilemma of Accountability in Modern Government: Independence versus Control, edited by Bruce Smith and Douglas Hague, 3- 69. London: Macmillan, 1971.

Smith, Lincoln. "Recent Trends in the Appointment of Commissioners." Ohio State Law Journal 13, (1952): 479 -502 .

Stewart, Richard B. "The Reformation of American Administrative Law." Harvard Law Review 88, no. 8 (1975): $1669-1813$.

Stith K. "Rewriting the Fiscal Constitution: The Case of Gramm-Rudman-Hollings." California Law Review 76, no. 3 (1988): 593 - 668.

Stolberg, Sheryl. "And in This Corner, Fed Choice is Blip on Some Senators' Radar." New York Times, January, 31, 2006. http://www.nytimes.com/2006/01/31/business/31bernanke.html?pagewanted=1\&_r=1 (accessed January, 2012)

Strauss, Peter. "Overseer, or “The Decider?” The President in Administrative Law.” The George Washington Law Review 75, no. 4 (2007): 696 - 760.

Strauss, Peter. Administrative Justice in the United States. Durham, NC: Carolina Academic Press, 2002.

Strauss, Peter. "The Place of Agencies in Government: Separation of Powers and the Fourth Branch." Columbia Law Journal 84, no. 3 (1984): 573 - 669.

Strøm, Kaare. "Parliamentary Democracy and Delegation." In Delegation and Accountability in Parliamentary Democracies, edited by Kaare Strøm, Wolfgang Müller, and Torbjörn Bergman, 55-220. Oxford: Oxford University Press, 2006.

Sullivan, Andy. "House bans some earmarks amid ethics concerns" Reuters, 10 March 2010. http://www.reuters.com/article/2010/03/11/us-usa-congress-earmarks-idUSTRE62959V20100311 (accessed January, 2014).

Swire, Peter. "Incorporation of Independent Agencies into the Executive Branch." Yale Law Journal 94, no. 7 (1985): 1766- 1986.

Syrier, Christian. The Investigative Function of the European Parliament: Holding the EU executive to account by conducting investigations. Nijmegen: Wolf Legal Publishers, 2013.

Tallberg, Jonas. "Executive Power and Accountability in the European Union.” In The Illusion of Accountability in the European Union, edited by Sverkerk Gustavsson, Christer Karlsson, and Thomas Persson, 111-125.New York: Routledge, 2009.

Tallberg, Jonas. "Delegation to Supranational Institutions: Why, How, and with What Consequences?” West European Policy 25, no. 1 (2002): 23-46.

Thatcher, Mark, and Coen, David. "Reshaping European Regulatory Space: An Evolutionary Analysis." West European Politics 31, no. 4 (2008): 806-836.

Thatcher, Mark, and Stone Sweet, Alec. “Theory and Practice of Delegation to Non-Majoritarian Institutions.” In The Politics of Delegation, edited by Mark Thatcher, and Alec Stone Sweet, 1-19. London: Frank Cass, 2003.

Toggenburg, Gabriel. "The EU Fundamental Rights Agency: Satellite or Guiding Star? Raison d'être, tasks and challenges of the EU's new agency." SWP Comments 5, German Institute of International and Security Affairs, 2007. http://www.swp-berlin.org/fileadmin/contents/products/comments/2007C05_07_toggenburg_ks.pdf (accessed January, 2014).

van Gerven, Walter. 'Which form of accountable government for the European Union?' Netherlands Yearbook of International Law, Vol. 36 (2005): 227 - 258.

van Ooik, Ronald. "The Growing Importance of Agencies in the EU: Shifting Governance and the Institutional Balance." In Good Governance and the European Union: Reflections on Concepts, Institutions and Substance, vol. 49, edited by Deirdre Curtin, and Ramses Wessel, 125 -152. Cambridge: Intersentia, 2005.

Veerman, Gert-Jan, and Mulder, Robin. Wetgeving met Beleid. Den Haag: Boom Juridische uitgevers, 2010.

Verhey, Luc. "Political Accountability: A Useful Concept in EU Inter-Institutional Relations?” In Political Accountability and European Integration, edited by Luc Verhey, Phillipp Kiiver, and Sandor Loeffen, 55-70. Groningen: Europa Law Publishing, 2009. 
Verhey, Luc. "Good Governance: Lessons from Constitutional Law." In Good Governance and the European Union: Reflections on Concepts, Institutions and Substance, vol. 49, edited by Deirdre Curtin, and Ramses Wessel, 49-68. Cambridge: Intersentia, 2005.

Verhey, Luc, and Claes, Monica. "Introduction: Political Accountability in a European Perspective." In Political Accountability in Europe: Which Way Forward?: A Traditional Concept of Parliamentary Democracy in an EU Context, edited by Luc Verhey, Hansko Broeksteeg and Ilse van den Driessche, 3-26. Groningen: Europa Law Publishing, 2008.

Verhey, Luc, Claes, Monica, and Broeksteeg, Hansko. "Political Accountability in the European Union: Conceptual Analysis and Future Prospects." In Political Accountability in Europe: Which Way Forward?: A Traditional Concept of Parliamentary Democracy in an EU Context, edited by Luc Verhey, Hansko Broeksteeg and Ilse van den Driessche, 301- 335. Groningen: Europa Law Publishing, 2008.

Verhoeven, Amaryllis. "Democratic Life in the European Union, According to its Constitution.” In: Curtin D. and Wessel R. (eds.) Good Governance and the European Union: Reflections on Concepts, Institutions and Substance, vol. 49, edited by Deirdre Curtin, and Ramses Wessel, 153-174. Cambridge: Intersentia, 2005.

Verkuil, Paul. "The Purposes and Limits of Independent Agencies.” Duke Law Journal 37, no. 2 (1988): 257 279.

Vos, Ellen. "European Agencies and the Composite EU Executive." In European Agencies in between Institutions and Member States, edited by Michelle Everson, Cosimo Monda, and Ellen Vos, 11-48. Alphen aan de Rijn: Wolters Kluwer, forthcoming 2014.

Vos, Ellen. "Independence, Accountability and Transparency of European Regulatory Agencies." In Regulation through Agencies in the EU: A New Paradigm of European Governance, edited by Damien Geradin, Rudolphe Muňoz, and Nicholas Petit, 120-140. Cheltham: Edward Elgar, 2005.

Vos, Ellen. "Agencies and the European Union." In Agencies in European and Comparative Law, edited by Luc Verhey and Tom Zwart, 113-148. Cambridge: Intersentia, 2003.

Vos, Ellen. "Reforming the European Commission: What Role to Play for the EU Agencies?" Common Market Law Review 37, no. 5 (2000): 1113-1134.

Walker D. in: The committee print of "Congressional Oversight: A "How-to" Series of Workshops, sponsored by the Speaker and the Chairman, House Rules Committee, organized and conducted by the CRS, 1999.

Wallace, Helen. "The Institutional Setting: Five Variations on a Theme." In Policy making in the European Union, 4th ed., edited by Helen Wallace and William Wallace, 3-37. Oxford: Oxford University Press, 2000.

Weale, Albert. "New Modes of Governance, Political Accountability and Public Reason" Government and Opposition 46, no. 1 (2011): 58-80.

Weiler, Joseph. The Constitution of Europe: Does the New Clothes have an Emperor? And Other Essays on European Integration. Cambridge: Cambridge University Press, 1999.

Weiler, Joseph. "Does Europe Need a Constitution? Demos, Telos and the German Maastricht Decision.” European Law Journal 1, no. (1995): 219-258.

Weingast, Barry, and Moran, Mark. "Bureaucratic Discretion or Congressional Control? Regulatory Policymaking by the Federal Trade Commission.” Journal of Political Economy 91, no. 5 (1983): 765-800.

Welborn, David. Governance of Federal Regulatory Agencies. Knoxville, TN: The University of Tennessee Press, 1977.

Westlake, Martin, and Galloway, David. The Council of the European Union, $3^{\text {rd }}$ ed. London: John Harper Publishing, 2004.

Wiley, Richard. “'Political' Influence at the FCC.” Duke Law Journal 37, no. 2 (1988): 280-285.

Williams R. "Regulations: What can go Wrong.” Working Paper No. 09-18, Mercantus Center, George Mason University, 2009.

Wilson, James. Bureaucracy: What Government Agencies Do and Why They Do It. New York: Basic Books, 1989.

Wilson, Woodrow. Constitutional Government in the United States. New York: Columbia University Press, 1908.

Wilson, Woodrow. Congressional government: A Study in American Politics. Boston: The Riverside Press, 1885. 
Wolfensberger D. in: The committee print of "Congressional Oversight: A "How-to" Series of Workshops, sponsored by the Speaker and the Chairman, House Rules Committee, organized and conducted by the CRS, 1999.

Yataganas, Xénophon. "Delegation of Regulatory Authority in the European Union: The Relevance of the American Model of Independent Agencies." Jean Monnet Working Papers 03/01 (2001). https://infoeuropa.eurocid.pt/files/database/000036001-000037000/000036463.pdf (accessed January, 2014).

Yesilkagit, Kutsal, and van Thiel, Sandra. "Political Influence and Bureaucratic Autonomy." Public Organization Review 8, no. 2 (2008): 137-153.

Zinzani, Marco. Market Integration through 'Network Governance': The Role of European Agencies and Networks of Regulators. Cambridge: Intersentia, 2012.

Zwart, Tom, and Verhey, Luc, eds. Agencies in European and Comparative Perspective. Cambridge: Intersentia, 2003.

Zwart, Tom. "Independent Regulatory Agencies in the US." In Agencies in European and Comparative Law, edited by Luc Verhey and Tom Zwart, 3-18. Cambridge: Intersentia, 2003.

Zweigert, Konrad. and Kötz H. Introduction to Comparative Law, 3rd ed. Oxford: Clarendon Press, 1998. 


\section{B. Table of Cases}

For the EU (sorted according to the year of the judgment):

Case 9-56,.Meroni \& Co., Industrie Metallurgiche, S.p.A v High Authority of the European Coal and Steel Community, 1956.

Case 138/79, SA Roquette Frères v Council of the European Communities Judgment of the Court of 29 October 1980, Isoglucose.

Case C-70/88, European Parliament v Council of the European Communities, 1990, ECR I-2041, Chernobyl.

Joined Cases C-154/04 and C-155/04, the Queen, on the application of Alliance for Natural Health and Others v Secretary of State for Health and National Assembly for Wales, 2005.

Case C-301/02, P Carmine Salvatore Tralli v ECB, 2005, ECR I-4071.

Case C-217/04, United Kingdom of Great Britain and Northern Ireland v European Parliament and Council of the European Union, 2006.

Case C-270/12 Action brought on 1 June 2012 - United Kingdom of Great Britain and Northern Ireland v Council of the European Union, European Parliament.

\section{For the US (sorted alphabetically):}

Barenblatt v. U.S. 360 U.S. 109, 79 S.Ct. 1081 U.S. 1959.

Bowsher v. Synar 478 U.S. 714, 106 S.Ct. 3181 U.S.Dist.Col.,1986.

Buckley v. Valeo 424 U.S. 1, 96 S.Ct. 612 U.S.Dist.Col. 1976

Canning v. NLRB 705 F.3d 490 C.A.D.C.,2013.

Eastland v. U.S. Servicemen's Fund 421 U.S. 491, 95 S.Ct. 1813 U.S.Dist.Col. 1975

Free Enterprise Fund v. Public Company Accounting Oversight Board 130 S.Ct. 3138 U.S.,2010

J. W. Hampton, Jr., \& Co. v. U.S. 276 U.S. 394, 48 S.Ct. 348 (Mem) U.S., 1928

Heart of Atlanta Motel Inc. v. 379 U.S. 241, 85 S.Ct. 348 U.S.Ga. 1964.

Humphrey's Executor v. U.S. 295 U.S. 602, 55 S.Ct. 869 U.S. 1935.

INS v. Chadha 462 U.S. 919, 103 S.Ct. 2764 U.S.,1983.

Kilbourn v. Thompson 103 U.S. 168, 1880 WL 18803 U.S.,1880

Lincoln v. Vigil 508 U.S. 182, 113 S.Ct. 2024 U.S.N.M.,1993.

Marshall Field \& Co. v. Clark 143 U.S. 649, 12 S.Ct. 495 U.S. 1892

McCulloch v. Maryland 17 U.S. 316, 1819 WL 2135 U.S.,1819

McGrain v. Daugherty 273 U.S. 135, 47 S.Ct. 319 U.S., 1927.

Metropolitan Washington Airports Authority v. Citizens for Abatement of Aircraft Noise, Inc. 501 U.S. 252, 111 S.Ct. 2298 U.S.Dist.Col.,1991

Minnesota Chippewa Tribe v. Carlucci 358 F.Supp. 973 D.C.D.C., 1973

Mistretta v. United States 488 U.S. 361, 109 S.Ct. 647 U.S.Mo.,1989.

Morrison v. Olson 487 U.S. 654, 108 S.Ct. 2597 U.S.Dist.Col.,1988

Myers v. U.S. 272 U.S. 52, 47 S.Ct. 21 U.S., 1926

Panama Refining Co. v. Ryan 293 U.S. 388, 55 S.Ct. 241 U.S. 1935

Schechter Poultry Corporation v. U.S. 295 U.S. 495, 55 S.Ct. 837 U.S. 1935.

South Dakota v. Dole 483 U.S. 203, 107 S.Ct. 2793 U.S.S.D.,1987

Train v. City of New York 420 U.S. 35, 95 S.Ct. 839 U.S.Dist.Col. 1975.

U.S. v. Ferreira 54 U.S. 40, 1851 WL 6673 U.S., 1851

Watkins v. U.S. 354 U.S. 178, 77 S.Ct. 1173 U.S. 1957.

Wayman v. Southard 23 U.S. 1, 1825 WL 3149 U.S., 1825

Whitman v. American Trucking Associations 531 U.S. 457, 121 S.Ct. 903 U.S.,2001

Wiener v. U.S. 357 U.S. 349, 78 S.Ct. 1275 U.S. 1958.

Youngstown Sheet \& Tube Co. v. Sawyer 343 U.S. 579, 72 S.Ct. 863 U.S. 1952 


\section{Reports and Other Official Documents}

Administrative Conference of the United States. Guide for members. 2011.

Analytical Fiches. Interinstitutional Working Group on EU Agencies. http://europa.eu/agencies/regulatory_agencies_bodies/index_en.htm (accessed April 2013).

Centraal Bureau voor de Statistiek. Verdeling belastingopbrengsten (visualisatie). http://www.cbs.nl/nlNL/menu/themas/overheid-politiek/cijfers/extra/belasting-animatie.htm (accessed February, 2010).

Committee on Budgetary Control. Directorate for Budgetary Affairs DG for Internal Policies of the Union. Handbook 2009 for new members of the Committee on Budgetary Control. DV1785742EN.Doc. 2009.

Congressional Research Service Report Congressional Staff: Duties and Functions. By John S. Pontius, and Faye M. Bullock. Report RL30807. 2003.

Congressional Research Service. Committee Controls of Agency Decisions. By Louis Fisher. Report RL33151. 2005.

Congressional Research Service. Committee Types and Roles. By Valerie Heitshusen. Report 98-241. 2011.

Congressional Research Service. Congressional Oversight Manual. By Frederick M. Oleszek, Walter Kaiser, Todd Tatelman. Report RL30240. 2011.

Congressional Research Service. Congressional Research Service of the Library of Congress for Fiscal Year 2012. Annual Report, 2013 edition.

Congressional Research Service. Congressional Research Service of the Library of Congress for Fiscal Year 2010. Annual Report, 2011 edition.

Congressional Research Service. Congressional Salaries and Allowances. By Ida Brudnick. Report RL30064. 2014.

Congressional Research Service. House of Representatives and Senate Staff Levels in Member, Committee, Leadership, and Other Offices, 1977-2010. By Eric Petersen, Parker Reynolds, and Amber H. Wilhelm. Report. R41366. 2010.

Congressional Research Service. Legislative Vetoes After Chadha. By Louis Fisher. Report RS22132. 2005.

Congressional Research Service. Recess Appointments: Frequently Asked Questions. By Henry Hogue. Report RS21308. 2013.

Congressional Research Service. REINS Act: Number and Types of "Major Rules" in Recent Years. By Copeland, Curtis, and Carey Maeve P. Report R41651. 2011.

Congressional Research Service. The Congressional Appropriations Process: An Introduction. By Sandy Streeter. Report 97-684. 2008.

Dietrich-Schulz, Elisabeth. Parliamentary Library, research and archive services of Europe: description of the Parliamentary Library, Research and Archive Services of Europe + Israel, the United States of America, Council of Europe, European Parliament and Assembly of the WEU. Vienna, Austria 2008.

Eurobarometer 'The euro area, 2010. Public attitudes and perceptions. Summary', Report \#306 December 2010.

European Commission. 'European Police College: no budget discharge, funding for 2011 partly frozen'. [press release]: 7 October 2010.

European Commission. "Draft General Budget of the European Commission for the Financial Year 2012."

Working Document part III COM (2011) 300 - May 2011, Bodies set up by the European Union and having Legal Personality.

European Commission. Breakthrough as EU Institutions Agree Common Approach on Agencies. [press release] 13 June 2012.

European Commission. EU Budget 2007: Financial Report. 2008.

European Commission. European Union Public Finance 2008, $4^{\text {th }}$ ed.

European Commission. Meta-study on the decentralized agencies: cross-cutting analysis of the evaluation findings. Final Report 2008.

European Commission. Public Opinion in the European Union, Standard Eurobarometer 77, First Results, Spring 2012. July 2012. 
European Parliament, Checks and balances of soft rule-making in the EU, Study for the European Parliament, by

Linda Senden and Ton van den Brink, PE 462.433. March 2012.

European Parliament, the Council of the EU and the European Commission. Decentralised Agencies (annexed the

Common Approach). June 182012.

European Parliament. Investiture Procedure of the 2004-2009 Commission - Hearings of the Commissioners Designate. European Parliament. Parliamentary Debate '2008 Discharge', Wednesday, 21 April 2010. 2009/2077(DEC). Strasbourg.

European Parliament. Report of 26 March 2003 on the initiative by the Kingdom of Denmark with a view to adopting a Council Act amending the Council Act of 3 November 1998 adopting Rules on the confidentiality of Europol information (13875/2002 - C5-0553/2002 - 2002/0823(CNS)).

European Parliament. Report on a strategy for the future settlement of the institutional aspects of Regulatory Agencies (2008/2103(INI)), Opinion of European Parliament's Committee of Budgets. July 162008.

European Parliament. Report on the proposal for a regulation of the European Parliament and of the Council amending Regulation (EEC) No 302/93 on the establishment of a European Monitoring Centre for Drugs and Drug Addiction as regards the Director's term of office (COM(2005) 0190 - C6-0145/2005 - 2005/0076(COD)). November 28, 2005.

European Parliament's Committee on Budgetary Control. Budgetary Support Unit. Agencies' Discharge. By Fabia Jones. Brussels: Belgium. Directory General Internal Policies of the Union, 2006.

European Parliament's Committee on Budgetary Control. Policy Department on Budgetary Affairs. Best practice in governance of agencies - A comparative study in view of identifying best practice for governing agencies carrying out activities on behalf of the European Union. By Werner Jann, Tobias Bach, Julia Fleischer, Thurid Hustedt. ATR 02L 072. Potsdam: Germany. Directory General Internal Policies of the Union, 2008.

European Parliament's Committee on Budgets and Budgetary Control. Policy Department on Budgetary Affairs. Opportunities and feasibility of establishing common support services for EU agencies. Report PE 411.2642009.

European Parliament's Committee on Budgets. Budgetary Support Unit. Agencies: Origin of Tasks, Local Conditions and Staffing. By Fabia Jones. ATR 03 L 006. Brussels: Belgium. Directory General Internal Policies of the Union, 2007.

European Parliament's Committee on Budgets. Policy Department on Budgetary Affairs. Agencies' buildings. By Fabia Jones. ATR 02K067. Brussels: Belgium. Directory General Internal Policies of the Union, 2009.

European Parliament's Directorate for Information. Hearing of the nominee to be the first Director of the European Food Safety Authority (EFSA). 17 October 2002.

Geslain-Laneelle, Catherine. Questionnaire. February 20, 2006.

Haug, Jutta. Policy Department on Budgetary Affairs. Budgetary implementation of EU agencies: the use of EC appropriations by agencies and the assigned revenue instrument. By François Javelle. ATR 2K 066. Brussels: Belgium. Directory General Internal Policies of the Union, 2008.

House of Commons European Scrutiny Committee, Article 308 of the EC Treaty, Twenty-ninth Report of Session 2006-07, 4 July 2007.

Interinstitutional Agreement of 1995 codified in Annex IX of the Rules of Procedure governing the setting-up of committees of inquiry.

Kovacic, William. The Federal Trade Commission at 100: Into Our $2^{\text {nd }}$ Century: The Continuing Pursuit of Better Practices. Report. January 2009.

Motion for a Resolution 'Further to Question for Oral Answer O-93/05 pursuant to Rule 108(5) of the Rules of Procedure By Jo Leinen and Janusz Lewandowski. winding up the debate on the question for oral answer to the Council on the draft interinstitutional agreement presented by the Commission on the operating framework for the European regulatory agencies'. November 24, 2005.

National Commission on the Causes of the Financial and Economic Crisis in the United States. Financial Crisis Inquiry Commission pursuant to Public Law 111-21. Financial Crisis Inquiry Report. 2011.

Office of Management and Budget. American Conference of United States. Fiscal Year 2013 Budget Justification. 2012. 
Organization of the Congress. Joint Committee on the Organization of Congress. Final Report December, 1993.

Ramboll Management-Eureval-Matrix. The Ramboll evaluation: evaluation of 26 decentralised agencies. Final Report Vol. III. 30-CE-0230814/00-05. December 2009.

Report on the crisis of the Equitable Life Assurance Society (2007), the Equitable Life Committee of the European Parliament (A6-0203/2007 4). June 4, 2007.

Securities and Exchange Commission. General Accountability Office. Performance and Accountability report of Fiscal Year 2011.

Securities and Exchange Commission. In Brief: Fiscal Year 2012 Congressional Justification. 2011.

Securities and Exchange Commission. In Brief: Fiscal Year 2013 Congressional Justification. 2012.

Task Force Report on Regulatory Commissions, Appendix N of the Hoover Commission report, United States Commission on Organization of the Executive Branch of the Government, Washington, 25, DC, 1949. In The Independent Federal Regulatory Agencies, The Reference Shelf, Vol. 31, No. 2, edited by Leon Salomon, 19-25. Ipswich, MA: The H.W. Wilson Company, 1959.

The committee print of "Congressional Oversight: A "How-to" Series of Workshops, sponsored by the Speaker and the Chairman, House Rules Committee, organized and conducted by the CRS, 1999.

The European Court of Auditors. The European Union's Agencies: Getting Results. Special Report No 5, 2008.

The Testimony of Stephen J. Crimmins before the House of Representatives Committee on Government Oversight and Reform, Subcommittee on Government Organization, Efficiency and Financial Management and Subcommittee on TARP and Financial Services Joint Hearing "Financial Management, Work Force and Operation at the SEC: Who's Watching Wall Street's Watchdog?. March 10, 2011.

Transport Committee. House of Commons. The work of the Civil Aviation Authority: Government Response to the Committee's Thirteenth Report of Session 2005-06. Fifth Special Report of Session 2006-07, 2007.

US Congress. House of Representatives. Committee on Government Reform. Does Congress Delegate Too Much Power to Agencies and What Should be Done about It?: Hearing Before the Subcommittee on National Economic Growth, Natural Resources, and Regulatory Affairs. 106 ${ }^{\text {th }}$ Congress, $2^{\text {nd }}$ session, June 14, 2000. 



\section{APPENDIX 1 \\ The Political Accountability Arrangements of $35 \mathrm{EU}$ Agencies}

Appendix 1 offers a detailed overview of relevant accountability arrangements from the founding acts of $35 \mathrm{EU}$ agencies, listed in the order of the official web-page of EU agencies:

1. Agency for the Cooperation of Energy Regulators (ACER)

2. Body of European Regulators for Electronic Communications (BEREC), the Office

3. Community Plant Variety Office (CPVO)

4. European Agency for Safety and Health at Work (EU-OSHA)

5. European Agency for the Management of Operational Cooperation at the External Borders (Frontex)

6. European Agency for the operational management of large-scale IT systems in the area of freedom, security and justice (IT Agency)

7. European Asylum Support Office (EASO)

8. European Aviation Safety Agency (EASA)

9. European Banking Authority (EBA)

10. European Centre for Disease Prevention and Control (ECDC)

11. European Centre for the Development of Vocational Training (Cedefop)

12. European Chemicals Agency (ECHA)

13. European Environment Agency (EEA)

14. European Fisheries Control Agency (EFCA)

15. European Food Safety Authority (EFSA)

16. European Foundation for the Improvement of Living and Working Conditions (Eurofound)

17. European GNSS Agency (GSA)

18. European Institute for Gender Equality (EIGE)

19. European Insurance and Occupational Pensions Authority (EIOPA)

20. European Maritime Safety Agency (EMSA)

21. European Medicines Agency (EMA)

22. European Monitoring Centre for Drugs and Drug Addiction (EMCDDA)

23. European Network and Information Security Agency (ENISA)

24. European Police College (Cepol)

25. European Police Office (Europol)

26. European Railway Agency (ERA) 
27. European Securities and Markets Authority (ESMA)

28. European Training Foundation (ETF)

29. European Union Agency for Fundamental Rights (FRA)

30. Office for Harmonization in the Internal Market (OHIM)

31. The European Union's Judicial Cooperation Unit (Eurojust)

32. Translation Centre for the Bodies of the European Union (CdT)

33. European Defence Agency (EDA)

34. European Union Institute for Security Studies (EUISS)

35. European Union Satellite Centre (EUSC).

The Table below is divided into six columns.

The first column gives the name of the agency, including its official abbreviation and founding act, specifies the legislative involvement of the European Parliament (if any), and mentions the type of the agency from the functional perspective, where possible using the following classification: information-gathering, service-providing, cooperation-providing, advisory, or decision-making in accordance the Ramboll evaluation of 26 decentralized agencies.

The second column presents the appointment and removal conditions and compositions of agencies' top level officials, such as management/ administrative boards/councils' members and (executive) directors/presidents. It also briefly mentions other possible organs that the founding act may establish.

The third column highlights the presence of hearings obligations in agencies' founding acts. For the sake of giving a succinct overview of all possible formulations of such provisions, this columns distinguishes between three types of hearings: (1) an appointment hearing when there is a formal provision that an agency's director can be invited to make a statement and to answer to the questions of MEPs upon his or her appointment; (2) an extension of the term hearing when there is a formal provision that an agency's director can be invited to make a statement and to answer to the questions of MEPs upon the extension of his or her term of office; and (3) a performance hearing when there is a formal provision that an agency's director can be invited to or is obliged to report about his or her duties or on any subject concerning the agency's operation before the European Parliament and/or the Council.

The fourth column specifies types of reports that agencies are obliged to send to the Council and the European Parliament and the presence, if any, of an evaluation and/or review clause in agencies' founding acts.

The fifth column shows the 2010 budget of each agency and indicates the source of financial means. In a few cases, it specifies other resources than the EU budget, if the difference between the other resources and the received contribution from the EU budget is significant. 
The sixth column shows whether an agency's founding act mentions that an agency is independent or autonomous (keeping the terms of agencies' founding acts) and what is implied by that. It uses the established terms such as personal and financial independence or autonomy, the terms that are not necessarily used in founding acts but which help to make the column short and facilitate comparative overview. 


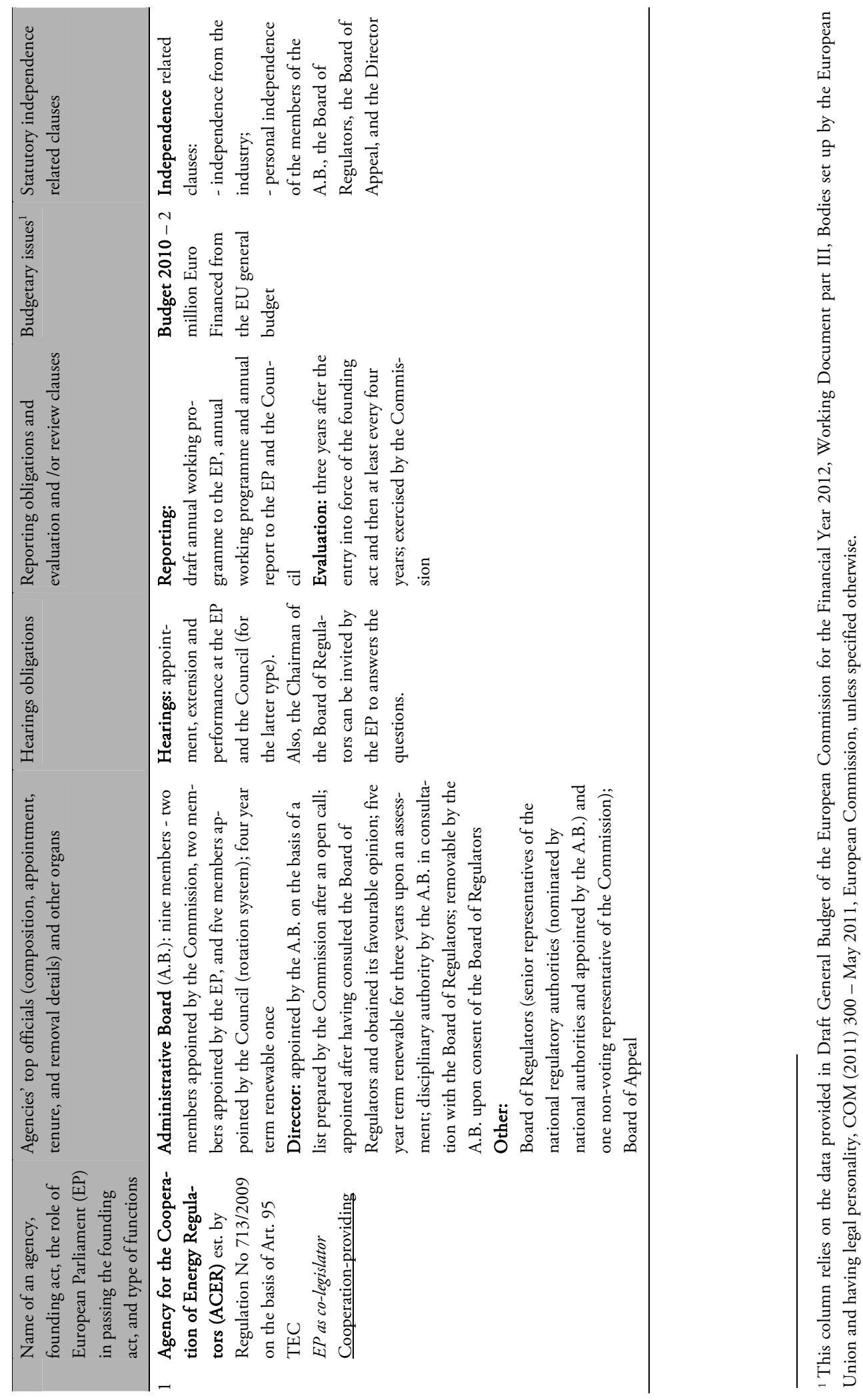




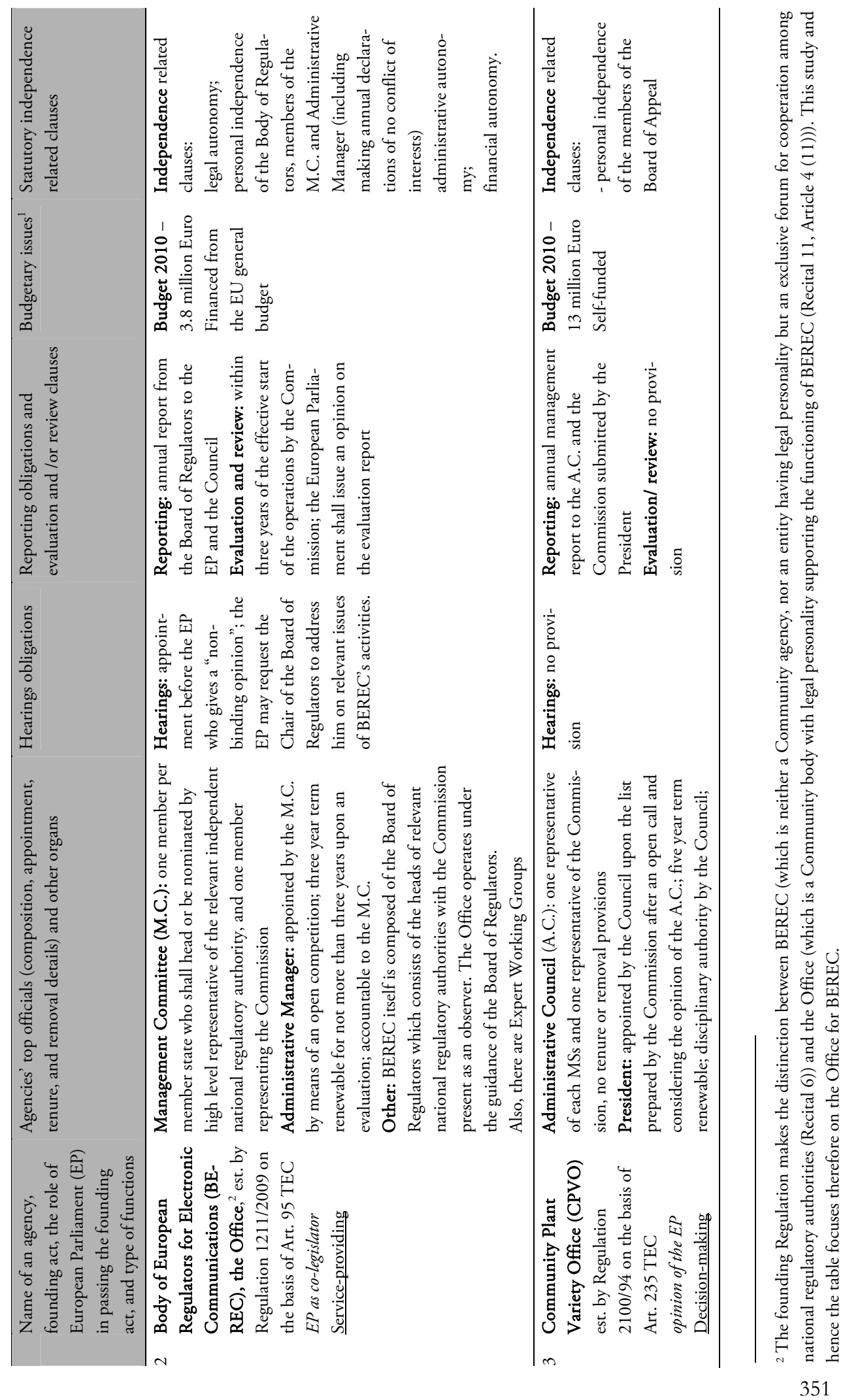




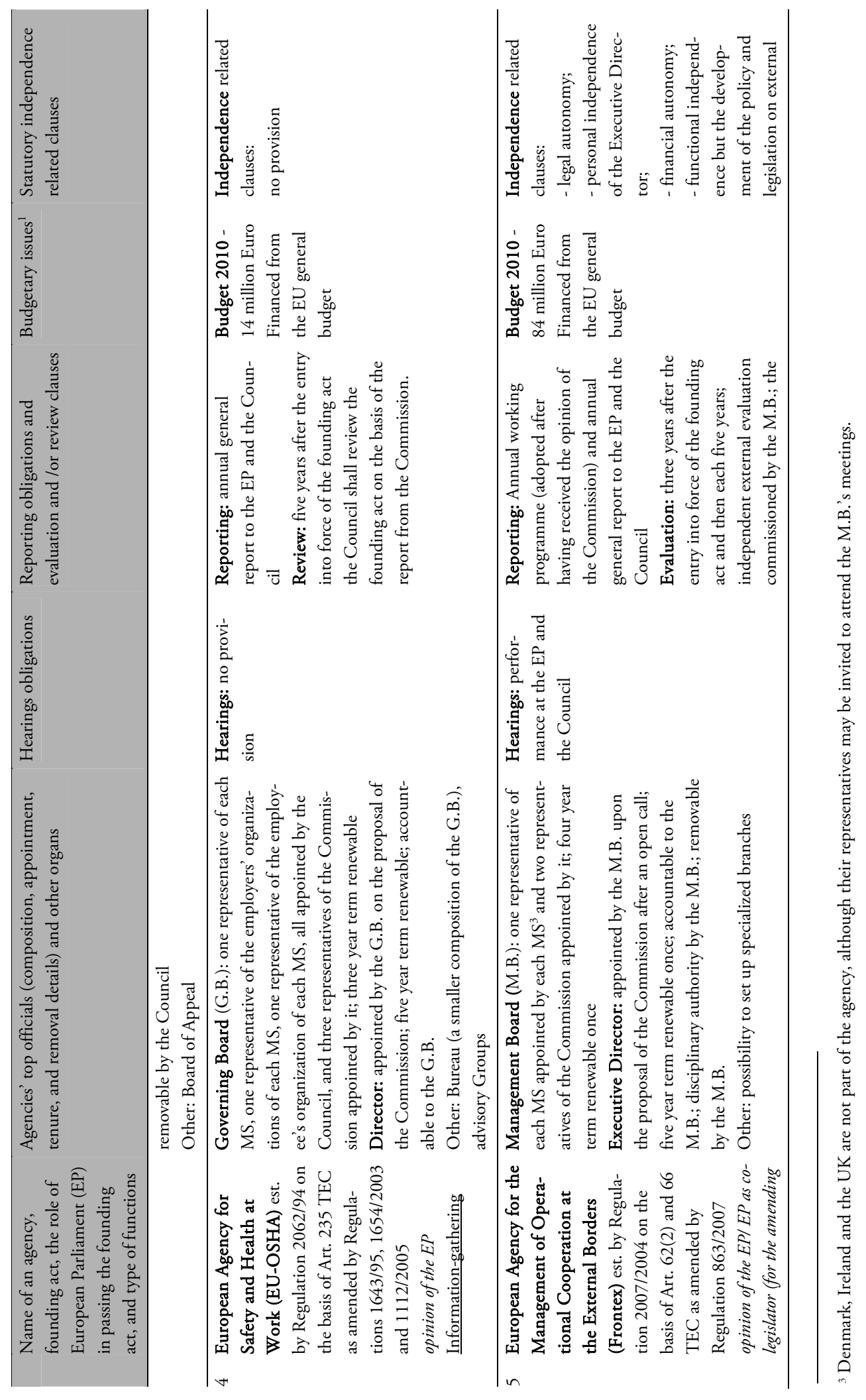




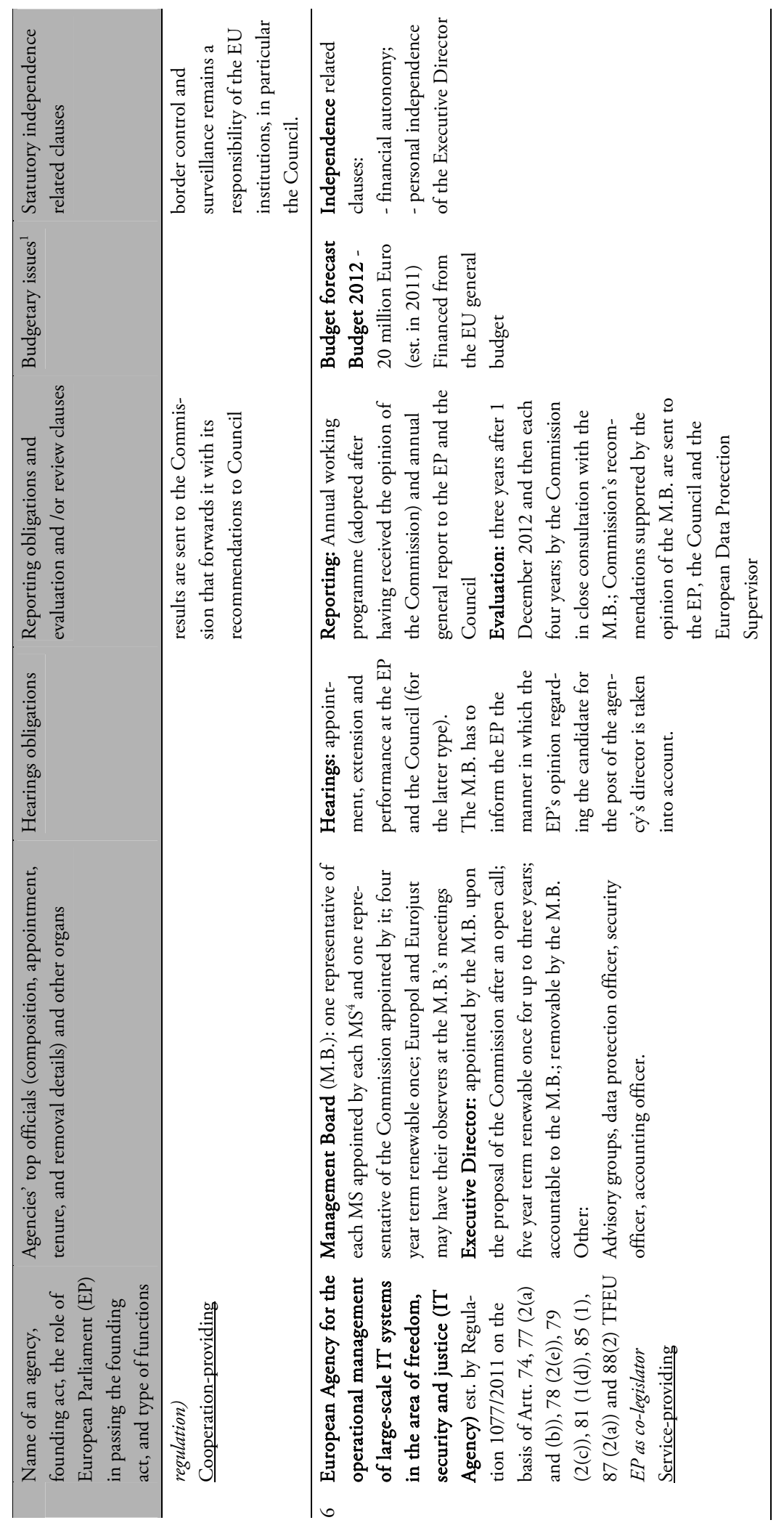

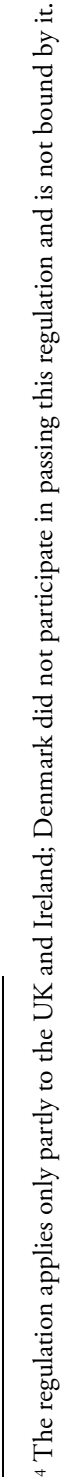




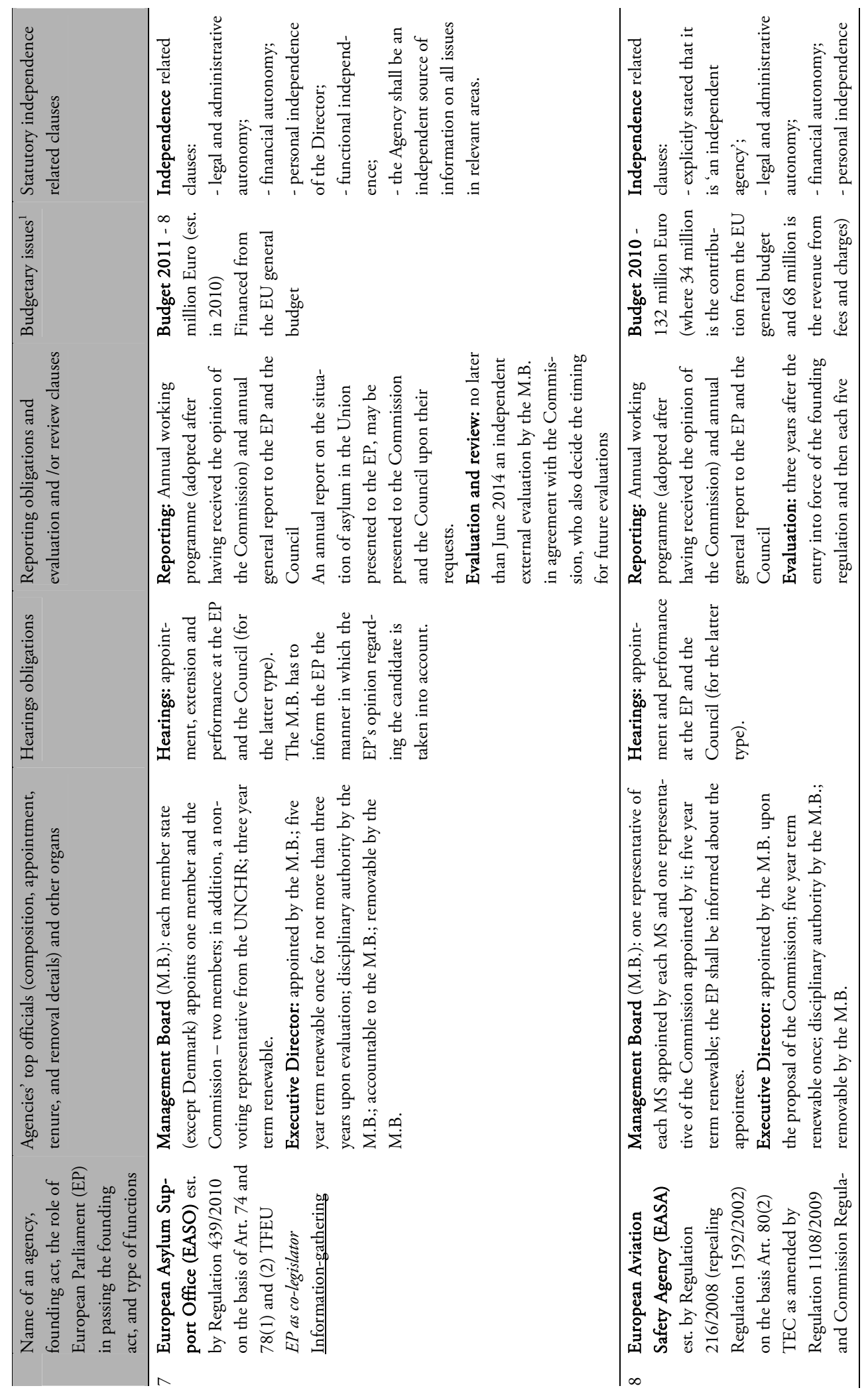




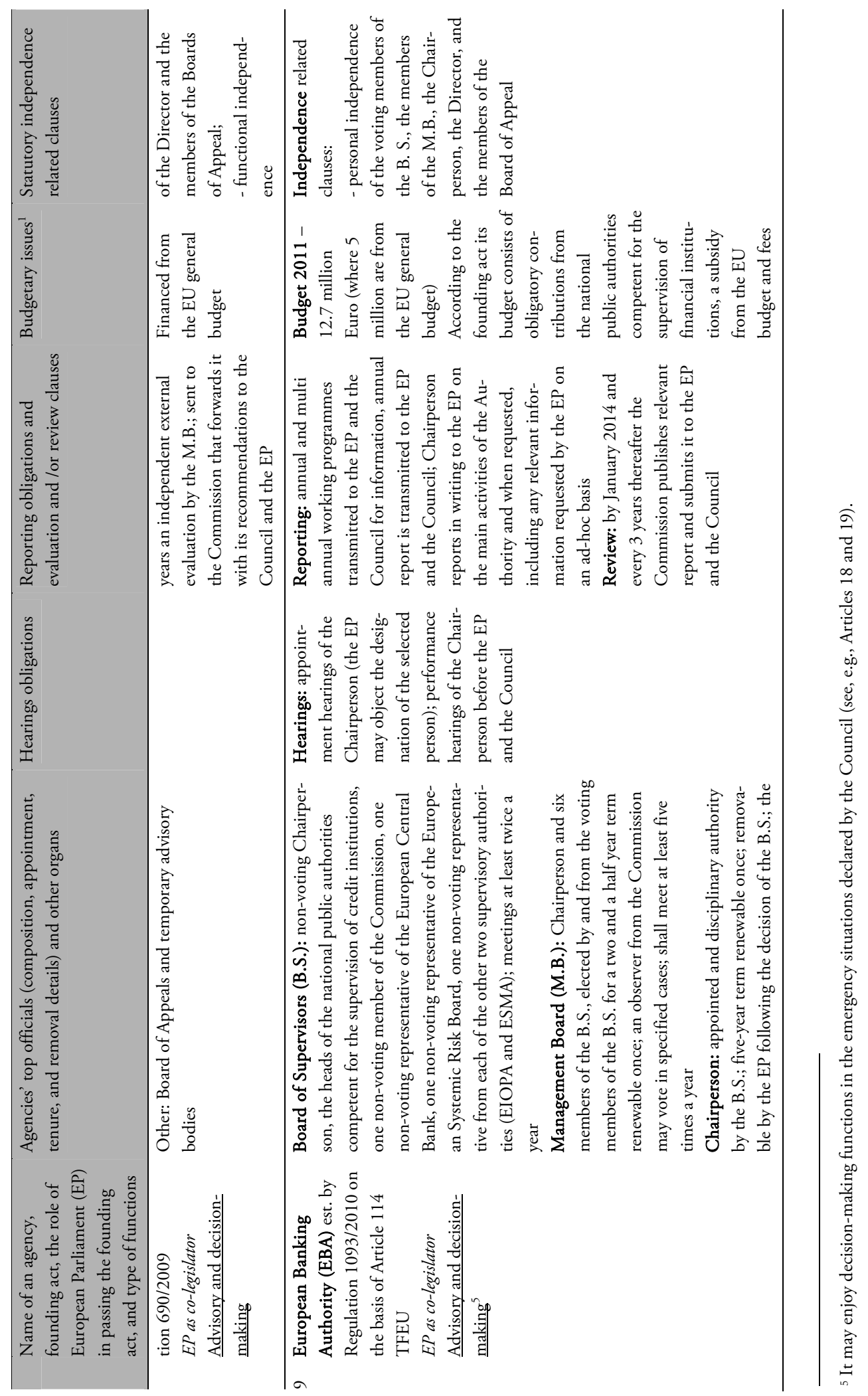




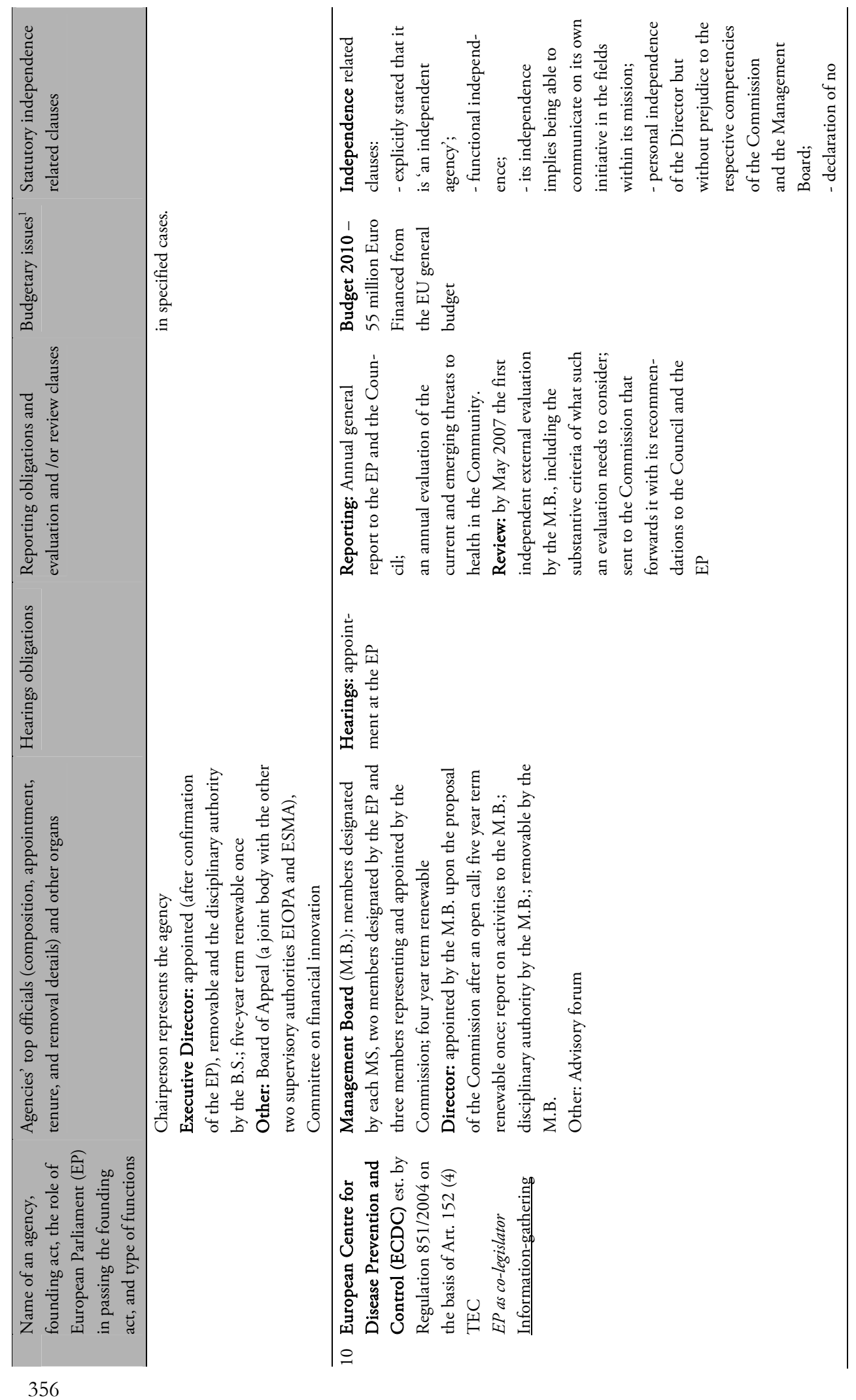




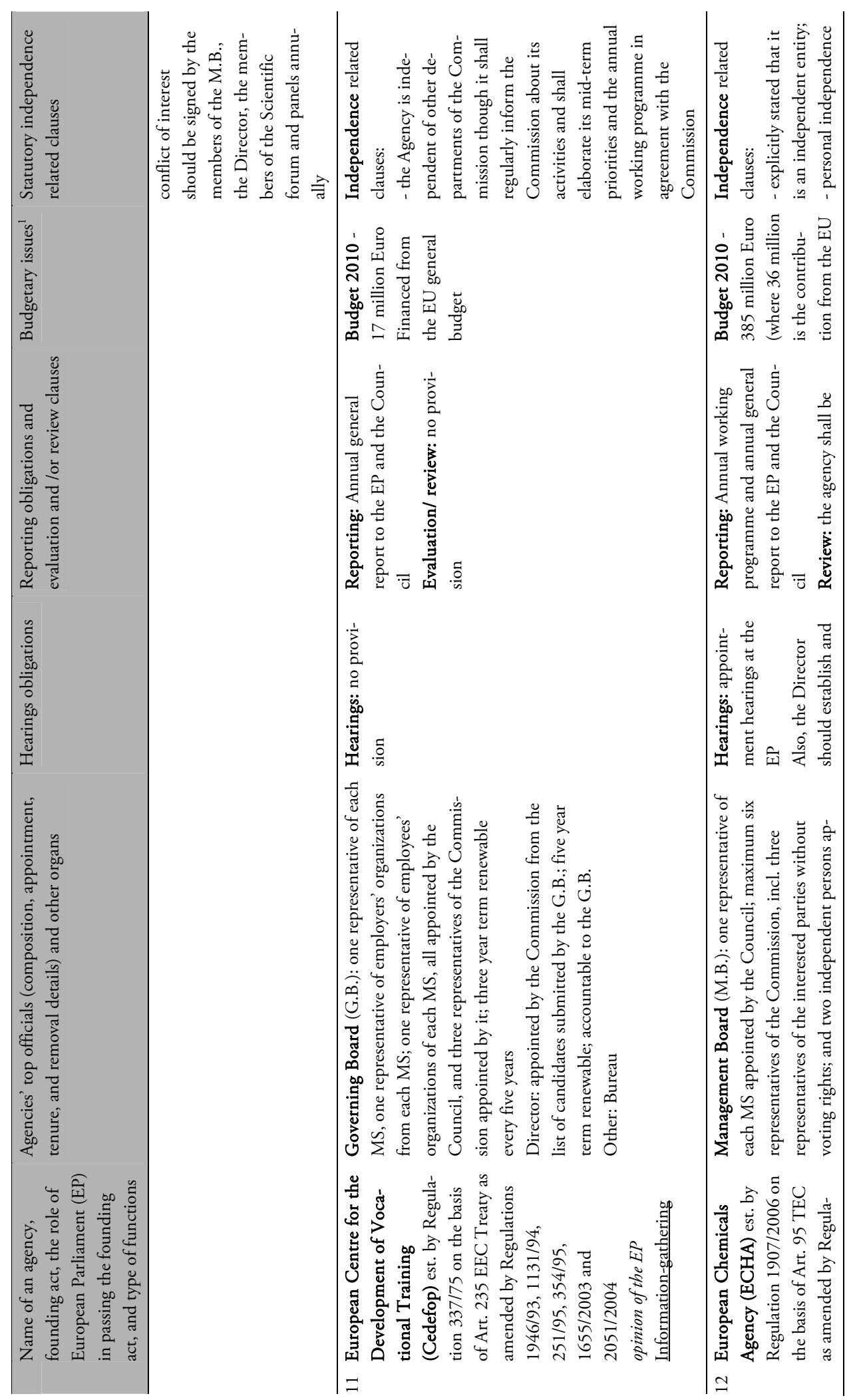




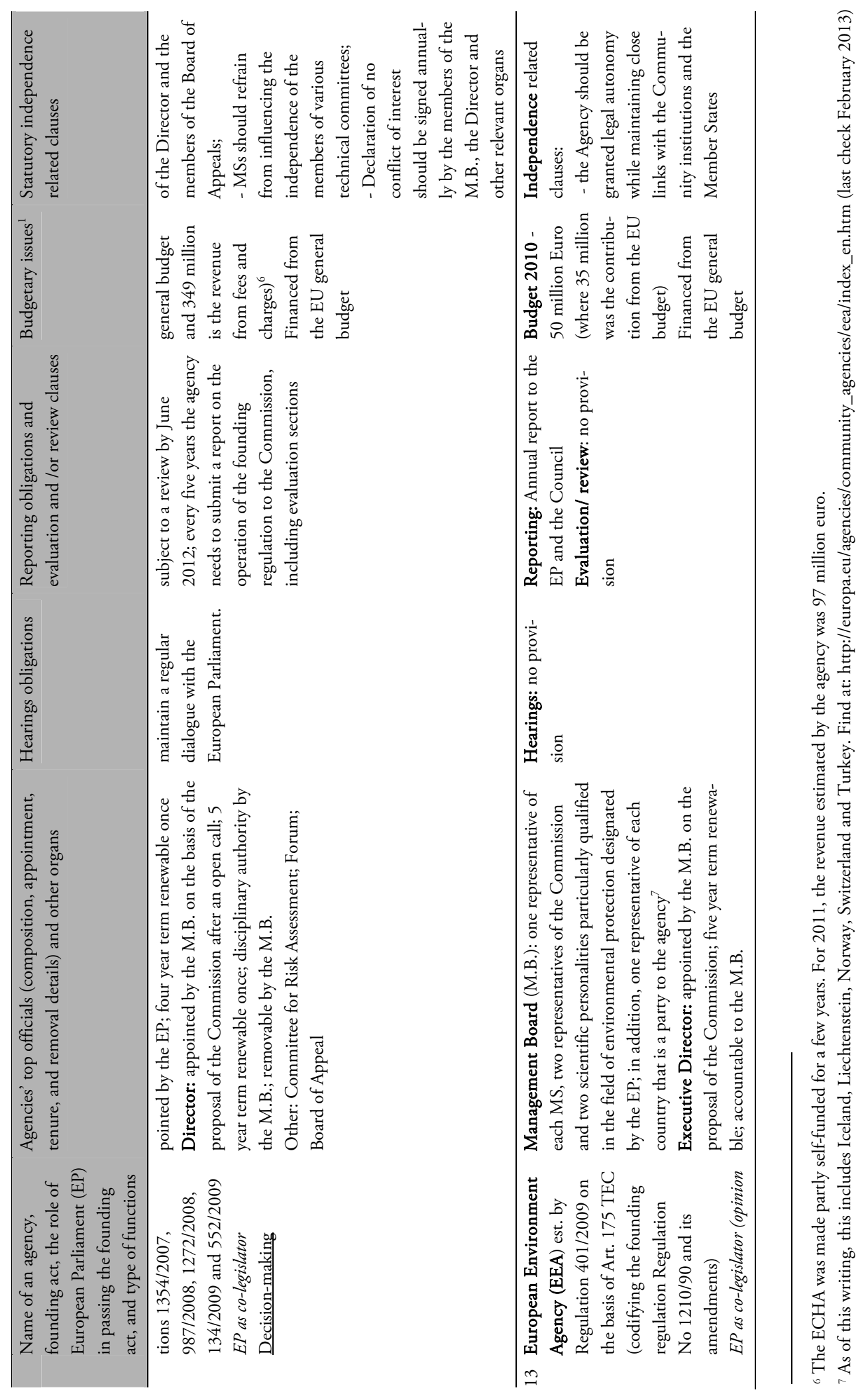




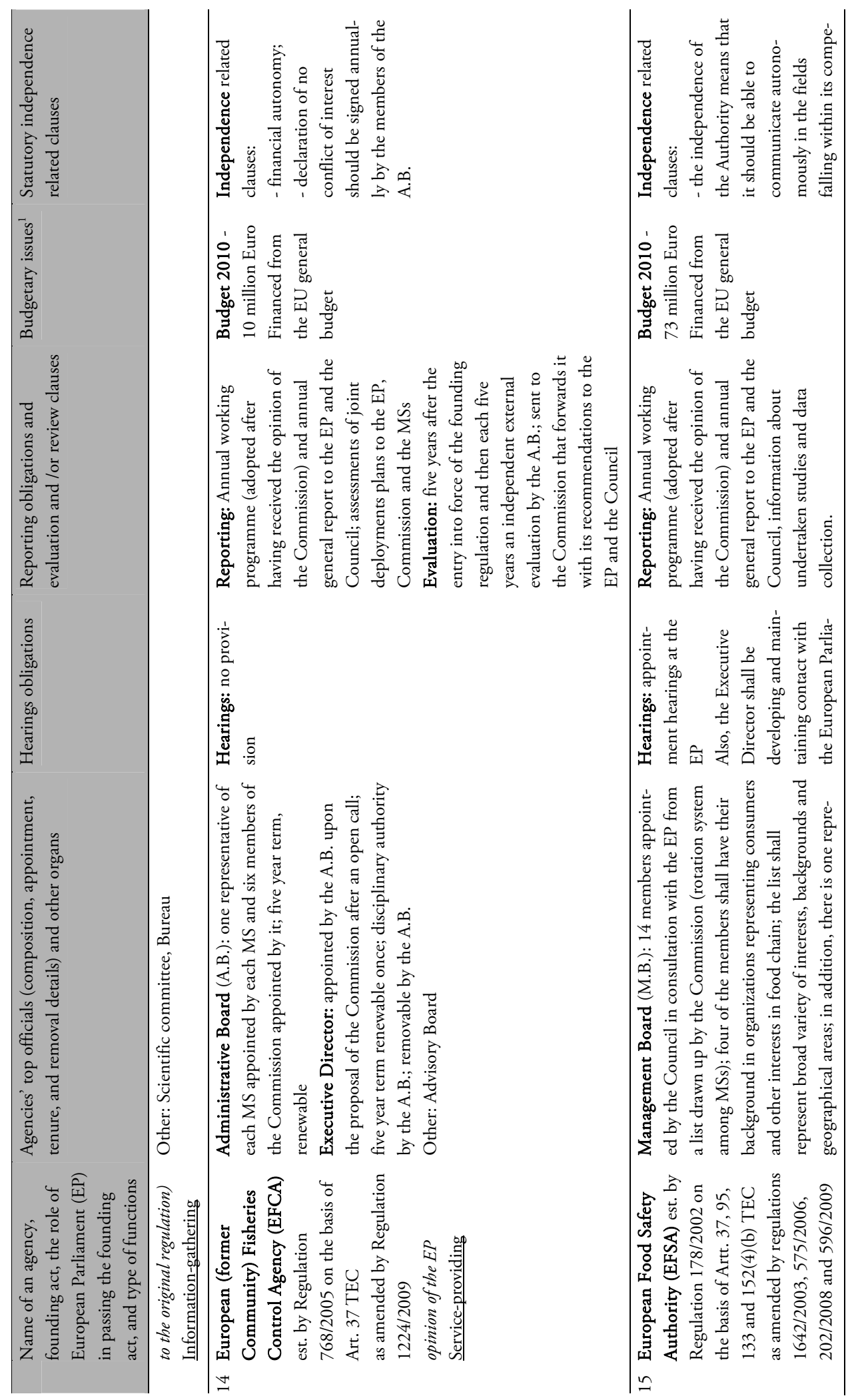




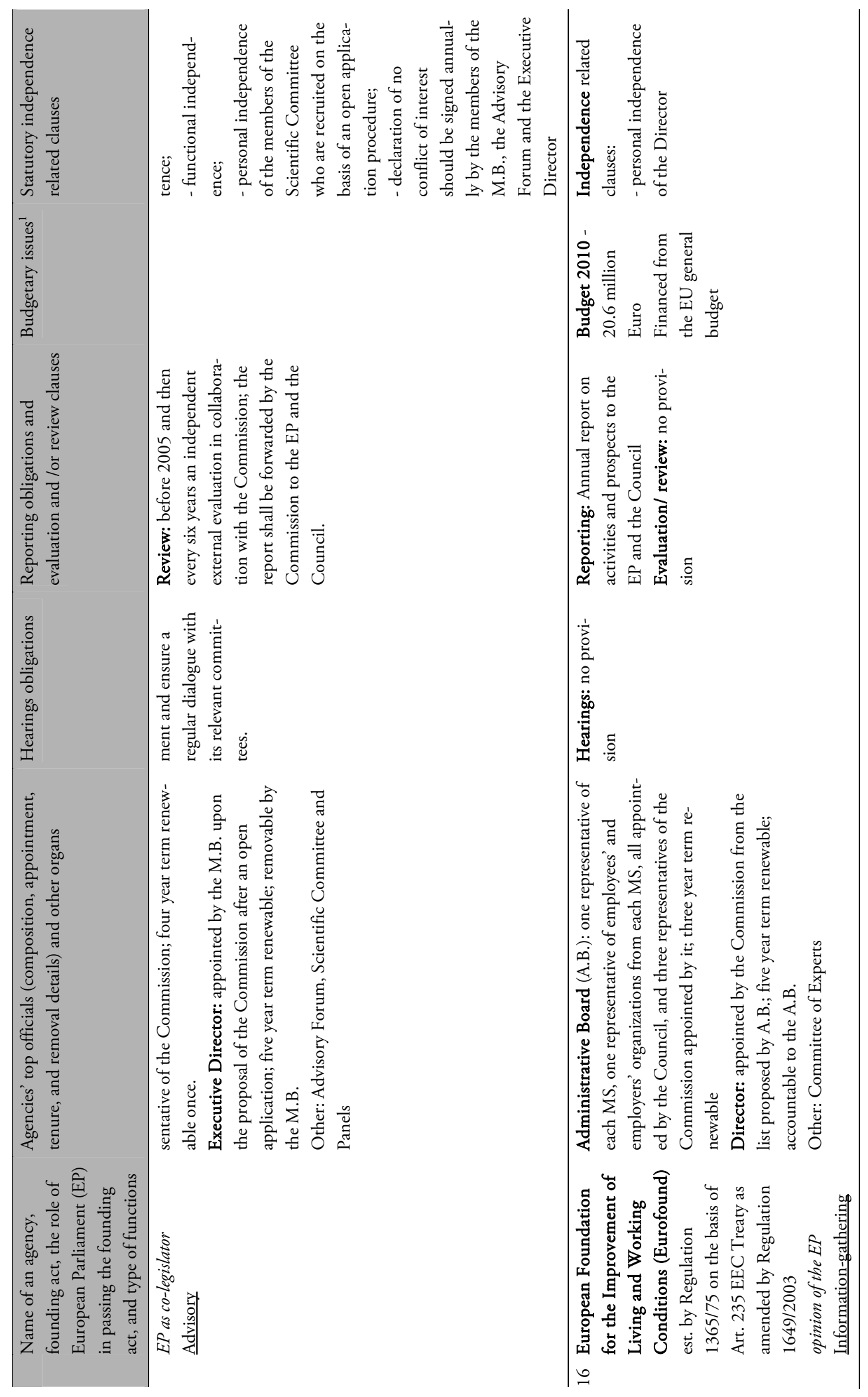




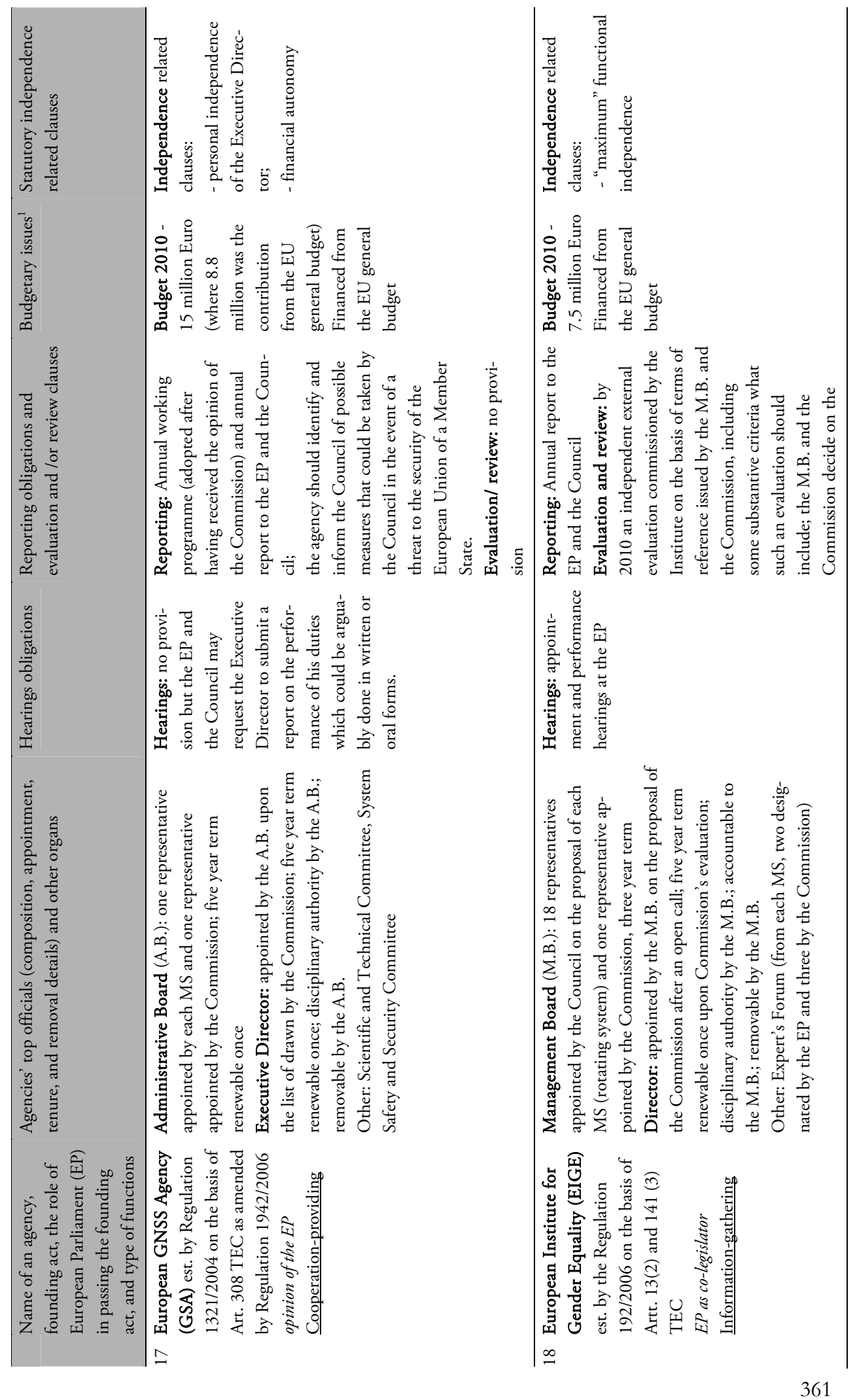




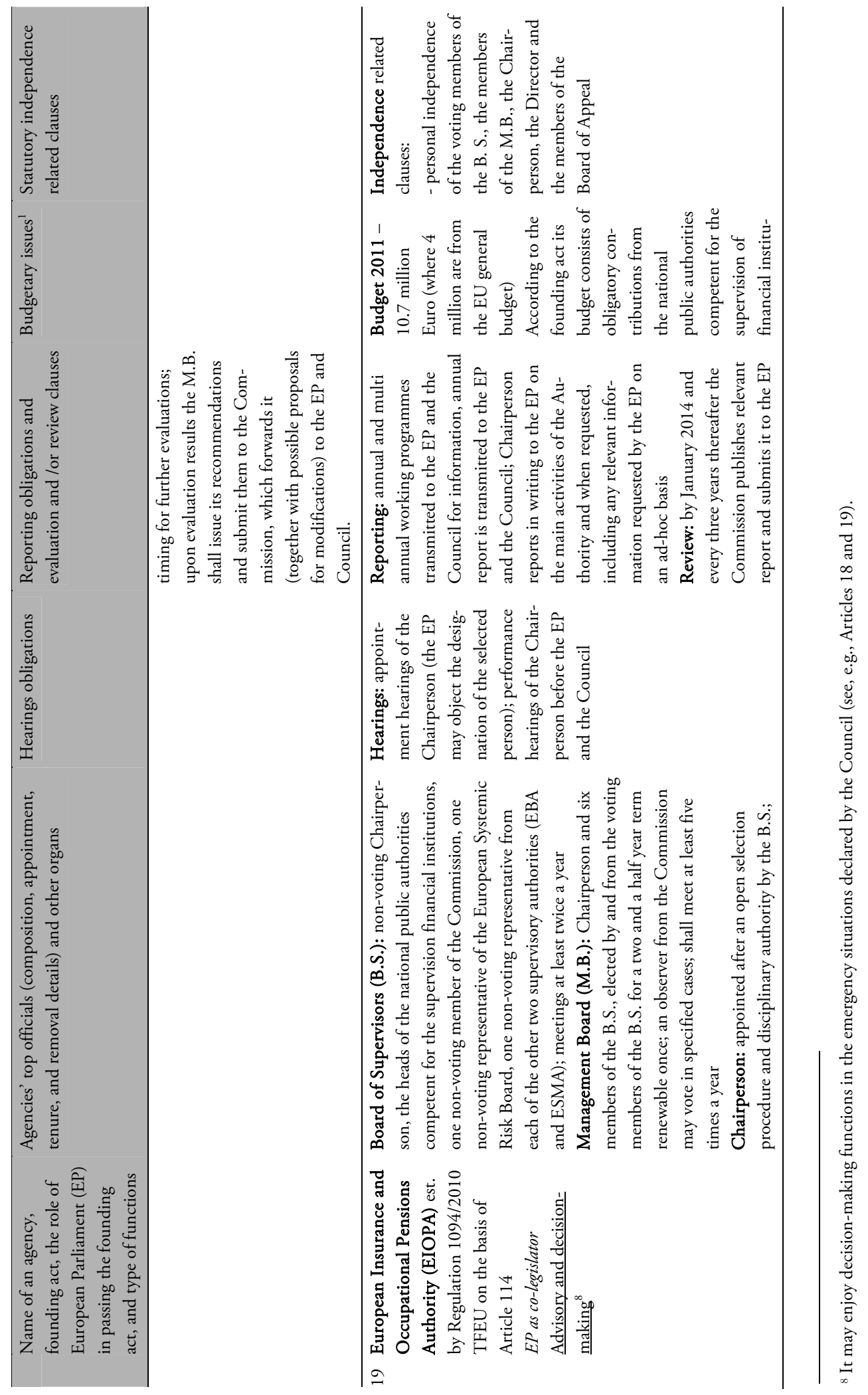




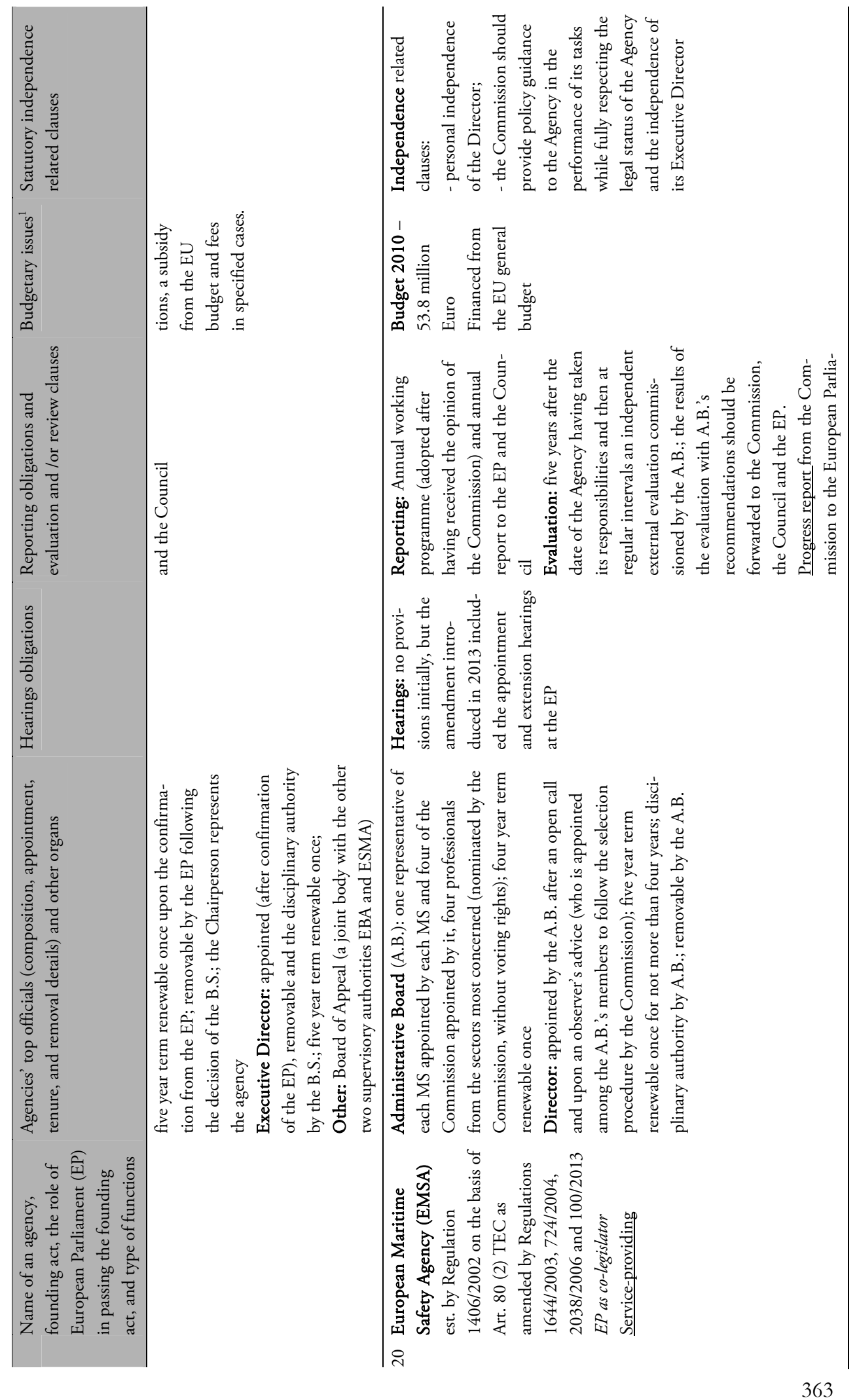




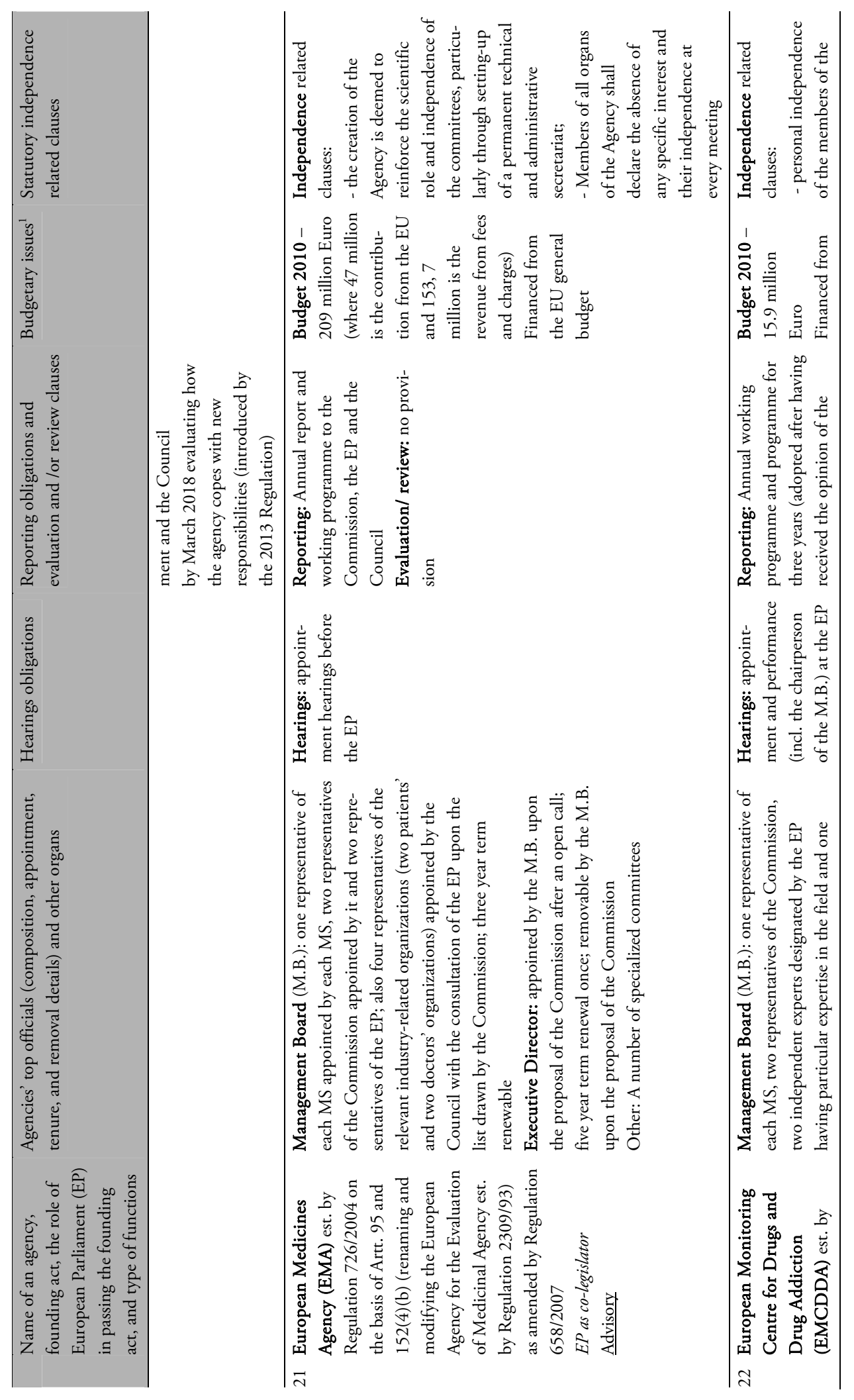




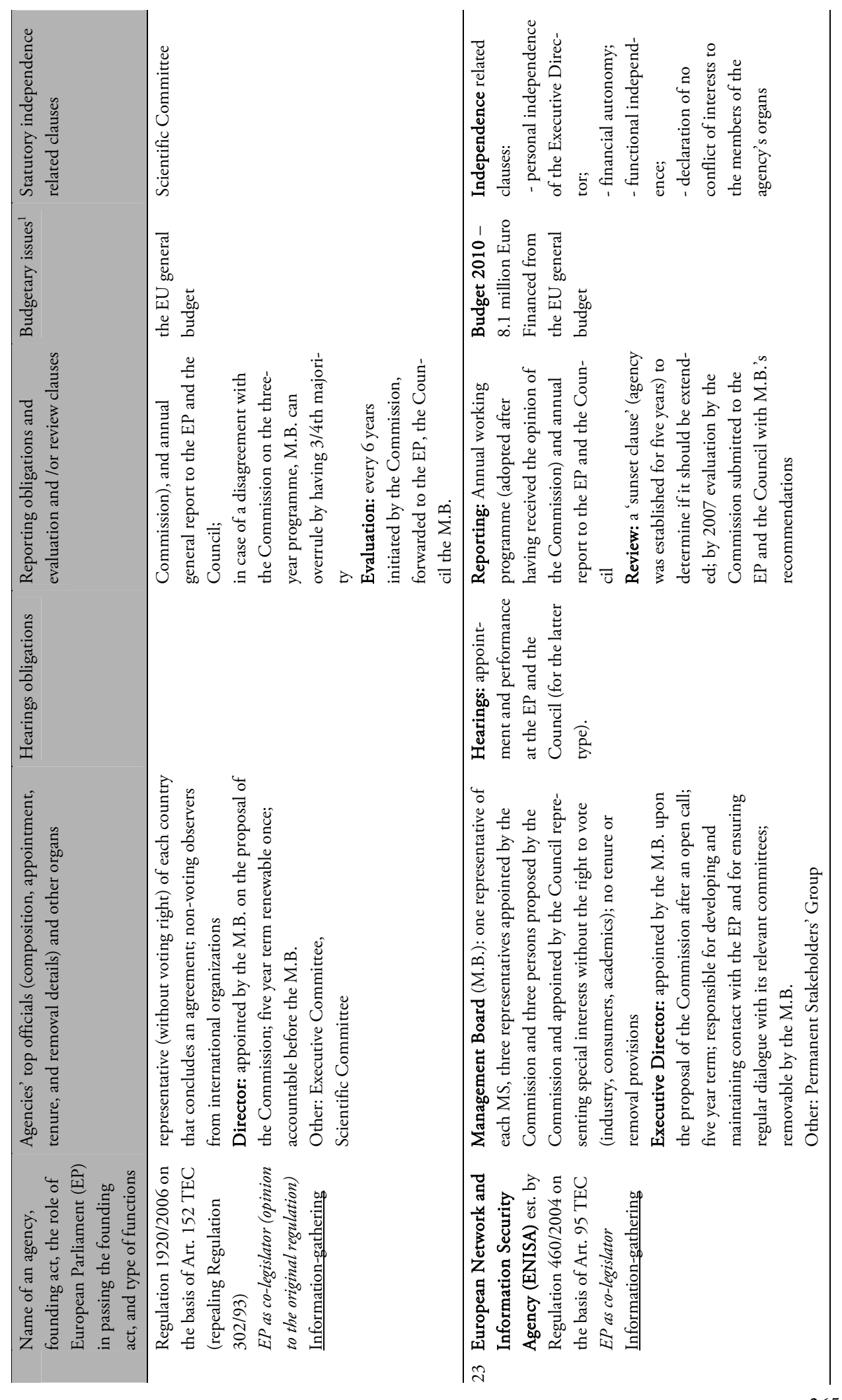




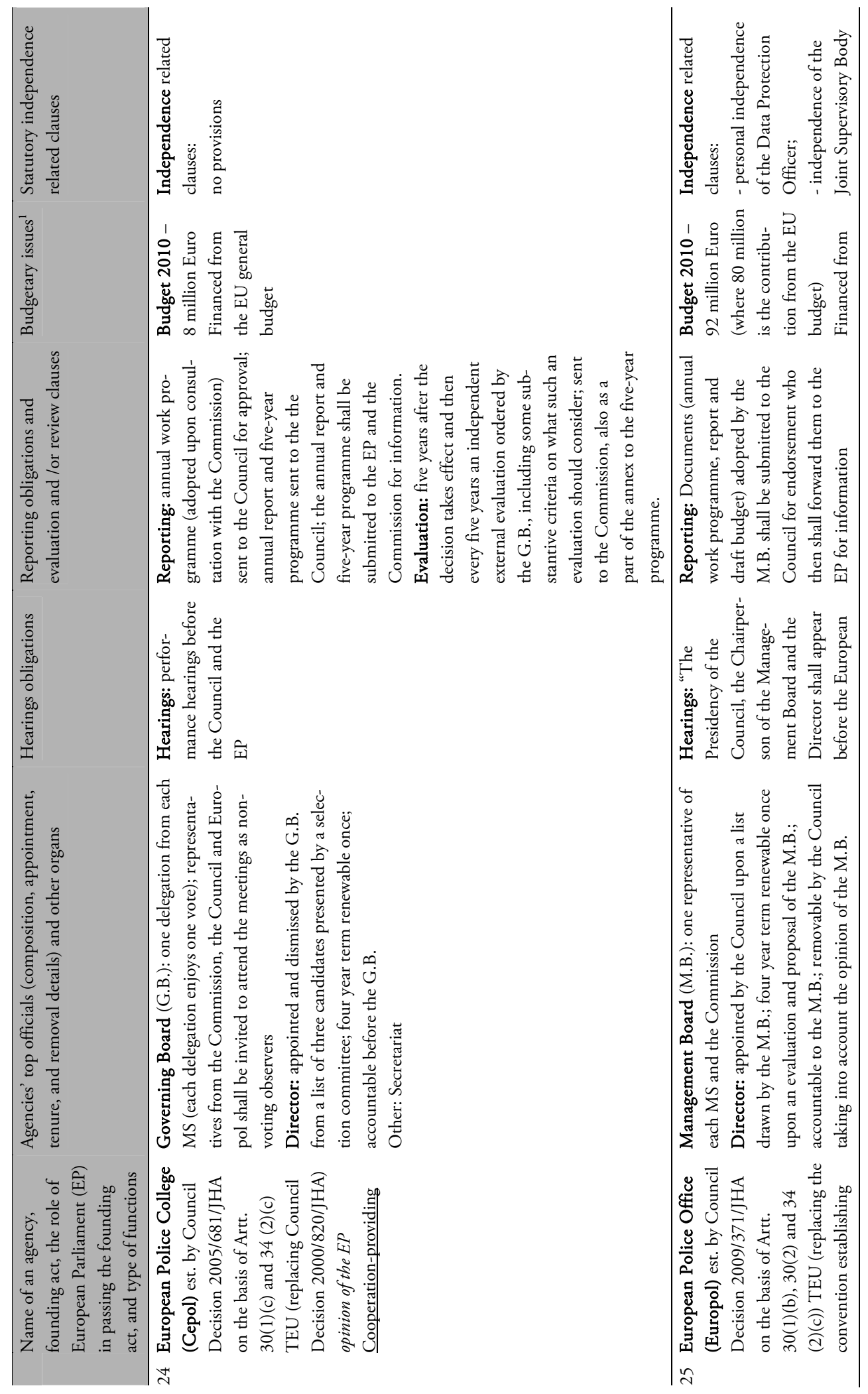




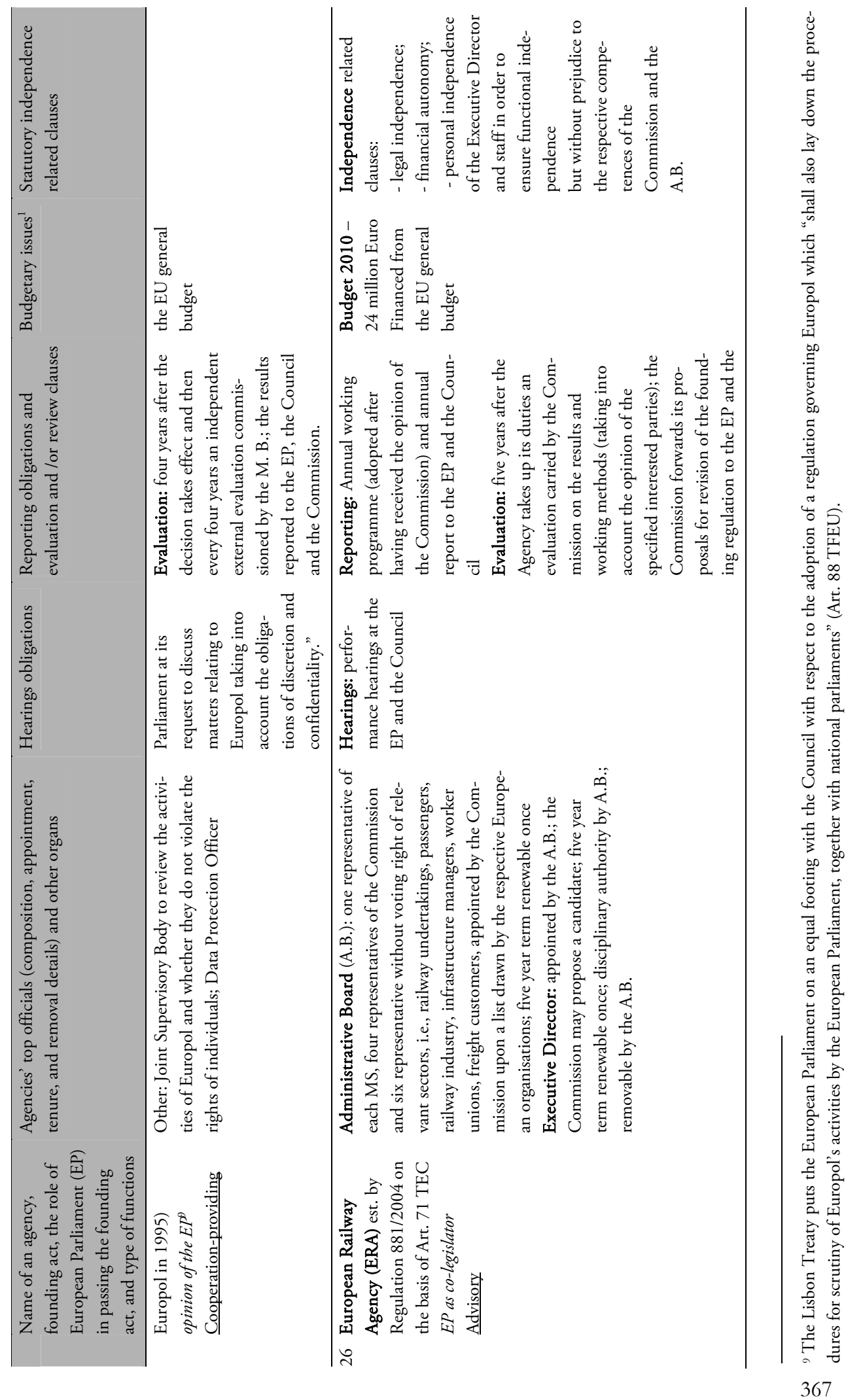




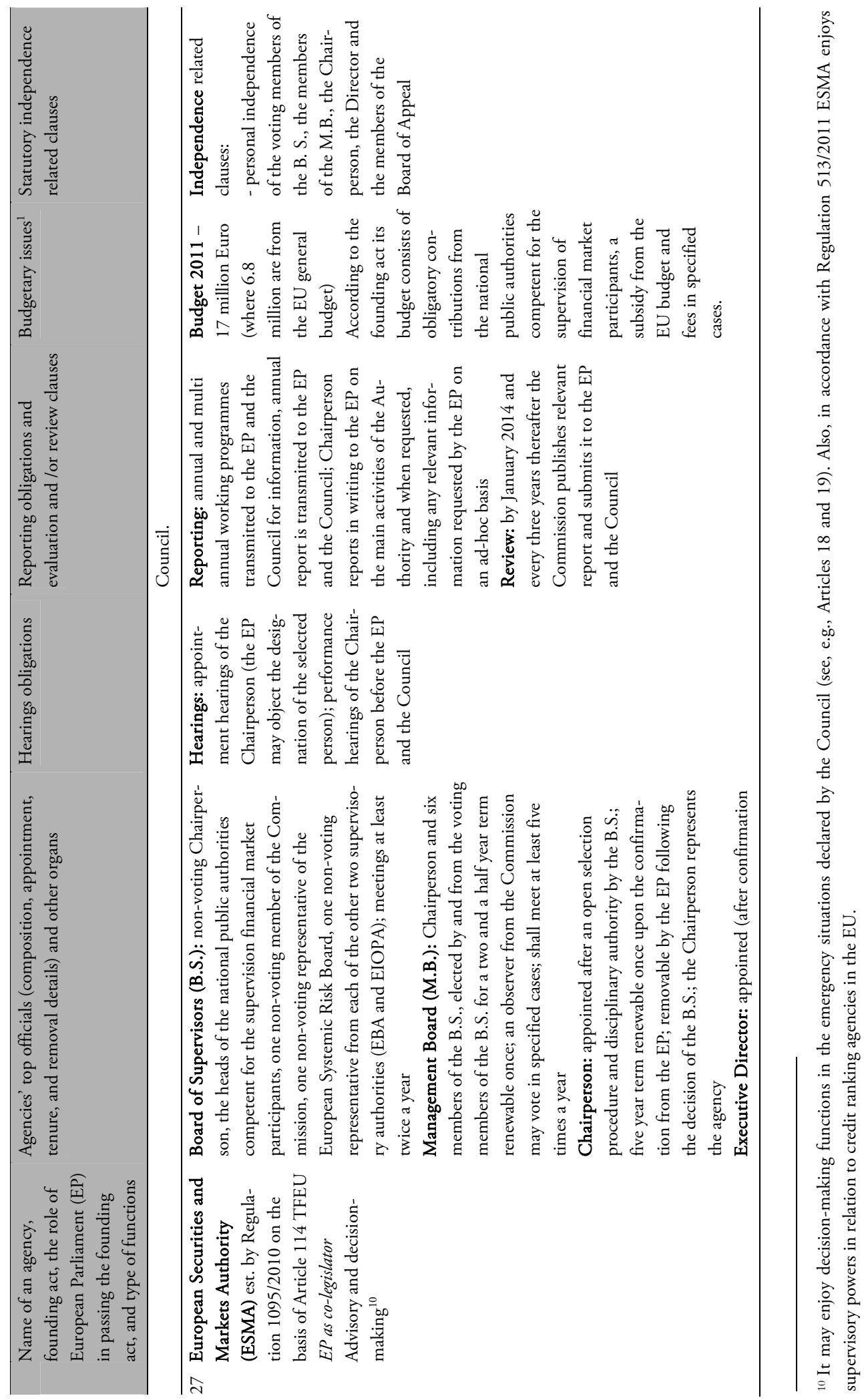




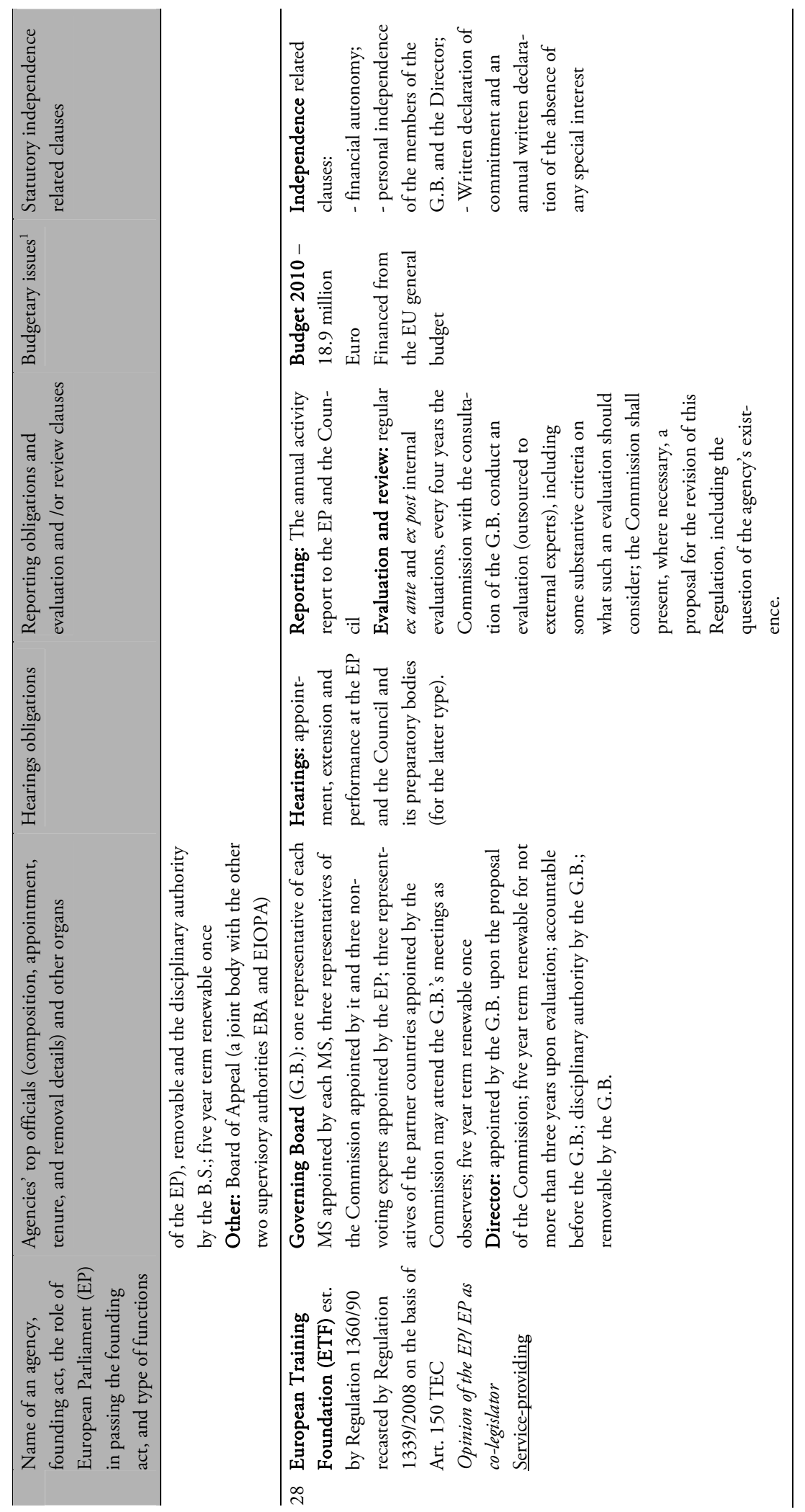




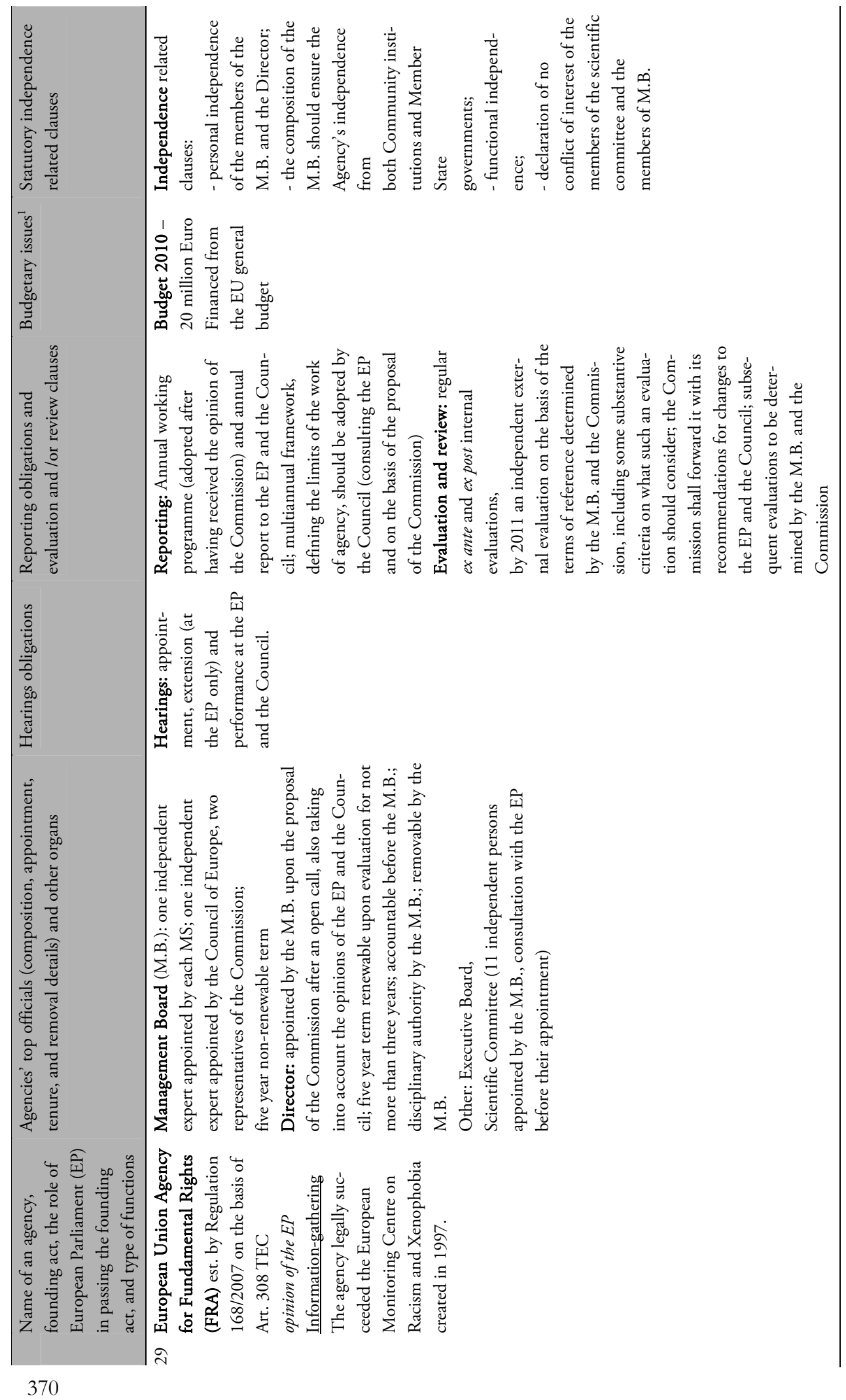




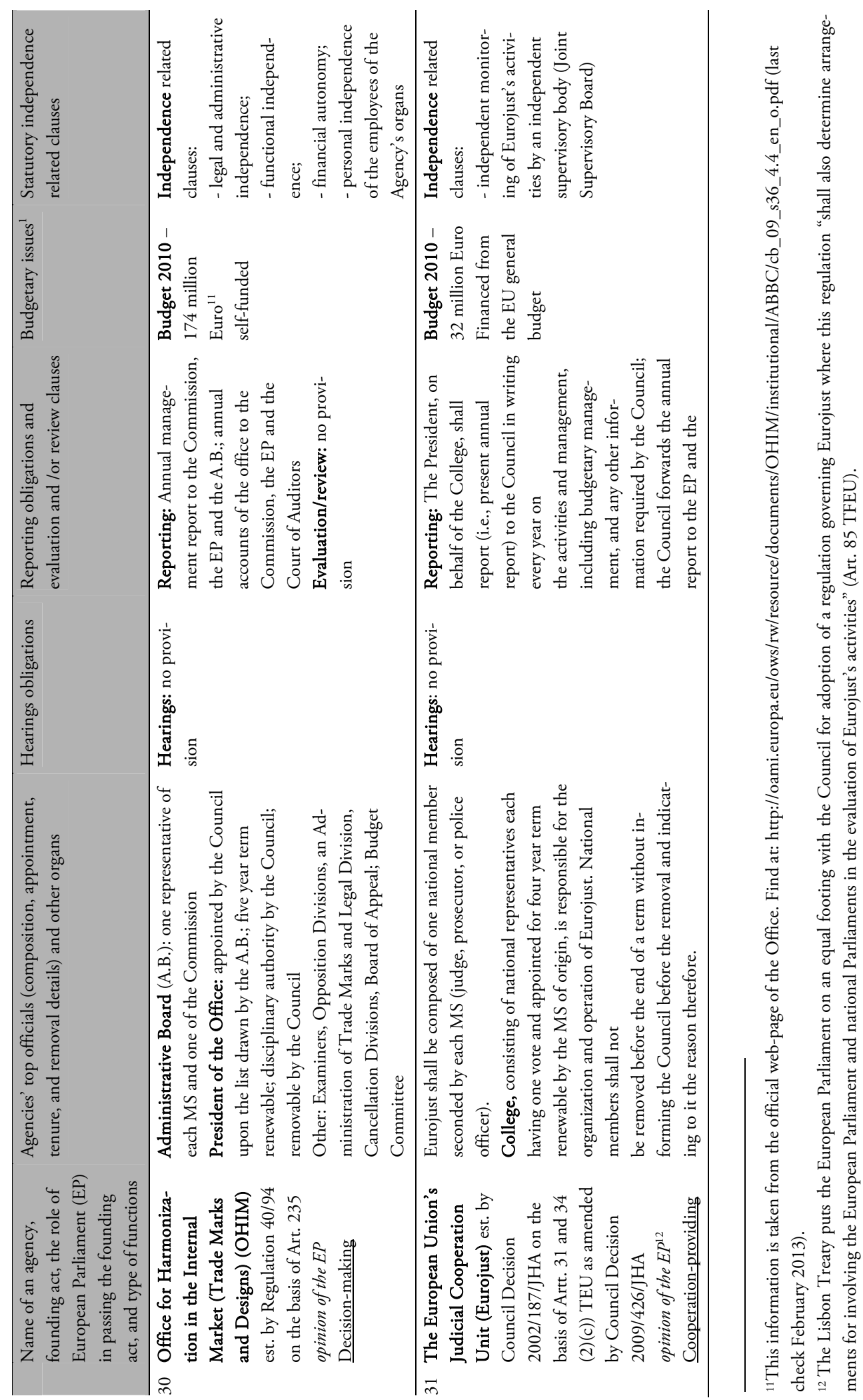




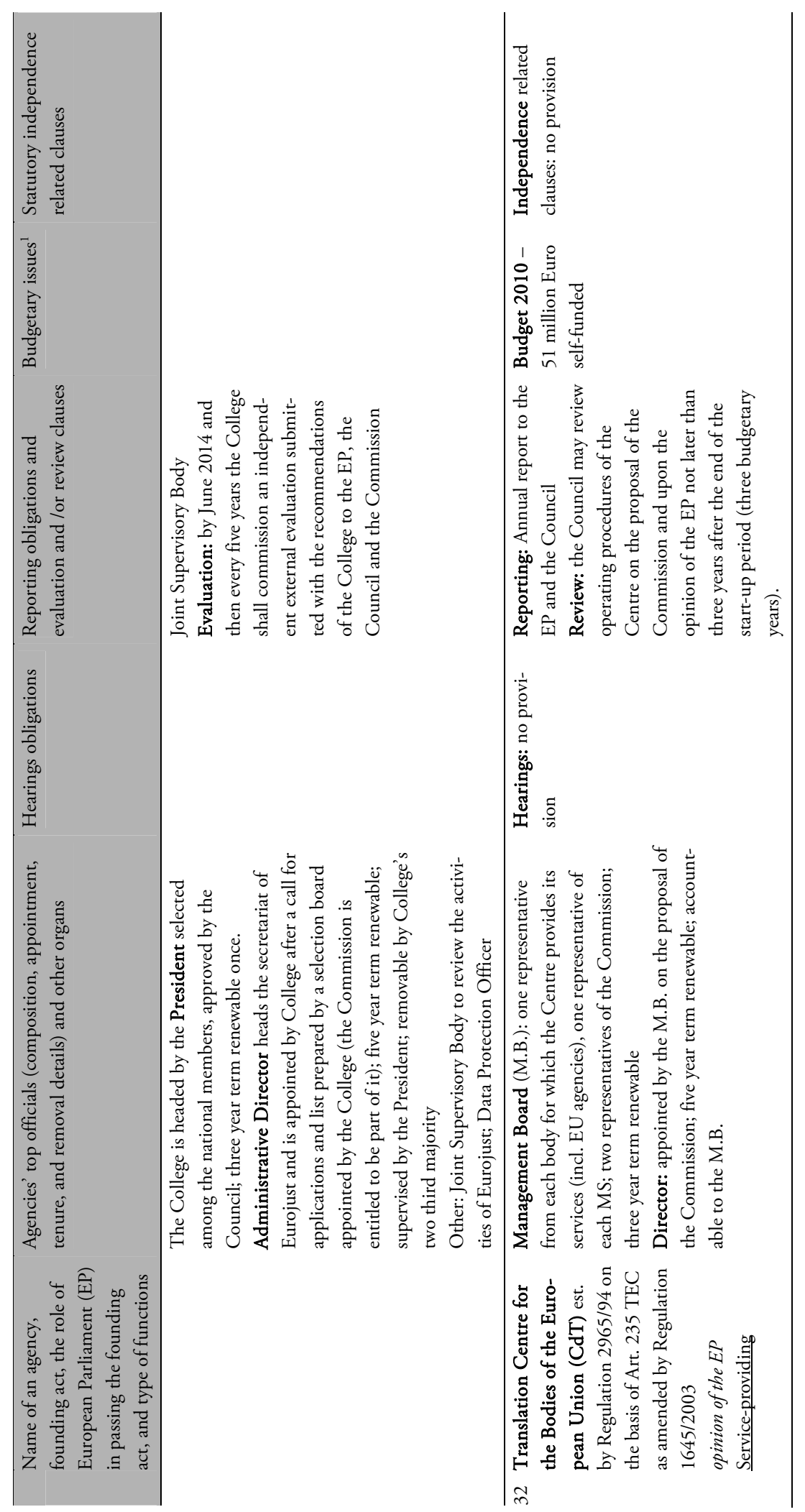




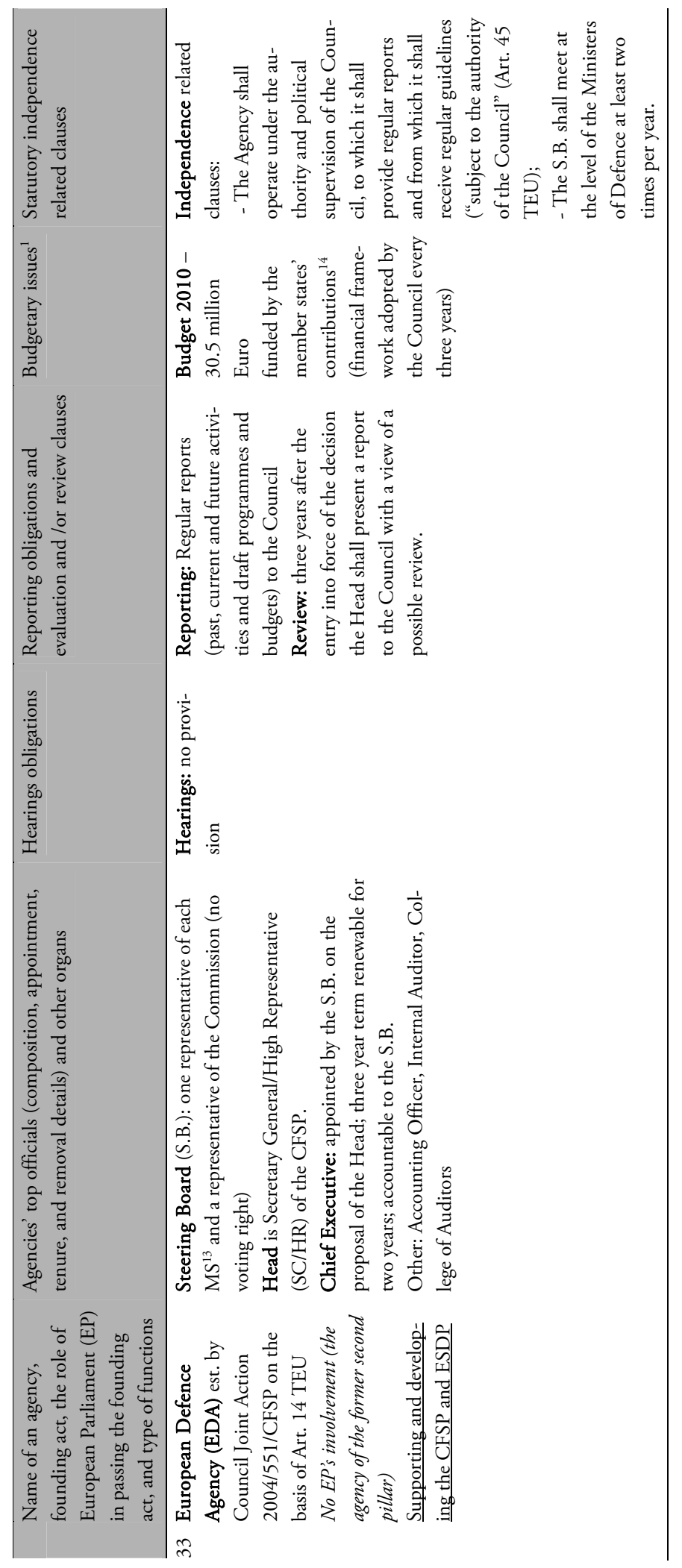

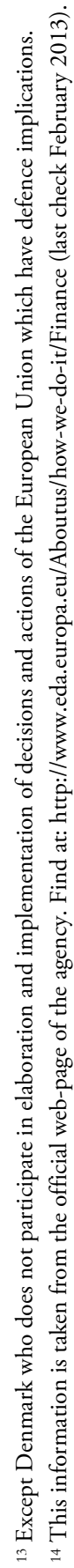




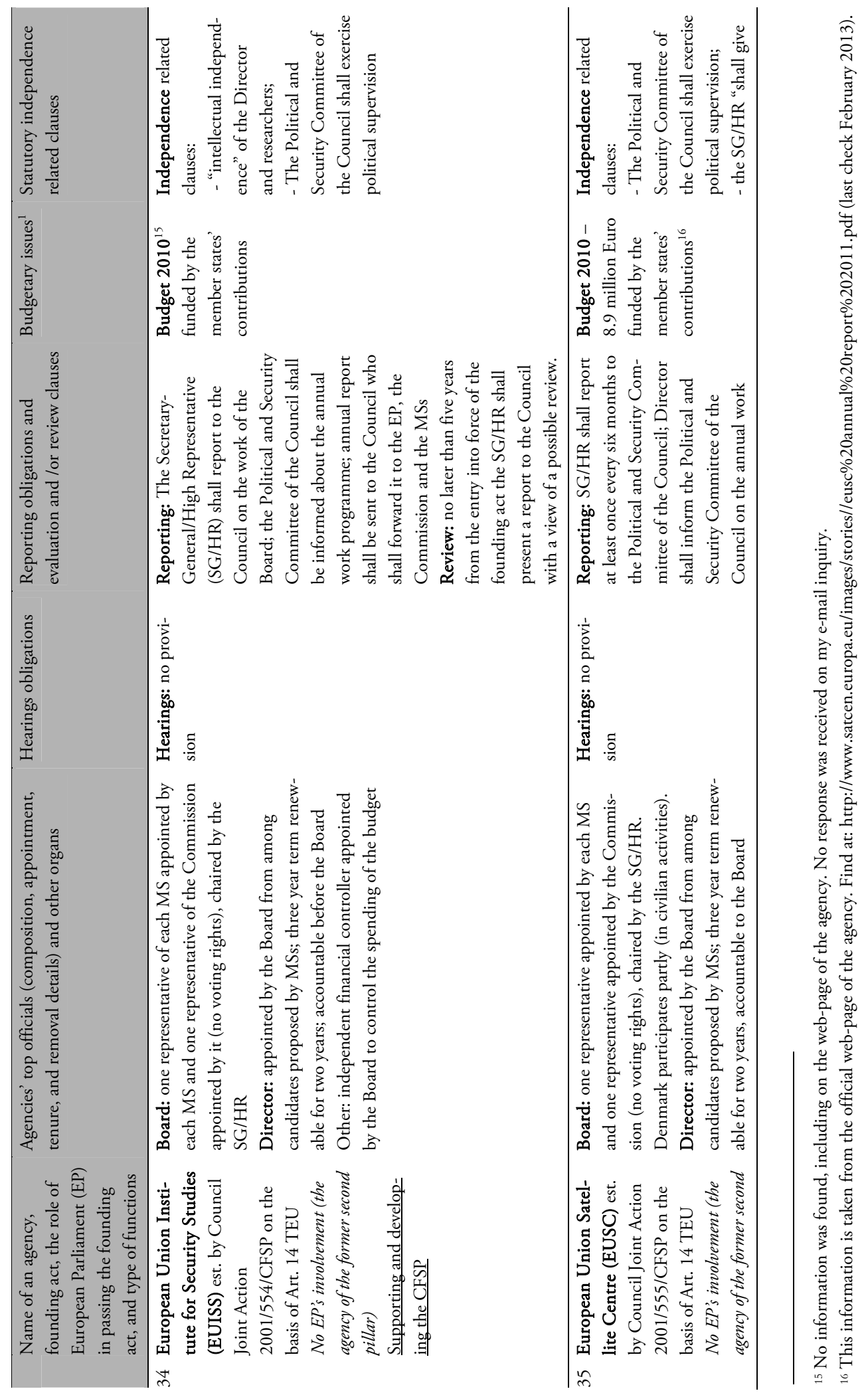




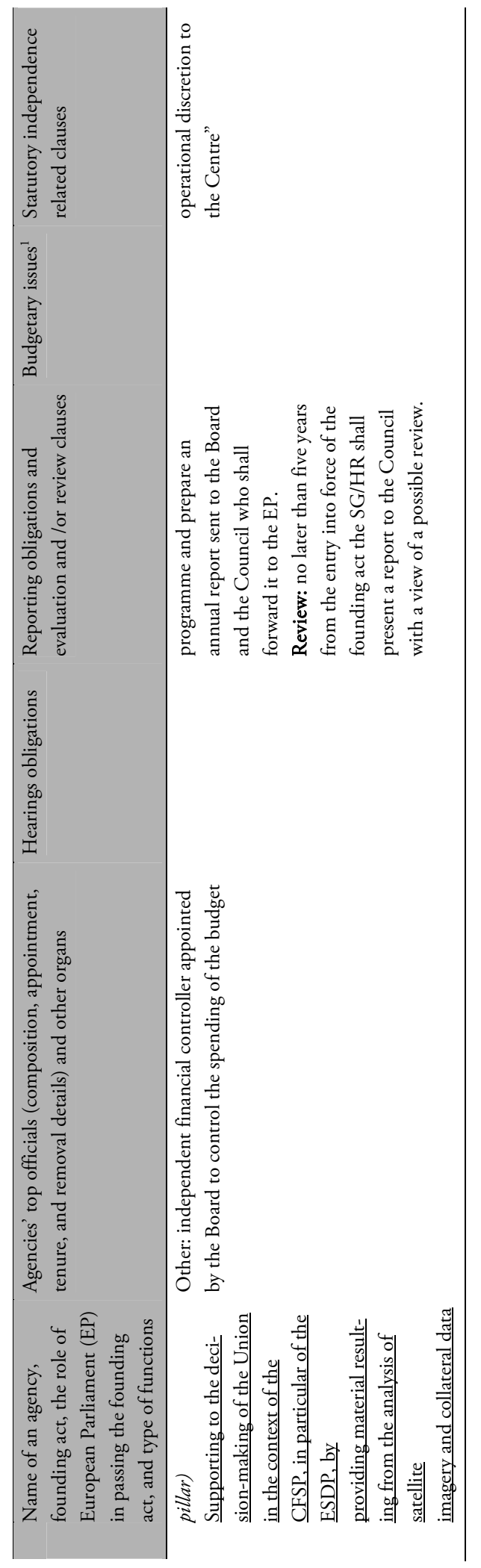





\section{APPENDIX 2}

\section{European Parliament's Committees Scrutinizing EU Agencies}

Results of my e-mail inquiry directed to all standing committees of the European Parliament with the questions concerning their supervision over EU agencies and using the practice of appointing liaison officers to keep contact with EU agencies ${ }^{1}$ (September 2011):

\begin{tabular}{|c|c|c|}
\hline & $\begin{array}{l}\text { Responsibilities over } \\
\text { EU agencies }\end{array}$ & Practice of appointing liaison members \\
\hline AFET (Foreign Affairs) & $\begin{array}{l}\text { No agencies under its } \\
\text { jurisdiction }\end{array}$ & $\mathrm{n} / \mathrm{a}$ \\
\hline DEVI (Development) & $\begin{array}{l}\text { No agencies under its } \\
\text { jurisdiction }\end{array}$ & $\mathrm{n} / \mathrm{a}$ \\
\hline $\begin{array}{l}\text { INTA (International } \\
\text { Trade) }\end{array}$ & $\begin{array}{l}\text { No agencies under its } \\
\text { jurisdiction }\end{array}$ & $\mathrm{n} / \mathrm{a}$ \\
\hline BUDG (Budgets) & $\begin{array}{l}\text { No response received } \\
\text { (but probably similarly } \\
\text { to CONT committee } \\
\text { all agencies financed } \\
\text { from the EU general } \\
\text { budget) }\end{array}$ & \\
\hline $\begin{array}{l}\text { CONT (Budgetary } \\
\text { Control) }\end{array}$ & $\begin{array}{l}\text { All agencies funded } \\
\text { from the EU general } \\
\text { budget }\end{array}$ & $\begin{array}{l}\text { "Budget control has a specific rule to play as far as agencies } \\
\text { are concerned, namely we grant them discharge or not every } \\
\text { year. <...> So normally we have a report on them all once a } \\
\text { year. We can invite them to the committee to be questioned } \\
\text { about their accounts and operations (we do not discuss their } \\
\text { working plans)." For every discharge for a given year the } \\
\text { committee appoints a rapporteur for the agencies discharges, } \\
\text { sometimes the Court of Auditors issues special reports also } \\
\text { on an Agency, then "we appoint a rapporteur who will make } \\
\text { a working document which will be added to the annual } \\
\text { discharge report." }\end{array}$ \\
\hline $\begin{array}{l}\text { ECON (Economic and } \\
\text { Monetary Affairs) }\end{array}$ & No response received & \\
\hline
\end{tabular}

\footnotetext{
${ }^{1} \mathrm{I}$ am very grateful for cooperation in this inquiry to the secretariats of 14 (out of 20) permanent specialized committees of the European Parliament and for individual reactions of Parliament's individual members, namely Chair Leinen (ENVI), Chair Reul (ITRE), Vice-Chair Gurmai (AFCO), MEP Hassi (ENVI), and MEP Yannakoudakis (ENVI).
} 


\begin{tabular}{|c|c|c|}
\hline & $\begin{array}{l}\text { Responsibilities over } \\
\text { EU agencies }\end{array}$ & Practice of appointing liaison members \\
\hline $\begin{array}{l}\text { EMPL (Employment } \\
\text { and Social Affairs) }\end{array}$ & $\begin{array}{l}\text { ETF, Eurofound, EU- } \\
\text { OSHA, and Cedefop }\end{array}$ & $\begin{array}{l}\text { Regular contacts and using the practice of appointing com- } \\
\text { mittee staff members as liaisons: } \\
\text { ETF - Erika Schulze } \\
\text { Eurofound - Jan van der Velden } \\
\text { EU-OSHA - Artemissia Kefalopoulou } \\
\text { Cedefop - Oama Camasoiu. }\end{array}$ \\
\hline $\begin{array}{l}\text { ENVI (Environment, } \\
\text { Public Health and Food } \\
\text { Safety) }\end{array}$ & $\begin{array}{l}\text { ECDC, ECHA, EEA, } \\
\text { EFSA, and EMA }\end{array}$ & $\begin{array}{l}\text { A contact person is appointed to each agency: } \\
\text { ECDC - MEP Yannakoudakis (ECR) } \\
\text { ECHA - MEP Hassi (Greens) } \\
\text { EEA - MEP Gerbrandy (ALDE) } \\
\text { EMA - MEP Roth-Berendt (S\&D) } \\
\text { Agencies' directors brief the committee regularly. } \\
\text { Chair Leinen wrote that the practice of appointing liaisons } \\
\text { has proven to be helpful for oversight purposes. }\end{array}$ \\
\hline $\begin{array}{l}\text { ITRE (Industry, Re- } \\
\text { search and Energy) }\end{array}$ & $\begin{array}{l}\text { ENISA, ACER, and } \\
\text { GSA }\end{array}$ & $\begin{array}{l}\text { "Our Committee has designed contact groups and liaison } \\
\text { Members to enhance cooperation and exchange of infor- } \\
\text { mation with these agencies. The contact groups may also } \\
\text { meet representatives of the agencies outside the ITRE- } \\
\text { meetings for a more informal exchange of views. Heads of } \\
\text { agencies are invited, } 1-2 \text { times a year, to report on current } \\
\text { achievements and future challenges of their agency in the } \\
\text { ITRE Committee. Furthermore, ITRE regularly organize } \\
\text { delegations to these agencies to discuss current and future } \\
\text { challenges and to get an insight of the agency work on the } \\
\text { spot. According to Art. } 12 \text { of the REGULATION (EC) No } \\
713 / 2009, \text { two members and their alternates in the adminis- } \\
\text { trative board of ACER shall be appointed by the European } \\
\text { Parliament. The basic acts of the other above mentioned } \\
\text { agencies do not foresee such a possibility." }\end{array}$ \\
\hline $\begin{array}{l}\text { IMCO (Internal Mar- } \\
\text { ket and Consumer } \\
\text { Protection) }\end{array}$ & No response received & \\
\hline $\begin{array}{l}\text { TRAN (Transport and } \\
\text { Tourism) }\end{array}$ & $\begin{array}{l}\text { ERA, EASA, and } \\
\text { EMSA }\end{array}$ & $\begin{array}{l}\text { "We regularly (on average once a year) invite the Agencies' } \\
\text { Directors to hear their work programme, activities, etc. A } \\
\text { small delegation of TRAN Members also goes once per } \\
\text { legislature to visit the Agencies. The TRAN Committee also } \\
\text { drafts opinions to the Budgetary Control Committee on the } \\
\text { annual discharges of the Agencies. In principle, the whole } \\
\text { Committee follows the agencies. However, when a report or } \\
\text { an opinion is drafted (e.g. Fleckenstein report on the Regula- } \\
\text { tion on EMSA), a rapporteur is appointed upon recommen- } \\
\text { dation by the TRAN Coordinators." }\end{array}$ \\
\hline $\begin{array}{l}\text { REGI (Regional Devel- } \\
\text { opment) }\end{array}$ & $\begin{array}{l}\text { No agencies under its } \\
\text { jurisdiction }\end{array}$ & $\mathrm{n} / \mathrm{a}$ \\
\hline
\end{tabular}




\begin{tabular}{|c|c|c|}
\hline & $\begin{array}{l}\text { Responsibilities over } \\
\text { EU agencies }\end{array}$ & Practice of appointing liaison members \\
\hline $\begin{array}{l}\text { AGRI (Agriculture and } \\
\text { Rural Development) }\end{array}$ & $\mathrm{CPVO}$ & No liaison, contacts from time to time \\
\hline PECH (Fisheries) & EFCA & $\begin{array}{l}\text { "We have a regular contact with the Agency, formally in the } \\
\text { Hearings and one or two presentations every year, and every } \\
\text { two years there is a fisheries committee delegation to Vigo. } \\
\text { Informally quite often by phone or e-mail. There is an } \\
\text { Administrator as liaison officer with the Agency, only to } \\
\text { coordinate information and meetings." }\end{array}$ \\
\hline $\begin{array}{l}\text { CULT (Culture and } \\
\text { Education) }\end{array}$ & No response received & \\
\hline JURI (Legal Affairs) & No response received & \\
\hline $\begin{array}{l}\text { LIBE (Civil Liberties, } \\
\text { Justice and Home } \\
\text { Affairs) }\end{array}$ & No response received $^{2}$ & \\
\hline $\begin{array}{l}\text { AFCO (Constitutional } \\
\text { Affairs) }\end{array}$ & $\begin{array}{l}\text { No agencies under its } \\
\text { jurisdiction }\end{array}$ & $\mathrm{n} / \mathrm{a}$ \\
\hline $\begin{array}{l}\text { FEMM (Women's } \\
\text { Rights and Gender } \\
\text { Equality) }\end{array}$ & EIGE & $\begin{array}{l}\text { "We have regular contacts, presentation of the annual work } \\
\text { programme by the Director and visit the institute every } 2 \\
\text { years. The issue of appointing liaisons was never discussed in } \\
\text { the committee." }\end{array}$ \\
\hline PETI (Petitions) & $\begin{array}{l}\text { No responsibilities } \\
\text { regarding EU agencies } \\
\text { except to the extent } \\
\text { that it may look into } \\
\text { the substance of } \\
\text { petitions addressed to } \\
\text { it on this subject }\end{array}$ & $\mathrm{n} / \mathrm{a}$ \\
\hline
\end{tabular}

${ }^{2}$ According to Busuioc, LIBE committee has jurisdiction over Eurojust and Europol and does not use the practice of appointing liaisons (Busuioc (2010) P. 113). 



\section{APPENDIX 3}

\section{The Political Accountability Arrangements of 16 US Independent Regulatory}

\section{Agencies}

Appendix 3 offers a detailed overview of 16 US independent regulatory agencies:

1. the Board of Governors of the Federal Reserve System (the Fed)

2. the Commodity Futures Trading Commission (the CFTC)

3. the Consumer Product Safety Commission (CPSC)

4. the Federal Communications Commission (the FCC)

5. the Federal Deposit Insurance Corporation (the FDIC)

6. the Federal Energy Regulatory Commission (the FERC)

7. the Federal Housing Finance Agency (the FHFA)

8. the Federal Maritime Commission (the FMC)

9. the Federal Mine Safety and Health Review Commission (the FMSHRC)

10. the Federal Trade Commission (the FTC)

11. the United States International Trade Commission (the USITC)

12. the National Labor Relations Board (the NLRB)

13. the Nuclear Regulatory Commission (the NRC)

14. the Occupational Safety and Health Review Commission (the OSHRC)

15. the Postal Regulatory Commission (the PRC)

16. the Securities and Exchange Commission (the SEC).

The detailed overview of 16 IRAs is presented in the table below which is divided into five columns. The first column presents the name of an agency, its establishment year, and the field it regulates. The appointment and removal clauses are introduced by the second column, which includes the following information: (1) the number of members on agencies' management boards, (2) their tenure, (3) the statutory requirement of serving the staggered terms, (4) the statutory bi-partisanship requirement for appointment of members (not more than a majority of the same political affiliation), (5) other special eligibility clauses, and (6) the way of designation of the chairman. The third column gives examples of agencies' reporting obligations. The issues concerning agencies' budgets are presented in the fourth column, which, for illustrative purposes, includes agencies' budgets of 2010, the source of finance, and the relationship with the OMB during the annual budgetary proce- 
dure. The final column gives an overview of the statutory language about agencies' independence (whether agencies' founding acts mention 'independence) and shows in how much agencies are distant from the Department of Justice in the sense of having the authority to represent themselves in courts. In doing that, the table reflects on all essential elements of independence (see Chapter 3.1.2.1.). 


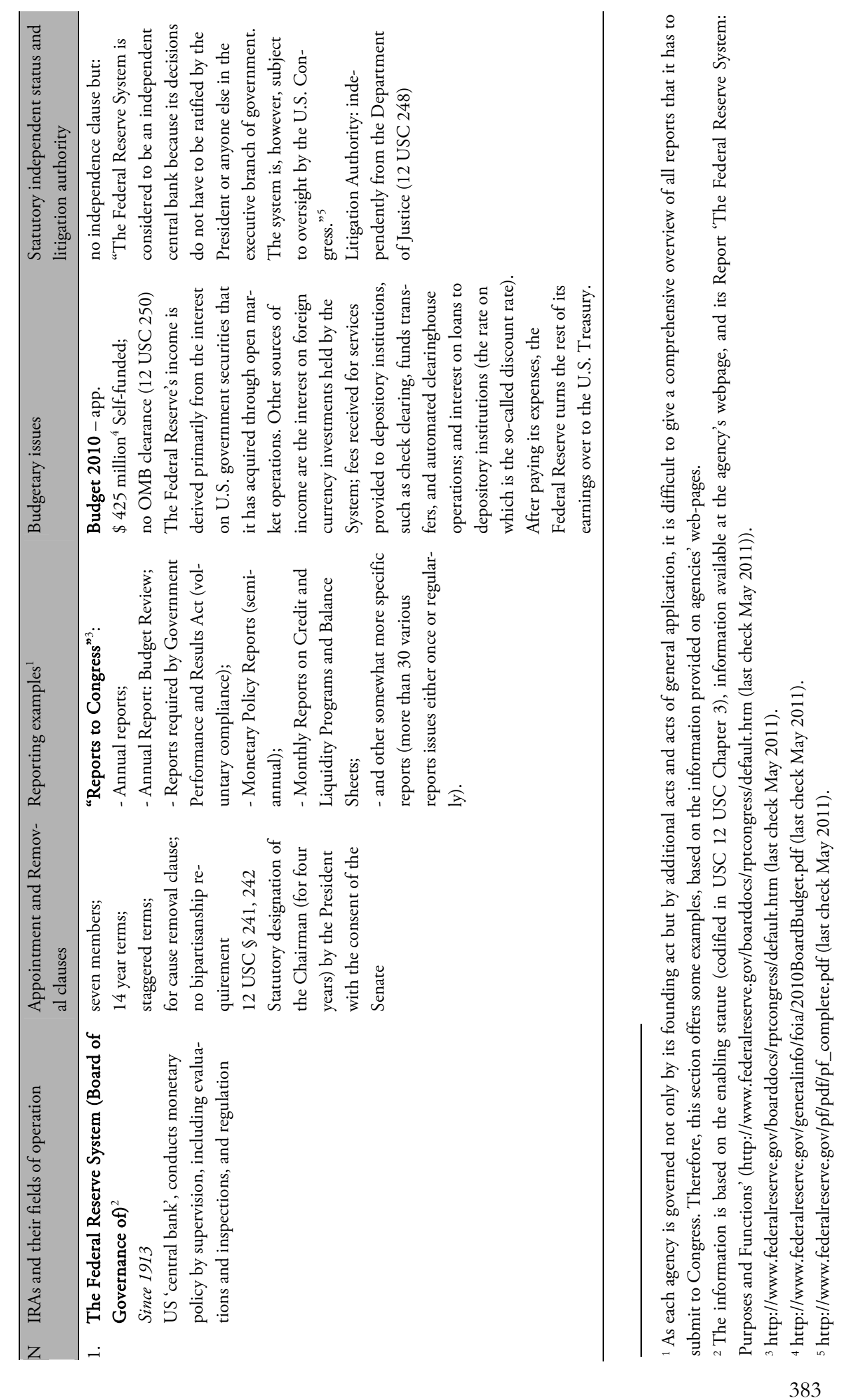




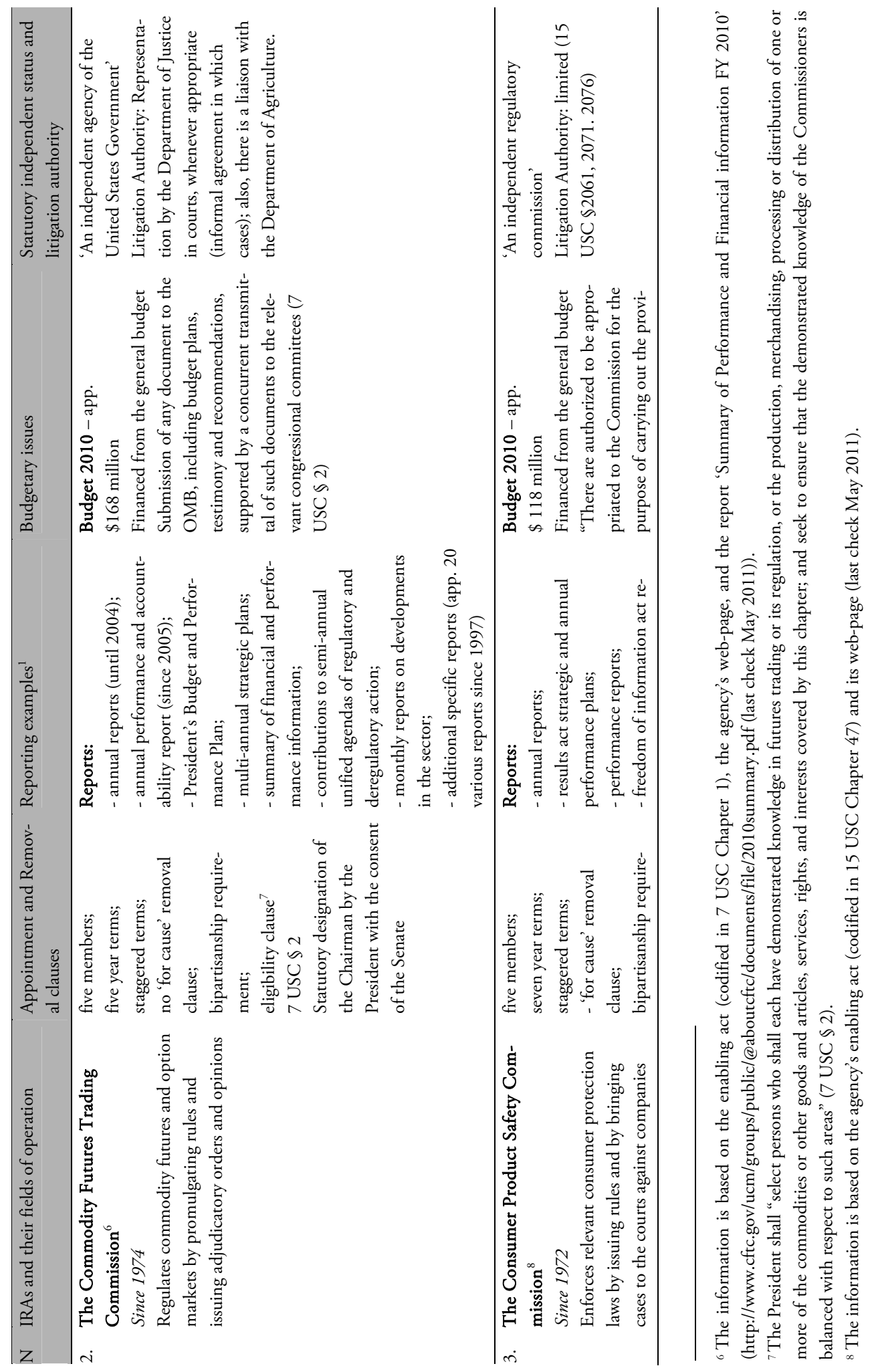




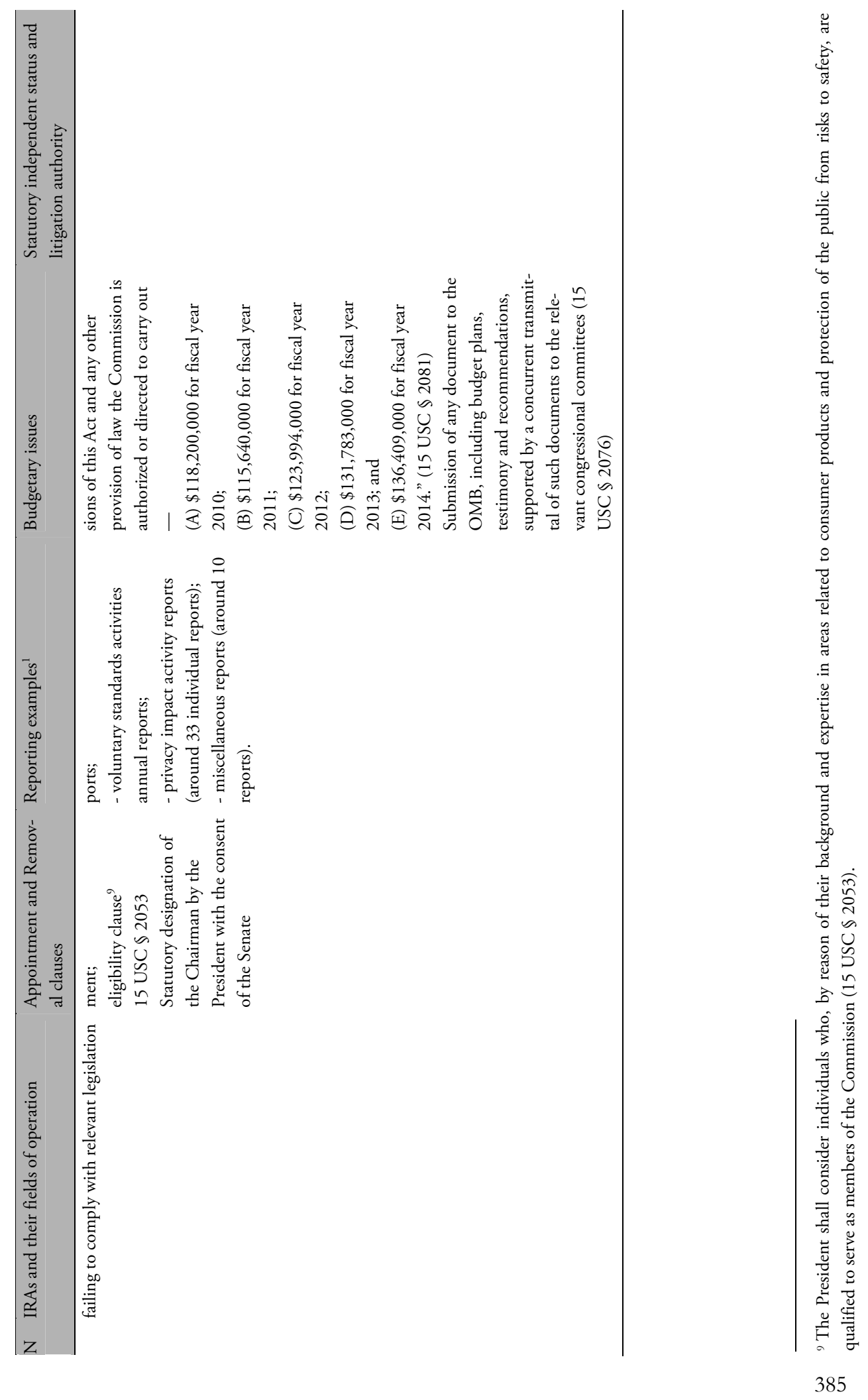




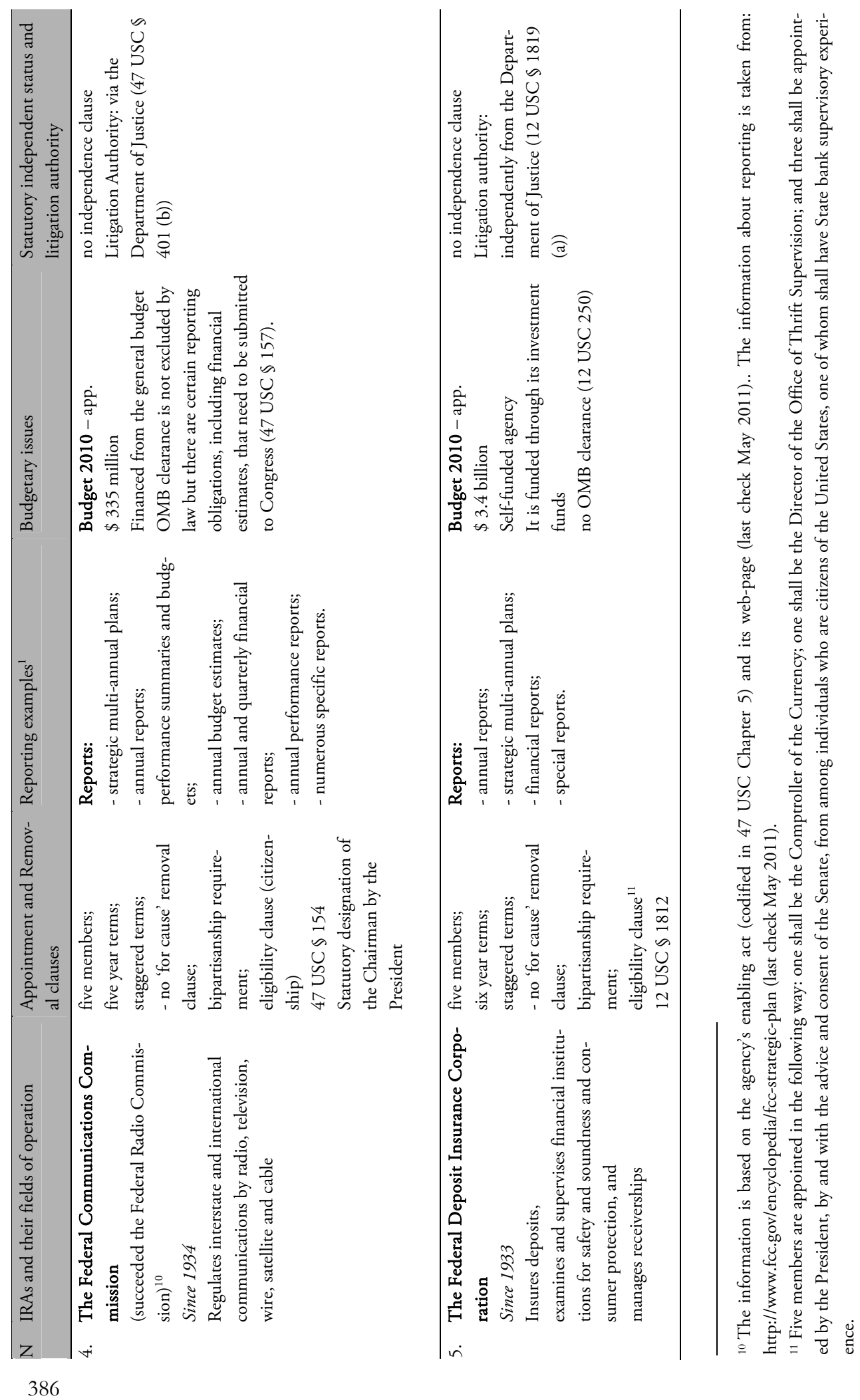




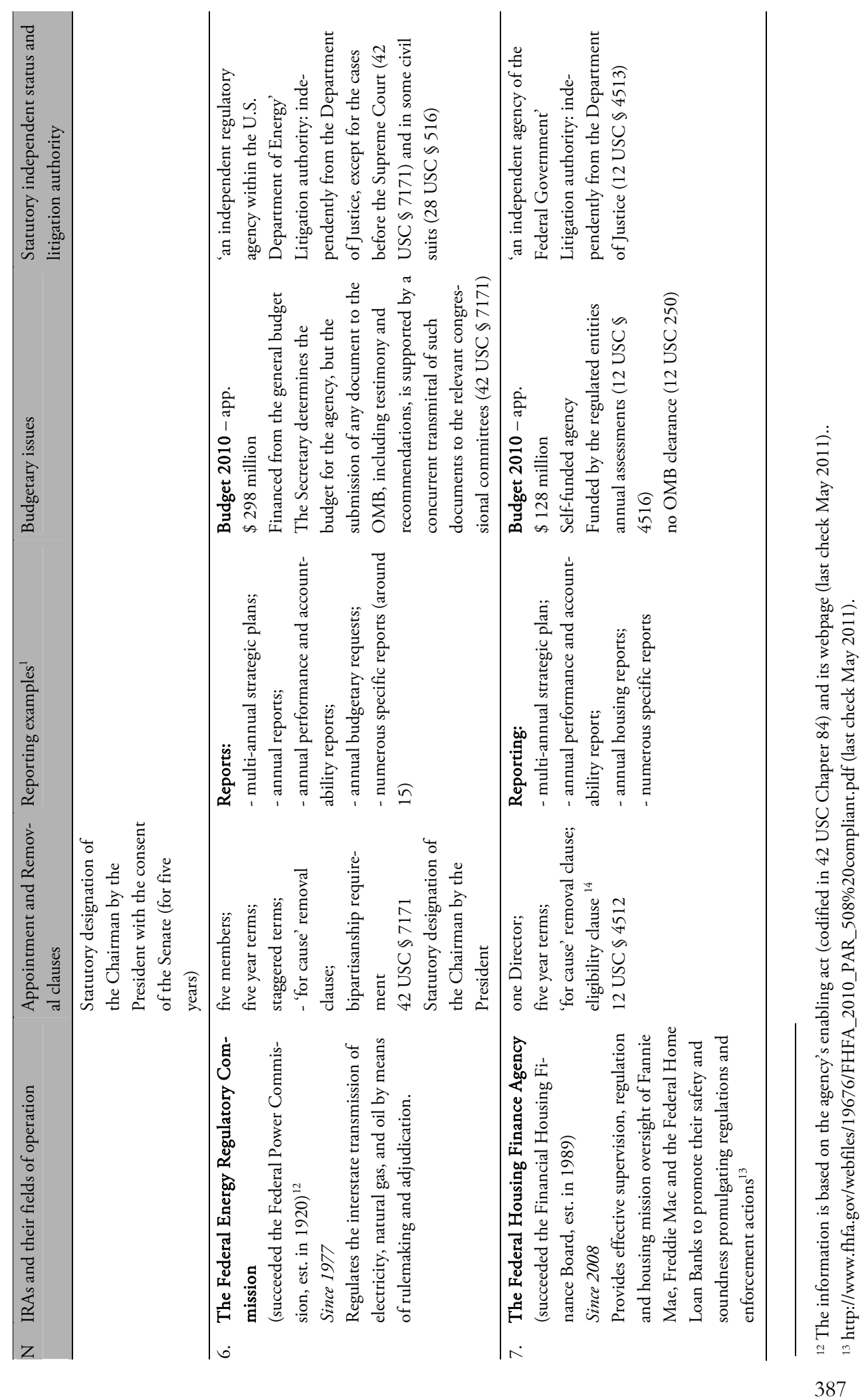




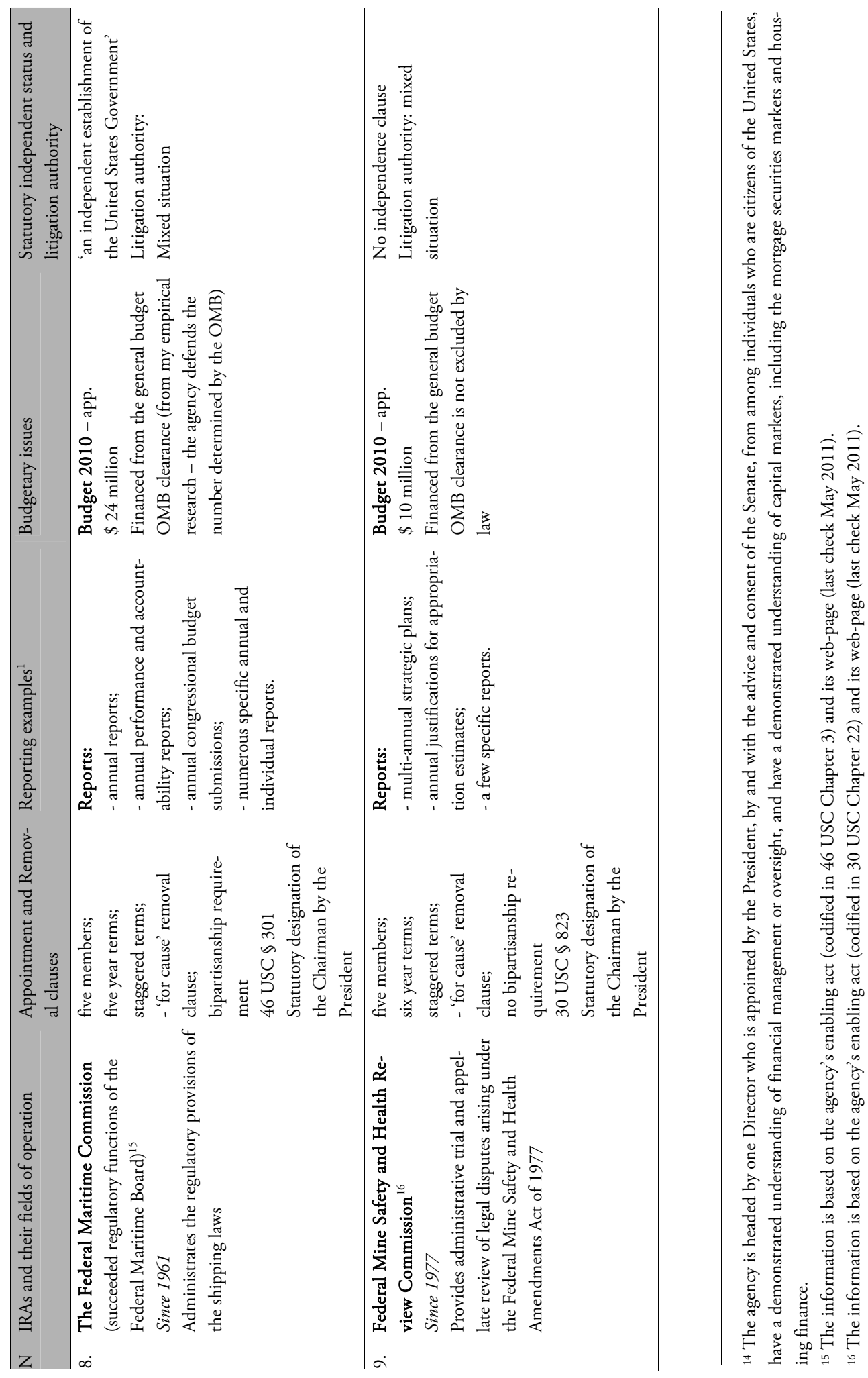




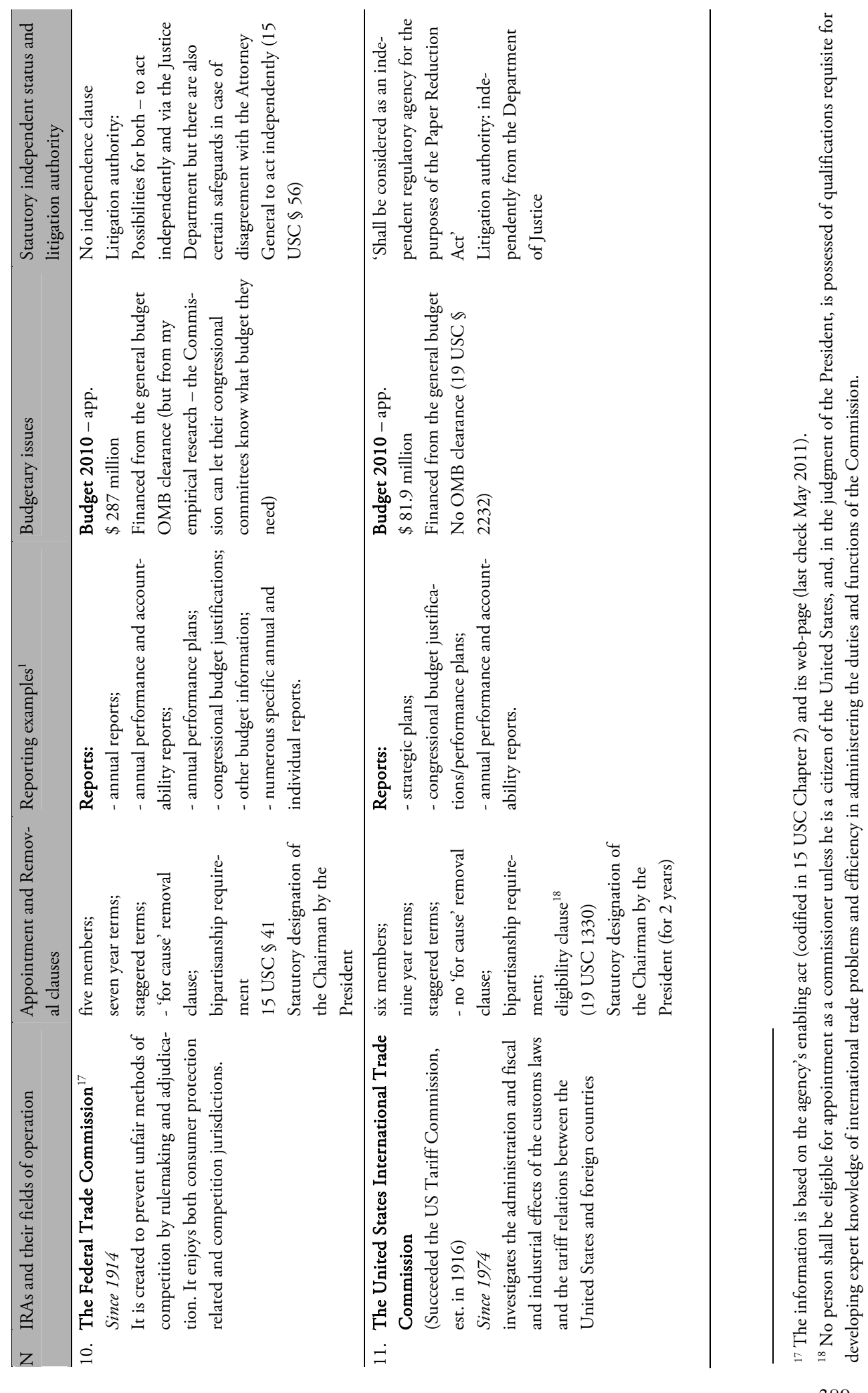




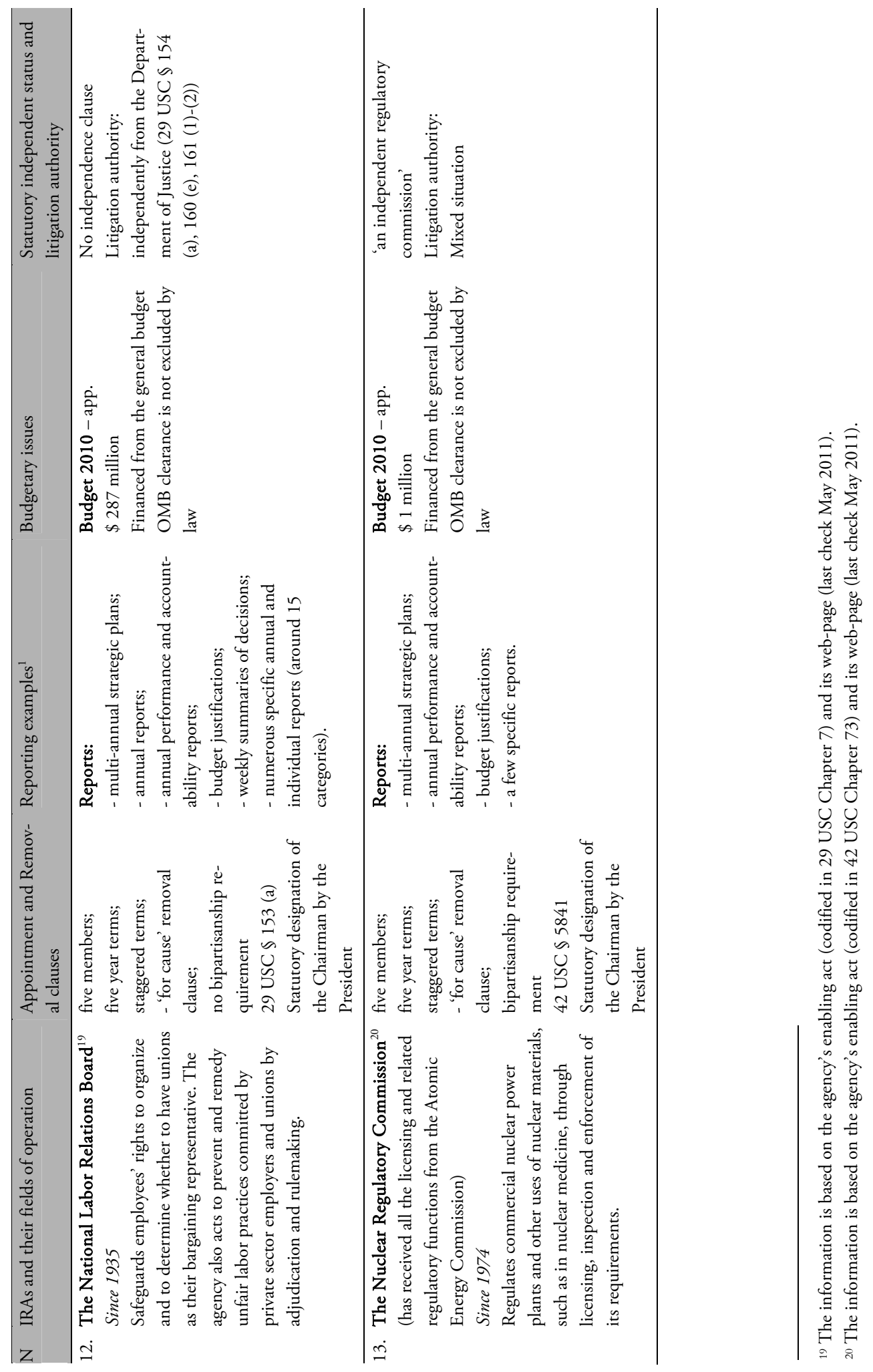




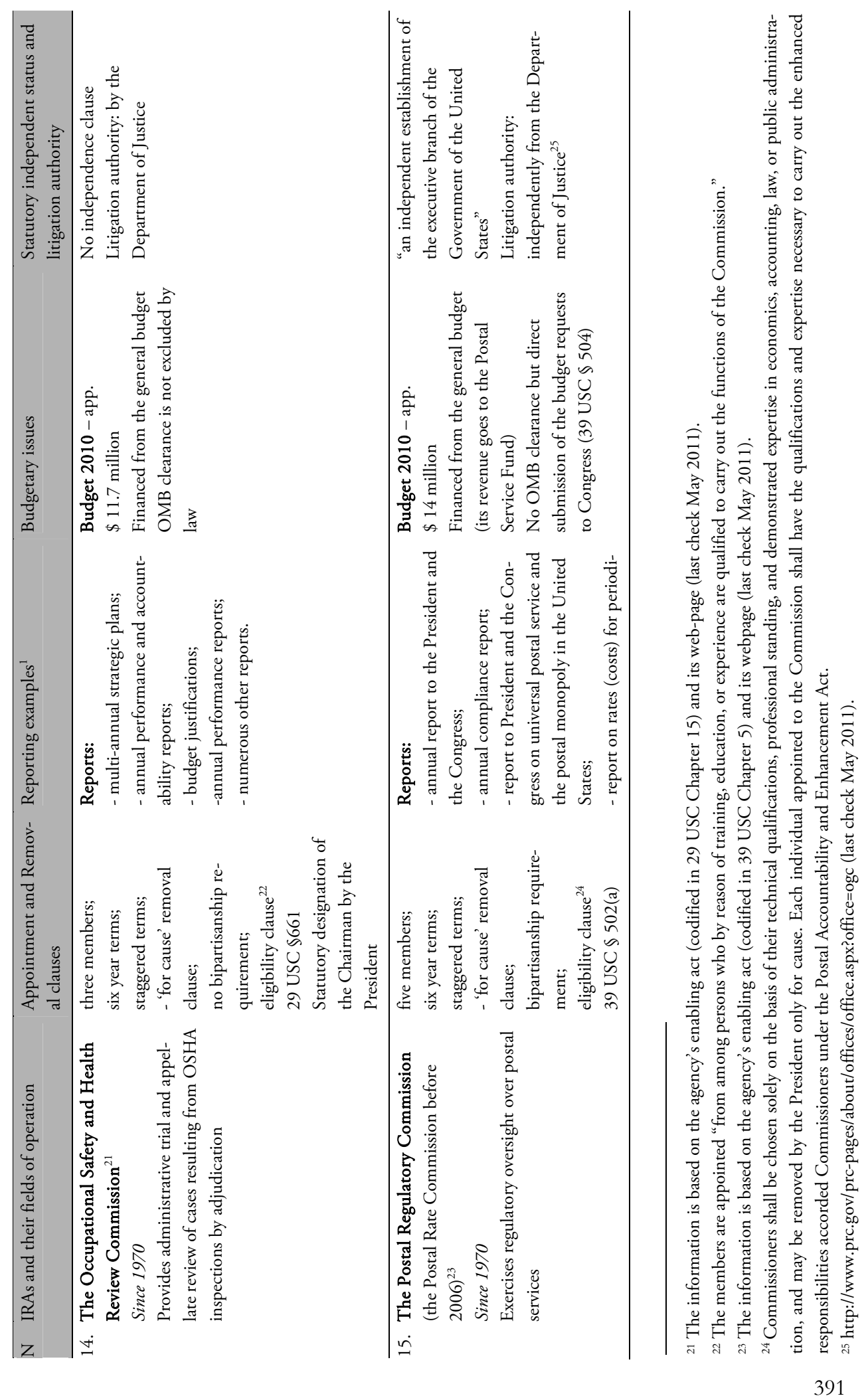



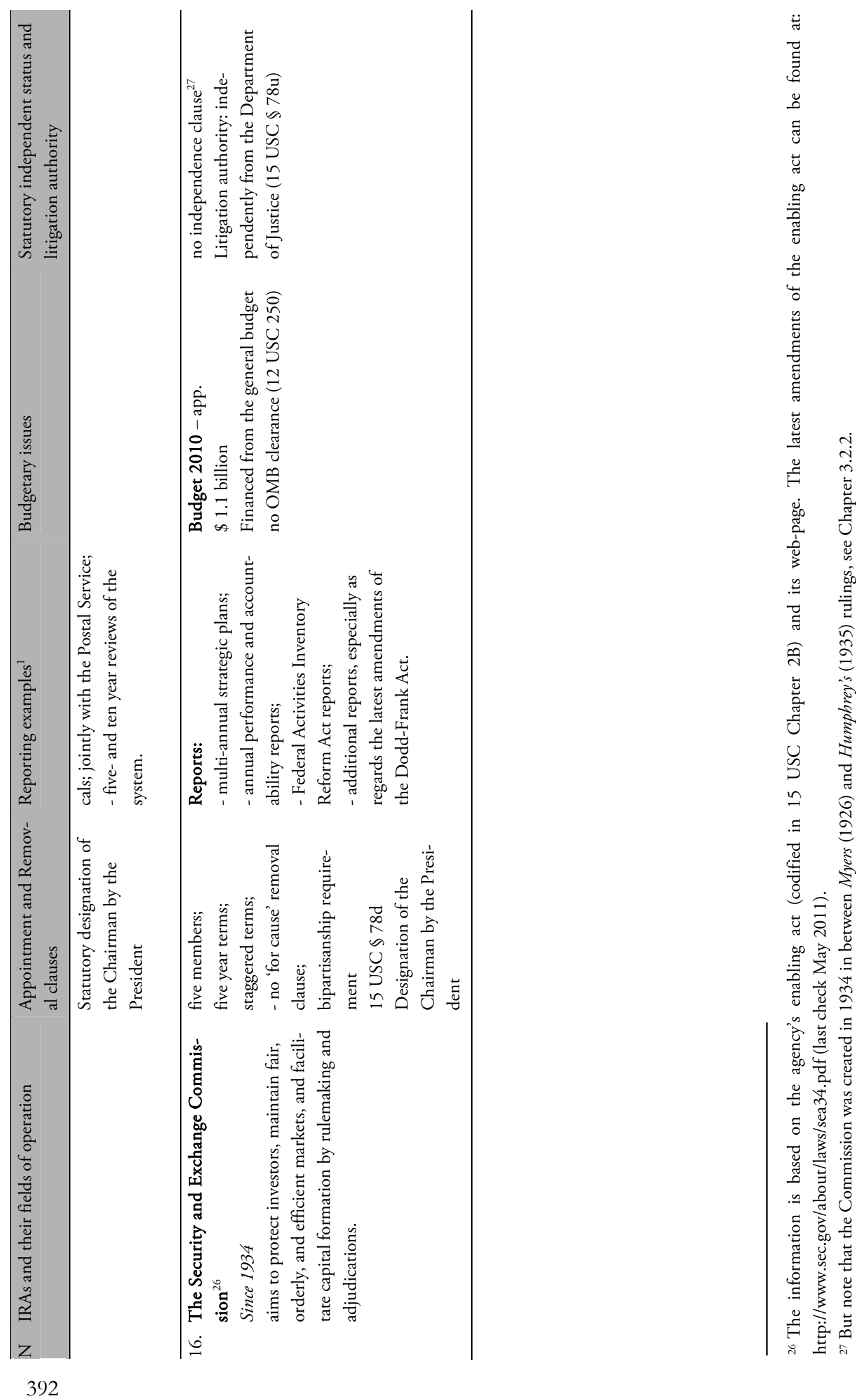


\section{Summary (in Dutch)}

De groeiende omvang van delegatie naar EU-agentschappen heeft de democratische geloofwaardigheid van de Europese Unie onder druk gezet. Het heeft ook bovendien voor gezorgd dat de politieke accountability van EU-agentschappen een saillante politieke en juridische kwestie is geworden. Het ter verantwoording roepen van agentschappen is een uitdagende taak, vooral wanneer de locus van de uitvoerende macht is verspreid en voorbij de grens van de natiestaat is verschoven. De onderzoeksvraag die deze studie tracht te beantwoorden luidt als volgt: hoe is de politieke accountability van EU-agentschappen vormgegeven en wat moeten de Europese representatieve instellingen overwegen wanneer zij de huidige accountability mechanismen aanpassen tijdens de lopende hervorming van de werking van EU-agentschappen? Deze vraag wordt beantwoord met behulp van een vergelijkende benadering, die een vergelijking impliceert tussen relevante EU en VS wetgeving en praktijken, door middel van bestudering van multidisciplinaire literatuur en het uitvoeren van semi-gestructureerde interviews, waarbij de laatstgenoemden alleen voor illustratieve doeleinden bedoeld zijn. Het boek bestaat uit 6 hoofdstukken die zijn samengevat in deze sectie.

Tijdens het analyseren van de politieke accountability van EU-agentschappen, ook vanuit een vergelijkend perspectief, werd deze studie vanwege de afwezigheid van een relevant algemeen kader geconfronteerd met de vraag hoe politieke verantwoording onderzocht en beoordeeld zou moeten worden. Naast een korte introductie tot het onderwerp, de relevante definities, de methode, de benadering en de bronnen gebruikt in deze studie geeft Hoofdstuk 1 antwoord op deze vraag. In navolging van de definitie van Bovens, het 'principal-agent' karakter van de relatie tussen representatieve instituties en onafhankelijke agentschappen en de institutionele en persoonlijke eigenschappen van de verantwoordende actor, in casu het agentschap, stelt deze studie een onderzoekskader van vijf dimensies vast waarbinnen politieke accountability kan worden gevormd en uitgeoefend. Deze dimensies omvatten: (1) de oprichting van en de delegatie van bevoegdheden naar onafhankelijke agentschappen door vertegenwoordigende lichamen, (2) de benoeming en verwijdering van leidinggevenden door vertegenwoordigende lichamen, (3) statutaire regeling van verantwoordingsaspecten inzake het functioneren van agentschappen, (4) financieel toezicht en (5) (parlementaire) controle. Deze vijf dimensies omvatten aspecten van institutionele (1, $3-5)$ en persoonlijke (2), ex ante ( 1 - 3) en ex post $(2,4,5)$ aard, waardoor een meer volledig onderzoek naar politieke accountability in een bredere institutionele omgeving mogelijk is (zie hoofdstuk 1).

Met behulp van de bevindingen verkregen in de genoemde vijf dimensies is politieke accountability beoordeeld en vervolgens vergeleken op basis van de volgende formule; na- 
melijk politieke accountability = de beschikbaarheid van verantwoordingsmechanismen + het ontwerp van verantwoordingsmechanismen en verantwoordingsverplichtingen + praktische toepassing van verantwoordingsmechanismen. De formule bevat de elementen die het beoordelen van verantwoordingscapaciteit (verantwoordingsmechanismen) en verantwoordingskwaliteit (ontwerp en toepassing in de praktijk) en het maakt mogelijk de bron van potentiele problemen te identificeren. Dit laatste maakt het beter mogelijk om geschikte oplossingen te bedenken. Na het vaststellen van het analytische kader vervolgt het boek met een diepgaand onderzoek en een beoordeling van de politieke accountability van EUagentschappen (hoofdstuk 2).

De analyse van de politieke accountability van EU-agentschappen in hoofdstuk 2 wijst uit dat, bij gebrek aan wettelijke kaders die de oprichting en verantwoordingsplichten van agentschappen reguleren, EU-agentschappen soms zijn ingesteld zonder functionele noodzaak en met verantwoordingslacunes met betrekking tot de Europese representatieve instituties. Zo ontbreekt het bij sommige oprichtingsaktes aan evaluatie, controle en ontslagclausules. Hoewel er drie typen hoorzittingclausules voor bestuurders van agentschappen zijn, worden deze niet regelmatig toegepast. Slechts 18 van de 35 oprichtingsaktes schrijven voor dat een hoorzitting gehouden moet worden ten behoeve van kandidaten voor de functie van hoofd van EU-agentschappen, 16 van de 35 directeuren van agentschappen kunnen uitgenodigd worden om de prestaties van het agentschap toe te lichten, en in slechts zes van de 35 gevallen bieden oprichtingsaktes de mogelijkheid tot het ondervragen van een hoofd van een agentschap alvorens hij/zij een termijnverlenging kreeg. Hier wordt een correlatie opgemerkt tussen enerzijds de groeiende wetgevende bevoegdheden, en daarmee de groeiende betrokkenheid, van het Europees Parlement in het vaststellen van oprichtingsaktes en anderzijds de groeiende hoeveelheid verantwoordingsverplichtingen van agentschappen, zoals verslagleggingsverplichtingen.

Bovendien, terwijl sommige parlementaire commissies van het Europees Parlement de gewoonte hebben ontwikkeld om vertegenwoordigers aan te stellen ten behoeve van het contact met agentschappen, wordt er door andere commissies geen toezicht uitgeoefend op agentschappen, zelfs wanneer deze agentschappen onder de jurisdictie van deze commissies vielen ingevolge het parlementair procedureel reglement. Doordat er nauwelijks formele regels zijn opgesteld door beide Europese vertegenwoordigende instellingen en vanwege de weinig transparante manier van opereren van de Raad, wordt het bemoeilijkt te concluderen of en hoe toezicht, zowel in kwantitatieve als in kwalitatieve zin, op alle EUagentschappen plaatsvindt. Het gebied van financieel toezicht op EU-agentschappen lijkt het meest geharmoniseerd te zijn wat betreft accountability, hoewel ook hier uitzonderingen bestaan, te weten zes zelf-financierende agentschappen. Omdat het instellen van zelffinancierende agentschappen nauwelijks een relatie met de EU-vertegenwoordigende instellingen (in het bijzonder het Europees Parlement) impliceert, vertoont de politieke accountability van deze agentschappen aanzienlijke tekortkomingen. 
Uiteindelijk concludeert dit hoofdstuk dat de drie EU instituties betrokken lijken te zijn in een politiek spel met als inzet wie controle mag uitoefenen over EU-agentschappen, hetgeen resulteert in de grote bestaande variatie van accountability arrangementen. Dat politieke onderhandelingen waarschijnlijk zouden blijven bestaan, veelal de bepalende factor met betrekking tot de oprichting en het functioneren van EU-agentschappen, wordt beargumenteerd op basis van het feit dat de onderhandelingen van de Interinstitutionele Werkgroep betreffende het opereren van EU-agentschappen resulteerde in de niet juridisch bindende 'Gemeenschappelijke Aanpak' voor EU-agentschappen.

Op basis van de bevindingen van de vijf besproken dimensies wordt het vervolgens mogelijk politieke verantwoordelijkheid te beoordelen aan de hand van de eerder beschreven formule (de beschikbaarheid van verantwoordingsmechanismen, het ontwerp van verantwoordingsmechanismen en verantwoordingsverplichtingen en hun praktische toepassing). De politieke accountability van EU-agentschappen wordt op alle drie elementen als problematisch beoordeeld. Over het algemeen zouden het Parlement en de Raad over verschillende verantwoordingsmechanismen kunnen beschikken om de drie stadia van accountability adequaat in te richten. Echter, in individuele gevallen zijn (vergelijkbare) EU agentschappen onderworpen aan verschillende sets van verantwoordingsplichten, zonder duidelijke argumentatie die het bestaan van deze verschillen rechtvaardigt. Bovendien hindert het ontwerp van verantwoordingsplichten, onder andere vanwege korte en algemene formuleringen van rapportageplichten en een gebrekkig samenspel van verantwoordingsmechanismen, de accountability van agentschappen. Tot slot ondervindt de praktische toepassing van de bestaande mechanismen voor verantwoording een aantal uitdagingen, onder meer vanwege willekeurige controles van de prestaties van agentschappen en vanwege praktische beperkingen wat betreft het gebruik van dergelijke sanctioneringsinstrumenten (zoals het sluiten van agentschappen). Het wordt aangetoond dat overmatige diversiteit en gebrekkige onderbouwing van verantwoordingsarrangementen de stand van zaken domineerde en het wordt beargumenteerd dat, gelet op de complexiteit van EU-structuren en het fundamentele karakter van het concept van politieke accountability, de ruwweg 35 bestaande verantwoordingsmodellen van EU-agentschappen van twijfelachtige noodzaak waren. Een beperkt aantal verantwoordingsmodellen zou enerzijds een systeem kunnen creëren dat duidelijk, transparant en met redenen omkleed zou zijn, maar dat anderzijds ook flexibiliteit zou toelaten. Dit zou op zijn beurt de legitimiteit van de EU-structuren en processen vergroten.

In hoofdstuk 3 neemt deze studie een 'vergelijkende wending'. In dit hoofdstuk wordt eerst de politieke accountability van 16 Amerikaanse onafhankelijke agentschappen onderzocht met betrekking tot de vijf genoemde dimensies. Het wordt aangetoond dat de relatie tussen het Congres en Amerikaanse onafhankelijke agentschappen gekarakteriseerd kan worden als volwaardig, omdat het Congres zelf een divers scala aan interacties met agentschappen ontwierp, waarbij ze nauwelijks wordt beperkt door de Grondwet (vanwege het 
feit dat agentschappen daarin niet worden genoemd) of door het hooggerechtshof tijdens de interpretatie van de bestaande lacunes in de Grondwet.

Deze volwaardige relatie impliceert een scala van manieren waarop het Congres zou kunnen worden betrokken bij het bestuur van onafhankelijke agentschappen. Er wordt gewezen op het feit dat er vrijwel geen verschillen bestaan tussen de manieren waarop het Congres onafhankelijke en andere agentschappen binnen de uitvoerende macht ter verantwoording kon roepen. Dit wordt verklaard door de betekenis van het concept van onafhankelijkheid in de Amerikaanse context, dat een afstand van de politieke invloed van de President in plaats van het Congres impliceert. Tegelijkertijd wordt aangetoond dat het beperken van de controle van de President over onafhankelijke agentschappen slechts de oorsprong van politieke invloed van de ene politieke institutie, namelijk de President, richting de andere, namelijk het Congres, verschoof. Vandaar beïnvloedt politiek onafhankelijke agentschappen in de VS op een aantal manieren. In navolging van de 'separation of parties, not powers' theorie lijken besluiten betreffende de instelling van onafhankelijke agentschappen, de delegatie van bevoegdheden aan deze en de mate van toezicht uitgevoerd door de kamers van het Congres over onafhankelijke agentschappen en andere kwesties (zoals de wijze waarop de benoeming of het ontslag van topambtenaren bij onafhankelijke agentschappen plaatsvindt) af te hangen van de politieke meerderheden in het Congres en het Witte Huis of in het bestuur van de onafhankelijke agentschappen zelf.

Ondanks het feit dat politiek wellicht van invloed is op het vermogen van het Congres om haar verantwoordingsinstrumenten te gebruiken, zijn ook verschillende mechanismen betreffende de wijze waarop het Congres onafhankelijke agentschappen tot verantwoording kan roepen geanalyseerd. Deze omvatten hoorzittingen ondersteund door sterke formele bevoegdheden tot het 'subpoena' van getuigen, in aanvulling op verschillende 'brandalarmen', hetgeen een solide pakket van statutaire reguleringen impliceert dat het Congres, haar ondersteunende lichamen en de belanghebbende partijen in staat stelt om agentschappen te controleren. De instelling van expert-ondersteuningsagentschappen verbetert de mogelijkheid tot het uitoefenen van toezicht door het Congres, wat met name relevant lijkt te zijn bij het aangaan van de uitdaging hoe adequaat toezicht gehouden kan worden over een grote hoeveelheid uitvoerende instituties. Toch bllijft de grootste uitdaging van toezicht door het Congres de lage hoeveelheid prikkels voor gekozen politici om op continue wijze toezicht te houden. Gezien de regelmatigheid en de mogelijkheid om alle drie fasen van toezicht te behartigen wordt 'the annual appropriations process' aangevoerd als Het verantwoordingsinstrument dat het Congres tot haar beschikking heeft.

Met behulp van de reeds vermelde formule wordt de politieke accountability van onafhankelijke agentschappen als gedeeltelijk problematisch beoordeeld. Er wordt uitgewezen dat politieke accountability op een duidelijke manier is georganiseerd, omdat Amerikaanse onafhankelijke agentschappen onderworpen zijn aan zeer vergelijkbare verantwoordingsplichten die op zodanige wijze zijn ontworpen dat ze de verantwoordingsrelatie bevorderen. 
Zo kunnen rapportageverplichtingen zeer specifiek zijn vormgegeven en bevorderden ze de accountability, omdat ze analytische rapportages vereisten, zoals de verplichtingen om redenen te geven en resultaten ten aanzien van voorgenomen plannen te rapporteren. Hoewel de analyse van het systeem van politieke accountability van Amerikaanse onafhankelijke agentschappen een aantal verontrustende momenten blootlegt, zoals het hoge aantal (technische) rapporten die onnodige kosten voor het functioneren van agentschappen met zich mee kunnen brengen zonder de gewenste resultaten te leveren en een belemmering kunnen vormen voor politieke verantwoording, toont het anderzijds ook de oplossingen die het Congres heeft ingezet om die problemen aan te pakken. Wat betreft het eerder genoemde voorbeeld over het grote aantal rapporten is de oplossing van het Congres om extra personeel aan te nemen, om expert ondersteuningsagentschappen in te stellen en om een directe verantwoordelijkheidslink tussen de (onafhankelijke) agentschappen en het publiek te bewerkstelligen, met als doel de kans dat rapportages worden gelezen en de kans dat agentschappen gecontroleerd worden te verhogen. Hoewel het Congres onafhankelijke agentschappen inderdaad kan controleren met behulp van haar 'geweldige arsenaal' aan krachtige verantwoordingsmechanismen, doet het Congres dit niet altijd op adequate wijze omdat het gebruik van dat arsenaal afhankelijk is van de politieke meerderheden op 'Capitol Hill' en in het Witte Huis dan wel in het bestuur van de onafhankelijke agentschappen zelf. In navolging van Madisons nalatenschap, die stelt dat de regering eerst haar onderdanen dient te controleren en vervolgens haarzelf controle dient op te leggen, wordt geconcludeerd dat de grootste uitdaging voor politieke verantwoording in de VS in de tweede stap lijkt te liggen.

Het tweede doel van het onderzoeksproject, namelijk het bieden van beleidsaanbevelingen betreffende de zaken die de vertegenwoordigende EU instituties in overweging moeten nemen wanneer ze de verantwoordingsarrangementen van onafhankelijke agentschappen aanpassen, wordt door middel van een vergelijking tussen de VS en de EU behaald. Hoofdstuk 4 biedt een vergelijkende analyse van de systemen van politieke accountability van onafhankelijke agentschappen in de EU en de VS. Gebaseerd op vergelijkende inzichten wordt in hoofdstuk 5 een drietal beleidsaanbevelingen gedaan die de vertegenwoordigende EU instituties kunnen overwegen in de lopende hervorming van de werking van EUagentschappen.

De vergelijkende analyse van hoofdstuk 4 is in verschillende opzichten waardevol. Ten eerste helpt de analyse te waarderen wat de vertegenwoordigende EU-instellingen reeds bezitten. Uit de vergelijking blijkt het dat het Amerikaanse Congres en het Europees Parlement vrij gelijkwaardig zijn wat betreft hun vermogen verantwoordingsplichten op te dragen aan onafhankelijke agentschappen. In het algemeen beschikken de representatieve instellingen in beide rechtsordes over mogelijkheden om de prestaties en financiën van agentschappen te beoordelen met behulp van rapporten en hoorzittingen, om onderzoek naar specifieke gebeurtenissen te verrichten en om agentschappen te sanctioneren middels, 
bijvoorbeeld, het aanpassen van de functies, het budget en de organisatiestructuren van agentschappen. Om de persoonlijke verantwoordingslijn van ongekozen topambtenaren richting het volk te garanderen, kunnen representatieve instituties in zowel de VS als de EU betrokken zijn bij het benoemen en verwijderen van hoge functionarissen bij agentschappen. Dit wil echter niet zeggen dat individuele verantwoordingsmechanismen niet verschillen qua kracht; dat is zeker het geval. Zo heeft het Europees Parlement niet de bevoegdheid van het Congres om getuigen te dagvaarden en beschikken de kamers van het Congres niet over de bevoegdheid van het Europees Parlement 'to give a discharge'. Het meest opvallende verschil betreft echter de benadering die de wetgever gebruikt met betrekking tot de organisatie van politieke verantwoording van afzonderlijke agentschappen: waar de VS grote uniformiteit vertoont, wordt politieke verantwoording in de EU gekenmerkt door grote diversiteit. Daarom wordt beargumenteerd dat een meer uniforme maar flexibele aanpak noodzakelijk is om duidelijkheid, rechtvaardiging en differentiatie tussen agentschappen te verzekeren. Dit is ook essentieel voor het bevorderen van de legitimiteit van de EU.

Ten tweede biedt de vergelijkende analyse de EU een aantal lessen om te overwegen en werden een aantal alarmerende problemen geïdentificeerd. Een voorbeeld van een leerervaring betreft de kwesties van specificiteit en formulering van verantwoordingsverplichtingen: zo zou een hogere specificiteit gekoppeld met verslagleggingsverplichtingen de verantwoordingsrelatie met representatieve instituties positief kunnen beïnvloeden. Het waarschuwingssignaal betreft een te hoge mate van verslagleggingsverplichtingen, hetgeen niet alleen een overvloed aan werk voor agentschappen kan betekenen, maar ook bij het Congres een te hoge werkdruk veroorzaken.

Verder brengt de vergelijking een aantal overeenkomsten aan het licht die de noodzaak voor verder onderzoek demonstreren. Dit betreft, bijvoorbeeld, het belang van het ter verantwoording roepen van agentschappen en de voordelen die de jaarlijkse begrotingsprocedure biedt om agentschappen te controleren. De voordelen van deze procedure betreffen onder andere de aangebrachte regelmaat in de discussie over de prestaties van agentschappen. Deze regelmaat resulteert uit het feit dat agentschappen uiteindelijk financieel afhankelijk zijn voor hun dagelijkse activiteiten. Dit vormt een aanwijzing dat het mogelijk is om de jaarlijkse financiële toezicht procedures centraal te maken bij het proces van politieke accountability. Beide rechtsordes demonstreren bovendien soortgelijke problemen, bijvoorbeeld over het bestaan van milde instellings- en delegatienormen waardoor de wetgever een scala aan instellingen binnen de uitvoerende macht, soms zonder functionele noodzaak, met verantwoordingstekorten kan creëren. Op dit punt staan beide rechtsordes voor de uitdaging dat de representatieve organen het aan prikkels ontberen om op regelmatige basis toezicht uit te oefenen op de prestaties van agentschappen. Dergelijke gelijksoortige problemen wijzen op de moeilijkheid waarmee eenduidige oplossingen geformuleerd kunnen 
worden om deze uitdagingen aan te pakken, wat op zijn beurt de noodzaak voor verder onderzoek in de toekomst benadrukt.

Met betrekking tot de beleidsaanbevelingen zoals omschreven in hoofdstuk 5, beargumenteert deze studie de noodzaak van (1) een verdragsbepaling die de mogelijkheden om EU agentschappen op te richten en om zekere bevoegdheden aan hen te delegeren vaststelt, ondersteund door een verplichting om een verantwoordingskader voor EU-agentschappen in secundaire wetgeving te creëren; (2) een juridisch bindend verantwoordingskader (in de vorm van secundaire wetgeving) gebaseerd op een 'streamlining approach'; en (3) 'selfenforcing' regels voor de EU representatieve instellingen om te verzekeren dat zij toezicht uitoefenen op EU-agentschappen. Deze maatregelen zijn essentieel voor de legitimering van EU-agentschappen, om hun politieke verantwoording op een duidelijke maar flexibele manier te organiseren en om de toezichthoudende verantwoordelijkheden van de EU representatieve instituties te bevorderen. De Uniewetgever wordt daarmee uitgenodigd om de bestaande verantwoordingsarrangementen van EU-agentschappen aan te passen op basis van goede redenen en op transparante wijze, om zo bij te dragen aan een reductie van het vermeende EU legitimiteitstekort. Er wordt gesteld dat de politieke accountability van EUagentschappen niet alleen verantwoordingsverplichtingen van agentschappen betreft, maar dat het ook impliceerde dat vertegenwoordigende instellingen hun verantwoordelijkheden om goede accountability mechanismen in te stellen moeten vervullen, dat ze de relevante verantwoordingsregels toe moeten passen en daarvoor ook zelf verantwoording af dienen te leggen.

Ten slotte geeft hoofdstuk 6 een evaluatie met betrekking tot het bereiken van de doelen van deze studie en zette het een aantal richtingen waarin verder onderzoek noodzakelijk is uiteen.

$\mathrm{Al}$ met al heeft deze studie met behulp van haar eigen analytisch kader de politieke accountability van alle 35 EU-agentschappen bestudeerd en beoordeeld. Het heeft de bestaande verantwoordingsmechanismen en bronnen van verantwoordingsproblemen onderzocht en getracht te verklaren. Met behulp van inzichten uit vergelijkend onderzoek met de VS bood de studie de EU representatieve instituties drie beleidsaanbevelingen om in overweging te nemen wanneer ze de bestaande verantwoordingsarrangementen van EUagentschappen aanpassen. 



\section{Curriculum Vitae}

Miroslava Scholten is a Postdoctoral Researcher at the Utrecht Centre for Regulation and Enforcement in Europe (RENFORCE) and a member of the Europa Institute at the Faculty of Law, Economics and Governance of Utrecht University.

She holds a 'specialist degree' in International Relations from the North-West Academy of Public Administration, Saint-Petersburg, Russia (2005, with distinction); an Executive Master's degree in International and European Relations and Management (2006, with distinction) and an LLM degree in International and European Law (2008) from the University of Amsterdam, the Netherlands. Her extra curriculum educational activities include participation in the 'EU studies' programme at Aarhus Business School upon a scholarship awarded on merit by the Danish Ministry of Foreign Affairs and the summer course in American Law offered by the Amsterdam-Leyden-Columbia summer school. With respect to her professional development, Ms. Scholten worked as $\mathrm{PhD}$ researcher at the Faculty of Law of Maastricht University and Montesquieu Institute, the Netherlands, and as consular department specialist at the Representation of the Russian Ministry of Foreign Affairs in Saint-Petersburg. Also, she completed a number of internships: at the City Administration of Saint-Petersburg, Russia, at the International Tribunal for the Law of the Sea (ITLOS) in Hamburg, Germany, and at the Netherlands Institute of International Relations 'Clingendael' in the Hague. Ms. Scholten received the 2012 Europe Award for the best scientific article from the Montesquieu Institute and the 2009 Hans Smit Award for the best participant from the Columbia summer school on American Law. 